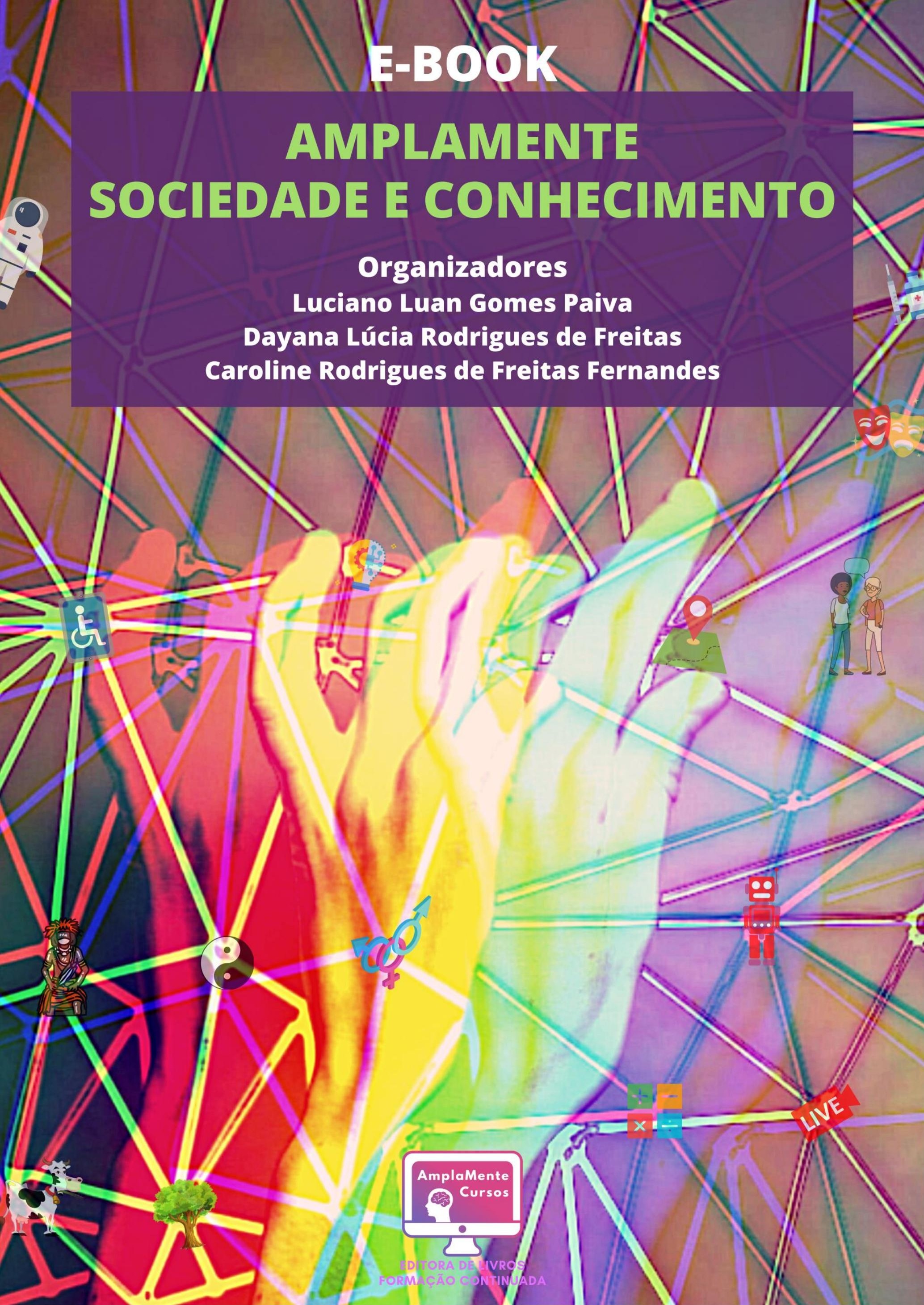




\title{
E-BOOK
}

\section{AMPLAMENTE: SOCIEDADE E CONHECIMENTO}

$2^{\circ}$ EDIÇÃO. VOLUME 01.

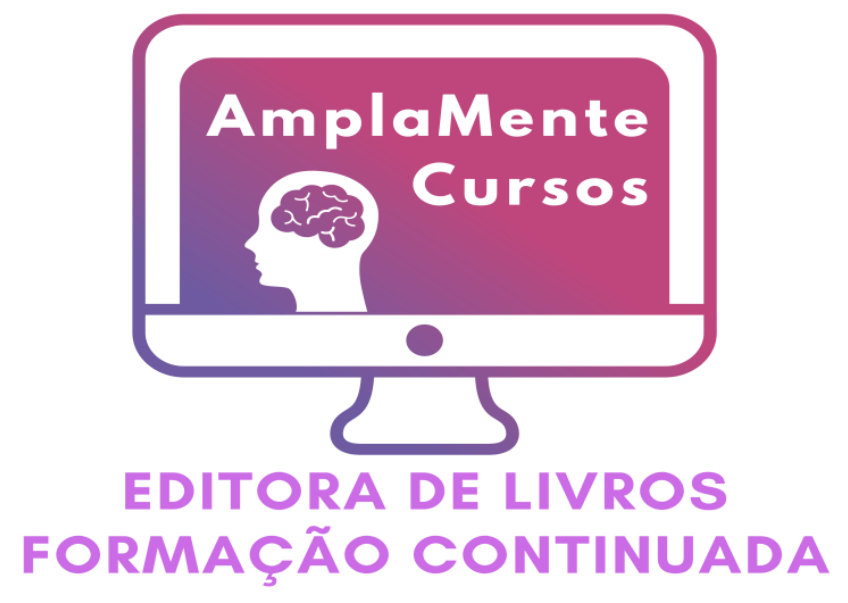

\author{
ORGANIZADORES \\ Luciano Luan Gomes Paiva \\ Dayana Lúcia Rodrigues de Freitas \\ Caroline Rodrigues de Freitas Fernandes
}

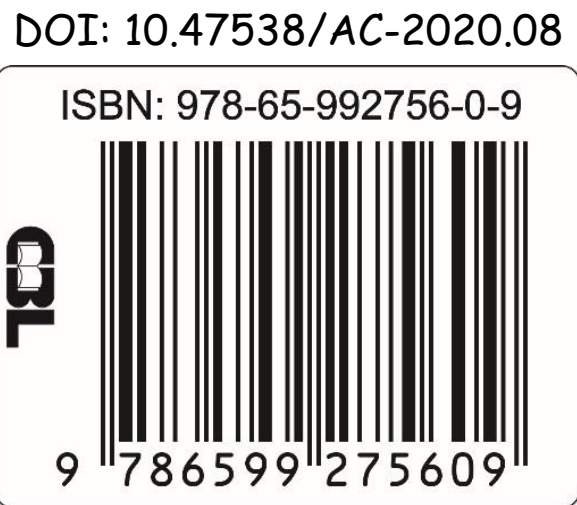




\section{AMPLAMENTE: SOCIEDADE E CONHECIMENTO $2^{\circ}$ EDIÇÃO. VOLUME 01.}

Dados Internacionais de Catalogação na Publicação (CIP)

(Câmara Brasileira do Livro, SP, Brasil)

Amplamente [livro eletrônico] : sociedade do conhecimento / organização Luciano Luan Gomes Paiva, Dayana Lúcia Rodrigues de Freitas, Caroline Rodrigues de Freitas Fernandes. -- 2. ed. -- Natal, RN : Amplamente Cursos e Formaçăo Continuada, 2020 .

\section{Bibliografia}

Vários autores.

ISBN $978-65-992756-0-9$

1. Ciências humanas 2. Ciências sociais 3 . Inovaçăo tecnológica 4. Pesquisa I. Paiva, Luciano Luan Gomes. II. Freitas, Dayana Lúcia Rodrigues de. III. Fernandes, Caroline Rodrigues de Freitas.

Índices para catálogo sistemático:

1. Ciências sociais : Estudo e ensino 300.7

Amplamente Cursos e Formação Continuada CNPJ: $35.719 .570 / 0001-10$ E-mail: publicacoes@editoraamplamente.com.br www.amplamentecursos.com Telefone: (84) 999707-2900 Caixa Postal: 3402 CEP: 59082-971

Natal- Rio Grande do Norte - Brasil

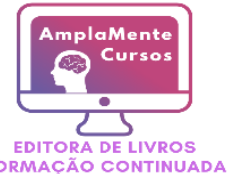




\section{CONSELHO EDITORIAL}

Dr. Damião Carlos Freires de Azevedo

Dra. Danyelle Andrade Mota

Dra. Débora Cristina Modesto Barbosa

Dra. Elane da Silva Barbosa

Dra. Eliana Campêlo Lago

Dr. Everaldo Nery de Andrade

Dr. Jakson dos Santos Ribeiro

Dra. Josefa Gomes Neta

Dra. Maria Inês Branquinho da Costa Neves

Dr. Maykon dos Santos Marinho

Dr. Rafael Leal da Silva

Dra. Ralydiana Joyce Formiga Moura

Dra. Roberta Lopes Augustin

Dra. Viviane Cristhyne Bini Conte

Dr. Wanderley Azevedo de Brito

\section{CONSELHO TÉCNICO CIENTÍFICO}

Ma. Ana Claudia Silva Lima

Esp. Bruna Coutinho Silva

Ma. Camila de Freitas Moraes

Me. Carlos Eduardo Krüger

Esp. Caroline Rodrigues de Freitas Fernandes

Me. Clécio Danilo Dias da Silva

Me. Fabiano Eloy Atílio Batista

Ma. Heidy Cristina Boaventura Siqueira

Me. Jaiurte Gomes Martins da Silva

Me. José Flôr de Medeiros Júnior

Me. Josicleide de Oliveira Freire

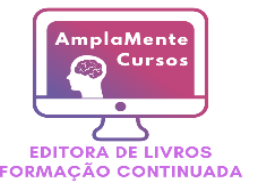




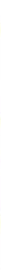

\section{SUMÁRIO}

CAPÍTULO I 14

A DIMENSÃO TRINITÁRIA NA PRÁXIS LITÚRGICA: UMA LITURGIA PNEUMATOLÓGICA

Valmir Rodrigues Pereira

DOI - Capítulo: 10.47538/AC-2020.08-01

CAPÍTULO II . .29

A EVOLUÇÃO HISTÓRICA DA PROFISSÃO: EMPRESÁRIO DE FUTEBOL

Walter Reyes Boehl; Mauro Castro Ignácio;

Bruna da Silva Brogni; Anderson da Silveira Farias;

Guilherme de Oliveira Gonçalves.

DOI - Capítulo: 10.47538/AC-2020.08-02

CAPÍTULO III .38

A EXPRESSÃO CULTURA DO ESTUPRO E DA PEDOFILIA NA MÍDIA/MÚSICA: A NORMALIZAÇÃO DO MAL

Júlia Leite Nunes; Danielle Cevallos Soares.

DOI - Capítulo: 10.47538/AC-2020.08-03

CAPÍTULO IV .46

A MORTE NA PSICANÁLISE E NA LITERATURA: KAFKA E CAMUS Thales do Rosário de Oliveira DOI - Capítulo: 10.47538/AC-2020.08-04

CAPÍTULO V.

A MULTIPARENTALIDADE E SEUS EFEITOS À LUZ DA JURISPRUDÊNCIA

Waldilene de Araujo Lima.

DOI - Capítulo: 10.47538/AC-2020.08-05

CAPÍTULO VI . .62

A PSICOLOGIA DO ESPORTE EM UM GRUPO DE BAILARINAS DE UMA ESCOLA DE BALÉ PRIVADA NO OESTE BAIANO

Filipe Ribeiro Junqueira; Giovana Fernandes Leite; Marla Jalinne Ventura; Shimony Coelho Machado.

DOI - Capítulo: 10.47538/AC-2020.08-06

CAPÍTULO VII. 69

ANÁLISE DE USABILIDADE DO SISTEMA INTEGRADO DE GESTÃO DE ATIVIDADES ACADÊMICAS DA UNIVERSIDADE FEDERAL RURAL DA AMAZÔNIA

Mariane Siqueira Borges; Danilo de Souza Novaes;

Aleksandra do Socorro da Silva; Silvana Rossy de Brito.

DOI - Capítulo: 10.47538/AC-2020.08-07 


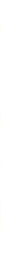

CAPÍTULO XVI 180

COMPILAÇÃO DE ENSAIOS DE UMA PESQUISADORA TRANS EM TEMPOS DE PANDEMIA

Fernanda Bravo Rodrigues

DOI - Capítulo: 10.47538/AC-2020.08-16

CAPÍTULO XVII. 191

CONCURSO DE FOTOGRAFIA: UMA ESTRATÉGIA METODOLÓGICA POTENCIALMENTE EFICAZ PARA A CONSTRUÇÃO SIGNIFICATIVA DE CONHECIMENTO

Manuel Bruno Caetano Sanguineto; Ana Paula Freitas da Silva;

José Ayron Lira dos Anjos.

DOI - Capítulo: 10.47538/AC-2020.08-17

CAPÍTULO XVIII .204

CORPORALIDADES: A MEDICALIZAÇÃO DO CORPO E AS PERSPECTIVAS DE AGÊNCIA SOBRE A TRANSEXUALIDADE

Daniel da Silva Stack

DOI - Capítulo: 10.47538/AC-2020.08-18

CAPÍTULO XIX 219

DESAFIOS À ATENÇÃ̃ INTEGRAL EM SAÚDE DA POPULAÇÃO NEGRA: BREVES CONSIDERAÇÕES

Eloyse Valéria da Silva; Anny Luize de Araújo Silva;

Gleyce Karenina França Queiroz de Souza; Fernanda Ellen da Silva Soares.

DOI - Capítulo: 10.47538/AC-2020.08-19

CAPÍTULO XX

ECONOMIA CRIATIVA: INOVAÇÃO, DIVERSIDADE CULTURAL, SUSTENTABILIDADE E INCLUSÃO SOCIAL NA REGIÃO DO VALE DO RIO CUIABÁ

Antônio Ananias mota júnior; Rodrigo Ribeiro de Oliveira;

Raquel Martins Fernandes; Maria Geni Pereira Bilio.

DOI - Capítulo: 10.47538/AC-2020.08-20

CAPÍTULO XXI .238

EDUCAÇÃO AMBIENTAL PARA A DEFESA JURÍDICA DO MEIO AMBIENTE

Ana Flávia Monteiro Diógenes; Leda Mourão da Silva.

DOI - Capítulo: 10.47538/AC-2020.08-21

CAPÍTULO XXII

ELABORAÇÃO DE CERVEJA ARTESANAL COM LÚPULO FRESCO

Bianca de Lima; Lucas Tomazi de Souza; Bruno Telli Ceccato;

Cristhian de Lemos Gabiatti; João Francisco Marchi;

Claudia Eugênia Castro Bravo; Ellen Porto Pinto.

DOI- Capítulo: 10.47538/AC-2020.08-22 


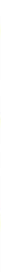

CAPÍTULO XXIII .255

HÁ SEMPRE ALGUÉM MAIS PRISIONEIRO QUE EU: A PESTE DA NEGLIGÊNCIA E A SAÚDE DE REFUGIADOS EM TEMPOS DE PANDEMIA

Lucas Tadeu Gonzaga Diniz; Ana Carolina Guimarães Cerbino;

Amanda Patrícia Vasconcelos Matos; Catarine Wiggers de Campos.

DOI - Capítulo: 10.47538/AC-2020.08-23

CAPÍTULO XXIV .269

MARIELLE FRANCO: SÍMBOLO DE LUTA E RESISTÊNCIA DE UM PASSADO PRESENTE (2018-2020)

Francisca Josileni da Cunha Siqueira; Sylha Suane Camilo Chacon.

DOI - Capítulo: 10.47538/AC-2020.08-24

CAPÍTULO XXV .281

MEIO AMBIENTE E TURISMO: REGULAMENTAÇÕES DE POLÍTICAS PÚBLICAS PARA A PRÁTICA DO ECOTURISMO NO BRASIL

Rodrigo Holmes Dias de Lima; Valdecir da Silva Júnior.

DOI - Capítulo: 10.47538/AC-2020.08-25

CAPÍTULO XXVI 293

O DESABASTECIMENTO DA VACINA PENTAVALENTE NO ANO DE 2019 E SEUS POSSÍVEIS IMPACTOS NO ANO DE 2020: UMA ANÁLISE TEMPORAL

Aline Grandis Guimarães; Daniela Lacerda Santos;

Gustavo Emanuel Martins Ferreira Torres;

Joana Gonzalez Ambrosio Izzo do Amaral.

DOI - Capítulo: 10.47538/AC-2020.08-26

CAPÍTULO XXVII 306

ÓLEOS ESSENCIAIS NO CONTROLE DE Colletotrichum tropicale EM MANGA (Mangifera indica L.)

Lívia Francyne Gomes Chaves; Renata Pereira Lima;

Debora Cristina da Silva; Mayara Oliveira de Lima;

Geórgia de Souza Peixinho; Mayra Machado de Medeiros Ferro;

Maria Helloá Costa de Oliveira; Edna da Rocha Amorim.

DOI - Capítulo: 10.47538/AC-2020.08-27

CAPÍTULO XXVIII .316

ONCOLOGIA, EUTANÁSIA, ORTOTANÁSIA E DISTANÁSIA NO MUNDO: DILEMAS ÉTICOS, LEGAIS E RELIGIOSOS

Andreza Jeronimo Gomes; Gabriel da Silva Santos;

Juliana Rocha Vieira; Karla Zilá de Oliveira Lino;

Maria Denislane Temoteo Ferreira; Vania Paiva Martins;

David Emanuel Eufrásio Nascimento; Liene Ribeiro de Lima.

DOI - Capítulo: 10.47538/AC-2020.08-28 


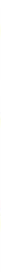

toda faz-se atuante. A realidade cristã não é somente deísta, cristianistica ou espiritualista. Não se nega a efetiva ação trinitária no ceio da comunidade cristã.

A expressão mais evidente da proximidade Trindade está na Liturgia. E em particular nos referimos à relação do Espírito Santo. Este é que atualiza, transforma, santifica e conduz a Igreja na celebração do Mistério. O Paráclito enviado pelo Pai a pedido do Filho, incita os cristãos a viverem a experiência escatológica no "já" da Liturgia pneumatológica. Pois é o Espírito de Deus que torna presente, atual o Reino eterno, implantado por Jesus Cristo, no mundo.

É o Espírito que transforma não apenas às oblatas em Corpo e Sangue de Cristo, como também transubstancia a Igreja em corpo místico do mesmo Cristo cabeça. A Trindade sendo perfeita, ontologicamente, na comunhão entre si (pericorese), a comunidade dos fiéis também é exortada a espelhar-se.

Mas para lidar com esta dimensão pneumática, fundamentamos nossa pesquisa nas reflexões do grande teólogo do século XX, Yves Congar (1904-1995)3. Este é visto como um dos maiores teólogos da eclesiologia cristã, que precede e caminha junto ao Concílio Ec. Vaticano II (1962-1965). Sendo, deste Concílio, precursor e consultor. (Alcançou o cardinalato conferido pelo papa João Paulo II em 1994, mas o usufruiu por pouco tempo, pois veio a óbito um ano depois [1995]).

Além disto, fez a eclesiologia cristã voltar-se para o ecumenismo, na busca da evangelização mais frutuosa. Suas investidas foram pautadas na necessidade de resolver os problemas do século fazendo observações da própria realidade de modo concreto. Possuindo um pensamento assistemático e pouco abstracionista. Sua construção teológica tem raízes na filosofia tomista, em que acreditava ser ela uma chave para abertura à realidade vigente.

No apogeu do Concílio Vaticano II, Congar foi um, dentre tantos, responsável pela redação da Lumen Gentium (LG), Dei Verbum (DV) e da Gaudium et Spes (GS). Passando por momentos difíceis em sua vida, experimentando campos de concentração (Colditz e Lübeck), ainda foi capaz de produz muitas obras, dentre elas a trilogia "Creio no Espírito Santo". E é onde encontramos nossas preliminares para falarmos de uma liturgia pneumatológica. Principalmente o volume terceiro da coleção. Buscamos com isso, vislumbrar a importância de se conhecer a beleza oculta da Liturgia cristã.

\footnotetext{
${ }^{3}$ Cf. MONDIN, Batista. Os Grandes Teólogos do Século XX: teologia contemporânea. São Paulo: Paulus, 2003. p. 587-618.
} 


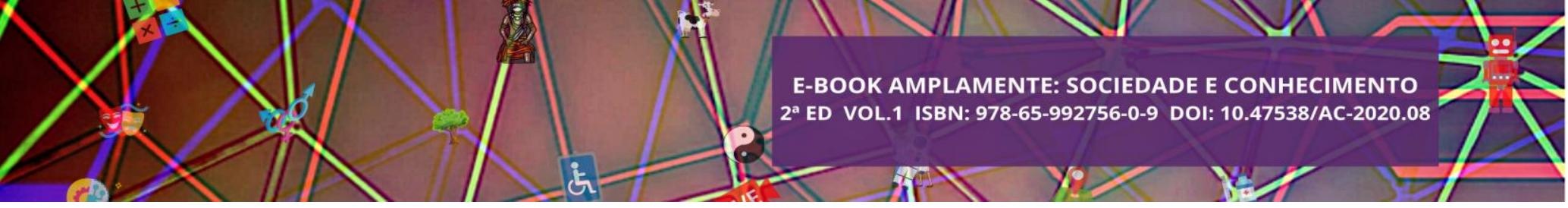

\section{BREVE PANORAMA SOBRE O CONCEITO DE LITURGIA E SEU FUNDAMENTO}

Tendo nossa fé fundamentada no Mistério pascal de Cristo, somos levados a perceber a profundidade da celebração litúrgica do cristianismo católico. Desse modo, as palavras do Cristo Jesus na última ceia4 é de primaz importância na vida da Igreja, antes mesmo de enviar à comunidade de discípulos pelo mundo anunciando a Boa-Nova (BÍBLIA, Mc 16, 15).

E tomou um pão, deu graças, partiu e deu-o a eles, dizendo: "Isto é o meu corpo que é dado por vós. Fazei isto em minha memória" E, depois de comer, fez o mesmo com a taça, dizendo: "Essa taça é a Nova Aliança em meu sangue, que é derramado por vós" 5 .

A mesma concepção celebrativa, ordenada por Jesus, é expressa por Paulo, ao escrever à comunidade de Corinto. Esta encontrava-se em dificuldade para viver, verdadeiramente, a Ceia do Senhor (Kyrios) (BÍBLIA, 1Cor. 11, 17-27). O que ele transmite foi recebido do próprio Cristo, em sua conversão a cominho de Damasco, mas que, do mesmo modo, não nega a importância da Tradição Apostólica. Sendo que, afirmar o recebimento desse relato institucional pelo próprio ressuscitado, é autenticá-lo pela relevância da Tradição.

O fazer de Cristo Jesus, antes de sua morte, é perpetuado pela Igreja primitiva e nos chega no tempo presente. Como houve diversas modificações no modo de celebrar, mantendo as palavras de Jesus do relato institucional, também pode-se dizer que há diversas compreensões sobre as significações do conceito de Liturgia.

Um primeiro sentido é encontrado nos relatos verotestamentários, no livro do Levítico. A "tribo" de Levi é escolhida pelo próprio Deus para exercer os serviços cultuais. É uma casta separada para este objetivo, exclusivamente. Assim, “os levitas foram então admitidos para fazer o seu serviço na Tenda da Reunião, na presença de Aarão e dos seus filhos. Conforme o que Iahweh havia ordenado a Moisés a respeito dos levitas, assim se fez com eles" (BÍBLIA, Nm 8, 22). Todo o capítulo oitavo do livro

\footnotetext{
${ }^{4}$ A partir dos relatos dos sinóticos (Mt, Mc e Lc) e do evangelista João, podemos perceber uma diferenciação redacional, principalmente quanto a intenção deste último. Nos sinóticos podemos dizer que há a celebração da Páscoa, pois o desenvolver dos textos tem por base a dimensão histórica, enquanto que o relato de João considera uma cronologia teológica, ou seja, Jesus morre ao mesmo tempo que o cordeiro dos ritos pascais judaicos. Isto com o objetivo de enfatizar que o próprio Cristo é o novo e verdadeiro Cordeiro expiatório. Para melhor análise, segue indicação bibliográfica: GIRAUDO, Cesare. Num só Corpo: tratado mistagógico sobre a eucaristia. Francisco Taborda (trad.). $2^{a}$ ed. São Paulo: Loyola, 2003. p. 127-143. (Coleção Theologica).

5 Lc 22, 19-21.
} 


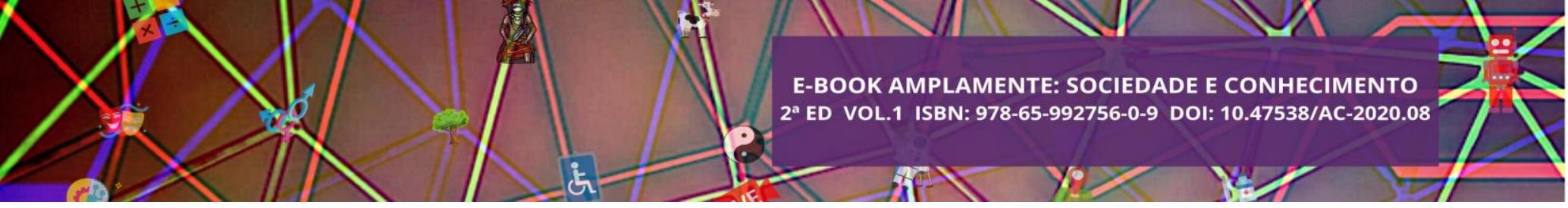

dos Números nos concede esta dimensão primordial dos levitas ao culto ${ }^{6}$.

Na tradução grega do AT chamada dos LXX, 'liturgia' indica sempre, sem exceção, o 'serviço religioso' prestado pelos levitas a Javé, primeiro na 'tenda' e depois no templo de Jerusalém. Era, portanto, termo técnico que designava o culto público e oficial segundo as leis cultuais levíticas, diferente do culto 'privado', ao qual, na mesma tradução dos LXX, os autores se referem principalmente usando os termos 'latria' ou 'dulia'.?

Os Levitas são os primeiros a exercerem atividades sacerdotais no Antigo Testamento, ou seja, representam os primitivos sacerdotes judeus. O culto que incluíam ritos sangrentos (cruentos), sacrifícios de animais, com Jesus Cristo, tudo toma nova dimensão. Os animais sacrificados, no AT, nos relatos neotestamentários, tem sua culminância no Filho de Deus encarnado, que coloca-se como Cordeiro para expiação dos pecados de toda a humanidade, o que antes seria referido somente a alguns. Desta maneira, Scott Hahn (2017) intensifica a importância do Cristo que se coloca como vítima expiatória perfeita: "O sacrifício de Jesus realizou o que todo o sangue de milhões de ovelhas e touros e bodes jamais conseguiu. [...] Nem o sangue de um quarto de milhão de cordeiros salvaria a nação de Israel, muito menos o mundo"»8.

No NT, Jesus Cristo leva a esmo todas as atividades cultuais judaicas. Destarte, “A palavra 'liturgia' [...] [não] é empregada para designar somente a celebração do culto divino, mas também o anúncio do Evangelho e a caridade em ato" ${ }^{9}$. Mediante perfeição celebrativa, em síntese, Cristo é Sacerdote, Profeta e Rei. Incluindo-se, também, como o verdadeiro sacrifício, cuja nação não mais precisa de animais para elevar culto à Deus, pois Ele mesmo se faz próximo em seu Filho encarnado. Com isto, "Ele não precisa, como os Sumos Sacerdotes, oferecer sacrifícios a cada dia, primeiramente por seus pecados, e depois pelos do povo. Ele já o fez uma vez por todas, oferecendo-se a si mesmo" (BÍBLIA, Hb. 7, 27).

O culto instaurado, mesmo não sendo com a terminologia de Liturgia, passa a

6 O livro do Levítico é denominado como sendo o coração do Pentateuco, a Torah. Nesse sentido, o Levítico é evidenciação do povo que tornou-se "posse" de Iahweh. Todas as suas posturas ético-sociais remetem-se a esta pertença a Deus. Dentre toda a dimensão da Aliança, "o culto torna-se, neste sentido, a ocasião e a máxima expressão da relação de comunhão do povo eleito com Deus”. FERNANDES, Leonardo Agostini. A Bíblia e a sua Mensagem: introdução à leitura e ao estudo da Bíblia. Rio de Janeiro: PUC-Rio, 2010. p. 168. A estruturação do livro em questão pauta-se num aspecto legislativo e de narrações históricas. Sendo que as leis elaboradas saem da própria situação sócio-política e religioso-cultural. Vejamos: "Lv 1 - 7: Prescrições sobre os sacrifícios; Lv 8- 10: Investidura dos sacerdotes; Lv 11 - 16: Prescrições a respeito do que é puro ou impuro; Lv 17 - 26: Lei da Santidade; Lv 27: Apêndice ao Condigo da Santidade" (Ibid. p. 94).

7DICIONÁRIO DE LITURGIA. Isabel F. Leal Ferreira (trad.). São Paulo: Paulinas, 1992. p.639. (Dicionários EP).

8 HAHN, Scott. O Banquete do Cordeiro: a missa segundo um convertido. São Paulo: Loyola, 2014. p. 38.

9 CIC, par. 1070. 


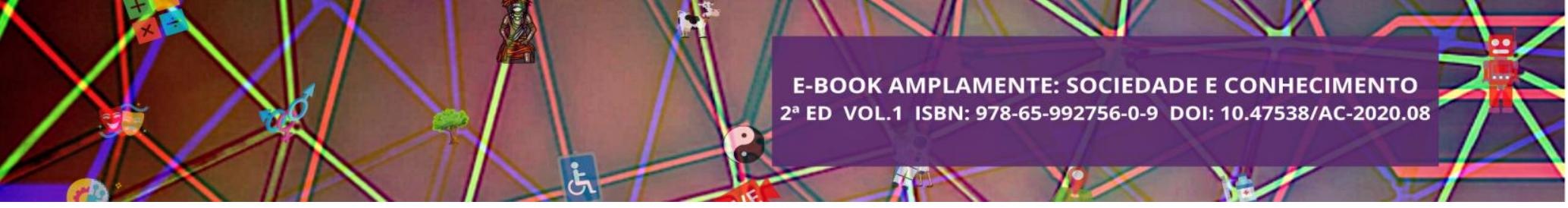

considerar um novíssimo conteúdo. Cristo Jesus é seu fundamento, diferentemente do culto judaico. Contudo, não se exclui a íntima relação originante do Cristianismo ao Judaísmo. Isto se torna evidente pelo fato da última Ceia se realizar em um contexto plenamente judaico. Em particular, a intenção de Jesus não era de repetir àquilo que já era prática na tradição judaica.

A configuração da Ceia de Jesus Cristo com seus discípulos é observada a partir dos elementos que não foram inseridos: pães ázimos, o cordeiro, ervas amargas, e tantos outros. Houve, mediante contexto e sentido, uma nova Ceia dentro da ceia judaica. Uma nova (Liturgia) dentro da tradicional liturgia judaica. Há uma continuidade na descontinuidade litúrgico-religiosa entre cristianismo e judaísmo.

Um conhecimento mais aprimorado da fé e da vida religiosa do povo judaico, tais como são professadas e vividas ainda hoje, pode ajudar a compreender melhor certos aspectos da liturgia cristã. Para os judeus e para os cristãos, a Sagrada Escritura é uma parte essencial de suas liturgias: para a proclamação da Palavra de Deus, a resposta a esta palavra, a oração de louvor e de intercessão pelos vivos e pelos mortos, o recurso à misericórdia divina. A Liturgia da palavra, em sua estrutura própria, tem sua origem na oração judaica. A Oração das horas, bem como outros textos e formulários litúrgicos, tem seus paralelos na oração judaica, o mesmo acontecendo com as próprias fórmulas de nossas orações mais veneráveis, entre elas o Pai-Nosso. Também as orações eucarísticas inspiram-se em modelos da tradição judaica. As relações entre liturgia judaica e liturgia cristã - mas também a diferença de seus conteúdos - são particularmente visíveis nas grandes festas do ano litúrgico, como a Páscoa. Cristãos e judeus celebram a Páscoa; Páscoa da história, orientada para o futuro, entre os judeus; Pascoa realizada na morte e na Ressurreição de Cristo, entre os cristãos, ainda que sempre à espera da consumação definitiva ${ }^{10}$.

No decorrer da história, é perceptível as transformações das celebrações impulsionadas pela Ceia do Senhor. Fundamentando-se na ideia de que, a liturgia cristã "liberta-se do solo materno judaico em que Jesus o havia transmitido" "11. Além de não possuir uma intenção de permanência com a mesma estrutura da época.

Como se observa, não só o exercício, como o termo Liturgia passa por progressos. Ele aparece em escritos extrabíblicos, dentre eles, a Didaqué, a princípio. A Didaqué refere a dignidade de se celebrar a Ceia aos domingos e em comunidade. Ademais, o conceito aparece, frequentemente, em seu uso científico; ou seja, nas

10 CIC, par. 1096

11 ASSUNÇÃO, Rudy Albino de. O Sacrifício da Palavra: a liturgia da Missa segundo Bento XVI. São Paulo: Ecclesiae, 2016. p. 67. 


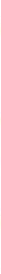

pesquisas acadêmicas. De modo especial, na construção de livros de cerimonias e ritos para determinadas circunstâncias cultuais. Liturgia, em tempos antigos, era considerada mais em um viés legislativo. Além disto, era aplicada para referir-se às diversas famílias litúrgicas.

Infelizmente, este legítimo uso do termo, que permitia falar de 'liturgia' oriental, ocidental, latina, galicana, hispânica, ambrosiana, etc. e queria indicar os diversos modos em que o culto cristão se via expresso ao longo dos séculos nas diversas igrejas, foi mal entendido por alguns e se criou a equivalência "liturgia = ritualidade cerimonial e rubrical" $" 12$.

Nesse interim, a significação litúrgica, sem negar o que já havia construído ao longo dos anos, sendo ela mais eficiente para nós, e próxima, encontra-se na primeira Constituição, a Sacrosanctum Concilium (SC), do Concílio Ecumênico Vaticano II $(1962-1965)^{13}$. Ela exprime de modo eficiente o caráter profundo e sobrenatural de toda celebração litúrgica. Demonstrando, assim, o Cristo sempre presente na Igreja e em suas ações. Cristo não está somente nas espécies eucaristizadas, pão e vinho, como exprimiu o concílio de Trento (1545-1563), mas encontra-se presente em todos os envolvidos na Liturgia (cf. SC, $\left.\mathrm{n}^{\circ} 7\right)$.

Por antonomásia, ela é continuação da ação salvífica de Deus no mundo, em seu Filho Jesus, por intermédio da Igreja. A Liturgia é manifestação exterior e visível do que é invisível. Nela se experimenta continuamente o Mistério pascal de Cristo ${ }^{14}$, compreendido como sendo sua vida, morte e ressurreição.

A Liturgia, como se sabe, é o fazer memória (anámneses ${ }^{15}$ ), é atualização de todo o Mistério salvífico de Cristo para com os homens. É anamnese do Pai para os filhos; de Jesus Cristo para Deus; e também é anamnese do Espírito Santo, pois sempre está a nos recordar os "fatos salvífico" $"$. Tudo realizando-se "[...] [no] rito litúrgico [que] traz na sua materialidade o significado e o poder do Verbo de Deus. [...] A liturgia é a modalidade particular do culto $[\ldots]^{\prime 17}$. E é nesta celebração ritual que se faz a memória eclesial.

A Igreja é continuadora da obra redentora de Jesus Cristo na humanidade. O

12 DICIONÁRIO DE LITURGIA. Isabel F. Leal Ferreira (trad.). São Paulo: Paulinas, 1992. p.639. (Dicionários EP). 13 LÓPEZ MARTIN, Julián. No Espírito e na Verdade: introdução teológica à liturgia. Rio de Janeiro: Vozes, 1996. v. I. p. 324-326. 14 ASSUNÇÃO, 2016, p. 48-49.

15 CIC, par. 1103.

16 LÓPEZ MARTIN, 1996, p. 195.

17 Cf. DICIONÁRIO DE LITURGIA. Isabel F. Leal Ferreira (trad.). São Paulo: Paulinas, 1992.p.645. (Dicionários $\mathrm{EP})$. 


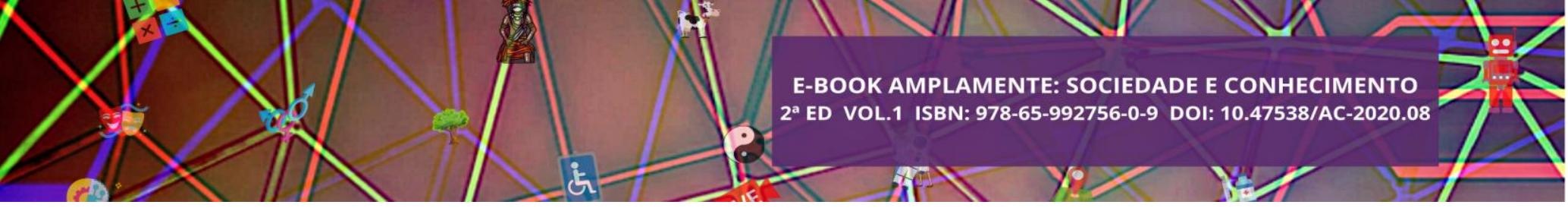

Verbo encarnado concede à sua Igreja "[...] a plenitude do culto divino" (cf. SC, no 5). Assim, o simbolismo ${ }^{18}$ tem, por objetivo, evidenciar o que se pretende realizar. E é por meio dos símbolos que Deus efetua o seu Reinado na comunidade dos fiéis. Na ação litúrgica, Jesus Cristo santifica todos os homens, pois Ele mesmo é o Santo por excelência. E por isso se diz que é o Cristo, em si e com seus membros (Igreja/Povo) "Christus totus”, a realizar o rito a celebrar ${ }^{19}$.

A Liturgia é ação de Deus, em Jesus Cristo, unido a seu rebanho, a Igreja. Desse modo, “a palavra 'liturgia' significa originalmente 'obra pública', 'serviço da parte do povo e em favor do povo" 20 - é dele para ele mesmo. Assim, é prática de unidade pertencente aos batizados nela inseridos. Ademais, como a criação-encarnação-morteressureição-ascensão são fatos realizados pela Trindade, da mesma forma se declara sobre a Liturgia. Esta tem atuante, em si, as três Pessoas da Trindade. Àquele que concede os dons aos neófitos $^{21}$, é o mesmo que santifica a Igreja, de modo especial, na ação litúrgica.

É o tu de Deus, o $e u$ de Cristo e o nós da Igreja colocados em união por meio do Espírito Santo. Por isto que todas as orações da Igreja são dirigidas a Deus, no Filho, pelo poder do Espírito. E como se professa no Símbolo da fé (creio). Como a criação, no Mistério pascal, é levada ao renascimento, consequentemente, na Liturgia a criação é recriada pela presença do Espírito santificador (cf. Jo 16, 4-15). A comunidade apostólica recebe do Kyrios o Espírito (Bíblia, Jo 20,21) ${ }^{22}$ que os conduzirá sempre, por toda parte, e os defenderá até a consumação dos tempos. Por consequência, o acontecimento mais sublime encontra-se em Pentecostes. Os discípulos, com Maria, recebem o Paráclito como línguas de fogo (Bíblia, At 2, 1-4).

O Espírito Santo não deixa a comunidade cristã se esquecer do Mistério pascal, além de conceder os dons necessários para à missão e conferir-lhe a capacidade de

18 Cf. CIC, par. 1145-1152.

19 Cf. CIC, par. 1136-1144.

20 CIC, par. 1069.

21 Karl Rahner (1904-1984), em sua conferência sobre a não extinção do Espírito de 1962, profetiza sobre a importância que se deve conceder a ação do espirito Santo. O mesmo não tem poder de agir somente na hierarquia da Igreja, mas sonda todos os lugares da Igreja. Segundo Rahner, o Espírito é capaz de falar e agir por meio dos fiéis. Nesse sentido, os que constituem o corpo eclesial precisam ser valorizados mediante dignidade pneumática. Mas mesmo que não elimine o Espírito Santo, o homem (Igreja) é capaz de "[...] sufocar o Espírito que sempre quer renovar a face da terra. Podemos matar a vida de Deus no mundo, tornar ateus, vazios e absurdos os espaços da existência”. RAHNER, Karl. Não Extingais o Espírito. Alfred Josef Keller (trad.). São Paulo: Loyola, 2018. p. 21. (Coleção Leituras Teológicas).

${ }^{22}$ ASSUNÇÃO, 2016, p. 49-51. 


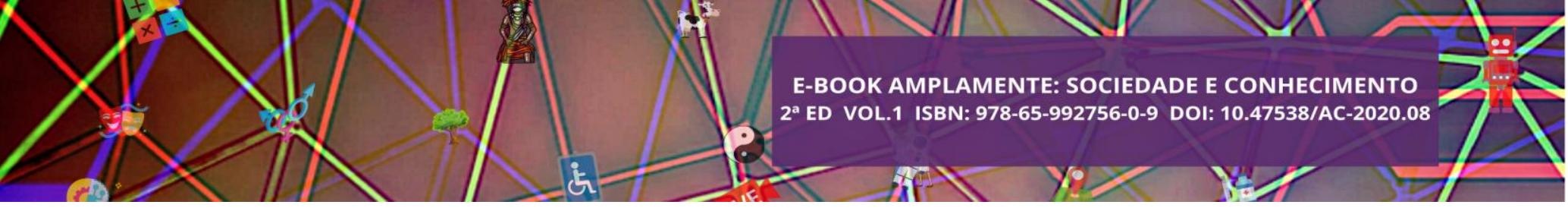

abertura ao Mistério que se propõe celebrar ${ }^{23}$. A fé em Cristo é proveniente da ação do Espírito, ou seja, "a graça do Espírito Santo procura despertar a fé, a conversão do coração e a adesão à vontade do Pai" (CIC, par.1098). Tudo o que d'Ele se origina precisa ser exercido no poder do mesmo.

Em suma podemos dizer que,

A obra de Cristo na liturgia é sacramental porque seu mistério de salvação se torna presente nela mediante o poder do Espírito Santo; porque seu corpo, que é a Igreja, é como que o sacramento (sinal e instrumento) no qual o Espírito Santo dispensa o mistério da salvação; porque por meio de suas ações litúrgicas a Igreja peregrina já participa, por antecipação, da liturgia celeste. A missão do Espírito Santo na liturgia da Igreja é preparar a assembleia para encontrar-se com Cristo; recordar e manifestar Cristo à fé da assembleia; tornar presente e atualizar a obra salvífica de Cristo por seu poder transformador e fazer frutificar o dom da comunhão na Igreja ${ }^{24}$.

De fato, o Espírito Santo leva a perfeita comunhão àqueles que, desde já, comungam das "coisas" sagradas dispensadas pela Igreja - comunhão dos santos nas coisas santas. A Liturgia é obra de Cristo, tendo a si mesmo como conteúdo, "realizada por meio do Espírito Santo" 25 . É contundente dizer que, a base teológica da Liturgia a partir das pesquisas, precedentes ao Concílio Vaticano II, de Cipriano Vagaggini (19091999), em sua essência, pauta-se na História da Salvação. É a vivência plena, atual da obra de nossa redenção.

\section{ESTRUTURA DA LITURGIA ROMANA}

A celebração litúrgica possui uma estrutura fixa e outra móvel, ou seja, que pode ser adaptada segundo costumes e tradições. Mas desde que não denigra o seu verdadeiro sentido. Esta constitui-se de duas grandes partes: liturgia da Palavra e Eucaristia. E estas subdivididas em pequenas partes. Sendo que a primeira grande parte tem por objetivo culminar-se na segunda.

A) Liturgia da Palavra

1) Entrada;

2) (Sinal da Cruz)

3) Saudação;

\footnotetext{
${ }^{23}$ Cf. VAGAGGINI, Cipriano. O Sentido Teológico da Liturgia. São Paulo: Loyola, 2009. p.197-199.

${ }^{24}$ CIC, par. 1111-1112.

${ }^{25}$ ASSUNÇÃO, 2016, p. 49.
} 


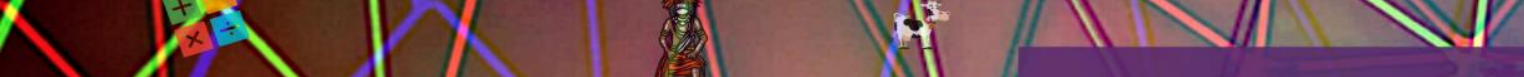

4) Ato Penitencial;

5) Hino de Louvor;

6) Oração da Coleta.

7) Leituras;

8) Profissão de Fé;

9) Preces da Comunidade.

B) Liturgia Eucarística

1) Preparação das oferendas;

2) Oração Eucarística (anáfora)

i. Ritos finais

Dentro do conjunto da celebração Eucarística há a anáfora escolhida pelo presidente da celebração, ou proposta pelo Magistério/Conferência episcopal, cuja atuação é "in persona Christi”, possuindo também uma estrutura estabelecida, que não se altera - que pode ser encontrada em todas as anáforas da Liturgia romana. Esta é de caráter epiclético.

Prefácio;

1. Santo;

2. (Pós-Santo);

3. Epiclese sobre os dons (oferendas);

4. Relato Institucional;

5. Anamnese (que é a própria oferenda);

6. Epiclese sobre os comungantes (sobre os fiéis);

7. Intercessões;

8. Doxologia.

Não existe somente anáforas romanas. Além desta há diversas orações. As de teor Anamnético: anáfora de constituição Apostólica; da Tradição Apostólica; a de São Thiago; de São Basílio; São João Crisóstomo; anáfora da tradição hispânica; anáfora da Igreja ambrosiana. De cunho epiclético: anáfora dos apóstolos Addai e Mari; de Serapião; de São Marcos; e as anáforas romanas ${ }^{26}$.

Por que separamos as orações eucarísticas em anamnética e epiclética? Isto se configura pelo fato de haver, antes do relato institucional, a apresentação da secção

\footnotetext{
${ }^{26}$ Cf. GIRAUDO, Cesare. Num só Corpo: tratado mistagógico sobre a eucaristia. Francisco Taborda (trad.). $2^{\mathrm{a}}$ ed.
} São Paulo: Loyola, 2003. p. 255-412. (Coleção Theologica). 


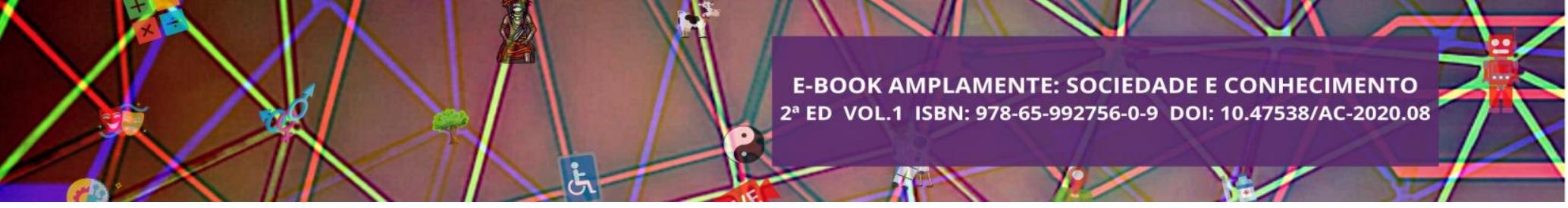

anamnética ou epiclética. Ou seja, "conforme a posição em que se é enxertado, o embolismo eucarístico confere à anáfora uma dinâmica oracional de tipo anamnético ou de tipo epiclético"27. E compreendendo o embolismo como sendo a intensificação escriturística em vista do pedido a realizar.

\section{A DIMENSÃO EPICLÉTICA DAS ANÁFORAS E SEU SENTIDO TEOLÓGICO- SACRAMENTAL}

$\mathrm{Na}$ história da Liturgia, tendo por objetivo a busca por sua definição e estruturação, houve àqueles que acreditavam no dinamismo epiclético ocorrendo antes do relato institucional, outros após; e outros, ainda, tinham a convicção de que o Espírito Santo encontrava-se atuante dentro do próprio relato institucional. Caso este prescrito nas liturgias orientais.

Ademais, um dos grandes desafios litúrgicos estavam na definição exata da transubstanciação. Contudo, mediante estudos, concluiu-se que toda a oração ${ }^{28}$ eucarística é importante para com as espécies que serão eucaristizadas (Quam oblationem). Mas de modo peculiar, a invocação sobre os dons, pão e vinho, para se transubstanciarem em Corpo e Sangue de Cristo $^{29}$, é preciso antes das palavras da instituição, onde o Sacerdote, "nomine Christi”, suplica a presença do Espírito Santo com as palavras: "Na verdade, ó Pai, vós sois santo e fonte de toda santidade. Santificai, pois, estas oferendas, derramando sobre elas o vosso Espírito, a fim de que se tornem para nós o Corpo e Sangue de Nosso Senhor Jesus Cristo, o vosso Filho e Senhor nosso "30. Por Deus ser Santo, numa dinâmica embolística, o súplica para enviar o Espírito Santificador. Nesse sentido,

\footnotetext{
${ }^{27}$ GIRAUDO, 2013, p. 251.

${ }^{28}$ Sobre o conceito Oração, Yves Congar nos mostra que a mesma encontra-se na ordem do amor, na ordem de Deus; e em um segundo momento, a Oração está ligada ao nível de pedintes, ao apenas satisfazer os desejos por parte daquele que pede. CONGAR, Yves. "Ele é o Senhor e dá a Vida". $2^{\mathrm{a}}$ ed. São Paulo: Paulinas, 2010. v. II. p.161. (Coleção Creio no Espírito Santo, nº 2).

${ }^{29}$ BENTO XVI, Papa. Sacramentum Caritatis. Exortação pós-sinodal. São Paulo: Paulinas,2007. p.20-21.

${ }^{30}$ Trecho da oração eucarística segunda. Em todas as orações eucarísticas, mesmo modificando alguns termos iniciais, sempre haverá uma implicação de pedido a Deus para que envie o Espírito Santo, para transformar as oblatas em Corpo e Sangue de Cristo, cuja memória Ele mesmo ordenou à comunidade de discípulos. Somente o Cânon Romano (Oração eucarística I) que não segue a mesma linha oracional. A mesma se dirige a Deus por Jesus Cristo, Filho D'ele para santificar e abençoar as oferendas apresentadas no Altar do Sacrifício. Ademias, analisamos: "Pai de misericórdia, a quem sobre os nossos louvores, nós vos pedimos por Jesus Cristo, vosso Filho e Senhor nosso, que abençoeis + estas oferendas apresentadas em vosso altar". MISSAL ROMANO. 10 ed. São Paulo: Paulus, 2006. p.469. Também confirmamos esta diferença oracional, em relação as demais, no desenvolver do Cânon Romano: "Dignai-vos ó Pai, aceitar e santificar estas oferendas, a fim de que se tornem, para nós o Corpo e o Sangue de Jesus Cristo, vosso Filho e Senhor nosso". MISSAL ROMANO. 10a ed. São Paulo: Paulus, 2006.p.472. Segundo o doutorando em sacramentologia (Eucaristia), padre César Tiago, "O Cânon Romano falta a dimensão pneumatológica. A presença do Espírito Santo na liturgia foi uma insistência dos Padres do oriente no Concílio
} 


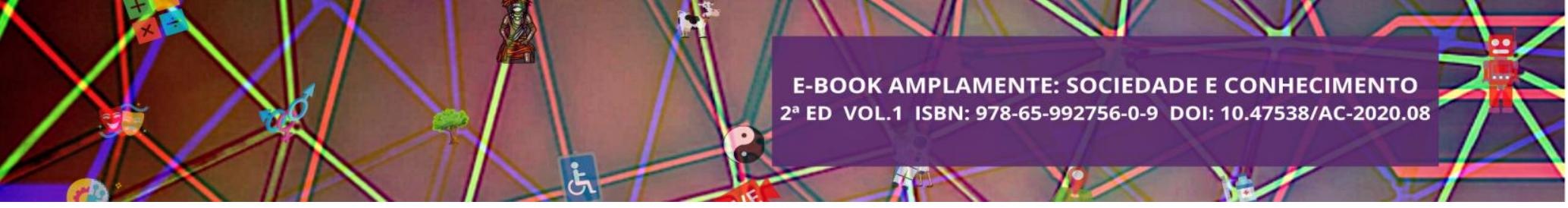

A epiclese ("invocação sobre") é a intercessão na qual o sacerdote suplica ao Pai que envie o Espírito Santificador para que as oferendas se tornem o Corpo e o Sangue de Cristo, e para que ao recebê-los os fiéis se tornem eles mesmos uma oferenda viva a Deus. [...] A epiclese é também a oração para o efeito pleno da comunhão da assembleia com o mistério de Cristo. A Igreja pede, pois, ao Pai que envie o Espírito Santo para que faça da vida dos fiéis uma oferenda viva a Deus por meio da transformação espiritual à imagem de Cristo $[\ldots]^{31}$.

Do modo, é o que Cirilo de Jerusalém destaca, ao se referir a epiclese na celebração eucarística, em sua quinta catequese mistagógica: "Depois de santificados por esses hinos, suplicamos ao Deus benigno que envie o Espírito Santo sobre os dons colocados, para fazer do pão corpo de Cristo e do vinho sangue de Cristo. Pois tudo o que o Espírito Santo toca é santificado e transformado" ${ }^{32}$. Mas tal feito não somente é aplicado às oblatas, mas também é, como mencionado, referido à comunidade cristã celebrante.

A epiclese sobre os comungantes tem por finalidade fazê-los plenamente corpo místico de Cristo, ou seja, Àquilo mesmo que estão participando e recebendo na celebração. O Sacerdote, em nome da comunidade, pede a Deus: “E nós vos suplicamos que, participando do Corpo e Sangue de Cristo, sejamos reunidos pelo Espírito Santo num só corpo",33.

Numerosas epicleses pedem que o Espírito Santo realize não somente a consagração dos dons no corpo e sangue de Cristo, não só a santificação dos mesmos, mas também produza no fiel os frutos da comunhão. [Comumente, a comunhão espiritual gera um efeito idêntico ao propriamente sacramental, em espécies]. [...] a manducação espiritual que, normalmente, supõe a sacramental, tem uma tal força que pode atingir o efeito do sacramento sem que se tenha recebido o sacramento ${ }^{34}$.

Diante da grandeza de conteúdo dos textos litúrgicos, percebe-se que a linguagem é revestida de um sentido pneumático; que reforça a peculiar necessidade de se fazer real a atuação do Paráclito. Determinados termos utilizados na celebração litúrgica intensifica seu caráter. "Podemos, entretanto, citar termos peneumatológicos como: efundir, infundir, enviar, santificar, consagrar, receber, assumir, cumular,

[Ecumênico] Vaticano II. Por isso as outras orações sempre menciona[m] [Ele]. Lembrando que o Cânon Romano era a única OE presente no missal de Pio V". Mesmo assim, acredita-se que, o uso do termo santificar leva a expressar, indiretamente, o anseio de se obter a presença do Espírito Santo na transubstanciação das oblatas, apesar de não conter um dinamismo pneumático como as demais Anáforas (Rudy Assunção).

31 CIC, par. 1105; 1109; 1353.

32 JERUSALÉM, São Cirilo de. Catequeses Mistagógicas. 2a ed. Rio de Janeiro: Vozes, 2004.p.48-49.

33 MISSAL ROMANO. $10^{a}$ ed. São Paulo: Paulus, 2006. p.480. Parte da oração eucarística II.

34 CONGAR, Yves. O Rio da Vida Corre no Oriente e no Ocidente. São Paulo: Paulinas, 2005. v. III. p. 341-345. (Coleção Creio no Espírito Santo, nº 3). 


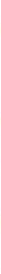

realizar, completar, perseverar, dirigir, confirmar, acender, refulgir, etc."35. Não apenas os verbos de significância pneumática, como também há, junto a eles, expressões corporais que contribuem para a evidenciação do Espírito na Liturgia: imposição das mãos; a "inspiração" sobre alguém ou algum objeto.

Além disso, a disposição de cada pessoa para acolher o mistério celebrado na própria vida é de suma importância. A atuação do $H U A H$, o sopro divino, se concretiza na abertura contínua da Igreja. E a partir disto que, “[...] toda ação litúrgica autêntica é epiclese do Espírito, epifania do Espírito, sacramento do Espírito"36. Acredita-se que, na celebração eucarística, encontra-se um contínuo Pentecostes, sobre o Cristo na Eucaristia e sobre a comunidade dos fiéis ${ }^{37}$.

O sacramento eucarístico é, segundo Agostinho (354-430), ação perfeita do Espírito Santo. O sacramentário gregoriano também afirma: "hóstia que é por muitos oferecida e se torna um só corpo de Cristo pela efusão do Espírito Santo"38. Mesmo com o uso de terminologias, a efetivação da consagração é por força do Espírito Santo (S. Pedro Damião). Santo Tomás (1225-1274), apesar da tendência em determinar o sentido exato da transubstanciação, chega a declarar que Cristo realiza seu Mistério na Igreja, na Liturgia, por meio do Espírito. Por meio deste, Cristo se faz presença.

Em suma, "a vida da Igreja é toda ela epiclética" 39 na vivência dos sacramentos. Como pontua Julián López (1945), há uma “epiclese permanente” na Igreja, em sua Liturgia. E não só o Espírito age, toda a Trindade é invocada quando se pronuncia invocações a uma das três Pessoas. Neste caso o Pneuma. "O momento-cume da epiclese permanente é a invocação solene e sacerdotal da oração eucarística ou das demais orações sacramentais, mas a celebração está marcada e impregnada de epiclese, tanto quanto anamnese" ${ }^{40}$. Sem mais delongas, Yves Congar ao citar o padre JeanClaude Sagne, intensifica a importância da nossa relação com o Espírito de Deus, "pois a função do Espírito é tanto ser o desejo de Deus em Deus quanto o desejo de Deus em nós"41. É Deus sendo tudo em todos no Espírito (Bíblia, 1 Cor. 15, 28).

\footnotetext{
${ }^{35}$ DICIONÁRIO DE LITURGIA. Isabel F. Leal Ferreira (trad.). São Paulo: Paulinas, 1992.p.365. (Dicionários EP).

${ }^{36}$ DICIONÁRIO DE LITURGIA. Isabel F. Leal Ferreira (trad.). São Paulo: Paulinas, 1992. p.367. (Dicionários EP).

${ }^{37}$ Cf. CONGAR, 2005, p.325-326.

${ }^{38}$ CONGAR, 2005, p. 332.

${ }^{39}$ Cf. CONGAR, 2005, p. 353-362.

${ }^{40}$ LÓPEZ MARTIN, 1996, p.196.

${ }^{41}$ CONGAR, 2010, p.161.
} 


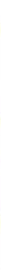

\section{APRECIAÇÃO FINAL}

O que poderemos abstrair de tudo aquilo que foi exposto até o presente momento? O que fica mais evidente na vida comunitária cristã? Quais são os desafios de se viver, de fato, uma Liturgia pneumática? A Trindade é sentida na experiência cristã? As celebrações litúrgicas são experimentadas como sendo pneumáticas, plenificada pela intimidade trinitária?

Não extinguir o Espírito, como quis K. Rahner, é passo fundamental para uma verdadeira experiência com o salvador do mundo. Estamos em um período em que o papel do Espírito Santo na vida da Igreja é de máxima importância. Ele nos concede a presença de Deus e de seu Filho. É Ele quem nos capacita para lidar com as diversas circunstâncias da existência, especialmente no encontro com o Senhor. Ele nos abre à graça da eternidade.

O Pneuma torna a Igreja, cada vez mais, capaz de atualizar o Mistério pascal de Cristo, fazendo com que seja presença eficaz na comunidade dos fiéis. Ele é o pedagogo por excelência de todo àquele que se abre a sua manifestação. Como exprime o apostolo dos gentios: "Não sabeis que sois templo de Deus e que o Espírito de Deus habita em vós?" (Bíblia, 1 Cor. 3,16).

O Espírito Santo nos concede a vida de Cristo fazendo-nos um com Ele (Jesus Cristo). Somos, assim, filhos no Filho, pelo poder do Espírito. Este sempre esteve atuante na história humana. Toda a criação e redenção se perfez e continua a realizar-se na ação trinitária. Caso contrário cairíamos na heresia modalista.

Destarte, os crentes rezam a partir do artigo de Fé: Crê-se no Pai, no Filho, e no Espírito Santo. Pois é Ele mesmo na criação, na encarnação e na santificação do povo eleito - hoje, corpo místico de Cristo. E toda esta síntese se vivência na Liturgia. Com isso, "O Espírito e a Igreja cooperam para manifestar o Cristo e sua obra de salvação na liturgia" (CIC, par. 1099). Além do mesmo Espírito ser "a memória viva da Igreja" (Ibid.). Isto para não ser esquecida e não esquecer do seu próprio fundador. Este age nas entrelinhas da vida humana no poder do Santo Espírito.

\section{REFERÊNCIAS}

\section{Obra primária:}




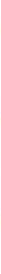

CONGAR, Yves. O Rio da Vida Corre no Oriente e no Ocidente. São Paulo: Paulinas, 2005. v. III. p.301-362. (Coleção Creio no Espírito Santo, nº 3).

\section{Obras secundárias:}

ASSUNÇÃO, Rudy Albino de. O Sacrifício da Palavra: a liturgia da Missa segundo Bento XVI. São Paulo: Ecclesiae, 2016.

BENTO XVI, Papa. Sacramentum Caritatis. Exortação pós-sinodal. São Paulo: Paulinas, 2007.

BÍBLIA DE JERUSALÉM. São Paulo: Paulus, 2016.

CATECISMO DA IGREJA CATÓLICA. São Paulo: Loyola, 2000.

COMPÊNDIO DO CONCÍLIO VATICANO II: constituições, decretos e declarações. $30^{\text {a }}$ ed. Rio de Janeiro: Vozes, 1969. p. 257-306.

CONGAR, Yves. "Ele é o Senhor e dá a Vida”. 2a ed. São Paulo: Paulinas, 2010. v. II. p.153-162. (Coleção Creio no Espírito Santo, nº 2).

CONGAR, Yves. Revelação e Experiência do Espírito. 2a ed. São Paulo: Paulinas, 2009. v. I. p.139-152. (Coleção Creio no Espírito Santo, no 1).

DICIONÁRIO DE LITURGIA. Isabel F. Leal Ferreira (trad.). São Paulo: Paulinas, 1992. (Dicionários EP).

FERNANDES, Leonardo Agostini. A Bíblia e a sua Mensagem: introdução à leitura e ao estudo da Bíblia. Rio de Janeiro: PUC-Rio, 2010.

GIRAUDO, Cesare. Num só Corpo: tratado mistagógico sobre a eucaristia. Francisco Taborda (trad.). $2^{a}$ ed. São Paulo: Loyola, 2003. (Coleção Theologica).

HAHN, Scott. O Banquete do Cordeiro: a missa segundo um convertido. São Paulo: Loyola, 2014.

JERUSALÉM, São Cirilo de. Catequeses Mistagógicas. $2^{\mathrm{a}}$ ed. Rio de Janeiro: Vozes, 2004.

LÓPEZ MARTIN, Julián. No Espírito e na Verdade: introdução teológica à liturgia. Rio de Janeiro: Vozes, 1996. v. I.

MISSAL ROMANO. 10ª ed. São Paulo: Paulus, 2006.

MONDIN, Batista. Os Grandes Teólogos do Século XX: teologia contemporânea. São Paulo: Paulus, 2003. p. 587-618.

RAHNER, Karl. Curso Fundamental da Fé: introdução ao conceito de cristianismo. São Paulo: Paulus, 2015. p.165-170. (Coleção Teologia Sistemática). 


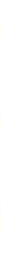

RAHNER, Karl. Não Extingais o Espírito. Alfred Josef Keller (trad.). São Paulo: Loyola, 2018. (Coleção Leituras Teológicas).

SILVA, Michel Pagassi. Entrarei no Altar de Deus: cerimonial da sagrada liturgia no rito romano. $2^{\mathrm{a}}$ ed. São Paulo: Cultor de Livros, 2014. v. I.

VAGAGGINI, Cipriano. O Sentido Teológico da Liturgia. São Paulo: Loyola, 2009. 


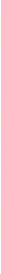

Com o avançar dos anos, essa figura passou de um mero representante de atletas que discutia e celebrava contratos trabalhistas com clubes para um gestor de carreiras de jogadores. Atualmente, os empresários de futebol possuem diversas funções em se tratando da carreira de jogadores, como: a negociação de direitos de imagem, a busca por patrocínios e publicidades, gestão de ativos patrimoniais, além de realocação em clubes, entre outros (BOEHL, 2018). Essas atribuições foram surgindo e sendo incorporadas de acordo com as demandas dos mercados, aos poucos os empresários de futebol foram assumindo encargos o que de certo jeito determinou uma ressignificação de seus papeis junto ao cenário futebolístico.

Posto isso, o objetivo deste artigo, oriundo de uma pesquisa maior que visa compreender o cenário vivido pelos empresários no âmbito do futebol, consiste em historicizar a evolução desse papel. Despontar como e quais foram os motivos que forçaram suas transformações. Desse modo, se faz instrumental para compreensão desses fenômenos, no que tange seus aspectos administrativos e econômicos, a utilização de contextualidades do universo do esporte. A metodologia empregada fora baseada em evidências documentais. Embora, fique evidente que haja interlocuções de campo em nossa narrativa, para este não utilizaremos diretamente.

\section{O TERMO NATIVO: EMPRESÁRIO}

Antes de seguirmos em frente, precisamos deixar claro o porquê de não utilizarmos nesta pesquisa o vocábulo "intermediário" e sim "empresário" ou "empresário de futebol". A escolha não estaria tão somente baseada em estética literária, mas em um compromisso com a arena a qual nos operamos. Desde o surgimento da referida carreira, algumas nomenclaturas foram adotadas para designar a função. Dentre as identificações temos: "agentes desportivos", "agentes FIFA", "agentes", "procuradores", "empresários", "intermediários agente", "mediador", "representante", "mandatário", "manager", "prestador de serviço" (EZABELLA, 2009). Cabe ressaltar que dentre essas, algumas foram imposições da Federação Internacional de Futebol (FIFA) e não uma categoria êmica. A definição vigente, imposta pela FIFA e compactuada pela Confederação Brasileira de Futebol (CBF) é "intermediário".

Durante as nossas investigações de campo, essa arbitrariedade se mostrou pouco eficiente, e os vocábulos "empresário" ou "empresário de futebol" se apresentaram 


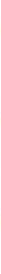

muito mais expressivas, mais vulgares, para não se dizer absolutas, pois mesmo que, em raras situações, o verbete "agente" tenha emergido. Embora tenha sido de certo modo uma determinação da FIFA às suas afiliadas a utilização do termo "intermediário", pouco observamos o seu uso efetivo entre os nossos interlocutores nos espaços de trânsitos futebolísticos. No campo, ficou evidenciado que a designação da FIFA e da CBF não obteve a eficácia desejada, pois, nem os empresários, nem os familiares, nem os dirigentes e muito menos os jogadores tinham por hábito assim se referirem. Derradeiramente, não encontramos de fato o vocábulo "intermediário" circulando desenvolto entre os agentes do campo. O termo que suponhamos então que seja razoavelmente o nativo seria "empresário", sem a devida complementação "de futebol". Todavia, para efeitos de harmonia acadêmica, assumiremos ora um ora outro.

\section{O DESENVOLVIMENTO DA PROFISSÃO}

Até meados da década de 1920, os contratos profissionais dos jogadores eram estabelecidos entre clubes e jogadores de futebol, cabendo somente aos clubes a definição das cláusulas e dos valores contratuais. Nessa relação de iniquidade, a vontade e a força do jogador não tinham poder, restando ao atleta a assinatura do documento ou ficar sem exercer a sua profissão.

No entanto, em 1925, nos Estados Unidos, esse formato de disparidade começou a ser desfeito, quando o agente Charles "Cash and Carry" Pyle, com sua expertise de business em outras áreas, veio a interferir no processo, com o escopo de contrabalançar as relações laborais. C. C. Pyle realizou a primeira a negociação de um contrato de trabalho, entre o jogador de futebol americano Harold "Red" Grange e o Chicago Bears (EZABELLA, 2009). O empresário conseguiu barganhar a remuneração do seu cliente, elevando-a para três mil dólares por partida (MARQUES, 2017). Foi, então, com base nesse episódio e outros que desse decorreram, que se materializou uma nova relação comercial: a tríade jogador-empresário-clube de futebol (NEQUESAURT, 2007).

O acréscimo progressivo de empresários de futebol, sucedidos de diferentes arenas profissionais, não fora bem digeridos pelos mandatários que temiam a redução de poder sobre os atletas no instante de suas contratações (MARQUES, 2017). A relação de poder que beneficiava os clubes, à medida que ao atleta restava somente o aceite ou não dos termos contratuais nas condições ofertadas, inexoravelmente deixavam de 


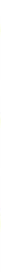

existir. Ademais, não fora somente a diminuição de força dos clubes, os atletas foram sendo aos poucos empoderados, aumentando sua capacidade de barganha, que porventura possibilitaram exigências de cláusulas contratuais e de valores.

A ampliação em números de empresários aconteceu nomeadamente a partir dos anos setenta (EZABELLA, 2009; COUTINHO FILHO, 2016). Foi nesse momento que a justiça estadunidense, após inúmeros casos de reclamações trabalhistas por parte de atletas, que reivindicavam o direito ao livre trabalho, determinou como inconstitucional a aplicação das denominadas "cláusulas de reserva" ${ }^{47}$ nos contratos dos esportistas (EZABELLA, 2009). As cláusulas de reserva eram artimanhas utilizadas pelos clubes como dispositivo a restringir a liberdade de negociação dos jogadores, as quais deixavam os jogadores amarrados ao clube, impedindo sua livre transferência a outro clube empregador (COUTINHO FILHO, 2016). Mediante esse cenário, com novas composições relacionais, o espaço propício possibilitou o surgimento cada vez mais de novos agentes. Ainda, outro elemento que se mostrou crucial para a expansão da carreira de empresário foi o surgimento de novas ligas profissionais esportivas, as quais acabaram determinando maiores disputas entre clubes pelos principais jogadores e pelos jovens promissores (EZABELLA, 2009).

De acordo com Ezabella (2009), em 1994, com o interesse em aperfeiçoar a organização da atividade dos representantes de jogadores de futebol ao redor do mundo e proteger os futebolistas, a Federação Internacional de Futebol promulgou a primeira regulamentação, batizada de Players' Agents Regulations, alterada em dezembro de 1995, entrando em vigor somente em $1^{\text {o }}$ de janeiro de 1996 (CRUZ; CUNHA, 2014). As mudanças ocorridas durante o seu transcurso devem-se às adequações necessárias por conta da Sentença $\operatorname{Bosman}^{48}$ (EZABELLA, 2009). Antes da decisão judicial do Tribunal de Justiça da União Europeia e do regulamento da Federação Internacional de Futebol (FIFA), os jogadores não tinham liberdade de circulação ao fim do contrato. Com a nova regulamentação e a inerente ampliação de transferências de jogadores e

\footnotetext{
${ }^{47}$ Restringia a liberdade do jogador de escolher onde iria trabalhar. Os contratos eram padronizados e todos tinham uma cláusula que permitia ao clube a renovação automática com o jogador por um preço que a instituição podia unilateralmente fixar (CASTELLO, 2017).

${ }^{48}$ Para a Europa, o Caso Bosman é considerado simbólico em relação ao fim do passe. Segundo Rodrigues (2007), o acórdão proferido em favor do jogador belga Jean-Marc Bosman revolucionou o mercado de transferências no futebol da Europa, determinando o fim do passe. A alforria dos jogadores de futebol europeu inicia quando o jogador belga Bosman tem decisão favorável à sua ação judicial contra o RFC Liège, o qual pleiteava o rompimento de seu vínculo com o clube. De quebra, o veredito final garantiu a livre circulação de jogadores e terminado com o limite de três jogadores estrangeiros por equipe em campo (GIGLIO, 2013).
} 


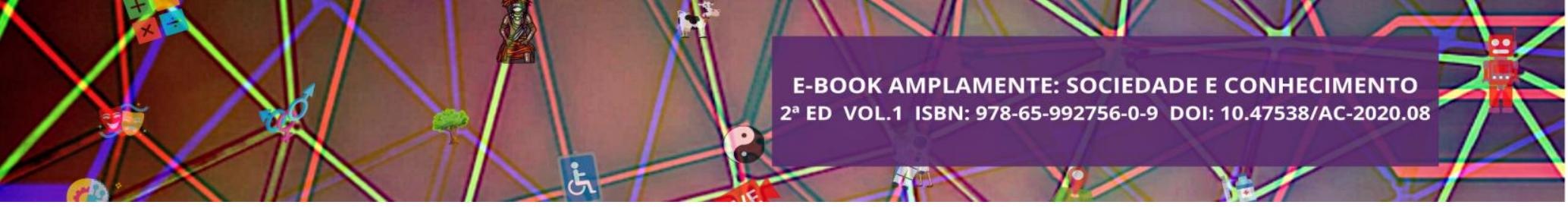

discussões de contratos, as atuações dos empresários foram potencializadas, estimulando o acréscimo de mais agentes ao ramo (MARQUES, 2017).

No ano 2000, segundo Ezabella (2009), a Federação Internacional de Futebol obrigou-se a fazer modificações em seu regulamento por conta de incontáveis reivindicações de incompatibilidade entre o seu regramento e o princípio da livre concorrência na Europa. Após as pertinentes alterações de maneira a dirimir as inconsistências legais, em $1^{\circ}$ de março de 2001, passou a vigorar o novo regulamento, que incumbia a cada entidade esportiva de futebol nacional, baseado nas normas da FIFA e nas legislações locais, a criação do seu próprio regulamento. Porém, antes de sua publicação deveria ser submetido ao crivo do Comitê de Jogadores da FIFA para a sua aprovação (EZABELLA, 2009). Além disso, a normativa internacional delegava às confederações e associações a emissão de licenças para o exercício da atividade do empresário, transferindo a responsabilidade que outrora era da FIFA para as entidades nacionais (MARQUES, 2017).

Como não surtiram os efeitos esperados, a FIFA achou melhor substituí-lo. À vista disso, em $1^{\circ}$ de janeiro de 2008, publicou o Regulamento de Agentes de Jogadores, substituindo integralmente o anterior (MARQUES, 2017). No novo conjunto de regras, entre os objetivos encontravam-se o interesse em alargar o controle sobre a atividade dos agentes, a inibição da atividade de não licenciados e a salvaguarda da transparência nas participações dos agentes. No regulamento novo, instaurou-se a obrigatoriedade da posse de licença do agente. Para tal, dever-se-ia seguir os passos seguintes: pedido de inscrição junto à Associação Nacional do seu país; apresentação de documentação; submeter-se a exame de múltipla escolha envolvendo normas internas do país de origem do agente, como aquelas envolvendo direitos civis e trabalhistas e a regulamentação internacional vigente na FIFA à época; contratação de seguro de responsabilidade civil, para os candidatos aprovados; compromisso com o Código Deontológico ${ }^{49}$; renovação da licença, com realização de nova avaliação após 5 anos de vigência.

A FIFA modificou mais uma vez a sua regulamentação a respeito dos empresários de futebol. Em 2014, foi publicado o Regulations on Working with Intermediaries da FIFA ou como conhecido popularmente por RIFIFA. O documento sugeria uma série de medidas a serem adotadas pelas suas afiliadas, fazia parte das normativas que as entidades nacionais deveriam confeccionar os seus próprios

\footnotetext{
${ }^{49}$ Relativo à deontologia, à ciência dos deveres morais, especialmente os deveres inerentes a certas profissões,
} 


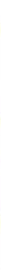

regulamentos. A principal medida do novo dispositivo foi delegar às confederações associadas à tarefa de disciplinar, o exercício da atividade dos empresários de futebol.

A Confederação Brasileira de Futebol (CBF) por seu turno acatou todos os pareceres do texto e, em $1^{\circ}$ de abril de 2015, publicou o Regulamento Nacional de Intermediários (RNI). No ordenamento nacional, uma das alterações primordiais foi adotar a sugestão da FIFA para o desígnio da ocupação de "Agente" ou "Agente FIFA" para "Intermediário" (SOARES DE ALMEIDA, 2018). O instrumento, além de modificar a terminologia, alterou ainda a norma de licenciamento para um novo dispositivo de cadastro obrigatório. O RNI 2015, em certa medida, acabou promovendo a ascensão de pessoas tidas como comuns ${ }^{50}$ a esse espaço. Uma vez que, eliminou a obrigação de realizar provas de conhecimentos, sobre regras, estatutos e regulamentos da FIFA e da CBF, como: noções de direito civil e de direito contratual. Entretanto, conservou indispensável a comprobação de idoneidade, o pagamento das taxas e a contratação de seguro contra danos contratuais (BOEHL, 2018). Outra questão a relevar foi a instituição do limite máximo em três por cento sobre o total bruto do salário do jogador, correspondente ao período de vigência do contrato relativos a pagamentos de honorários aos empresários.

Em 22 de dezembro de 2014, por pressão imposta pela União das Associações Europeias de Futebol (em inglês: Union of European Football Associations) ou simplesmente UEFA, a FIFA por meio da Carta Circular no 1464 alterou o artigo 18 bis e criou o artigo 18-ter do Regulations on the Status and Transfer of Players (Regulamento de Transferências de Jogadores FIFA), vedando a participação de terceiros em direitos econômicos de futebolistas. A normativa começou a valer a partir de $1^{\circ}$ de maio de 2015. Para os contratos anteriores a 31 de dezembro de 2014, que estivessem em vigência, o dispositivo não alcançariam. Com a medida, apenas clubes poderiam possuir percentuais de direitos econômicos. Nem mesmo o próprio jogador poderia ter parte em seus direitos. Um dos argumentos para tal deliberação foi o intuito de eliminar a presença de investidores no futebol.

A partir de 2018, a Regulamento de Transferências de Jogadores (CBF) passou anualmente a publicar seus regulamentos. Em 21 de dezembro de 2017, a CBF promulgou o RNI 2018, que começou a vigorar a partir de $1^{\circ}$ de janeiro de 2018.

\footnotetext{
${ }^{50}$ Normalmente, os empresários eram ex jogadores de futebol, bacharéis em direito, profissionais da educação física. Comuns seriam pessoas não especialistas na área.
} 


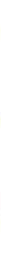

Algumas alterações relativas ao último regramento ocorreram, como forma de aperfeiçoar as relações entre empresários e abrandar as ações judiciais e as demandas da Câmara Nacional de Resolução de Disputas (CNRD) da entidade. A principal seria a responsabilização solidária do novo empresário (intermediário), no pagamento de compensação ao empresário anterior, ou seja, o atleta ou técnico ao assinar dois contratos de representação com períodos concomitantes ou quando existir rescisão unilateral e sem justa causa deve-se indenizar o prejudicado.

Ao final de 2018, em 14 de dezembro, a CBF publicou o RNI 2019, com vigência a partir do terceiro dia do ano seguinte. Dentre as alterações a mais substancial, foi a obrigatoriedade de apresentação de Declaração de Participação de Intermediário para todas as intermediações realizadas, até mesmo as sem comissionamento, como forma de prestação de contas, junto à CBF. Ainda, a exigência da entrega de cópia do contrato de representação ao seu cliente; clubes, jogadores ou técnicos poderão consultar a CBF sobre contratos de representação vigentes; clubes, jogadores ou quaisquer interessados poderão solicitar à CBF o registro, no sistema de intermediários, por mútuo acordo, da rescisão de um contrato de representação. Em relação a direitos econômicos, em maio de 2019, a FIFA promulgou o Regulamento sobre Status e Transferência de Jogadores. A mudança a ser avultada foi a remoção da proibição dos jogadores de participarem dos seus próprios direitos econômicos.

Em 7 de janeiro de 2020, a CBF mais uma vez renovou o seu regulamento de empresários de futebol. No RNI 2020, a alteração de dois para três anos o prazo máximo para a duração dos contratos de representação, sem renovação automática, foi a principal modificação. Para os empresários fora de certa forma um avanço tímido, todavia de grande relevância para o atual cenário.

\section{CONSIDERAÇÕES FINAIS}

Desde que os empresários deixaram de ser apenas um representante dos jogadores e passaram a ocupar uma posição notória nas negociações, além de assumirem o papel de gestor da carreira dos atletas, mudanças institucionais e práticas ocorreram. Junto com a profissão nomenclaturas surgiram para designar o ofício, algumas foram estabelecidas como a vigente advinda da FIFA e adotada pela CBF de “intermediário", porém não adotada pelos sujeitos que transitam no meio do futebol. 


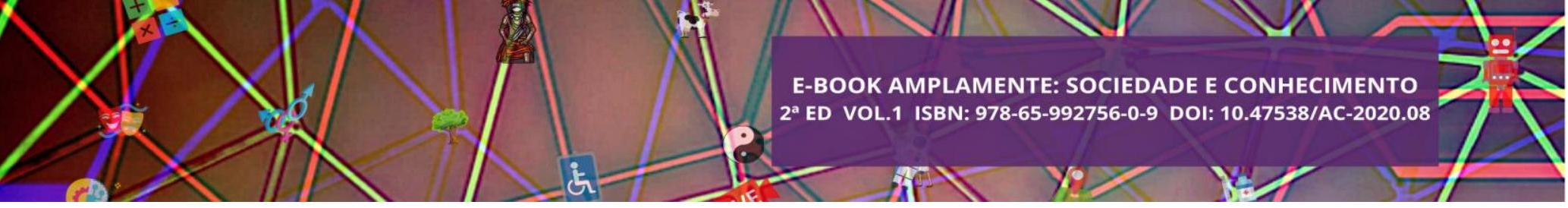

Enquanto, o termo "empresário" possa ser entendido do nativo nesse espaço, por ser o termo mais recorrente entre os que circulam no meio, mesmo não sendo institucionalizado.

Cabe interpretar que nos últimos cem anos a profissão cresceu e foi se alterando de acordo com as demandas. A relação tríade jogador-empresário-clube de futebol se fortaleceu a ponto de atualmente as transações praticamente não se realizarem sem a participação do empresário. Essa relevância se materializou na ampliação no número dos empresários, e com efeito do crescimento vieram as regulamentações da profissão propostas pela FIFA e pela CBF nos últimos anos.

\section{REFERÊNCIAS}

BOEHL, Walter Reyes. Intermediários de futebol: as relações com os jogadores de base (menores de 16 anos). 2018, 88 f.. Trabalho de Conclusão e Curso (Graduação) Faculdade de Educação Física, Fisioterapia e Dança, UFRGS, Porto Alegre, 2018.

CARDOSO, Nuno Mauro Soares. Intermediário FIFA: percurso para o sucesso. 2016. 63 f. Dissertação (Mestrado) - Curso de Ensino de Educação Física nos Ensinos Básico e Secundário, UTAD, Vila Real, 2016.

CASTELLO, Bruno Froener. Salário e desempenho de esportistas profissionais: uma análise da NBA na temporada 2015-2016. 2017. 100 f. Trabalho de conclusão submetido ao Curso (Graduação) - Curso de Ciências Econômicas da Faculdade de Ciências Econômicas, UFRGS, Porto Alegre, 2017.

CONFEDERAÇÃO BRASILEIRA DE FUTEBOL. Regulamento da Câmara Nacional de Resolução de Disputas 2018. Disponível em: <https://conteudo.cbf.com.br/cdn/201712/20171221165506_0.pdf〉. Acesso em: 17 mai. 2018.

CONFEDERAÇÃO BRASILEIRA DE FUTEBOL. Regulamento Nacional de Intermediários 2015. Disponível em: <https://conteudo.cbf.com.br/cdn/201505/20150504162750_0.pdf>. Acesso em: 08 fev. 2018 .

CONFEDERAÇÃO BRASILEIRA DE FUTEBOL. Regulamento Nacional de Intermediários 2018. Disponível em: <https://conteudo.cbf.com.br/cdn/201712/20171221163653_0.pdf>. Acesso em: 08 fev. 2018.

CONFEDERAÇÃO BRASILEIRA DE FUTEBOL. Regulamento Nacional de Intermediários 2019. Acesso em: 21 abr. 2019. CBF. Regulamento Nacional de Intermediários 2015.2 Disponível em: <https://conteudo.cbf.com.br/cdn/202001/20200109152750_818.pdf>. Acesso em: 21 


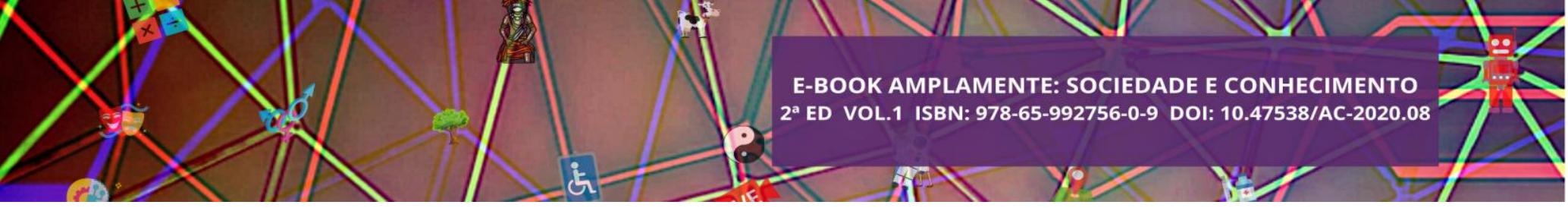

abr. 2019.

CONFEDERAÇÃO BRASILEIRA DE FUTEBOL. Regulamento Nacional de Intermediários 2020. Disponível em: <https://conteudo.cbf.com.br/cdn/202001/20200109152750_818.pdf>. Acesso em: 05 mar. 2020.

COUTINHO FILHO, José Eduardo. A regulação do intermediário desportivo no ordenamento jurídico brasileiro - uma análise acerca do futebol. Centro de Pesquisa e Desenvolvimento Desportivo, (C) Comité Olímpico de Portugal, 2016

CRUZ, Marcio; CUNHA, Júlio Araujo Carneiro. Rede de agentes de atletas profissionais de futebol: Domínio das transferências do Brasil para o exterior. 2014.

DAMO, Arlei. Do Dom à profissão: a formação de futebolistas no Brasil e na França. São Paulo: Aderaldo \& Rothschild Ed. Anpocs, 2007.

EZABELLA, Felipe Legrazie. O agente FIFA à luz do direito civil brasileiro. 2009. 148 f. Tese (Doutorado) - Departamento de Direito Civil da Faculdade de Direito, USP, São Paulo, 2009.

MARQUES, Fernanda Duarte de Barros. Intermediação no futebol profissional: regime e âmbitos contratuais. 2017, 107 f. Dissertação (Mestrado). Faculdade de Direito. ULL, Lisboa, 2017.

NEQUESAURT, Tiago. Jogador, dirigente e empresário de futebol: relações que transcendem a bola. 2007. 124 f. Monografia (Especialização) - Programa de PósGraduação em Administração, Escola de Administração, UFRGS, Porto Alegre, 2007.

RODRIGUES, Francisco Xavier Freire. O fim do passe e a modernização conservadora no futebol brasileiro (2001-2006). 2007. $346 \mathrm{f}$. Tese (Doutorado) Programa de Pós-Graduação em Antropologia Social, UFRGS, Porto Alegre, 2007.

SOARES DE ALMEIDA, Caroline. Do sonho ao possível: projeto e campo de possibilidades nas carreiras profissionais de futebolistas brasileiras. $2018.254 \mathrm{f}$. Tese (Doutorado) - Programa de Pós-Graduação em Antropologia Social, UFSC, Florianópolis, 2018. 


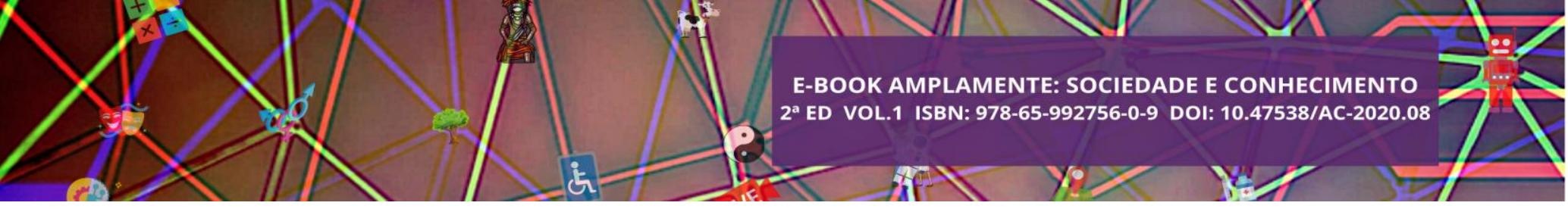

\title{
CAPÍTULO III
}

\section{A EXPRESSÃO CULTURA DO ESTUPRO E DA PEDOFILIA NA MÍDIA/MÚSICA: A NORMALIZAÇÃO DO MAL}

\author{
Júlia Leite Nunes ${ }^{51}$; Danielle Cevallos Soares ${ }^{52}$. \\ DOI - Capítulo: 10.47538/AC-2020.08-03
}

\section{RESUMO:}

É axiomático que as mulheres sempre foram vistas como objetos, instrumento de prazer e satisfação masculina, além de "máquina reprodutora" e, deste modo, a cultura de estupro e pedofilia são chagas do corpo social que se desenvolvem desde os primórdios da humanidade, ainda que de forma abstrusa e encobertada. Hodiernamente, esses mesmos pensamentos, dizeres e piadas misóginas ainda são perpetuados normalizando as práticas de estupro e suas eventuais implicações, tais como agressão e morte. Assim, o presente artigo tem como objetivos: apontar as implicações da normalização da prática de estupro em meios midiáticos, como a música, dilucidar as letras que sutilmente corroboram esse mal e demonstrar a complexidade da disseminação da visão da mulher apenas como um objeto no corpo social. Utilizando-se das metodologias explicativa, pois são identificados fatores que colaboram para ocorrência do fenômeno social estudado, descritiva, pelo fato de abordar como esse acontecimento se desenvolve na sociedade e exploratória, por apresentar sua repercussão imperceptível na comunidade, além de possuir fonte bibliográfica. O conteúdo estudado e suas implicações em mulheres e vulneráveis serão analisados no presente artigo.

PALAVRAS-CHAVE: Culpabilização das vítimas. Novinha. Forma discreta.

\section{INTRODUÇÃO}

Inicialmente, é primordial destacar o conceito de estupro que significa manifestação de poder, mais precisamente o poder exercido sobre as mulheres, assim, cultura de estupro é a culpabilização das vítimas de assédio sexual e normalização do comportamento sexual violento dos homens pela mídia, cultura popular, sociedade e as instituições sociais. Essa chaga é uma consequência da naturalização de atos e comportamentos machistas, sexistas e misóginos, que estimulam agressões sexuais e outras formas de violência contra as mulheres (NAÇÕES UNIDAS BRASIL, 2016).

51 Graduação em andamento em Direito, Universidade do Estado de Mato Grosso, UNEMAT, Brasil. julinhaleinunes@gmail.com

52 Graduação em Direito pela Universidade do Estado de Mato Grosso (2009). Professora efetiva Universidade do Estado de Mato Grosso - UNEMAT. E-mail: cevallos.danielle@ unemat.br 


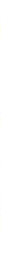

Logo, faz-se primordial discorrer sobre tal revés e como esse se manifesta de forma sutil em nosso meio social, nomeadamente em músicas.

É inexorável que é fundamental destacar e discorrer sobre pensamentos e atitudes da sociedade atual que corrobora para a cultura de estupro. As mulheres sempre foram vistas como objeto que pode ser descartado, esse pensamento lamentavelmente é perpetuado de gerações em gerações. Segundo Izabel Solyszko, professora, assistente social e doutoranda em Serviço Social na Universidade Federal do Rio de Janeiro (UFRJ), vivemos em uma sociedade patriarcal que considera que nós mulheres somos sujeitos de segunda categoria, ou em alguns casos, que não somos sujeitos e podemos ser utilizadas ou destruídas (GALILEU, 2016). Desse modo, mulheres são enxergadas como simples coisa, isto é, como apenas um corpo público, que pode ser usado, descartado e violentado sem nenhuma consequência desastrosa, a não ser para o corpo e psicológico da mulher, ademais essa visão contribui para o assédio e violência de gênero.

Vale ressaltar que desde o nascimento a cultura de estupro se faz presente na vida do ser humano, isso é notório quando nasce uma criança e já é predeterminado todos os seus comportamentos se for menino ou menina. Como aponta Arielle Sagrillo, doutoranda em psicologia forense na Universidade de Kent, na Inglaterra,

A sociedade cria expectativas muito grandes para ambos os gêneros. Desde cedo dizemos a esses sujeitos o que eles devem ser, antes mesmo que possam descobrir o que querem, o que lhes afeta e como lidam com suas próprias emoções (GALILEU, 2016).

Dessa forma, desde criança a mulher é criada para ser dócil, gentil, delicada e perfeita todos os momentos, além de ser ensinada a ter responsabilidades sobre a família, companheiro e até mesmo de suas agressões sofridas. Diante disso, torna-se plausível citar um trecho do livro Missoula de Jon Krakauer,

Na verdade, foi uma atitude bastante comum as mulheres não gritarem ou chamarem a polícia nos casos de estupro que processei', diz Roe, 'ao menos em parte porque não são programadas para reagir assim. Somos educadas para sermos agradáveis e para não criarmos atritos. Somos criadas para sermos amáveis. Espera-se que as mulheres resolvam problemas sem fazer uma cena - espera-se que elas façam coisas ruins desaparecerem como se jamais tivessem acontecido (KRAKAUER, 2016).

Esse livro é de grande importância também para analisar a forma como a comunidade e as instituições sociais tratam a mulher perante um caso de assédio, 


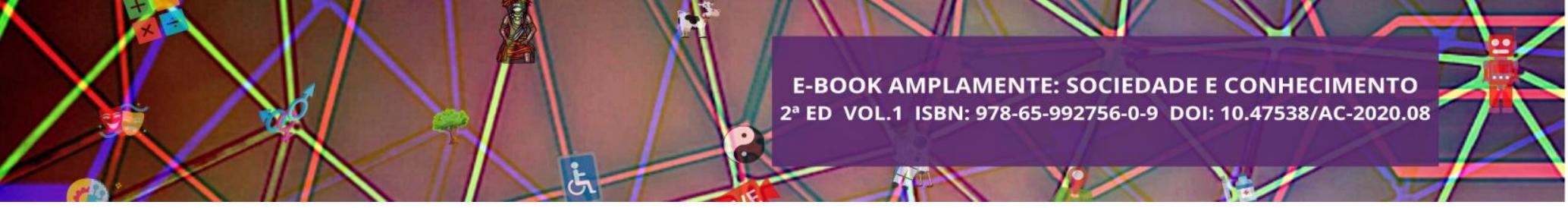

estupro e assassinato. Isto é, acusam a mulher como facilitadora da violência, por conta de seu comportamento-roupa justa e curta, horário inapropriado para andar na rua-, ou seja, levam mais em consideração a atitude da vítima do que os fatos, além disso vitimiza e dá o benefício da certeza ao agressor e coloca-se em dúvida a palavra/testemunho da mulher como se fosse mentirosa e leviana. Desse modo, torna-se fundamental ainda citar outro trecho do livro supratranscrito, "caras bêbados que podem ter 'cometido erros' quase sempre recebem o benefício da dúvida. O mesmo não vale, porém, para garotas bêbadas.” (KRAKAUER, 2016) Além disso, é de suma importância destacar trecho do estudo "A cultura do estupro" do site Drauzio tal o qual corrobora com o transcrito acima:

Por meio da culpabilização da vítima, estimulamos que as mulheres estupradas se escondam e acabem protegendo seus algozes. Afinal, é comum elas ouvirem de policiais e da própria família que estavam embriagadas, usavam roupas curtas e apertadas, que andavam sozinhas à noite ou não deixaram claro que não desejavam o ato sexual. A vítima, portanto, sente medo e vergonha de denunciar (DRAUZIO, 2019).

Com isso, pode-se afirmar que o estupro é o único crime que se coloca em incerteza na palavra da vítima, sendo essa única testemunha no caso, normalmente.

Outrossim, o corpo social contemporâneo tem como principais características, o patriarcalismo, o racismo e o capitalismo. Desse modo esses três pilares fazem com que as mulheres sejam objetificadas, mercantilizadas tornando ultimamente natural a sua agressão, violência e morte.

Destarte, é importante frisar que o estupro não se constitui apenas como agressão e morte da vítima, pois é imperioso destacar que esse ato ilícito também se configura quando não há o consentimento da mulher para relações sexuais e até atos considerados "amorosos" -bater, puxar e dar tapa-, o que acontece normalmente em relacionamentos amorosos, mas é tão sutil e imperceptível que não é detectado e nem considerado por muitos.

\section{ELEMENTOS TEXTUAIS}

\section{CULTURA DO ESTUPRO}




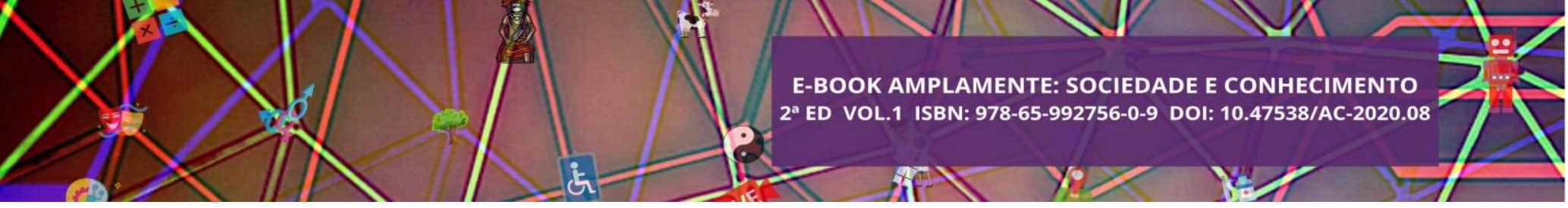

$\mathrm{Na}$ cultura machista e na sociedade patriarcal são diversos os mecanismos utilizados para desqualificar e propiciar o estupro, como a música. Assim, toma-se como ponto de referência e análise sintática a música Surubinha de leve do Mc Diguinho, é valido destacar que essa obra teve grande repercussão por se tratar de uma letra que estimula a violência das mulheres e possuir uma linguagem agressiva. Segue a letra (LETRAS, 2019),
Pode vim sem dinheiro
Mas traz uma malandra!
(Pode vim sem dinheiro) (chama, chama)
(Mas traz uma malandra, aí!) (chama, chama)

Nesse parágrafo, observa-se que no evento convocado pela composição não precisa levar dinheiro, mas uma malandra, isto é, uma mulher, corroborando assim para o pensamento aludido de que a mulher é um objeto, um corpo público que pode ser usado e trocado igual o dinheiro. Seguindo (LETRAS, 2019),

\begin{tabular}{|c|}
\hline Só uma surubinha de leve, surubinha de leve \\
Com essas mina maluca \\
Taca a bebida, depois taca e fica \\
Mas não abandona na rua \\
Taca a bebida, depois taca e fica \\
Taca a bebida, depois taca e fica \\
Ta-taca a bebida, depois taca e fica \\
Mas não abandona na rua \\
\hline
\end{tabular}

Diguinho fala de embebecer a mulher para tornar mais fácil sua dominação taca a bebida, depois taca e fica -, violência, estupro e por último abandonar na rua, como simples coisa - esse verso foi mudado pelo cantor após inúmeras críticas na internet depois de seu lançamento-.

Outrossim, a música possui grande influência nos indivíduos, assim coopera para disseminação de práticas misóginas, ideia de que a mulher é um objeto que pode ser deixado - jogado - na rua, e normalização do estupro.

\section{PEDOFILIA}




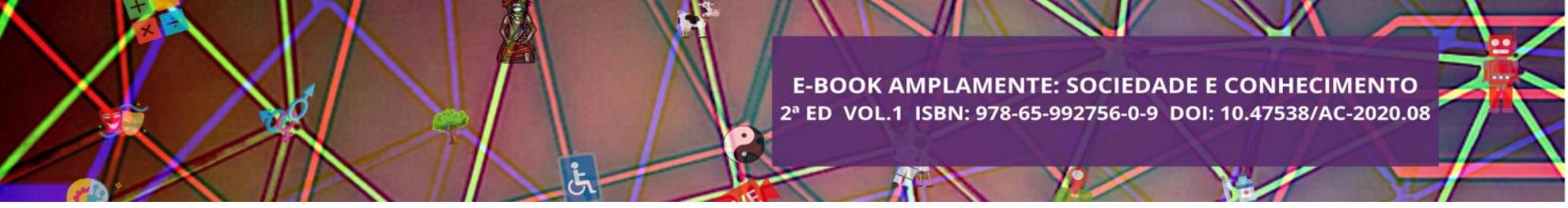

Um outo ponto a ser discutido nesse artigo é a incitação à pedofilia, ou melhor, o estupro de vulneráveis nas músicas e como isso é difundido de forma discreta. A música Ela é do tipo do Kevin o Chris traz de forma clara o acontecimento de tal crime (LETRAS, 2019).

\begin{tabular}{|c|}
\hline Ela é do tipo que gosta muito de conversar \\
Mas não fica de papapa \\
Vai se despindo deitando na minha cama \\
Prontamente conversando, ela tira a minha roupa \\
Essa menina mete muito gostoso \\
Dá pra ver que ela gosta do que faz \\
Novinha safada e simpática \\
Deixou o Kevin com gosto de quero mais \\
Vai, rebola pro pai, vai novinha, vai \\
Descendo, descendo
\end{tabular}

Colocando em arguição, o termo novinha indica que é uma menina menor de 14 anos de idade, frágil e vulnerável, constituindo-se então uma cena de pedofilia - "ela tira minha roupa" e "essa menina mete muito gostoso" -. Para uma melhor observância, pedofilia é uma forma doentia de satisfação sexual. Trata-se de uma perversão, um desvio sexual, que leva um indivíduo adulto a se sentir sexualmente atraído por crianças (JUSBRASIL, 2015).

Para se caracterizar melhor como um ato criminoso faz-se plausível a observância da primeira parte do art.217-A do Código Penal: “Ter conjunção carnal ou praticar outro ato libidinoso com menor de 14 (catorze) anos" (CANAL CIÊNCIAS CRIMINAIS, 2016).

Dessa forma, praticar ato libidinoso-cópula vaginica-com uma pessoa menor de 14 anos caracteriza-se como crime de estupro de vulneráveis, analogamente a música o cantor diz que "essa menina mete muito gostoso", constituindo-se um ato libidinoso, como o dispositivo descreve. Outro ponto é o verso "ela gosta do que faz", assim, por mais que a vítima tenha algum consentimento do ato a ser praticado isso não afasta a ocorrência do fato típico, conforme o que decidiu a $3^{\text {a }}$ seção do STJ em agosto de 2015 , em recurso representativo de controvérsia, no qual ficou assentado que

Para a caracterização do crime de estupro de vulnerável, previsto no artigo 217-A do Código Penal, basta que o agente tenha conjunção carnal ou pratique qualquer ato libidinoso com pessoa menor de 14 anos. O consentimento da vítima, sua eventual experiência sexual 


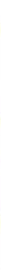

anterior ou a existência de relacionamento amoroso entre o agente e a vítima não afastam a ocorrência do crime (CANAL CIÊNCIAS CRIMINAIS, 2016).

Esse entendimento é plausível, pois o estupro viola grosseiramente a dignidade e a integridade moral e sexual dos vulneráveis, isto é, menores de 14 anos, ainda que haja consentimento por parte desses não há um entendimento e ciência do que está acontecendo consigo e os efeitos que pode decorrer.

Seguidamente, é correto afirmar que as vítimas de estupro têm sua dignidade humana e sexual violada de modo brutal, assim destaca-se as consequências/implicações dessa chaga. Os danos psicológicos causados são

Distúrbios do sono são comuns, depressão, transtorno de estresse póstraumático, sentimento de degradação e perda da autoestima, sentimento de despersonalização ou desrealização, culpa, ansiedade, temor de andar ou ficar só. Medo das pessoas atrás delas e de multidões, temores sexuais, pesadelos repetidos recapitulando o estupro, síndrome do pânico, tendências suicidas e problemas com relacionamentos íntimos (JUS BRASIL, 2019).

Sendo assim, a vida social e sexual de tais indivíduos sofre dispêndio irreparáveis mesmo com a condenação do agressor.

\section{CONSIDERAÇÕES FINAIS}

Portanto, diante dos argumentos supracitados conclui-se que a cultura do estupro e da pedofilia são chagas que se perpetuam de geração em geração, propalando visões e pensamentos misóginos e sexistas que contribuem para o feminicídio, agressão e violência contra a mulher e vulneráveis. Essa perpetuação se dá modo sutil e discreto, através de propagandas, filmes e músicas, como analisadas.

Diante disso, cito o site Fórum que traz formas de combater tal revés, por meio de algumas atitudes que a própria sociedade pode exercitar como: parar de dividir as mulheres entre boas e vadias-essas ultimas conforme a cultura popular seriam aquelas que "facilita" a conduta do agressor, com o uso de roupas curtas e apertadas-;não naturalizar o assédio e o termo "quero uma novinha" - que vem sendo utilizado frequentemente nas músicas - não culpar a vítima - como já foi dissertado -; não fazer piada com o termo estupro, pois isso se torna normal e naturalizado; combater a ideia de que o corpo da mulher é público, ou seja, pode ser usado e descartado como um 


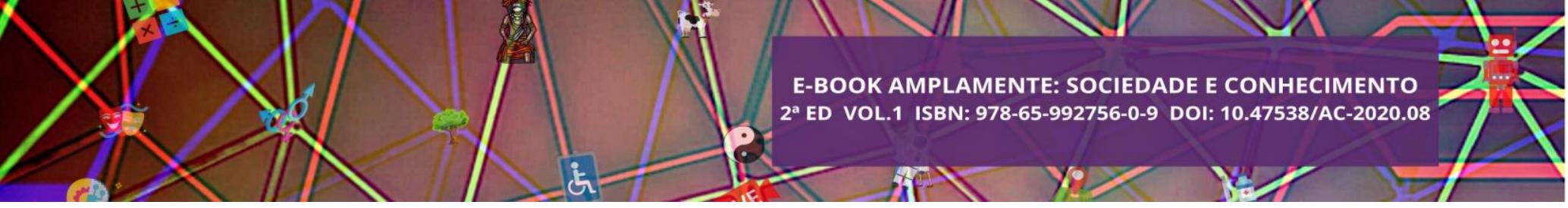

simples objeto; e ensinar para as crianças de forma lúdica de como a pedofilia pode acontecer, isso evita e detecta tal revés.

Por fim, destaca-se que a lei não ampara de forma plena a mulher e os menores de 14 anos, isto é não traz segurança, pois não intimida o agressor nem pune como deveria, pois aplica uma sanção branda. Desse modo, torna-se primordial o combate de tais patologias tanto por parte do Estado como detentor do jus puniendi quanto da sociedade como disseminadora de pensamentos e condutas.

\section{REFERÊNCIAS}

CANAL CIÊNCIAS CRIMINAIS. Estupro de vulnerável sem contato físico e a cultura patriarcal dominante. 2016.Disponível em:

<https://canalcienciascriminais.com.br/estupro-de-vulneravel/>. Acesso em: 29 de out.de 2019.

DRAUZIO. A cultura do estupro. Disponível em:< https://drauziovarella.uol.com.br/para-as-mulheres/a-cultura-do-estupro/> . Acesso em :29 de out. de 2019.

GALILEU. 6 coisas que você precisa entender sobre a cultura do estupro. 2016.Disponível em:<https://revistagalileu.globo.com/Sociedade/noticia/2016/06/6coisas-que-voce-precisa-entender-sobre-cultura-do-estupro.html>. Acesso em:29 de out. de 2019.

JUS BRASIL. Quais as consequências psicológicas do estupro?. Disponível em: <https://lobo.jusbrasil.com.br/artigos/344162361/quais-as-consequencias-psicologicasdo-estupro> Acesso em: 29 de out. de 2019.

JUSBRASIL. Pedofilia no Estatuto da Criança e Adolescente: art. 241-E e sua interpretação constitucional.2015.Disponível em:

$<$ https://jus.com.br/artigos/41178/pedofilia-no-estatuto-da-crianca-e-adolescente-art241-e-e-sua-interpretacao-constitucional>. Acesso em: 29 de out. de 2019.

JUS. Estupro: o mal que assola a sociedade desde os primórdios. 2018.Disponível em:< https://jus.com.br/artigos/67300/estupro-o-mal-que-assola-a-sociedade-desde-osprimordios $>$. Acesso em: 29 de out. de 2019.

KRAKAUER, Jon. Missoula: O estupro e o sistema judicial em uma cidade universitária. Companhia das Letras.2016.

LETRAS. Ela é do tipo. Disponível em:< https://www.letras.mus.br/mc-kevin-ocris/ela-e-do-tipo/>. Acesso em:29 de out.de 2019.

LETRAS. Só surubinha de leve. Disponível em: <https://www.letras.mus.br/mcdiguinho/so-surubinha-de-leve/>. Acesso em: 29 de out. de 2019. 


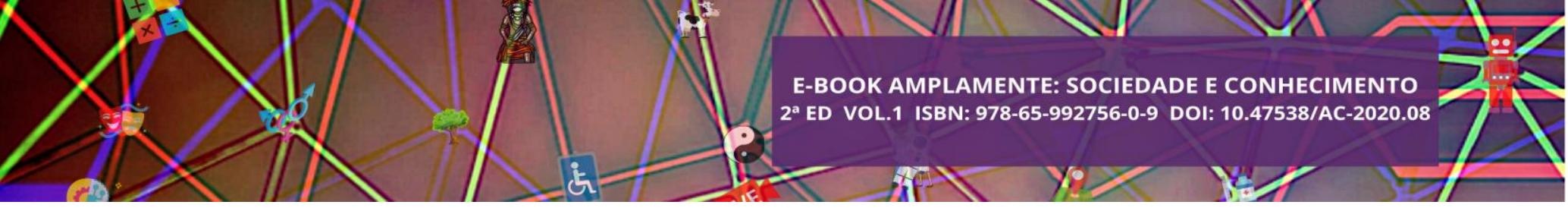

NAÇÕES UNIDAS BRASIL. Por que falamos de cultura do estupro?

2016.Disponível em:< https://nacoesunidas.org/por-que-falamos-de-cultura-doestupro/>.Acesso em:29 de out. de 2019.

REVISTA FORUM.16 formas de combater a cultura do estupro.2016.Disponível em: <https://revistaforum.com.br/blogs/ativismodesofa/16-formas-de-combater-acultura-do-estupro/>. Acesso em: 29 de out.de 2019. 


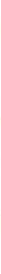

História. Isto porque a morte não faz parte de uma categoria específica; é uma questão que atravessa várias áreas do conhecimento, e uma questão essencialmente humana.

\section{A VISÃO DA PSICANÁLISE SOBRE A MORTE}

Ao sermos inseridos a um determinado grupo social após o nascimento, são jogados a nossa individualidade os conceitos criados como certos e errados por esse meio. Assim, nos é imposto uma busca pela felicidade criada e construída. A partir desse instante frente ao mundo, uma névoa de expectativas começa a definir socialmente o que é o prazer, que traz troféus de ganho social e maior voz que demonstra seu nível de felicidade como um termômetro na forma de status frente ao grupo. Assim, é no seio da cultura que a pulsão de morte ganha suas contenções, por meio dos ideais culturais que fornecem um contraponto à sabotagem da pulsão de morte. Nesse sentido, é fundamental a instauração do superego e a sublimação das pulsões por meio dos ideais fornecidos pela cultura, como a ciência, a religião, as artes e demais instituições.

A busca da felicidade está intimamente ligada à busca da sensação de prazer, que seria nada mais e nada menos que uma sensação agradável ligada à satisfação de uma vontade pessoal. O prazer opõe-se à dor e ao sofrimento e, por isso, esse conceito se faz tão importante, pois é a fuga desse sentimento de desprazer que nos faz observar algum sentido na vida e nos tende a crer que a esta vale a pena ser vivida, uma vez que o espirito do homem nutre uma profunda rejeição por toda a forma de desordem.

O ser humano tende, consciente e inconscientemente, a manter-se vivo em uma luta diária contra o relógio da natureza sem ao menos saber, no plano material, qual é sua função desde o nascimento. A pulsão de vida é a organização da vida em impulsos conservadores "que obrigam a repetição", é a constante fuga da morte futura em ações que tendem a minimizar, psicologicamente e cada vez mais, o medo da mudança das ações comportamentais que podem levar ao encontro com a morte.

Freud descreve a pulsão de morte como uma pulsão biológica que pressiona para o retorno ao inorgânico, o organismo reagindo a qualquer perturbação pela tentativa de reencontrar o "status quo". É possível imaginar que Freud sublinhou, de maneira parcialmente defensiva, o aspecto biológico, o que permitiu que outros, e às vezes ele mesmo, apresentassem suas ideias sobre a pulsão de morte como uma especulação 


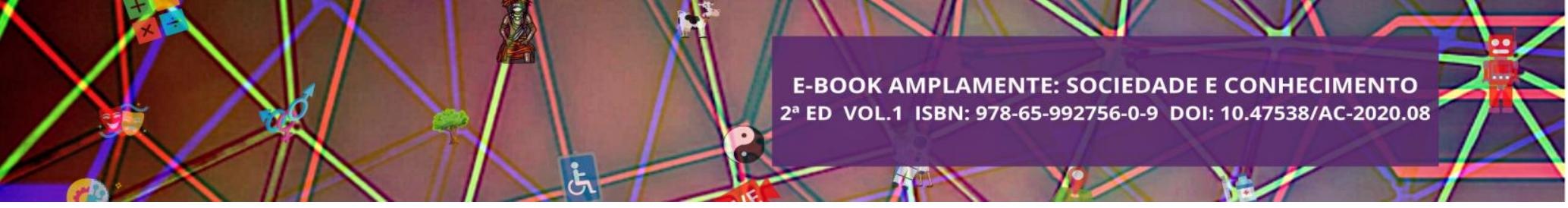

biológica. Esperava que sua formulação fosse julgada como chocante e encontrasse uma grande resistência, o que realmente ocorreu.

A ideia é que a pulsão de morte trabalha como uma força de eliminação ou delimitação, uma vez que o objetivo é por fim aquilo que nos tira a felicidade, nesse caso a destruição passa a ser uma forma de por fim a desordem. Nas suas formas mais elementares, manifesta-se como destruição, em busca de paz pelo vazio. No entanto, o esforço visa um retorno à calma e ao silêncio, pois qualquer solução é menos perturbadora que o caos. Á medida que aumentam os meios, os resultados podem ser alcançados de outra forma que não seja a eliminação, a pulsão de morte nem sempre nos levará a um extremo de autoextermínio, mas é uma possibilidade da qual não pode ser ignorada.

\section{A MORTE COMO RECURSO LITERÁRIO}

A literatura, tanto a literatura de ficção como a ensaística, pode nos falar da doença e da medicina de um modo original e revelador, mais revelador às vezes de que os próprios manuais médicos. Exemplos não faltam. Temos A morte de Ivan Illich, de Leon Tolstói uma dilacerante narrativa sobre um homem que tem uma doença grave e não consegue comunicar-se com seus médicos ou com sua família; A montanha mágicall, de Thomas Mann, no qual a tuberculose faz com que pessoas examinem suas vidas; isto sem falar nas obras de médicos- escritores como Anton Tchekhov, Guimarães Rosa, Pedro Nava. Maravilhosas descobertas podem ser feitas no comum território partilhado pela medicina e pela literatura.

A melancolia é uma das grandes matérias-primas da arte. Mas como tudo que é humano também é hipócrita se leva mais a sério a ressalva de maneirar na dose do que de realmente discutir como resolver os problemas de saúde pública como a depressão e o suicídio. Todas às vezes em que o suicídio aparece na arte e na mídia, o principal argumento para puxá-lo de volta para a gaveta dos assuntos que não podem ser nomeados é para que não cause o "Efeito Werther".

Diversos clássicos da literatura já abordaram o assunto de maneira semelhante, como Romeu e Julieta, de Shakespeare, e Anna Karenina, de Tolstói, por exemplo. Mas o nome do fenômeno vem do romance Os sofrimentos do jovem Werther, do alemão Johann Wolfgang von Goethe, cujo protagonista se mata após ser rejeitado por sua 


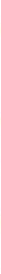

amada Charlotte. O tom realista, depressivo e passional do livro, publicado em 1774, quando a literatura era a principal mídia entre os adolescentes, provocou uma comoção entre os jovens da época, que seguiram Werther e também se suicidaram. O livro foi banido em diversos lugares, retirado de circulação, queimado em praça pública por um

Arcebispo de Milão e algumas edições chegaram a incluir um aviso: "Seja homem e não me siga".

Por isso, o termo é usado para descrever o aumento das mortes quando um suicídio é midiatizado. O fenômeno goethiano é comprovado pela ciência: médicos da Universidade de Viena analisaram 98 casos de suicídio de famosos e perceberam que reportagens sensacionalistas que glamourizavam a morte de celebridades estimulavam o "suicídio por imitação". A recomendação das autoridades de saúde é que não se simplifique, romantize, mostre a forma como alguém cometeu suicídio e nem justifique o comportamento suicida como heroísmo ou vingança.

No clássico O Mito de Sísifo, Albert Camus descreve o ato como a única questão filosófica realmente séria: "Julgar se a vida vale ou não a pena ser vivida significa responder à questão fundamental da filosofia" (CAMUS, 2016, p.10). Único ou rodeado por outros problemas filosóficos, o fato é que precisamos falar sobre as vítimas, as causas, as pessoas afetadas e as formas de evitá-lo. Enquanto os índices de suicídio têm diminuído na maioria dos países, as taxas brasileiras avançam. Entre 2002 e 2012, o número de casos subiu 33,6\%, bem acima dos $11 \%$ de crescimento da população no mesmo período. Entre adolescentes de 10 a 14 anos, o aumento chegou a $40 \%$, de acordo com o último levantamento do Mapa da Violência.

\section{A MORTE REPRESENTADA EM “A METAMORFOSE” DE FRANZ KAFKA}

A Metamorfose conta a história de Gregor Samsa, um caixeiro viajante (que provém o sustento da família parasitária) acaba subitamente se metamorfoseando em um inseto horrendo. Tão horrendo que Kafka optou por não dar muitos detalhes sobre sua aparência, fazendo com que a imaginação do leitor trabalhe para criar a figura mais asquerosa possível, o senso comum imagina o inseto kafkiano como sendo uma barata, mesmo que Kafka nunca tenha usado esse inseto em específico como uma referência.

A relação de Gregor com sua família não é das melhores (exceto com a sua irmã), o que pode servir para traçar um paralelo com a vida do autor, que também não 


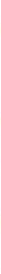

se dava bem com seu pai, me fazendo acreditar que a obra fala bastante sobre Kafka. Com o passar do tempo vemos como a visão da família de Gregor em relação a ele só piora, fazendo com que o isolamento, tanto físico como psicológico, se torne cada vez mais intenso, consumindo lentamente o resto da sua humanidade e identidade.

A Metamorfose é uma obra que trata sobre nossa relação com a solidão e a perda de nossa identidade, que a meu ver só existe com um reflexo do nosso convívio com outras pessoas. Quem sou eu? Quem é Gregor? Esse se trata de um dos maiores dilemas da humanidade e que faz parte do nosso coro particular de demônios, mas que permanece sem uma resposta concreta, a não ser que você pergunte "Quem eu penso que sou? Quem pensam que eu sou?’. Toda a melancolia de observar o desaparecimento da figura de Gregor só se torna pior ao pensarmos que somos os únicos observando esse processo, o que deixa todo o peso de sua morte em nossas mãos.

A metamorfose de Gregor no monstruoso inseto é apenas um recurso literário que leva o leitor a reflexão bem mais complexa sobre a metáfora que esta por trás do tal recurso que é a melancolia. Ao fim do livro podemos ver a morte de Gregor como sendo um momento de libertação e cada cultura tem uma forma diferente de lhe dar com a morte. No ocidente, por exemplo, ela é vista de maneira negativa, a morte é a única experiência que absolutamente todos irão experimentar inevitavelmente.

O fato de tratarmos a morte como algo não natural, equivocadamente faz com que criamos mecanismos de defesa que nos impede uma relação mais concreta com o outro na tentativa de evitar o inevitável que é o contato com a morte. O que nos faz entrar em uma situação de redundância, pois o medo de perder pessoas nos faz perder pessoas todos os dias e conexões são sempre desfeitas, deixando assim bem claro a atuação da pulsão de morte no que diz respeito a eliminar o caos, a busca da paz pelo vazio e o retorno à calma.

\section{A MORTE REPRESENTADA EM “O ESTRANGEIRO” DE ALBERT CAMUS}

Com relação à obra de Albert Camus, O estrangeiro, escrita em 1975, havia na Europa um ambiente intelectual já familiarizado pelo diálogo entre filosofia e literatura, sobretudo com as publicações dos romances e contos de Sartre. O cenário do pós-guerra foi, portanto, fundamental para esses pensadores desenvolverem suas visões de mundo. Em suma, a herança da segunda guerra mundial será para Camus, e também para outros 


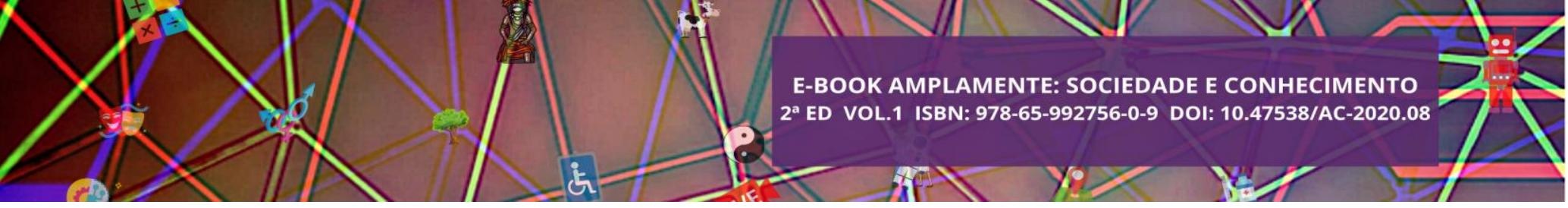

escritores, a de um mundo onde se perderam todas as referências de verdade, moral e o significado à priori de uma existência. É diante disso que Camus irá formular a ideia de absurdo, e aplicá-la constantemente em sua literatura.

A narrativa de $\mathrm{O}$ estrangeiro se sucede uma série de acontecimentos após a morte da mãe de Mersault que levam a crer que este estaria envolto em um profundo processo de indiferença com toda a existência, porém sem negá-la. Voltando do funeral da mãe, logo em seguida Mersault, conhece uma garota na praia, a leva para o cinema para ver um filme de comédia, passa a reencontrá-la periodicamente, mas nesse tempo todo não chega a demonstrar mais sinais de luto. O luto de Mersault é o luto da falta de sentido da existência, do abismo que existe entre as ações dos indivíduos e o significado delas, e, de acordo com Camus “... essa densidade e essa estranheza do mundo, isso é absurdo" (CAMUS, 2015, p. 29).

O ponto culminante da trajetória do protagonista de $\mathrm{O}$ estrangeiro é quando por motivos absurdos e banais ele acaba por matar um árabe em uma praia. Vendo que a sua indiferença ao mundo passa a ser utilizada contra ele mesmo, quando os acusadores constantemente relembram ao júri a psicologia fria de um homem que não chorou no enterro da mãe, Mersault passa a perceber que não existe redenção para um homem que levou a vida inteira de maneira absurda. Mas é no momento em que aguarda a sua execução que Mersault apresenta um paradoxo: Mesmo levando à indiferença as ultimas consequências, demonstrando que todas as coisas no mundo possuem igual valor, ele também confessa que a vida definitivamente merece ser vivida.

E é nesse ponto que Mersault encarna o espírito típico do existencialismo, mesmo percebendo que não existe uma unidade no mundo, o que o faz valer a pena é a subjetividade, a qual para kierkegaard seria a única verdade possível. E é essa a jornada que o sujeito deve encarar para poder se curar do desespero, ou se sobrepor ao absurdo: "Pois quando tento captar esse eu no qual me asseguro, quando tento defini-lo e resumilo, ele é apenas água que escorre entre meus dedos. (...) para sempre serei estranho a mim mesmo" (CAMUS, 2015, p. 33).

\section{REFERÊNCIAS}

CAMUS, Albert. O estrangeiro. Rio de Janeiro: Bestbolso, 2015.

CAMUS, Albert. O mito de sísifo. Rio de janeiro: Bestbolso, 2016. 


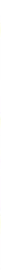

FADIMAN, James e FRAGER, Robert. Teorias da personalidade. São Paulo: Harbra, 1986.

FREUD, Sigmund. Além do princípio de prazer. Porto Alegre: L\&PM, 2016.

FREUD, Sigmund. Neurose, psicose, perversão. Belo Horizonte: Autêntica, 2016.

FREUD, Sigmund. O mal - estar na civilização, novas conferências introdutórias à psicanálise e outros textos (1930 - 1936). São Paulo: Companhia das letras, 2010.

FREUD, Sigmund. Totem e tabu, contribuição à história do movimento

psicanalítico e outros textos (1912-1914). São Paulo: Companhia das letras, 2012.

KAFKA, Franz. A metamorfose. São Paulo: Companhia das letras, 1997. 


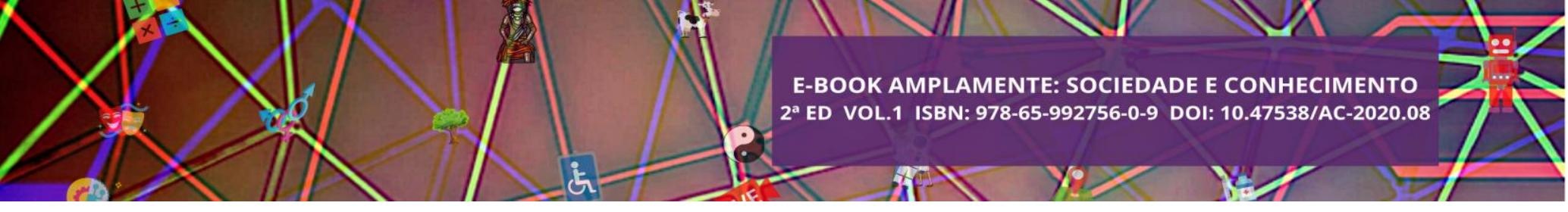

\title{
CAPÍTULO V
}

\section{A MULTIPARENTALIDADE E SEUS EFEITOS À LUZ DA JURISPRUDÊNCIA}

\author{
Waldilene de Araujo Lima ${ }^{54}$. \\ DOI - Capítulo: 10.47538/AC-2020.08-05
}

\section{RESUMO:}

O presente trabalho visa discutir a multiparentalidade consoante o entendimento da jurisprudência, e os efeitos decorrentes de tal instituto. A multiparentalidade consiste na existência concomitante da paternidade biológica e socioafetiva engendrando na formação de linhas ascendentes plurais para o mesmo filho. Para que se alcançasse o objetivo mencionado, utilizou-se o método qualitativo, pois realizou-se um estudo exploratório a partir da pesquisa bibliográfica, o que ocorreu por meio de análise de doutrina, legislação, artigos científicos e periódicos. Também se realizou pesquisa documental por meio de busca jurisprudencial. A partir do entendimento do Supremo Tribunal Federal, a multiparentalidade servirá como norte nos julgamentos em todas as instâncias do Poder Judiciário, de modo que tanto a paternidade biológica quanto a socioafetiva deverá ser conhecida em forma de igualdade (já que nenhuma sobrepõe a outra) quando o pai biológico e o pai socioafetivo tratarem-se de pessoas distintas. Dessa forma, com a realização deste estudo, pôde se vislumbrar que a jurisprudência admite os efeitos do reconhecimento da multiparentalidade, quais sejam: alteração do nome, por conseguinte, o registro civil, exercício do poder familiar por ambos os pais, direitos sucessórios e previdenciários, bem como o direito aos alimentos. Este entendimento sem dúvida está em consonância ao princípio da dignidade da pessoa humana, também resguarda os direitos fundamentais, e concretiza o princípio da afetividade. Além disso, representa a solução para vários impasses uma vez que não restringe direitos, mas amplia a proteção jurídica para uma relação já existente.

PALAVRAS-CHAVE: Multiparentalidade. Efeitos. Paternidade. Afetividade.

\section{INTRODUÇÃO}

Este estudo tem por proposta elencar os principais efeitos oriundos do reconhecimento da multiparentalidade, que é um instituto em que se reconhece o exercício concomitante da paternidade socioafetiva e da paternidade biológica.

\footnotetext{
${ }^{54}$ Pós-graduanda em Direito Constitucional pelo Instituto Elpídio Donizetti. E-mail: waldileneal@gmail.com.
} 


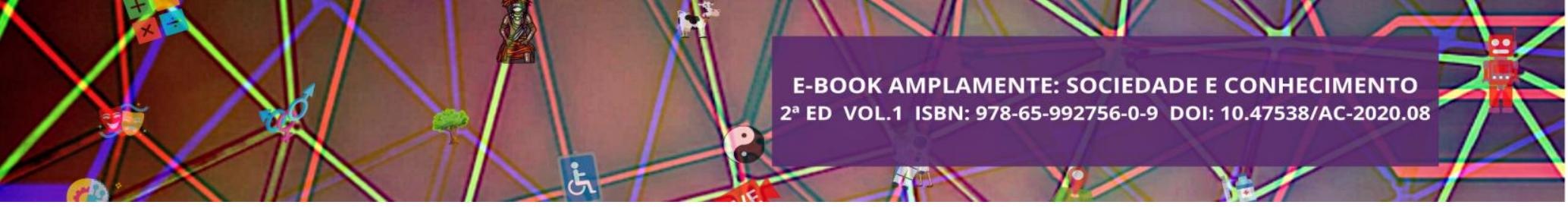

Isto demonstra que a família ao longo dos anos tem sofrido uma grande evolução, já que não se concebe a família formada apenas pelo pai e mãe, unidos pelo casamento, e a prole.

Para se alcançar o referido objetivo é utilizado o método qualitativo, pois é realizada pesquisa bibliográfica por meio da análise da doutrina, legislação, artigos e periódicos. Em conjunto, fomenta-se pesquisa documental tendo em vista a análise de jurisprudência.

Desse modo, no primeiro tópico se analisará os aspectos da família, como a historicidade. Em seguida, se evidenciará a questão da filiação, conceito e previsão legal e de que forma este evoluiu para se chegar ao instituto da multiparentalidade.

Por fim, analisa-se o instituto da multiparentalidade e seus efeitos à luz da doutrina, e do atual entendimento da jurisprudência, especialmente do Supremo Tribunal Federal.

\section{ASPECTOS E HISTORICIDADE DA FAMÍLIA}

Todo homem ao nascer, passa a pertencer a determinado organismo familiar, ligando-se a ela durante toda a sua vida, mesmo que forme uma nova família. É no âmbito familiar que se concebe os mais variados tipos de relações, sejam eles pessoais ou patrimoniais, os quais ocorrem através de seus componentes. É na família que se criam hábitos, sentimentos e posicionamentos que poderão ser determinantes na vida da pessoa.

Com este raciocínio é que a Constituição Federal de 1988 (BRASIL, 1988) ampara e protege a família, elevando esta a nível constitucional, e ao mesmo tempo protege a dignidade humana, que é fundamento da República Federativa do Brasil, consoante o artigo $1^{\circ}$, inciso III, CF/88.

Ressalte-se que o termo família provém do latim famulus, que significa "escravo doméstico", e foi concebido em Roma no intuito de servir como base para denominar os grupos submetidos à escravidão agrícola.

$\mathrm{Na}$ Antiguidade, não havia afeto entre os familiares, e o propósito da união era apenas conservar seus bens, e caso houvesse crise, buscava-se preservar a honra e as vidas. Os filhos também não tinham infância, já que no momento que adquiriam porte 


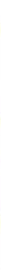

físico para o trabalho, já começavam a realizar os afazeres domésticos juntamente com os adultos.

No direito romano, a família era organizada pelo princípio da autoridade, sendo que o pater familias (chefe de família) exercia sobre os filhos direitos de vida e também de morte, além de subjugar a sua mulher. Em razão disso, o pai poderia vender seus filhos, ou castigá-los, e ainda aplicar penas corporais, e caso fosse necessário, tirar-lhes a vida (GONÇALVES, 2018).

$\mathrm{Na}$ Idade Média, as relações de família eram regidas apenas pelo direito canônico, e o casamento religioso era o único conhecido, mas a família passou por grandes transformações internamente, em sua composição e nas relações existentes entre seus componentes, e no que tange às normas de sociabilidade. Em tal época, tinham o ideal de amparo aos seus membros doentes, inválidos e aos que não tinham como prover seu próprio sustento.

Já na Idade Moderna, com a ideia de Estado Nacional, é retirada da família a ideia de defesa e assistência, de modo que os cidadãos passam a contar, em tese, com a proteção estatal.

Com a Revolução Industrial, a família deixa de ser uma unidade de produção, outrora comandada por seu chefe, e cada membro passa trabalhar nas fábricas. A família que antes produzia os bens para sua subsistência passa a ter como característica a função econômica.

Na Idade Moderna, na pós-revolução, com base em princípios democráticos e da dignidade, não se considera como família apenas a relação entre homem e mulher que se unem pelo matrimônio, mas abarca-se outras formas de união.

Quanto à pós-modernidade, a família modifica seus costumes, seus valores e passa a ser fincada no afeto e valoriza a dignidade humana. Passa a ter novos comportamentos e princípios, sendo que há a independência econômica da mulher, a igualdade e emancipação dos filhos, a possibilidade do divórcio, a questão da afetividade e reciprocidade alimentar, dentre outros, tornando assim a família mais maleável e adaptável às concepções que a humanidade possui.

Logo, coexistem os mais diversos tipos de famílias, como a casamentária, união estável, concubinária, monoparental, homossexual, etc. E convivem as normas e princípios voltados à justiça, a valorização dos direitos humanos, da verdade, da realização pessoal, da busca pelo prazer, deixando-se de lado o conformismo e a 


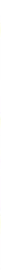

comodidade. Ou seja, a família desprende-se do preconceito e de normas comportamentais pré-estabelecidas e busca a real felicidade.

\section{QUESTÕES ATINENTES À FILIAÇÃO}

No que tange a filiação, esta também é fincada no afeto e convivência, e não tem por fonte apenas os laços consanguíneos, mas sobretudo o amor e a convivência, como exemplo disto, tem-se a filiação socioafetiva.

Recentemente, ante as transformações históricas, culturais e sociais, o direito de família foi seguindo seus próprios rumos, adaptando-se a realidade apresentada, não tendo mais o caráter canonista, dogmático e intocável, havendo liberdade quanto à manutenção ou desfazimento da relação conjugal.

A filiação é uma “[...] relação jurídica decorrente do parentesco por consanguinidade ou outra origem, estabelecida particularmente entre os ascendentes e descendentes de primeiro grau", de acordo com Tartuce (2018, p. 792). Ou seja, a filiação é uma relação jurídica que ocorre entre pais e filhos, cuja origem pode ser consanguínea ou não, como a afetiva.

No que tange à prova da filiação, se faz por meio de certidão do termo de nascimento registrada no Registro Civil, ou pela extração de material genético dos pais (teste de DNA).

O artigo 1.605 do Código Civil dispõe que a filiação pode ser provada por qualquer modo admissível em direito: "I- quando houver começo de prova por escrito, proveniente dos pais, conjunta ou separadamente; II- quando existirem veementes presunções resultantes de fatos já certos”.

Somados a esses meios de prova a posse de estado de filho que, apesar de não ter previsão expressa no Código Civil, é amplamente aceita na doutrina e na jurisprudência pátria, tendo por fundamento o artigo 1.593 que afirma: "O parentesco é natural ou civil, conforme resulte de consanguinidade ou outra origem".

A paternidade socioafetiva funda-se na posse do estado de filho, pressupondo a comprovação de três requisitos, quais sejam: a reputação, o tratamento e o nome. Sobre o conceito de paternidade socioafetiva, veja-se:

Situações há em que a filiação é, ao longo do tempo, construída com base na socioafetividade independentemente do vínculo genético, prevalecendo em face da própria verdade biológica. Estamos, pois, a 


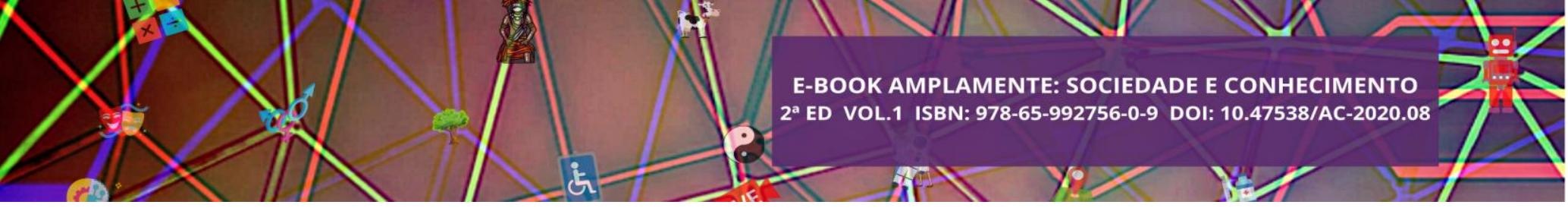

tratar da paternidade ou maternidade sociafetiva (GAGLIANO; PAMPOLHA FILHO, 2018, p. 629).

Logo, exige-se a comprovação da posse de estado de filho no processo de reconhecimento da paternidade ou maternidade socioafetiva, independentemente da existência de vínculo genético com outrem.

\section{OS EFEITOS ORIUNDOS DA MULTIPARENTALIDADE}

O Código Civil ao tratar das relações de parentesco afirma no artigo 1.593 que "O parentesco é natural ou civil, conforme resulte de consanguinidade ou outra origem". Assim, percebe-se que o legislador não deu prevalência ao critério biológico, deixando a cláusula genérica "outra origem" para abarcar novas formas de parentesco além do consanguíneo.

Tendo em conta essa cláusula aberta deixada pelo legislador, a doutrina bem como a jurisprudência vem reconhecendo que uma pessoa pode ter vínculos parentais, não somente um, aquele tradicional, originado dos laços de sangue.

Diante disso, existe a possibilidade de se ter mais de um vínculo paterno. São diversas as formas pelas quais isso pode acontecer, mas "a ocorrência mais corriqueira, sem dúvida, se dá por meio do vínculo de paternidade ou maternidade socioafetiva, quando constituído sem a exclusão dos pais biológicos" (SCHREIBER; LUSTOSA, 2016, p. 852).

Nesse sentido, o Supremo Tribunal Federal no julgamento do Recurso Extraordinário no 898060/SC, em Repercussão Geral, sob relatoria do Ministro Luiz Fux (julgado em 21 e 22/09/2016, Info 840), discutiu à luz do artigo 226, caput, CF/88, a prevalência da paternidade socioafetiva em detrimento da biológica, e fixou a seguinte tese: “A paternidade socioafetiva, declarada ou não em registro público, não impede o reconhecimento do vínculo de filiação concomitante baseado na origem biológica, com os efeitos jurídicos próprios”. Assim, se determinada pessoa foi registrada e manteve vínculo com alguém que, supostamente, era seu pai, mas depois descobre que seu pai biológico é outro, tal situação não impede que o filho postule o reconhecimento da paternidade biológica, bem como os direitos oriundos dessa relação, sem prejuízo da manutenção da paternidade socioafetiva que perdurou.

Da análise do julgamento proferido pelo STF, podem-se extrair as seguintes conclusões: o Supremo reconhece a existência da multiparentalidade, e a paternidade 


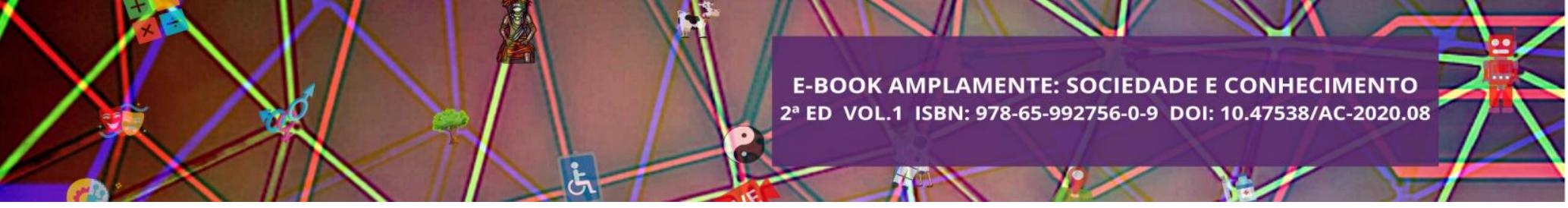

socioafetiva, não sendo esta inferior à paternidade biológica, ambas podem existir concomitantemente.

Não se exige para caracterização da paternidade o prévio registro em cartório, mas o convívio diário, a afetividade; o registro civil é formalidade legal, que pode ser desconstituída em caso vício de consentimento (erro ou dolo), como vem decidindo os tribunais superiores.

Também pode acontecer a seguinte situação: o filho ter sido registrado pelo pai biológico, mas acaba por postular o reconhecimento da paternidade socioafetiva, em virtude de ter convivido integralmente com outro indivíduo, a quem denomina e reconhece como pai.

Nesse sentido, o Tribunal de Justiça do Distrito Federal (TJ-DF) decidiu:

\section{CIVIL E PROCESSUAL CIVIL. AÇÃO DE RECONHECIMENTO DE PATERNIDADE. SENTENÇA EXTRA PETITA. INOCORRÊNCIA. PATERNIDADE BIOLÓGICA. EXAME DE DNA. PATERNIDADE REGISTRAL E AFETIVA. MELHOR INTERESSE DO MENOR. MULTIPARENTALIDADE. [...] 3. O mero vínculo genético, por si só, não é suficiente para afastar a paternidade de cunho afetiva. Em algumas situações, a filiação afetiva pode-se sobrelevar à filiação biológica, em razão da relação de carinho e afetividade construída com o decorrer do tempo entre pai e filho. [...] 6. O conceito de multiparentalidade exsurge, pois, como uma opção intermediária em favor do filho que ostenta vínculo de afetividade com o pai afetivo e com o pai registral, sem que se tenha de sobrepor uma paternidade à outra. [...]. 7. Rejeitou-se a preliminar. Negou-se provimento aos apelos (TJ- DF, Apelação Cível ${ }^{\circ}$ 20130610055492, $3^{\text {a }}$ Turma Cível, Publicado no DJE: 16/02/2016, Julgamento 03/02/2016, Relator Flavio Rostirola). (grifo nosso)}

Impende destacar que a decisão proferida pelo TJ-DF supracitada teve como fundamento a dignidade da pessoa humana e baseou-se no princípio do melhor interesse.

Vê-se, então, que os tribunais brasileiros estão atentos às novas formas de filiação, considerando os laços de afetividade, dando prevalência ao indivíduo que se interessa em exercer, concretamente, o papel de genitor, cuidando, sustentando, educando, ainda que não possua vínculo biológico. A doutrina pátria também reconhece essa possibilidade.

Não mais se pode dizer que alguém só pode ter um pai e uma mãe. Agora é possível que pessoas tenham vários pais. Identificada a pluriparentalidade, é necessário reconhecer a existência de múltiplos vínculos de filiação. Todos os pais devem assumir os encargos 


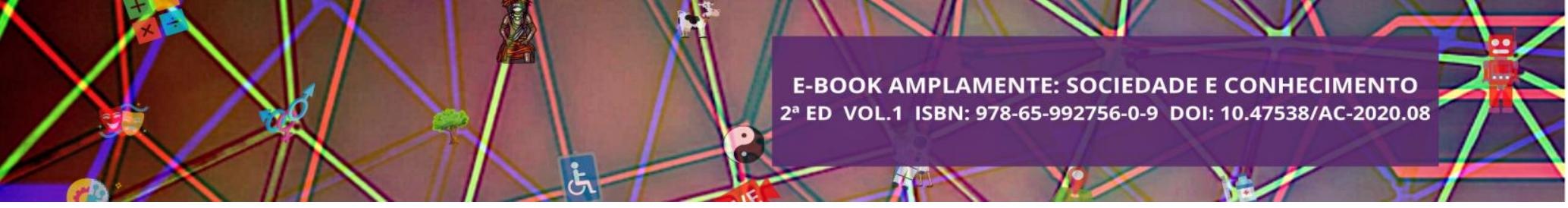

decorrentes do poder familiar, sendo que o filho desfruta de direitos com relação a todos. Não só no âmbito do direito das famílias, mas também em sede sucessória [...] (DIAS, 2017, p. 370).

Por essa razão, atualmente, é viável que uma pessoa tenha dois pais: um biológico e outro socioafetivo, podendo desfrutar dos direitos inerentes à filiação.

Assim, pode-se apontar como reflexo da multiparentalidade "o nome", por conseguinte, do registro de nascimento, o qual deve retratar a realidade. Logo, se a multiparentalidade é reconhecida, uma pessoa pode ter em seu registro o nome de mais de um pai.

A respeito, o Tribunal de Justiça do Rio Grande do Sul, na Apelação Cível no 70064909864 RS, de relatoria do Desembargador Alzir Felippe Schmitz (Oitava Câmara Cível, julgado em 16/07/2015) determinou a alteração do registro civil de infante para constar o nome do pai socioafetivo, além do nome do pai biológico, haja vista a inexistência de proibição legal. Também se determinou o patronímico do pai socioafetivo ao autor ao patronímico da menor, sem prejuízo da manutenção do patronímico do pai biológico.

Outro efeito jurídico é no tocante aos alimentos. Consoante o Enunciado $n^{\circ} 341$ da IV Jornada de Direito Civil: "Para os fins do art. 1.696, a relação socioafetiva pode ser elemento gerador de obrigação alimentar”.

Uma vez comprovado o binômio necessidade-possibilidade exigido pelo art. 1.694, $\S 4^{\text {o }}$ do Código Civil, o filho pode pleitear alimentos de ambos os pais (registral e socioafetivo, biológico e socioafetivo).

Outro efeito decorrente do reconhecimento da multiparentalidade é o direito a herança. Logo, o filho será herdeiro necessário dos dois pais, sendo-lhe garantida a metade dos bens da herança, isto é, a legítima, na forma dos artigos 1.845 e 1.846, ambos do Código Civil.

O exercício do poder familiar, que é o poder atribuído aos pais quanto à criação dos filhos enquanto menores, é mais um efeito decorrente da multiparentalidade, e implica diversas atribuições aos pais, nos termos do artigo 1.630 do Código Civil, como cuidar da educação dos filhos, exercer a guarda, conceder ou não consentimento para o filho casar, para viajar ao exterior ou mudar a residência permanente para outro local, nomear-lhes tutor, entre outras funções inerentes ao convívio familiar. 


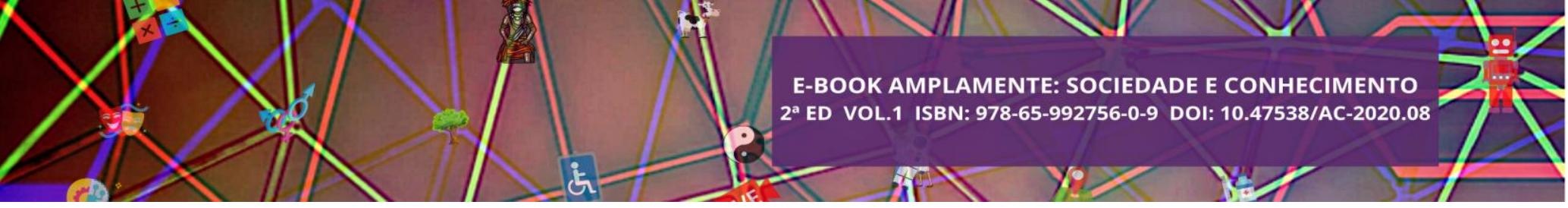

Por fim, a questão previdenciária é também reflexo da multiparentalidade, ou seja, o filho será beneficiário de ambos os pais, pois o artigo 16, I, da Lei 8.213/91 prevê que:

Art. 16 - São beneficiários do Regime Geral de Previdência Social, na condição de dependente do segurado:

I- o cônjuge, a companheira, o companheiro e o filho não emancipado, de qualquer condição, menor de 21 (vinte e um) anos ou invalido ou que tenha deficiência intelectual ou mental ou deficiência grave. [...]

O filho é dependente de $1^{\mathrm{a}}$ classe, dispensando a comprovação de dependência econômica para gozar dos benefícios previdenciários. Mas restará a norma previdenciária definir sobre a cumulação dos benefícios diante da existência de dois pais para um só indivíduo.

Ante o exposto, é notório que não se pode fechar os olhos para a realidade, tendo em conta que novas formas de família foram surgindo e, hoje, podem coexistir diversos vínculos parentais, decorrendo daí um conjunto de direitos e deveres.

\section{CONSIDERAÇÕES FINAIS}

Como visto, o estado de filiação consiste em um vínculo jurídico que liga o pai ao filho, implicando um conjunto de direitos e deveres, podendo decorrer da lei ou de outra origem.

A multiparentalidade é instituto recente no direito de família, e se refere à existência de mais de um vínculo paternal, e geralmente ocorre quando uma pessoa possui um pai biológico e outro socioafetivo.

Viu-se que o parentesco socioafetivo tem origem na posse de estado de filho, que exige a comprovação de alguns elementos: a reputação, o tratamento ou nome. Em resumo: a convivência familiar que manifesta a existência da filiação.

Nessa esteira, o reconhecimento da paternidade socioafetiva não desconfigura $o$ vínculo biológico existente com outro pai. Atualmente, não há prevalência de um desses tipos de filiação, pelo contrário, é possível que os dois sejam reconhecidos e coexistam.

Assim, os principais efeitos decorrentes dessa situação jurídica são: alteração do nome, por conseguinte, o registro civil, exercício do poder familiar por ambos os pais, direitos sucessórios e previdenciários, bem como direito aos alimentos. 


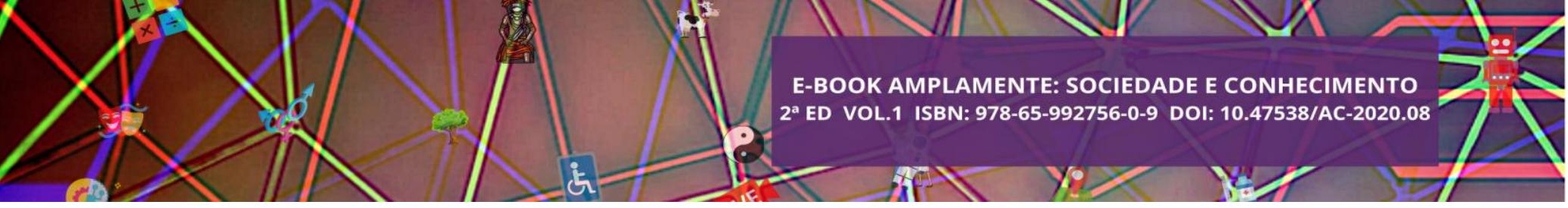

Destarte, conclui-se que, conferir validade a este instituto efetiva a dignidade da pessoa humana, preserva os direitos fundamentais das pessoas envolvidas, bem como promove o princípio da afetividade que é marca principal no seio familiar.

\section{REFERÊNCIAS}

BRASIL. Constituição da República Federativa do Brasil de 1988. Disponível em: <http://www.planalto.gov.br/ccivil_03/constituicao/ConstituicaoCompilado.htm>. Acesso em: 07 Jun. 2020.

. Lei no 8.213, de 24 de julho de 1991. Dispõe sobre os Planos de Benefícios da Previdência Social e dá outras providências. Disponível em:

<http://www.planalto.gov.br/ccivil_03/leis/L8213cons.htm>. Acesso em: 07 Jun. 2020.

. Lei no 10.406 de 10 de Janeiro de 2002. Código Civil. Disponível em:

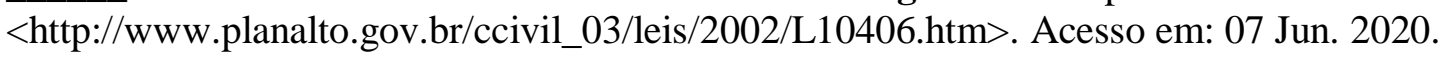

. IV Jornada de Direito Civil - Enunciados aprovados. Disponível em:

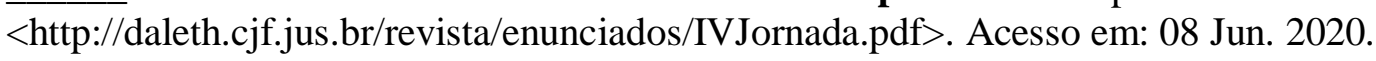

DIAS, Maria Berenice. Manual de Direito das Famílias. 12. ed. São Paulo: Revista dos Tribunais, 2017.

GAGLIANO, Pablo Stolze; PAMPOLHA FILHO, Rodolfo. Novo curso de direito civil: direito de família. 20. ed. São Paulo, Saraiva: 2018.

GONÇALVES, Carlos Roberto. Direito civil brasileiro: direito de família. vol. 6. 16. ed. São Paulo: Saraiva, 2018.

JUSBRASIL. TJ-DF - Apelação Cível: APC 20130610055492. Disponível em: <https://tjdf.jusbrasil.com.br/jurisprudencia/305579722/apelacao-civel-apc-20130610055492>. Acesso em: 10 Jun. 2020.

TJ-RS - Apelação Cível: AC 70064909864 RS - Inteiro Teor. Disponível em: <https://tj-rs.jusbrasil.com.br/jurisprudencia/211663570/apelacao-civel-ac-70064909864rs/inteiro-teor-211663580>. Acesso em: 0 Jun. 2020.

SCHREIBER, Anderson. LUSTOSA, Paulo Franco. Efeitos jurídicos da multiparentalidade. Legal effects of multiparentality. Pensar, Fortaleza, v. 21, n. 3, p. 847873, set./dez. 2016.

SUPREMO TRIBUNAL FEDERAL. Acompanhamento Processual: RE 898060.

Disponível em:

<http://www.stf.jus.br/portal/jurisprudenciarepercussao/verAndamentoProcesso.asp?inciden te $=4803092 \&$ numeroProcesso $=898060 \&$ classeProcesso $=R E \&$ numeroTema $=622>$. Acesso em: 13 Jun. 2020.

TARTUCE, Flávio. Direito civil: direito de família. vol. 5. 14. ed. Rio de Janeiro: Forense, 2018. 


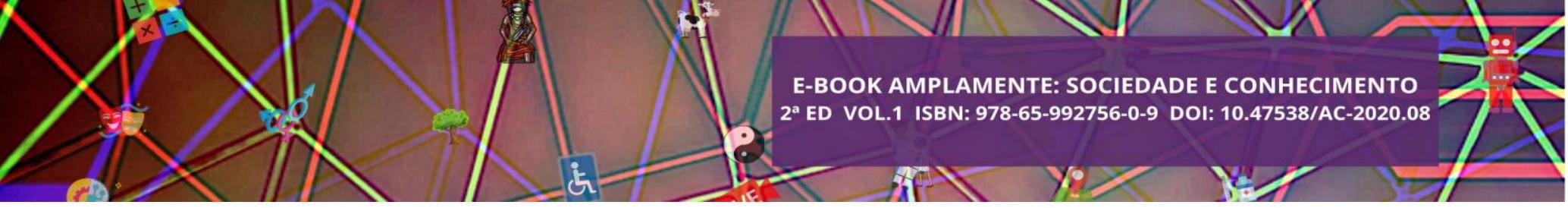

dos esportistas e como este, além de esporte se caracteriza como um espaço de enfoque social, e educacional (RUBIO, 1999).

Brandão e Lordelo, (2017) afirmam em seu artigo realizado com um grupo de meninas pequenas participantes de uma escola de balé, que a relação com o esporte é geralmente caracterizada pelo viés da sociabilidade, pela importância do aprimoramento e progressão de nível, além do anseio com o mundo do espetáculo.

Já, Carbonera e Carbonera (2008) trazem a importância das emoções e sentimentos na dança voltada para a questão infantil, na qual a criança necessita ter a sensação de alegria ao movimentar-se, e expressar por meio desses movimentos sua motivação e expressões mais francas, sentimentos reprimidos, através da experiência da dança.

O balé surgiu na França, aproximadamente há mais de trezentos anos, era praticado na corte do rei Luiz XIV (HACKETT, 1990). O balé clássico não é um esporte considerado de fácil execução, sendo que este exige prática constante e muita disciplina; entretanto, pode apresentar-se muito prazeroso quando se tem a oportunidade de, por exemplo, apresentar para amigos e familiares (HACKETT, 1990).

Logo, verifica-se que tal processo de compreender, analisar e estudar as influências do esporte no comportamento do indivíduo é crucial para a ciência psicológica, o presente trabalho buscou identificar qual a relação do balé como esporte para um grupo de crianças pequenas em uma escola privada no oeste da Bahia.

\section{MÉTODO}

Este estudo é baseado em um relato de experiência, voltado a dois encontros realizados em uma escola de balé privada de balé no oeste da Bahia, com cinco alunas. O mesmo é pré-requisito parcial de avaliação na disciplina de Psicologia e Esporte. As entrevistas ocorreram em horário parcial de aula de balé das alunas, sendo a turma escolhida de acordo com a disponibilidade do horário dos acadêmicos e escola em conjunto.

Nos encontros as pautas trazidas foram ansiedade, expectativas, técnica de respiração diafragmática e técnica de exposição imaginária, além do trabalho expositivo visual acerca de bailarinas que se apresentam como diferentes do padrão comum de bailarinas. Trataremos no estudo o termo alunas, visto que não havia participantes do 


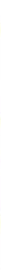

sexo masculino nesta turma. Durante a realização das atividades foram utilizadas dinâmicas, papel, caneta e fotos, e principalmente, círculo de conversa com elas afim de compreender suas percepções acerca do assunto.

\section{DESENVOLVIMENTO}

No dia do primeiro encontro com as alunas do balé, os estagiários se deslocaram até a escola, para observar o comportamento delas. Os estagiários chegaram no início da aula e ficaram afastados das alunas para fazer a observação, nela pode-se observar que a professora durante a aula faz a todo momento intervenções sobre a performance das alunas, corrigindo de forma incisiva, quando necessário, mas também a todo o momento elogiava quando via alguma evolução ou quando os passos eram feitos com maestria. Essa postura incisiva sobre o comportamento das alunas, visando corrigir e aperfeiçoar comportamentos já é descrito na literatura da psicologia do esporte como fator decisivo, para que o competidor de alto rendimento ou não, alcance seus objetivos (BELINELI, 2013).

Ao final da aula, os estagiários reuniram as alunas no meio do salão de dança e se apresentaram como discentes do curso de psicologia de uma faculdade da cidade, e foram logo questionadas se conheciam o que um psicólogo fazia, o que logo foi respondido pela maioria, de forma positiva.

Logo após foi solicitado que as alunas se apresentassem, mas antes de informar o nome e o porquê de estarem fazendo balé deveriam fazer um passo que gostassem. $\mathrm{E}$ assim foi feito, cada aluna anterior a informar os dados fez o passo o qual foi reproduzido pelos estagiários, favorecendo assim o início dessa relação, gargalhadas surgiram devido à falta de conhecimento prático sobre essa atividade esportiva por parte de alguns estagiários.

As respostas sobre o porquê da pratica do balé se restringiram a "eu sempre quis, e pedi para os meus pais para fazer o ballet" e também "minha mãe queria que eu fizesse", as que responderam que a escolha foi por parte da mãe, foram questionadas se gostam efetivamente da pratica e o que acharam dessa atitude de suas mães, elas foram enfáticas em dizer que amam e que ficam felizes em as mães terem às colocado no balé. Não é de se estranhar que algumas das respostas se voltam ao contexto familiar, já a maioria dos teóricos trazem que os pais têm papel decisivo na entrada da criança no 


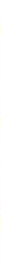

esporte, como também no que toca a manutenção da permanência da mesma no esporte (GABARRA; RUBIO; ÂNGELO, 2009).

Após as apresentações, uma dinâmica foi realizada, nela as meninas tiveram que escrever em um papel o que sentiam durante a pratica do balé e se o medo de alguma forma era presente, e estes papeis foram trocados entre elas mesmas e elas teriam que dizer se compartilhavam daquele mesmo sentimento e o que pensavam sobre aquilo.

Algumas das respostas que sucederam foram "feliz e animada", "fico com as mãos suadas durante as apresentações", "tenho medo de cair" e "alegre e feliz", elas foram questionadas sobre essas respostas, e foi observado certo receio de cometer erros durante as apresentações nos festivais, isso gera nervosismo nelas, o que não de se estranhar, já que segundo Lavoura e Machado (2008) estudos demonstram que o medo é um estado emocional básico, fundamental e está frequentemente presente em esportistas. Isso faz com que elas não apresentem com toda a eficiência durante suas apresentações devido o pensamento estar envolvido nesses medos. Ao final da atividade os estagiários informaram, que brevemente, haveria um novo encontro com elas e se despediram delas, bem como da professora.

No dia 28 de maio de 2019 foi realizada a segunda intervenção com cinco meninas de uma escola de ballet. A primeira atividade foi desenvolvida encima da demanda trazida pelas alunas na intervenção anterior, onde as mesmas relataram se sentirem ansiosas antes da apresentação que acontece todo fim de ano e exporem também pensamentos de fracasso antes desta apresentação, como "eu acho que vou cair no palco", “ eu não vou conseguir fazer os passos”, “eu vou errar".

A técnica inicialmente aplicada foi a Respiração Diafragmática, pois segundo Rangé (2011) é um processo psicofisiológico que envolve respostas somáticas e autônomas, informes verbais de tranquilidade e bem-estar e estado de aquiescência motora. É um processo de aprendizagem que inclui o controle da respiração em situações estressantes e o reconhecimento e posterior relaxamento da tensão muscular. Apenas uma das alunas relatou que conhecia a técnica porque a sua mãe dava aula de pilates e a sua vó com sua tia usavam para dar aula de Ioga, porém ela ainda não a tinha utilizado.

Nesta técnica, de acordo com Vera e Vila (1996) a pessoa aprende padrões de baixas taxas de respiração; inspiração e expiração profundas e amplas e respiração diafragmática, por consequência esse padrão estimula o controle parassimpático sobre o 


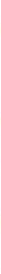

funcionamento cardiovascular, alterando o ritmo cardíaco associado à fase inspiratória e expiratória de cada ciclo respiratório.

A segunda técnica realizada foi a Reestruturação Cognitiva e em seguida a Exposição Imaginária. Segundo Mululo et al (2009), a técnica de Reestruturação Cognitiva ajuda o/a paciente a identificar os pensamentos automáticos distorcidos, questionar as bases desses pensamentos à luz das evidências reais (via questionamento socrático ou experimentos comportamentais) e construir alternativas menos tendenciosas e padronizadas. Assim, nós a lembramos das suas falas na intervenção anterior sobre seus pensamentos expostos antes da apresentação final de todos os anos.

Logo em seguida aplicamos a técnica de Exposição Imaginária que, de acordo com Mululo et all (2009) visa expor o paciente às situações ansiogênicas gradativamente por uma hierarquia, criada com o paciente, até que a ansiedade naturalmente comece a diminuir (habituação). Pode ser feita por meio da imaginação ou ao vivo. Então pedimos para as alunas fecharem os olhos e começassem a pensar no dia da apresentação e logo em seguida pensassem nos passos que são realizados e com excelência porque já ensaiaram por um ano, então elas já sabem, então precisam apenas manter a confiança nelas mesmas e pensarem que já conseguiram.

Após a utilização dessas técnicas nos apresentamos a elas um questionamento: "O que a pessoa precisa para ser bailarina?". Apenas duas responderam e com as seguintes palavras: "Comportada" e "bonita". Logo em seguida mostramos imagens de bailarinas negras, com deficiência visual, plus size e uma com o padrão social inserido: a branca e magra. Elas ficaram impressionadas e demostraram bastante interesse em saber mais sobre todas essas bailarinas, em especial das bailarinas com deficiência visual, pois as mesmas ficaram se questionando como elas fazem apresentações e aprendem os passos sem enxergar.

Para Sassaki (2010), a inclusão social é parte importante de uma sociedade, pois através dela, os indivíduos aprendem a lidar, respeitar e conviver com as diferenças entre as pessoas. Muitas vezes ao deparar-se com o diferente, novas experiências são vividas e novos conhecimentos são adquiridos. Por esse motivo, foi de grande importância levar esses modelos para a turma, visando a inclusão no esporte.

Os autores Junior e Caputo (2014) afirmam que a inclusão social é um processo que contribui para a construção de uma nova sociedade através de transformações nos ambientes físicos e na maneira de pensar das pessoas. Então, no final dessa atividade 


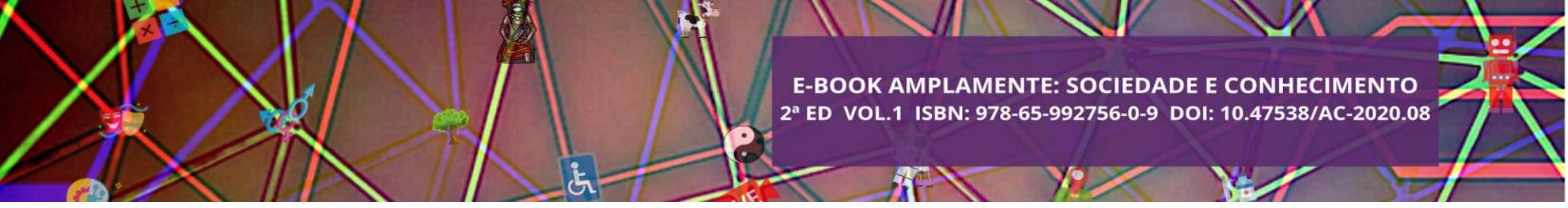

nós pedimos um feedback com a mesma pergunta com que começamos e elas relatam uma completando a frase da outra que: "para ser bailarina não precisa ser branca", "não precisa ser magra" e "não precisa enxergar", onde encerramos falando a elas que para ser bailarina é preciso apenas ter o desejo e interesse na dança, não dando importância aos padrões inseridos pela sociedade.

\section{CONSIDERAÇÕES FINAIS}

A psicologia do esporte, embora mais comumente ligada a questão de esportes coletivos, ou de esportes individuais de alta performance como esportistas profissionais e afins, também trabalha com esportes individuais e de atletas não profissionais, como praticantes do esporte por hobby ou por alguma caraterística particular subjetiva que lhe causa interesse e o mantêm na pratica deste (MATIAS; GRECO, 2010). Como o balé que, embora praticado coletivamente com uma turma, cada bailarina é examinada individualmente pela professora ou professor.

Foi observado que o balé como dança e esporte no grupo no qual foi realizado os encontros, contribui para o viés da sociabilidade, da interação das bailarinas umas com as outras, como afirma Brandão e Lordelo (2017) em seu artigo.

Já a dança como inclusão, é um tópico de extrema relevância que deve ser trabalhado não somente no balé com crianças pequenas, mas sim, com todas as categorias e estilos de dança, visto que a dança não se limita as questões corporais somente, mas sim na forma subjetiva que cada um se utiliza para expressar seus movimentos daquilo que sente, fato que foi destacado na fala das meninas que, como analisaram nas imagens, ser bailarina vai além das capacidades físicas, está no sentir e no conjunto de ações que envolvem o esporte, como o espetáculo e a progressão pessoal nos níveis de balé.

Portanto, sugere-se mais estudos na área da psicologia do esporte em conjunto com a dança, visto sua importância na construção pessoal do sujeito, suas características tanto individuais quanto grupais, e suas multifaces interagindo com as subjetividades de cada sujeito.

\section{REFERENCIAS}




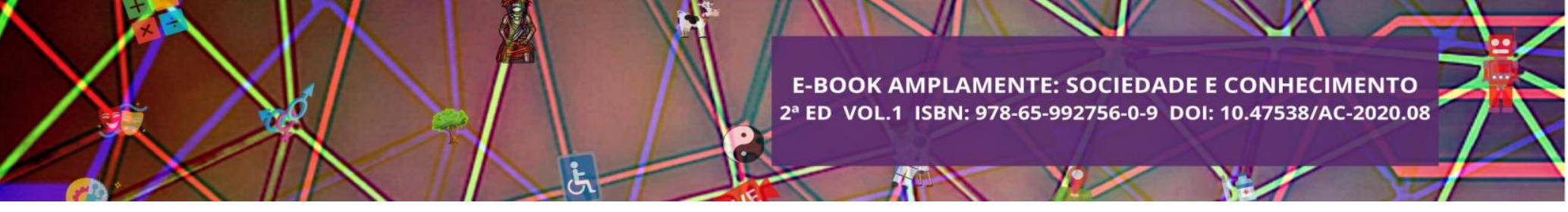

BELINELI, Lays Fernanda. Análise do comportamento e esporte: capacitação comportamental com uso de feedback. 2013. Dissertação (Mestrado em Análise do Comportamento). Universidade Estadual de Londrina, Centro de Ciências Biológicas, Programa de Pós-Graduação em Análise do Comportamento, 2013.

BRANDÃO, Anna Paula; LORDELO, Lia da Rocha. "Significados de atividades extracurriculares para crianças bailarinas". Revista Psicologia Escolar e Educacional, SP, v. 21, n. 3, set/dez. 2017. p. 477-486.

CARBOnERA, Daniele; CARBONERA, Sergio Antonio. A Importância da Dança no Contexto Escolar. 2008. Monografia (Pós-Graduação em Educação Física Escolar). Faculdade Iguaçu - Instituto de Estudos Avançados e Pós-Graduação - ESAP, 2008.

GABARRA, Letícia Macedo; RUBIO, Katia; ÂNGELO, Luciana Ferreira. A psicologia do esporte na iniciação esportiva infantil. Revista Psicologia para América Latina, México, n. 18, nov. 2009.

JUNIOR, Antonio Bernardino Gomes; CAPUTO, Gabriel Alonso. A inclusão social e o esporte na infância: um estudo de caso no centro municipal de educação integrada de Penápolis-SP. 2014. Trabalho de Conclusão de Curso (Graduação em Educação Física). Centro Universitário Católico Salesiano Auxilium - UNISALESIANO, 2014.

LAVOURA, Tiago Nicola; MACHADO, Afonso Antonio. Investigação do medo no contexto esportivo: necessidades do treinamento psicológico. Revista Brasileira de Psicologia do Esporte, São Paulo, v. 2, n.1, jun. 2008. p. 1-28.

\section{MATIAS, C. J. A. DA S.; GREGO. P.J. COGNIÇÃO \& AÇÃO NOS JOGOS} ESPORTIVOS COLETIVOS. Revista Ciências \& Cognição, Minas Gerais, v. 15, n. 1, jan. 2010. pp. 252-271.

MULULO, Sara Costa Cabral; MENEZES, Gabriela Bezerra de; FONTENELLE, Leonardo; VERSIANI, Marcio. Terapias cognitivo-comportamentais, terapias cognitivas e técnicas comportamentais para o transtorno de ansiedade social. Revista Psiquiatria Clínica, São Paulo, v. 36, n. 6, 2009. p. 221-228.

RANGÉ, Bernard. (2011). Psicoterapias Cognitivo- comportamentais: um diálogo com a psiquiatria. Porto Alegre: Artmed. 2011.

RUBIO, Katia. A psicologia do esporte: histórico e áreas de atuação e pesquisa. Revista Psicol. Cien. Prof., Brasília, v. 19, n. 03, 1999. p. 60-69.

SASSAKI, Romeu Kazumi. Inclusão: construindo uma sociedade para todos. Rio de Janeiro: Editora WVA. 2010.

SINGER, R. N. (1993). Sport Psychology: na integrated approach. In: SERPA, S.; ALVES, J.; FERREIRA, V.; BRITO, A. P. (Org). Actas do $8^{\circ}$ Congresso Mundial de Psicologia do Desporto. Lisboa: ISSP, SPD, FMH. pp. 130-145.

Vera, M. N. e Vila, J. (1996). Técnicas de relaxamento. Em Caballo, V. E. (Ed.). Manual de técnicas de terapia e modificação do comportamento (pp. 147-166). São Paulo: Santos. 


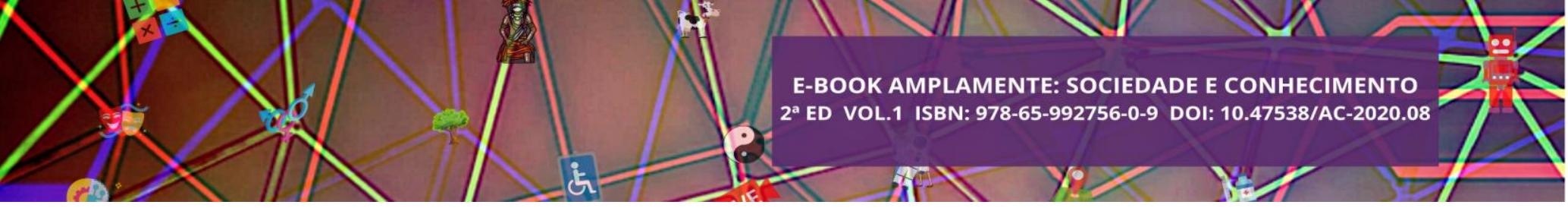

sociedade educacional, onde para atender às demandas de mercado adotou ferramentas de auxílio ao processo de aprendizado, como a utilização das mais diversas mídias.

A utilização dessas ferramentas como suporte às aulas contribuiu para o desenvolvimento de ambientes capazes de ultrapassar os limites das salas de aula. Tais ambientes são comumente denominados de ambientes virtuais de aprendizagem (AVAs).

Com a crescente demanda o desenvolvimento de novos AVAs cresceu significativamente. Neste contexto, encontra-se o Sistema Integrado de Gestão Acadêmica de Atividades (SIGAA), desenvolvido pela Universidade Federal do Rio Grande do Norte (UFRN) em 2006, o qual foi adquirido por mais de vinte Instituições Federais de Ensino Superior (IFES), dentre eles a Universidade Federal Rural da Amazônia (UFRA).

O SIGAA UFRA é utilizado por discentes, docentes, técnicos administrativos, os quais realizam diferentes funções. Logo, o sistema oferece interfaces diferenciadas, partindo deste ponto, a avaliação de usabilidade deste sistema é de grande importância, tendo em vista seus impactos para a comunidade acadêmica. Assim, o objetivo deste trabalho é propor melhorias à interface do SIGAA UFRA, a partir de uma avaliação heurística. Este artigo está organizado em 5 seções: na seção 2, descrevemos aspectos relacionados à Ambientes Virtuais de Aprendizagem, na seção 3, aspectos de Usabilidade. Na seção 4 apresentamos a metodologia da pesquisa, na seção 5, os resultados e na seção 6 as considerações finais.

\section{AMBIENTES VIRTUAIS DE APRENDIZAGEM}

$\mathrm{O}$ avanço da tecnologia e o surgimento da internet transformaram o modo do ensino-aprendizagem existente no mundo até a primeira metade do século XX. O uso do computador e da internet tornaram-se ferramentas essenciais no processo educativo da sociedade moderna.

A necessidade de desenvolver novas técnicas para acompanhar as exigências do mercado de trabalho possibilitando às pessoas que não possuíam condições, por vários motivos, de comparecer fisicamente num ambiente de ensino presencial, fez com que surgisse a Educação a Distância (EaD).

O Decreto $N^{\circ}$ 5.622, de 19 de Dezembro de 2005 caracteriza EaD como: 


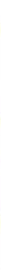

Modalidade educacional na qual a mediação didático-pedagógica nos processos de ensino e aprendizagem ocorre com a utilização de meios e tecnologias de informação e comunicação, com estudantes e professores desenvolvendo atividades educativas em lugares ou tempos diversos.

No histórico da $\mathrm{EaD}$ existem três gerações, a primeira geração é chamada de educação por correspondência, a segunda geração é conhecida como teleducação ou telecursos e a terceira geração é a geração dos ambientes interativos, a qual é a mais usada nos dias atuais.

A terceira geração da EaD adequa-se às necessidades da sociedade, utilizando recursos digitais (som, vídeo, imagem, texto) em ambientes virtuais disponíveis na internet para o processo de ensino-aprendizagem, chamados de Ambientes Virtuais de Aprendizagem (AVAs).

Os AVAs são sistemas de ensino-aprendizagem à distância, utilizados por meio da internet, os quais permitem a disponibilização de recursos tecnológicos educacionais, interação entre atores, avaliação e suporte. Tem como objetivo a melhoria do ensinoaprendizagem, podendo ser utilizado além dos limites da sala de aula.

Almeida (2003) define AVAs como sistemas computacionais disponíveis na internet, destinados ao suporte de atividades mediadas pela TIC os quais permitem interações entre múltiplas mídias e recursos. Sob o mesmo ponto de vista, para Cortelazzo (2009, p. 117) AVAs "são espaços virtuais de compartilhamento de conhecimento e interação, mediados pelo computador com o auxílio da Internet”.

A difusão da internet permitiu a criação de AVAs, os quais possibilitam a comunicação independente do lugar em que os usuários se encontram e do tempo, podendo ser de forma síncrona (tempo real) ou assíncrona (tempos diferentes).

Um exemplo de AVA, o Sistema Integrado de Gestão de Atividades Acadêmicas (SIGAA), é um sistema criado em 2006 pela Universidade Federal do Rio Grande do Norte (UFRN), possui código aberto, porém é necessário comprar uma licença para utilizar (software comercial).

O SIGAA é um sistema utilizado por várias universidades e institutos federais do Brasil criado com o propósito de informatizar os procedimentos da área acadêmica e é dividido nos seguintes módulos: graduação, pós-graduação (stricto e lato sensu), ensino técnico, ensino médio e infantil, submissão e controle de projetos e bolsistas de pesquisa, submissão e controle de ações de extensão, submissão e controle dos projetos 


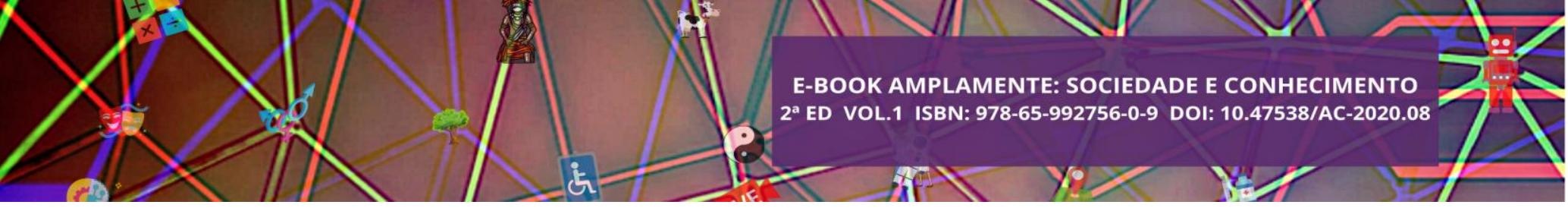

de ensino (monitoria e inovações), registro e relatórios da produção acadêmica dos docentes, atividades de ensino a distância e um ambiente virtual de aprendizado denominado Turma Virtual (SINFO-UFRN).

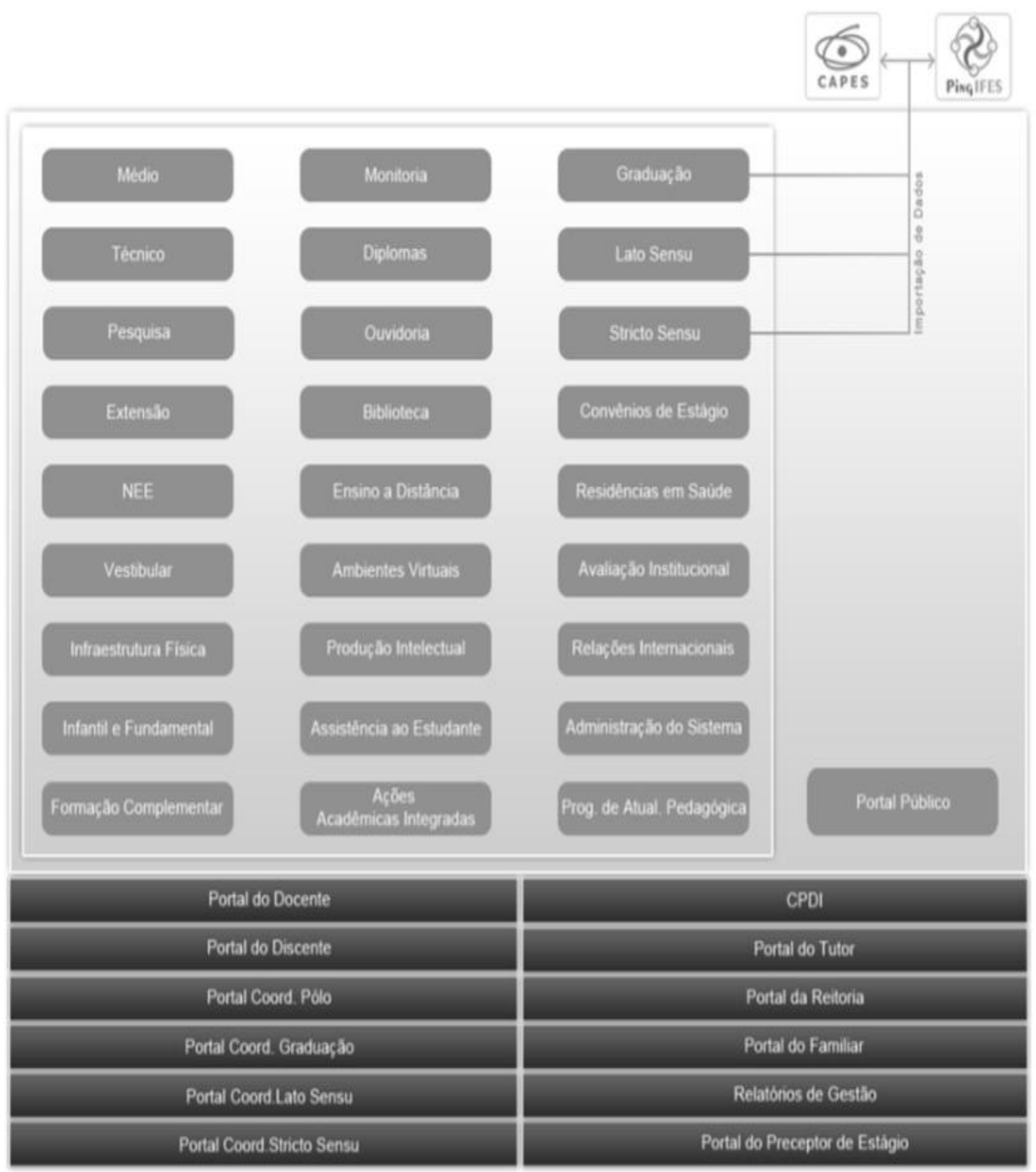

Figura 1. Módulos do SIGAA

O SIGAA ainda oferece uma vasta lista de funcionalidades para todos os tipos de usuários. No portal do discente, o usuário pode acessar operações relativas ao ensino, pesquisa e extensão, se inscrever para ser fiscal do vestibular, participar de fóruns do 


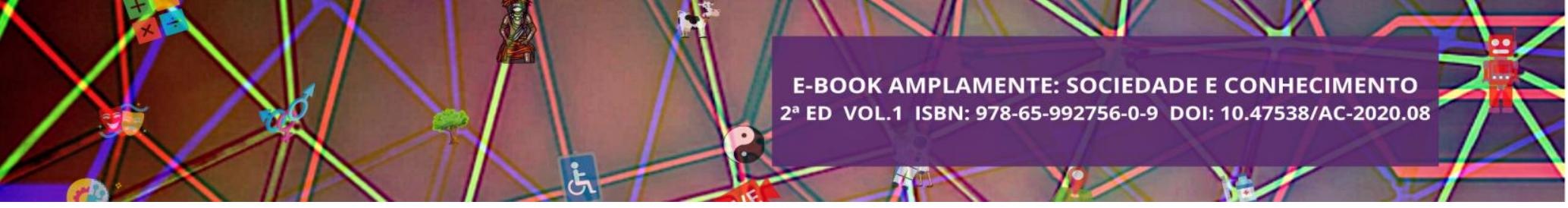

seu curso, bem como criá-los, solicitar bolsa, auxílio-alimentação e moradia, entre outros (SINFO, 2016).

\section{USABILIDADE}

A tecnologia trouxe uma nova forma de ensinar e aprender, logo esta não pode se tornar uma barreira ao processo. Entretanto, existem problemas de interface que afetam de modo significativo as ações executadas.

De acordo com a Internacional Standard Organization (ISO/IEC) podemos apontar duas definições de usabilidade:

- $\quad$ ISO 9126 “A usabilidade refere-se à capacidade de um software de ser compreendido, aprendido, utilizado e ser atrativo para o utilizador, em condições específicas de utilização";

- $\quad$ ISO 9241 "Usabilidade é a efetividade, eficiência e satisfação com a que um produto permite atingir objetivos específicos a utilizadores específicos num contexto de utilização específico".

Nielsen (1993) diz que a usabilidade é um atributo de qualidade que avalia quão fácil uma interface é de usar, ou a medida de qualidade da experiência de um usuário ao interagir com um produto ou um sistema. Adicionalmente, Rebelo (2009) afirma que "usabilidade é o fator que garante ao usuário a facilidade de uso". Podemos concluir que a usabilidade está intrinsecamente associada à utilização de métodos e técnicas que facilitem o processo de utilização e interação de produtos, ainda em sua fase de elaboração (criação).

Segundo Zaharias e Poylymenakou (2009), o aumento na diversidade de usuários, os avanços tecnológicos e mudanças radicais nas tarefas de aprendizagem apresentam desafios significativos e possibilitam a definição do contexto do uso de aplicações de aprendizagem.

Partindo da necessidade de existirem aplicações de aprendizagem que possibilitem a melhoria do processo educativo surgem os AVAs - ambientes interativos com ferramentas para ensinar, aprender, comunicar e gerenciar materiais - onde a usabilidade é um dos aspectos mais importantes a ser considerado para evitar a confusão nos usuários, permitindo que a interação seja natural e intuitiva.

Logo, levando em consideração que o ambiente precisa ser "amigável” aos olhos dos usuários. Preece, Rogers e Sharp (2005, p. 339) afirmam que "a avaliação é 


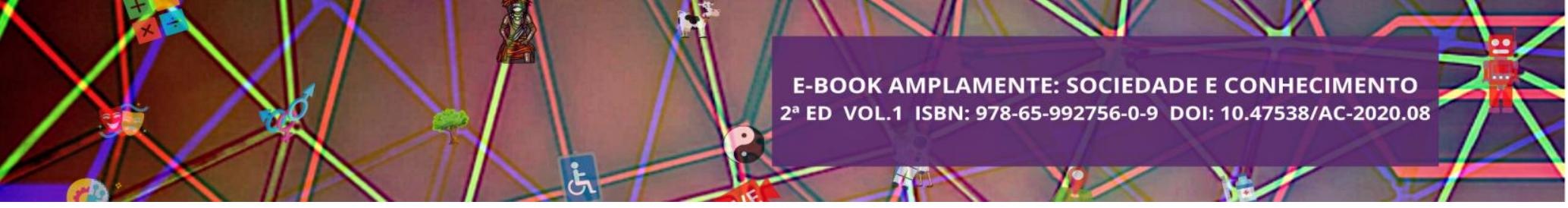

necessária para a certificação de que os usuários podem vir a utilizar o produto e apreciá-1o”.

Segundo Nielsen (1993, citado por LIMA, 2007), usabilidade está relacionada com facilidade de aprendizado, eficiência, facilidade de memorização, quantidade de erros e satisfação do usuário.

A usabilidade é dividida nas seguintes metas:

- Ser eficaz no uso (eficácia);

- Ser eficiente no uso (eficiência);

- Ser segura no uso (segurança);

- Ser de boa utilidade (utilidade);

- Ser fácil de aprender (learnability);

- Ser fácil de lembrar como se usa (memorability).

Eficácia é uma meta bastante geral e se refere a quanto um sistema é bom em fazer o que se espera dele.

Eficiência se refere à maneira como o sistema auxilia os usuários na realização de suas tarefas.

Segurança implica proteger o usuário de condições perigosas e situações indesejáveis.

Utilidade refere-se à medida na qual o sistema propicia o tipo certo de funcionalidade, de maneira que os usuários possam realizar aquilo de que precisam ou que desejam.

Capacidade de aprendizagem (learnability) refere-se a quão fácil é aprender a usar o sistema.

Capacidade de memorização (memorability) refere-se à facilidade de lembrar como utilizar um sistema, depois de já se ter aprendido como fazê-la - algo especialmente importante para sistemas interativos que não são utilizados com muita frequência.

Faz-se necessário definirmos métodos para avaliar a usabilidade desses sistemas, segundo González et al. (2009), os métodos de avaliação de usabilidade são diferentes de outros métodos porque revelam algo sobre a interação entre o usuário e a coisa: algum aspecto de eficácia, eficiência e satisfação. Para se ter uma avaliação positiva, o usuário deve ser capaz de completar a tarefa (eficácia), fazer somente o esforço 


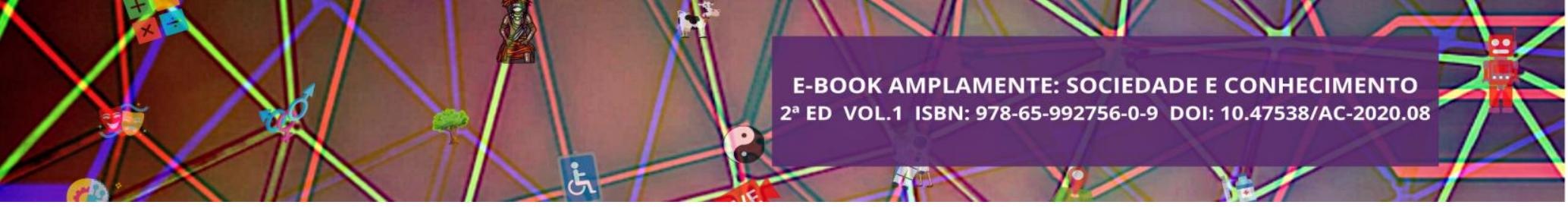

necessário para concluir a tarefa (eficiência) e ficar feliz com a experiência ao executar a tarefa (satisfação).

O objetivo da avaliação de usabilidade é encontrar problemas que possam ser eliminados precocemente ou pelo menos, minimizados, de modo que as necessidades dos usuários sejam atendidas de forma satisfatória e eficiente.

Rocha e Baranauskas (2003) dividem a avaliação em quatro grupos de métodos, que são experimentos controlados; métodos de avaliação interpretativo; inspeção de usabilidade (do inglês predictive evaluation) e testes de usabilidade;

\section{METODOLOGIA DE PESQUISA}

O método selecionado para fazer a avaliação de usabilidade do ambiente SIGAA UFRA foi a avaliação heurística proposta por Jakob Nielsen e Rolf Molich em 1990. Esse método de inspeção de usabilidade consiste em avaliar a interface baseada na lista de heurísticas de usabilidade ou regras de senso comum. Nielsen (1993) afirma que um número adequado para a realização da avaliação é de três a cinco avaliadores. Sendo possível avaliar o grau de gravidade de cada problema, priorizando os mais sérios, de resolução imediata.

Para Nielsen e Molich (1990), a avaliação heurística é um método em que o avaliador procura problemas de usabilidade na interface utilizando um conjunto de princípios (heurísticas) para fazer a análise e interpretação.

Neste trabalho, usamos as dez heurísticas de usabilidade propostas por Nielsen e Molich (1990), que são:

- Visibilidade do status do sistema: O Sistema deve manter os usuários informados sobre o que está acontecendo, através de feedbacks adequados no tempo razoável;

- Compatibilidade do sistema com o mundo real: O sistema deve falar a língua do usuário, com palavras, frases e conceitos familiares para o usuário, seguindo as convenções do mundo real e fazendo a informação aparecer numa lógica ordenada e natural;

- Controle e liberdade do usuário: Possibilidade do usuário de desfazer erros cometidos sem intenção utilizando "saídas de emergência" como fazer e desfazer; 


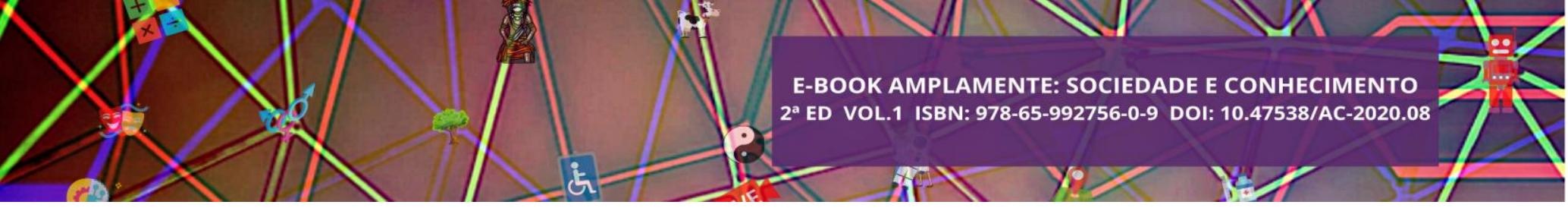

- Consistência e padrões: Seguir convenções para que o usuário não fique confuso com diferentes palavras, situações ou ações;

- Prevenção de erros: a utilização de boas mensagens de erro, ajudam a prevenir a ocorrência de um problema. Eliminar condições passíveis de erro ou verificar e apresentar uma opção de confirmação para os usuários antes deles executarem a ação;

- Reconhecimento em vez de lembrança: Redução do esforço cognitivo dos usuários fazendo objetos, ações e opções visíveis. As instruções para uso do sistema devem estar visíveis ou facilmente recuperáveis quando necessário;

- Flexibilidade e eficiência de uso: Aceleradores, como atalhos por exemplo, podem acelerar a interação com o sistema. Permite que usuários adequem as ações realizadas frequentemente;

- Estética e design minimalista: Informações desnecessárias não devem estar presentes nos diálogos. Toda informação extra, pode fazer informações necessárias passarem despercebidas;

- Ajuda aos usuários de reconhecer, diagnosticar e recuperar-se de erros: Mensagens de erro devem ser expressas claramente, indicando o problema e sugerindo uma possível solução;

- Ajuda e documentação: As documentações devem ser fáceis de encontrar e devem ser focadas nas tarefas do usuário, listando, com objetividade, os passos a serem seguidos.

Um dos pontos positivos relacionado a esse método é que os avaliadores não precisam de um treinamento em usabilidade, eles aprendem sobre os princípios que suportam uma boa usabilidade ao realizarem as avaliações;

O método de avaliação heurística tem se tornado um dos métodos mais comuns para encontrar problemas de usabilidade pelo fato de ser rápido, barato e fácil em comparação com outros métodos de avaliação. Além dessas vantagens, não precisa de um planejamento avançado, nem de muitos avaliadores e de acordo com Nielsen e Molich (1990) é intuitivo e facilmente ensinado para outros possíveis avaliadores. Considerando essas vantagens, foi escolhido para avaliar a usabilidade do SIGAA UFRA.

\section{ANÁLISES}




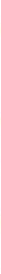

Para Nielsen (1994), a avaliação heurística envolve ter um pequeno número de avaliadores para examinar a interface e julgar sua conformidade com os princípios de usabilidade, conhecidas como heurísticas.

$\mathrm{Na}$ avaliação heurística, um único avaliador pode realizar a avaliação, porém este não conseguirá encontrar todos os erros de usabilidade da interface, apenas cerca de 35\% deles (Nielsen e Molich, 1990; Nielsen, 1994). Em geral, a avaliação é realizada com 3 a 5 avaliadores, podendo ser estendida a um número maior de avaliadores, dependendo das características do sistema. Nielsen (1994) afirma que 5 avaliadores conseguem encontrar cerca de $75 \%$ dos problemas de usabilidade de interface.

Para a realização da avaliação, elaboramos um questionário, baseado nas dez heurísticas de Nielsen, com alternativas de grau de severidade e espaço para comentários. Selecionamos oito estudantes do curso de Bacharelado em Sistemas de informação, cursando o $5^{\circ}$ ou $7^{\circ}$ semestre da UFRA, os quais já cursaram a disciplina de IHC (Interação Humano-Computador) e utilizam o sistema frequentemente para serem os avaliadores.

A severidade do problema é embasada numa escala de valor desenvolvida por Nielsen, que está apresentada a seguir na tabela 1.

\begin{tabular}{|c|c|l|}
\hline Escala & Tipo & \multicolumn{1}{|c|}{ Descrição } \\
\hline 0 & Irrelevante & $\begin{array}{l}\text { Não afeta a operação da interface, não sendo } \\
\text { visto como um problema de interface. }\end{array}$ \\
\hline 1 & Simples & $\begin{array}{l}\text { Existem problemas para serem corrigidos, se } \\
\text { houver tempo extra no projeto. }\end{array}$ \\
\hline 2 & Médio & $\begin{array}{l}\text { Problema que pode afetar ligeiramente a } \\
\text { execução da tarefa. Pode ser corrigido com } \\
\text { baixa prioridade. }\end{array}$ \\
\hline 3 & Grave & $\begin{array}{l}\text { Problema que causa confusão e interfere na } \\
\text { execução da tarefa. Deve ser reparado com } \\
\text { alta prioridade. }\end{array}$ \\
\hline 4 & Catastrófico & $\begin{array}{l}\text { O avaliador não pode completar a tarefa por } \\
\text { causa do problema. Deve ser corrigido } \\
\text { imediatamente. }\end{array}$ \\
\hline
\end{tabular}




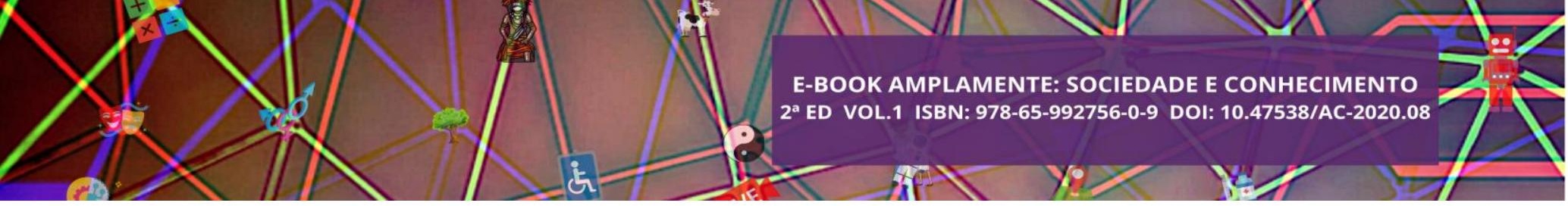

Após a avaliação heurística realizada no ambiente SIGAA UFRA, foram encontrados alguns problemas de usabilidade do ponto de vista do discente. A severidade dos problemas foi julgada de acordo com a interação dos usuários com o sistema.

Consolidamos as respostas dos formulários em forma de tabela, onde os problemas são separados pelas dez heurísticas e consideramos os graus de severidade relevantes para a necessidade de melhorar a interface do ambiente.

\section{RESULTADOS}

Após a aplicação dos formulários, obtivemos os resultados descritos na tabela 2 com os graus de severidade dos problemas encontrados separados para cada heurística.

Tabela 2. Porcentagem dos graus de severidade dos problemas encontrados

\begin{tabular}{|l|c|c|c|c|c|}
\hline PROBLEMA & Irrelevante & Simples & Médio & Grave & Catastrófico \\
\hline $\begin{array}{l}\text { Quanto a } \\
\text { visibilidade do } \\
\text { status do } \\
\text { sistema. }\end{array}$ & $37,5 \%$ & $0 \%$ & $37,5 \%$ & $12,5 \%$ & $12,5 \%$ \\
\hline $\begin{array}{l}\text { Quanto a } \\
\text { compatibilidade } \\
\text { do sistema com } \\
\text { o mundo real. }\end{array}$ & $37,5 \%$ & $0 \%$ & $37,5 \%$ & $0 \%$ & $25 \%$ \\
\hline $\begin{array}{l}\text { Quanto ao } \\
\text { controle e } \\
\text { liberdade do } \\
\text { usuário. }\end{array}$ & $12,5 \%$ & $0 \%$ & $12,5 \%$ & $33,3 \%$ & $41,7 \%$ \\
\hline $\begin{array}{l}\text { Quanto a } \\
\text { consistência e } \\
\text { padrões. }\end{array}$ & $37,5 \%$ & $0 \%$ & $25 \%$ & $12,5 \%$ & $25 \%$ \\
\hline $\begin{array}{l}\text { Quanto a } \\
\text { prevenção de } \\
\text { erros. }\end{array}$ & $25 \%$ & $6,25 \%$ & $25 \%$ & $31,25 \%$ & $12,5 \%$ \\
\hline $\begin{array}{l}\text { Reconhecimento } \\
\text { ao invés de } \\
\text { lembrança. }\end{array}$ & $0 \%$ & $8,3 \%$ & $25 \%$ & $25 \%$ & $33,4 \%$ \\
\hline $\begin{array}{l}\text { Flexibilidade e } \\
\text { eficiência de } \\
\text { uso. }\end{array}$ & $21,88 \%$ & $15,63 \%$ & $28,12 \%$ & $28,12 \%$ & $6,25 \%$ \\
\hline $\begin{array}{l}\text { Estética e design } \\
\text { minimalista. }\end{array}$ & $0 \%$ & $12,5 \%$ & $50 \%$ & $0 \%$ \\
\hline
\end{tabular}




\begin{tabular}{|l}
\hline \\
$\qquad$\begin{tabular}{l|l|c|c|c|c|}
\hline $\begin{array}{l}\text { Auxiliar os } \\
\text { usuários a } \\
\text { reconhecer, } \\
\text { diagnosticar e } \\
\text { corrigir erros. }\end{array}$ & $25 \%$ & $12,5 \%$ & $0 \%$ & $50 \%$ & $12,5 \%$ \\
\hline $\begin{array}{l}\text { Ajuda e } \\
\text { documentação }\end{array}$ & $25 \%$ & $12,5 \%$ & $0 \%$ & $50 \%$ & $12,5 \%$ \\
\hline
\end{tabular}
\end{tabular}

Uma análise da média geral do grau de severidade dos problemas apontados pela pesquisa identificou que 29,27\% dos problemas foram considerados graves, $23,02 \%$ irrelevantes, $20,31 \%$ foram tidos como médios enquanto $18,14 \%$ foram considerados catastróficos e 9,27\% simples, como aponta o gráfico da figura 2.

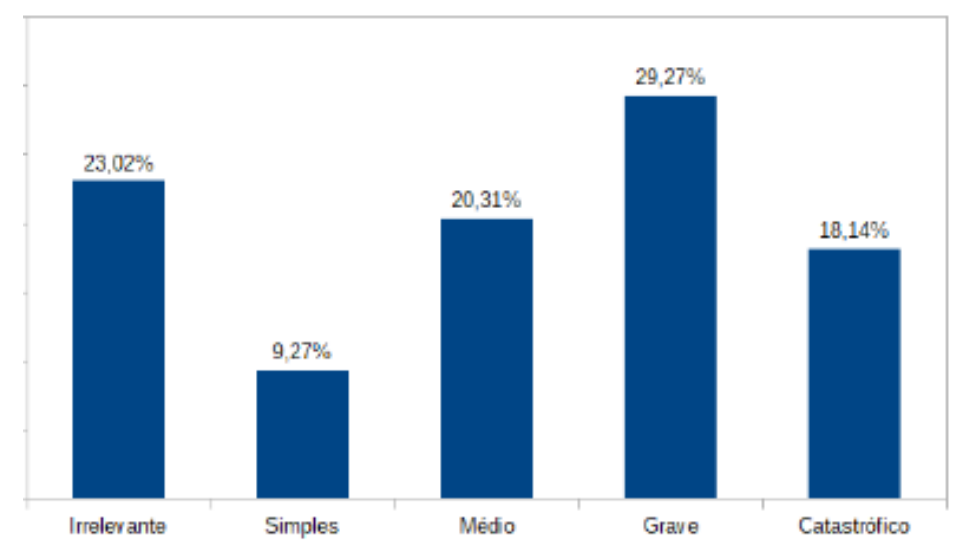

Figura 2. Módulos do SIGAA

\section{CONSIDERAÇÕES FINAIS}

O SIGAA é um AVA rico em funcionalidades que suprem as demandas da comunidade acadêmica como um todo, tais funcionalidades são divididas por diferentes perfis de usuários, de maneira complementar ao processo de ensino-aprendizagem existente no século XXI.

A UFRA aderiu ao SIGAA como forma de substituir vários sistemas anteriormente utilizados de forma descentralizada. A integralização da universidade a partir de um sistema informatizado fez com que a adesão fosse bem aceita pelas equipes responsáveis pelo estudo das funcionalidades e decisão final de aquisição do AVA, porém as funcionalidades ainda não estão completamente funcionais.

Durante a avaliação heurística alguns problemas, precisam ser corrigidos baixo, alto, e imediato grau de prioridade, foram constatados. Como apresentado na tabela 2 e 


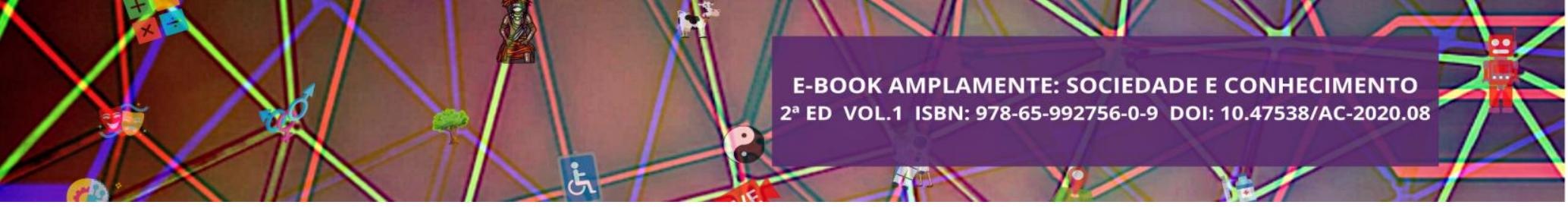

na figura 2, podem-se destacar as heurísticas "Quanto ao controle e liberdade do usuário" e "Flexibilidade e eficiência de uso" como as mais catastróficas do ponto de vista dos avaliadores, tendo que ser corrigidas com imediato grau de severidade, em especial. Com essas correções, pode-se afirmar que a interação do usuário com o ambiente será otimizada.

É importante ressaltar que a avaliação heurística pode deixar passar despercebidos alguns erros que podem ser descobertos a partir de outras avaliações de usabilidade.

Para trabalhos futuros sugere-se a realização de outros testes de usabilidade para localizar outros problemas do ambiente bem como de avaliação de usabilidade do SIGAA UFRA mobile.

\section{REFERÊNCIAS}

ALMEIDA, M. E. B. (2003) Educação a distância e tecnologia: contribuições dos ambientes virtuais de aprendizado.” In:WORKSHOP DE INFORMÁTICA NA ESCOLA, São Paulo.Anais...São Paulo: p. 96-107.

CORTELAZZO, I. B. C. (2009) Docência em ambientes de aprendizagem online. Salvador: Edufba".

GONZÁLEZ, M. et al. (2009) Quantitative analysis in a heuristic evaluation experiment. Advances in Engineering Software", v. 40, n. 12, p. 1271-1278.

LAUDON, K. C.; LAUDON, J. (2011) “Management information systems.” New Jersey: Prentice Hall.

NIELSEN, J; MOLICH, R. (1990) "Heuristic evaluation of user interfaces. In: Proceedings of the conference on Human factors in computing systems." ACM. p. 249-256.

NIELSEN, J.; MACK, R. L. (1994) “Usability inspection methods.” United States:John Wiley \& Sons.

NIELSEN, J. (1995) "Severity ratings for usability problems.” Papers and Essays, v. 54, https://www.nngroup.com/articles/how-to-rate-the-severity-of-usabilityproblems/,Setembro.

O AMBIENTE Virtual de Aprendizagem (2016), http://www.nead.feituverava.com.br/index.php/faq/30-o-ambiente-virtual-deaprendizagem, Agosto. 


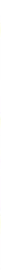

OLIVEIRA, H. S.; SAVOINE, M. M. (2011) “Aplicação do método de avaliação heurística no sistema colaborativo HEDS.", Revista Científica do ITPAC, Araguaína, v. 4, n. 3.

OZTEKIN, A.; KONG, Z. J.; UYSAL, O. (2010) "UseLearn: A novel checklist and usability evaluation method for eLearning systems by criticality metric analysis.", International Journal of Industrial Ergonomics, v. 40, n. 4, p. 455-469.

PIERRE, R. S. S. Q.et al. (2015), "study on heuristics evaluation: evaluation shopping+ application. Procedia Manufacturing, v. 3, p. 912-919. PREECE, J; ROGERS, Y; SHARP, H. (2005) “Design de interação.” Porto Alegre:Bookman.

REBELO, I. B. (2009) Interação e avaliação: apostila. Brasília, DF: [s.n.]. Última atualização novembro de 2009, http://www.irlabr.wordpresss.com,Agosto.

ROCHA, H. V.; BARANAUSKAS, M. C. C. (2003) "Design e avaliação de interfaces humano-computador." São Paulo: Unicamp.

SINFO UFRN (2016).

https://www.info.ufrn.br/wikisistemas/doku.php?id=suporte:sigaa:visao_geral, Julho.

TORI, R. (2010) Educação sem distância. São Paulo: Senac.

ZAHARIAS, P.; POYLYMENAKOU, A. (2009) "Developing a usability evaluation method for e-learning applications: Beyond functional usability.", Intl. Journal of Human-Computer Interaction, v. 25, n. 1, p. 75-98. 


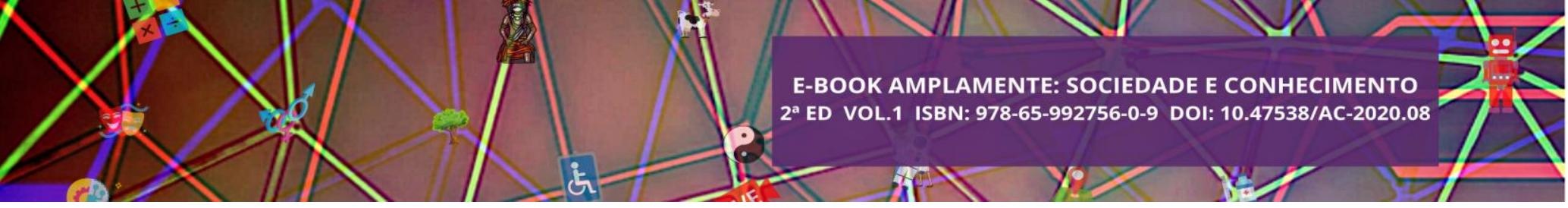

Por muitos anos a questão social não era vista como um problema relacionado a formulações de políticas pelo governo de assistência, sendo o indivíduo sempre apontado como o principal responsável pelo seu bem estar e pela dos seus membros familiares. Foi a partir da Constituição Federal Brasileira de 1988, que o Estado implanta o projeto da seguridade social - sendo está composta por três serviços, a Previdência social, a Assistência Social e a Saúde - que proporcionou um avanço nos direitos sociais. E, em conjunto com a Lei O Orgânica da assistência Social (LOAS), $\mathrm{n}^{\circ}$ 8.742/1993, a Seguridade Social toma uma dimensão maior em que é vista como algo universal, que deve ser utilizada por aqueles que necessitam e responsabiliza o estado em gerar seu acesso.

Com o passar do tempo às políticas púbicas necessitam se adaptar as necessidades com as quais a população se depara e, sendo a proteção à família uma das principais enfoques das políticas sociais, o presente trabalho teve como intuito compreender o processo histórico das políticas sociais direcionadas a família e como estas se adaptaram as configurações familiares que surgiram como o passar do tempo, com enfoque na garantia do direito a convivência familiar.

\section{POLÍTICA DE ASSISTÊNCIA SOCIAL E PROTEÇÃO SOCIAL}

Com a Proclamação da República em 1889, uma nova forma de organização política surgiu. Contudo, está assegurava as condições formais da representação burguesa, num momento de consolidação, gerando como consequência desse processo a questão social.

Na década de 1930, diversas mudanças aconteciam na sociedade como o desenvolvimento da industrialização que serviu para dar ignição a novas políticas sociais desenvolvidas pelo governo como medidas de proteção, já que o acelerado processo de urbanização acabou por ampliar a exploração dos trabalhadores, gerando novos processos de luta e organização.

Com o avanço do capitalismo, por volta de 1930, a situação de vida dos trabalhadores que possuíam uma carga horaria de trabalho excessiva e exploratória era de pobreza extrema, aumento as desigualdades entre classes e produzindo o que hoje é 


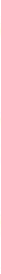

compreendida como "questão social" ${ }^{\text {, }}$. Até então, o bem estar dos indivíduos estava sob responsabilidade de sua família e seus membros ${ }^{67}$. Para amenizar a situação, o governo desenvolveu medidas de proteção, contudo, essas não eram eficazes, pois visavam apenas manter o controle das classes e só procedia com ações que iam de encontro aos interesses das classes economicamente dominantes.

Assim essas medidas de proteção estavam voltadas aos interesses da burguesia, visto que a proteção social, no Brasil, surge vinculada ao trabalho, em que somente aqueles que possuíam empregos com carteira assinada tinham o direito à proteção social pública. Foi a partir do processo de redemocratização do país nos anos 1980 que novas mudanças foram desencadeadas no âmbito das políticas de proteção social, sendo estas institucionalizadas através da Constituição Federal de 1988 (BRASIL, 1988), implantando o conceito de seguridade social. Esta reúne as políticas de saúde, previdência e assistência social, pautada para o acesso aos direitos sociais, independentemente da situação do indivíduo no mercado de trabalho.

A partir da Constituição Federal de 1988, foi regulamentada a Lei de $n^{\circ} 8.742$, de 07 de dezembro de 1993, intitulada Lei Orgânica da Assistência Social (LOAS), instrumento legal que regulamenta os pressupostos constitucionais, ou seja, aquilo que está escrito na Constituição Federal, nos Arts. 203 e 204, em normas e critérios, em forma de leis e objetivos a serem alcançados e mantidos, no qual novos conceitos e modelos de assistência social passaram a ser investidos no Brasil, explicitando como direito de cidadania universal, a garantia às necessidades básicas dos segmentos populacionais vulneráveis pela pobreza e pela exclusão social.

A assistência social, direito do cidadão e dever do Estado, é Política de Seguridade Social não contributiva, que provê os mínimos sociais, realizada através de um conjunto integrado de ações de iniciativa pública e da sociedade, para garantir o atendimento às necessidades básicas (BRASIL, 1993).

No artigo $2^{\circ}$ da LOAS, é apresentado seus principais objetivos quais sejam: a proteção à família, à maternidade, à infância, à adolescência e à velhice; o amparo às

66 Segundo Iamamoto (1998, p. 27) “A Questão Social é apreendida como o conjunto das expressões das desigualdades da sociedade capitalista madura, que tem uma raiz comum: a produção social é cada vez mais coletiva, o trabalho torna-se mais amplamente social, enquanto a apropriação dos seus frutos mantém-se privada, monopolizada por uma parte da sociedade".

67 [...] referida como "familismo", a característica indica o papel desempenhado pela família no bem-estar de seus membros, por meio de transparência intrafamiliar de natureza material e imaterial, especialmente das atividades de cuidados prestados pelas mulheres. $\mathrm{O}$ alto valor conferido à família e o baixo grau de individuação de seus membros expressariam tal características. (DRAIBE, 2007, p.41) 


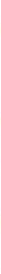

crianças e adolescentes carentes; a promoção da integração ao mercado de trabalho; a habilitação e reabilitação das pessoas portadoras de deficiência e a promoção de sua integração à vida comunitária; a garantia de 1 (um) salário mínimo de benefício mensal à pessoa portadora de deficiência e ao idoso que comprovem não possuir meios de prover a própria manutenção ou de tê-la provida por sua família (BRASIL, 1993).

Duas décadas depois da LOAS, durante o governo do Presidente Lula, a Política Nacional de Assistência Social (PNAS) é definida por meio da $4^{\mathrm{a}}$ Conferência Nacional de Assistência Social e aprovada pelo Conselho Nacional de Assistência Social (CNAS) em 2004, após um longo tempo de resistência e debate. Compreendendo a Assistência Social na área da Seguridade Social como Política Social, dentro do Sistema de Proteção Nacional Brasileiro.

A PNAS/2004 rege-se pelos seguintes princípios democráticos dispostos na LOAS: Supremacia do atendimento às necessidades sociais sobre as exigências de rentabilidade econômica; Universalização dos direitos sociais, a fim de tornar o destinatário da ação assistencial alcançável pelas demais políticas públicas; Respeito à dignidade do cidadão, à sua autonomia e ao seu direito a benefícios e serviços de qualidade, bem como à convivência familiar e comunitária, vedando-se qualquer comprovação vexatória de necessidade; Igualdade de direitos no acesso ao atendimento, sem discriminação de qualquer natureza, garantindo-se equivalência às populações urbanas e rurais; Divulgação ampla dos benefícios, serviços, programas e projetos assistenciais, bem como dos recursos oferecidos pelo Poder Público e dos critérios para sua concessão (BRASIL, 1993).

A partir de todo esse processo, a assistência social passou a ser vista fora do campo da filantropia e de cunho caritativo, se tornando um dever do Estado para com a sociedade, exigindo formulação de políticas com diretrizes, objetivos e princípios. É um campo de conquistas para erradicação da pobreza, das desigualdades sociais e regionais, da proteção social como direito, servindo para o processo de democratização do país.

Assim, as políticas sociais que foram incorporadas pelo capital como forma de garantir e legitimar a dominação de classes assegura a manutenção da força de trabalho. No entanto, estas também são resultantes da luta de classes, sendo assim, frutos da 


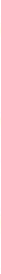

organização da classe trabalhadora ${ }^{68}$ e não são concedidas pelo Estado (BEHRING; BOSCHETTI, 2009).

\section{AS FAMÍLIAS NO CONTEXTO BRASILEIRO}

A relação da família sempre teve grande importância no desenvolvimento da sociedade. O processo de socialização e construção da personalidade tem início desde os primeiros anos de vida, em que são desenvolvidas a partir das características psíquicas da relação das crianças com os pais, pessoas próximas, objetos e o seu meio. Sendo assim, a família como instituição, assume um papel importante na formação da identidade do indivíduo, no qual os genitores são considerados como as pessoas responsáveis durante o processo de desenvolvimento da criança e/ou adolescente, como também são tidos como referência em sua formação, na construção de valores e no processo de formação social das crianças.

Com o passar dos anos, o modelo de configuração familiar vem se transformando e, hoje, não se pode limitar ao modelo composto por pai, mãe e filhos, pois existem vários tipos de formação familiar em nossa sociedade, tendo cada uma, suas características e especificidades.

Com o desenvolvimento econômico, com o avanço das sociedades e com o conhecimento cientifico, as funções e conceitos da instituição família não desaparecem, mas se ampliam de maneira significativa com intuito de englobar as novas estruturas familiares que se desenvolveram junto à evolução da sociedade; como por exemplo, a família monoparental, recomposta e unipessoal. Gerando assim, um "alargamento" nos conceitos de família, tentando agora englobar os inúmeros tipos existentes.

$\mathrm{Na}$ atual sociedade, é comum à existência de famílias de pais separados, outras em que a mulher é a provedora financeira, ou em que só existe o pai que exerce também o papel da mãe, além da família tradicional formada por pai, mãe e filhos, que ainda é pregada com muita força na sociedade moderna como o modelo ideal de família.

Mesmo com os avanços que a política de assistência no Brasil obteve após a Constituição Federal Brasileira de 1988, está não acompanha as novas configurações familiares, em que:

\footnotetext{
${ }^{68} \mathrm{O}$ recorte de classe apresentado nesta discussão foi particularmente interpretada no âmbito da sociabilidade capitalista em que há apenas duas classes: a capitalista (burguesa) e o proletariado (trabalhadora), definidas a partir da função/tarefa que desenvolvem na sociedade.
} 


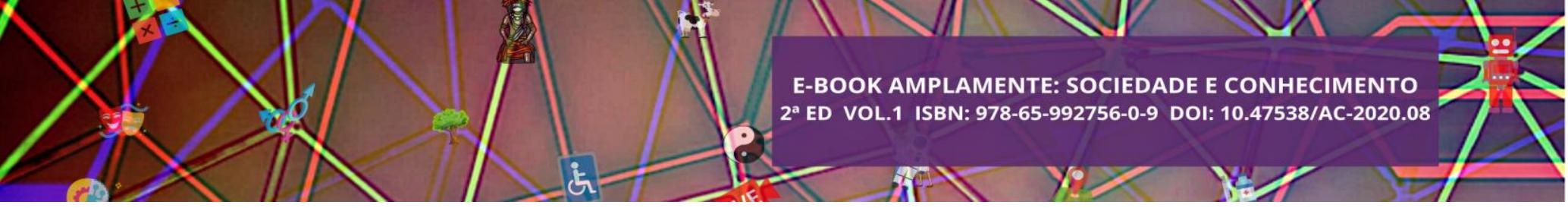

Algumas dessas mudanças, apontadas em grande parte do mundo, são: a) as famílias apresentam-se cada vez menores; b) elas são chefiadas por mulheres em percentuais que aumentam de forma rápida; c) mais mulheres entram no mercado de trabalho e as famílias necessitam de novos arranjos para a criação de seus filhos; d) crescem as distâncias entre a casa e o trabalho nas grandes cidades, o que leva a que crianças permaneçam mais tempo sem a presença dos pais; e) a dinâmica dos papéis parentais e de gênero estão se modificando em diversas sociedades (RIZZINI, 2006, p. 35).

Se analisada, as mudanças na visão da infância pobre e de suas famílias no Brasil, é possível observar que, por volta de 1985, era compreendido motivos como "maus tratos", "desintegração familiar", "doenças do menor" entre outros, como negligência, sem saber a real perspectiva de vida daqueles usuários. Sobre as atuais circunstâncias, as famílias em situação de vulnerabilidade social são culpabilizadas pela situação em que seus filhos se encontram, sendo considerada como negligente por não poder ofertar condições dignas de saúde, educação, lazer e segurança, a família é alvo de acusação sendo responsabilizada, unicamente, desconsiderando o que por lei, é responsabilidade tanto da família, quanto da sociedade e do Estado.

\section{O DIREITO À CONVIVÊNCIA FAMILIAR SOB O PARADIGMA DA PROTEÇÃO INTEGRAL}

A condição de crianças e adolescentes em fase de desenvolvimento não os distância de sua concepção de sujeito como qualquer outro cidadão perante o Estado visando como prioridade o dever de condições dignas para seu desenvolvimento, físico e psíquico.

O Estatuto da Criança e do Adolescente (ECA), promulgado no Brasil em 1990, surgiu a partir da Convenção Internacional sobre os direitos da Criança aprovados pela ONU em 1989. Esta protege o conceito de família como núcleo essencial na qual também se encontra disposto acerca dos direitos, da proteção integral e regulamentada a relação da família, da comunidade e do Estado com estes indivíduos, visando o melhor para seu desenvolvimento.

O ECA aprofundou as normas que a Constituição Federal de 1988, apresentando para a população mais jovem do país, a garantia como direitos fundamentais o direito à vida, à saúde, à alimentação, à educação, ao lazer, à profissionalização, à cultura à dignidade, ao respeito, à liberdade e à convivência familiar e comunitária. 


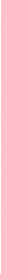

A lei considera a família como primeiro interessado ao bem estar da criança e do adolescente e determina como dever do Estado suprir as insuficiências da família, sejam materiais ou de outra ordem, como a saúde. Porém, a partir do momento em que a família não cumpre com a sua função de resguardar o bem estar da criança ou do adolescente, o Estado tem fundamento para aplicar medidas de suspensão e destituição do poder familiar, legalmente previstas.

Desde o final do século XIX e durante grande parte do século XX, a institucionalização configurou-se, em maior ou menor grau, como uma das principais políticas postas em prática pelo Estado para lidar com o dito "menor" ou "menor em situação irregular", como ficou designado a partir de 1979. Todo um aparato institucional foi sendo edificado durante a história brasileira cuja tônica focalizava a institucionalização, como é o caso do Serviço de Assistência ao Menor (SAM) e da Fundação do Bem-Estar do Menor (Funabem), apenas para citar os dois mais conhecidos (PRINCESWAL, 2013, p. 23).

Contudo, enquanto o Artigo 226, da Constituição Federal de 1988 afirma que a família é a base da sociedade e possui especial proteção do Estado, é encontrada dificuldade no que diz respeito às políticas públicas que assegurem a capacidade dos pais em dar uma vida adequada a seus filhos, com relação a emprego, uma possibilidade de renda, segurança, apoio e aos cuidados.

No Brasil, muitas famílias se encontram em situação de pobreza e miséria, e devido a ausência ou ineficiência de políticas públicas que garantam a possibilidade destes cuidados, estas acabam por ser classificadas como negligentes, que de acordo com Nascimento (2012) pode ser considerada quando a família:

[...] não cuida do filho, não provê alimentação, higiene, vestuário e outros tantos cuidados, quando se diz que relaxa o olhar atento, e ele sofre um acidente, quando doente não busca socorro médico. Enfim, quando seu modo de ser mãe não está em acordo com normas de proteção instituídas. É preciso lembrar que esses modelos da boa higiene, da boa alimentação, do bem cuidar, do correto tratamento médico foram historicamente construídos, pautados em verdades estabelecidas a partir de um campo de forças específico compatível com a lógica capitalista (NASCIMENTO, 2012, p. 41).

Assim, partindo da compreensão de que o Brasil é um país marcado por uma desigualdade de renda no qual as oportunidades de ter uma vida digna se torna difícil para muitos, as famílias que não portam condições para garantir o acesso as necessidades básicas de seus filhos, por muitas vezes são classificadas como “desestruturadas". Sendo assim, este ordenamento é ligado a condições financeiras, e as 


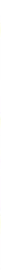

famílias que não podem ofertá-las, são tidas como "incapaz" de cuidar dos seus filhos e negligentes.

No entanto, não há como desconsiderar que existem situações de negligência em que as crianças e/ou adolescentes podem estar sendo colocadas em situação de risco, porém há casos em que o compreendido como negligência se dá por reflexos de situações resultantes de aspectos financeiros e sociais, em que se deve considerar o cenário nacional e o contexto familiar em que essas famílias estão inseridas.

\section{CONSIDERAÇÕES FINAIS}

O presente trabalho buscou aclarar a relação entre as políticas sociais e a família, a partir de uma breve análise histórica. Dessa forma, é perceptível que a construção política do modelo familiar acompanhou as necessidades sociais, tendo em vista que os indivíduos possuem seu primeiro contato social e formação coletiva a partir da instituição familiar.

Assim, através de uma análise histórica a partir das políticas sociais e proteção brasileira, a instituição familiar e seus dimensionamentos que formalizam a sua negligência. Nesse sentido, percebeu-se ao longo da análise documental aqui presente, que o percurso de reformulação do modelo familiar, necessário com o surgimento de novas formas de sua constituição social, legalmente, não acompanhou seu desenvolvimento real, o que acaba por influenciar diretamente na dinâmica legislativa que circunda a temática familiar.

Tais influências promovem certa dualidade no que se difunde as definições de práticas de negligência e seus rebatimentos frente a sociedade, principalmente no que diz respeito a Constituição Federal de 1988 e a letra da lei que preconiza a atuação das políticas públicas brasileiras, em que apenas muito recentemente coloca nas mãos do Estado, a responsabilidade pelos indivíduos em situação de vulnerabilidade social.

Desse modo, também é evidente que a dualidade das formulações legislativas sociais brasileiras não acompanha a realidade populacional. O Brasil retém em suas dimensões populacionais uma grande desigualdade de renda, além da ineficiência de suas políticas públicas, o que acaba por influenciar na desestruturação familiar e agrega novas condições para a negligência, trazendo ao Estado a responsabilidade pelos indivíduos em situação de vulnerabilidade, principalmente a criança e o adolescente. 


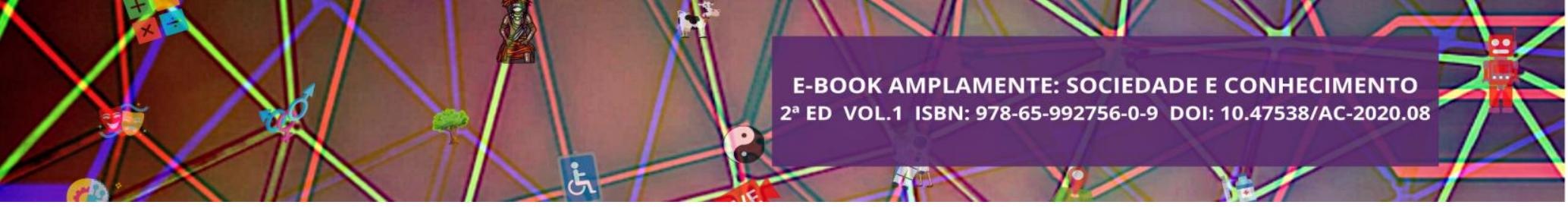

Pontuando, a insuficiência de condições básicas para cuidar de seus filhos é um dos principais motivos para que crianças e adolescentes estejam sobre proteção do Estado, em situação de acolhimento institucional, ainda que, de acordo com o art. 23 do ECA, a falta ou a carência de recursos materiais não constitui motivo suficiente para a perda ou a suspensão do pátrio poder.

\section{REFERÊNCIAS}

BRASIL. 1990. Lei n 8.069, de 13 de Julho de 1990. Disponível em: <http://www.planalto.gov.br/ccivil_03/leis/18069.htm>. Acesso em: 06 de agos. de 2020.

BRASIL. LEI Nº 8.742, DE 7 DE DEZEMBRO DE 1993. Dispõe sobre a organização da Assistência Social e dá outras providências. Disponivel em http://www.planalto.gov.br/ccivil_03/leis/18742.htm

BRASIL. LEI No 8.069, DE 13 DE JULHO DE 1990. Dispõe sobre o Estatuto da Criança e do Adolescente e dá outras providências. Disponível em http://www.planalto.gov.br/ccivil_03/leis/18069.htm

BRASIL. Constituição Da República Federativa Do Brasil De 1988. Brasília, DF. Disponível em http://www.planalto.gov.br/ccivil_03/constituicao/constituicao.htm.

CONSELHO NACIONAL DE ASSISTÊNCIA. Norma Operacional Básica do Sistema Único de Assistência Social - NOB/SUAS. Resolução n ${ }^{\circ} 33$, de 23 de dezembro de 2012, mimeo.

. Política Nacional de Assistência Social - PNAS/2004; Norma

Operacional Básica - NOB/SUAS. Brasília: Ministério do Desenvolvimento Social e Combate a Fome - Secretaria Nacional de Assistência Social, 2005.

IAMAMOTO, Marilda. O Serviço Social na Contemporaneidade: trabalho e formação profissional. São Paulo, Cortez, 1998.

LOAS ANOTADA. Lei Orgânica da Assistência Social. Ministério do Desenvolvimento Social e Combate à Fome. Brasília. 2009.

NASCIMENTO, Maria Livia. Abrigo, pobreza e negligência: percursos de judicialização. Psicologia \& Sociedade, v. 24, 2012 p. 39-44.

PRINCESWAL, Marcelo (Comp.). O direito à convivência familiar e comunitária sob o paradigma da proteção integral. In: ASSIS, Simone Gonçalves de; FARIAS, Luís Otávio Pires (Org.). Levantamento Nacional das Crianças e Adolescentes em Serviços de Acolhimento. São Paulo: Hucitec Editora, 2013. p. 23-63.

RIZZINI, I.; RIZZINI, I.; NAIFF, L.; BAPTISTA R. (Coord.). Acolhendo crianças e adolescentes: experiências de promoção do direito à convivência familiar $\mathrm{e}$ 


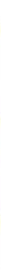

comunitária no Brasil. São Paulo: Cortez; Brasília, DF: Unicef; CIESPI ; Rio de Janeiro, RJ: PUC-Rio, 2006. 


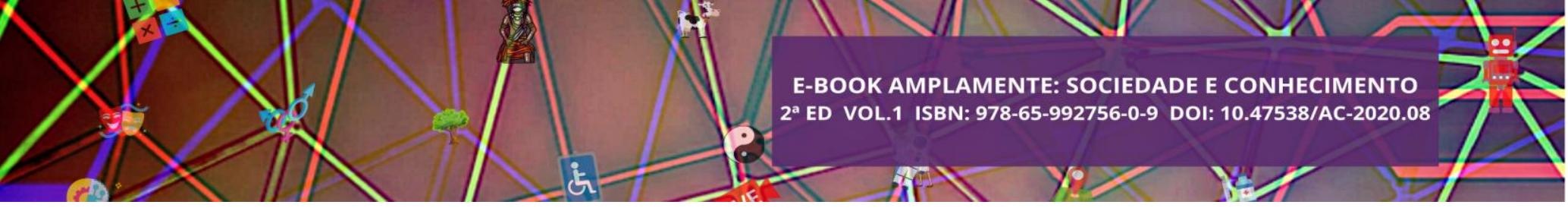

de preservar a ordem jurídica e econômica, simultaneamente à atividade de promoção de políticas públicas e proteção das minorias.

Todavia, quando se realiza uma análise retrospectiva, de forma a retroceder às origens históricas e ao modus operandi do Estado e as sucessivas mutações da maneira de se proceder nas relações para com o corpo social, percebe-se que os métodos de permanência do domínio e a difusão da ideia de legitimidade governamental não foram de natureza e credibilidade duvidosas somente nos períodos históricos temporalmente mais aproximados de sua gênese. Assim, até mesmo a existência do Estado pode ser questionada ante as noções políticas sustentadas pelas críticas próprias da denominada sociedade libertária e de todos os cidadãos adeptos à defesa aguerrida das liberdades públicas e à repulsa das inferências estatais no transcorrer da vida particular de seus "súditos".

E, para tanto, o economista Murray Newton Rothbard, em seu livro "Anatomia do Estado", traz inúmeras contribuições à essa acalorada discussão, razão pela qual seus apontamentos, tão profundos e instigantes, serem utilizados como fonte primária para o desenvolvimento de uma sintética revisão bibliográfica, no intuito de trazer à tona não apenas outra visão sócio-política, mais rigorosa e liberal, quanto a razão de ser do ente estatal, como todos os estratagemas comumente utilizados por governantes em todas as partes do mundo, para se manterem no poder, ao mesmo tempo em que pretende transmitir aos seus governados a impressão de que a presença do Estado na vida das pessoas é uma realidade inevitável, justificada, inclusive, pelos registros da tradição e pelas ideias de pensadores, pretéritos e contemporâneos, acerca da importância de se preservar a identidade dessa organização instituída, e, se possível for, até mesclá-la com a imagem e a percepção pessoal das pessoas submetidas ao poder oficializado.

Nesse sentido, sem vinculação a preconceitos sobre matérias políticas ou a pensamentos predominantes em determinados grupos sociais, suscita-se as dimensões da teorização mais libertária, oponente dos juízos estatizantes e voltados à supremacia do poder público sobre a esfera privada, que, por vezes, legitima-se em prejuízo da produção particular, das liberdades individuais, da construção de valores e princípios independentes relacionados ao papel da máquina estatal, da crítica independente do cidadão observador da realidade social e do ideal de não intervenção. Por isso, a análise de uma bibliografia de natureza revisionista é atividade essencial na edificação do pensamento político e científico independente, o que justifica constantes remissões à 


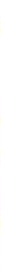

literalidade do pensamento do principal autor consultado e dos pensadores por ele citados, os quais trazem questionamentos bastante incisivos, contribuindo sobremaneira para o esclarecimento dos saberes aqui apresentados.

\title{
ESTADO VERSUS SOCIEDADE
}

O Estado, seja por meio de propagandas governamentais, seja pela maciça concepção teórico-social propagada pelos canais da oralidade tradicional e assistemática, é invariavelmente percebido como o ente magnânimo responsável pela exterminação dos males sociais e pela implementação da ordem e da paz pública. Por essa ótica, inevitável se torna a ideia de que a existência propriamente dita do Estado é, por si só, um fator positivo na história da ordem política, nacional e internacional, o que corrobora ainda mais a edificação de novas medidas destinadas ao seu fortalecimento em variados aspectos institucionais, em especial no que se refere aos patamares econômico e bélico.

Tradicionalmente, a literatura científico-política molda o Estado nesses mesmos moldes, identificando-o estritamente com as essências sociais. À guisa de exemplo, para Maluf (2010, p. 1), “O Estado é uma organização destinada a manter, pela aplicação do Direito, as condições universais de ordem social”. Segundo o autor

\begin{abstract}
No plano político, onde se encara o Estado principalmente como fato social, os conceitos emitidos pelos autores decorrem das construções doutrinárias. Uns consideram o Estado como organismo natural ou produto da evolução histórica, outros como entidade artificial, resultante da vontade coletiva manifestada em um dado momento. Uns o conceituam como objeto de direito (doutrinas monárquicas), outros como sujeito de direito, como pessoa jurídica (doutrinas democráticas). Outros ainda o consideram como a expressão mesma do direito, incluindo em uma só realidade Estado e Direito (teoria monista) (MALUF, 2010, p. 20).
\end{abstract}

Em oposição a tais doutrinas tradicionais, responsáveis por mesclar a noções de Estado e sociedade civil, como se ambos fossem, por razões espontâneas e voluntaristas, duas forças atuantes em cooperação mútua, num elo de harmonia constante, Rothbard (2019, p. 13) traz à tona esse entendimento quase universal, segundo o qual esse mesmo Estado é normalmente entendido como uma organização social, com fins evidentemente humanitários, e que existe tão somente para satisfazer objetivos sociais, sendo, portanto, a expressão máxima da sociedade; noção essa intensificada na literatura e no cenário 


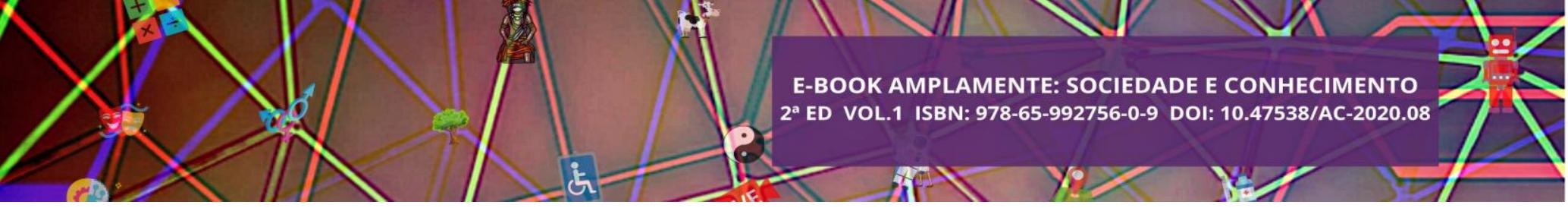

público pelo nascimento e desenvolvimento dos regimes democráticos. A esse respeito, o autor leciona a seguinte lição:

Com o advento da democracia, a identificação do Estado com a sociedade foi redobrada, e hoje é comum ouvir apelos sentimentais, como "nós somos o governo", que violam praticamente todos os princípios de razão e bom senso. O termo coletivo útil "nós" permitiu lançar uma camuflagem ideológica sobre a realidade da vida política. Se "nós somos o governo", então, qualquer coisa que um governo faça a um indivíduo não é apenas justa e não tirânica, mas também "voluntária" de parte do indivíduo em questão (RUTHBARD, 2019, p. $14)$.

Percebe-se, pois, que essa estratégia política, de cunho majoritariamente publicitário e manipulador, é, por sinal, a tentativa de angariar créditos de legitimação a toda e qualquer ação perpetrada pelo Estado, pois, segundo esse raciocínio, quando o ente maior colocar em prática alguma política pública, ou apenas um ato isolado de governo, está necessariamente balizado com o consentimento social, uma vez que, se Estado e sociedade são uma coisa só, ou seja, o governo, não há espaço para o argumento de que o Governo possa atuar em sentido contrário aos interesses populares, pois é a própria sociedade representada que, em determinado momento, concedeu pleno aval e autorização incondicionada de ampla e legítima representação ${ }^{70}$. Assim,

Se o governo incorreu numa dívida pública enorme que deve ser paga para benefício de outro, a realidade desse fardo é obscurecida pela afirmação de que "nós devemos a nós mesmos"; se o governo recruta um homem, ou o prende por opinião dissidente, então, ele "está fazendo isso a si próprio" - logo, não há nenhum problema (ROTHBARD, 2019, p. 14).

Logo, a lição que deve prevalecer é a de que "não somos o governo" e "não somos o Estado". Esses, isolada ou conjuntamente considerados, são entes distintos da sociedade que os sustenta, com capital político e econômico. A sociedade, dessa forma, é um fenômeno de expressão primária, sustentador da realidade artificial formada por Estados e Governos, pois, caso não fosse essa a realidade dos fatos, não haveria motivos para revoltas populares e demais atos de manifestação da inconformidade social com os destinos políticos traçados por dirigentes estatais.

70 No que se refere ao sistema de representação majoritária próprio do regime democrático, Rothbard $(2019$, p. 15) esclarece o que seria um verdadeiro agente ou representante popular: aquele que estivesse diretamente subordinado às ordens dos seus representados, podendo ser demitido a qualquer momento, caso contrariasse os desejos e interesses daqueles que o elegeram. Nota-se, desse modo, que, ao menos no Brasil, a população carece de tais agentes de fidedigna representatividade. 


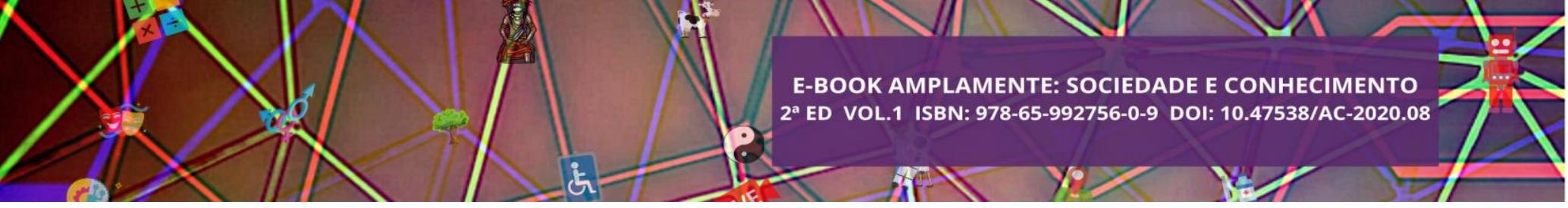

Diante disso, verificado o que o Estado "não é", deve-se, por conseguinte, esclarecer o que ele de fato "é", sem camuflar alguns aspectos incômodos da realidade por receio de rudeza e inconveniência político-literária. Em poucas palavras,

(...) o Estado é aquela organização na sociedade que busca manter um monopólio do uso da força e da violência em uma determinada área territorial; especificamente, é a única organização na sociedade que obtém sua receita não pela contribuição voluntária ou pelo pagamento por serviços providos, mas através da coerção. Enquanto outros indivíduos ou instituições obtêm seus rendimentos pela produção de bens e serviços e pela venda pacífica e voluntária desses bens e serviços a outros, o Estado obtém sua receita pelo uso da compulsão; isto é, pelo uso e pela ameaça da prisão e da baioneta (ROTHBARD, 2019, p. 16).

Ainda na tarefa de definir a essência obscura do Estado, esse revela ser a “organização dos meios políticos", a "sistematização do processo predatório sobre um determinado território" (OPPENHEIMER apud ROTHBARD, 2019, p. 22). Segundo o autor, existem duas formas que o homem tem à sua disposição para conseguir os recursos necessários à subsistência, quais sejam, o trabalho próprio (meio econômico) e o furto, sendo esse último politicamente conceituado como a apropriação forçada e unilateral do produto do trabalho dos outros, também denominado "meio político". Por essa razão, o magistério do referido economista se refere ao Estado como o resultado prático dos meios políticos organizados, pois, em acurada análise, seus atos oficiais de reabastecimento do erário nada mais são que empreitadas ilegítimas de apropriação da riqueza alheia.

É por essa razão que Rothbard (2019, p. 23) alude à atuação estatal como atividade tipicamente parasitária, visto que se sustém por meio da apropriação dos produtos do trabalho de outrem. E, dessa compreensão, deduz-se que "a produção deve sempre preceder à predação, o livre mercado é anterior ao Estado". Esse, aliás, "nunca foi criado por um 'contrato social'; ele sempre nasceu da conquista e da exploração" (ROTHBARD, 2019, p. 23).

Numa lição mais contundente, poder-se-ia concluir o seguinte:

O Estado reivindica e exerce o monopólio do crime. [...] Ele proíbe o homicídio privado, mas ele próprio organiza o assassínio em uma escala colossal. Ele pune o roubo privado, mas ele próprio coloca inescrupulosamente suas mãos em tudo que quiser, seja propriedade dos seus cidadãos ou de estrangeiros (NOCK apud ROTHBARD, 2019, p. 23). 


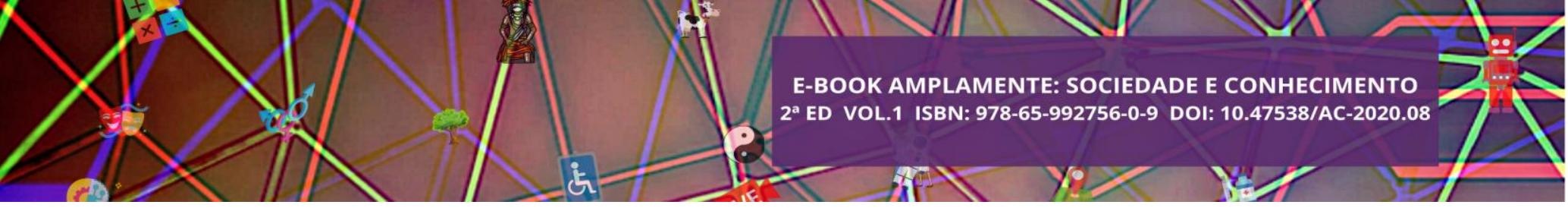

Por fim, ao menos no que diz respeito à formulação de uma definição original de Estado, há o esclarecimento que se segue:

O Estado, em sua gênese, [...] é uma instituição social, imposta por um grupo vitorioso de homens sobre um grupo derrotado, com o único propósito de regular o domínio do grupo vitorioso de homens sobre o grupo derrotado, e de garantir a si mesmo contra a revolta interna e os ataques externos. Teleologicamente, esse domínio não tinha outro propósito senão a exploração econômica dos derrotados pelos vitoriosos (OPPENHEIMER apud ROTHBARD, 2019, p. 24).

Tem-se, pois, por parte da teoria revisionista desses autores, a compreensão de que o Estado, sob a ótica da sociedade defensora das nuanças da liberdade cívica e social, atentando-se aos seus métodos de automanutenção, não é essencialmente uma entidade com propósitos altruístas, benévolos, vez que, por inevitável, deve buscar recursos para garantir o seu desenvolvimento, o que também implica na utilização de mecanismos institucionais e legais de salvaguarda do próprio poderio, antes mesmo de se voltar aos interesses sociais, mesmo que com ações políticas de abrangência fragmentada e campos de ação bastante seletos.

O Estado, nesse sentido, para que apareça no cenário público como instrumento político e pretenso defensor de direitos e garantias, surge no debate histórico como instituição de espírito fundamentalmente hierárquico, colocando-se acima das pessoas que fornecem continuamente os recursos de que precisa para ostentar sua própria grandeza, e, por esse caminho, vale-se da produção livre de particulares, confiscando-as compulsoriamente, com a finalidade primeira de se preservar nos seus meios de subsistência e a necessidade de interferência social.

\section{ESTRATÉGIAS DE GOVERNO E DE ESTADO PARA A MANUTENÇÃO DO PODER E DA INFLUÊNCIA}

Para que consiga se manter em posição estratégica de influência e interferência no desenvolvimento da sociedade, como forma de estabilização de seu status de superioridade alegadamente necessária para assegurar o bem-estar social, o Estado, por intermédio de seus agentes e toda a ordem de mandatários do poder, temporário (democracia) ou permanente e questionável (autoritarismo), necessita de determinado instrumental de persuasão social, ou seja, para que de fato não perca a continuidade de seu poderio, precisa manter a sociedade convicta de que toda a extensão de seu poder é 


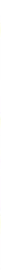

legitimado pela vontade popular e é direcionado a fins sábios e consistentes. Pois, a partir do momento em que a estrutura social percebe que o poder já não é mais utilizado para fins apropriados e o Estado não mais apresenta fundamentos políticos viáveis que justifiquem o exercício do controle social, a sociedade mesma questiona a razão de ser dessa suntuosa estrutura burocrática a ponto de fragilizar representatividade dos detentores do poder lhes concedido pela massa do eleitorado, uma vez que "todo poder emana do povo, que o exerce por meio de representantes eleitos, ou diretamente, nos termos desta Constituição" (art. 1º, parágrafo único, da Constituição Federal, de 1988).

Logo, de acordo com Rothbard (2019, p. 25-27), para se manterem no poder, os governantes necessitam acalmar o ânimo da sociedade por eles governada, mantendo-a em condição de "aceitação ativa ou resignada da maioria dos cidadãos". Para tanto, lançam mão de um "modus operandi" perfeitamente identificável, pois se realiza pelo emprego sistemático de métodos de duas naturezas, a saber, o econômico, de curto prazo, e o ideológico, de longo prazo - o principal e mais eficiente, inclusive. Assim, em curto ou médio prazo, “(...) um dos métodos para segurar apoio é através da criação de interesses econômicos legalmente garantidos", com vistas a “(...) obter o consentimento da maioria" da população submetida ao poder estatal.

Segundo o citado autor, o instrumento essencial para que a sociedade, em sua expressão majoritária, seja persuadida, e aceite os mandos e desmandos de seus governantes, é a propagação persistente das ideias de que "o seu governante é bom, sábio e, pelo menos, inevitável, e certamente melhor do que outras possíveis alternativas" (ROTHBARD, 2019, p. 28). Ademais, existem pessoas política e taticamente apostas para exercerem esse papel imprescindível à proteção da imagem do Estado e dos governantes: os intelectuais.

A missão dos intelectuais para assegurar a aparência de legitimidade dos poderosos governantes é estratégia antiga, haja vista o “(...) desejo ardente dos professores da Universidade de Berlim de formar a 'brigada intelectual da Casa de Hohenzollern"” (ROTHBARD, 2019, p. 29). E a realidade justificadora da intervenção sistêmica da atividade intelectual para tal finalidade é presente até nos dias de hoje, pois, no ambiente em que a aversão ao conhecimento é um sentimento persistente, em especial pelo viés da confirmação, todo aquele que tenha a disposição para pensar e saber mediano sobre técnicas de comunicação em massa, no final, acaba por incutir o 


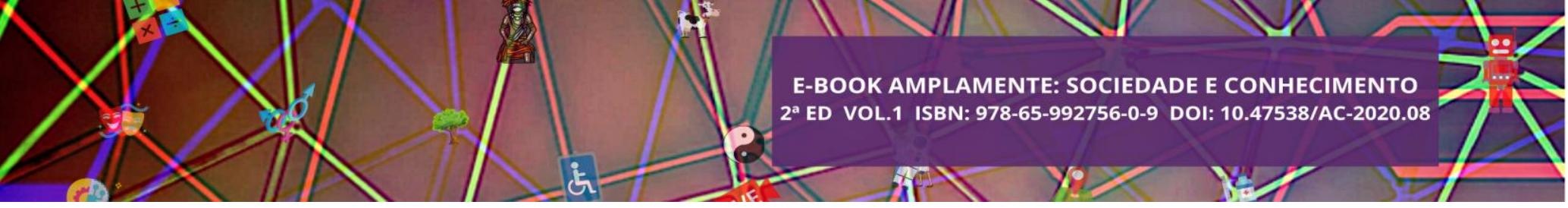

produto de suas reflexões nas mentes dos que se recusam a exercitar o pensamento crítico. Aliás, promover essa ideologia,

(...) é a tarefa social vital dos "intelectuais". Pois as massas de homens não criam suas próprias ideias ou de fato pensam com essas ideias de forma independente; elas seguem passivamente as ideias adotadas e disseminadas pelo grupo de intelectuais. Os intelectuais são, portanto, os "formadores de opinião" na sociedade. E, como é precisamente de uma modelagem de opinião de que o Estado mais desesperadamente necessita, torna-se clara a razão da secular aliança entre o Estado e os intelectuais (ROTHBARD, 2019, p. 28).

Uma lição é bastante clara: o Estado precisa dos serviços prestados pelos intelectuais, na medida em que esses passam uma visão remodelada da realidade àqueles que não gostam, ou simplesmente se recusam, pelo motivo que for, a efetuar uma análise original da realidade presente e disponível a qualquer observação criteriosa e genuína. No entanto, há de se perguntar: "Mas os intelectuais precisam do Estado?", ou ainda, "Há alguma vantagem pessoal no prestação de 'serviços intelectualizados' ao Estado?".

De novo, a respeito da atuação desses intelectuais ${ }^{71}$, dentre eles o historiador oficial ou "curial", o autor responde tais questões com inquestionável maestria:

É evidente que o Estado precisa de intelectuais; não é tão evidente por quê os intelectuais precisam do Estado. Posto de forma simples, podemos afirmar que o sustento dos intelectuais no livre mercado nunca está garantido, pois o intelectual depende dos valores e das escolhas das massas dos seus compatriotas, e é precisamente uma das características das massas o desinteresse por assuntos intelectuais. $\mathrm{O}$ Estado, por outro lado, está disposto a oferecer aos intelectuais um nicho seguro e permanente no seio do aparato estatal; e, por conseguinte, um rendimento seguro, além de um arsenal de prestígios. Pois os intelectuais serão generosamente recompensados pela importante função que executam para os governantes do Estado, grupo do qual eles agora fazem parte (ROTHBARD, 2019, p. 29).

A tarefa dos intelectuais consiste basicamente na prática da persuasão da sociedade, de modo a convencer as pessoas submissas ao governo de que seus governantes são homens prudentes, ponderados, predestinados ao exercício glorioso do poder, ou seja, dirigentes vocacionados para lidar com todo o aparato estatal e com as relações intrínsecas a essas plataformas políticas legalmente instituídas, formatadas. E, para isso, o caminho a ser seguido se divide em duas linhas de argumentação, quais

\footnotetext{
${ }^{71}$ Por óbvio, nem todos os intelectuais se sujeitam a esse papel de sustentadores de governantes e das pretensas infalibilidade e imprescindibilidade de seus respectivos governos em períodos específicos da história perante a massa popular.
} 


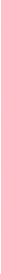

sejam, “(...) a) os governantes estatais são homens bons e sábios (...), muito melhores e mais sábios do que seus bons, porém simples, súditos", e, de forma indissociável, o convencimento de que "b) o controle por um governo forte é inevitável, absolutamente necessário, e muito melhor do que os males indescritíveis que sucederiam à sua queda" (ROTHBARD, 2019, pp. 31-32).

Há outros estratagemas de persuasão, tais como,

(...) o de instilar medo em relação a quaisquer sistemas alternativos de governo ou não governo. Os governantes atuais, alegava-se, oferecem aos cidadãos um serviço essencial pelo qual eles devem ser muito gratos: a proteção contra criminosos e saqueadores esporádicos (ROTHBARD, 2019, p. 32-33).

Além disso, Rothbard (2019, p. 33) orienta que um mecanismo no qual os governantes têm sido bem-sucedidos é o método de fazer com o povo tenha medo dos governantes de outros Estado. Desse modo,

São muitas e sutis as armas ideológicas que o Estado tem usado ao longo dos séculos. Uma das melhores tem sido a tradição. Quanto mais tempo o domínio de um Estado tem sido capaz de se manter, mais poderosa é essa arma; pois, assim, a Dinastia X ou o Estado Y têm peso aparente de séculos de tradição atrás de si. A adoração aos antepassados torna-se, então, um meio nada sútil de adoração aos antigos governantes (ROTHBARD, 2019, p. 34-35).

No entanto, registre-se que "A maior ameaça para o Estado é a crítica intelectual independente" (ROTHBARD, 2019, p. 35). Essa crítica, nota-se, parte de um intelectual livre, desprendido das amarras nas quais os intelectuais acima retratados se encontram aguilhoados e, paradoxalmente, em razão delas, são comumente alçados ao patamar de defensores do poder e de aparências de legitimação popular por intermédio de persuasão estratégica. Constata-se, pois, que a máxima segundo a qual os governantes do Estado têm profundo temor em relação a pessoas despertas e bem orientadas no que concerne à realidade política e social vigentes não é apenas um brocardo que corresponde aos comentários populares e às críticas sociais, engendradas por aqueles que se recusam a somente receber orientações ideológicas pré-definidas e autossuficientes de origem externa e intimamente ligada aos dirigentes estatais.

O que se destaca nesse contexto é a contundência com que os governantes se voltam contra aqueles que entoam discursos e críticas autônomos, verdadeiramente independentes, desligados das relações de poder. Com isso, o Estado contra-ataca, na medida em que, 


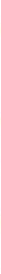

Ante tal exposição, depreende-se que, se o Estado, na pessoa de seus governantes e toda a sorte de colaboracionistas, credita sua roupagem de legitimação política e o senso coletivo da necessidade da presença da figura estatal hierarquizada e impositiva no curso da história para a manutenção da ordem e do bem-estar cívico ao resultado de estratégias organizadas e racionalizadas de persuasão da sociedade, para manter a aceitação ativa ou a passividade resignada de um povo, no mínimo, o desenvolvimento desnudado da gerência estatal certamente não corresponderia aos anseios e interesses flagelados da sociedade, e, talvez, desse origem a manifestações explícitas de descontentamento popular a ponto de abalar as estruturas orgânicas e ideológicas sobre as quais o ente público e seus respectivos gerenciadores se assentam.

\section{INTELECTUAIS E O SISTEMA JUDICIÁRIO: MANTENEDORES DA LEGITIMIDADE (E SOBREVIVÊNCIA) DO ESTADO}

Conforme lembra Rothbard (2019, p. 43), ao rememorar as lições do mestre Bertrand de Jouvenel, o Estado, por meio da atuação orquestrada de intelectuais, obtém o ambiente propício e a uma sociedade bastante receptiva aos carimbos intelectuais de legitimidade e virtude presentes nas suas práticas estatais, haja vista a "necessidade crucial de 'legitimidade' para a sobrevivência de qualquer governo, essa legitimação significando aceitação majoritária básica do governo e de suas ações" (BLACK apud ROTHBARD, 2019, p. 45-46). E nessa toada,

(...) o Estado transformou largamente o próprio recurso judicial, de um dispositivo limitador a outro instrumento que concede legitimidade às ações governamentais. Pois, se um decreto judicial de "inconstitucionalidade" é um poderoso limitador ao poder do governo, um veredito implícito ou explícito de "constitucionalidade" é uma arma poderosa para promover a aceitação pública de um crescente poder governamental (BLACK apud ROTHBARD, 2019, p. 45).

O Estado e seu governantes estatais precisam, portanto, de um aparato de natureza igualmente estatal e estrutura pública magnânima, que lhes chancele os atos governamentais e lhes atribua o título legitimador da ponderação normativa sob o aval do atributo da constitucionalidade, em particular por ser reconhecido por instituição pertencente à própria máquina estatal e que oferte à sociedade a marca indiscutível da promoção e proteção dos princípios indispensáveis à tutela social e das instituições democráticas. 


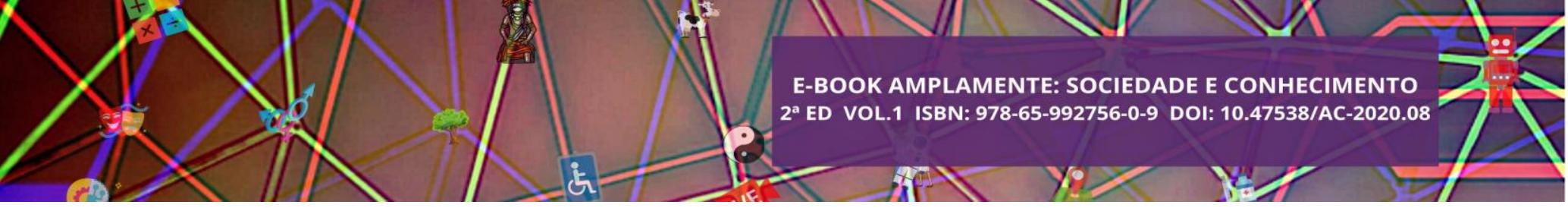

Nesse processo de legitimação, a participação das Supremas Cortes

(...) tem sido a de validação, não de invalidação. O que um governo com poderes limitados precisa, no início e sempre, é de algum meio de convencer o povo de que ele fez tudo o que é humanamente possível para se manter dentro dos seus limites. Essa é a condição de sua legitimidade, e a sua legitimidade, no longo prazo, é a condição de sua sobrevivência. E a Corte, através da sua história, agiu para legitimar o governo (ROTHBARD, 2019, p. 48).

O paradoxo científico-político que emerge dessa discussão é facilmente perceptível, posto que:

Para Black, essa "solução", embora paradoxal, é tranquilamente autoevidente: "O poder final do Estado [...] deve parar onde a lei o retém. E quem estabelecerá o limite, e quem fará cumprir o limite, contra o poder supremo? O próprio Estado, obviamente, através dos seus juízes e de suas leis. Quem controla o moderado? Quem ensino o sábio? (ROTHBARD, 2019, p. 48-49).

Constata-se, pelos ensinamentos de Rothbard (2019, p. 51-52), que John C. Calhoun foi um dos primeiros teóricos políticos que identificou essa suntuosa brecha, de acordo com a qual se pode conferir a missão de delimitar a atuação do governo à Suprema Corte, no exercício de seu poder de interpretação final das diretrizes constitucionais. Nesse raciocínio, por ser, em última análise, um dos braços do próprio Estado a ditar decisões baseadas em atividades de interpretação, de nada adiantaria prever limites legais e teóricos à ação estatal sem que, num só tempo, houvesse a existência de meios legislativos aptos a garantir, de fato, que tais limites fossem respeitados através outros meios designados a preservar a observação da extensão de cada ato governamental.

Segundo o autor, a simples presença de limites teóricos à ação estatal, sem o correspondente instrumental indispensável à efetiva limitação prática da atuação governamental, resultaria no conflito entre duas frentes, a do partido dominante e a do partido menor e mais fraco. Esse, postularia pela imediata implementação de medida legais contundentes e eficientes no objetivo de se restringir as interferências do Estado; aquele (o partido dominante e poderoso), por outro lado, defenderia a manutenção do status quo e externaria, com todas suas forças, a repulsa à ideia da criação de restrições efetivas ao exercício do poder, sendo que, por seu maior campo de influência, certamente teria suas reivindicações atendidas. 


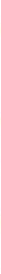

Logo, na ausência de medidas restritivas do poder, no mundo fenomênico, terse-ia apenas uma legislação de conteúdo impreciso e com inúmeras frestas pelas quais o poder poderia ter seu campo de ação indevidamente estendido, e, com evidência no campo jurídico, restaria tão somente uma contenda de interpretações. O resultado desta equação seria ditado pelo sábio moderador dos conflitos sociais, o sistema judicial, conforme explanado acima. Desse modo, o que restaria à sociedade é a solução alcançada por um dos braços poderosos do Estado para dar fim a questões relacionadas à legitimidade e expansão do poderio estatal criadas pela própria estrutura iniciadora da celeuma originária.

\section{CONSIDERAÇÕES FINAIS}

Embora em análises modernas o Estado seja comumente retratado como organismo social direcionado à consecução de metas e anseios de ordem eminentemente social, principalmente em suas próprias campanhas de publicidade oficial, ele é, em sua essência histórica, a estrutura que, em muitos aspectos da vida produtiva dos cidadãos, interferiu e intervém de forma evidente na vida privada e possui sua fonte de subsistência na atividade de predação, por meio da qual busca no riqueza privada sua principal fonte de manutenção, o que custeia, também, seus estratagemas responsáveis por acobertar sua face predatória e por garantir as aparências de legitimação popular, ainda que constantemente atente contra os interesses das pessoas que produzem a mesma riqueza que o mantém.

De igual forma, não se pode esquecer que o Estado, ao passo que deve assegurar o mantimento de suas forças estatistas por meio de arsenal burocrático e custoso, também necessita do contínuo auxílio dos mecanismos de reforço ideológico. Tal papel, como fora abordado, incumbe primordialmente aos intelectuais atrelados às contraprestações governamentais, visto que a vida desses colaboradores de armas ideológicas se mostra muito mais cômoda e próspera mediante o recebimento lisonjeiro de variadas benesses e privilégios fornecidos pelos governantes, cujas legitimidade aparente e aceitação passiva ou resignada da massa popular são, em grande medida, frutos creditados às ações de propaganda maciça de ideias e pensamentos pré-definidos formulados pelos colaboradores ativos das atividades intelectuais, substituintes da crítica autônoma, verdadeira e independente do povo governado, que, por não ser tão 


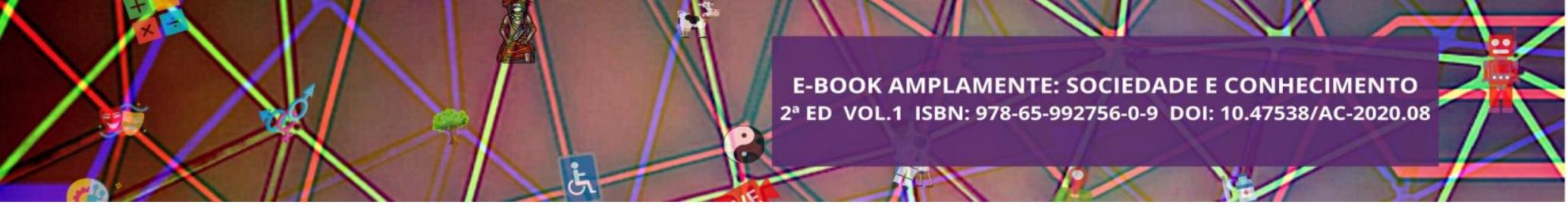

afeito ao hábito de observação ativa e sócio-política, entrega-se aberta e passivamente aos ideais e valores previamente formulados.

Ademais, na tentativa de manter a credibilidade - não raramente fragilizada diante da sociedade, o Estado e seus governantes podem se deparar com duas realidades distintas: ou a) não haverá, no ordenamento jurídico pátrio, uma série de limitações ao exercício do poder, de forma a inviabilizar atos governamentais abusivos e desarrazoados, ou b) a máquina estatal sofrerá restrições à sua atuação oficial em razão de expressas enunciações do conjunto de normas jurídicas vigentes em seu território.

No primeiro caso, encontra-se o ambiente perfeito para a expansão do poder e a manipulação do ideário coletivo, a fim de justificar a existência e a extensão do domínio e das influências internas; e, nesse cenário juridicamente desolado, sob a perspectiva da parcela social mais atingida pelos desvarios governamentais, o campo normativo é deveras indeterminado quanto aos limites balizadores das investidas estatais, sendo que, no final das contas, a tarefa de ponderação e restauração da ordem e do equilíbrio legal será incumbência do sistema judiciário, que, ou declara a inconstitucionalidade de determinadas ações arbitrárias de governo e restabelece a harmonia pública, ou profere a declaração de constitucionalidade e, novamente, chancela a natureza dos atos estatais praticados e, em especial, em determinadas situações, autoriza a estratégia expansiva e articulada de dominação.

Na segunda hipótese (presença de restrições legais ao poder estatal), por outro lado, a sociedade terá a certeza de que, no âmbito interno, o Estado, ao menos em tese, não exacerbará no exercício de seus poderes instrumentais, de modo que, em caso de indevida transposição de restrições, o próprio sistema judiciário, dessa vez, mais atrelado ao texto normativa, fará com que a ordem seja mantida e os abusos sejam corrigidos em prol dos interesses da denominada coletividade potencial ou efetivamente prejudicada por investidas estatais ilegítimas.

Portanto, apesar das metas institucionais voltadas à concretização de políticas públicas e outras ações oficiais de natureza aparentemente humanitária, a sociedade deve ficar atenta para que, no intuito de não ser confundida com a figura mesma do Estado, permaneça ciente de que o poder e o domínio sempre estão numa tentativa incessante de conquistar mais espaços de influência e de controle, objetivo para o qual são empreendidas variadas e sutis ferramentas de manipulação ideológica, engendradas principalmente por governantes e intelectuais a serviço do governo vigente, de modo a 


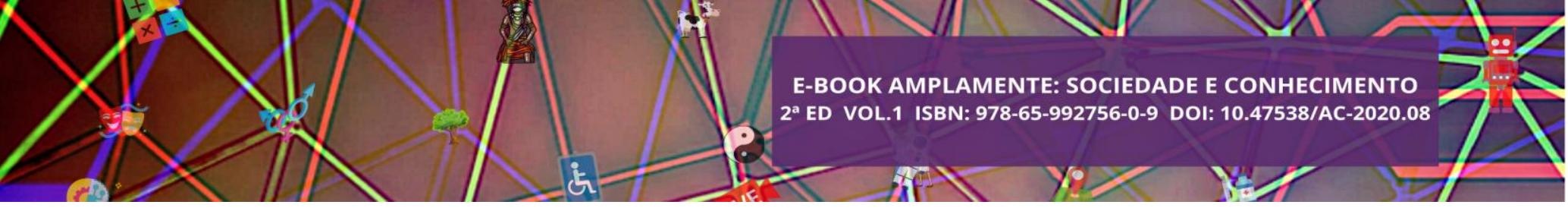

suprimir a ameaçadora crítica intelectual independente, apropriar-se de forma desmedida das riquezas privadas, enfraquecer a autonomia e a individualidade dos cidadãos obrigados a manter a máquina pública, e, de modo inevitável, interferir ilegalmente no exercício das liberdades públicas, sob a justificativa pueril de se preservar a incolumidade das estruturas de poder.

\section{REFERÊNCIAS}

BRASIL. Constituição (1988). Constituição da República Federativa do Brasil. Brasília: Senado, 1988.

MALUF, Sahid. Teoria geral do estado. 30. ed. São Paulo: Saraiva, 2010.

ROTHBARD, Murray Newton. Anatomia do Estado. Campinas/SP: Vide Editorial, 2019. 


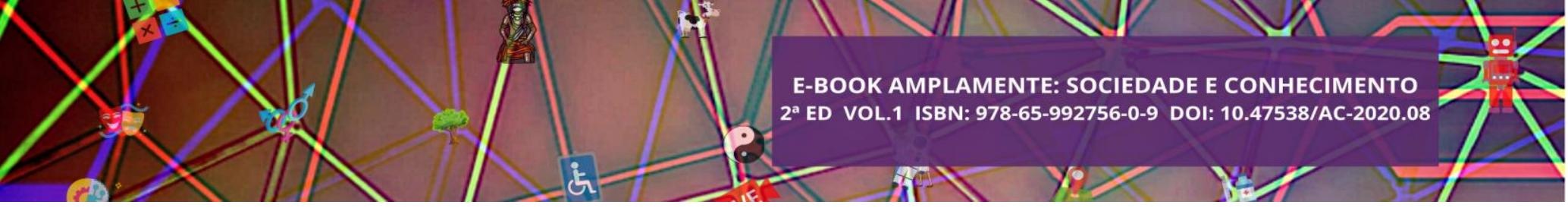

significativo para outras leis no Brasil abordadas no corpo deste trabalho.

Esta pesquisa se configura como bibliográfica onde foram consultados, artigos, livros e sites jurídicos, sendo esta modalidade de pesquisa muito significativa para este estudo, possibilitando refletir sobre a realidade dos portadores do Transtorno do Espectro Autista, nas políticas e leis que buscam minimizar as dificuldades de inserção social e o aparato legal que garante seus direitos.

Este artigo objetiva descrever o conceito de autismo e em detrimento do senso comum, sobre o TEA, descrevendo panoramicamente a evolução dos conceitos sobre esse transtorno e por fim, descrever objetivamente as principais leis que oferecem direitos e que resguardam o portador de TEA e seus cuidadores.

Por fim, nessa esteira histórica, o artigo busca descrever a importância da criação de Leis e Políticas Públicas em favor dos portadores do TEA e seus cuidadores. Este artigo se justifica em razão das do aumento de denúncias de descumprimento dos dispositivos normativos, bem como pela falta de interesses de ente público em propiciar as políticas públicas necessárias ao fortalecimento da inclusão do autista no meio social em geral, e com isso promovendo uma margem para a prática da exclusão e preconceito contra aqueles que o sofrem somente por serem diferentes.

\section{CONCEITOS SOBRE O TRANSTORNO DO ESPECTRO AUTISTA (TEA)}

O autismo é um transtorno que atinge o desenvolvimento dos infantes desde os primeiros anos primeiros anos de vida, especialmente em determinados aspectos como linguagem, interação social, comportamento etc.

Vale salientar que as manifestações entre as crianças podem ser variadas, desde sintomas mais brandos a mais agressivos. inclusive há casos que são associados a outros tipos de enfermidades como deficiência mental, distúrbios diversos (alimentar, sono, obsessivo-compulsivo), sendo, portanto, muito complexo de classificar os graus ou níveis do autismo.

Sobre a manifestação do autismo é importante ressaltar que a variação da manifestação nas crianças. Em algumas crianças de maneira mais branda, enquanto em outras, eles aparecem de modo mais agressivo. Há também casos em que é possível haver uma associação com outros tipos de enfermidades, como deficiência mental, 


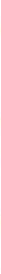

distúrbio alimentar, do sono ou transtorno obsessivo-compulsivo. Assim por haver tantas variáveis, é difícil classificar precisamente os graus de autismo.

O Transtorno do Espectro Autista (TEA) é denominado pela associação americana de psiquiatria - APA (2013), como um transtorno do neuro desenvolvimento. Sobre isso, destacamos que o termo autismo foi surgiu pela primeira vez em 1911, por Eugen Bleuler, um psiquiatra suíço que buscava em seus estudos descrever características da esquizofrenia.

No entanto, a denominação do autismo toma uma proporção maior em 1943, por meio do psiquiatra Leo Kanner, que em suas pesquisas já tratavam de características do autismo de forma relevante (CUNHA, 2015).

É importante destacar características peculiares da criança com TEA. “[...] o TEA é definido como um distúrbio do desenvolvimento neurológico que deve estar presente desde a infância, apresentando déficit nas dimensões sociocomunicativas e comportamental” (SCHMIDT, 2013). Considerando a indivisibilidade dessas dimensões.

A tabela abaixo busca trazer informações sobre a evolução do termo ao longo das décadas.

Tabela 1: Evolução dos conceitos sobre TEA

\begin{tabular}{|c|c|c|}
\hline Ano & Pesquisadores & Evento \\
\hline$(1906)$ & Plouller & $\begin{array}{l}\text { Precursor do termo Autista na literatura psiquiátrica. Estudos } \\
\text { sobre o processo de pacientes que apresentavam demência } \\
\text { precoce. }\end{array}$ \\
\hline$(1911)$ & Bleuler & O primeiro a disseminar o termo Autismo \\
\hline$(1943)$ & Leo Kanner & $\begin{array}{l}\text { Como psiquiatra infantil, descreveu estudo sobre } 11 \text { crianças } \\
\text { que apresentavam dificuldades de interação social nos } \\
\text { princípios de suas vidas. (Cunhou o termo Distúrbio } \\
\text { Autístico do Contato Afetivo). }\end{array}$ \\
\hline (1944) & Hans Asperger & $\begin{array}{l}\text { Iniciou um estudo definido por ele como Psicopatia Autista, } \\
\text { com manifestação apenas no sexo masculino, levando em } \\
\text { consideração: aspectos da família, aspectos físicos e } \\
\text { comportamentais na aplicação de testes de inteligência. }\end{array}$ \\
\hline$(1949)$ & Leo Kanner & $\begin{array}{l}\text { Apresentou o termo "Autismo Infantil Precoce", observando } \\
\text { que as alterações iniciaram nos dois primeiros anos. } \\
\text { Considerando a natureza básica do autismo ligada à } \\
\text { esquizofrenia infantil e que esta poderia ser sua manifestação } \\
\text { precoce. }\end{array}$ \\
\hline$(1947)$ & Bender & Cunhou o termo "esquizofrenia infantil". \\
\hline$(1952)$ & Malher & $\begin{array}{l}\text { Fez menção aos termos: Psicose autística (a mãe não é } \\
\text { percebida como elemento externo) e psicose simbiótica } \\
\text { (apego obstinado aos pais temporariamente. }\end{array}$ \\
\hline$(1967)$ & Rutter & $\begin{array}{l}\text { Propôs uma definição a partir de } 4 \text { critérios: ausência de } \\
\text { interesse social; dificuldade na comunicação verbal e não- }\end{array}$ \\
\hline
\end{tabular}




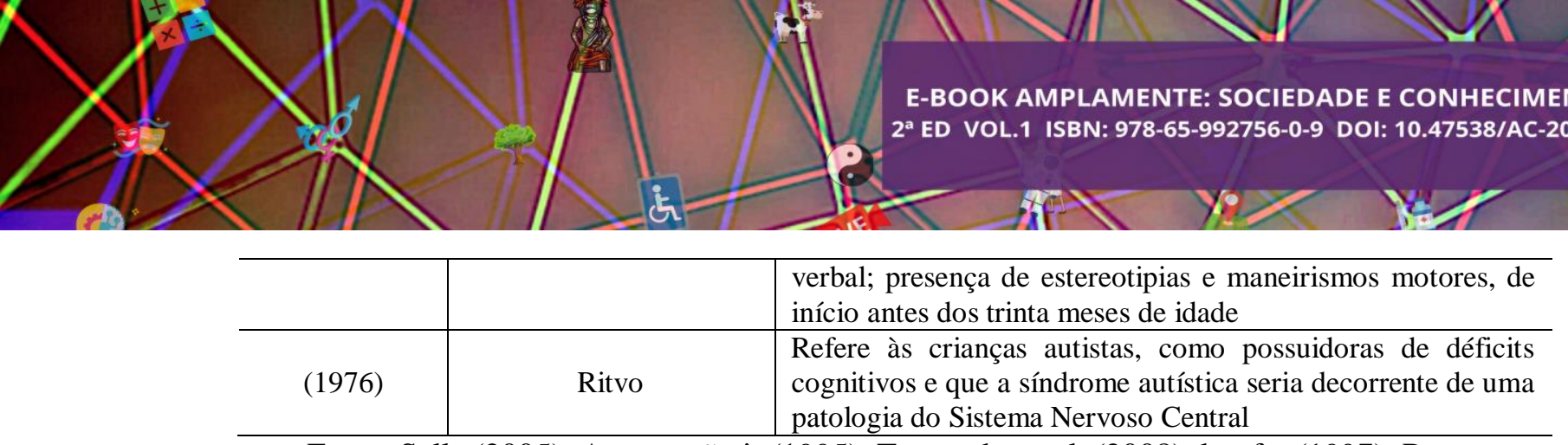

Fonte: Salle (2005); Assumpção jr (1995); Tamanaha et al. (2008); kupfer (1997); Rutter

(1967); klin (2006); Ritvo (1976).

Com a evolução dos conceitos, o autismo, na CID-10 (OMS, 1993), passou a ser considerado um distúrbio do desenvolvimento (F84), e, no DSM-IV (APA, 1994), como transtornos globais do desenvolvimento, com a inclusão de critérios específicos de algumas patologias, tornando-se mais específico e característico que anteriormente no DSM-III-R, conforme tabela.

Tabela 2: Conceito de Autismo no CID E DSM

\begin{tabular}{c|l|l}
\hline Ano & \multicolumn{1}{|c}{ Pesquisadores } & \multicolumn{1}{c}{ Evento } \\
\hline \multirow{3}{*}{$(1980)$} & DSM III-R & $\begin{array}{l}\text { Autismo como uma nova classe de transtornos da infância } \\
\text { integrando os transtornos globais do desenvolvimento } \\
\text { (TGD). }\end{array}$ \\
\hline \multirow{3}{*}{$(1993)$} & CID 10 & $\begin{array}{l}\text { F84 Transtornos invasivos do desenvolvimento } \\
\text { F84.0 Autismo Infantil. } \\
\text { F84.1 Autismo atípico }\end{array}$ \\
\hline \multirow{2}{*}{ DSM-IV (APA) } & $\begin{array}{l}\text { Transtornos crônicos, caracterizados por prejuízos graves e } \\
\text { abrangentes em diversas áreas do desenvolvimento: } \\
\text { Habilidades de interação social e recíproca, habilidades da } \\
\text { comunicação, ou a presença de comportamento, interesse e } \\
\text { atividade estereotipada. }\end{array}$ \\
\hline
\end{tabular}

Fonte: DSM-III, 1980; CID-10, 1993; DSM-IV, 1994

É importante salientar que as pessoas com TEA também tem os direitos garantidos pela Constituição Federal de 1988 e outras leis nacionais, de forma igualitária. Dessa forma, as crianças e adolescentes autistas possuem todos os direitos previstos no Estatuto da Criança e Adolescente (Lei 8.069/90), e os maiores de 60 anos estão protegidos pelo Estatuto do Idoso (Lei 10.741/2003).

\section{ALGUMAS LEIS QUE CONTEMPLAM OS PORTADORES DO TEA}

A tabela abaixo busca demonstrar um pouco das leis que podem ser acessadas pelos portadores do TEA.

Tabela 3: Leis com aplicação ao TEA

\begin{tabular}{c|c|c}
\hline $\mathbf{N}^{\mathbf{0}}$. & LEI & DESCRIÇÃO \\
\hline & Passou a existir a Política Nacional de Proteção dos Direitos \\
\hline
\end{tabular}




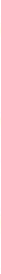

a) A Cartilha dos direitos da pessoa com autismo. Comissão de defesa dos direitos da pessoa com autismo da OAB/DF (2015), que objetivou compilar à época a Legislação vigente, especifica para as pessoas com TEA, buscando esclarecer, orientar e conscientizar;

b) Lei de Diretrizes e Bases da Educação Nacional (LDB), Lei no 9.394/96, na Política Nacional da Educação Especial na Perspectiva da Educação Inclusiva (2008);

c) As Diretrizes Nacionais para Educação Especial na Educação Básica (RESOLUÇÃO CNE/CEB No 2, DE 11 DE SETEMBRO DE 2001).

\section{LIMITAÇÕES A PARTIR DO TRANSTORNO DO ESPECTRO AUTISTA}

Limitações na comunicação oriundas do transtorno são frequentes. Em casos extremos, os pequenos autistas não conseguem, realmente, progredir na comunicação verbal. As Interações sociais são prejudicadas, uma vez que o isolamento é uma característica que se manifesta com muita frequência nesse grupo. Além disso, em muitos casos, também ocorrem dificuldades no estabelecimento das relações sociais que se dão por meio de interações curtas. Variação no comportamento: os brinquedos são explorados pelos autistas de maneira restrita, com enfoque apenas em detalhes ou em uma especificidade do objeto. Sobretudo, apresentam comportamentos repetitivos e auto estimulatórios, intolerância a mudanças na rotina ou na disposição do ambiente.

\section{CONSIDERAÇÕES FINAIS}

Mesmo sabendo que a grande maioria dos portadores do TEA, consegue frequentar a escola regular, só quem é portador do TEA ou é cuidador de um portador, sabe mensurar as dificuldades em se lidar dia a dia não só com o TEA, mas também com o preconceito das pessoas. Assim, uma vez que o autismo não tem cura, e também não pode ser considerado, propriamente como uma doença, e sim uma condição "NEURODIVERSA", e que afeta diretamente em diversas faculdades como a comunicação, a cognição, a expressão etc. Frequentemente os pais de crianças com o TEA descrevem cada conquista na educação e desenvolvimento como de grande relevância. Além de que os portadores do TEA estão também sujeitos as todas as demais doenças. 


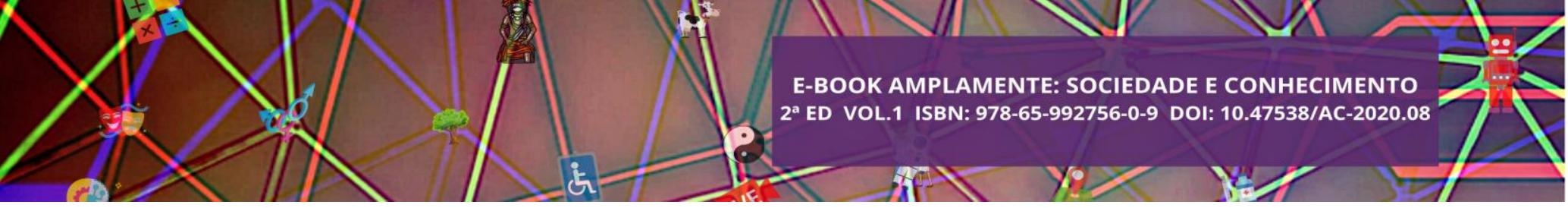

Os autistas são contemplados com os mesmos direitos de qualquer outra pessoa.

As leis que emanam da sociedade visam oportunizar ao portador do TEA mais oportunidades, na expectativa de minimizar os prejuízos diversos ao portador do TEA, e também do cuidador que está mais próximo do mesmo. É importante ressaltar que estas leis alcançam também planos de saúde, respectivamente em seus atendimentos, vetando qualquer tipo de discriminação ao portador do TEA.

No âmbito escolar é necessário além das leis, uma mudança de cultura que contemple toda os colaboradores do ambiente escolar, permitindo não só a matrícula do aluno, mas efetivamente o seu aprendizado. Isso se dará também com a ofertando aos docentes: tempo, formação e qualificação necessários para lidar com os portadores do TEA.

Portanto, como posso "abraçar" a causa dos autistas e difundi-la na sociedade? Permita-se explorar o universo singular do portador do TEA. Conheças as leis e passe disseminá-las. Seja "empático". Converse com os pais de autistas e coloque-se no lugar deles. "[...] Assim como um diamante precisa ser lapidado para brilhar, uma pessoa com autismo merece e deve ser acolhida, cuidada e estimulada a se desenvolver" (SILVA et al, 2012, p. 06).

\section{REFERÊNCIAS}

AMERICAN PSYCHIATRIC ASSOCIATION. Diagnostic and Statistical Manual of Mental Disorders, Third Edition (DSM-III). Arlington, VA: American Psychiatric Association, 1980.

AMERICAN PSYCHIATRIC ASSOCIATION. Diagnostic and statistical manual of mental disorders: DSM-IV. 4th ed. Washington, DC: American Psychiatric Association, 886 p., 1994.

AMERICAN PSYCHIATRIC ASSOCIATION. Diagnostic and Statistical Manual of Mental Disorders, Fifth Edition (DSM-V). Arlington, VA: American Psychiatric Association, 2013.

ASSUMPÇÃO JUNIOR, F.B.; Conceito e classificação das síndromes Autísticas. In: SCHAWATZMAN, J.S.; Assumpção Júnior FB. Autismo infantil., 2 ed, São Paulo: Memnon;,1995.

BRASIL, Planalto. Decreto 6.949, de 25 de Agosto de 2009. Promulga a convenção internacional sobre os direitos das pessoas com deficiência e seu protocolo facultativo, assinados em New York, em 30 de Março de 2007. Disponível 


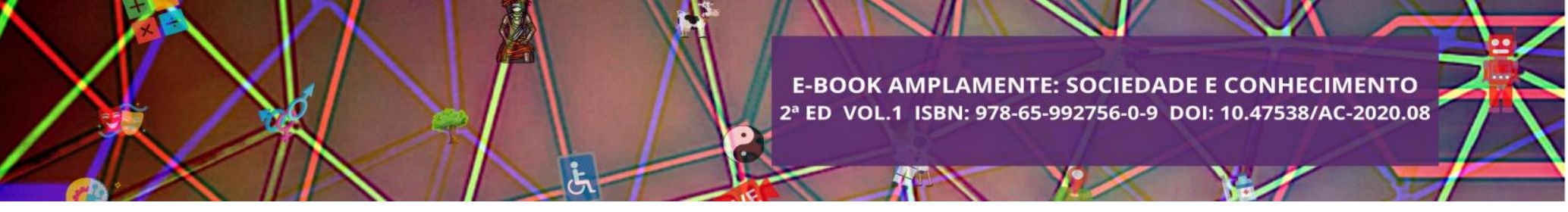

BRASIL. Planalto. Política nacional de proteção dos direitos da pessoa com transtorno do espectro autista. Lei $\mathrm{n}^{\circ} 12.764$ de 27 de dezembro de 2012. Disponível em <http://w.w.w.planalto.gov.br/ccvil_03/_ato2011-2014/lei/112764html>. Acessado em 09 de junho de 2020.

CID10. Busca de CID10. Disponível

em:<http://www.cid10.com.br/buscadescr?query=f84> Acesso em 09 de Junho de 2020.

CUNHA, Eugenio. Autismo e inclusão: psicopedagogia práticas educativas na escola e na família. 6 ed. Rio de Janeiro: Wak Ed. 2015.

KLIN, A.; Autismo e Síndrome de Asperger: uma visão geral. Rev Bras Psiq,v.28, (Supl I), p. 3-11, 2006.

$\mathrm{OAB}$. Cartilha dos direitos da pessoa com autismo. Comissão de defesa dos direitos da pessoa com autismo da OAB/DF. 2015. Disponível em:

<https://issuu.com/oabdf/docs/cartilhadosdireitosdapessoacomautis>. Acesso em $13 \mathrm{de}$ junho de 2020.

KUPFER,M.C.M.; Modelos de atendimento à criança psicótica. Boletim de Psicologia, v.48, n.109, p.77-96, São Paulo, 1997.

RITVO,E.R.; Autism: diagnosis, current research and management. New York: Spectrum; 1976.

RUTTER, R. Distúrbios psicóticos da infância precoce. Im: COPREN, A; WALK, A. Recent. Associação Médico Psicológica, 1967.

SALLE, E. Autismo infantil sinais e sintomas. In: CAMARGOS JR.,W. (coord.) Transtornos Invasivos do Desenvolvimento: 3o Milênio 2ed. Brasília: CORDE, 2005,p $11-15$

SCHMIDT, Carlo. Autismo, educação e transdisciplinaridade. In: SCHMIDT, C (org) Autismo, educação e transdisciplinaridade. Campinas, SP: Papirus, 2013.

SILVA, Ana Beatriz Barbosa; GAIATO, Mayra Bonifácio; REVELES, Leandro Thadeu. Mundo singular: entenda o autismo. Fontanar, 2012. Disponível em: http://lelivros.love/book/download-mundo-singular-ana-beatriz-barbosa-silva-em-epubmobi-e-pdf/. Acesso em 15 de junho de 2020.

TAMANANHA, A.C.;PERISSIONOTO,J.,CHIARI,B.M.; Uma breve revisão histórica sobre a construção dos conceitos do Autismo Infantil e da síndrome de Asperger. Rev Soc Bras Fono,v.13, n.3, p.296-299, 2008. 


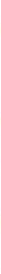

distintas perspectivas para os alimentos, desde a produção, que engloba atividades agrárias e pecuárias, até a industrialização, a forma de distribuição e seu impacto sociocultural e ambiental. Por isso, alimentar-se vai além da nutrição do corpo, relaciona-se a fatores sociais e também sensoriais.

Ao analisarem-se os hábitos alimentares da sociedade brasileira, constata-se que a mesma o concebe de forma mecânica. Isso se dá desde a escolha dos alimentos, até o preparo e o desperdício de parte de alguns produtos, em especial de legumes e verduras.

Por isso, a importância de abordagens em torno da problemática do desperdício alimentar, o que deu origem ao projeto de oferta, para um grupo de jovens e adultos residentes no KM 02, bairro periférico do município de Santa Maria, de uma oficina sobre reaproveitamento alimentar. A atividade compôs-se de encontros quinzenais, com diálogos acerca dos assuntos de interesse comum sobre a rotina de refeições e formas de alimentar-se do grupo.

É necessário observar a questão socioeconômica do grupo, o qual muitas vezes passa por situações de privações, não tendo o hábito de consumo de determinados alimentos. Ao limitar os sujeitos em relação às opções de produtos a serem ingeridos, bem como impõe, em suas rotinas, o ato de cozinhar, os mesmos tipos de alimentos.

É também objetivo do projeto ao qual se vincula a atividade aqui analisada, oferecer às pessoas em idade produtiva, porém sem emprego, conhecimentos sobre educação para o trabalho. Esses conhecimentos, mesmo que genéricos, poderão possibilitar reflexões críticas acerca do meio no qual se vive e as problemáticas do mesmo, o que poderá representar alternativas para uma melhor qualidade de vida.

A ideia de associar nutrientes a partes pouco usuais dos alimentos, seus o sabores e a forma como são conceituados cultural e socialmente, o que torna um alimento saboroso, como se molda a familiaridade com determinadas texturas, cheiro e consistência. Sabendo da relevância da indústria alimentar na construção do que é imposto como algo gostoso e nutritivo, prático e com um preço acessível.

Por vezes, ignorando a quantidade absurda de produtos comestíveis e com alto valor nutricional, como as Plantas Alimentícias não Convencionais (PANC), sendo pouco abordadas. Esta problemática de cunho sócio alimentar impacta de forma direta no meio ambiente e deve ser observada não apenas pela esfera da fome, mas também, pelo lado do impacto que o desperdício provoca. Pensar no aproveitamento integral dos alimentos é, também, refletir sobre práticas sustentáveis. 


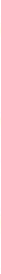

Ao refletir-se as relações entre homem e natureza, a formação da sociedade e as complexas relações entre as ações humanas e o meio ambiente, recebem-se as transformações ocorridas ao longo dos tempos. A educação ambiental é, portanto, uma estratégia de formação e promoção da consciência coletiva acerca dos problemas dos grupos sociais.

O diálogo entre os sujeitos, a respeito dos seus hábitos e suas práticas, é necessário para o fortalecimento destes grupos sobre suas rotinas. Com base nesses pressupostos, a proposta de uma oficina sobre aproveitamento integral dos alimentos surgiu como forma de dialogar a necessidade de abordar os hábitos alimentares entre as diferentes classes sociais, analisando-se o meio e valorizando as práticas dialógicas. Neste sentido, o ideário freireano (2005) contribui na medida em que propõe o diálogo como um caminho através do qual os homens constroem suas significações enquanto homens.

Para Paulo Freire (2005), o diálogo é parte existencial do sujeito, e é nesta prática que existe o refletir e o agir, e assim, a capacidade de transformar o sujeito, e não reduzir o diálogo a um ato que consiste em reproduzir ideias de um sujeito para outro. A prática dialógica deve ser uma conquista para a libertação dos homens.

Analisar a importância do diálogo, de como através dele o conhecimento é construído, permite a troca de experiências acerca de uma temática tão vital quanto a alimentação, as razões para a escolha de alimentos processados em detrimento daqueles "in natura", a cadeia alimentar de cada produto e os apelos midiáticos dos setores industriais, o meio em que estes sujeito encontram-se, o ato de cozinhar em sua forma mais rotineira. Relações dialógicas sobre essas questões têm como propósito construir análise crítico reflexivas acerca de ato de comer.

Ao abordar-se o aproveitamento total do alimento, refletiu-se sobre receitas que utilizam apenas parte de alimentos, descartando o restante. Este ato ocorre sem que haja a reflexão sobre o desperdício econômico de alimentos, muito embora o problema maior esteja no desperdício nutricional, pois o hábito do descarte é tratado por muitas famílias com naturalidade, independentemente da situação econômica dos grupos familiares.

Por isso, não há incentivo para o consumo integral dos alimentos, as cascas das frutas e legumes, assim como os talos e folhas das verduras acabam sendo facilmente desprezados. Mas, paradoxalmente, milhares de pessoas vivem em situação de fome e desnutrição, tendo negado seu acesso ao alimento por questões geográficas, 


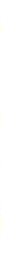

sociopolíticas e econômicas. Assim, a relevância da pesquisa reside na importância da educação sócio alimentar, em especial entre populações que vivem em situações de vulnerabilidade estrutural.

\section{DESENVOLVIMENTO (RESULTADOS E DISCUSSÃO)}

O trabalho tem por base o ideário proposto por Paulo Freire (2005) e de Miguel Arroyo (2014), em especial a ideia de que a educação é uma importante estratégia para a promoção de um sujeito capaz de analisar criticamente sua situação social, econômica, seu poder de escolha e a forma com que o meio em que ele se insere é capaz de influenciar em sua qualidade de vida. Visando explorar o conhecimento empírico em torno das escolhas alimentares, analisa-se também a forma de pensar para além das atividades domésticas.

Através do pensamento freireano (2005) e das reflexões propostas por Miguel Arroyo (2014), é possível observar a importância do lócus da pesquisa, onde os sujeitos, pelo acesso à educação e ao conhecimento, alcançam a consciência acerca do seu papel na sociedade, até o conhecimento empírico desenvolvido em casa, na comunidade, permitindo ao sujeito lutar para recuperar sua humanidade, atentando-se para que o oprimido não venha a tornar-se um opressor. É preciso, então, estimular relações dialógicas e generosas na luta contra as relações de poder que oprimem os sujeitos.

É possível observar, então, que o meio no qual os sujeitos estão inseridos, ou seja, suas comunidades, os influenciam sem que, muitas vezes, esse processo possa ser percebido. Observa-se este fenômeno ao tratar-se dos hábitos alimentares, como o costume de trocar receitas dentro de uma comunidade, dividir insumos, considerando que na maioria das vezes os sujeitos de uma mesma comunidade têm acesso aos mesmo programas de televisão.

Através dos quais se constrói um apelo midiático para o consumo de determinados tipos de alimentos, em detrimento de outros. Tais práticas são reproduzidas e refletem-se na forma com que cada família compõe suas refeições. Ainda assim, existem dúvidas a respeito de como a relação entre os hábitos alimentares e o apelo para determinado tipo de alimento, sem questionar o seu valor nutricional.

$\mathrm{Na}$ primeira oficina, foram levados alimentos processados como macarrão instantâneo, salgadinho à base de milho, biscoito água e sal e suco em pó. Foi questionado sobre quais alimentos o grupo considerava "saudáveis" e o qual a 


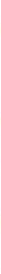

periodicidade de consumo destes produtos.

Houve o consenso de que o salgadinho à base de milho não seria uma boa escolha. Porém, o grupo não conseguiu ter clareza sobre qual, entre o pão e o biscoito água e sal, é o mais saudável, muitas vezes associando a saciedade de determinado alimento ao fato dele ser saudável.

Quanto a questão do macarrão instantâneo e sua diferença frente ao macarrão de sêmola, um dos mais comuns e de fácil acesso. Ao final foi mostrada uma laranja e questionado o que era mais saudável, o suco da fruta ou o suco em pó. Também foi levado a margarina e debateu-se sobre a manteiga e a maionese, a composição destes alimentos ser, basicamente gordura, ainda assim houve resistência para a compreensão dos malefícios deste tipo de gordura para a saúde.

$\mathrm{Na}$ segunda oficina a temática foi higienização e conservação dos alimentos. Empiricamente, higienizar frutas e legumes apenas com água, prática revelada pelos sujeitos do grupo, visto que o consumo de alimentos "in natura" é esporádico na rotina de alimentação.

$\mathrm{Na}$ terceira oficina promoveu-se um debate sobre temperos e a confecção de sal temperado para as participantes utilizarem em casa e questionado a quantidade de sal que o grupo costumava utilizar em suas receitas.

$\mathrm{Na}$ quarta oficina, foram abordados os principais alimentos que normalmente não são utilizados de forma integral e receitas envolvendo estes, buscando desmistificar as partes pouco usuais e com alto valor nutricional que é desperdiçado.

$\mathrm{Na}$ quinta oficina, foi questionado o que é um alimento saudável e o que é consumido diariamente na alimentação pelo grupo, reforçando os hábitos alimentares com a qualidade de vida.

É possível refletir não apenas sobre o conjunto de decisões, mas é necessário levar em consideração o privilégio de poder escolher qual alimento será consumido, observando-se o poder aquisitivo para possuir determinado alimento, tal como a quantidade de refeições que o sujeito fará durante o dia e a qualidade do alimento consumido, e a posteriori ingerido e como será aproveitado, representa o lugar que este sujeito ocupa na sociedade.

Os hábitos alimentares perpassam questões sociais, considerando o poder aquisitivo dos sujeitos, e estão diretamente ligados a escolha de um alimento, em detrimento de outro. Por exemplo, ao fazer-se a escolha da proteína de valor mais 


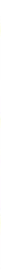

acessível, muitas vezes opta-se por aquela de melhor valor nutricional. $\mathrm{O}$ fator praticidade também aparece como relevante nos diálogos abordados durante as oficinas.

$\mathrm{Na}$ oficina em que foi proposta a produção de um tempero natural, pois a maioria do grupo utiliza produtos industrializados que possuem alto teor de sódio e conservantes, questionou-se sobre a escolha por estes produtos. A resposta do grupo fundamentou-se na praticidade, estando acima do sabor e do valor do produto.

O papel da indústria dos alimentos é propor praticidade para a vida do sujeito. Na maioria das vezes é sobre a praticidade que são feitos os apelos midiáticos. Oferecer alimentos de baixo valor nutricional, por um preço baixo, mas que proporcione praticidade tem sido o mote das campanhas publicitárias da área da alimentação.

Cabe ressaltar que, em diálogo com a comunidade envolvida nas oficinas, todos os participantes do grupo, quando questionadas, responderam que sofrem de algum problema crônico de saúde. Os principais problemas apontados foram: diabetes, pressão alta e ansiedade.

A crescente produção dos produtos processados, juntamente com a popularização dos mercados, colaborou para o consumo exacerbado de alimentos industrializados.

A possibilidade de alimentar-se com dignidade pressupõe viver com dignidade. Os sujeitos então, coletivamente, podem renascer na luta e pela luta por libertação, com trabalho libertador, não opressor, livre, que traga a alegria de viver. O pensamento freireano (2005) nos aponta que sem a fé nos homens o diálogo é uma farsa. Ao fundarse no amor, na humildade, o diálogo atinge uma relação horizontal, na qual a confiança no outro é uma consequência óbvia.

\section{CONCLUSÃO}

Ao concluir a série de oficinas, foi possível perceber-se a importância dos diálogos acerca das questões sócio alimentares e como está intimamente ligada a qualidade de vida do grupo. Neste estudo de caso, observou-se o poder da indústria dos alimentos na escolha dos sujeitos, ficou evidente que os apelos midiáticos, ao abordarem determinados alimentos de forma saudável e nutritiva, estimula seu consumo, sem haver uma análise crítica acerca daquele produto.

Utilizar instrumentos do campo da sociologia, da educação ambiental e dos 


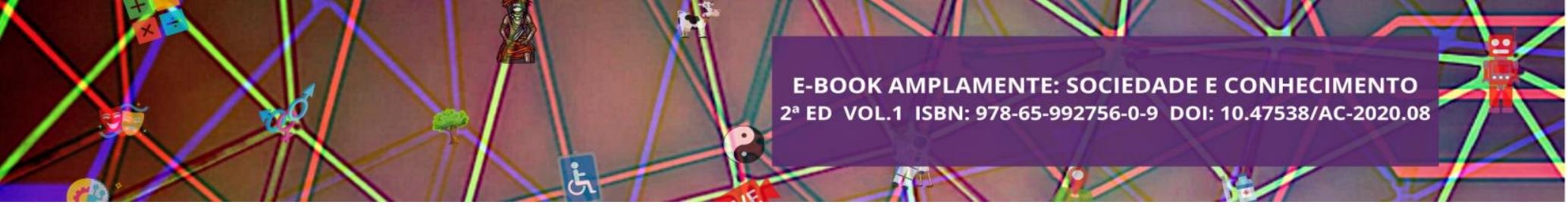

ensinamentos freireanos e também as ideias de Miguel Arroyo (2014) para nortear a pesquisa, possibilitou aproximar a fragilidade estrutural e reflexão dos diálogos sobre a temática alimentar. Construir um conhecimento inicial para promover a autonomia dos sujeitos em relação ao ato de preparar e escolher seus alimentos e os questionamentos da repetitividade da rotina alimentar, requer além de criatividade, acesso a estes alimentos.

A questão social dos hábitos alimentares perpassa o prato de comida. É muito mais complexa, ao dialogar, e levar alimentos acessíveis, e ainda assim encontrar dificuldades, pois, a região onde este grupo reside, limita suas escolhas alimentares.

Pensar uma educação capaz de analisar criticamente o lugar destes sujeitos na sociedade, o conhecimento empírico para além das atividades domésticas. Considerando o cotidiano deste grupo como o aqui e o agora, com perspectivas pouco analisadas sobre a qualidade de vida, o futuro e os impactos ambientais causado pelo desperdício alimentar e o consumo exacerbado de alimentos processados.

Ao escolher a temática de aproveitamento do alimento, foi possível dialogar sobre saúde, hábitos alimentares e sustentabilidade, com uma abordagem descontraída, mas jamais desprezando o poder transformador da educação através do diálogo, as mudanças possíveis a partir do trabalho coletivo e troca de experiências.

\section{REFERÊNCIAS}

ARROYO, Miguel. Outros sujeitos, outras pedagogias. Rio de Janeiro: Vozes, 2014. FREIRE, Paulo. Pedagogia do Oprimido. Rio de Janeiro: Paz e Terra, 42. ${ }^{\text {a }}$ ed., 2005. 


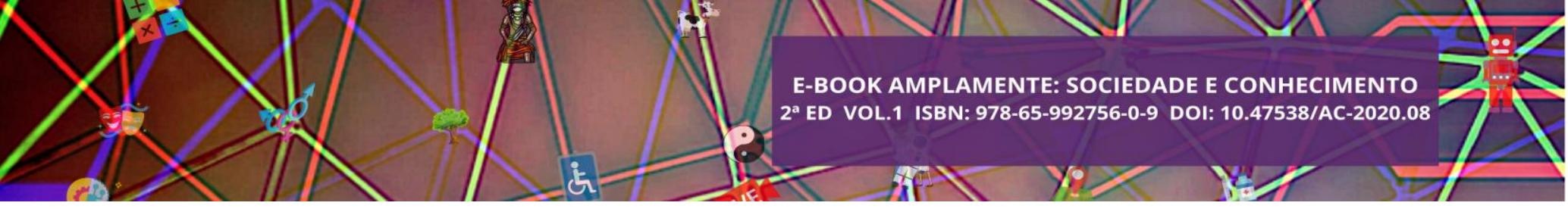

\title{
CAPÍTULO XII
}

\section{AS PRIMEIRAS MULHERES “PIONEIRAS" SE FORMAM NA ESCOLA NAVAL BRASILEIRA: ADEUS MINHA ESCOLA QUERIDA!}

\author{
Hercules Guimarães Honorato \\ DOI - Capítulo: 10.47538/AC-2020.08-12
}

\section{RESUMO:}

A Escola Naval (EN) recebeu em 2014 a primeira turma de aspirantes mulheres em seu curso de graduação. As "pioneiras", como foram denominadas, significavam à época apenas $1,5 \%$ do total do corpo discente, um coletivo que desconhecia, como companheiros de farda, a figura feminina. O objetivo deste estudo foi identificar as dificuldades enfrentadas pelas primeiras aspirantes em sua inclusão, sua integração e seu desenvolvimento como mulheres e militares no decorrer dos quatro anos vividos na EN. A abordagem desta investigação é de cunho qualitativo, tendo como metodologia principal um questionário com perguntas abertas e fechadas para as doze aspirantes. As instituições de formação superior militar desejam que as suas cadetes/aspirantes conheçam as representações sociais e militares, descubram sua vocação, apreendam o estilo de vida da tropa e os valores militares. Além disso, aspira-se a que se conscientizem sobre os comportamentos desejáveis que deverão seguir na profissão castrense, de dedicação à Força e à Pátria, sem se esquecerem de que são mulheres e cidadãs, integrantes da sociedade brasileira. Apesar de toda a dificuldade que travaram diariamente para vencer as batalhas do cotidiano, as pioneiras têm uma carreira que enche de orgulho os seus corações, que amplia o patriotismo, que ensina respeito mútuo e hierarquia, e que valores como companheirismo, cordialidade e lealdade sempre serão cultivados. Ao final, ficou evidenciado, nas respostas ao questionário, que elas estão se preparando para dar continuidade à carreira militar, porém, com a certeza de que ainda há desafios pela frente e que, mostrando a capacidade intelectual, física e profissional que possuem, conquistarão um espaço maior no meio militar. As doze aspirantes mulheres se formaram em dezembro de 2017. Podemos afirmar, portanto, que este foi o reconhecimento da Marinha por quatro anos dedicados à construção do ser marinheiro, independentemente do seu gênero.

PALAVRAS-CHAVE: Escola Naval brasileira. Ensino superior militar. Inclusão de gênero.

79 Escola Superior de Guerra. E-mail - hghhhma@gmail.com 


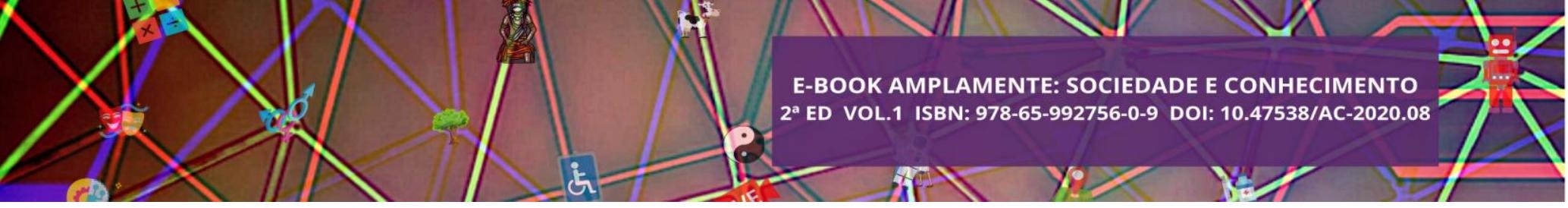

\title{
INTRODUÇÃO
}

\author{
"Adeus, minha Escola querida \\ Adeus, vou à Pátria servir; \\ Adeus, camaradas gentis, adeus, adeus, \\ Adeus, eu vou partir, eu vou partir. [...]" \\ (Letra e música do Aspirante Luiz F. de Magalhães)
}

A Marinha do Brasil (MB) foi a pioneira na admissão de mulheres em seus quadros em 1980, cujo objetivo principal era a necessidade de liberar o militar operativo para as "atividades relacionadas diretamente com a preparação e o emprego do Poder Naval" (MENDES, 2010, p. 1). Ao longo dos anos, acompanhamos uma evolução com cessão de novas oportunidades no quadro do Corpo Feminino nas Forças Armadas brasileiras, que, seguindo a experiência positiva da Marinha, incorporaram mulheres em suas fileiras: a Aeronáutica em 1982 e o Exército em 1992. Cada uma das Forças Armadas foi ampliando o percentual feminino efetivo conforme suas necessidades e experiências com o trabalho durantes esses mais de 30 anos.

Seguindo na vanguarda, a MB abrilhantou o contexto histórico da inclusão de gênero quando, em 2012, promoveu a Dr ${ }^{\mathrm{a}}$. Dalva Maria Carvalho Mendes ao posto de Contra-Almirante, sendo a primeira mulher a atingir o mais alto cargo da profissão militar. Nesse caminhar, podemos salientar que a construção da identidade do militar sempre esteve associada à figura do homem, seja na Marinha, no Exército ou na Força Aérea, o que se tornou, antropológica e socialmente, uma construção histórica de conquistas vitoriosas e recuos sentidos, tendo um grande desafio, que era a entrada das mulheres em um mundo até então exclusivamente masculino.

Em 2014, a Escola Naval (EN) recebeu a primeira turma de Aspirantes do sexo feminino em seu curso de graduação. Futuramente, atuariam na área de apoio como Oficiais do Corpo de Intendentes da Marinha (CIM). As "pioneiras", como foram denominadas, significavam à época apenas $1,5 \%$ do total do corpo discente, um coletivo que desconhecia, como companheiros de farda, a figura feminina, e que, a partir daquele ano, estaria lado a lado nas ordens-unidas, nas formaturas, nas salas de aula, nas atividades esportivas, em síntese, no dia a dia da caserna.

Atualmente, a EN possui Aspirantes mulheres em todos os quatro anos da graduação, em um total de 46, sendo 12 no último ano, o foco de nosso estudo, 10 no terceiro, 11 no segundo e 13 no primeiro. Podemos verificar que nem todas conseguiram o sucesso de ultrapassar as barreiras de uma formação rígida acadêmica e 


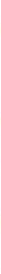

de limites inerentes as atividades de educação física, mas continuam com o sonho de saírem Oficiais da Marinha do Brasil, bacharéis em "Ciências Navais".

Assim exposto, o objetivo deste estudo é identificar as dificuldades enfrentadas pelas primeiras Aspirantes em sua inclusão, sua integração e seu desenvolvimento no decorrer dos quatro anos vividos na EN. A abordagem desta investigação é de cunho qualitativa, tendo como metodologia principal um questionário com perguntas abertas e fechadas para as doze Aspirantes. A questão que norteou este estudo foi: como se desenvolveram como militares e mulheres durante a graduação na EN em um espaço predominantemente masculino?

\section{A MULHER NAS FORÇAS ARMADAS VIA FORMAÇÃO SUPERIOR}

O trabalho feminino teve o seu ponto de ruptura, no que tange ao reconhecimento da sociedade como força de trabalho, durante a Revolução Industrial. Os novos fatores introduzidos pela industrialização afetaram a força de trabalho de ambos os sexos. "A mulher, antes considerada mais fraca para o trabalho braçal, poderia contar com instrumentos que fariam a produção depender menos de força física." (SOUTO MAIOR, 2008 apud TREVISO, 2008, p.23). A busca pela igualdade de gênero no mercado de trabalho é alvo de discussões desde a inserção da mulher na esfera trabalhista, principalmente no que tange a assuntos em que sua colocação irá lhe exigir maiores condições físicas, como é o caso da carreira militar.

Toda essa evolução e os movimentos para equalização de oportunidades entre homens e mulheres não poderiam deixar o trabalho nas Forças Armadas fora deste processo, pois enquanto as mulheres estiverem excluídas deste círculo restrito, a instituição não desenvolverá todo o seu potencial. Em um estudo realizado pelo Instituto Igarapé $^{80}$, alguns mitos sobre a entrada de mulheres nas Forças Armadas do Brasil foram quebrados, como aquele que afirma que a presença de mulheres afeta a moral e a coesão das tropas, ao contrário, estudos demonstram que a integração melhora a moral e o profissionalismo dos combatentes.

Como Força Armada brasileira, a MB destacou-se como pioneira ao admitir mulheres em seu quadro no ano de 1980, como já comentado. O quadro 1 apresenta a

80 Situado na cidade do Rio de Janeiro, tem como objetivo propor soluções inovadoras a desafios sociais complexos, por meio de pesquisas, novas tecnologias, influência em políticas públicas e articulação. Disponível em: https://igarape.org.br/sobre/sobre-o-igarape/. Acesso em: 06 out. 2017. 


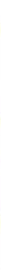

evolução da incorporação de mulheres militares explicitando as principais formas de ingresso do Corpo Feminino, que representaram marcos históricos e legais, e seus respectivos anos de admissão, bem como os quadros e corpos que foram constituindo ao longo de suas carreiras militares.

Quadro 1 - Admissão das Mulheres nas três Forças Armadas

\begin{tabular}{|c|c|c|c|}
\hline FORÇA & MARINHA & FORÇA AÉREA & EXÉRCITO \\
\hline $\begin{array}{c}\text { ANO DE } \\
\text { ADMISSÃO }\end{array}$ & 1980 & 1982 & 1992 \\
\hline $\begin{array}{l}\text { QUADRO / } \\
\text { CORPO }\end{array}$ & $\begin{array}{l}\text { Corpo Auxiliar Feminino da } \\
\text { Reserva }\end{array}$ & Corpo Feminino da Reserva & $\begin{array}{l}\text { Quadro Complementar } \\
\text { de Oficiais }\end{array}$ \\
\hline $\begin{array}{c}\text { MARCO } \\
\text { LEGAL }\end{array}$ & Lei ${ }^{\circ} 6.807$, de 1980 & Lei no 6.924 , de 1981 & Lei $\mathrm{n}^{\circ} 7.831$, de 1989 \\
\hline $\begin{array}{c}\text { ANO DE } \\
\text { ADMISSÃO }\end{array}$ & 2014 & 1995 & 2017 \\
\hline $\begin{array}{l}\text { QUADRO / } \\
\text { CORPO }\end{array}$ & $\begin{array}{l}\text { Aspirantes da Escola Naval } \\
\text { Intendência }\end{array}$ & $\begin{array}{c}\text { Cadetes da Academia da Força } \\
\text { Aérea Intendência }\end{array}$ & $\begin{array}{c}\text { Cadetes da Escola } \\
\text { Preparatória de Cadetes } \\
\text { do Exército }\end{array}$ \\
\hline $\begin{array}{c}\text { MARCO } \\
\text { LEGAL }\end{array}$ & Lei n ${ }^{\circ} 12.704$, de 2012 & $\begin{array}{c}\text { Aviso ministerial } \\
\mathrm{n}^{\mathrm{o}} .006 / \mathrm{GM} 3 / 024, \text { de } 1995\end{array}$ & Lei $n^{\circ} 12.705$, de 2012 \\
\hline $\begin{array}{c}\text { ANO DE } \\
\text { ADMISSÃO }\end{array}$ & 2019 & 2003 & 2018 \\
\hline $\begin{array}{l}\text { QUADRO / } \\
\text { CORPO }\end{array}$ & $\begin{array}{l}\text { Aspirantes da Escola Naval } \\
\text { Armada e Fuzileiros Navais }\end{array}$ & $\begin{array}{c}\text { Cadetes da Academia da Força } \\
\text { Aérea Pilotos }\end{array}$ & $\begin{array}{c}\text { Cadetes da Academia } \\
\text { Militar de Agulhas } \\
\text { Negras }\end{array}$ \\
\hline $\begin{array}{c}\text { MARCO } \\
\text { LEGAL }\end{array}$ & $\begin{array}{c}\text { Memorando ET-2017/03- } \\
01142 \text { de } 10 / 04 / 17\end{array}$ & 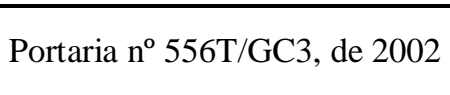 & Lei ${ }^{\circ} 12.705$, de 2012 \\
\hline
\end{tabular}

Fonte: Ministério da Defesa.

Atualmente, as mulheres em formação superior militar participam das academias militares congêneres. A Aeronáutica foi a pioneira na inserção de mulheres nas suas fileiras da Academia da Força Aérea (AFA), admitindo, em 1995, para o Quadro de Intendentes, e oito anos depois, em 2003, também foi aberto a elas o Curso de Formação de Oficiais Aviadores. A Marinha foi a força armada sucessora, que incorporou, em 2014, ao seu Corpo de Intendentes da Marinha da EN doze mulheres. Por fim, quarenta jovens se apresentaram na Escola Preparatória de Cadetes do Exército (ESPCEX), em Campinas/SP, e estarão formando fileiras na Academia Militar das Agulhas Negras (AMAN), em 2018, podendo se incorporar ao quadro de Material Bélico ou ao serviço de Intendentes.

O ingresso da mulher na carreira militar, portanto, simboliza um grande avanço na busca pela igualdade de gênero, sendo então um "marco nacional, com importantes 


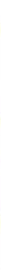

repercussões e reflexos, não apenas no âmbito das Forças Armadas, mas na sociedade brasileira de modo geral" (ANDRADA; PERES, 2012, p. 54), abrindo desta maneira novas expectativas profissionais para a esfera militar e evidenciando a grande importância da integração entre homens e mulheres.

\section{AS PRIMEIRAS “SENTINELAS DOS MARES"}

Com o advento da entrada das primeiras Aspirantes mulheres, a EN passou a contar com a presença de três Oficiais que foram nomeadas e designadas para enfrentarem esse novo desafio. A primeira a integrar essa equipe foi uma pedagoga e, posteriormente, uma intendente da Marinha e uma psicóloga. O que também se tornou um fato precursor foram as presenças dessas mulheres militares compondo o quadro de oficiais do setor do Comandante do Corpo de Aspirantes. Vale ressaltar ainda que essa quebra de paradigma foi importante para que se começasse a imbuir uma nova conduta aos oficiais e alunos que já pertenciam à Escola, fazendo com que todos, corpo docente e discente, se familiarizassem com a presença de companheiras femininas a partir daquele momento.

Foi no dia 12 de janeiro de 2014 que as "pioneiras" chegaram à Ilha de Villegagnon, para se apresentarem e iniciarem o período de adaptação, momento em que, pela primeira vez, haveria o contato entre homens e mulheres que estavam ali com o mesmo propósito, tornarem-se Aspirantes. O período em questão, é o momento em que ocorre a transição da vida civil para a vida militar, é a fase em que aprendem sobre as regras e os atributos basilares da formação militar-naval, a hierarquia e a disciplina. No Estágio de Adaptação, segundo Honorato e Rabello (2014, p. 11), “os novatos não têm tempo nem para pensar, com todos os momentos ocupados por algumas atividades, desde físicas, militares e até burocráticas".

Ao passarem por essas semanas de árduo treinamento e aprendizado, puderam conquistar suas platinas e galgar ao posto de Aspirantes da Marinha. Porém, ainda era o começo de um grande caminhar com muitos óbices que foram vencidos. A integração entre os gêneros dentro da turma fora iniciada na adaptação; no entanto, ainda seria algo fomentado dentro do Corpo de Aspirantes por mais quatro anos. As Aspirantes participaram ativamente de vários setores da EN. No esporte, destacam-se por estarem frequentemente no pódio nas competições; no acadêmico, algumas compõem o quadro 


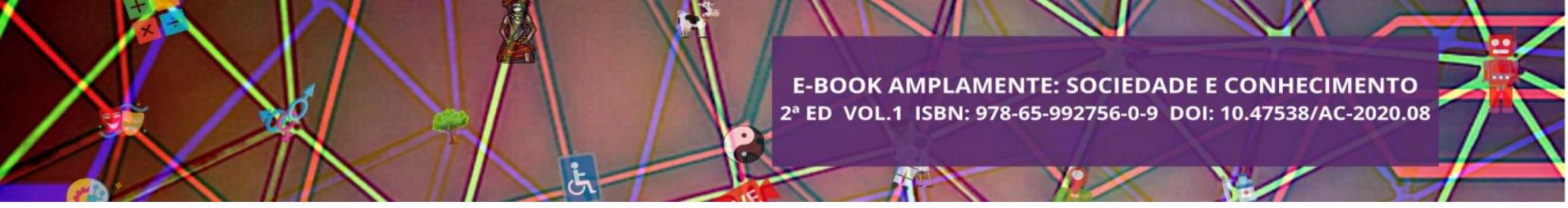

de monitoras de disciplinas; no setor sociocultural, fazem parte de alguns cargos da Sociedade Acadêmica Phoenix Naval e estão sempre envolvidas na elaboração dos eventos; entre outras atividades. Ademais, é importante informar que 5 (cinco) delas participaram como adaptadoras, seja como auxiliares ou encarregadas, nos diversos setores da adaptação, em 2016 e 2017, onde conseguiram demonstrar a liderança que possuem, transformando homens e mulheres civis em militares.

A Capitão de Corveta (IM) Geórgia Rita Macieira Ramos Nizer, uma das primeiras oficiais que chegaram à instituição para auxiliar na integração e desenvolvimento das Aspirantes, relatou que:

As 12 Aspirantes, conseguiram durante esses anos angariar lugares que não imaginávamos, elas sem dúvidas ultrapassaram as expectativas que as depositamos. Mas, cabe a mim também salientar que ainda há inúmeros espaços na Escola Naval que próximas Aspirantes das turmas subsequentes podem conquistar, e mostrar cada vez mais a capacidade que a Mulher Militar tem de exercer as mesmas funções que os homens.

\section{DISCUSÃO E CONCLUSÕES}

Esta pesquisa teve como principal instrumento de coleta de dados um questionário com perguntas abertas e fechadas às 12 Aspirantes, com o objetivo de compreender como foi o processo de integração entre os gêneros. A fim de preservar a identidade das respondentes quando suas respostas forem mencionadas, elas foram denominadas pelo código alfanumérico "Asp.1" a "Asp.12”, escolhidas aleatoriamente, sem nenhum critério de ordem.

$\mathrm{Na}$ pergunta que tratava de conhecer qual a grande dificuldade enfrentada durante os quatro anos de graduação militar em relação à integração com os colegas de gênero masculino da sua própria turma, a resposta foi unânime - a diferença imposta pela própria organização. As seguintes respostas podem ratificar: "normas diferentes impostas, como não poder circular nos corredores dos camarotes e diferença nos serviços por sermos mulheres” (Asp.12); “das diferenças, principalmente nos primeiros anos, quando cursamos disciplinas distintas dos demais, ou pelo fato de termos deixado de cursar certos assuntos" (Asp.4). Além disso, acrescentando a essa questão, a Asp.8 contribuiu com outro ponto de vista: "A desconfiança quanto à nossa competência e 


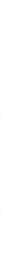

capacidade de cumprir todas as atividades necessárias aqui. Quebrar essa situação inicial demandou certo tempo e nos manteve 'distantes' da turma por um tempo".

Como as novas Aspirantes representavam um ineditismo na formação superior militar da MB, a presença delas no início incomodava sobremaneira os homens, pois acreditavam que elas possuíam privilégios: “o fato de 'levarmos vantagens' se torna uma desculpa constante quando conquistamos algo por mérito e esforço próprio" (Asp.4); "ainda existem alguns que acham que somos muito privilegiadas" (Asp.9).

Um ponto relevante levantado no desvelar da questão 2 foi o fato de que todas acreditavam que esses inconvenientes ao longo do curso, apesar de não terem sido extintos, foram atenuados. A Asp.12 assevera que "aos poucos conseguimos quebrar as barreiras iniciais e fazê-los entender que não queremos ser tratadas de forma diferente, mas nos misturar a eles", o que foi ratificado pela Asp.10, "essa dificuldade persistiu, mas aos poucos foi diminuindo, devido ao tempo de convívio que fortaleceu os laços de fraternidade".

Uma pergunta avaliou como está sendo, hoje, a relação delas com o universo masculino, tanto com os Aspirantes quanto com os Oficiais na caserna, depois de quatro anos de relacionamento. Umas revelaram estarem tranquila, outras de muito profissionalismo, ou mesmo normal; "a convivência se dá com muita fluidez se comparado ao início, vejo que somos mais, de certa forma, 'aceitas' e estamos melhor inseridas" (Asp.1). O que chamou a atenção, porém, foi a observação exposta no que se refere ao relacionamento com os Oficiais: “alguns Oficiais recém-embarcados na EN possuem uma dificuldade em lidar com a presença das Aspirantes femininas” (Asp. 4).

Por serem minoria, diversas vezes ficavam em situação de destaque, sendo a todo instante vigiadas, fato este que levou a indagá-las sobre a possível existência da diferença no tratamento entre elas e os Aspirantes masculinos. A Asp.6 diz que "é perceptível que o Oficial masculino muda de certa forma seu comportamento quando está falando com Aspirante do sexo feminino". A Asp.7 revela que ocorreram casos pontuais de discrepâncias no tratamento, mas que em geral é de modo análogo.

A última questão retratada nesta análise tem o intuito de saber quais serão os maiores desafios das futuras Tenentes Intendentes após sua graduação. A maioria posiciona a conciliação entre a família e o trabalho, mas houve também duas respostas interessantes - a primeira é da Asp.6: "manter o respeito pelo meu trabalho e profissão não por ser mulher, mas por dar o meu melhor e fazer tudo de forma correta"; a 


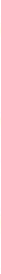

segunda, da Asp.11, expõe que o maior desafio será "lidar com os mais modernos, tendo em vista que a cultura do país ainda não se adaptou ao fato de ver mulher em posição de liderança”.

Existe um aumento da participação das mulheres em diversas ocupações profissionais, até pouco tempo notadamente masculinas. A mudança estrutural nas relações entre gêneros evoluiu consideravelmente nos últimos anos e, como somos frutos de uma construção social histórica, uma vez abertas as oportunidades, as mulheres estão demonstrando seu valor e sua capacidade de decisão e liderança.

A história das mulheres nas academias militares começou com a AFA, em 1996, e agora termina o ciclo de conquistas com a entrada de quarenta jovens brasileiras na graduação do Exército. A mulher, independentemente do seu ambiente de trabalho, é um ser à procura de deixar de ser apenas o Outro, procurando ser realmente o Sujeito, ativo e igual em todos os aspectos e atividades de nossa vida em sociedade.

As instituições de formação superior militar desejam que as suas Cadetes/Aspirantes conheçam as representações sociais e militares, descubram sua vocação, apreendam o estilo de vida da tropa e os valores militares. Além disso, aspiram-se a que se conscientizem sobre os comportamentos desejáveis que deverão seguir na profissão castrense, de dedicação à Força e à Pátria, sem se esquecerem de que são mulheres e cidadãs, integrantes ativas de uma sociedade que busca respaldo para um país forte e desenvolvido.

Tudo o que foi exposto em curtas pinceladas mostra o caminho pelo qual as "pioneiras" conseguiram estabelecer no Corpo de Aspirantes, evidenciando que é possível fazer com êxito as mesmas atividades, antes executadas exclusivamente pelos Aspirantes masculinos. Enfatizamos que, apesar de toda a dificuldade e da luta que travaram diariamente para vencer as batalhas do cotidiano, as Aspirantes pioneiras têm uma carreira que enche de orgulho os seus corações, que amplia o patriotismo, que ensina respeito mútuo e à hierarquia, e em que valores como companheirismo, cordialidade, lealdade serão sempre cultuados.

Ao final, o que ficou evidenciado nas respostas ao instrumento de coleta de dados foi que elas estão se preparando para dar continuidade à carreira militar, porém, com a certeza de que ainda há desafios pela frente e que, mostrando a capacidade intelectual, física e profissional que possuem, conquistarão cada vez mais um espaço maior no meio militar. 


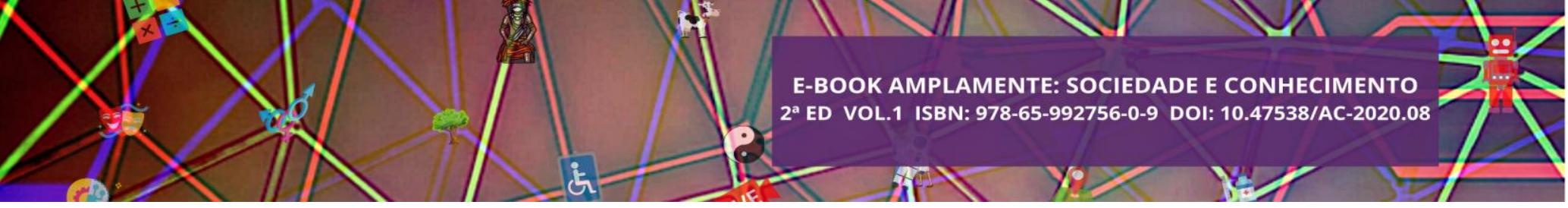

Em dezembro 2017, ano da formatura da Turma "Alte Gastão Motta", onde são integrantes participativas, podemos afirmar que este é o reconhecimento da Marinha do Brasil por quatro anos dedicados a construção do ser marinheiro, independente do seu gênero. Assim, como bem escrito no hino da epígrafe introdutória, poderão cantar a plenos pulmões e com lágrimas nos olhos: “Adeus, minha Escola querida, Adeus, vou à Pátria servir, Adeus, camaradas gentis, adeus, adeus, Adeus, eu vou partir, eu vou partir".

\section{REFERÊNCIAS}

ANDRADA, S. A. de; PERES, H. M. Mulheres a bordo: 30 anos da mulher militar na Marinha do Brasil. Rio de Janeiro: Hmperes \& Associados, 2012.

HONORATO, H. G.; RABELLO, D. de A. As primeiras aspirantes da Escola Naval: inclusão, trajetórias iniciais e boas-vindas às novas "sentinelas dos mares". Revista de Villegagnon, Rio de Janeiro, ano IX, n.9, p.6-15, 2014.

MENDES, L. C. K. B. Subsídios sobre a presença da mulher na MB. Brasília, DF: Centro de Comunicação Social da Marinha, 2010.

TREVISO, M. A. M. A discriminação de gênero e a proteção à mulher. Revista do Tribunal Regional do Trabalho $3^{\mathbf{a}}$ Região, Belo Horizonte, v.47, n.77, p.21-30, jun. 2008. 


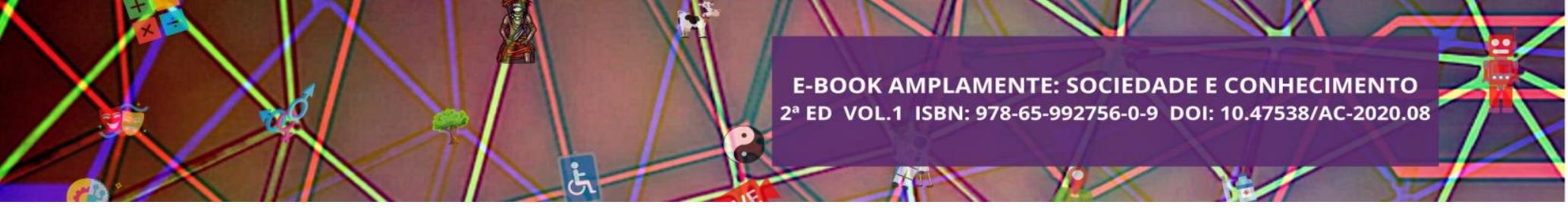

resistência no campo das práticas artísticas numa perspectiva sensorial e perceptiva. Para tanto, partimos de uma investigação inicial sobre a obra de Michel Foucault na inflexão entre o poder disciplinar (FOUCAULT, 1975) e o dispositivo sexualidade (FOUCAULT, 1988a), visando elucidar como o corpo se torna objeto do exercício de poder na produção de indivíduos sujeitados e dóceis como forma de dominação. Buscase ainda apontar o poder como resistência a partir do cuidado de si e na experiência estética (FOUCAULT, 1988b; 1988c), pensando a produção de modos de enfrentamento aos dispositivos de controle impostos. Neste sentido, a pesquisa considera a estética não como uma teoria do belo ou das formas harmoniosas, mas modos de fazer inerentes às práticas artísticas e comuns (RANCIÈRE, 2000).

\section{DESENVOLVIMENTO}

\section{O CORPO E O DISPOSITIVO SEXUALIDADE}

Para iniciar nossa investigação é necessário pensar o papel das sociedades disciplinares nesse contexto. Os mecanismos disciplinares se caracterizam como dispositivos, entendidos como um conjunto heterogêneo composto por linhas de natureza diversas. Foucault (1984) denomina o dispositivo como um, "conjunto decididamente heterogêneo que engloba discursos, instituições, organizações arquitetônicas, decisões regulamentares, leis, medidas administrativas, enunciados científicos, proposições filosóficas, morais, filantrópicas" (FOUCAULT, 1984, p. 244). Os mecanismos disciplinares incidem historicamente sobre o corpo, enquadrando-o, regulando-o e extraindo dele suas potencialidades. Assim, o poder disciplinar se caracteriza como um conjunto de técnicas surgidas no processo de transformação dos modos de dominação exercidos pelo Estado, incidindo sobre os sujeitos e seus corpos: "A disciplina fabrica corpos submissos e exercitados, corpos dóceis" (FOUCAULT, 1975, p. 119). Para Noelma Sousa e Antônio Basílio de Menezes (2010), os mecanismos disciplinares enquanto dispositivos capturam, normatizam e impõe uma disciplinarização aos corpos. "Os dispositivos do poder disciplinar caracterizam-se pela minúcia e pelo detalhe. Nesse sentido, o corpo será submetido a uma forma de poder que irá desarticulá-lo e corrigi-lo através de uma nova mecânica do poder" (SOUSA; MENESES, 2010 p. 26). Trata-se da consolidação de uma maquinaria de poder, de tecnologias de disciplinarização cujo objetivo maior é a produção de indivíduos mediante a manutenção das relações de 


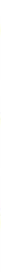

dominação, pressupondo a captura de nossa experiência corporal, psíquica, e subjetiva do mundo.

Os mecanismos disciplinares nos possibilitam a passagem de uma discussão sobre a gestão dos corpos para a da gestão da vida como um todo, levando o autor refletir sobre o surgimento do biopoder a partir do dispositivo sexualidade. Em sua obra História da Sexualidade 1: A vontade de saber (1988a), Foucault postula a sexualidade como um dispositivo histórico. Não como algo natural e inerente aos indivíduos e ao qual se revelaria somente por meio de uma ciência do sexo e nem mesmo como uma força reprimida como base de um poder repressor. $\mathrm{O}$ autor coloca a sexualidade como:

A grande rede da superfície em que a estimulação dos corpos, a intensificação dos prazeres, a incitação ao discurso, a formação dos conheci- mentos, o reforço dos controles e das resistências, encadeiam-se uns aos outros, segundo algumas grandes estratégias de saber e de poder (FOUCAULT, 1988a, p. 100).

Tanto os dispositivos quanto os corpos se encontram inseridos no plano das relações de poder, entendido aqui como uma "multiplicidade de correlações de forças imanentes ao domínio onde se exercem e constitutivas de sua organização. O jogo que através de lutas e afrontamentos incessantes as transforma, reforça, inverte" (FOUCAULT, 1988a, p. 88). Tomando como ponto de partida o poder disciplinar, podemos pensar que, para além do corpo, os dispositivos investem também sobre a sexualidade, exercendo formas de controle sobre as práticas sexuais e suas variações como marco de uma necessidade de gestão no contexto dos fenômenos de população.

Foucault desenvolverá o conceito de dispositivo sexualidade, que através de uma incitação aos discursos sobre o sexo promove a captura do mesmo, no plano das relações de poder. O autor inicia sua discussão partindo de uma crítica as sociedades vitorianas como modelo de uma sociedade austera e repressiva em relação ao sexo. Como contraponto, reporta aos costumes do século XVII, onde as práticas sexuais não se manifestavam como tabu e os códigos morais eram menos rígidos se comparados ao vitorianismo no século XIX (FOUCAULT, 1988a, p. 08). Observamos na análise genealógica do pensador francês, a indicação (mesmo no contexto das sociedades vitorianas) de uma proliferação dos discursos sobre o sexo, em detrimento da sustentação de uma hipótese repressiva. Esta se caracteriza como um modo de leitura sobre a sexualidade e sua relação com as sociedades e o Estado a partir da lógica da repressão. Desse modo, a manifestação da sexualidade não seria livre, mas objeto de 


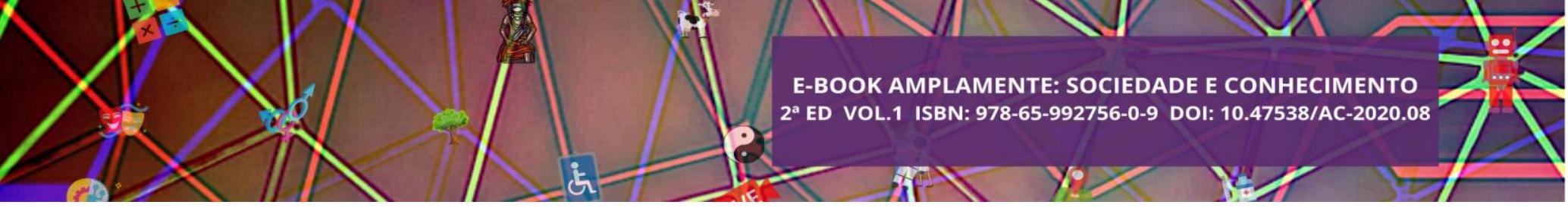

poder e controle, uma vez que, por exemplo, ela pode pôr em perigo a organização social e do trabalho. No entanto, o autor não refuta o componente da repressão, mas o realinha como coadjuvante, num projeto muito mais abrangente. "As dúvidas que gostaria de opor a hipótese repressiva têm por objetivo muito menos mostrar que essa hipótese é falsa do que recolocá-la numa economia geral dos discursos sobre o sexo no seio das sociedades modernas a partir do século XVII" (FOUCAULT, 1988a, p. 16). Paralelamente à constituição dos discursos sobre a repressão, o que se evidencia ao longo dos períodos posteriores é uma incitação cada vez maior dos discursos sobre as práticas sexuais, ao invés de um silenciamento destas sob a ótica das interdições. Ao invés disso, Foucault entende esse poder sobre o sexo na forma da proliferação de múltiplos mecanismos, que passam a lhe controlar e regular; ao mesmo tempo em que lhe esquadrinham, o retiram de sua obscuridade e o tornam apreensível a partir das relações de saber/poder. Trata-se, portanto, de um dispositivo que tem por função, a colocação do sexo em discurso, propiciando a captura e a produção de verdades sobre este:

Não somente foi ampliado o domínio do que se poderia dizer sobre o sexo e foram obrigados os homens a estendê-lo cada vez mais; mas, sobre- tudo, focalizou-se o discurso no sexo, através de um dispositivo completo e de efeitos variados que não se pode esgotar na simples relação com a lei e a interdição. Censura sobre o sexo? Pelo contrário, constitui-se uma aparelhagem para produzir discursos sobre o sexo, cada vez mais discursos, suscetíveis de funcionar e de serem efeito de sua própria economia (FOUCAULT, 1988a, p. 26).

Cada vez mais os campos de saber como a biologia, a psicologia, a psiquiatria e a psicanálise, o retiram de seu lugar de obscuridade, o desmembram e o revestem em suas teias discursivas, fazendo proliferar uma série de tecnologias sobre o sexo e os corpos. $\mathrm{O}$ dispositivo sexualidade captura e controla o corpo, inserindo-o numa maquinaria de poder que se caracteriza pela produção racional de discursos científicos. Para Foucault (1988a), os comportamentos inerentes a uma sexualidade polimorfa foram extraídos dos corpos dos homens, de seus prazeres, na mesma medida que foram neles reorganizados.

Trata-se de pensar os efeitos de verdade que são produzidos pelos discursos instituídos. O poder pode até reprimir o sexo, mas ao exercer suas forças, promete libertá-lo ao preço de submetê-los a sua lógica de regulação. Ele captura e fabrica ao mesmo tempo a sexualidade, o corpo e a subjetividade, num movimento de imposição de práticas de dominação pelos dispositivos, configurando uma gestão dos corpos, das 


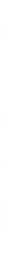

populações e da vida. De acordo com Oscar Cirino (2007), essa sexualidade faz do corpo seu alvo: "as relações de poder operam sobre ele de modo imediato; elas o investem, o marcam, o dirigem, o supliciam, submetem-no a trabalhos, obrigam-no a cerimônias, exigem-lhe sinais" (CIRINO, 2007, p. 28). O dispositivo sexualidade e os demais dispositivos de controle como inflexão do poder disciplinar agem, portento, a nível dos corpos, afetando-os. Eles lhe esquadrinham e formatam. Eles lhe moldam e regulam, produzindo modos de normalização das condutas. O corpo e o sexo são capturados por meio de uma diversidade de mecanismos que permitem a constituição de formas de saber/poder como estratégias de dominação. Estes constituem-se nas relações de poder, numa teia de discursiva que visa, além da instituição de uma racionalidade sobre algo considerado obscuro, a sua gestão estratégica.

Tanto o poder disciplinar como o dispositivo sexualidade, que se apropriam do sexo e dos corpos produzindo sujeitos e controlando nossas práticas, pensamentos e desejos, se inserem no projeto maior de um biopoder (FOUCAULT, 1988a). Para além do controle sobre esses domínios, institui-se um movimento de captura da vida como um todo, identificado inicialmente na proposta de regulação e gestão dos fenômenos populacionais. Daí o sexo surgir como questão estratégica, associado a temas tais como o controle da natalidade e da mortalidade, das doenças e epidemias, das guerras, etc. A magnitude desse biopoder como estratégia de dominação se revela na formulação máxima do preceito "causar a vida e devolver à morte". A gestão da vida se alinha assim, na lógica do biopoder como forma de dominação, à produção de uma estética pré-moldada produzida pelos dispositivos. Nosso corpo, nossa sexualidade e nossa subjetividade são fabricadas nas interfaces desses dispositivos, regulando assim nossas formas de existir. Portanto, o estudo da obra de Foucault nos leva, no desenvolvimento de nossa pesquisa a pensar: mediante a grandiosidade da arquitetura dessa maquinaria de poder, como produzir resistência as formas de dominação impostas e que penetram o âmago da subjetividade? Como instaurar formas de existência que escapem aos processos de captura engendrados pelos dispositivos e que mesmo os subvertam? Nossa aposta é de que a experiência estética no campo da arte se torne uma função de desvio. Não uma estética pré-moldada pelas possibilidades dadas pe- los dispositivos, mas a estética como produção de si por si, num movimento autônomo. Ou seja: "práticas refletidas e voluntárias através das quais os homens não somente se fixam regras de conduta, como também procuram se transformar, modificar-se em seu ser singular" 


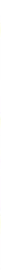

(FOUCAULT, 1988b, p. 15). Daí a proposta de um retorno à senso-realidade e à percepção como modo de acesso à experiência (DEWEY, 1980; MERLEAU-PONTY, 1994) para além das codificações impostas pelos dispositivos. Tal movimento se torna possível através do estabelecimento de um diálogo entre o cuidado de si (FOUCAULT, 1988b; 1988c) e a instauração das práticas no campo da arte interativa (CLARK, 1980). É preciso neste momento, estabelecer a diferença entre o biopoder como dominação e o biopoder como resistência.

\section{BIOPODER: ENTRE A DOMINAÇÃO E A RESISTÊNCIA}

Como vimos anteriormente, Foucault formula o conceito de poder como um jogo de relações complexas de força. Cabe salientar que este não é propriedade de alguém, de um grupo de indivíduos, ou concentrado em uma instituição. O poder se exerce. Ele atravessa a todos sem exceção. Ele tem por função a sua perpetuação através de estratégias complexas, tendo por alicerce, os dispositivos de controle tais como a sexualidade, a doença mental, etc, numa lógica de produção e consolidação desses saberes. O autor não se preocupa em defini-lo numa perspectiva macroscópica. Ao contrário, deseja investigar sua dimensão microscópica, seus minuciosos desdobramentos em nossa sociedade: “o que está em jogo é determinar quais são, em seus mecanismos, em seus efeitos, em suas relações, esses diferentes dispositivos de poder que se exercem, em níveis diferentes da sociedade, em campos e com extensões tão variadas" (FOUCAULT, 1975, p. 19).

Essas relações se produzem na interface entre saber e poder. Isto é: na reorganização das formas de dominação do Estado e na configuração da nova maquinaria disciplinar, as relações de poder se caracterizam pela extração dos saberes inerentes aos sujeitos e suas práticas, realinhando-as e submetendo-as aos saberes científicos como forma de regulação. Neste sentido, a maquinaria e os dispositivos que a compõem estendem seus domínios sobre os sujeitos, incidindo diretamente sobre as subjetividades, criando formas preconcebidas de ser e estar no mundo segundo a lógica da dominação imposta como modo de controle,

Temos antes que admitir que o poder produz saber (e não simplesmente favorecendo-o porque o serve ou aplicando-o porque é útil); que poder e saber estão diretamente implicados; que não há relação de poder sem constituição correlata de um campo de saber, nem saber 


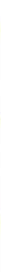

que não suponha e não constitua ao mesmo tempo relações de poder (FOUCAULT, 1975, p. 30).

Contudo, mesmo diante da maquinaria instituída do poder percebe-se este como possuidor não só de uma face de dominação, mas de resistência. Em sua pri- meira face, o objetivo é capturar os corpos e a subjetividade, exercendo-se por meio das práticas disciplinares e de biorregulação, formas de controle constante:

A proliferação, os nascimentos e a mortalidade, os níveis de saúde, a duração da vida, a longevidade, com todas as condições que podem fazê-la variar; tais processos são assumidos mediante toda uma série de intervenções e controles reguladores: uma biopolítica da população (FOUCAULT, 1988a, p. 131).

Porém, em sua outra face, o autor nota que o poder não está na posse de nenhum de nós e nem habita num ponto fixo. Neste sentido, ele pressupõe não somente sujeição as formas estabelecidas, mas a possibilidade de instauração de resistências. Pensar as correlações de poder somente como forma de dominação por parte dos dispositivos equivaleria, segundo o autor, a desconhecer seu caráter relacional. Por outro lado,

Elas não podem existir senão em função de uma multiplicidade de pontos de resistência que representam, nas relações de poder o papel de adversário, de alvo, de apoio, de saliência que permite a preensão. Esses pontos de resistência estão presentes em toda a rede de poder (FOUCAULT, 1988a, p. 91).

Não sendo detidas exclusivamente por ninguém, mas exercidas por todos, as relações de poder configuram-se como inerentes ao corpo social, permitindo manifestações heterogêneas, propiciando, como nos mostra Guilherme Castelo Branco (2001), a produção de linhas de fuga frente as correlações de forças antes estabelecidas.

Foucault desenvolveu uma concepção nominalista do poder, na qual ideias de posse do poder, de origem do poder, de campo de ação do poder, entre outras, são substituídas pela hipótese de que o poder está disseminado por todas as partes do mundo social, numa trama complexa e heterogênea de relações de poder, na qual as resistências ao poder também tomam parte e presentificam-se (CASTELO BRANCO, 2001, p. 03).

Onde há poder, há sempre resistência, sendo uma coextensiva a outra. Podemos pensar, por exemplo, revoltas a determinadas formas de controle social, demonstrando que estas não se configuram como uma dominação irreversível. Para Foucault, os afrontamentos dessas forças microscópicas intensas promovem a ruptura dos efeitos hegemônicos do poder. 


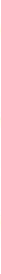

Como destaca Auteríves Maciel Junior (2014), o poder como forma de dominação tomou a vida como seu objeto. A fim de pensarmos a vertente do poder como resistência, Foucault fala sobre as práticas de si como um movimento de criação de formas de existência. Não se trata de práticas orientadas e reguladas pelos valores produzidos pelos dispositivos e sim de práticas autônomas de produção de valores segundo uma atitude de apropriação de si e do mundo. Essas práticas, estão intricadas numa dimensão moral associada ao mudo grego e diferem da nossa herança cristã: "neste sentido, o código moral se apresenta no cruzamento do complexo saber-poder que se encontram em pressuposição recíproca no interior de um dispositivo" (MACIEL JUNIOR, 2014, p. 3). Podemos então observar na leitura de História da sexualidade 2, o uso dos prazeres bem como no História da Sexualidade 3, o cuidado de si (FOUCAULT, 1988b; 1988c), uma reflexão sobre a dimensão moral regulada não por valores externos (Deus, o sexo como expressão do pecado e o corpo/carne como expressão de uma fraqueza), mas uma estética regulada na própria arte do existir, no enfrentamento das forças ali onde elas se desenrolam, em vez de por exemplo, simplesmente rejeitá-las como inerentes a manifestação de um espírito maligno. Se o cidadão grego realiza um ato de renúncia, ele se dá não em função de fugir do pecado, mas decorre do enfrentamento das forças em sua experiência, avaliando até que ponto estas podem se apoderar de seu corpo e subtrair seu domínio de si. Ele não as rejeita, mas decide usufruir delas ou não mediante seu uso lúcido. Tal façanha se desenvolve no exercício da temperança (sophrosune/ $\sigma \omega \varphi \rho o \sigma v ́ v \eta)$ : “Ora, embora essa relação com a verdade, constitutiva do sujeito temperante não conduza a uma hermenêutica do sujeito, como será o caso da espiritualidade cristã, ela abre, em compensação, para uma estética da existência" (FOUCAULT, 1988b, p. 82). No cuidado de si (FOUCAULT, 1988c) o homem deve, portanto, agir de maneira voluntária e refletida no exercício de sua conduta moral.

Essas práticas se fazem numa relação muito peculiar com o saber. Não se trata de uma moral instituída pelos mecanismos de produção de verdades, de internalização de saberes produzidos pelos dispositivos de controle, mas de uma verdadeira cultura de si baseada na elaboração de um campo singular de saber:

Por essa expressão é preciso entender que o princípio do cuidado de si adquiriu um alcance bastante geral: o preceito segundo o qual convém ocupar-se consigo mesmo é em todo caso um imperativo que circula entre numerosas doutrinas diferentes (...); desenvolveu-se em 


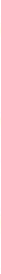

procedimentos, em práticas e em receitas que eram refletidas, desenvolvidas, aperfeiçoadas e ensinadas; ele constituiu assim uma prática social (...); ele proporcionou, enfim, um modo de conhecimento e a elaboração de um saber (FOUCAULT, 1988c, p. $50)$.

As práticas de si levam o sujeito a pensar e agir no contexto de uma partilha simétrica dos jogos da verdade, numa lógica renovada de construção de subjetividades, estabelecendo-se assim uma nova dimensão do exercício da biopolítica. Trata-se do biopoder como resistência. Autoprodução e gestão da vida. Consequentemente, o cuidado de si aparece como uma saída possível à biopolítica como forma de dominação, no enfrentamento das verdades que se impõem ao indivíduo no contexto de uma sujeição aos dispositivos de controle. Desse modo, destacamos a importância do retorno promovido por Foucault à cultura grega na era clássica, a fim de pensar a biopolítica como forma de resistência. O jogo da produção de verdades explicitado na geopolítica dos dispositivos pode então ser tomada como produção de uma relação de saber/poder dada no plano da vida singular de cada um, podendo ser apropriada e ressignificada, estabelecendo assim um plano de autonomia do sujeito.

\section{CONSIDERAÇÕES FINAIS}

Foucault (1988b) reporta ao termo enkrateia ( $\varepsilon \gamma \kappa \rho \alpha ́ \tau \varepsilon ı \alpha)$ como a arte da relação consigo, sendo esta a essência de uma estética presente no cuidado de si. Nela devemos desenvolver a temperança, visando o enfrentamento, domínio e usufruto das forças que nos cercam, sem que percamos nossa condição de liberdade. A discussão sobre a biopolítica é importante no desenvolvimento de nossa pesquisa no campo da arte. Ela nos abre a possibilidade de refletir sobre a possibilidade de produção de novos modos de subjetivação segundo essa perspectiva autônoma. Para tanto, é necessário desconstruir (numa proposta de cuidado de si baseada na experimentação artística) os arranjos produzidos pelos dispositivos de controle durante séculos reificados como matriz de nossa cultura. E não se trata somente de uma desconstrução cognitiva. É necessário penetrar o campo dos afetos, o plano da experiência, de modo a romper os efeitos desses mecanismos arraigados em nossa constituição. Daí a arte nos convida a uma verdadeira inflexão da estética a uma estésis. Para Hélia Borges (2019) "a experiência estésica, ao operar nas bordas do corpo, realiza um trabalho de desabrochamento de algo que permanecia congelado no corpo, por meio da ativação de 


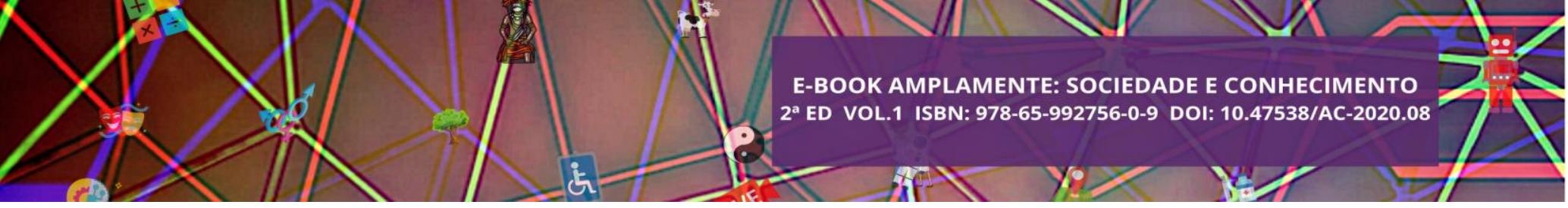

sua sensibilidade física e mental" (BORGES, 2019, p. 04). De modo que a arte nos convida a habitar a experiência no seu cerne, na relação consigo e com o mundo, no plano perceptivo/sensorial inerente ao universo fenomenológico. O cuidado e a estética de si assumem assim uma função estratégica ao desenvolvimento futuro desta pesquisa, seja nos estudos envolvendo a experiência artística no contexto da obra de Lygia Clark, ou na proposta de investigação da estética no campo da produção coletiva a partir das experiências nas batalhas de Rap. Em ambos os casos surge a possibilidade de pensar as formas de resistência aos dispositivos de poder que promovem a captura dos processos de subjetivação em prol da afirmação de uma biopolítica como ressignificação da vida em sua autonomia.

\section{REFERÊNCIAS}

BORGES, H. A poética do corpo: Uma leitura do trabalho de Angel Vianna. Revista Performatus, Rio de Janeiro, RJ, v. 20, n. 1, p. 01-08, jan. 2019.

CASTELO BRANCO, G. As resistências ao poder em Michel Foucault. Trans/Form/Ação, São Paulo, SP, v. 24, n. 1, p. 237-248, jul. 2001.

CLARK, L. Lygia Clark. Rio de Janeiro: Funarte, 1980.

CIRINO, O. O desejo, os corpos e os prazeres em Michel Foucault. Mental, Barbacena, MG, v. 5, n. 8, p. 77-89, jun. 2007.

DEWEY, J. A arte como experiência. In: Coleção Os Pensadores. São Paulo: Abril Cultural, 1980, p. 89-105.

FOUCAULT, Michel. Vigiar e punir. História da violência nas prisões. Rio de Janeiro: Ed. Vozes 1975.

Microfísica do poder. Rio de Janeiro/São Paulo: Paz e terra, 1984.

História da sexualidade, vol. 1. A vontade de saber. São Paulo:

Edições Graal, 1988a.

. História da sexualidade, vol. 2. O uso dos prazeres. São Paulo:

Edições Graal, 1988b.

Graal, 1988c.

História da sexualidade, vol. 3. O cuidado de si. São Paulo: Edições

MACIEL JR, A. Resistência e prática de si em Foucault. Trivium, Rio de Janeiro, RJ, v. 6, n. 1, p. 01-08, jun, 2014. 


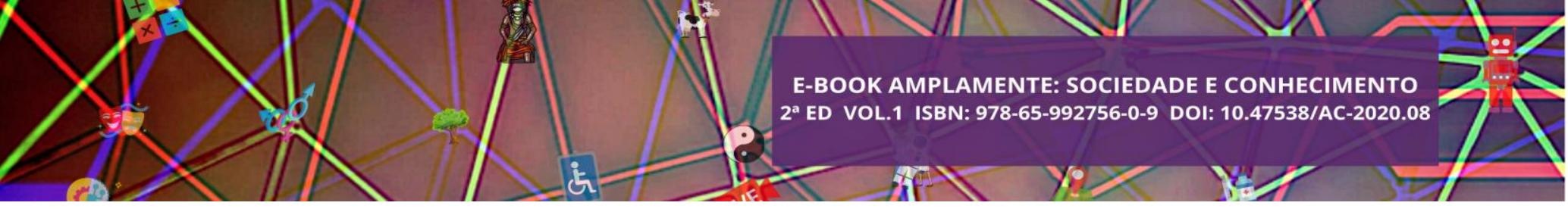

\title{
CAPÍTULO XIV
}

\section{ATIVIDADE ANTIFÚNGICA DE EXTRATOS AQUOSOS SOBRE O DESENVOLVIMENTO DE Rhizoctonia solani}

\author{
Leimi Kobayasti ${ }^{84}$; Rafael Marquês Ribeiro ${ }^{85}$ \\ DOI - Capítulo: 10.47538/AC-2020.08-14
}

\section{RESUMO:}

Em busca de novas medidas de controle de doenças, o uso de plantas medicinais, ervas aromáticas e condimentares, vem sendo utilizados em estudos, visando à redução do uso de agrotóxicos, com resultados promissores. Nesse contexto, o presente trabalho tem como objetivo avaliar a atividade fungitóxica, in vitro, dos extratos aquosos de Curcuma longa (açafrão), Cuminum cyminum (cominho) e Piper nigrum (pimenta-doreino) sobre o crescimento micelial de Rhizoctonia solani e, posteriormente, avaliar o efeito de diferentes concentrações do extrato de açafrão no desenvolvimento micelial desta mesma espécie fúngica. Os extratos aquosos de açafrão, cominho e pimenta-doreino foram incorporados ao meio de cultura na quantidade de $50 \mathrm{~mL}$ para $200 \mathrm{~mL}$ batata-dextrose-ágar (BDA). No segundo ensaio, para avaliar o extrato de açafrão foram incorporadas as concentrações de 100, 70 e $30 \%$ para $150 \mathrm{~mL}$ BDA. Houve diferença significativa na taxa de inibição para todos os extratos vegetais (açafrão, cominho e pimenta-do-reino) em relação à testemunha. $\mathrm{O}$ extrato aquoso do açafrão apresentou maior ação inibitória sobre o crescimento de R. solani, seguido de cominho e pimentado-reino, com porcentagens de inibição de 36,42\%, 24,32\% e 10,78\%, respectivamente. Quanto ao extrato de açafrão observou-se potencial fungitóxico significativo, as concentrações de $70 \%$ e $100 \%$ inibiram $43,47 \%$ e 59,29\% respectivamente.

PALAVRAS-CHAVE: Fungo fitopatogênico. Extratos vegetais. Controle alternativo.

\section{INTRODUÇÃO}

O modelo de produção agrícola em que está fundamentada a agricultura moderna requer muitas mudanças visando a melhoraria do sistema como um todo. Entretanto, essas mudanças devem ser realizadas de modo a não agravar os danos ambientais já gerados por décadas de uso indiscriminado e excessivo de produtos químicos (RODRIGUES, 2014). Para tanto, uma alternativa bastante promissora consiste no emprego de produtos de origem natural em substituição aos pesticidas

84 Doutorado em Agronomia (Fitopatologia) pela Universidade Federal de Lavras. Professora titular da Universidade Federal de Mato Grosso. E-mail: lemikobayasti@yahoo.com.br

85 Engenheiro Agrônomo, Bacharel formado pela Universidade Federal de Mato Grosso. E-mail: mrafaelribeiro@gmail.com 


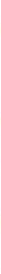

químicos, que são produzidos quase exclusivamente por multinacionais estrangeiras.

Com isso, além de diminuir a dependência em relação a tais agroquímicos, o que deverá reduzir os custos de produção e os indesejáveis impactos ambientais, o produtor também agregará valor ao seu produto, que ficará isento de várias substâncias consideradas tóxicas ao homem (CHALFOUN et al., 2009).

São considerados defensivos alternativos todos os produtos químicos, biológicos, orgânicos ou naturais que possuam as seguintes características: pouco ou nada tóxicos (Classe Toxicológica IV), baixa ou nenhuma agressividade ao meio ambiente e ao homem, alta capacidade de combate a insetos e microrganismos nocivos, custo reduzido para aquisição e emprego, simplicidade quanto ao manejo, aplicação e alta disponibilidade para aquisição (PENTEADO, 2001).

O crescimento da produção e da venda de orgânicos, nos últimos anos, aponta uma tendência dos consumidores de priorizar produtos com qualidades diferenciadas, incluindo preocupações com os impactos ambientais, os riscos à saúde, os valores éticos no processo produtivo e no abastecimento, a valorização dos produtores e dos trabalhadores rurais, entre outras (LIMA et al., 2020). Diante deste contexto, a ação de vários extratos brutos, óleos essenciais e compostos isolados de extratos de plantas aparecem como alvo de estudos de extrema importância na procura por defensivos naturais como alternativas para substituir os agrotóxicos. Além disso, o aumento da procura de produtos orgânicos auxilia na ampliação do interesse pela pesquisa destes produtos para manejo no controle de doenças de plantas.

A identificação de novos compostos químicos a partir de plantas nativas e/ou medicinais possibilita a obtenção de algumas substâncias capazes de controlar ou inibir o desenvolvimento dos fitopatógenos (SILVA et al., 2009). Considerando esse aspecto, metabólitos podem ser extraídos de folhas, flores, sementes, e outras partes da planta, em forma de extrato aquoso, etanólico ou outros solventes (SINGH et al., 1999), para utilização no controle de doenças. Ainda, os produtos naturais de plantas podem apresentar três atividades principais: antimicrobiana, agindo direto sobre o patógeno; indutores de resistência, ativando os mecanismos de defesa da planta por meio de moléculas bioativas e, como bioestimulantes do crescimento da planta (STADNIK e TALAMINI, 2004). Portanto, a exploração da atividade biológica de compostos presentes nos extratos brutos e óleos essenciais de plantas naturais pode se constituir 


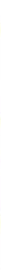

como mais uma forma potencial de controle alternativo de doenças em plantas cultivadas.

Rhizoctonia solani é uma espécie fúngica que infecta as raízes, sobrevive como saprófita no solo, apresenta uma enorme variedade de hospedeiros e é distribuído pela maior parte, senão por toda a massa de terra arável do mundo. É um microrganismo versátil pois é capaz de infectar e causar uma infinidade de doenças em plantas, incluindo podridão de sementes, tombamento ou damping off de pré e pós-emergência, podridão de caule, podridão radicular, decomposição de frutas e, em alguns casos, manchas foliares (HAVERSON, 2013). O patógeno é um habitante do solo, com grande capacidade saprofítica, podendo sobreviver durante longo período em restos de cultura ou de um ano para outro na forma de escleródios (MENDONÇA et al., 2000). As alternativas de controle químico destas doenças têm sido insatisfatórias para a redução da população do patógeno e da doença (SILVESTRI et al., 2005)

Vários estudos estão sendo realizados na busca de pesticidas naturais, e para identificar o potencial de produtos oriundos de vegetais no controle de fitopatógenos, primeiramente deve ser realizada uma pesquisa in vitro. E assim, destacamos o uso de Açafrão (Curcuma longa L.), Cominho (Cuminun cyminum L.) e Pimenta-do-reino (Piper nigrum L.), que sabemos possuir ação antifúngica comprovada, pois já foram demonstrados que diversos patógenos podem ser controlados com eficiência por meio desses extratos vegetais, sendo uma alternativa barata, de fácil preparo e eficaz para ser utilizado na agricultura (KIM et al., 2003; BARROS et al., 2013; SOUSA et al., 2014).

O açafrão ou cúrcuma (Curcuma longa) é classificada como uma espécie condimentar, pertencente à família Zingiberaceae. A espécie é originária do sudeste asiático e foi introduzida no Brasil onde se espalhou por vários estados (CECÍLIO FILHO et al., 2000). O açafrão apresenta um princípio ativo conhecido como curcumina, composto com princípio antifúngico (KIM et al., 2003) sendo descrita sua ação sobre a Rhizoctonia e outras espécies de fungos em diversas pesquisas, comprovando o potencial para o controle de fitopatógenos (SAJU et al., 1998; KIM et al., 2003; AMARAL e BARA, 2005; SOUSA et al. 2014).

$\mathrm{O}$ cominho (Cuminun cyminum) é originário da Ásia Central e pertencente a família Apiaceae (JORGE e VAZ, 2007). É um condimento facilmente encontrado no Brasil e é bastante utilizado por possuir compostos antioxidantes (GONÇALVES et al., 2015), antimicrobianos (JIROVETZ et al., 2005; GACHKAR et al., 2007) assim como 


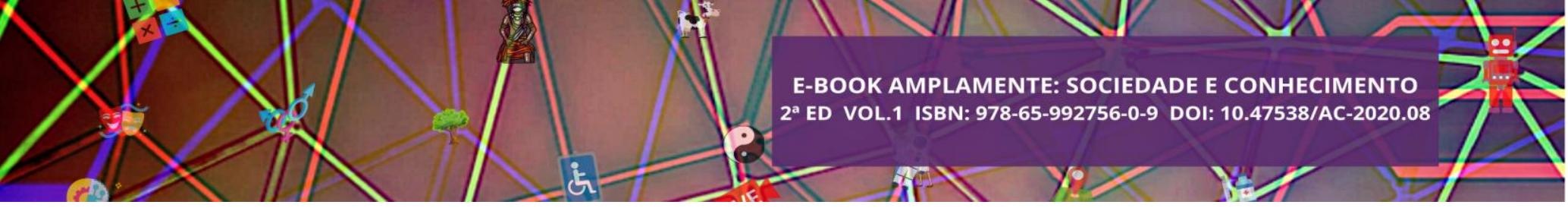

propriedades antifúngicas (PAI et al., 2010). A ação antifúngica do cominho sobre o fungo Rhizoctonia mostrou efeitos inibidores potentes (LEE et al., 2007), inibindo também o crescimento micelial de vários outros fungos fitopatogênicos, mostrando-se eficiente (OLIVEIRA, 2010; FARAG et al., 1989).

A pimenta-do-reino, também conhecida como pimenta-da-Índia, é uma planta trepadeira de grande produtividade e uma das mais valorizadas condimentares do mundo, com grande valor econômico, permitindo que a atividade desenvolvida pelos pipericultores seja altamente rentável (LIMA et al., 2010). Segundo Silva e Bastos (2007), compostos flavonoides presentes em pimentas são altamente oxigenados e possuem atividade antimicrobiana. Ensaios realizados in vitro demonstraram ação fungistática do extrato de pimenta-do-reino inibindo o desenvolvimento micelial de algumas espécies de fungos em condições de ambiente controlado (DIAS et al., 2016; BARROS et al., 2013).

Diante deste contexto, este trabalho teve por objetivo testar a viabilidade dos extratos vegetais de açafrão (Curcuma longa), cominho (Cuminun cyminum) e pimentado-reino (Piper nigrum) no controle, in vitro, de Rhizoctonia solani e avaliar o efeito de diferentes concentrações do extrato de açafrão no desenvolvimento micelial desta mesma espécie fúngica.

\section{MATERIAL E MÉTODOS}

Os experimentos foram conduzidos no Laboratório de Fitopatologia da Faculdade de Agronomia e Zootecnia - FAAZ, da Universidade Federal de Mato Grosso - UFMT, campus de Cuiabá. O experimento foi realizado em duas etapas, a primeira para avaliar a ação antifúngica, in vitro, dos extratos vegetais de açafrão (Curcuma longa), cominho (Cuminum cyminum) e pimenta-do-reino (Piper nigrum) sobre o desenvolvimento micelial do fungo $R$. solani, e a segunda etapa, verificação de concentrações do extrato aquoso que teve maior redução do crescimento micelial na primeira etapa.

O isolamento de $R$. solani foi feito a partir de amostras de sementes de feijão (Phaseolus vulgaris), tipo carioca, cultivado em meio BDA (batata-dextrose-ágar), à temperatura de $22 \pm 2^{\circ} \mathrm{C}$ e fotoperíodo de 12 horas. Após a obtenção da cultura axênica 


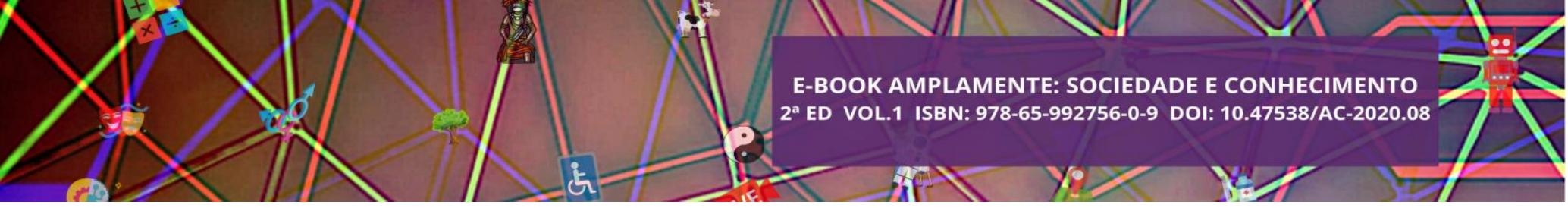

do fungo, estes foram mantidos em placas de Petri, e armazenados em geladeira, durante toda a condução dos experimentos.

Os extratos foram obtidos a partir de açafrão, cominho e pimenta-do-reino, adquiridos no mercado local, na sua forma comercial em pó. Para a obtenção dos extratos, foram pesados 50,0 g de cada material vegetal e se acrescentou $200 \mathrm{~mL}$ de água destilada e esterilizada, o qual foi colocado sobre agitação por uma hora, sendo em seguida centrifugado a $5000 \mathrm{rpm}$ durante 15 minutos. Após a centrifugação, o mesmo foi filtrado com auxílio de papel filtro, obtendo assim o extrato aquoso pronto para uso, sendo mantido em erlenmeyers envolvidos em papel alumínio para sua conservação, sob refrigeração, até o momento da instalação dos ensaios, período que durou 12 horas.

Para avaliar a ação antifúngica dos extratos puros (concentração de 100\%) sobre o crescimento micelial do fungo, ao meio de cultura BDA foi acrescido de $50 \mathrm{~mL}$ do extrato aquoso puro em $200 \mathrm{~mL}$ de BDA, incorporado após a autoclavagem. Foi feita a homogeneização do meio + extrato aquoso e, vertidos $10 \mathrm{~mL}$ em cada placa de Petri de $9 \mathrm{~cm}$ de diâmetro. No centro dessas placas foi transferido um disco de BDA, de 0,5 cm de diâmetro, contendo estruturas miceliais de R. solani. As placas foram incubadas em BOD a $22 \pm 2^{\circ} \mathrm{C}$ com fotoperíodo de 12 horas, por três dias.

Os experimentos foram montados com três tratamentos (açafrão, cominho e pimenta-do-reino, com a utilização do extrato puro adicionado ao meio) e uma testemunha, BDA puro, sem extrato. O delineamento foi inteiramente casualizado com cinco repetições, sendo cada repetição composta por quatro placas de Petri.

As avaliações foram realizadas por meio de medições do diâmetro das colônias desenvolvidas em meio de cultura + extrato (média de duas medidas diametralmente opostas) com auxílio de uma régua milimetrada. Estas avaliações foram realizadas até o $3^{\circ}$ dia, período em que o fungo levou para colonizar toda a superfície do meio de cultura da testemunha, obtendo-se uma média para cada repetição.

Para avaliar a ação antifúngica do extrato de açafrão sobre o desenvolvimento micelial de R. solani, foram utilizadas três concentrações: 100\% (50 mL), 70\% (30 mL) e $30 \%$ (15 mL) do extrato aquoso. A quantia proporcional da referida concentração foi incorporada em $150 \mathrm{~mL}$ de BDA, após a autoclavagem e feita à homogeneização. Em seguida, o meio BDA + extrato aquoso de açafrão foi vertido em placas de Petri de $9 \mathrm{~cm}$ de diâmetro com $10 \mathrm{~mL}$ por placa. No centro das placas, foi colocado um disco de 0,5 $\mathrm{cm}$ de diâmetro, contendo estruturas miceliais de $R$. solani. As placas foram vedadas 


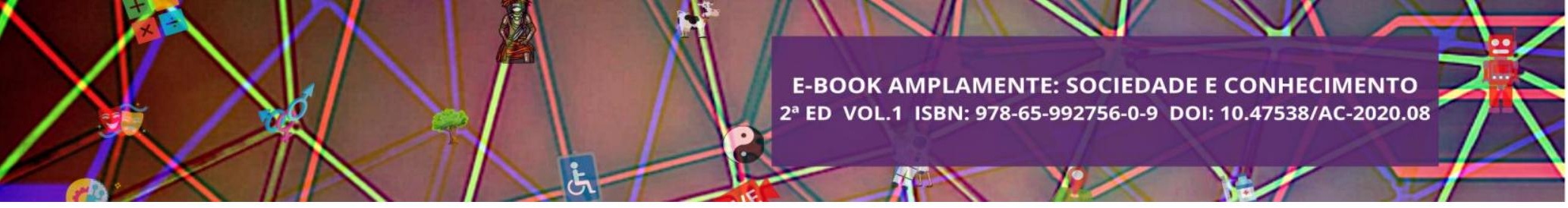

com papel filme, e incubadas em BOD a $22 \pm 2^{\circ} \mathrm{C}$ com fotoperíodo de 12 horas, durante três dias.

Os experimentos foram montados em delineamento inteiramente casualizado utilizando três tratamentos (concentrações do extrato a 100\%, 70\% e 30\%) e uma testemunha, meio BDA sem extrato. Cada tratamento foi composto por cinco repetições, sendo essas repetições compostas por duas unidades amostrais (placas de Petri). As avaliações foram realizadas por meio de medições do diâmetro das colônias desenvolvidas em meio BDA (média de duas medidas diametralmente opostas) com auxílio de uma régua milimetrada. Estas foram realizadas até o terceiro dia, período em que a testemunha levou para preencher a placa de Petri, obtendo-se uma média para cada repetição.

Para avaliar a porcentagem de inibição do crescimento micelial (PIC) foi utilizada a fórmula de Abbott (1925) abaixo:

\section{$\underline{\mathrm{PIC}}=($ Dtest - Dtrat $) \times 100$}

Dteste

onde:

Dtest $=$ Diâmetro da testemunha;

Dtrat $=$ Diâmetro do tratamento. (repetições)

Os dados obtidos nesse estudo foram submetidos à análise de variância e as médias comparadas pelo teste de Tukey a $5 \%$ de probabilidade sendo esta realizada utilizando-se o programa SASM-Agri® (CANTERI et al., 2001).

\section{RESULTADOS E DISCUSSÕES}

Sobre os efeitos dos extratos de açafrão, cominho e pimenta-do-reino no crescimento micelial de $R$. solani, in vitro, foi observado que todos os tratamentos apresentaram diferença significativa quando comparados à testemunha, bem como foi possível verificar que todos os extratos inibiram o crescimento micelial. Entretanto, o extrato de açafrão foi o que apresentou maior redução de crescimento micelial, diferindo dos demais como demonstra a Tabela 1. 
Tabela 1. Crescimento micelial de Rhizoctonia solani sob ação dos extratos vegetais de açafrão, cominho e pimenta-do-reino. UFMT, campus Cuiabá, MT. 2020.

\begin{tabular}{ccc}
\hline Extrato vegetal & \multicolumn{1}{c}{ Crescimento micelial $(\mathrm{cm})$} & $\begin{array}{c}\text { Porcentagem de inibição de } \\
\text { crescimento - PIC }(\%)\end{array}$ \\
\hline Testemunha & $8,39 \mathrm{a}^{*}$ & $0 \mathrm{~d}$ \\
Açafrão & $5,33 \mathrm{~d}$ & $36,42 \mathrm{a}$ \\
Cominho & $6,35 \mathrm{~b}$ & $24,32 \mathrm{~b}$ \\
Pimenta-do-reino & $7,49 \mathrm{c}$ & $10,78 \mathrm{c}$ \\
\hline C.V. $(\%)$ & 2,15 & 9,79 \\
\hline
\end{tabular}

* Médias seguidas da mesma letra nas colunas não diferem entre si pelo teste Tukey a 5\% de probabilidade.

O extrato de açafrão apresentou menor crescimento micelial, consequentemente, apresentou maior porcentagem de inibição (36,42\%), comparado aos demais tratamentos, demonstrando o seu potencial no controle de $R$. solani, em condições in vitro. A ação antifúngica do açafrão é comprovada por outros estudos como o de Saju et al. (1998) que observaram ação inibidora de $72,9 \%$ do crescimento micelial de Rhizoctonia e, conseguindo inibir, em 100\%, outras espécies fúngicas como Colletotrichum gloeosporioides, Sphaceloma cadamomi e Pestalotia palmarum.

Da mesma forma, Amaral e Bara (2005) observaram a eficiência dos extratos de açafrão na concentração de $1 \%$, onde alcançou uma inibição de $61,1 \%$ do crescimento de $R$. solani e Fusarium oxysporum. Kim et al. (2003) também observaram a atividade antifúngica do açafrão, in vitro, para $R$. solani inibindo $63 \%$ do seu crescimento, além de outros fungos fitopatogênicos como Erysiphe graminis, Phytophthora infestans e Botrytis cinerea.

O extrato aquoso de cominho também apresentou uma porcentagem de inibição de $24,32 \%$ sobre $R$. solani, quando comparado à testemunha. De acordo com outras pesquisas, Lee et al., (2007) também obtiveram 83\% de inibição micelial de $R$. solani comprovando a efetividade do cominho. E Oliveira (2010) também demonstrou o uso do cominho na inibição de outros fungos fitopatogênicos.

O extrato de pimenta-do-reino foi o que apresentou menor porcentagem de inibição $10,78 \%$, logo, apresentou também maior média de crescimento, $7,49 \mathrm{~cm}$. A média de crescimento de $R$. solani, ao $3^{\circ}$ dia, chegou próxima à média de crescimento 


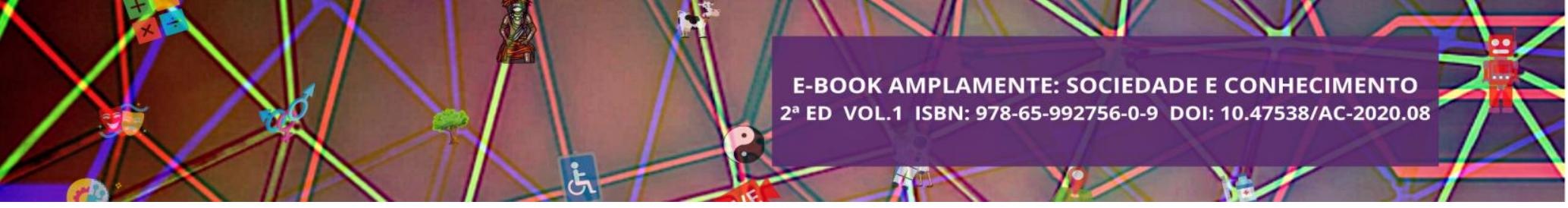

da testemunha $(8,39 \mathrm{~cm})$, podendo ser considerado, nesta pesquisa, como o extrato com menor potencial inibidor quando comparado aos extratos de açafrão e cominho, porém, ainda assim o extrato de pimenta-do-reino apresentou diferença significativa da testemunha.

Vários pesquisadores já demonstraram a propriedade da pimenta-do-reino no controle de diversos patógenos fúngicos. Barros et al. (2013), verificaram que tanto o crescimento micelial como a produção de conídios dos fungos Acremonium sp. e Fusarium verticillioides, foram reduzidos a partir do uso de extratos de pimenta do reino na concentração de $30 \%$ e, havendo ainda redução do crescimento micelial em até $42 \%$ em F. verticilioides. Marcondes et al. (2014) também evidenciaram o uso do extrato de pimenta-do-reino na redução do desenvolvimento de C. gloeosporioides e Fusarium moniliforme. Dias et al. (2016), utilizando metodologia semelhante à do presente trabalho, também observaram percentual de inibição de 43,25\% do extrato de pimenta-do-reino sobre o fungo Lasiodiplodia theobromae.

Outros pesquisadores utilizando espécies do gênero Piper demonstraram eficiência em seus experimentos utilizando R. solani (LEE et al., 2001; LOBATO et al., 2007). E outros ainda, diversificando as espécies fúngicas (LEE et al., 2001; LOBATO et al., 2007; SILVA e BASTOS, 2007; SILVA et al., 2012; DONDE et al., 2013; NASCIMENTO, 2015). Todos estes trabalhos evidenciam o uso do gênero Piper e da pimenta-do-reino, nas diferentes concentrações ou tipos de extratos, com potencial de uso no controle de fungos fitopatogênicos.

A diferença de crescimento e porcentagem de inibição entre os diferentes extratos pode ser explicada pelo fato de que as plantas avaliadas nesta pesquisa possuem particularidades dos compostos químicos na qual são constituídas. Segundo Silva (2006) a quantidade e a composição química dos extratos de plantas são influenciadas por diversos fatores, entre eles, fatores genéticos, idade da planta, o tipo de solo onde a planta é cultivada e o seu habitat, fatores climáticos, o tipo do tecido e horário de coleta do material vegetal, assim como conservação dos extratos após processamento.

\section{EFEITO, IN VITRO, DAS CONCENTRAÇÕES DE EXTRATO DE AÇAFRÃO SOBRE O CRESCIMENTO MICELIAL DE Rhizoctonia solani}




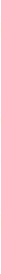

Nas concentrações do extrato de açafrão sobre $R$. solani, foi observada redução gradativa no crescimento micelial à medida que se aumentou a concentrações no meio de cultura. Todas as concentrações utilizadas reduziram o crescimento micelial de $R$. solani em relação a testemunha. O extrato de açafrão demonstrou maior porcentagem de inibição quando se utilizou a concentração de 100 e $70 \%$, como pode ser observado na Tabela 2.

Tabela 2. Efeito das concentrações de extrato aquoso de açafrão sobre o crescimento micelial de Rhizoctonia solani. UFMT, campus Cuiabá, MT. 2020.

\begin{tabular}{ccc}
\hline $\begin{array}{c}\text { Tratamento/ concentração } \\
\text { açafrão }(\%)\end{array}$ & $\begin{array}{c}\text { Crescimento micelial } \\
(\mathrm{cm})\end{array}$ & $\begin{array}{c}\text { Porcentagem de inibição de } \\
\text { crescimento - PIC }(\%)\end{array}$ \\
\hline Testemunha & $8,20 \mathrm{a}$ & $0,00 \mathrm{~d}$ \\
100 & $3,34 \mathrm{~d}$ & $59,26 \mathrm{a}$ \\
70 & $4,63 \mathrm{c}$ & $43,47 \mathrm{~b}$ \\
30 & $5,49 \mathrm{~b}$ & $33,04 \mathrm{c}$ \\
\hline C.V. $(\%)$ & 6,11 & 11,51 \\
\hline
\end{tabular}

* Médias seguidas da mesma letra nas colunas não diferem entre si pelo teste Tukey a 5\% de probabilidade

Na concentração de $100 \%$ (50 mL) a porcentagem de inibição foi de 59,26 \% apresentando menor crescimento $(3,34)$ quando comparado a outras concentrações $(70 \%$ e 30\%). Para a concentração de $70 \%$ (30 mL) houve inibição de $43,47 \%$ do crescimento de $R$. solani e apresentou crescimento de crescimento 4,63 cm. A concentração de $30 \%$ (15 mL) apresentou porcentagem de inibição de 33,04\% e crescimento 5,89, apresentando também diferença significativa quando comparada à testemunha.

As porcentagens de inibição do crescimento micelial dos extratos mostram-se inversamente proporcionais às médias de crescimento do fungo como observado na Tabela 2. Assim, nota-se que o extrato aquoso de açafrão apresentou satisfatória inibição de crescimento do fungo em concentração de $30 \%$ (33,02\%), quando comparado á dose $0 \%$ (testemunha), inferindo que houve uma redução expressiva do crescimento micelial, evidenciando a fungitoxicidade do extrato em baixas concentrações, ou seja, o extrato é eficiente para controle mesmo em concentrações menores. O controle fúngico chega a um pico de inibição de 59,26\% na maior concentração do extrato utilizada a 100\%, mostrando que as concentrações mais elevadas têm um impacto maior sobre $R$. solani. 


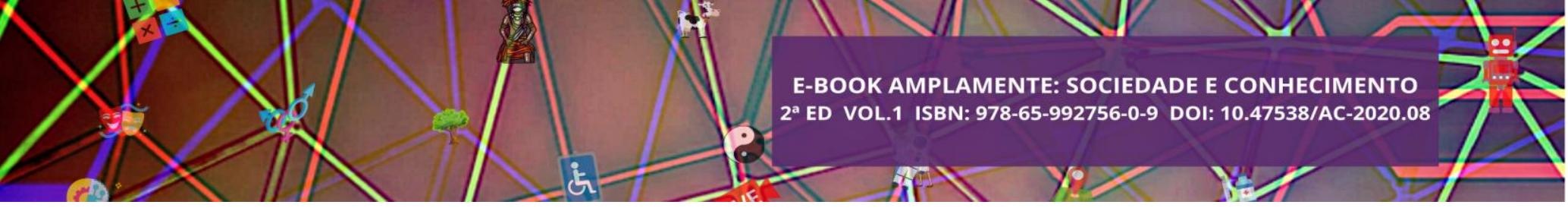

Diversos autores verificaram o efeito inibitório do extrato de açafrão sobre fungos, corroborando com os nossos resultados. Becker et al. (2004) verificaram que os extratos de açafrão a 5\% contra Septoria glycines e Cercospora kikuchii e, na concentração de $5 \%$ e $10 \%$ contra oídio (Microsphaera diffusa) em soja em condições de campo, proporcionaram o mesmo nível de controle que o fungicida utilizado para comparação. Amaral e Bara (2005) observaram uma porcentagem de inibição de $61,1 \%$ sobre o fungo R. solani, utilizando uma concentração do extrato de açafrão a $1 \%$. BalbiPeña et al. (2006), também verificaram que o extrato de açafrão em concentrações de $10 \%$ e $15 \%$ inibiram o crescimento micelial de Alternaria solani em 38,2 e $23,2 \%$ e, a esporulação em 71,7 e 87\%, respectivamente. Sousa et al. (2014), observaram que houve inibição do crescimento do fungo Colletotrichum lindemunthianum, proporcional ao aumento da concentração do extrato de açafrão, pois na dose de $4,0 \mathrm{mg} / \mathrm{mL}$ apresentou $32,24 \%$ de inibição.

De forma que nossos resultados são animadores, comprovando que o açafrão apresenta propriedade inibitória com potencial para ser utilizado no controle alternativo de doenças de plantas, necessitando apenas de mais estudos sobre sua ação contra fitopatógenos assim como para os diferentes padrões de preparo do seu extrato. Os estudos de extratos naturais para uso no controle de doenças em detrimento do uso de produtos químicos sugerem uma opção promissora no manejo integrado de doenças de plantas.

\section{CONCLUSÕES}

Os extratos de açafrão, cominho e pimenta-do-reino mostraram-se eficientes na inibição do crescimento micelial do fungo Rhizoctonia solani. Os extratos de cominho e de pimenta-do-reino inibiram em $24,32 \%$ e $10,78 \%$, respectivamente, o crescimento micelial de $R$. solani.

O extrato aquoso do açafrão mostrou-se o mais eficiente no controle, in vitro, de R. solani, inibindo o crescimento do mesmo em até $56,26 \%$, demostrando que o aumento na concentração do extrato aquoso de açafrão, aumenta consequentemente o poder de inibição deste extrato. 


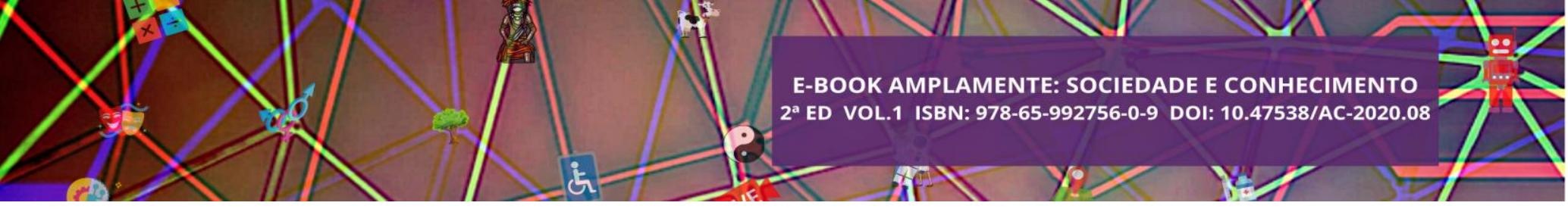

\title{
CAPÍTULO XV
}

\section{COMBATE À DESERTIFICAÇÃO}

\author{
Flávio Pedro Silva de Lima ${ }^{86}$; Paulo Soares da Fonseca ${ }^{87}$
}

DOI - Capítulo: 10.47538/AC-2020.08-15

\section{RESUMO:}

$O$ presente trabalho tem como enfoque principal, o processo de desertificação que vem assolando o mundo e, conseguintemente, o Brasil. A desertificação é um fenômeno de proporções globais e que começou a chamar atenção da comunidade científica nos anos 30 do século XX, quando ocorreram intensos processos de degradação em alguns estados do meio oeste americano. O Direito Ambiental é um ramo do direito que surgiu da necessidade do homem proteger a si mesmo, o próximo e o ambiente em que vive das possíveis degradações que suas atividades ou quaisquer outras formas de interação entre ele e a natureza viessem a provocar nesta última. A consequência têm sido sua lenta, mas contínua degradação ambiental. A prevenção e o combate a esta degradação é o objeto da Convenção das Nações Unidas de Combate à Desertificação, da qual o Brasil é signatário. Em 1974, é realizada a Conferência Mundial sobre Desertificação, em Nairob. O Brasil, desde essa data tornara-se um dos países signatárias do documento final, ou seja, o Protocolo de Compromisso para Combater a Desertificação. A base legal na qual poderá dar suporte jurídico para enfrentar e tratar as ações provocadas pelo processo de desertificação, pelos juristas e nem tão pouco existe uma legislação capaz de combater dentro dos parâmetros legais apoiado em lei, entre os entes federativos. Assim sendo mesmo diante da problemática a legislação é inexiste.

PALAVRAS-CHAVE: Desertificação. Direito ambiental. Base legal.

\section{INTRODUÇÃO}

O trabalho ora apresentado tem por finalidade maior apresentar como seu objeto de estudo, o processo de desertificação no Brasil, mais especificamente na região Nordeste do país, com seu enfoque regional para a região do Seridó. A desertificação é um fenômeno de proporções globais e que começou a chamar atenção da comunidade científica nos anos 30 do século XX. O semiárido Nordestino com milhões de $\mathrm{km}^{2}$, precipitações baixas e variáveis, elevado risco da atividade agropecuária e nível tecnológico muito baixo, reúne os piores indicadores econômicos e sociais do país. A partir da reunia do Quênia, vários outros encontros internacionais têm sido realizado em

86 Mestrando em Ciências da Educação. Professor da Educação Básica no município de Guamaré/RN. E-mail: ggeocrn29@hotmail.com

87 Licenciado em Ciências Biológicas. Funcionário Público, Guamaré/RN. E-mail: Paullogomes32@gmail.com 


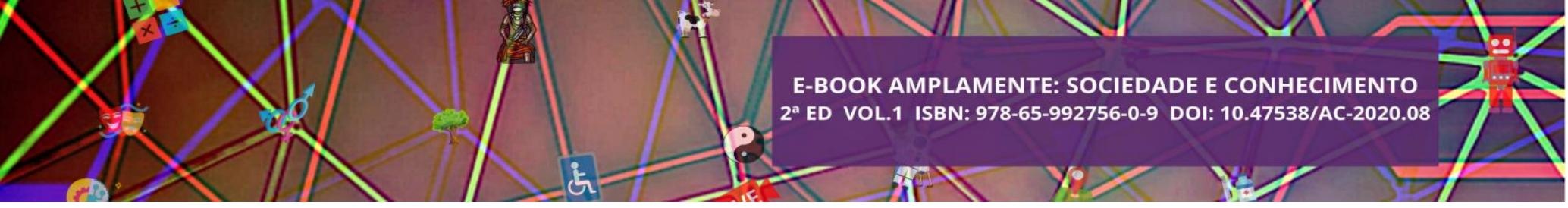

diferentes partes do planeta com o objetivo de encontrar soluções para enfrentar a problemática da desertificação pelo mundo a fora, foram realizados diversos acordos em nível internacional, tendo seu marco em 1992 com a Convenção-Quadro das Nações Unidas sobre Mudança do Clima. Em 1998, foi firmado o Protocolo de Kyoto,

Desse modo, apresentar-se-á em capítulos, assim denominados: capítulo 1. Marco Conceitual; capítulo 2. A desertificação; a desertificação no RN e base legal. O primeiro capítulo aborda a função do Direito Ambiental em sua legalidade e aplicabilidade. O segundo capítulo fala sobre o processo de desertificação em suas causas e consequências. Havendo, sobretudo, um traçado do perfil de mudanças nas leis sobre a situação do meio ambiente na região Nordeste.

Por fim, o último capítulo, que são as Considerações Finais, o qual faz uma breve abordagem sobre a importância dos aspectos abordados ao longo desse estudo para áreas diversas, mas que prima, sobretudo, a conscientização da população em relação ao tratamento adequado que se deve propiciar ao meio ambiente.

\section{MARCO CONCEITUAL}

\section{DIREITO AMBIENTAL}

O Direito Ambiental que teve sua gênese a partir da intervenção humana nas questões ecológicas e, posteriormente, na destruição que o sistema capitalista exerce no ambiente, o qual é motivado pelos meios de produção é classificado como direito de terceira geração.

O Direito Ambiental de terceira geração tem por características aspectos transindividuais e difusos. Vale dizer que Direito Ambiental Difuso ou Transindividual é todo aquele que protege interesses que vão além do individual e atingem um número indeterminado ou indeterminável de indivíduos. Tais interesses tocam os indivíduos sem, necessariamente, exigir que estes pertençam a grupos ou categoria determinados. Nessa perspectiva, trata-se, por isso mesmo, de um direito difuso, espalhado pela sociedade, do qual todos são titulares.

O Direito Ambiental fundamenta-se nos seguintes princípios, tais como: acesso eqüitativo aos recursos naturais, prevenção, reparação, qualidade, participação popular e publicidade. Para efeitos jurídicos, o art. $3^{\circ}$, I, da Lei n. 6.938/81, conceitua o meio 


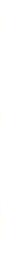

ambiente como "o conjunto de condições, leis, influência e interações de ordem física, química e biológica, que permite, abriga e rege a vida em todas as suas formas".

\section{DESERTIFICAÇÃO: CONCEITOS, CAUSAS E CONSEQUENCIAS}

A desertificação que atinge diferentes áreas do planeta torna-se objeto de preocupação mundial ainda na década de 30 do século passado. Quando foram identificadas as primeiras a sofrerem intenso processo de perda da qualidade dos solos nos Estados Unidos da América.

Sucessivos encontros e conferências internacionais sobre a problemática da desertificação são realizados com o objetivo de discutir os motivos que causam a perda de grandes quantidades de solo em todo o mundo e, ao mesmo tempo, traçar ações para combater o grave problema relacionado ao desgaste dos solos.

Em 1977 é realizada a I a conferência das Nações Unidas, sobre desertificação que foi realizada em Mairobi no Quênia, com o objetivo de traçar planos para enfrentar o avanço das áreas propicias a desertificação. Durante a Conferência, o conceito de desertificação foi então definido.

Desertificação é a diminuição ou a destruição do potencial biológico da terra e que pode conduzir, no seu limite, às condições semelhantes a desertos. Se constitui numa deterioração em larga escala dos ecossistemas e destrói ou diminui o seu potencial biológico, ou seja, é a diminuição ou destruição do cultivo de plantas e da criação de animais para diferentes propósitos, em um tempo em que o incremento da produtividade da terra é necessário para suportar o crescimento das populações, para satisfazer os requisitos de desenvolvimento. (UNCOD, 1977).

A primeira área diagnosticada como em processo de desertificação foi no meio oeste americano nos estados de Oklahoma, Kansas, Colorado, Novo México. Porém, outras áreas foram identificadas em adiantado processo de desertificação.

No continente Africano a desertificação está presente nas localidades próximas do deserto do Saara, em uma região conhecida como Sahel. Nessa área a desertificação trouxe como consequência a morte de meio milhão de pessoas, causada pela falta de alimentos. Dessa forma é perceptível o impacto ambiental, social e econômico que é consequência dos desgastes que afetam os solos.

Para a ONU 1977, desertificação é “A degradação da terra nas regiões áridas, semiáridas e sub-úmidas secas, resultantes das variações climáticas e atividades 


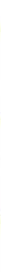

humanas". A degradação da terra envolve degradação dos solos e dos recursos hídricos, degradação da vegetação e da biodiversidade e diminuição da qualidade de vida das pessoas que ocupam as áreas afetadas pelo processo de desertificação.

Segundo dados da PNUMA, as terras semiáridas englobam um terço do planeta, abrigam um contingente populacional de aproximadamente um bilhão de pessoas e são responsáveis pela produção de $20 \%$ da disponibilidade de alimentos no mundo.

O processo crescente de desertificação que afeta os diversos países do mundo mereceu atenção especial e teve destaque na Agenda 21, que faz referência à desertificação como sendo. Desertificação é um processo que culmina com a degradação das terras nas zonas áridas, semiáridas e sub-úmidas secas, como resultado da ação de fatores diversos, com destaque para as variações climáticas e as atividades humanas.

A desertificação é um processo global com graves incidências para o meio ambiente. Há muito que a comunidade internacional reconheceu que a desertificação constitui, em escala mundial, um dos graves problemas com implicações sociais, econômicas e ambientais. Mais de 110 países têm terras secas que potencialmente sofrem risco de desertificação. Segundo o Instituto, os continentes perdem anualmente 24 bilhões de toneladas de terra. A desertificação afeta, anualmente, cerca de $30 \%$ da área total da Terra.

Segundo Conti (1988), Cerca de 1/3 das terras emersas do globo, isto é, 50 milhões de quilômetros quadrados, ou aproximadamente seis vezes a dimensão do Brasil, apresentam condições de aridez e aí vivem um bilhão de habitantes ou $20 \%$ da humanidade. As regiões hiperácidas, ou de aridez absoluta correspondem a 4\% desse total.

É inegável a importância da conferência Queniana de 1977, já que esse evento teve suma importância no que diz respeito à identificação das áreas susceptíveis à desertificação, como também contribuiu de forma a traçar metas que possam amenizar as causas e consequências que o processo de destruição dos solos pode provocar tanto para o meio ambiente como para as populações que ocupam essas áreas.

A Conferência das Nações Unidas trouxe importantes contribuições na luta contra o avanço e efeitos que a desertificação, tanto para as sociedades quanto para os ecossistemas. A reunião do Quênia resultou em por em práticas ações com o objetivo de amenizar os efeitos da desertificação, tais ações como as seguintes: 


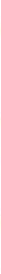

- Na inserção de regiões áridas e semiáridas no âmbito das discussões, mostrando que a relação pobreza x problemas ambientais necessitava de um enfrentamento direto pela comunidade internacional;

- Definição do conceito sobre desertificação, o que passou a ser adotado em todo o mundo, o que motivou vários países a darem mais atenção ao meio ambiente;

- Na criação do Plano de Ação para Combater Desertificação (PACD).

As causas mais frequentes da Desertificação estão associadas ao uso inadequado do solo e da água no desenvolvimento de atividades agropecuárias, na mineração, na irrigação mal planejada e no desmatamento indiscriminado. Podendo apresentar problemas como: a) Vulnerabilidade às secas, que impactam diretamente a agricultura de sequeiro e a pecuária; b) Desmatamento resultante da pecuária extensiva e do uso de madeira para fins energéticos; c) Perda de dinamismo de atividades industriais e comerciais; d) Gestão municipal sem planejamento e comprometimento com objetivos em longo prazo; entre outros que podem ser responsáveis pelos problemas que causam a desertificação.

Vários são os fatores que causam a desertificação referente a esses aspectos naturais elaborados ao longo dos séculos pelas forças da natureza, mas também contribuem para promover à destruição dos solos. As causas antrópicas aceleram o ritmo dessa degradação, principalmente em ambientes frágeis. Sendo as mudanças climáticas e geológicas responsáveis pelos fatores naturais que promovem degradação ambiental entre a pobreza e os processos de desertificação são intrínsecos.

Há consenso em se identificar que a pobreza é fator resultante dos processos de desertificação e simultaneamente, como fator realimentador. No caso do Brasil, em que se verifica que a gradativa perda da capacidade produtiva dos recursos naturais, inclusive da fertilidade natural dos solos, reduz de forma implacável a possibilidade de produção de riqueza, contribuindo, entre outras consequências, com a redução da renda das pessoas.

A combinação dos elementos 'pobreza e desigualdade', promove nas Áreas Suscetíveis à Desertificação (ASD) uma evidente aceleração dos processos de degradação. Um grande número de pequenos trabalhadores rurais, detentores de pequenas áreas para a prática da agricultura com baixa ou média fertilidade natural e dependendo que as atividades sejam destinadas à produção de alimentos para a o alto consumo ou para o cultivo de plantas forrageiras que servirá para alimento de para o 


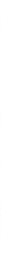

animal; essas são as formas de utilização do solo pelo pequeno produtor rural assentado nas áreas propicias a desertificação.

O Combate às causas da desertificação só terá eficiência se for combatido grave problema enraizado no cotidiano dos pequenos produtos das áreas afetado pelos efeitos da desertificação como, por exemplo, o combater à pobreza e à desigualdade existente no campo.

A partir da década de 1990, a discussão aumentou devido às consequiências trágicas que o fenômeno vinha desencadeando em alguns países do mundo, principalmente na África, vitimando milhares de pessoas e degradando extensas áreas nesse continente, fato que promoveu a degradação ambiental.

Atendendo às exigências do CCD, que obriga os países a criarem o programa de Ação Nacional de combate à desertificação que, no caso do Brasil, é executado pelo ministério do meio ambiente (MMA); a partir de 2004 passou a ser chamado de programa de Ação Nacional de combate á Desertificação e Mitigação dos Efeitos da seca (PAN-Brasil) lançado no final do ano de 2008.

A desertificação se expande pelos vários países no mundo. Esse fenômeno já é presente em mais de 100 países, principalmente nas áreas que estão localizadas no norte e sul da África, no Oriente Médio, na Ásia Central, noroeste da China e Austrália, sudoeste americano, oeste da América do Sul e no nordeste brasileiro, por isso é considerado um grave problema global.

Segundo Cavalcante (2001), "no Brasil existem quatro áreas, que são reconhecidas como núcleos de Desertificação, onde é intensa a degradação”. Juntas elas somam 18,7 mil km² e estão presentes nos municípios de Gilbués, no Piauí; Seridó, no Rio Grande do Norte; Irauçuba, no Ceará e Cabrobó, em Pernambuco.

As regiões áridas, semiáridas e sub-úmidas secas, também chamadas de terras secas, ocupam mais de $37 \%$ de toda a superfície do planeta, abrigando mais de um bilhão de pessoas, ou seja, 1/6 da população mundial, cujos indicadores sociais são: baixo nível de renda, baixo padrão tecnológico, baixo nível de escolaridade e o acesso a alimentação básica é inserta; já que a fome é preocupante nessa áreas do planeta.

Contudo, a evolução do aspecto mencionado ocorre em cada lugar de modo específico e apresenta dinâmica influenciada por esses lugares. No Brasil, as áreas semiáridas somam $13 \%$ das terras que compõem o polígono das secas e que abrangem a 


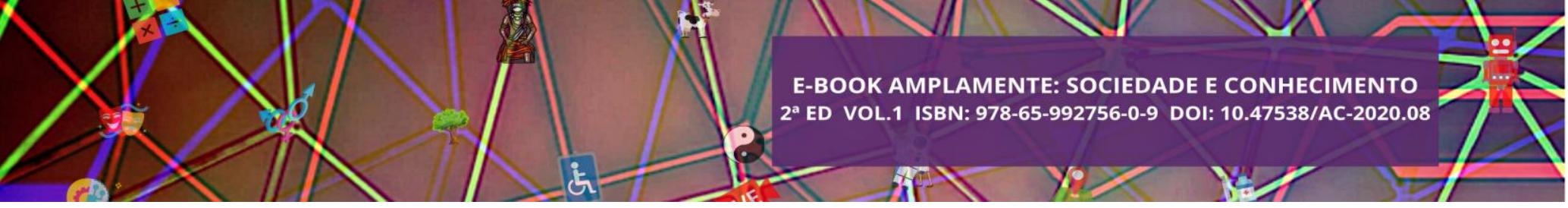

região do semiárido nordestino. Assim, 10\% das terras presentes no polígono das secas sofrem desertificação grave. Segundo estudos do ministério do meio ambiente.

Expulsos das áreas que apresenta grave processo de desertificação, os moradores dessas áreas tendem a migrar para os centros urbanos das pequenas, médias e grandes cidades, levados pela falta de perspectivas de sobrevivência em seu habitat de costume que, na maioria dos casos, é seu referencial social e cultural, os quais são obrigados a deixar sua história de vida.

Passando a procurar condições mais favoráveis de sobrevivência, esses migrantes tendem a agravar os problemas encontrados nas cidades, principalmente quanto aos problemas de infraestrutura (transporte, saneamento, abastecimento, entre outros) já existentes nos centros urbanos. Verifica-se também um aumento nos níveis de desemprego e violência urbana.

\section{A DESERTIFICAÇÃO}

A problemática da desertificação tem sido objeto de estudo por esse ser um assunto que está presente em todo o mundo, provoca prejuízos ao meio ambiente, pois a destruição dos solos também promove consequências para o homem que é atingido diretamente.

Fatores naturais têm causado a desertificação em todo o mundo que, por sua vez, é agravado pelas ações humanas que descaracteriza o meio para fins econômicos, como: agricultura, pecuária e mineração e que acabam agravando o problema da desertificação.

A ação antrópica estaria na origem da modalidade de desertificação, mencionada, com a retirada predatória e, em grande escala, dos recursos naturais. $\mathrm{O}$ processo pode ser agravado se coincidir com a ocorrência de estiagens severas e frequentes, resultando numa drástica redução do potencial hídrico.

Assim sendo, a desertificação pode ser percebida no desgaste dos solos, dos recursos hídricos, da biodiversidade e da própria qualidade de vida que se manifesta nas regiões áridas e semiáridas.

Os impactos da desertificação são de ordem social, ambiental e econômico. Tais impactos são perceptíveis quanto aos seguintes fatores: destruição da biodiversidade, 


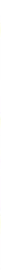

diminuição dos recursos hídricos disponíveis e redução da área destinada à produção agrícola.

Já os impactos sociais envolvem a transferência do homem do campo para os grandes centros urbanos, motivados pela falta de uma política que fixe o trabalhador rural no campo e redução da unidade familiar. Economicamente os prejuízos financeiros atingem as cifras em torno de 800 milhões de dólares ao ano para o Brasil.

As principais causas da desertificação são: salinização dos solos motivados pelas práticas da irrigação irregular, a criação de animais e a pratica da pecuária extensivas, com a retirada da cobertura vegetal, contribui para o esgotamento dos solos e dos recursos hídricos; procedimentos intensivos e que enfrentam dificuldades de si adaptarem às condições ambientais.

Dessa forma, a degradação das terras secas consiste na perda da produtividade biológica e econômica das terras agrícolas, das pastagens e das áreas de matas nativas devido às variabilidades climáticas.

Assim sendo, a degradação avança quando se aplica ao solo formas inadequadas de manejo da terra que vem provocando degradação dos solos, bem como dos biomas que estão inseridos nessas áreas afetadas pelo grave problema da desertificação e também provoca a destruição da biodiversidade.

\section{A DESERTIFICAÇÃO NO MUNDO}

A desertificação que acontece em todo o mundo e está presente nos cinco continentes habitados do planeta, América, África, Ásia, Europa e Oceania.

No continente americano as áreas que sofrem com intenso processo de desertificação encontram-se no sudoeste dos Estados Unidos, que também sofre processo perca da qualidade dos solos, tal fato pode ser encontrado também na parte oeste da América do Sul e nordeste do Brasil, principalmente na região classificada como semiárida.

Já na África duas são as áreas que o processo de desertificação já é bastante acentuado, com destaque para região que envolve as bordas do deserto do Saara, conhecida como SAHEL ao norte, ao sul desse continente também pode se verificar que é a área que sofre maior processo de desgaste dos solos. Sendo possível identificar esse processo na Ásia Central, o noroeste da China, e a Austrália. 


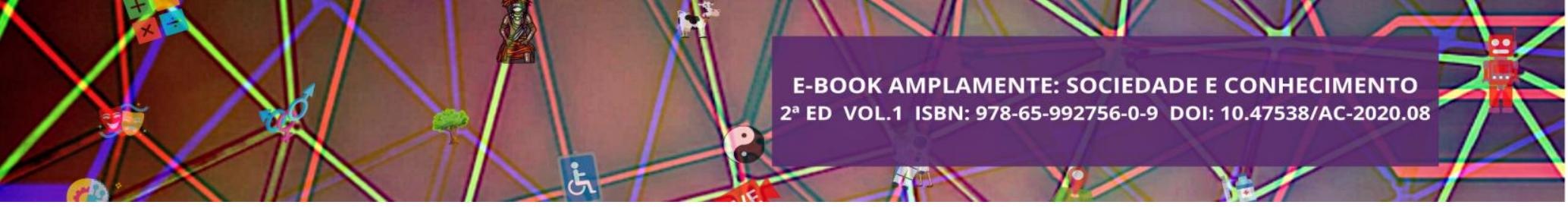

\section{A DESERTIFICAÇÃO NO BRASIL}

No Brasil, as áreas que podem vir a ocorrer os processos de desertificação são as que apresentam características áridas, semiáridas e sub-úmidas secas que se encontram normalmente na Região Nordeste. Aparecendo casos também na região Sudoeste, Sul e Norte do país, com destaques nos estados de Pernambuco, Piauí, Paraíba, Ceará, Rio Grande do Norte, Rio Grande do Sul, além do Mato Grosso do Sul e Amazônia, ambos nas regiões Centro-Oeste e Norte.

Além das áreas destacadas, aparece a região sudoeste do estado do Rio Grande do Sul com destaque aos municípios de Alegrete, São Francisco de Assis, Santana do Livramento, Rosário do Sul, Uruguaiana, Quaraí, Santiago e Cacequí, que são atingidos pela desertificação e sofrem com os processos erosivos desde 2003, provocados pela atividade agropecuária extensiva.

O mapa da susceptibilidade do Brasil, elaborado pelo MMA a partir de trabalho realizado pelo Centro de Sensoriamento Remoto do IBAMA, determinou três categorias de susceptibilidade: Alta, Muito Alta e Moderada. As duas primeiras referem-se respectivamente às áreas áridas e semiáridas definidas pelo índice de aridez. A terceira é resultado da diferença entre a área do Polígono das Secas e as demais categorias. Assim, de um total de 980.711,58 km2 de áreas susceptíveis, 238.644,47 km2 são de susceptibilidade Muito Alta, 384.029,71 km2 são de susceptibilidade Alta e 358, 037,40 km2 são moderadamente susceptíveis.

Além destas áreas com níveis de degradação difusos, podem ser citadas quatro áreas com intensa degradação, segundo a literatura especializada, os chamados Núcleos de Desertificação. São eles: Gilbués-PI, Irauçuba-CE, Seridó-RN e Cabrobó-PE, totalizando uma área de $18.743,5 \mathrm{~km}^{2}$.

No nordeste brasileiro as áreas suscetíveis à desertificação alcançam 980.711 km2, distribuídos em oito estados do Nordeste e no norte do Estado de Minas Gerais. Na região do Seridó, a área afetada é de aproximadamente $2.341 \mathrm{~km} 2$ e a pressão antrópica, que contribuiu para este processo, foi relativa às queimadas, o cultivo do algodão, pastoreio e ao desmatamento, principais responsáveis pela perda da diversidade florística (LUETZELBURG, 1923). 


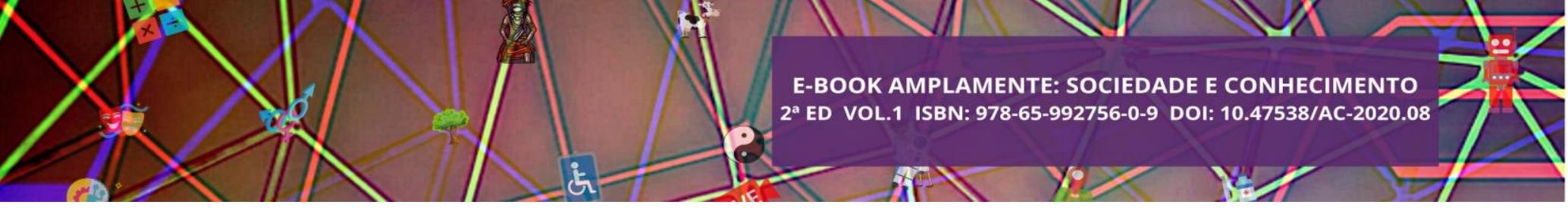

\section{A DESERTIFICAÇÃO NO NORDESTE BRASILEIRO}

No Brasil, o Nordeste é a área onde a presença de fatores que causam a desertificação é maior, pois o clima semiárido atrelado à grande quantidade de insolação, desmatamento e a falta de conhecimentos capazes promover a ausência manejar de forma correta o solo, contribuiu para que várias áreas de desertos se formem nessa região brasileira.

Umas vastas áreas de terras presentes no Nordeste que estão sob o domínio da desertificação e que apresentam grau de desgaste dos solos envolvem quatro grandes núcleos presentes nos seguintes estados da região: Rio Grande do Norte, Piauí, Ceará e Pernambuco.

Embora as áreas destacadas sofram com o desgaste dos solos e causem preocupação a respeito da formação de voçorocas, o que, por sua vez, trará consequências graves para as áreas afetadas com o desgaste de solos.

O desenvolvimento das atividades de preparação do Plano Nacional de Combate à Desertificação - PNCD leva em consideração os dois níveis de ocorrência do fenômeno voçorocas, sendo que as ações requeridas para cada um deles serão de naturezas diferentes.

A região geográfica do Nordeste é composta por nove estados, Ceará, Piauí, Maranhão, Pernambuco, Alagoas, Sergipe, Paraíba, Bahia e Rio Grande do Norte. Devido a sua grande diversidade de paisagens essa região é subdividida em quatro grandes sub regiões. O Meio- Norte, A zona da Mata, O Agreste e O Sertão.

O polígono das secas corresponde a uma área criada em 1951 pelo governo federal. É uma área presente no Sertão, cuja principal característica é a escassez de chuvas causadas por fatores naturais, como: a circulação dos ventos e as correntes marítimas que impedem a formação das chuvas, e também a fatores humanos como o desmatamento e as queimadas. Essa área abrange praticamente todo o Nordeste brasileiro, conforme apresenta o mapa abaixo. 


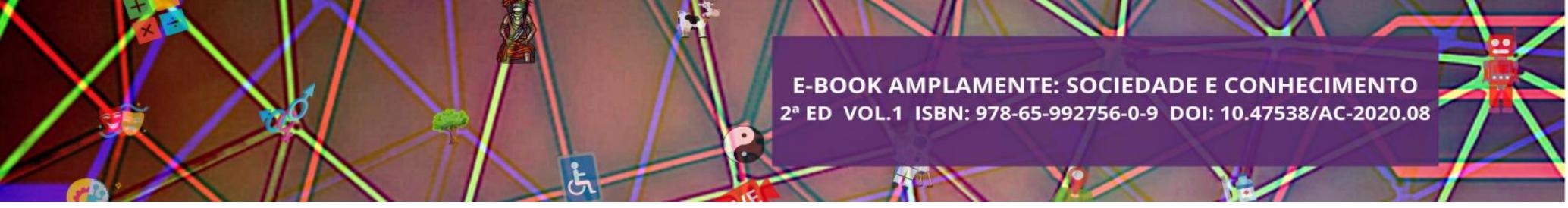

Enquanto a população urbana quase triplicou nos últimos 30 anos, a rural foi reduzida de 812,9 a 740,1 mil habitantes no mesmo período. “A série histórica revela uma migração crescente campo-cidade a partir de 1970, sendo que no período 19912000 esse fenômeno ocorreu de forma mais lenta, provavelmente em decorrência dos programas de assentamento rural, que incentivam e viabilizam a permanência do homem no campo" (PERFIL DO ESTADO DO RIO GRANDE DO NORTE, p 34).

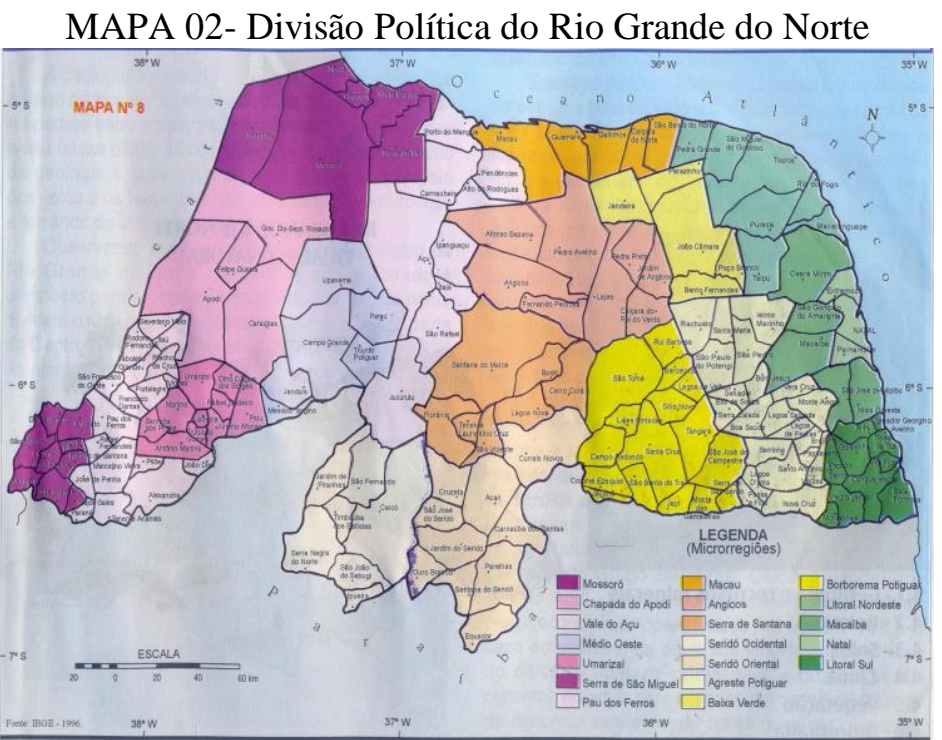

FONTE: FELIPE, José Lacerda Alves; CARVALHO, Edílson Alves de. Atlas escolar do Rio Grande do Norte, 2004.

As características naturais do Rio Grande do Norte, com ênfase aos seus aspectos climáticos e sua cobertura vegetal, apresentam exemplares presentes em regiões semiáridas. Sua trajetória histórica foi marcada por um processo de ocupação territorial, baseado inicialmente na agricultura e na pecuária, e reorganizado através do desenvolvimento de outras atividades como a produção de sal, a mineração, a extração da cera de carnaúba, entre outros.

O Estado do Rio Grande do Norte está inserido na área do polígono das secas e, consequentemente é um dos graves problemas que afetam a região - a falta de chuvas regulares que, embora ocorra precipitação, essas por sua vez são mau distribuídas

Levando em conta às condições climáticas, o Rio Grande do Norte caracteriza-se por apresentar temperatura média anual em torno de $25,{ }^{\circ} \mathrm{C}$, com máxima de $31^{\circ}, \mathrm{C}$ e mínima de $21^{\circ} \mathrm{C}$, pluviometria bastante irregular (em termos de quantidade e período) e umidade relativa do ar, com variação média anual de 59\% a 76\%. Em decorrência de 


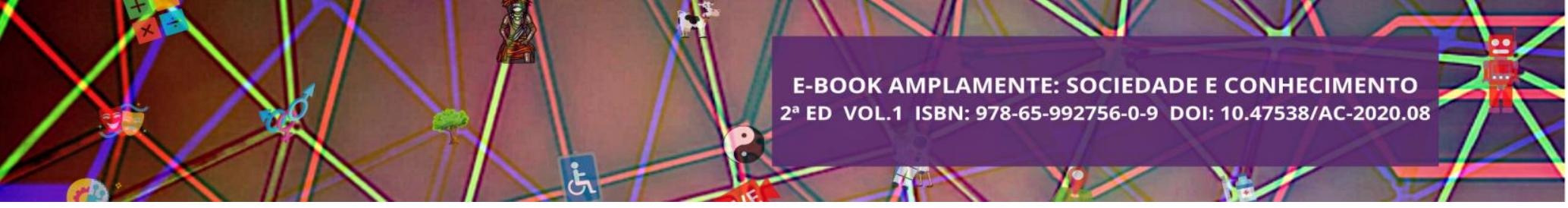

sua localização geográfica próxima ao Equador, predominam as elevadas temperaturas, verificando-se entre a presença do sol na grande maioria do ano, apresentando em média 2.400 e 2.700 horas por ano de insolação.

Segundo Carvalho; Gariglio; Barcellos (2000) a desertificação no estado do Rio Grande do Norte é motiva de preocupação desde a década de 70.

As informações apresentadas permitem inferir que, possivelmente no início dos anos de 1990, a desertificação já tinha afetado 72,5\% do território potiguar, em níveis de intensidade variados e sinalizavam para estatísticas preocupantes, principalmente em função da representatividade que assumia as áreas com estágios de ocorrência classificados como grave e muito grave. Um outro aspecto importante refere-se à abrangência populacional, visto que nas áreas afetadas moravam $41,7 \%$ do contingente estadual, ressaltando-se que, na região com nível de desertificação muito grave, residiam $11 \%$ dos potiguares (CARVALHO; GARIGLIO; BARCELLOS, 2000).

A identificação dos estudos sobre a desertificação no Rio Grande do Norte denota que a preocupação com o problema já se fazia presente nos últimos decênios do século XX, sendo sintomático que, em 1997, tenha sido criado o Grupo de Estudos sobre Desertificação no Seridó - GEDS.

O referido grupo, que envolve diversas instituições, "foi fruto de um processo de reflexão em torno das questões da seca, das alternativas de convivência com este fenômeno e do combate direto aos processos desencadeadores da desertificação" e tem como objetivo fomentar estudos e debates sobre o tema, articulando ações capazes de promover o desenvolvimento sustentável no Seridó (IDEMA, 2004).

Sendo assim o mapa da desertificação no Rio Grande no Norte apresenta-se conforme o mapa abaixo: 


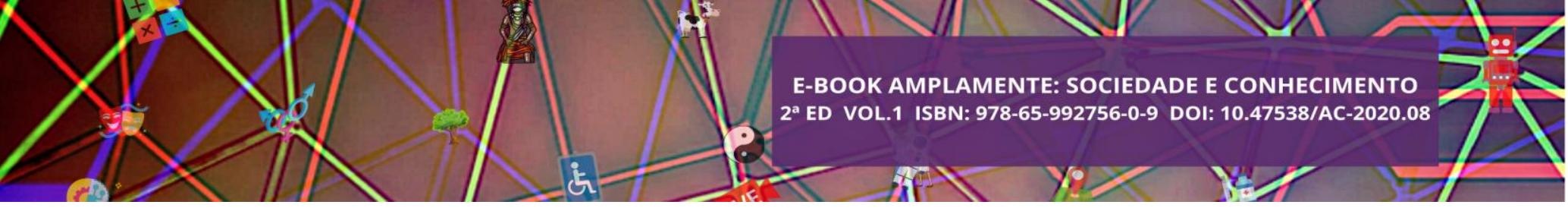

vem sendo submetida a intensos trabalhos de prospecção e mineração, criando núcleos de desertificação" (SOBRINHO 1982 apud 2002).

O Núcleo de Desertificação do Seridó ocupa 4.093,803 km² do território do Rio Grande do Norte e abriga uma população de 152.578 habitantes. A população urbana residente nas circunscrições do núcleo corresponde a $84,71 \%$ e a população rural a apenas 15,28\%. Os sete municípios do Núcleo, hoje, apresentam como traço marcante o desenvolvimento do setor terciário, com ênfase nos pequenos negócios urbanos e nos segmentos dos serviços sociais, e das atividades mineiras, com realce para a cerâmica. No Rio Grande do Norte o município de maior expressão territorial e demográfica é Caicó.

A atividade econômica desenvolvida na região do Seridó Potiguar que tem contribuído para promover a inclusão do Rio Grande do Norte na área critica quanto à desertificação. Dentre as atividades econômicas do Rio Grande do Norte que contribuem para a degradação ambiental estão: a agropecuária; a mineração - com destaque para a produção ceramista e a panificação.

\section{BASE LEGAL}

Os princípios gerais do Direito Internacional do Meio Ambiente podem ser contemplados como uma espécie de fio condutor que perpassa o ordenamento Jurídico ambiental dando-lhe sustentação, ao mesmo tempo em que lhe confere gerência ao nortear as ações necessárias aos Estados para evitar a degradação do meio ambiente em prol de um desenvolvimento de uma política ambiental comum.Sendo assim os tratados internacionais exerce um papel importante a constituição de direitos voltados à proteção do meio ambiente.

\section{CONFERÊNCIAS INTERNACIONAIS}

Inúmeros encontros internacionais têm sido realizados em várias partes do mundo sobre a tutela da ONU, cujo objetivo principal é encontrar situações que visam intensificar ações para atenuar os efeitos causados pela desertificação em várias partes do mundo. Entre elas merece destaque:

- A primeira Conferência das Nações Unidas sobre a Desertificação foi realizada em Nairob, Quênia, no ano de 1977. Porém, somente em 1994 foi criada a Convenção 


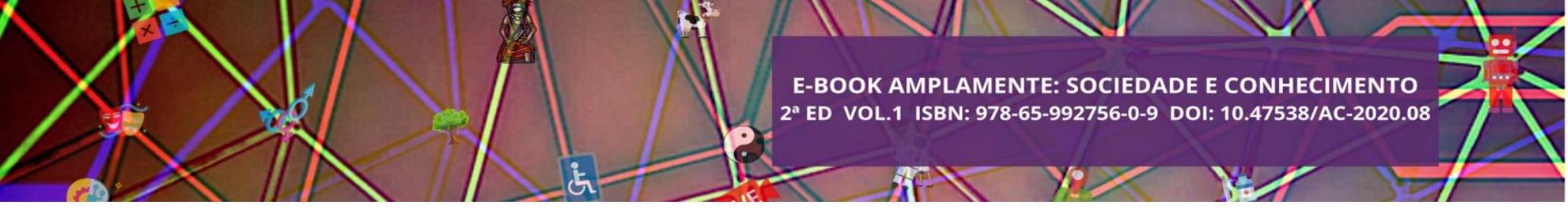

das Nações Unidas de Combate à Desertificação, nessa conferência ficou estabelecido o conceito de desertificação como sendo à degradação da terra nas zonas áridas, semiáridas e sub-úmidas secas;

- A $8^{a}$ Conferência das Partes (COP 8) da Convenção das Nações Unidas de Combate à Desertificação, realizada na Espanha em 2007, sobre desertificação cujo principal objetivo foi discutir a situação mundial referente aos avanços das áreas desertificadas no mundo, e ao mesmo tempo traçar condições com o objetivo de reduzir as áreas afetadas em decorrência da desertificação em todo o planeta. Traçou objetivo com a intenção de reduzir as terras degradadas pela desertificação, segundo a conferência da Espanha deve promover ações como: I. a prevenção e/ou redução da degradação das terras, II. a reabilitação de terras parcialmente degradadas, e III. a recuperação de terras degradadas".

II. Segunda Conferência Internacional sobre Clima, Sustentabilidade e Desenvolvimento em Regiões Semiáridas. (ICID 2010) realizada na cidade de Fortaleza em agosto de 2010, resultou em ações que devem ser direcionadas com o objetivo de enfrentar as causas que provocam a destruição do meio ambiente nas regiões Secas (Áridas, Semiáridas, Subúmidas Secas). Voltadas para atender a necessidade de frear o avanço da desertificação nas áreas propicias a esse fenômeno que atinge não só o Brasil mais em várias outras partes do mundo faz recomendações para enfrentar tais problemas.

A urgência para responder aos desafios e oportunidades atuais e emergentes sobre clima, desenvolvimento e sustentabilidade em Regiões Secas não deve ser subestimada. A Comunidade internacional mostrou sua intenção de colocar o desenvolvimento das Regiões Secas na agenda internacional com o lançamento, na ICID 2010, da Década das Nações Unidas sobre Desertos e Luta Contra a Desertificação 2010-2020. Em vista das contribuições da ICID 2010 e dos novos cenários de mudanças climáticas globais que intensificam o imperativo do desenvolvimento das Regiões Secas, a alvorada desta nova Década das Nações Unidas é um reconhecimento bem-vindo de que ação decisiva para o bem estar da humanidade e dos ecossistemas nas Regiões Secas do planeta (DECLARAÇÃO DE FORTALEZA, 2010, p. 08).

Nessa perspectiva, os emissores de gases, com efeito, estufa deve ser responsabilizado através da aplicação do princípio do "poluidor-pagador" e outras medidas semelhantes. 


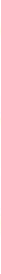

Isso deveria gerar recursos adicionais para financiar novos investimentos em medidas de adaptação. Inovações financeiras para avançar o desenvolvimento sustentável sob condição de mudança climática deveriam incluir também: (i) fundos para financiar adaptação e atividades associadas de desenvolvimento sustentável nas Regiões Secas, tais como o proposto Fundo Caatinga, no Brasil; (ii) pagamento por serviços ecológicos e outros serviços ambientais, inclusive o estabelecimento de um fundo para redução de emissões de degradação de terras e de desertificação, na linha dos fundos existentes para redução de emissões de desmatamento e degradação de florestas em áreas de florestas tropicais, conhecidos como REDD; e (iii) instrumentos de seguro e de compensação por danos relacionados com o clima (DECLARAÇÃO DE FORTALEZA).

A política Nacional do Meio Ambiente-PNMA deve ser compreendida como o conjunto dos instrumentos legais, técnicos, científicos, políticos e econômicos à promoção do desenvolvimento sustentável da sociedade e, consequentemente, da relação econômica que se entrelaçam diante do estado e/ou nação brasileira. A implementação da PNMA faz-se a partir de princípios que são estabelecidos pela própria constituição Federal e pela legislação ordinária (ANTUNES, 2006).

$\mathrm{O}$ artigo $2^{\circ}$ da Lei $\mathrm{n}^{\circ}$ 6938/ 81, fica estabelecida os princípios legais que dever guiar a Política Nacional do Meio Ambiente a segurar, ao país, ao desenvolvimento sócio econômico, melhoria da qualidade de vida de todos os nativos do Brasil e suas gerações, que se encontram ordenado nos incisos I e X. Estes princípios estão submetidos aos princípios gerais do Direito Ambiental.

Na contramão do País, o Estado de Pernambuco sai na vanguarda ao Institui a Política Estadual de Combate à Desertificação e Mitigação dos Efeitos da Seca, e dá outras providências. A Lei $N^{\circ}$ 14.091, de 17 de junho de 2010. A referida lei dispõe, em seu artigo $1^{\circ}$ : “Art. $1^{\circ}$ Esta Lei institui a Política Estadual de Combate à Desertificação e Mitigação dos Efeitos da Seca, fixa seus princípios, objetivos, diretrizes e instrumentos".

Dos estados inseridos dentro da área delimitada pela ONU, como a área susceptível à desertificação, Pernambuco é a primeira Unidade da Federação a criar normas para amenizar a problemática da desertificação, suas causas, consequências e, ao mesmo tempo, traça meios para promover o controle social, através de mecanismos que garantam "á sociedade informações, representação técnica e participação na formulação de políticas voltadas para combater a desertificação".

O PAN-BRASIL é um programa de apoio ao desenvolvimento sustentável, cujo foco é a recuperação, a preservação, a conservação dos recursos naturais e o combate à 


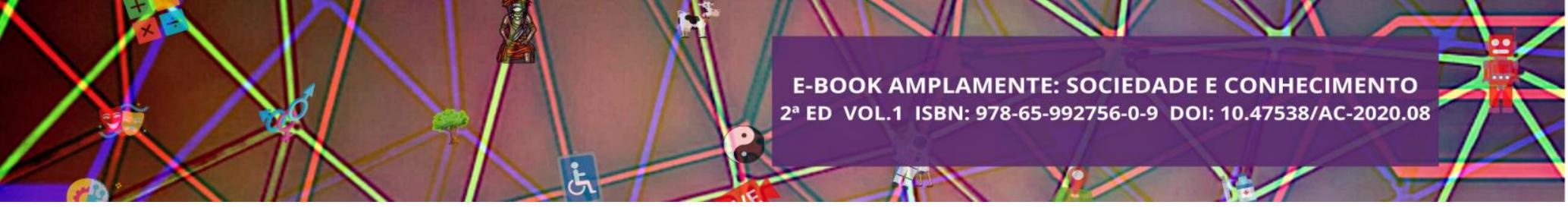

pobreza. Esse programa atuará, assim, no sentido de estimular e promover mudanças no modelo de desenvolvimento em curso no Semiárido Brasileiro.

Conforme referido na Agenda 21, o combate à desertificação deve conferir prioridade à implementação de medidas preventivas para as terras atingidas pela degradação ou que estejam apenas levemente degradadas. Destaca também que as áreas seriamente degradadas não devem ser negligenciadas.

O PAN-BRASIL tem como objetivo geral estabelecer diretrizes e instrumentos legais e institucionais que permitam aperfeiçoar a formulação e execução de políticas públicas e investimentos privados no Semiárido Brasileiro, no contexto da política de combate à desertificação e mitigação dos efeitos da seca e de promoção do desenvolvimento sustentável.

O capítulo 12 da agenda 21, ponta ações que devem ser tomadas para promover o controle e o combate às áreas em processo de desertificação no Brasil. Poderão ser tomadas ações preventivas para as terras que ainda não se encontram em grave processo de degradação dos solos, mais também devem ser tomadas providencias para frear a desertificação em criticas onde esse problema já se torna por demais graves.

A Lei n. ${ }^{\circ} 6.938 / 81$ conceitua meio ambiente, em seu artigo $3^{\circ}$, inc. I como "o conjunto de condições, leis, influências e interações de ordem física, química e biológica, que permite, abriga e rege a vida em todas as suas formas". Além disso, ela define instrumentos capazes de preservar e restaurar os processos ecológicos, tais como, o zoneamento ambiental, criação de espaços territoriais protegidos, etc. Estes dispositivos de maior relevância quanto ao tema para demonstrar que o Brasil possui as diretrizes e instrumentos, inclusive de ordem constitucional, para promover a proteção do meio ambiente, sem que isto prejudique o seu desenvolvimento econômico, desde que este se dê baseado em princípios de sustentabilidade ecológica.

Preocupado com o grave problema da desertificação que atinge principalmente as regiões áridas do nordeste brasileiro e a falta de uma política capaz de combater e disciplinar as causas que contribuem para o aumento da desertificação em nosso país e a consequentemente falta de um código legal que discipline as ações referentes ao tema. Desde o ano de 2007, tramita no congresso Federal uma proposta com o objetivo de instituir a Política Nacional de Combate e Prevenção à Desertificação e Mitigação dos Efeitos da Seca. 


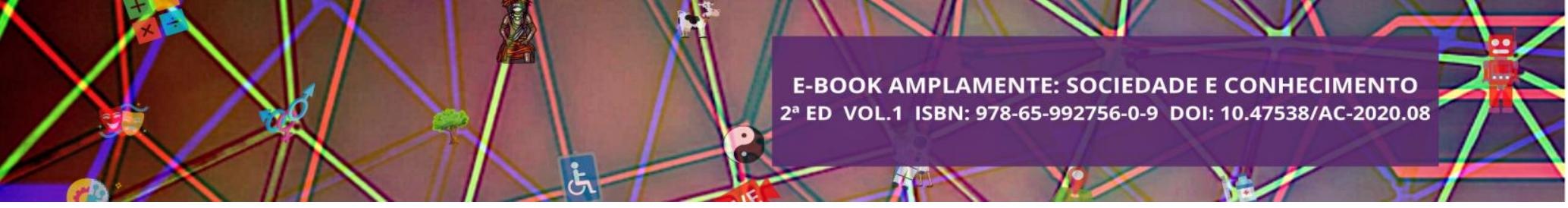

Quanto aos Objetivos do projeto de criação da política Nacional de Combate e prevenção á desertificação e mitigação dos efeitos da Seca:

Art. $2^{\circ}$ A Política Nacional de Combate e Prevenção à Desertificação e Mitigação dos Efeitos da Seca tem por objetivos:

I - prevenir e combater a desertificação e recuperar as áreas afetadas, em todo o território nacional;

II - apoiar o desenvolvimento sustentável nas áreas susceptíveis à desertificação, por meio do combate à pobreza e às desigualdades sociais, do estímulo ao uso sustentável dos recursos naturais, da conservação do meio ambiente e do fomento de uma prática agrícola adaptada às condições ecológicas locais em uma abordagem consistente com a Agenda 21;

III - instituir mecanismos de proteção, conservação e recuperação de mananciais, vegetações e solos degradados nas ASD;

IV - integrar a gestão de recursos hídricos com as ações de prevenção e combate à desertificação;

$\mathrm{V}$ - estimular o desenvolvimento de pesquisas científicas e tecnológicas voltadas ao aproveitamento sustentável dos recursos locais;

VI - fomentar pesquisas e a ampliação do conhecimento sobre o processo de desertificação e a ocorrência de secas, bem como a recuperação de áreas afetadas ou degradadas;

VII - promover a agricultura familiar e a segurança alimentar nas áreas de risco ou afetadas pela desertificação;

VIII - promover a educação ambiental das comunidades afetadas e dos diferentes setores da população, inclusive gestores, sobre o problema da desertificação e sobre a promoção de tecnologias sociais de convivência com a seca;

IX - fortalecer as instituições públicas e responsáveis pelo combate e prevenção à desertificação;

$\mathrm{X}$ - coordenar as organizações da sociedade civil, envolvida com o combate e prevenção à desertificação;

XI - fomentar os sistemas agroecológicos, bem como a diversificação de produtos destinados ao consumo familiar e ao mercado.

Vale ressaltar que o projeto de lei acima ainda não foi aprovado pelo congresso nacional embora a relevância do tema, o Brasil ainda não desenvolveu um código de leis voltado para disciplinar. Mesmo o Rio Grande do Norte tendo cerca de $90 \%$ das suas terras inseridas nas áreas propícias à desertificação, o estado não apresenta uma lei específica que trate exclusivamente da problemática referente à desertificação com 


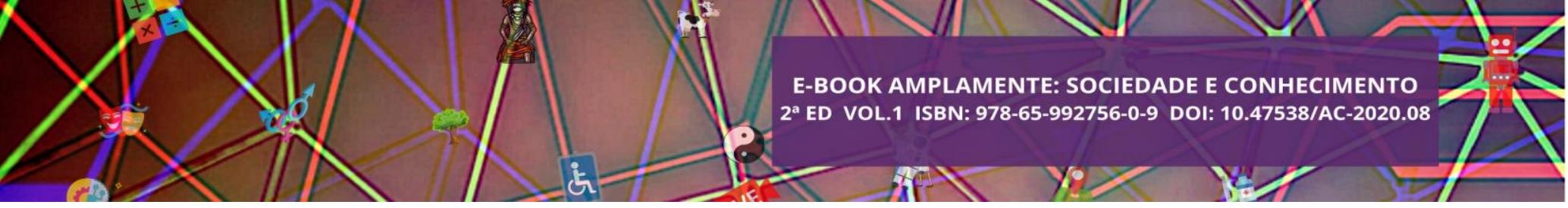

objetivos voltados para conter ou combater o desgaste dos solos, principalmente na região do Seridó.

O problema da desertificação começa a chamar a atenção daquelas pessoas que se preocupam com esse grave problema ambiental. É sugerido um projeto de lei que seja capaz de ordenar de forma jurídica, ações capazes de combater o dano ambiental.

A constituição estadual trata o tema do meio ambiente de forma abrangente o que ainda mostra o descaso por parte da unidade federativa em tratar dentro da forma da lei, ou seja, aparado por uma jurisdição legal. Dessa forma, a Constituição Estadual (p. 13), afirma:

Art. 150. Todos têm direito ao meio ambiente ecologicamente equilibrado, bem de uso comum do povo e essencial à sadia qualidade de vida, impondo-se ao Poder Público e à coletividade o dever de defendê-lo e preservá-lo, e de harmonizá-lo, racionalmente, com as necessidades do desenvolvimento socioeconômico, para as presentes e futuras gerações (CONSTITUIÇÃO ESTADUAL).

Motivado pela ausência de uma política estadual cujo foco seja combater o desgaste dos solos é sugerido um projeto de lei com a intenção de enfrentar os problemas da desertificação. O projeto de lei tem como objetivo criar à política estadual de combate a desertificação. E encontrar mecanismos e estudos a fim de conter tal processo, bem como recuperar áreas que já se encontram sofrendo essas consequências. “Art. $1^{\circ}$ Fica instituída a Política Estadual de Combate e Prevenção à Desertificação no Estado do Rio Grande do Norte". A proposta de um projeto de lei para Instituir uma política estadual de combate e prevenção a Desertificação no Estado do Rio Grande do Norte, é mais um ponto que comprova a existência de uma grande lacuna que precisa ser preenchida o mais rápido possível, já que as questões ambientais podem ser irreversíveis e a recuperação de áreas degrada podem não ser possíveis diante dos altos custos financeiros e sociais para tais regiões em questão.

Mesmo os municípios que sentem de perto os efeitos desastrosos da desertificação, após uma breve pesquisa não apresentam nenhuma ação ou, mesmo, um plano municipal com o objetivo de frear os efeitos que esta tem em sua área territorial, falta de uma política e até um projeto de educação capaz de garantir conhecimento para a população que sofre com a degradação do solo.

A grande preocupação é a demora em regulamentar um código de leis com normas que visam combater os efeitos, causas e consequências da desertificação no 


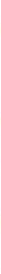

país, seja muito tarde, pois as áreas onde eram classificadas como regiões semiáridas, hoje se encontram em adiantado processo de formação de extensos desertos, que em muitos casos nada mais pode ser feito para o uso dos solos. Levando as consequências de pobreza e miséria as áreas afetadas pela desertificação.

\section{CONSIDERAÇÕES FINAIS}

É notória a urgência em se pleitear políticas públicas que primem pela preservação ambiental em face das necessidades do meio e da população, considerandose que a maior parte das alterações sofridas no solo é decorrente da falta de conhecimento da população em como lidar com tais diversidade, e consequência dos efeitos climáticos que ganham proporções alarmantes a cada ano, como o caso do aquecimento global.

Constata-se que não existem, ações públicas que viabilizem um trabalho de ordem educativa, principalmente nas áreas acometidas por climas semiáridos e que favorecem à desertificação.

Vale salientar que todo o processo de mudanças ambiental se deve mais ao desconhecimento de atitudes simples por parte da população, do que propriamente de investimentos em alta tecnologia.

Outros aspectos relevantes são a importância de serviços agregados à questão de conscientização da população, a citar: serviços meteorológicos, estudos geológicos e de assoreamento; além do posicionamento que a própria comunidade assume como meio de reeducar a população que reside em áreas de desertificação.

Assim sendo, o referido estudo assume caráter de ampliar pesquisas no sentido de combater o desconhecimento quanto ao processo de desertificação no meio educativo, porque através dela se concebe conhecimentos diversificados e em particular referentes à produção do conhecimento crítico-reflexivos da comunidade.

A base legal na qual poderá dar suporte jurídico para enfrentar e tratar as ações provocadas pelo processo de desertificação fica a quem da gravidade do problema, visto que no Brasil o tema desertificação não é tratado pelos juristas e nem tão pouco existe uma legislação que de sustentabilidade judicial capaz de combater dentro dos parâmetros legais apoiado em lei, seja ela: em nível Federal, Estadual e Municipal. Assim sendo mesmo diante da problemática a legislação é inexistente. É chegado o 


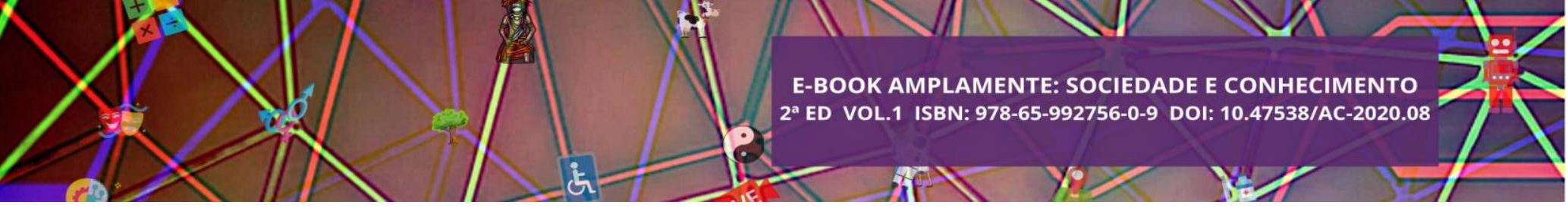

momento em que todos os entes federativos criem leis, resoluções, princípios que possam garantir perante a lei a conservação e o controle das áreas afetadas pelo problema da desertificação.

Importante lembrar que tal estudo não se esgota aqui, tento em vista o perfil de importância que assume no contexto econômico de diversas áreas do Brasil.

\section{REFERÊNCIAS}

AGENDA 21 BRASILEIRA. Ministério do Meio Ambiente. Projeto PNUD BRA/94/016, Brasília, 1999.

CARVALHO, Adaílton Epaminondas de; GARIGLIO, Maria Auxiliadora; BARCELLOS, Newton Duque Estrada. Caracterização das áreas de ocorrência de desertificação no Rio Grande do Norte. Natal: [s.n.], 2000.

CAVALCANTI, E. Para Compreender a Desertificação: Uma abordagem didática e integrada. Instituto Desert. Julho de 2001.

CONTI, J. B. A. In: Clima e Meio ambiente. Desertificação no mundo. São Paulo: Atual Editora, 1998. p. 64-75.

FELIPE, José Lacerda Alves. CARVALHO, Edílson Alves de. ROCHA, Aristotelina P. Barreto. Atlas Rio Grande do Norte: espaço geo-histórico e cultural. João Pessoa: GRAFSET, 2004.

IBAMA - Instituto Brasileiro do Meio Ambiente e dos Recursos Naturais Renováveis. Diagnóstico florestal do Rio Grande do Norte / Plano de manejo florestal para a região do Seridó do Rio Grande do Norte. Projeto PNUD/FAO/IBAMA/BRA/ 87/007. Natal: Ministério do Meio Ambiente, 1993. 45p.

Luetzelburg, P. V. Estudo botânico do Nordeste. Rio de Janeiro: Inspetoria Federal de Obras Contra as Secas, v.3, n.57, Série 1-A, p.197-250, 1923.

MILARÉ, Édis. Direito do Ambiente: doutrina, jurisprudência e glossário. 3. Ed. Rev., atual. e ampl. São Paulo: Editora Revista dos Tribunais, 2004.

Panorama da Desertificação no Estado do Rio grande do Norte: Ministério do Meio Ambiente. Secretaria de Recursos Hídricos, Natal - RN, 2005.

SILVA, José Afonso. Direito Ambiental Constitucional. São Paulo, Malheiros Editores, Ltda, 1994

VASCONCELOS SOBRINHO, João de. Desertificação no Nordeste do Brasil. Recife: UFPE, 2002.

http://www.camara.gov.br/sileg/MostrarIntegra.asp?CodTeor=529830 


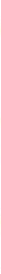

http://www.icid18.org. - Declaração de Fortaleza. Acesso em 15-11-2010

http://www.itamaraty.gov.br/sala-de-imprensa/selecao-diaria-de-noticias/midiasnacionais/brasil/agencia-brasil/2010/12 acesso em 21-12-2010. 


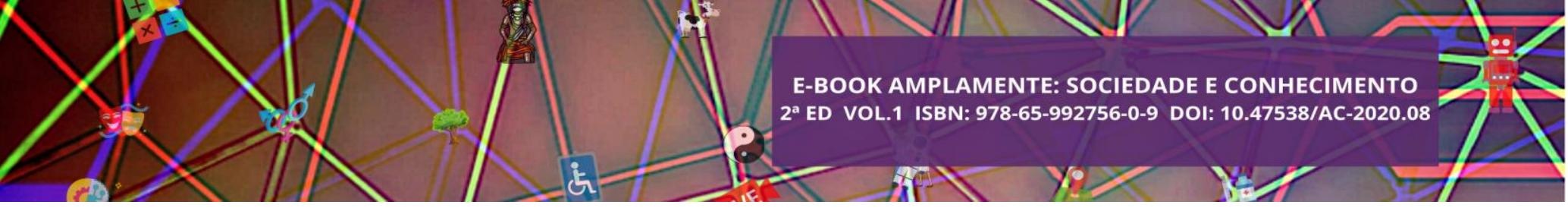

dos homens!" Aquela velha discussão, por sinal apropriadíssima, que é legítima diante das desigualdades, nesse caso, de gênero.

Mas bastam medidas estatais, em alguns países, a exemplo do Peru, que definem os dias para homens e mulheres transitarem em sociedade, em momentos de coronavírus, para que se perceba a invisibilidade das mulheres Trans, desde a ordem de um representante do povo que insiste em fixar o mundo ideal em azul e rosa, até ações desumanas de mulheres Cis que apontam o dedo para as mulheres Trans lhes informando que estão saindo nos dias errado. Isto é, nos dias determinados ao "feminino", pois, para elas os dias das mulheres trans saírem de casa seria nos dias apropriados ao seu destino designado ao nascimento por um genital que, portanto, nos condena (mulheres trans) a sermos eternamente homens.

Percebe-se que a discussão acerca dessa disputa identitária, em que nos deslegitimam algumas mulheres Cis, está para além do direito em dividir um banheiro, pois tal ação, ridícula diga-se de passagem, no mínimo vexatória, deixa explícito o não direito das mulheres trans em ocupar os mesmos espaços das mulheres cis em qualquer que seja o âmbito. Parece-me, numa análise simplista, que para essas mulheres Cis seria uma divisão do tipo "Feminino sagrado" X "Feminino profano", ou no último caso, simplesmente, profano.

Quero imaginar que essas ações não tenham partido de mulheres que têm consciência da luta do feminismo por igualdade, e não por reforço de uma Cultura patriarcal/machista que exclui dos privilégios sociais o plural. Acredito que com tantos segmentos feministas, principalmente o interseccional, que faz uma análise bem mais ampla das opressões, tal comportamento advindo de dessas mulheres cis, no mínimo, necessita ser revisto diante de que sociedade elas estão reproduzindo. Pois, da mesma forma que elas excluem as mulheres trans, também são excluídas por reforçar a ideologia patriarcal, a qual nessa lógica a diminuem diante do poder do macho/homem.

Se o vírus vai mudar a forma da humanidade ver o mundo não sei, penso que mais assertivo é refletir de que mundo estamos falando, ou melhor, quem pode pertencer a esse mundo perfeitinho, desenhado por pessoas com tão medíocre pensamento.

Vejo um imenso fetichismo "nesse novo mundo pós pandemia" bem excludente e reinterativo, a exemplo de outros eventos históricos que já tivemos. Um tipo de modelo que constrói o mundo "dos puros" em detrimento do extermínio de uma 


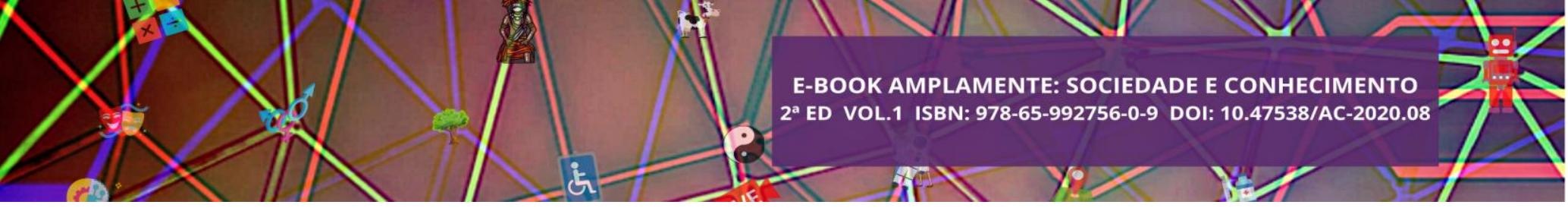

humanidade que, para esse tipo de mente alienada, não está nos parâmetros de serem vistos/lidos/respeitados como humanos. Todavia, aos que veem o mundo de forma plural, e respeitam as diversas existências, nos cabe o grito de indignação diante de ações tão neofascistas e segregacionista direcionadas às (R)existências (trans)humanas.

\section{TEMPOS DIFÍCEIS?}

Nesses dias que passaram, dias muito diferentes da dinâmica social que estamos habituados, me peguei pensando em alguns aspectos da nossa vida em sociedade. Sabe aquele ditado que diz: "às vezes é necessário se afastar para enxergar o óbvio"? Pois bem, esse ditado pode ser útil aqui, ou melhor dizendo, a este momento de isolamento social em virtude do coronavírus. Entretanto, tal análise - ou simplesmente um olhar não pode ser vista sem uma percepção de alguns marcadores que visam perpetuar a verticalização dos humanos dentro de enquadramentos que explicam, mas não justificam, seu lugar de pertencimento. Tal qual uma ordem biológica, os ditames socioculturais também fazem essa separação taxonômica no que tange ao "habitat natural" de ocupação, ou desocupação - por ser negada a oportunidade de se ocupar pelos ocupados dentro do sistema capitalista.

O diálogo é uma das formas de cuidar de quem amamos neste momento e fortalecer a relação. Lembrei-me de uma conversa corriqueira com meu amado companheiro, em que ele ressalta esse aspecto: "existem análises impossíveis de ser compreendidas se não levar em conta os marcadores sociais". Bingo, meu amor! De fato, pensar o social, sem, contudo, refletir suas intersecções de gênero, classe, raça, idade, sexualidade e sistema capitalista, seria paradoxal à compreensão da taxonomia social, a qual anteriormente me referi.

É notório que, neste cenário, violências de todos os tipos, principalmente a violência de gênero, no que tange ao âmbito privado, atingem a mulher e pessoas com qualquer performance que seja interpretada como feminina, tanto para casais lidos e/ou aceitos como normativos (Cisheteronormatividade), quanto para casais que, embora fora dessa bolha ideal, classificados como homoafetivos, reproduzem uma ordem machista e elegível em graus de masculinidade/feminilidade sobrecarregando de tarefas aos que se enquadram neste e não naquele lugar que designa de quem é o poder. Isto é, os que são 


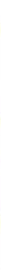

agraciados com privilégios em uma sociedade que reproduz, e, em sua maioria reforça o patriarcal/machismo.

Embora o vírus seja, externamente, democrático, no que concerne aos ideais dessa forma de governo, a cultura da desigualdade continua sua manutenção seletiva tanto no que diz respeito às classes quanto às raças. A falsa solidariedade burguesa, como diria Marx, nunca esteve tanto em moda. Essa nova roupagem que as classes favorecidas adotaram atende pelo nome de empatia, uma forma cínica de cuidados com "o próximo" para que a imunidade de alguns possa estar salvaguardada diante da pandemia. Mas por que essa empatia não existia antes?

Vejo a mídia mostrando praças lotadas de pessoas que, outrora, nem vistas eram, esperando por suas marmitas e sua laranja, pois, o mundo do nada aprendeu a empatia. Será? Conheço muito bem a realidade das ruas, pois, em me identificar como mulher transexual numa sociedade cisnormativa, já tive que vivenciar essa amarga experiência, e nunca vi tamanha empatia com os "desiguais" como presencio em tempos de coronavírus. Porém, o que me preocupa diante desses questionamentos não é o modelo " solidário ", mas o posterior a essa crise causada pela pandemia. Tudo voltará ao seu lugar? Quem se importará com a imunidade dos desvalidos? Será que o descaso, do sistema capitalista, irá se ancorar na prevista crise econômica para justificar sua natureza desigual?

Povo preto e pobre sendo constantemente assolado, massacrado, humilhado, disputando um tal de auxílio emergencial do governo para sobreviver. O racismo e o classismo fazendo suas vítimas para além do vírus, mas não fica bonito noticiar isso, né? Parece até "vitimismo", acusam. O capitalismo fazendo suas vítimas até mesmo entre os subalternos, a exemplo, da cafetina ${ }^{89}$ que mandou matar uma prostituta por ela não estar pagando suas diárias, em sua casa, em virtude da escassez de clientes. Vítimas, portanto, não apenas de um coronavírus, mas de uma estrutura social que no mínimo deve ser repensada.

Penso na pandemia não como uma oportunidade "divina" de repensarmos esse sistema, pois, os que se denominam cristãos, têm oportunidades todos os dias e fazem de conta que não veem. Penso sim, em uma oportunidade de reinventarmos esse mundo, essa estrutura hierarquizadora de seres humanos, cheia de desigualdades sistemáticas,

\footnotetext{
${ }^{89}$ Indivíduo que indiferente de gênero comanda um determinado espaço de prostituição e, por isso, tem que ser paga (o) para, teoricamente, permanecer fazendo a manutenção de segurança dos sujeitos que se prostituem.
} 


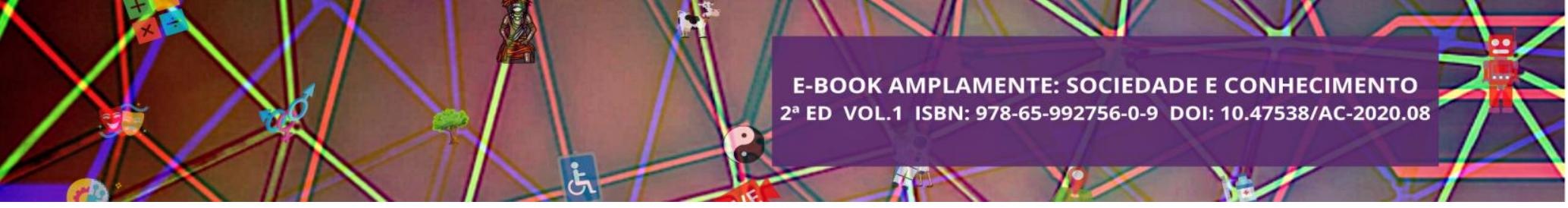

no que tange ao gênero, a classe, a raça ou outros marcadores além dessa tríade, que se intersectam. Qual mundo queremos diante desse comportamento democrático do coronavírus que desnaturaliza a máxima de que as coisas são assim porque são assim?

\section{UMA ANÁLISE CRÍTICA EM UM CENÁRIO DE PANDEMIA: CORONAVÍRUS, INDIVÍDUO TRANS E CIDADANIA NORMATIVA}

Corpos tombados, vencidos pela morte. Pessoas que se transformam em números ou lidas apenas como vítimas, sem identidade, sem humanidade. "Mais uma vítima foi vencida pelo coronavírus", noticiam. Histórias individuais deixadas para trás como se cada uma não importasse, ou somente algumas fossem dignas de serem lembradas ou distintas de um resto não digno de identificação.

Medidas de segurança social associadas a profilaxias são, incansadamente, tomadas dia a dia - haja visto o inimigo ser um patogênico invisível que tem ação rápida e até fatal nos seres humanos. Para isso, é feito um mapeamento do vírus com ajuda da biotecnologia e são pensadas medidas eficazes tanto no que tange ao seu combate (como uma vacina ou um soro), quanto às antropotécnicas sociais que assegurem aos "cidadãos" um menor risco de contágio - preservando-lhes o "nosso" bem maior, a vida.

Porém, sabe-se que não se pode comparar a análise do agente natural com o agente social que transforma ideais políticos em dispositivos de privilégios. Esses, por sua vez, separam, condicionam e determinam os indivíduos conforme sua raça, classe e gênero, por exemplo.

Sabe-se que o conceito de cidadania é histórico e, portanto, atende aos ideais de um determinado tempo e grupo. Entretanto, o que muda nesse conceito não é sua forma ideal, e sim, o conteúdo ideológico de sociedade que estrutura quem são os cidadãos de bem, como problematiza Jaeggi (2008), à sua época.

Por isso, não é somente olhar para história, numa atitude arrogante como propõe alguns "letrados", pressupondo que não a conhecemos. Mas é, antes de tudo, entender a singularidade histórica da formação social do seu País, no caso o Brasil, para entender a quem satisfaz a cidadania. Pois, ao deslocarmos o olhar homogeneizador da história, característico das relações de dominação a partir de quem conta essa história, diversificamos a análise.

Afinal de contas, nossa realidade sociocultural e histórica não é nenhum conto de fadas como nós mesmos sabemos. É, antes de tudo, um reforço do tipo ideal de 


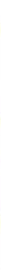

cidadãos que são "naturalmente" dignos de direitos. Essa tal cidadania democrática atende por uma identidade de gênero - somente cisgênero ${ }^{90}$, uma raça, uma classe dentre outros marcadores de privilégio e/ou opressão.

Nossa constituição de 1988, por exemplo, é composta por inúmeros direitos pensados como democráticos liberais para uma maior igualdade entre seus cidadãos. Todavia, nossa Carta Magna não tem uma sequência genética que se possa mapear a fim de sanar as destruições à vida humana que são causadas por uma estrutura sistêmica excludente. Dessa maneira, o homem, o racional, o imbatível por sua capacidade de pensar, construiu e constrói ideais em cima dos conceitos que possam assegurar seus privilégios.

A partir dessa consciência é que se pode pensar a quais interesses servem a cidadania hoje. É mister não se deixar enganar pelas exceções que, com muito esforço, alcançam um patamar de cidadania digna. O foco deve estar na regra geral do jogo que forja uma igualdade cínica, com relação aos conceitos, sem, contudo, ampliar a possibilidade de a exceção ser regra geral como assegura a Constituição, teoricamente. O olhar deslocado, por assim dizer, é emancipador àquele indivíduo que se pretende transformador dessa unilateralidade estrutural que está posta em nossa sociedade.

Nessa perspectiva, o vírus, e sua devastação na humanidade, não pode ser pensado isoladamente com suas biotecnologias de cura, sem, contudo, refletirmos os direitos individuais e sociais que são negados, historicamente, aos cidadãos acessarem, igualmente, por serem discriminados como não normativos. Nesse sentido, existe Cidadão vs cidadão, pautando a vida humana a um moralismo hierarquizador, causando um sofrimento ético-político que exclui os sujeitos "desiguais" de ter acesso ao direito fundamental, à vida.

Ressalto que esse texto não pretende fixar-se nas exceções de inclusões dos cidadãos que, outrora, moralmente, eram lidos como marginais, mas que com sua luta transformaram suas realidades em acessos eticamente construídos. Não que os mesmos não sejam de extrema necessidade - apesar de outras problemáticas que circundam essas exceções de inclusões -, mas por uma urgência de fala que há muito tempo me interpela, em discursos perversos repletos de ideais excludentes - os quais se pretendem inocentes - deferidos por Cidadãos com privilégios, que invisibilizam a minha condição de

90 Pessoas que foram designadas ao nascer como menino ou menina, através de seus genitais, e se identificaram com o formato binário, mulher/vagina e homem/pênis. 


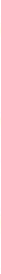

(R)existência em sociedade. Portanto, falarei de um lugar de sofrimento ético-político (SAWAIA, 1999), reitero, que disputa consciências no que concerne aos direitos das pessoas Trans ${ }^{91 .}$

Todo quadro de guerra supracitado causado pelo vírus como: iminência de morte, incerteza no amanhã, isolamento social, medo, desemprego, fome, descaso da saúde, etc, as pessoas trans já conhecem. A diferença é que, para além do vírus, o social também é em sua maioria nosso exterminador. Tal extermínio é percebido em ações violentas e dizimadoras de nossos corpos ao ceifarem nossas vidas, o que nos torna o país que mais mata pessoas trans no mundo. Ademais, em proporções estaduais, o Ceará é segundo do ranking em assassinatos de pessoas trans, perdendo apenas para São Paulo (ANTRA, 2019).

Nesse cenário (CIS)têmico, acumulamos não somente as estratégias perversas de exclusão (raça, classe, idade...), que outros cidadãos comuns acumulariam, mas acima de tudo somos corpos destinados a uma necropolítica (MBEMBE, 2011). Além disso, temos nossas vidas rodeadas por deslegitimações. A exemplo do sofrimento vexatório que muitas trans são acometidas, ao serem desfiguradas dos seus corpos, por suas famílias, e enterradas de paletó e gravata em nome de uma moral religiosa que ignora o direito de existirmos enquanto identidade feminina até na morte.

Outro dado alarmante é o da inexistência dos assassinatos de pessoas trans nos levantamentos oficiais, havendo, pois, subnotificação. O IBGE, por exemplo, trabalha apenas com a variável Sexo. Então, quando somos notificadas pelo senso de assassinatos o que será levado em consideração é um genital que se perpetua como determinante em nossa existência, apagando nossa história através da compulsão binária como única forma de se existir no mundo.

Embora tenha que reconhecer que alguns degraus, nessa curva de desigualdades, já foram galgados, ainda é incipiente sua eficácia como, por exemplo, o provimento de lei $73^{92,}$ de junho de 2018 (cuja função é retificação do prenome e sexo de pessoas trans, indiferentemente, de laudos ou cirurgias, conferindo uma conquista cidadã em um processo histórico de negação da nossa existência), o qual posso afirmar não ser eficiente, visto que sua eficácia não é abrangente o suficiente para impedir novas exposições ao nome antigo, identidade incompatível e provocadora de constrangimento.

\footnotetext{
${ }^{91}$ Neste texto usarei o prefixo trans para abarcar as identidades travestis e transexuais, especificamente. 92https://www.anoregsp.org.br/noticias/32433/provimento-n-73-do-cnj-regulamenta-a-alteracao-de-nome-e-sexo-noregistro-civil
} 


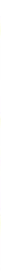

Ou seja, a lei não nos abarca em sua complexidade. Tenho inúmeros exemplos práticos individuais, já que falo de um lugar, que comprovam minha denúncia - porque esse é outro tipo de violência que também sofremos: temos, a todo instante, que dar sentido ao que falamos, empírica e racionalmente, para provarmos que somos capazes de concluir um raciocínio - mas me deterei no mais recente.

No dia 17/06/2019, fui contemplada pelo provimento 73 e tive o prenome e o sexo retificados. Com a certidão de nascimento em mãos dei entrada nos outros documentos para retificá-los (CPF, RG, Título, CTPS), dando fim a essa saga em 27 de dezembro.

Em julho de 2019, recebi minha carteira de estudante que, anteriormente, vinha com o nome social, garantido por uma resolução da Universidade Federal do Ceará UFC, e fui surpreendida com o prenome masculino, mesmo nos anos anteriores ter usufruído da política do nome social, e já haver retificado o prenome um mês antes. Mas quando procurei os órgãos responsáveis pelo vexame (EAEB [Entidade Estudantil de Apoio aos Estudantes do Brasil]) e ETUFOR [Empresa de Transporte Urbano de Fortaleza]), eles ficaram jogando o problema um para o outro.

Em virtude dos "meus privilégios", isto é, por não ser uma pessoa vista por eles como "leiga", e depois de eu zanzar bastante, de um lado para o outro, na intenção de resolver o infortúnio que eles me causaram, obtive o resultado da minha jornada em um dia. Pronto, a carteira de estudante com o prenome o qual eu conquistei e condizente a minha identidade estava disponível. Problema resolvido, né? NÃO!!! Este ano, por estar cursando o mestrado, na mesma Instituição, tive que solicitar o documento estudantil como qualquer outra cidadã de direitos, pressupõe-se. Pois pasmem, após um ano e com todos documentos retificados, me surpreendo novamente ao preencher, via internet por causa da pandemia, o meu número da CIA, pois, veio o nome anterior (masculino).

É uma sensação de impotência tão grande, por estar diante de mais um constrangimento. Deixo claro que com 41 anos a problemática não é mais nem a negação desumana da minha identidade, pois essa também é histórica e eu não fui a primeira nem serei a última a passar por esse desprazer. Porém, o que me incomoda é que se trata de um "direito adquirido", um marco histórico às (R)existências trans. Igualmente reforço que meu exemplo só destaca um tipo de sofrimento causado às trans com nome retificado. Pois, me deter a minúcias dessas outras humilhações sofridas por 


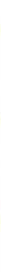

trans que não tem seu nome retificado ou que não possuem o marcador passabilidade, que as higienize, seria um outro texto.

Mas para que apenas possa se ter uma veracidade das subnotificações de nossa existência, que outrora falei, basta ligar os noticiários. Quantas pessoas trans mortas pela Covid-19 foram noticiadas na mídia? Então, não morreram trans na pandemia, ou esses corpos estão sendo notificados pelo critério de seus genitais?

Impactada pelos sentimentos que me atravessava naquele momento, recorri a alguns grupos de Whatsapp no intuito de me ajudarem diante daquele descaso. Algumas pessoas que se solidarizaram me indicaram a tentar entrar no site via CPF. Essa tentativa me da o nome ratificado, mas apaga todo meu histórico estudantil, o que não é condizente com as regras do provimento 73 , haja visto, as retificações feitas serem apenas em dois âmbitos: prenome e sexo. Dessa forma, os números dos meus documentos permanecem os mesmos, inclusive o da CIA.

Nessa opção é como se eu nunca tivesse carteira de estudante. Ou seja, ao invés da ETUFOR modificar o meu cadastro original, como propõe o provimento 73, eles mantêm e sugerem uma espécie de recomeço como se eu fosse uma outra pessoa, como se todos os meus documentos tivessem iniciado do zero. Lembrei-me tristemente da história de mudança de nome do homem trans, João Nery ${ }^{93}$. Ele perdeu todo seu passado para se tornar, legalmente, homem na sua documentação, na década de setenta, com as leis rígidas daquele período histórico.

Quanto despreparo, quanto atraso. Por que as instituições não seguem o que está proposto, legalmente, no provimento 73 , sem tentar inventar ideias constrangedoras como se estivessem nos prestando um favor?

Todo esse desgaste referente a política pública de retificação de prenome e sexo, para mim, só revela uma política não pensada em sua totalidade, pois um direito que lhe expõe, lhe humilha e deixa danos irreparáveis a sua existência não pode ser chamado de direito. Como disse, parece que estamos pedindo um favor a todo instante. Diante de toda tecnologia que vivemos, o provimento 73 não ser um "direito", diretamente, articulado com as instituições por meio de seus CIStemas institucionais? No mínimo perverso.

Somos invisibilizadas a todo instante seja num âmbito mais macro, como no micro, basta prestar atenção nos discursos, por exemplo, nas lives que ocorrem nesse

\footnotetext{
${ }^{93}$ Ver o livro, Viagem solitária, de João Nery.
} 


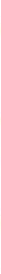

período de pandemia, em que estão a frente intelectuais, que compõem a área das humanas, discutindo desigualdades, marcadores sociais diante da crise sanitária. Eles falam de opressões no campo da raça, sexualidade, classe social, idade, mas quando o assunto é gênero sequer somos citadas na arena da discussão.

Desconhecimento no assunto? Discurso perverso de exclusão? Não sei. Ou melhor dizendo, desconfio. O locus acadêmico é quase que exclusivamente CIS, dessa forma, quando somos citadas, sutilmente, somos empurradas para uma categoria que não abarca nossa identidade, somos mencionadas no rol de orientações sexuais como se só existisse a possibilidade de gênero normativo cis.

Reproduzem, assim, em boa parte o discurso hegemônico de mulher/vagina e homem/pênis, embora muitos, hipocritamente, dizem ser abertos à pluralidade. Esse tipo de ação segregatória, que se pretende a única forma de se representar a questão de gênero essencialista, é campo de concentração simbólico meus caros! Ou seja, é sutilmente aprisionar as pessoas trans por sua infração de ousar dizer que existem para além desse modelo de gênero universal que é determinado por um genital.

É negar, portanto, a possibilidade de pertencimento à categoria de gênero aos sujeitos trans. Sendo assim, não levam em consideração teorias socioculturais que afirmam ser a identidade de gênero uma construção sociocultural e, portanto, plural, composta pelas práticas sociais que significamos a partir de performances masculinas ou femininas, em se tratando de binário.

Partindo dessa premissa somos mulheres pela nossa prática social que performamos, igualmente, a vocês mulheres Cis. Ou alguém anda com seus genitais de fora para determinar quem é homem ou mulher nessa forma simplista de essencializar os corpos? A expressão de gênero é complexa se pensarmos não como mentes colonizadas por um projeto eurocêntrico e etnocêntrico no sentido de Cultura(S).

Sei, também, que essas disputas são trincheiras políticas e que existe, por assim dizer, um latifúndio em que cada opressão, simbolicamente, ocupa um espaço por igualdade. Todavia, não se pode fazer uma análise, a partir dessa analogia, sem levar em consideração que as disputas nessas trincheiras não são homogêneas, não possuem os mesmos pontos de partida em busca dessa igualdade, e nem tão pouco um quantitativo político significativo para chegar nessa disputa, se não pensarmos a ideia de equidade. Basta olhar para a Universidade e ver quantas pessoas trans estão lá em algum nível de aprendizagem, graduação ou pós-graduação. 


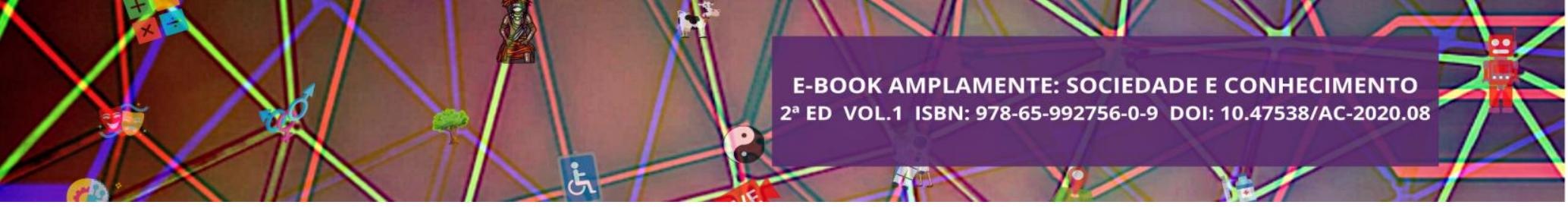

Será que esse latifúndio de disputa política, citado por algumas feministas cis, explica a contradição desses segmentos lutar por igualdade e em seus discursos nos deslegitimar e nos invisibilizar enquanto categoria de gênero? Seria, então, uma busca por igualdade reproduzindo a desigualdade e sem levar em consideração a equidade? Sentir na pele o isolamento, o medo iminente da morte é simplesmente humano, no que concerne a um patogênico invisível.

Contudo, também, é um momento, mais que oportuno, para se pensar outras dimensões que oprimem os indivíduos, no contexto sociocultural, e da mesma maneira letais nos seus significados de não possibilidade. Pois, a meu ver, as Ciências Humanas devem ser um dispositivo de revelação dos fenômenos - com métodos e epistemologias contrahegemônicas - que transformem e emancipem os sujeitos em relação às opressões de desigualdades vigentes em nossa sociedade. Marcadores sociais são para ser problematizados e não fetichizados. Espaços igualitários de disputas têm que ser plurais, equânimes e horizontais, e não apenas um âmbito de reprodução Cistêmica que atende a uma minoria privilegiada.

Penso ser necessário, tendo em vista este momento político de desmonte, os "cientistas" das humanas começarem a colocar em prática suas teorias de empatia, igualdade, equidade etc. Pois, a religião já observou essa dinâmica social e cooptou a ideia com intuito de fortalecer seu espaço político no latifúndio das disputas. Nesse sentido é racional pensar: que sociedade queremos politicamente? Nessa perspectiva questiono: De que Cidadania estamos falando? de que Estado democrático estamos falando? A quem servem esses dispositivos?

\section{REFERÊNCIAS}

ANTRA. Dossiê dos assassinatos e da violência contra travestis e transexuais brasileiras em 2019 / Bruna G. Benevides, Sayonara Naider Bonfim Nogueira (Orgs). - São Paulo: Expressão Popular, ANTRA, IBTE, 2020. 80p.

JAEGGI, R. Repensando a ideologia. Civitas: 2008, 8(1),137-165. DOI: http://dx.doi.org/10.15448/1984-7289.2008.1.4326.

MBEMBE, A. Necropolítica. N-1 Ediçoes, 2011.

SAWAIA, B. As artimanhas da exclusão. Petrópolis: Vozes, 1999. 


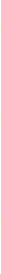

modo que este interaja com as novas informações, e juntos possam dar significado e aplicação ao novo assunto estudado.

Sendo assim, faz-se necessário relacionar a informação nova com o que se observa no contexto em que se vive; bem como, com o que se aprendeu anteriormente. Com esta finalidade é fundamental interagir com o meio e com outros sujeitos de modo a gerar problemas a serem solucionados e/ou entendimentos a serem negociados que remetam o aprendiz a refletir sobre suas próprias ideias e assim potencializar a aprendizagem significativa dos conceitos e suas aplicações.

Na visão de Ausubel et al (apud MOREIRA, 2006), o conhecimento préexistente na estrutura cognitiva pertinente ao se relacionar ao novo conhecimento é chamado de subsunçor, podendo este ter sido assimilado em espaços formais ou não de aprendizagem. Assim, é essencial o papel do professor como mediador entre o novo conhecimento e os aprendizes, orientando e motivando o aprendizado, promovendo nestes uma reflexão sobre o conhecimento formal a ser construído (DE PAULA; BIDA, 2008).

Esta motivação pode ser promovida por meio do uso de métodos de ensino, que permitam o engajamento dos estudantes na ação de aprender, como por exemplo, o uso de metodologias ativas, que permitam ao docente gerar situações que instiguem os alunos a serem proativos na construção do seu conhecimento (SANGUINETO, 2017). Neri de Souza e Bezerra (2013) descrevem que aprender ativamente exige iniciativa e o desenvolvimento de habilidades, que favoreçam a aprendizagem significativa.

A partir deste contexto, foi proposto um concurso de fotografias com o objetivo de contribuir para a aprendizagem significativa dos alunos na construção do entendimento do conceito de ciências e suas especificidades. Para isso objetivou-se que os alunos desenvolvessem e aplicassem o conhecimento de ciências em seu contexto diário; bem como, percebessem de que forma estes saberes estão presentes no seu cotidiano. A ação foi dividida em 3 etapas, a saber: Identificação dos conhecimentos prévios; Realização do concurso com a exposição das fotografias onde os estudantes deveriam fotografar o que entenderam como ciências em seu cotidiano, refletindo o conhecimento em construção como reflexo da ação proposta; e Complementar à construção do conhecimento a partir da reflexão acerca das suas escolhas e a dos seus colegas. Na última etapa os alunos deveriam mostrar as evoluções do que aprenderam e demonstrar o significado do que foi construído, possibilitando a organização mental e a 


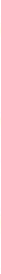

significação de suas escolhas bem como a inferência de uma aprendizagem significativa.

Considerando que os processos para a aprendizagem são diferentes para cada grupo e para cada aluno, traçou-se como objetivo comum fotografar cenas que remetessem, segundo seus entendimentos, a ideia de Ciências e suas diversas aplicações.

Com base nestas informações, traçou-se como objetivo de aprendizagem, a construção significativa do conceito de ciências básica e ciências aplicadas; refletindo suas especificidades. O foco da análise foi identificar traços de aprendizagem significativa acerca do conceito de ciências e suas especificidades. Foram analisadas as relações entre o conhecimento científico e o contexto social, as definições acadêmicas e o que se aprende em ambientes externos à escola, potencializando a ampliação dos seus entendimentos prévios a partir da reflexão sobre as relações entre os conhecimentos prévios e as novas informações.

\section{REFERENCIAL TEÓRICO}

O uso de metodologias ativas no ensino de ciência pode promover o envolvimento do aluno na construção do conhecimento de forma significativa. Neri de Souza e Bezerra (2013) corroboram com este pensamento, pois, na visão destes autores, o uso desses métodos exige maior envolvimento por parte dos estudantes, bem como, possibilita o desenvolvimento da autonomia dos estudantes elevando-os a agentes principais da aprendizagem. É importante ressaltar que segundo a Teoria da Aprendizagem Significativa a construção significativa do conhecimento é um processo idiossincrático e que, portanto, só ocorre mediante o interesse do aprendiz em tornar o que é ensinado significativo para si e, ainda, que o conhecimento é aprendido de forma substantiva a partir do que o aprendiz já conhece (MOREIRA, 2006).

Nestes moldes, entende-se a urgência em ampliar o uso de metodologias ativas com o objetivo de promover aprendizagem significativa (ou em potencializar isto), pois desta forma, a educação formal estará cumprindo de forma eficaz seu papel transformador da sociedade.

Com isso, compreender a aprendizagem significativa como uma forma de engajar o estudante em todo o processo anterior e posterior à construção do 


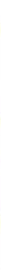

conhecimento, favorece a promoção de significado ao que se aprende. É importante ressaltar que durante o processo de construção de significados leva-se em consideração o conhecimento prévio, as informações cotidianas, a nova informação e suas relações com o objeto de estudo relacionado ao aluno, que podem contribuir para a aprendizagem (AUSUBEL et al, apud MOREIRA, 2006).

É fundamental na proposição de uma abordagem voltada a fomentar a aprendizagem significativa levar em consideração as diferentes relações entre os atores e os processos, pois segundo Novak (1977, 1981 apud MOREIRA, 2006) vê-se que o conhecimento é construído quando ocorrem à relação entre aprendizes, professores, conhecimentos, contextos e avaliações. Ou seja, devem-se apresentar formas e reflexões que levem a aprendizagem, e potencializem seus significados, de modo a favorecer a inter-relação de contextos do que se aprende com a história do aluno considerando suas vivências, percepções e posicionamentos (NOVAK apud MOREIRA, 2006).

Sobre isso Moreira (2005) ao tratar a aprendizagem significativa crítica pontua como um dos seus princípios o "do aprendiz como perceptor/representador", quando ressalta o papel do aprendiz como um preceptor do mundo que o cerca e de suas experiências. Sobre isso afirma que:

O perceptor decide como representar em sua mente um objeto ou um estado de coisas do mundo e toma essa decisão baseado naquilo que sua experiência passada (i.e., percepções anteriores) sugere que irá "funcionar" para ele. (MOREIRA, 2005 p. 10)

Outro princípio pertinente trazido por Moreira (2005) é o "Da diversidade de materiais instrucionais", quando coaduna com a ideia de Postman e Weingartner, estes pontuam o equívoco de muitos docentes em depender do livro didático como único material instrucional. Eles atribuem este entendimento equivocado a compreensão de que as informações trazidas pelo livro didático são verdades indiscutíveis, e que o aluno deve se apropriar destas sem questionamento. Em contraposição a essa ideia, a aprendizagem significativa crítica traz a necessidade de descompactar o conhecimento organizado nos livros didáticos e em outros materiais instrucionais, por meio de ações que estimulem o aluno a pensar sobre: “Qual o conhecimento envolvido? Que métodos foram utilizados e por quê? Quais os resultados e as interpretações possíveis? Em que isso implica na compreensão do fenômeno?”. A partir destes questionamentos, pode-se inferir que o aluno deve assumir uma postura ativa durante o processo de aprendizagem. 


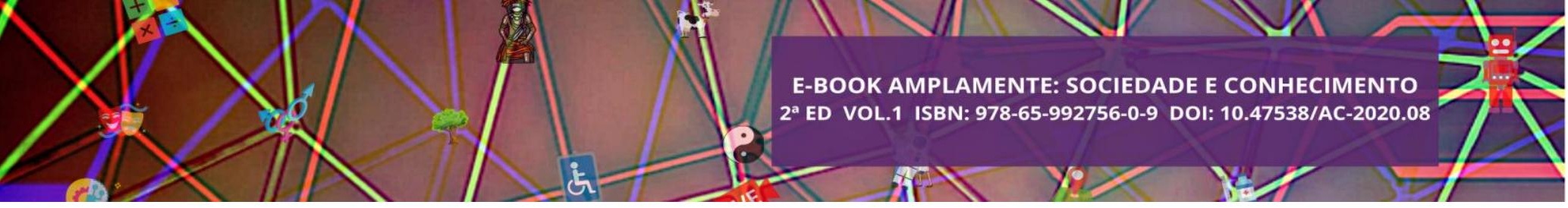

A participação ativa do estudante favorecida por uma abordagem de ensino centralizada no aluno é, segundo Moreira (2006), fundamental para possibilitar uma aprendizagem significativa. Para isso ressalta-se a importância do uso de distintas estratégias que, diferentemente das abordagens tradicionais, instiguem o aluno a questionar o conhecimento a ser aprendido e as suas próprias ideias. Deste modo, propiciando oportunidades para que os alunos se posicionem, atribuam significados, interajam dialogicamente com o professor e com os colegas, levando-os a construírem o conhecimento. Diante deste cenário, é importante ressaltar que o conhecimento sobre ciência deve ser difundido a fim de que os estudantes possam se posicionar criticamente em relação à ciência, a pesquisa e ao desenvolvimento científico.

\section{METODOLOGIA}

A metodologia utilizada foi dividida em 3 etapas: Identificar os conhecimentos prévios; Realizar concurso de fotografias e Significar as escolhas e refletir sobre possíveis relações. Esta metodologia foi aplicada em 3 turmas do $9^{\circ}$ ano do ensino fundamental II, de uma escola particular da cidade de Caruaru, com um total de 92 alunos.

\section{ETAPA 1 - CONHECIMENTOS PRÉVIOS}

Nesta etapa, apresentou-se aos estudantes textos científicos e populares, em forma de reportagens e artigos de opinião. Em seguida, pediu-se aos estudantes, que individualmente escolhessem um texto representasse ciência básica e outro ciência aplicada, e a partir destes construíssem o conceito de ciências básica/aplicada. Os grupos foram selecionados previamente e divididos em ordem alfabética com no máximo 5 integrantes, compondo um total de 21 grupos. Após esta divisão, foi proposto aos alunos que em grupo, discutissem os conceitos apresentados nos textos, e construíssem um conceito para cada proposição.

\section{ETAPA 2 - CONCURSO DE FOTOGRAFIA}




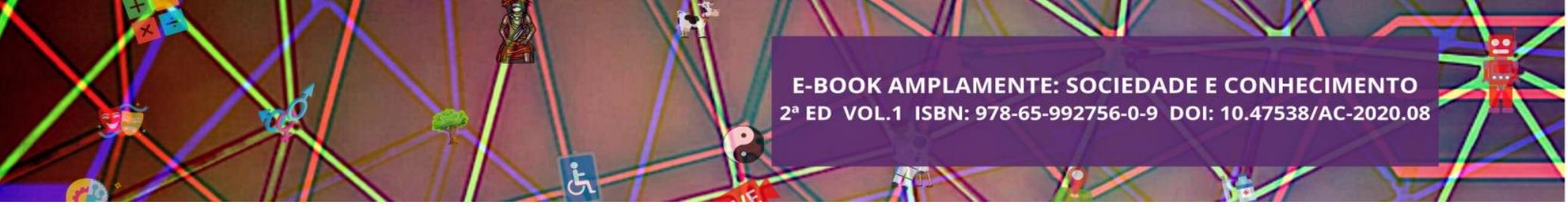

Foi solicitado que os estudantes fotografassem em seu cotidiano situações que lhes remetesse aos conceitos de ciência básica/ciência aplicada, e que elaborassem os conceitos destas por grupo. Para esta etapa foi dado um prazo de 15 dias consecutivos.

As fotografias foram avaliadas por um júri composto por 4 docentes e 1 fotógrafa, a partir da apresentação de cada grupo, utilizando critérios que foram sistematizados em um questionário tipo Likert.

\section{ETAPA 3 - SIGNIFICAÇÃO DAS ESCOLHAS E REFLEX̃̃O SOBRE AS RELAÇÕES}

No fechamento da atividade solicitou-se que os alunos em grupo discutissem e expusessem suas concepções (prévias e posteriores a ação) sobre o que foi proposto, a discussão dos textos, das fotografias e do que seria a ciência básica e a ciência aplicada, e em seguida, por escrito, conceituassem Ciências básica/Ciência aplicada segundo seus entendimentos, e pontuassem possíveis diferenciações no uso do conceito. As falas foram analisadas a partir da análise de conteúdo na perspectiva de Bardin e as unidades de sentido decorrentes foram comparadas com os entendimentos prévios dos alunos.

\section{AVALIAÇÕES}

$\mathrm{Na}$ avaliação buscou-se entender como aconteceu a evolução dos conceitos propostos e suas aplicações, a partir das relações colocadas pelos estudantes e seus contextos, analisando-se o conteúdo, as falas e as relações entre o que se conhece e as fotos.

Na primeira etapa, a avaliação foi feita analisando o conteúdo das escolhas dos estudantes em relação aos textos, e também, a construção dos conceitos iniciais a respeito do tema sugerido. $\mathrm{Na}$ segunda etapa, os avaliadores tentaram significar as escolhas dos alunos a partir de critérios organizados na forma de um questionário, baseado na escala de Likert et al (1993), com 9 perguntas descritas no quadro 1. 


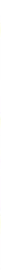

\section{ETAPA 1 - CONHECIMENTOS PRÉVIOS}

Sobre como os alunos entendiam as diferenças na definição entre Ciência básica e Ciência aplicada, e como os alunos aplicam estes entendimentos na exemplificação e na explicação das aplicações da ciência. Analisando os pré-questionários, observou-se que $18,47 \%$ dos alunos souberam responder e contextualizar o que era Ciência básica, enquanto $21,74 \%$ conseguiram explicar e aplicar o conhecimento do que seria Ciência aplicada.

Observou-se que os alunos que conheciam as diferenças e as aplicações dos conceitos em diferentes contextos, conseguindo demonstrar que a ciência básica está relacionada ao seu cotidiano, principalmente com suas aplicações nas tecnologias.

Os alunos ao se referirem as ciências aplicadas, pontuaram que esta pode colocada em prática de modo mais específico, podendo ser utilizada, por exemplo, na qualidade dos alimentos e seu tempo de conservação, uma vez que tal conhecimento depende da aplicação de conhecimentos químicos, que é uma das áreas das ciências, o que ficou evidente na fala a seguir:

A1: 'A ciência está presente no meu celular, que uso pra mexer na internet, em alguns lugares, a rede é melhor, porque tem mais satélites por perto'.

De acordo com a fala verifica-se que alguns alunos não foram capazes de diferenciar as especificidades da Ciência tomando-a como algo único e restrito:

A2: 'A diferença entre as aplicações do conhecimento de ciência básica e de ciências aplicadas se dá em quando se estuda isto, antes estudávamos ciências como um todo. Hoje estudamos ciências de forma dividida (Química, Física e Biologia)'. (Com grifo dos autores).

$\mathrm{Na}$ fala de A2, observou-se que estudantes tentaram visualizar diferença entre os dois conceitos, embora nem sempre, estes estivessem coerentes com o pensamento científico. Tendo como base o resultado inicial, percebeu-se a importância do conhecimento prévio dos alunos, visto que, conforme Ausubel (1978, apud MOREIRA 2006) este seria se pudéssemos isolar, a variável mais importante na construção do conhecimento e da aprendizagem de forma crítica e reflexiva.

\section{ETAPA 2 - CONCURSO DE FOTOGRAFIA}




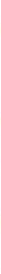

Nesta etapa, foi realizado o concurso de fotografias, onde os grupos expuseram suas fotos e falas, como forma de apresentar os conceitos de Ciência básica e Ciências aplicadas. Cada dupla de avaliador recebeu um questionário por grupo, para avaliar os 16 grupos (144 questionários).

A partir das avaliações, construiu-se o Gráfico 1, que permitiu identificar o grau de concordância/discordância de cada bloco de questionamento (Quadro 1).

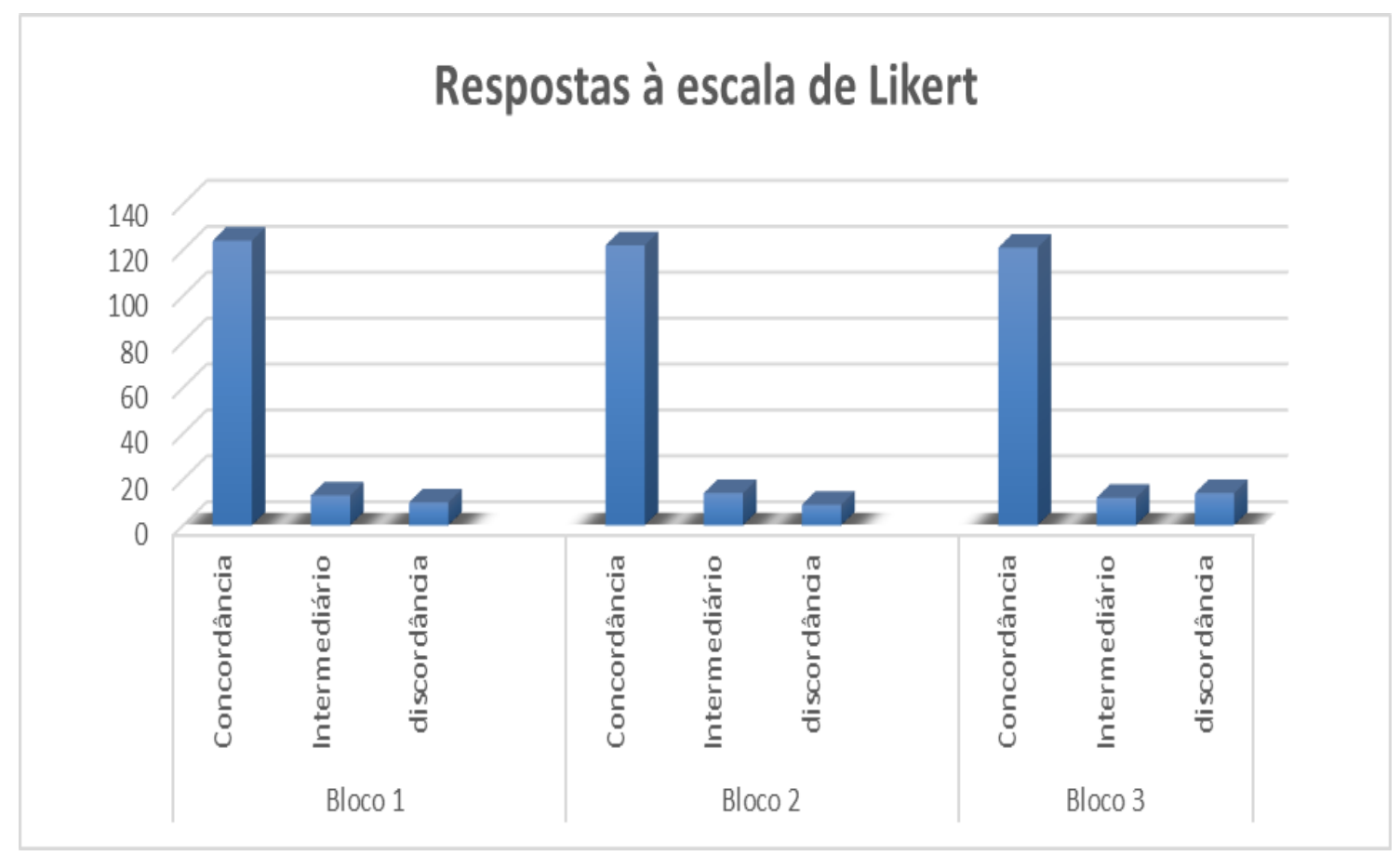

Gráfico 1. Respostas à Escala de Likert pelos avaliadores, de acordo com as apresentações.

Analisando o gráfico 1, observa-se que para o bloco 1 (O que se entende do conceito), 84,4\% das respostas concordam com as propostas das aplicações faladas pelos alunos e apresentadas nas fotografias, enquanto 6,8\% discordaram sobre tal proposta e 8,8\% não souberam responder. Estes resultados indicam uma evolução expressiva diante dos resultados apresentados na Etapa 1, que nos permite inferir que o envolvimento ativo dos estudantes na produção das fotografias e na construção dos conceitos, proporcionou maior eficácia na construção potencialmente significativa de tais conhecimentos.

Tal resultado sugere que para o aluno, torna-se mais fácil representar seu entendimento de ciências a partir de imagens (no caso fotografias) do que por palavras o que revela que a conceituação equivocada apresentada na etapa anterior pode não estar relacionada ao desconhecimento do que é ciências, mas apenas na dificuldade de 


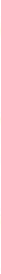

organizar seus entendimentos na forma de palavras. Este resultado pode ser muito útil em uma abordagem didática, pois caberia ao professor fazê-los refletir sobre as imagens selecionadas e a partir daí retratar seu entendimento na forma de palavras.

Para o bloco 2 (relação entre as fotos e os conceitos), 83\% das respostas concordavam com as aplicações faladas pelos alunos e apresentadas nas fotografias, enquanto 7,5\% discordaram e 9,5\% não souberam opinar. Estes resultados corroboram com a evolução da busca por melhores definições Ciência básica/Ciência aplicada, contribuindo assim para a construção de um significado coerente destes conceitos e de uma maior compreensão da evolução do que foi construído a partir do conhecimento prévio, sendo este o suporte para as novas informações.

No bloco 3 (qualidade das fotografias), esta análise foi importante para que fosse identificado como os estudantes conduziam suas apresentações, já que as fotografias eram analisadas antes das falas. Identificar a qualidade das imagens foi fundamental para iniciar a compreensão da forma como os alunos desenvolveram seus conhecimentos, $82,3 \%$ das respostas concordam com as aplicações faladas pelos alunos e apresentadas nas fotografias, enquanto $9,5 \%$ discordam e $8,2 \%$ não souberam responder.

Analisando os resultados, percebeu-se que os participantes ampliaram seus conhecimentos prévios, a partir da consolidação das novas informações, que foram aplicados em contextos específicos. Por exemplo, identificou-se que durante as discussões iniciais os alunos não notavam tanta diferença entre as aplicações de ciência básica e de ciência aplicada, entretanto nesta etapa eles conseguiam trazer justificativas que mostraram ramos específicos de ciência e a multiplicidade das ciências. Como vê-se na fala:

A3: 'em ciência vemos a química e a fisica, já nas ciências (aplicadas) vemos que precisamos de química e de física pra comer, feito no chocolate, precisa de uma temperatura certa pra fazer ele, $e$ pra comer também'.

A diferença que se observou nesta etapa se dá em decorrência da diferença percebida por eles entre o conceito de Ciência básica/Ciência aplicada, que percebem a ciência básica enquanto ramo de estudo, e as ciência aplicada enquanto relações entre estes ramos de estudo e o cotidiano, o que lhes permitiu aplicar esse novo conhecimento em novos contextos. 


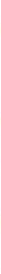

Diante deste resultado, percebeu-se que os estudantes conseguiram ampliar e construir conhecimentos e aplicá-los em diversos meios. Foi observado nas apresentações, que havia cenários de fotos montados com o intuito de apresentar a sua visão, até fotos espontâneas que consideravam os lugares comuns. Deste modo, percebeu-se assim como afirma Moreira (2006), que é fundamental para que a aprendizagem seja significativa, que o aprendiz tenha a capacidade de aplicar o que aprende em contextos variados desde seu cotidiano escolar até o extraescolar, conforme observado na apresentação do concurso de fotografia.

\section{ETAPA 3 - SIGNIFICAÇÃO DAS ESCOLHAS E REFLEX̃̃O SOBRE AS RELAÇÕES}

Nesta etapa, o professor, enquanto mediador sugeriu durante o debate, pontos para análise e discussão, onde cada estudante expôs sua opinião e argumentou e justificou suas escolhas, refletindo assim sobre as possíveis relações entre a ciência e as cenas escolhidas para serem fotografadas. Como se vê na fala de um dos estudantes:

A4: 'A ciência produz todo o conhecimento estudado, então não é possivel entender o mundo sem entender de ciência'.

Esta fala começa a retratar a evolução dos conceitos bem como as posteriores aplicações deles, já que mostra como o estudante passou a entender a ciência após a aplicação da metodologia, algo não se observava antes da mesma. De modo que, enquanto os estudantes conseguiam retratar suas visões, eles também eram capazes de reforçar seus pontos de vista, reconstruindo suas ideias iniciais, progredindo a implicações mais amplas e em diversos contextos. Ao analisarmos a evolução do entendimento de que as ciências estudadas como disciplinas específicas são diferentes, porém associáveis, aplicadas para fins tecnológicos e industriais é possível inferir aos alunos o início de um processo de diferenciação progressiva de como eles percebem o conceito de ciências.

Passado um mês do início da atividade, foi feito a retomada dos conhecimentos construídos, de forma que os estudantes pudessem revisitar o conhecimento trabalhado, aplicando-o de modo a demonstrar que o que foi construído foi, de fato, significativo.

Durante esta atividade, 68,5\% dos alunos conseguiram definir e aplicar em diferentes contextos o que aprenderam sobre ciência básica, enquanto 58,7\% conseguiram fazer o mesmo sobre ciência aplicada. Com estes resultados, pode-se 


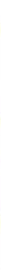

perceber uma evolução considerável dos resultados da etapa 1 (sobre os conhecimentos prévios), conforme se observa na fala do estudante A2, em um comparativo entre a etapa 1 e 3:

A2: 'A ciência (básica) é aquilo que a gente estuda, mas também, por exemplo, produz a tecnologia para fazer o avião, a ciência (aplicada) faz o avião voar'.

A partir dos dados analisados pode-se perceber que os estudantes apresentaram uma evolução potencialmente significativa, pois conseguiram desenvolver seus conceitos, e aplicá-los em diversos contextos. Conforme descrito por De Paula e Bida (2008), esta aprendizagem corrobora para o crescimento da compreensão do que se conhece, pois esta proporciona a ampliação destes conceitos em diferentes situações.

\section{CONSIDERAÇÕES FINAIS}

Conclui-se, portanto que a presente metodologia se caracteriza como ativa, pois observou-se o envolvimento ativo eficiente, reflexivo e contínuo dos alunos na construção do conhecimento.

Pode-se inferir também, que o processo de construção do conhecimento com o uso desta metodologia ativa gerou uma aprendizagem significativa, visto que, os estudantes conseguiram aplicar o conhecimento em diferentes contextos, chegando inclusive a extrapolar o ambiente da sala de aula, bem como resignificar seus conhecimentos prévios.

Sendo assim, conclui-se que a metodologia aplicada neste contexto escolar foi eficaz na produção de conhecimento significativo, visto que esta favoreceu a participação ativa dos estudantes nas atividades propostas após esta atividade pelo docente.

\section{REFERÊNCIAS}

DE PAULA, G. M. C., BIDA, G. L., A importância da aprendizagem significativa, Curitiba: Secretaria de educação do estado, 2008. Disponível em: http://www.diaadiaeducacao.pr.gov.br/portals/pde/arquivos/1779-8.pdf, acesso em: 17 de março de 2018 às $16 \mathrm{~h} 05 \mathrm{~min}$.

LIKERT, R., ROSLOW, S., MURPHY, G. (1993), A simple and reliable method of scoring the thursone altitude scales, Personnel Psychology, 46, 689-690. 


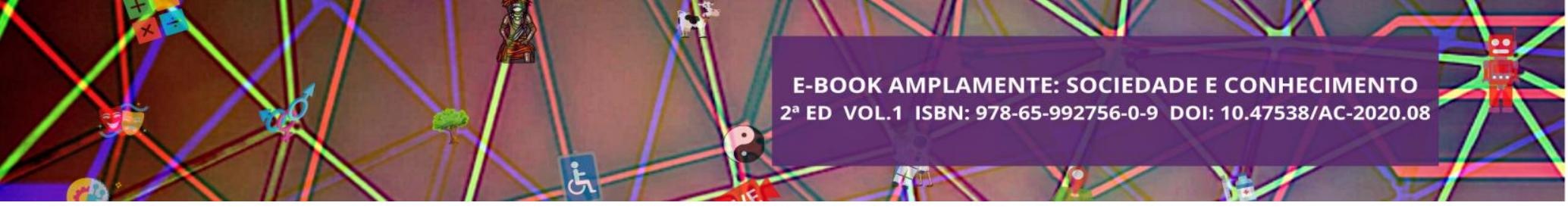

\title{
CAPÍTULO XVIII
}

\author{
CORPORALIDADES: A MEDICALIZAÇÃO DO CORPO E AS \\ PERSPECTIVAS DE AGÊNCIA SOBRE A TRANSEXUALIDADE
}

Daniel da Silva Stack
DOI - Capítulo: $10.47538 /$ AC-2020.08-18

\section{RESUMO:}

Este capítulo é parte do trabalho de conclusão de curso intitulado "Não é uma realidade de todo mundo": Acesso ao SUS por pessoas trans do município de Santa Maria a partir da normativa 2.803/2013. Para construção do trabalho três mulheres transexuais e dois homens transexuais foram entrevistados a partir de um roteiro, os dados obtidos e analisados integraram a construção desse capítulo. $\mathrm{O}$ acesso ao tratamento hormonal e a procedimentos cirúrgicos são a oportunidade de modificação corporal, ou seja, de transformar esse corpo em uma casa confortável, incorporando elementos na construção da identidade transexual. Acessar os meios para modificar o corpo não é tão simples como formulado na normativa 2.803/2013, pois, as modificações corporais estão condicionadas a fatores como classe social, raça/etnia, capital cultural e regionalidade. Dentro da luta por reconhecimento, respeito e reivindicações sociais os corpos transgêneros têm um peso político. A existência se torna resistência frente às normas de gênero que afastam do campo social cotidiano e os empurram à marginalidade. Um corpo transexual é circunscrito por camadas complexas e limitadas de agência dos sujeitos, é transpassado por saberes médicos que reforçam a binaridade de gênero, por estigmas que tentam exercer controle sobre seus corpos, mas também é a "tela" onde esses sujeitos constroem-se a si mesmos, a vir expressar sua identidade.

PALAVRAS-CHAVE: Transexualidade. Políticas Públicas. Reconhecimento. Sistema Único de Saúde.

\section{INTRODUÇÃO}

$\mathrm{O}$ acesso ao tratamento hormonal e a procedimentos cirúrgicos são a oportunidade de modificação corporal, ou seja, de transformar esse corpo em uma casa confortável, incorporando elementos na construção da identidade transexual. Acessar os meios para modificar o corpo não é tão simples como formulado na normativa $2.803 / 2013^{98,}$ tema principal de minha pesquisa, na ida ao campo com meus

97 Programa de Pós-Graduação em Ciências Sociais - PPGCS/UFSM, Santa Maria/RS. E-mail: danielsstack@ outlook.com

98 Normativa que regula o acesso de sujeitos transexuais a tratamento hormonal e cirúrgico no âmbito do SUS. 


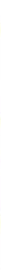

interlocutores pude perceber que as modificações corporais estão condicionadas a fatores como classe social, capital cultural e regionalidade.

É sobre essa "tela", o corpo, que inserimos aspectos que constituem nossa identidade, não restrita somente à limitadas definições de homens e mulheres. Nosso corpo faz-se presente como parte e assentamento do tecido social. Há um corpo fisiológico que adquirimos ao nascer - do qual não podemos nos desvincular - e um corpo social onde são inscritos sinais e projeções culturais.

Assim, o corpo não é somente uma coleção de órgãos arranjados segundo leis da anatomia e da fisiologia. É, em primeiro lugar, uma estrutura simbólica, superfície de projeção passível de unir as mais variadas formas culturais. Em outras palavras, o conhecimento biomédico, conhecimento oficial nas sociedades ocidentais, é uma representação do corpo entre outras, eficaz para as práticas que sustenta (LE BRETON, 2006, p. 29).

A biologia não consegue explicar os significados que construímos ao redor do corpo, mas tem legitimidade para normalizar sua existência e ações. A ordem biológica foi movida para justificar uma inferioridade natural da mulher, teoria que dizia a mulher se tratava de um homem com mau desenvolvimento corporal, a vagina foi vista como um pênis invertido, que não se desenvolveu exteriormente. Da mesma forma com a população negra, com as teorias racialistas e a frenologia que apontavam a suposta inferioridade, justificando pelo tamanho do crânio e outros atributos fisiológicos (HELMAN, 2003). Essas teorias dominaram o campo científico e construíram estigmas históricos presentes nas relações de mulheres e de negros. Essas situações evidenciam o caráter hegemônico do conhecimento científico, a necessidade e o poder de explicar as diferenças sociais por uma base biológica.

Com a atual produção da vida e existência, não temos um corpo puramente biológico, pois o corpo está em constantes mudanças que são frutos da ordem social. O ato de ir a academia, por exemplo, vai além da busca por saúde física, também apresenta a intenção de deixar o corpo sarado ${ }^{99}$, ser, então, reconhecido como bonito e atraente. Nossa alimentação também não pode ser vista como natural, já que as desigualdades sociais de acesso à alimentação básica são permeadas de relações políticas e o próprio alimento é produzido através de manipulações genéticas (trangênismo) constituídas pela humanidade. O corpo é, então, exercitado, alimentado, ornamentado e definido dentro

99 Miskolci (2017) traz que o uso do termo sarado surgiu com o pânico do HIV/AIDS, onde um corpo doente era medido pela magreza e um corpo musculoso então seria um corpo são. 


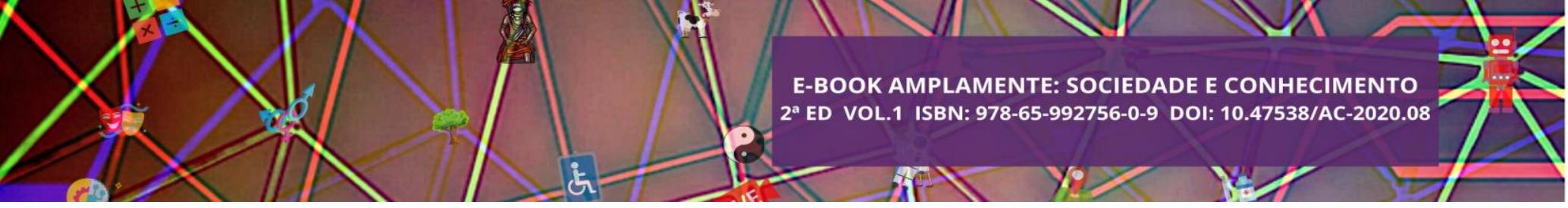

de teias culturais da qual não se pode desprendê-lo. Para analisar a corporalidade de pessoas transexuais deve-se ter em mente que todo o conhecimento produzido sobre o assunto é majoritariamente composto por pessoas cisgêneras.

A expressão corporal é socialmente modulável, mesmo sendo vivida de acordo com o estilo particular do indivíduo. Os outros contribuem para modular os contornos de seu universo e a dar ao corpo o relevo social que necessita, oferecem a possibilidade de construir-se inteiramente como ator do grupo de pertencimento. No interior de uma mesma comunidade social, todas as manifestações corporais do ator são virtualmente significantes aos olhos dos parceiros, elas só têm sentido quando relacionadas ao conjunto de dados da simbologia própria do grupo social. Não há nada de natural no gesto ou na sensação (LE BRETON, 2006, p. 9).

A percepção sobre o corpo é distinta na área médica, nas ciências psi (psicanálise; psicologia; psiquiatria) e para as ciências sociais. A área médica esteve muito ligada à funcionalidade; o que é acionador e definidor dessas percepções são as funções corporais, dos órgãos, tecidos, cromossomos etc. As ciências psi se detiveram em desenvolver seus estudos sobre o cérebro e a mente, buscaram sua justificação a partir das experiências do indivíduo (relação com mãe e pai, traumas etc.). As ciências sociais, por sua vez, veem o corpo como uma parte da cultura, o corpo dotado de "peles simbólicas", círculos concêntricos ao redor do indivíduo, sendo que as experiências variam de acordo com gênero, sexualidade, raça e tamanho.

O conceito de pele simbólicas, delineado anteriormente, significa que a existência do corpo é sempre moldada e alterada por noções culturais de espaço. Essas funções normalmente entendem as fronteiras do corpo para muito além da fronteira natural e física da pele. Em termos espaciais, essas pedras simbólicas - algumas visíveis, outras não - pode fazer o corpo (e o senso de self que ele contém) adquirir dimensões enormes (HELMAN, 2003, p. 37).

Como não podemos nos afastar desse corpo social, é através dele que os indivíduos leem uns aos outros, conjunto composto pela aparência física, trejeitos, vestuários, todos esses signos constituem as identidades que rotulamos de masculina e feminina.

Ser homem e mulher engendra, então, uma construção além dos órgãos sexuais, envolve uma performatividade de gênero (BUTLER, 2003) apoiadas no ideal de masculinidade e feminilidade. O sujeito que não corresponde a esse ideal de gênero consequentemente sofre sanções do grupo social nos diversos espaços que transitam. Guacira Louro (2000) nos conta como a escola apresenta um currículo oculto sobre as 


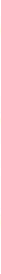

normas de gênero; dessa forma, é comum os relatos sobre bullying que LGBTs ${ }^{100}$ sofrem no ambiente escolar. Dentro da questão transgênera a evasão escolar é um presente cotidiano.

Krystal relata ter reprovado três vezes no primeiro ano do ensino médio em consequência de assédios e bullying praticados pelos colegas e professores. É em decorrência de ter o corpo como transgressor às normas de gênero que o estigma se alia como marca definidora de status social (GOFFMAN, 1988).

As escolas não suportam trabalhar com transexuais, pois empreendem toda uma maquinaria com vistas a estabelecer e reiterar a norma heterossexual. Talvez pelo afastamento das normas operado por essa experiência, pois uma vez iniciado o processo de transexualização, com a ingestão de hormônios, a colocação de próteses ou a retirada de partes do corpo, dificilmente se retrocede às normas de gênero e sexualidade. Esses são sujeitos que escapam à eficiente política de governo de corpos e subjetividades no funcionamento da maquinaria escolar (SANTOS, 2015, p. 10).

Para os saberes médicos construídos ao longo do século XX e XXI, o indivíduo transexual deve, no seu processo de transição de gênero, modificar seus trejeitos: para as mulheres transexuais suavizar a voz, os movimentos, uso de maquiagem, transicionar seu guarda roupa e construir uma nova identidade; dessa forma, criam-se dois polos, onde os indivíduos devem se fixar.

Diante dessas complexas experiências, como são complexas as experiências humanas em geral, o saber médico não pode justificar os "transtornos" por nenhuma disfunção biológica. Em última instância, são as normas de gênero que contribuirão para a formação de um parecer médico sobre os níveis de feminilidade e masculinidade presentes nos demandantes. Serão elas que estarão sendo citadas, em séries de efeitos discursivos que se vinculam às normas, quando, por exemplo, se julga ao final de um processo se uma pessoa é um(a) "transexual de verdade". Não existem testes clinicamente apropriados e repetíveis ou testes simples e sem ambiguidades. O que assusta é perceber que tão pouco conhecimento, credenciado como científico, tenha gerado tanto poder (BENTO; PELÚCIO, 2012, p. 573).

Dentro do espectro transgênero e da sexualidade houve um processo de patologização de todas as identidades de gênero e sexualidades divergentes da norma cis-heterossexual, desencadeando a busca por uma explicação biomédica desses fenômenos e, por consequência, a correção desses indivíduos (BENTO, 2006). Assim como o conceito de homossexualidade desenvolvido da relação de poder que a

100 O termo da sigla que comporta mais identidades é LGBTQIAP+, utilizo LGBT porque no que tange o sistema de saúde e políticas públicas somente Gays, Lésbicas, Bissexuais, Travestis e Transexuais são reconhecidos. 


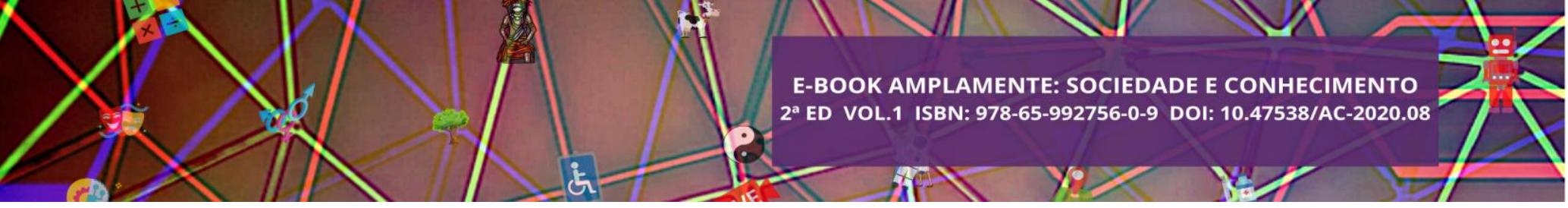

heterossexualidade exerce sobre sexualidades divergentes da norma (FOUCAULT, 2010), a categoria transexual surgiu a partir da década de cinquenta, como um conceito também "criado" da relação de poder da cisgeneridade sobre qualquer outra maneira de experienciar o gênero.

Questionar a transexualidade antes do século XX parece não fazer sentido, uma vez que até esse momento, transexuais não existiam como sujeitos. $\mathrm{O} / \mathrm{a}$ transexual consiste em um objeto inventado, como uma "espécie", com diagnóstico e tratamento específicos, em meio a disputas de poder. Assim, "[é] importante ressaltar que antes de 1950 não existiam definições ou caracterizações específicas para transexuais, isto é, não havia diferenciação entre transexuais, travestis e homossexuais". (SANTOS, 2015, p. 6).

Segundo Bento e Pelúcio (2012), houve a necessidade de se definir o "verdadeiro transexual" que apresenta um conjunto específico de características. Dentre elas a necessidade de eliminar todos os caracteres do sexo biológico e o desejo de adquirir todas as características do gênero oposto, assim como a propensão ao suicídio; essas definições da transexualidade estão presentes na normativa 2.803/2013 que regula o acesso ao tratamento hormonal. As definições e saberes médicos foram pautados na concepção da cisgeneridade sobre o que consideram disforia de gênero e, consequentemente, sua visão sobre a transexualidade.

Dentro das minhas entrevistas, conversei com um profissional da saúde, médico endócrino que atende alguns homens trans do município, a visão biomédica fez-se presente quando ele afirma que se deve fazer o diagnóstico para descobrir se a pessoa é transexual ou apenas travesti.

A Classificação Estatística Internacional de Doenças e Problemas Relacionados com a Saúde (CID-10) apresenta os códigos e a tipificação da doença que devem estar presentes em todos os diagnósticos para que tenham validade legal. $\mathrm{O}$ "transexualismo", por exemplo, é definido como "transtornos da identidade sexual (F64.0)". Além "do transexualismo", há o "travestismo bivalente (F64.1), o transtorno de identidade sexual na infância (F64.2), outros transtornos da identidade sexual (F64.8), o transtorno não especificado da identidade sexual (F64.9)", ou seja, eliminou-se, em 1973, o "homossexualismo" do DSM-8 e, em 1975, do CID-10, mas o que assistimos em seguida foi a uma verdadeira proliferação de novas categorias médicas que seguem patologizando comportamentos a partir do pressuposto heteronormativo, que exige uma linearidade sem fissuras entre sexo genital, gênero, desejo e práticas sexuais. (BENTO; PELÚCIO, 2012, p. 572). 


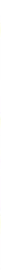

As definições de transexual e de travesti na área médica não estão ancoradas no pertencimento ou reconhecimento desses indivíduos, mas em uma definição biomédica sobre o assunto que acaba por reforçar a binariedade do gênero, dizendo que só podem existir homens e mulheres com distinção corporal bem delimitada entre si.

\section{A MODIFICAÇÃO DO CORPO: RAÇA, CLASSE E ESCOLARIDADE}

As pesquisas de Bento (2006), Lanz (2014) e essa pesquisa mostram que a busca pela modificação corporal não está vinculada apenas às definições tipicamente médicas do que seria a transexualidade e na busca por inserir os corpos dentro de uma definição de masculino e feminino. Ira, um de meus interlocutores, afirma:

[...] busquei ajuda de médicos pra eu mudar meu corpo, de uma forma que eu me sentisse melhor e confortável, não que eu almeje no futuro fazer uma cirurgia de readequação sexual. Eu não sinto vontade de ter um pinto pra ser homem, enquanto a isso está ok. Mas agora com meu corpo me sinto mais confortável com ele, embora tenha os seios que a gente chama de "intruso" dentro dos transhomens - Ira, 28 anos, realiza o tratamento hormonal pelo setor privado.

Embora parte de meus interlocutores transexuais se identificam a partir da “disforia de gênero”, “almejando eliminar todas as características do sexo ‘biológico’ e adquirir as do sexo oposto", como presente na normativa que regula o acesso ao tratamento hormonal, isso não é de fato uma regra. As vivências transexuais não são homogêneas, criar uma definição médica para transexualidade é excluir diversos corpos que não compartilham das mesmas vontades e desejos, mas experienciam a transexualidade a sua maneira. Ira sente-se confortável com as modificações que o hormônio produziu em seu corpo, não busca a cirurgia de readequação sexual, embora queira eliminar os seios que define de "intruso", Ira não se enquadraria dentro da definição hegemônica e médica do "transexual de verdade", pois, em sua visão foi necessário desconstruir as definições do que é ser homem, para assim poder reivindicar sua identidade enquanto trans-homem bissexual.

Em nossa cultura ocidental, modificações corporais, através de procedimentos cirúrgicos, são constantemente acionadas pelos indivíduos que detêm poder econômico para tal acesso. Dentro do escopo social existe uma concepção das modificações corporais que podem ser feitas pelos indivíduos e são aceitáveis no tecido social; essas 


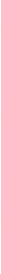

modificações são fruto de um processo histórico dentro dos tensionamentos da (a)normalidade.

No panorama atual o indivíduo pode de forma autônoma buscar realizar inúmeras cirurgias, desde que essas cirurgias não tragam a ambiguidade para o corpo. Modifica-se nariz, peitos, quadris, vagina, pênis mas desde que siga a cisgeneridade; portanto, uma mulher pode buscar de forma autônoma uma cirurgia de correção vaginal ${ }^{101}$; porém, o mesmo não se pode acontecer com uma mulher trans, a qual precisa justificar sua demanda através de um laudo patologizante de sua condição. Dessa forma o laudo médico sobre a transexualidade deve ser problematizado, uma vez que essa relação médico-paciente está permeada de relações de poder (FOUCAULT, 2010).

Se, para o Estado, os/as normais de gênero são aqueles/as que têm uma correspondência entre genitália, performance e práticas eróticas e se essa definição gera um modus operandi que exclui sujeitos que estão nos seus marcos, estamos diante de uma contradição com sua própria definição universalizante. A resposta para resolver essa contradição nos limites do DSM é a inclusão excludente. (BENTO; PELÚCIO, 2012, p. 577).

Dentro das narrativas dos meus interlocutores, diversas formas de violência foram relatadas quando os mesmos buscaram profissionais de saúde para tratamento relacionado à transição ou problemas de saúde.

As violências simbólicas habituais incluem o não respeito ao nome social, o tratamento por pronomes não adequados com a identidade de gênero do paciente, negligência médica e assédio sobre o corpo do paciente. Devemos lembrar que a medicina é constituída por pessoas com inclinações morais pautadas geralmente no senso comum, que estigmatiza sujeitos LGBTs constituídos como minorias sociais. Portanto, quando não se problematiza as definições de gênero e sexualidade na formação acadêmica, os profissionais reproduzem os estigmas sociais no seu atendimento médico-paciente. Cosima, uma de minhas interlocutoras, relata o assédio que sofreu em uma consulta com um médico urologista.

Outro tipo de violência que sofri nitidamente por ser uma mulher trans foi um assédio de um médico urologista. Precisei buscar esse especialista por estar com fortes dores na região pélvica. Chegando lá, me fizeram inúmeras perguntas do por que estar buscando esse

101 Para melhor aprofundamento ler "Ame seu corpo, inclusive sua vagina: estudo sociológico da produção discursiva sobre a autoestima vaginal e empoderamento feminino nas mídias digitais" tese de doutorado da socióloga Marcelle Jacinto da Silva, Universidade Federal do Ceará, Centro de Humanidades, Programa de Pós-graduação em Sociologia, Fortaleza, 2019. 


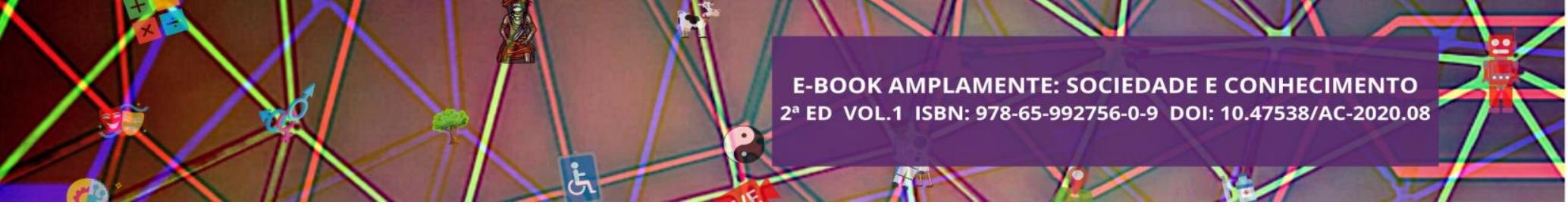

profissional. Tive de dar muitas explicações íntimas tanto a atendente quanto ao médico. Ele ficou muito surpreso e teceu comentários muito machistas e transfóbicos do tipo: "tu coloca muita mulher no chinelo", "nossa, como pode tu ter nascido homem e ser tão linda e feminina", etc. A gota d'água foi ele pedir pra me despir pra fazer alguns exames de imagem. Detalhe: ele quis fazer exame de imagem nos meus seios, que nada tinham a ver com a minha dor e procura. No meio dos exames ele fez mais comentário, alguns deles sórdidos. Ao se despedir ele disse: se perguntarem quem é o teu GINECOLOGISTA, diz que sou eu. Saí de lá péssima, suja, como se estivesse sido estuprada. Mas não cheguei a denunciá-lo. - Cosima, 26 anos, realiza o tratamento hormonal pelo setor privado.

Discutir gênero na formação profissional da área médica é o primeiro pressuposto para garantir o acesso universal aos serviços oferecidos (CARVALHO, 2015). Mesmo com o desenvolvimento de políticas públicas para a promoção da saúde de travestis e transexuais, a implementação dessas políticas encontram percalços.

A circulação dos corpos transexuais em espaços como a escola, trabalho e a universidade são restritas justamente por serem corpos vistos como transgressores das normas de gênero tidas como fixas e imutáveis (BENTO, 2006).

No próprio desenvolvimento da pesquisa consegui ter acesso a apenas duas pessoas trans que ingressaram no ensino superior tanto pela universidade pública como pela particular; ambas apresentam um perfil socioeconômico elevado e realizam a transição de gênero na rede privada. Houve uma dificuldade de encontrar sujeitos transexuais nos espaços como a universidade, dadas as dificuldades de inserção da população trans em espaços hegemonicamente cisgêneros.

A forma como vemos nosso corpo também é marcada pela classe à qual pertencemos, vimos que a noção de corpo para a área médica se diferencia muito das definições encontradas nas ciências sociais. As diferentes classes percebem o uso do seu corpo de formas distintas; sendo assim, o corpo pode ser visto de formas diferentes como, por exemplo, de forma mecânica, ou instrumento de trabalho intelectual.

As regras que determinam os comportamentos físicos dos agentes sociais e cujo sistema constitui sua "cultura somática", são produto das condições objetivas que elas traduzem na ordem cultural, ou seja, conforme o modo de dever-ser: são função, precisamente, do grau em que os indivíduos tiram seus meios materiais de existência de sua atividade física, da venda de mercadorias que são o produto dessa atividade, ou do emprego de sua força física e de sua venda no mercado de trabalho. (BOLTANSKI, 2004, p. 157). 


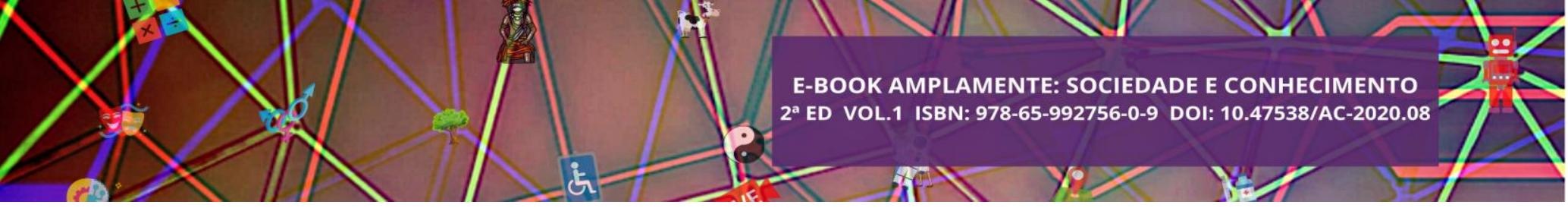

É através de significativos culturais que o corpo adquire outras dimensões. Cecil Helman (2003) mostrou através de seu estudo que dependendo do nível de instrução do indivíduo, seu gênero e classe são marcadores sociais que diferenciam a busca por assistência médica.

Da mesma forma, a classe atrelada à transexualidade traz percepções distintas de agência e transformações sobre o corpo. Todos os meus interlocutores nesta pesquisa fazem, até o momento, modificações corporais com o uso de hormônios; porém, o acesso a esse tratamento e as perspectivas de futuras modificações se delimita pela classe social.

A possibilidade de acesso ao conjunto de modificações ofertado pelo SUS é algo muito positivo para a autoestima de pessoas trans, mas também se torna um fardo para as mesmas que apresentam traços "mais marcados" pelo sexo anatômico, revelando sua condição enquanto transexuais (LANZ, 2014).

Krystal, a interlocutora que já citei anteriormente, revela os embates ainda presentes com seu corpo, afirmando que ter peito pequeno, cabelo curto e a marca de expressão de pelos faciais deslegitimam sua identidade transexual e a fazem se sentir "menos mulher".

Ira, que faz tratamento hormonal no setor privado, diz já ter pesquisado valores de cirurgias de mastectomia dupla ou bilateral, que é a remoção dos seios; ele consegue vislumbrar a possibilidade de realizar essa cirurgia. Por outro lado, Krystal afirma ter aceitado o fato de que nunca irá conseguir fazer a operação.

Assim, eu ainda sofro de disforia que é quando você não aceita o seu corpo no caso o corpo que não é designado ao meu gênero. $\mathrm{O}$ que mais me afetava era meu órgão sexual. Agora já me convenci que nunca irei conseguir fazer a redesignação de sexo, então tive que aceitar o fato de ser uma mulher com pênis - Krystal, 20 anos, realiza a transição de gênero por automedicação.

Ela relata inúmeras violências que sofreu por conta de ser transexual na escola, quando tentou se inserir no mercado de trabalho e rejeição por parte da família. Dessa forma, interrompeu a medicação pelo uso de pílula de forma autônoma por onze meses por não ter condições de comprar a medicação; retornou há dois meses da data da entrevista com a medicação injetável, com a ajuda de seu noivo que dá suporte financeiro ao tratamento. 


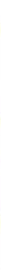

É importante trazer alguns condicionantes sociais que estão presentes na fala de Krystal em comparação com Ira. Krystal é de classe baixa, sua renda depende de seu noivo, com quem está junto há menos de um ano; ela não conseguiu concluir o ensino médio em decorrência de violências cotidianas, se assumiu enquanto mulher trans quando ainda frequentava o ensino médio. Dentro do seu universo do possível (BOURDIEU, 2007) ela não vislumbra a possibilidade de frequentar o ensino superior; o conhecimento que tem da transexualidade foi construído parte de forma autônoma, pela sua experiência enquanto transexual, e em parte a partir das definições hegemônicas de gênero.

Conheci Ira em 2018 em eventos sobre gênero e sexualidade dentro e fora da universidade. Ele se encontra no ensino superior engajado em espaços como o coletivo do qual faz parte, que discute constantemente novas perspectivas sobre gênero e transexualidade.

O capital cultural (BOURDIEU, 2007) de Ira é distinto do de Krystal, o que o possibilita repensar de forma acadêmica e teórica seu gênero, desconstruindo uma série de normas vigentes. Ele diz que gosta de ter cabelo comprido e que não se sente deslegitimado por ter o cabelo comprido e por ter vagina. Enquanto Krystal nos conta que o fato de não conseguir acessar o SUS e a rede privada para a cirurgia de redesignação sexual a forçaram a aceitar seu pênis em decorrência da impossibilidade de agência condicionada por sua classe. Dessa forma, a (des) construção do gênero é permeada pelos espaços que os sujeitos circulam.

Foi desenvolvido ao longo das décadas um vasto mercado para modificações corporais na área da estética, dentre as quais se destacam as cirurgias de feminização facial, operações que são feitas para deixar o rosto mais "feminino".

No seu trabalho, Aureliano Lopes (2017) acompanhou concursos nacionais de beleza com mulheres transexuais e a presença de empresas do ramo estético que promoviam palestras para mostrar as novas tecnologias que garantem uma harmonização do rosto sem deixar marcas perceptíveis. A presença de empresas desse nicho em espaços como esses, onde as pessoas trans que ali circulam se distinguem economicamente, denota uma estratégia do mercado em transformar em lucro a necessidade/vontade de adequação às normas de gênero por parcelas da população trans. Criando esse desejo como bem comercializável e negociável para determinadas classes sociais. 


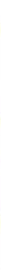

Como na pesquisa da socióloga Letícia Lanz (2014); a construção do corpo de pessoas transexuais e sua identidade se dá incorporando signos considerados masculinos e femininos. Corresponder às expectativas construídas sobre o sexo biológico afeta todos os indivíduos sociais de formas diferentes, porém, os únicos que repensam seu corpo e seu gênero são os que não condizem com esse ideal.

Há histórias e mais histórias envolvendo o constrangimento a que pessoas transgêneras são constantemente submetidas pela população cisgênera. Histórias comoventes e dolorosas, como a da travesti que foi espancada pelo pai até quase a morte ou da transexual que teve negada pelo SUS a sua cirurgia de readequação genital por não corresponder' de maneira alguma ao padrão de feminilidade exigido pelos médicos do SUS a fim de considerarem-na apta para a cirurgia de readequação genital (LANZ, 2014, p. 145).

\section{CONSIDERAÇÕES FINAIS}

Como já elencado, as percepções corporais e de identidade variam quanto à classe econômica e capital cultural. As pessoas trans são afastadas de esferas que constituem a base das pessoas cisgêneras, como família, escola, mercado de trabalho, independência econômica e socialização com o gênero que se identifica (LANZ, 2014). Portanto, com esses apontamentos, transexuais e travestis de estratos econômicos baixos e sem acesso às discussões epistemológicas do gênero têm disponível no seu campo de agência, as definições hegemônicas do gênero, que podem ser incorporadas ao construir sua identidade. Não que gênero e práticas corporais generificadas não sejam pensadas por transgêneros (elas já vêm sendo pensadas por vários movimentos trans desde a década de cinquenta), mas as possibilidades de discussão, desconstrução e reconstrução do corpo abrangem os critérios de classe e raça conjuntamente com as práticas do saber médico.

Repensar o gênero é, então, algo essencial não somente para pessoas trans, mas para pessoas cisgêneras, num momento em que a violência sofrida por pessoas trans advém de pessoas cis. No que tange à transexualidade, a cisgeneridade sempre se encontra num patamar de muitos privilégios sociais e, consequentemente, poder de controle sobre esses indivíduos.

Butler (2015) argumenta casos em que a vida humana é reduzida a representações nulas de dignidade humana, a corpos vazios de representações, o que ela chama de corpos abjetos. 


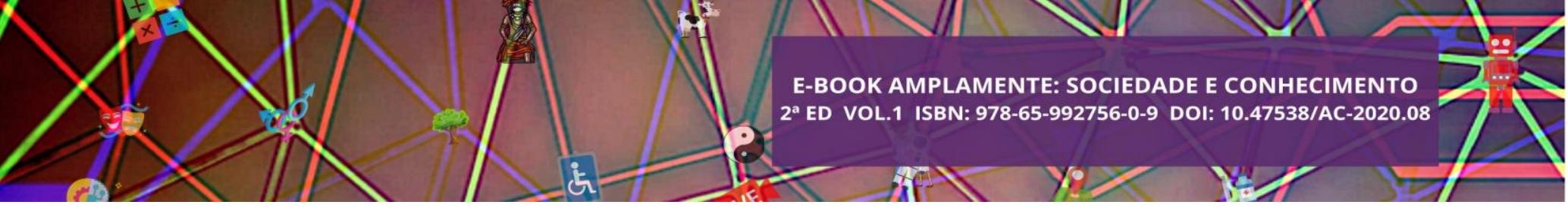

Esta matriz excludente pela qual os sujeitos são formados exige, pois, a produção simultânea de um domínio de seres abjetos, aqueles que ainda não são sujeitos, mas que formam o exterior constitutivo relativamente ao domínio do sujeito. $\mathrm{O}$ abjeto designa aqui precisamente aquelas zonas inóspitas e inabitáveis da vida social, que são, não obstante, densamente povoadas por aqueles que não gozam do status de sujeito, mas cujo habitar sob o signo do inabitável é necessário para que o domínio do sujeito seja circunscrito (BUTLER, 2015, p. 155).

A transexualidade e a travestilidade constituem essas zonas inóspitas, ou seja, o restante dos sujeitos sociais que são cisgêneros acabam por legitimar a violência praticada contra esses corpos. A pesquisa de Souza (2015) com travestis do município de Santa Maria (RS) evidencia como esses corpos são tidos como não passíveis do mínimo de respeito e cuidado com a saúde.

Um de meus interlocutores trans-homem relata a resistência que têm de usar banheiros públicos pela possibilidade de sofrer violência; é dessa forma que circular nesses espaços é restrito a somente uma possibilidade de existência desses corpos, definidos dentro da binaridade de gênero, seja por sujeitos cisgêneros ou por sujeitos transexuais passáveis.

Mulheres transexuais enfrentam um estigma social de vincular seus corpos a prostituição. Por não se inserirem no mercado de trabalho majoritariamente, travestis e transexuais recorrem à prostituição como única alternativa para conseguir sobreviver (SOUZA, 2015). Esses corpos encontram barreiras para circularem durante o dia, seu espaço de existência se limita a noite, em alguns casos nas "faixas" se prostituindo.

\footnotetext{
No começo desse ano larguei mais de 30 currículos e depois de longos meses fui chamada para ser entrevistada em um estabelecimento. Ao chegar lá a pessoa que ia me entrevistar me olhou da cabeça aos pés e riu, eu sem entender o por que perguntei: O que houve? e ela disse: não nada "querido". Aí fui me sentar para fazer a entrevista e ela falou o seguinte: Nem se dê o trabalho de sentar as entrevistas já acabaram [...] quando cheguei a saída a gerente se deu o trabalho de sair lá de dentro abrir a porta pra mim e perguntar o seguinte: $\mathrm{O}$ que você veio fazer aqui? Respondi que havia vindo para a entrevista, ela olhou bem no meu olho deu risada e disse: $O$ teu lugar não é aqui e sim na rua, nas faixas. Depoimento de Krystal - 20 anos.
}

A fala de Krystal mostra que a inserção em esferas sociais é restrita a alguns tipos de corpos. Quando a entrevistadora não dá a mesma oportunidade para ela que aos demais candidatos, ela reforça e legitima através de estigmas o espaço que esse corpo deve ocupar dentro da sociedade. Não é por acaso que o Brasil segue sendo o país que 


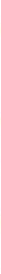

mais mata travestis e transexuais e, ao mesmo tempo, é o país que mais consome pornografia trans ${ }^{102}$. O cenário social brasileiro segue "abjetando" esses corpos de condições materiais de existência dignas e objetificando-os como um produto a ser consumido nas quadras a noite ou on-line.

A brutalização dos sujeitos se correlaciona à brutalização dos corpos. $\mathrm{Na}$ classificação de um determinado crime como homofóbico, a intensidade com que a violência é empregada e as marcas produzidas nos corpos das vítimas preenchem alguns dos critérios classificatórios utilizados pelo Movimento LGBT. O grau de violência, portanto, dimensiona a qualificação do crime e autoriza, em muitas ocasiões, a reivindicação das mortes pelo Movimento. Não acidentalmente, os relatórios formulados pelo Movimento do Espírito Lilás, relativos aos anos de 2011 e 2012, apresentam as informações que constam no primeiro parágrafo deste texto. A cabeça esmagada, às dezenas de facadas e o estrangulamento compõem o excesso, o inexplicável, e comprovam, de forma cabal, a ocorrência da homofobia. (FILHO, 2016, p. 326).

Na materialização de violências contra indivíduos LGBTs, com ênfase ao fato da população transexual e travesti apresentarem a expectativa de vida reduzida a metade de uma pessoa cisgênero ${ }^{103}$, a morte desses sujeitos é tida como algo positivo e constantemente transformada em espetáculo ${ }^{104}$.

Lanz (2014) vai dizer que eliminar esses corpos ambíguos na perspectiva de uma pessoa normativa é aceitável, pois esses corpos são considerados transgressores em relação à forma que, supostamente, deveriam ser. Em janeiro de 2019 foi noticiado que um homem assassinou e arrancou o coração de uma travesti ${ }^{105}$ afirmando se tratar de um demônio. A brutalidade que um corpo tido como transgressor sofre ultrapassa as margens do que pode ser concebido como crueldade. Em Santa Maria (RS) houve o homicídio de duas transexuais num intervalo de menos de vinte e quatro horas; os crimes ocorreram uma semana após a primeira parada de visibilidade transexual ${ }^{106}$ do município.

Dentro da luta por reconhecimento, respeito e reivindicações sociais os corpos transgêneros têm um peso político. A existência se torna resistência frente às normas de

102 O Brasil é o país que lidera crimes de ódio a travestis e transexuais segundo a ONG Transgender Europe e o país que busca com maior frequência o termo trans em plataformas de vídeos pornográficos. Disponível em: <encurtador.com.br/lxAKO> acesso em 14 de Novembro de 2019.

103 A expectativa de vida de uma pessoa trans é de 35 anos, enquanto uma pessoa cis no Brasil segundo dados do IBGE é de 75 anos, dados disponíveis em: <http://abre.ai/atzd> acesso em 14 de Nov de 2019.

104 Dandara foi morta por seis homens em 2017, sua morte foi filmada e circulou a internet, durante seu espancamento que envolveu pauladas, pedradas e depois sua execução a tiro, seus algozes se divertiam com o acontecido. Matéria disponível em: <http://abre.ai/atza> acesso em 14 de Nov de 2019.

105 Matéria completa disponível em: <http://abre.ai/aty7> acesso em 14 de Nov de 2019.

106 Matéria completa disponível em: <https://tinyurl.com/rxocf44> acesso em 14 de Nov de 2019 


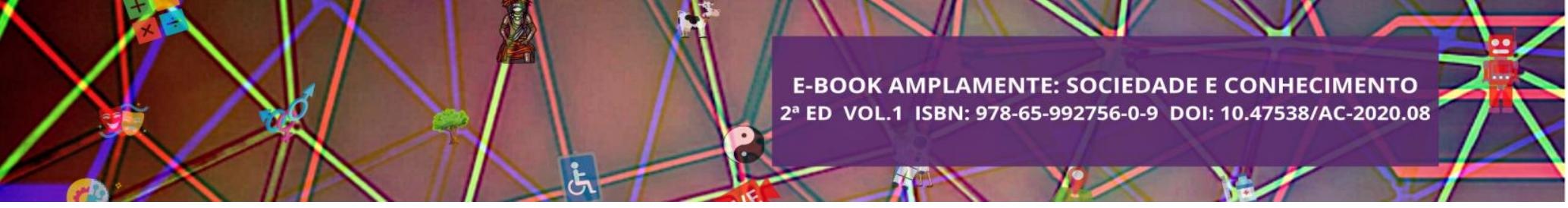

gênero que afastam do campo social cotidiano e os empurram à marginalidade. Um corpo transexual é circunscrito por camadas complexas e limitadas de agência dos sujeitos, é transpassado por saberes médicos que reforçam a binaridade de gênero, por estigmas que tentam exercer controle sobre seus corpos, mas também é a "tela" onde esses sujeitos constroem-se a si mesmos, como se identificam, é o vir a existir, parte de um processo libertador.

\section{REFERÊNCIAS}

BENTO, B. A. de M. Nome social para pessoas trans: cidadania precária e gambiarra legal. Contemporânea, São Carlos, 2014.

A reinvenção do corpo: sexualidade e gênero na experiência

transexual. Rio de Janeiro: Garamond, 2006.

BENTO, B; PELÚCIO, L. Despatologização do gênero: a politização das identidades abjetas. Florianópolis: Estudos Feministas, 2012. p.569-581.

BOLTANSKI, L. As classes sociais e o corpo. São Paulo: Paz e Terra, 2004.

BOURDIEU, Pierre. O poder simbólico. Rio de Janeiro: Bertrand Brasil, 2005.

Alegre, RS: Zouk, 2007.

BUTLER, J. Problemas de gênero: feminismo e subversão da identidade. Rio de Janeiro: Civilização Brasileira, 2003.

Vida precária in: Quadros de guerra: quando a vida é passível de luto?.

Rio de Janeiro: Civilização Brasileira, 2015.

CARVALHO, M. F. L. "Muito prazer, eu existo!" Visibilidade e Reconhecimento no Ativismo de Pessoas Trans no Brasil. Rio de Janeiro: UERJ, 2015.

FILHO, R. E. Corpos brutalizados: conflitos e materializações nas mortes de LGBT. São Paulo: Pagu, 2016.

FOUCAULT, M. História da sexualidade I: a vontade de saber. São Paulo, Graal, 2010.

GOFFMAN, E. Estigma: notas sobre a manipulação da identidade deteriorada. Rio de Janeiro: LTC, 1988.

HELMAN, C. G. Cultura, Saúde e Doença. Porto Alegre: Artmed, 2003. 


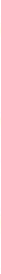

sua promoção, proteção e recuperação". Essa concepção de saúde como valor social e direito é fruto das proposições defendidas pelo movimento da reforma sanitária, o qual emergiu ainda durante a década de 1970. Nesse sentido, é vista como essencial para o exercício da cidadania, para a superação do racismo e para o fortalecimento da democracia.

A Política Nacional de Saúde Integral da População Negra (PNSIPN) é fruto das lutas travadas pelos movimentos sociais, principalmente pelo movimento negro, em torno da democratização da saúde. Apresenta princípios, diretrizes, objetivos e estratégias que norteiam as ações de cuidado voltadas à esse segmento populacional. Entretanto, é possível verificar dificuldades para a sua real implementação, principalmente pelo racismo institucional que ainda permeia as ações e atendimentos em saúde.

Considerando o exposto pretendemos identificar as principais barreiras que interferem no processo de cuidado e as possíveis ações que podem promover a atenção integral segura e eficaz para a população negra usuária do Sistem Único de Saúde, partindo da análise da PNSIPN.

\section{A POLÍTICA NACIONAL DE SAÚDE INTEGRAL DA POPULAÇÃO NEGRA: BREVE ANÁLISE}

A PNSIPN foi construída em meio à reinvindicações empreendidas principalmente pelo movimento negro que anceiava, na área da saúde, práticas que combatessem o racismo presente no âmbito das instituições e também promovessem a atenção universal, integral e equânime da população negra, respeitando toda a sua ancestralidade e historicidade.

Elaborada em consonância com a Constituição Federal tem como princípios fundamentais a dignidade da pessoa humana, o repúdio ao racismo e a defesa da igualdade. Corrobora com os princípios do SUS no tocante a universalidade do acesso, a qual se refere ao acesso universal em todos os níveis de atenção sem qualquer tipo de preconceito e/ou distinção; a integralidade da atenção, no sentido de que todas as necessidades devem ser atendidas em sua integralidade e assim pressupõe a intersetorialidade, interdisciplinaridade e articulação com outras políticas públicas; a equidade, isto é, ao reconhecimento das desigualdades e tratamento conforme as necessidades distintas; e a descentralização político-administrativa que consiste 


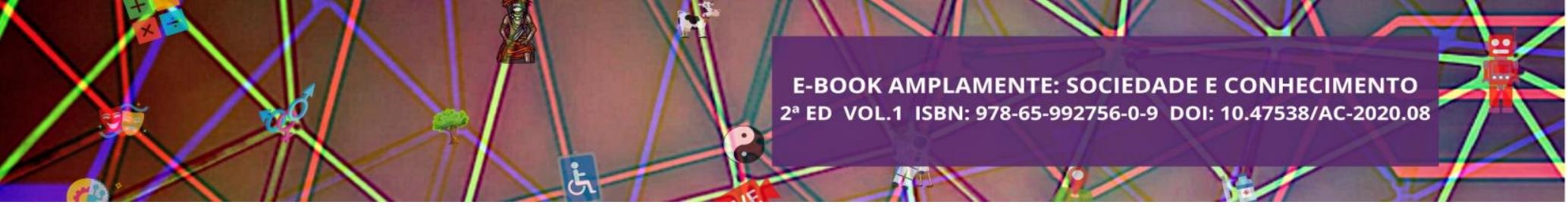

basicamente na responsabilidade dos três níveis de governo - federal, estadual e municipal.

A participação popular, na qual os/as usuários/as exercem o controle social e participam dos processos de formulação, execução e avaliação de políticas e ações, é também um princípio significativo. Vale ressaltar que é uma expressão do exercício da cidadania em regimes democráticos.

São diretrizes gerais da PNSIPN:

- Inclusão do tema racismo e saúde da população negra nos processos de formação e educação permanente dos trabalhadores e no exercício do controle social na saúde;

- Ampliação e fortalecimento da participação do Movimento Social Negro nas instâncias de controle social das políticas de saúde, em consonância com os princípios da gestão participativa do SUS, adotados no pacto pela saúde;

- Incentivo a produção do conhecimento científico e tecnológico em saúde da população negra;

- Promoção do reconhecimento dos saberes e práticas populares de saúde, incluindo aqueles preservados pelas religiões de matrizes africanas;

- Implementação do processo de monitoramento e avaliação das ações pertinentes ao combate ao racismo e à redução das desigualdades étnico-raciais no campo da saúde nas distintas esferas do governo;

- Desenvolvimento de processos de informação, comunicação e educação, que desconstruam estigmas e preconceitos, fortaleçam uma identidade negra positiva e contribuam para a redução das vulnerabilidades.

A garantia e a ampliação do acesso da população negra residente em áreas urbanas, rurais, e florestas às ações e serviços em saúde; a identificação, prevenção e combate dos casos de abuso, exploração e violência e a identificação das necessidades em saúde encontram-se inseridas no rol de objetivos específicos.

A partir de tais considerações é possível apreender a importância da construção e implementação da PNSIPN para a garantia do direito humano e constitucional à saúde. No entanto, algumas barreiras são identificadas no processo de implementação e é preciso desenvolver ações que as ultrapassem e garantam efetivamente a atenção integral e de qualidade, como destacaremos a seguir. 


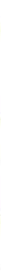

\section{BARREIRAS AO CUIDADO E AÇÕES NECESSÁRIAS NA PERSPECTIVA DA PNSIPN}

Retomando a discussão, a Política Nacional de Saúde Integral da População Negra objetiva a garantia da equidade para a efetivação do direito à saúde nas ações de promoção, prevenção, atenção, tratamento e recuperação de doenças e agravos, e a desconstrução do racismo institucional no âmbito do Sistema Único de Saúde.

Diversas barreiras impedem que os objetivos sejam concretizados em sua integralidade e derivam, ao menos em última instância, do racismo estrutural. A partir de uma perspectiva crítica e baseada em pressupostos do materialismo histórico compreendemos que o racismo é um fenômeno social historicamente determinado que serviu, e ainda serve, como dominação entre as classes sociais. As práticas racistas estão atreladas a concepção de uma suposta superioridade de uns sobre outros. A diversidade é transformada em desigualdade e esta se torna, por vezes, aceitável e justificável.

No Brasil, o racismo tem suas bases assentadas no regime da escravidão que teve início durante o processo de colonização e que perdurou por cerca de trezentos anos. Os resquícios de dado momento histórico são percebidos até os dias atuais, por meio de práticas de discriminação e inferiorização da pessoa negra em virtude de sua raça/cor. Diversos estudos mostram que a população negra é a mais atingida pelo desemprego, pelo analfabetismo e pelas condições de pobreza.

Deriva-se disso o chamado racismo institucional, que pode ser definido como:

[...] o fracasso coletivo de uma organização para prover um serviço apropriado e profissional para as pessoas por causa de sua cor, cultura ou origem étnica. Ele pode ser visto ou detectado em processos, atitudes e comportamentos que totalizam em discriminação por preconceito involuntário, ignorância, negligência e estereotipação racista, que causa desvantagens a pessoas de minoria étnica (DOCUMENTO DA COMISSION FOR RACIAL EQUALITY, 1999 apud SAMPAIO, 2003, p. 82).

Em outras palavras, o racismo institucional está presente no cotidiano do funcionamento das instituições, de maneira não explícita. $\mathrm{Na}$ área da saúde pode ser percebido na dificuldade de acesso aos serviços de saúde, na não-visibilidade das doenças que acometem mais a população negra e com isso a promoção, prevenção e tratamento não ocorre da maneira como deveria, nas formas de abordagem dos profissionais que, por vezes, é discriminatória. 


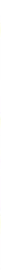

Uma barreira comumente percebida é a desigualdade racial em ações e atendimentos em saúde. Um estudo realizado pelas pesquisadoras Leal, Gama e Cunha (2005) buscou analisar as desigualdades sociais e no acesso e utilização de serviços de saúde em relação a cor da pele de puérperas que demandaram atenção hospitalar em razão do parto e mostrou que das mulheres que não conseguiram atendimento na primeira maternidade procurada $31,8 \%$ eram negras, $28,8 \%$ eram pardas e $18,5 \%$ eram brancas. No tocante a anestesia, a proporção de mulheres que não tiveram acesso foi maior entre negras e pardas, sendo $21,8 \%$ e $16,4 \%$ respectivamente. Com base nos resultados é possível perceber as desigualdades no atendimento em saúde.

A escassez de pesquisas científicas sobre as iniquidades que incidem na saúde da população negra é outro entrave. Conhecer as iniquidades em saúde, ou seja, as desigualdades que são sistemáticas, evitáveis e injustas, é de suma importância para pensar, elaborar, monitorar e avaliar ações mais efetivas. Outro problema é a falta de investimento de recursos necessários a efetivação das políticas e ao andamento do serviços. Quando não há recursos suficientes algumas ações são inviabilizadas.

Nesse sentido é essencial identificar as ações que podem ser desenvolvidas com o intuito de superar as barreiras e assegurar a garantia do direito à saúde. Reconhecer a ancestralidade e os valores culturais étnico-raciais está entre elas. Os/as profissionais que trabalham nas unidades de saúde devem realizar o levantamento de informações acerca da raça/cor, da religiosidade e das práticas de saúde tradicionais e afrobrasileiras, como também conhecer os valores culturais relacionados à memória, à ludicidade, ao cooperativismo, à religiosidade, à musicalidade etc., resgatando-os no processo de atendimento. Nessa perspectiva, uma estratégia possível de ser implementada é a pesquisa local sobre as histórias familiares da comunidade com vistas ao resgate da identidade e do fortalecimento de vínculos entre profissionais e usuários/as e de usuários/as entre si.

Outro aspecto a ser considerado é o da atualização e formação continuada sobre as principais doenças que acometem a população negra da região em que a unidade de saúde está instalada, para que se possa pensar em ações de promoção, prevenção e tratamento considerando as particularidades e realidade local. Ações de educação em saúde com os/as usuários/as são estratégias para a construção do autocuidado apoiado e da autonomia destes. Soma-se a isso à integração de práticas culturais de matrizes 


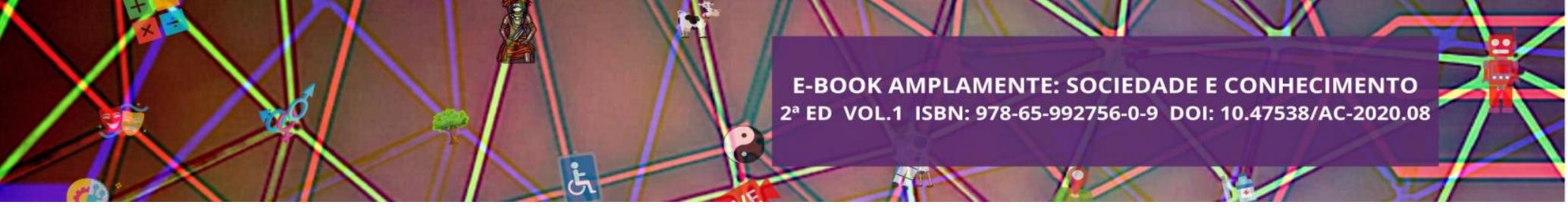

africanas nos planos terapêuticos, considerando que algumas práticas tradicionais podem auxiliar de certa maneira no tratamento.

A escuta ativa e a humanização no atendimento também contribuem para a qualidade da atenção ofertada. Os/as profissionais precisam estar atentos às necessidades que não são explícitas, pois estas podem refletir em um cuidado precário ou deficitário. Por fim, sinalizamos que também é necessário o maior investimento de recursos para a execução de políticas e serviços, porque a fragilidade no financiamento repercute na forma que a atenção é ofertada.

\section{CONCLUSÃO}

Observamos, com este estudo inicial, que a construção da Política Nacional de Saúde Integral da População Negra se constitui como um marco na luta e na defesa do direito à saúde integral, universal e de qualidade da população negra. Contudo, algumas barreiras impedem a sua efetiva implementação no Sistema Único de Saúde e requerem intervenções das instituições, dos/as profissionais e dos/as usuários/as.

\section{REFERÊNCIAS}

BRASIL. Constituição (1988). Constituição da República Federativa do Brasil. Brasília, DF: Senado Federal: Centro Gráfico, 1988.

BRASIL. Ministério da Saúde. Política Nacional de Saúde Integral da População Negra. 2007.

KALCKMANN, Suzana. SANTOS, Claudete Gomes dos. BATISTA, Luiz Eduardo. CRUZ, Vanessa Martins da. Racismo institucional: um desafio para a equidade no SUS?. Saúde e Sociedade. São Paulo, v. 16, n. 2, p. 146-155, 2007.

LEAL, Maria do Carmo. GAMA, Silvana Granado Nogueira da. CUNHA, Cynthia Braga da. Desigualdades raciais, sociodemográficas e na assistência ao pré-natal e ao parto, 1999-2001. Revista de Saúde Pública. São Paulo, 39(1):100-7, 2005.

SAMPAIO, Elias de Oliveira. Racismo Institucional: desenvolvimento social e políticas públicas de caráter afirmativo no Brasil. Interações Revista Internacional de Desenvolvimento. Campo Grande, v.4, n. 6, p. 77-83, 2003. 


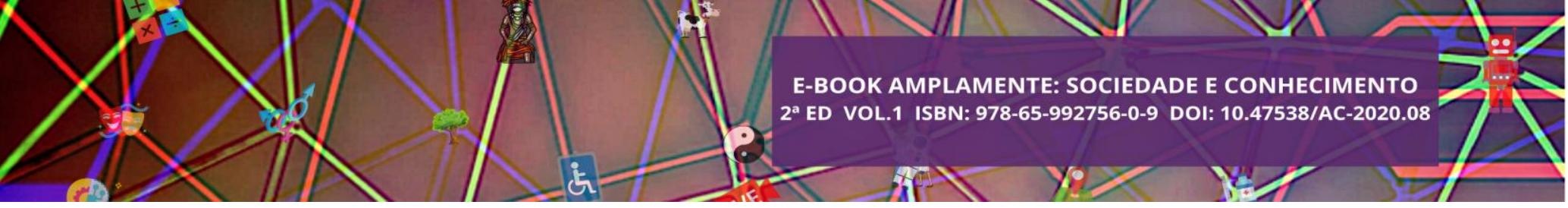

Estes espaços de convivência atraem classes sociais diversas com estratégias criativas diversificadas (música, comércio, lazer, entreterimento, conhecimento) que fomentam a economia em tempos de crise; e a convivência gera o bem-estar social, reduz a criminalidade, o estress, melhora a interação dos indivíduos com a cidade, cuidando da mesma. Reduz o desemprego, fomentando o trabalho autônomo.

De acordo com a Superintendência de Desenvolvimento da Economia Criativa de Mato Grosso: entre junho de 2015 - quando foram iniciadas as discussões acerca da economia criativa na Secretaria de Estado de Cultura - e dezembro de 2016, foram realizadas diversas atividades que contribuíram significativamente para inicio do desenvolvimento da economia criativa em Mato Grosso e para que, atualmente, o Estado seja reconhecido nacionalmente como um dos melhores ecossistemas de economia criativa e inovação do Brasil.

Percebe-se que os dados comprovam que o Estado de Mato Grosso obteve um crescimento considerável nesse segmento de atividade, sendo que dependerá de incentivos governamentais para que avance economicamente.

A pesquisa se justifica pela relevância econômica e social que o tema apresenta frente ao crescimento do Estado de Mato Grosso.

O objetivo desse estudo foi promover uma reflexão no que se refere ao aproveitamento de espaços de conveniência social em lugares que favoreçam o bemestar com sustentabilidade, a partir da economia criativa, nos ramos da cultura regional, lazer e artesanato.

\section{METODOLOGIA}

Para realização da pesquisa, tendo em vista os limites e possibilidades da mesma, foi realizado um diagnóstico em pesquisa exploratória sobre a região, na fase inicial, para delimitar os locais onde a pesquisa será realizada e os ramos de atividades. A abordagem é qualitativa e em cada local será realizado um estudo de caso.

O estudo de caso, para a compreensão de um caso particular em sua complexidade. De acordo com Stake:

A importância de algumas conclusões, ou resultados não dependem da possibilidade de generalizá-la a uma população (conjunto) de casos, o caso pode também não ser representativo, mas o estudo aprofundado de um problema escolar local pode ser iluminativo, isto é, 


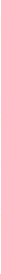

esclarecedor, para os educadores em outras escolas e em outros países

(STAKE, 2000, p. 15).

Neste sentido, para Stake, pode-se falar da possibilidade de generalização, na medida em que não se trata da "generalização científica", constituída e organizada através da experimentação e da indução. Este define,

O estudo de caso como 'generalização naturalística', onde o pesquisador primeiro e o leitor sucessivamente, encontram analogias e diferenças relativas a sua própria experiência. E como experiências e pessoas são diferentes, as generalizações também podem sê-lo, razão pela qual se impõe a necessidade de, no relato, fornecer um material rico e particularizado (STAKE, 2000, p. 28).

Os instrumentos utilizados são: observações, questionários e diário de campo; a amostragem dependerá da seleção a ser realizada na primeira etapa diagnóstica. $\mathrm{O}$ questionário se constitui num instrumento para obter informes através da fala dos atores sociais. Na seleção de sujeitos, os critérios de inclusão serão aqueles que possam oferecer dados significativos para o estudo. As questões do questionário foram definidas posteriormente, devido à necessidade de delimitação dos locais e de conhecimento exploratório da região, para especificar as questões, conforme os sujeitos e ramos de atividades.

Na medida do possível a observação se pautou na construção de alguns critérios baseados na diversidade, ou seja, os recortes foram feitos em função da possibilidade de analisar diferentes aspectos, tais como a constituição profissional, formação cultural e situação socioeconômica, índices de desenvolvimento, dentre outros.

A análise será realizada a partir dos dados coletados, dos indicadores econômicos e possíveis tratamentos estatísticos dos resultados.

\section{FUNDAMENTAÇÃO TEÓRICA}

Marino et al. (2012) realizaram uma revisão sistemática, encontrando 40 artigos, publicados no período de 1990 a 2011, abordando a criatividade e a inovação que tornaram-se temas essenciais nos ambientes organizacionais. No artigo, os resultados encontrados na pesquisa são apresentados de forma bem didática e de fácil compreensão, através de tabelas e gráficos.

As definições de criatividade encontradas nos artigos, reportam à capacidade, geração de ideias, desejo de criar, processo mental; dentre outros elementos. Destaca-se, 


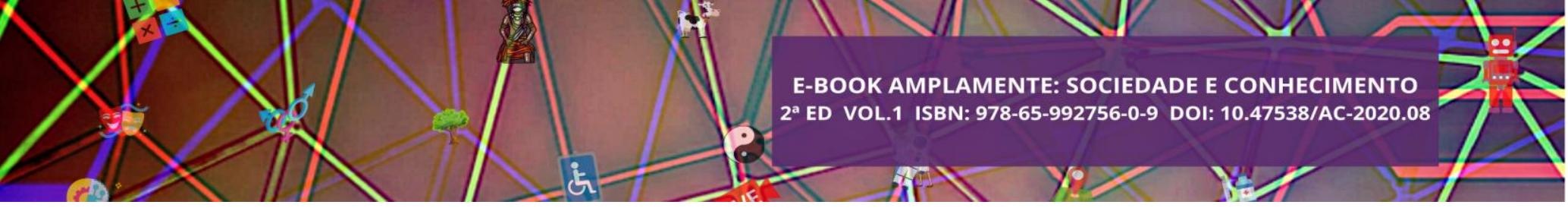

do estudo realizado, a análise dos fatores estimuladores e inibidores da criatividade; dos estimuladores foram alencados: - Ambiente adequado; - Cultura organizacional; Multidisciplinaridade; - Interdisciplinaridade; - Mudança de rotina; - Quebra de padrões e mente aberta; - Confiança; - Motivação; - Autonomia. E dos inibidores: - Paradigmas; - Conflitos; - Pressão para criar; - Alto nível de estresse ocupacional; - Tensão nos trabalhadores.

Nas mais diversas áreas do conhecimento, a criatividade apresenta sua relevância e contribuição para o ser humano. De acordo com esta pesquisa, uma grande parcela dos estudos publicados estão atrelados ao ramo da Psicologia. Além disso, verificou-se que as publicações apresentam ligação com a situação do cenário atual do mercado, em que a exigência por qualificação de serviços ou produtos é cada vez maior e a capacidade criativa torna-se gradativamente um diferencial competitivo para as organizações (MARINHO et al. 2012, p. 4).

Os autores propõem que a criatividade é aliada ao processo de inovação, seja na concepção, no desenvolvimento ou no seu aprimoramento, e pode ser apresentada de diversas formas. Preconizam o modelo integralista (interação entre criatividade e inovação). Consideram que as pesquisas nesta área poderia focar especificamente a criatividade e inovação de produtos e utilizar métodos de pesquisa aplicados, tais como a pesquisa-ação. Acrecenta-se ao que os autores apontam, a necessidade de pesquisas com métodos de pesquisa aplicada também na área econômica, com cálculos de estatística avançada para maior confiabilidade e segurança dos resultados.

Ao abordar a inovação e a criatividade, remonta-se a economia criativa. Indústrias Criativas: definição, limites e possibilidades, é um artigo que aborda o tema das indústrias criativas (BENDASSOLLI et al. 2009), este que refere-se ao segmento no ramo que envolve setores de serviços com atividades criativas e/ou artísticas diversas, os autores buscam conceituar os diversos usos do termo e diferenciar o mesmo da noção de indústria cultural.

Na década de 1990, o governo inglês define as indústrias criativas, como as de:

Publicidade, arquitetura, mercado de artes e antiguidades, artesanato, design, design de moda, cinema, software, softwares interativos para lazer, música, artes performáticas, indústria editorial, rádio, TV, museus, galerias e as atividades relacionadas às tradições culturais (BENDASSOLLI et al. 2009, p. 11). 


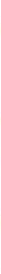

E a partir de estudos econômicos, percebeu-se o crescimento deste segmento. Os autores analisam diversas definições de vários autores para o termo indústrias criativas e percebem que a criatividade, a variedade, o tratamento da cultura como objeto cultural e a noção de propriedade intelectual são elementos que permeiam a definição deste setor.

As premissas que envolvem os negócios neste ramo, referem-se a interrelação entre arte, negócios e tecnologia; além da preponderância dos símbolos e signos sobre produtos materiais. Segundo os autores, a partir dos estudos realizados é possível perceber três grandes blocos de indústrias criativas; sendo que cada um deles denotam um elemento primordial para o ramo: - criatividade (enquanto forma de produção); variedade (como característica do produto); - consumo cultural (característica do consumo).

A partir dessas análises e de um exame da literatura, podem-se agrupar as características das indústrias criativas em três grandes blocos: o primeiro bloco refere-se a uma forma de produção que tem a criatividade como recurso-chave, que valoriza a arte pela arte, que fomenta o uso intensivo de novas tecnologias de informação e de comunicação, fazendo uso extensivo de equipes polivalentes; o segundo bloco abrange os contornos específicos dos produtos gerados, tais como a variedade infinita, a diferenciação vertical e a perenidade; e o terceiro bloco representa uma forma particular de consumo, que possui caráter cultural e apresenta grande instabilidade na demanda (BENDASSOLLI et al. 2009, p. 13).

A mudança da terminologia de indústria cultural para indústria criativa é associada pelos autores com uma conotação mais positiva da relação entre arte, tecnologia e negócios; no entanto, é preciso que aja pesquisas mais aprofundadas, que investiguem os negócios neste ramo e as políticas públicas para verificar se realmente esta mudança terminológica não é apenas uma renovação semântica.

Em seu artigo Alencar (1995), faz um recorte temático em relação às diversas problemáticas vividas hoje nas organizações, sendo abordado no mesmo: características de um clima favorável à criatividade nas organizações; e - o processo de resolução criativa de problemas.

Um clima favorável ao desenvolvimento de inovações e possibilidades criativas, perpassa por alguns elementos tais como: - Autonomia; - Sistema de premiação dependente do desempenho; - Apoio à criatividade; - Aceitação das diferenças e interesse pela diversidade entre os membros; - Envolvimento pessoal; - Apoio da direção. Com estes elementos presentes nas organizações, facilmente os colaboradores 


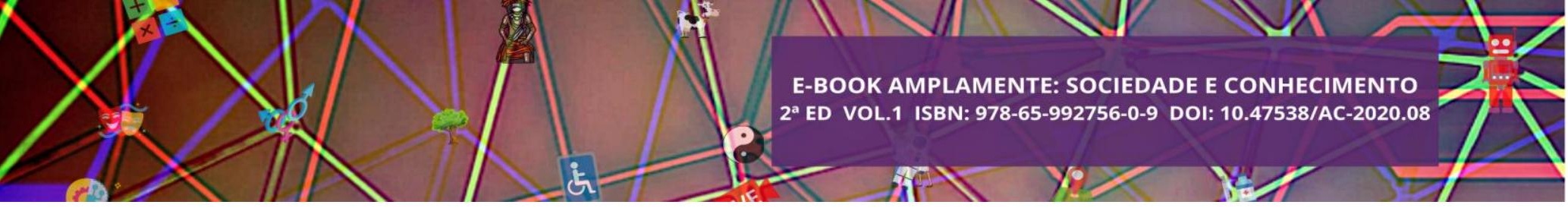

terão suas opiniões respeitadas, compartilhadas e até desenvolvidas em propostas concretas de inovação.

Já o processo de resolução criativa de problemas é um movimento que pode estar atrelado ao cotidiano das organizações:

Para tal, a melhor estratégia é conciliar o domínio do conhecimento com a aplicação de técnicas adequadas, como o brainstorming ("tempestade de ideias") ou a listagem de atributos, as quais favorecem a emergência de muitas respostas (ALENCAR, 1995, p. $10)$.

E após este processo inicial, segue-se a tentativa de respostas aos questionamentos levantados até o estabelecimento de ações.

A autora finaliza o artigo destacando a importância do favorecimento de condições para desenvolvimento criativo do ser humano em todos os âmbitos:

Para finalizar, destacamos que a inovação é forçosamente um desafio. $\mathrm{Na}$ sociedade atual, é também uma necessidade. O que importa é promover condições para o desenvolvimento das potencialidades presentes em todo ser humano e despertar a consciência das organizações para as potencialidades de seus recursos humanos, que na maioria das vezes não têm sido devidamente reconhecidas e aproveitadas (ALENCAR, 1995, p. 11).

Sendo assim, os autores apontam a criatividade e inovação como elementos primordiais para a economia atual; e a economia criativa ou indústria criativa, como área em crescimento, que carece de estudos acerca da mesma.

\section{RESULTADOS E DISCUSSÃO}

Os dados do Instituto Brasileiro de Geografia e Estatística - IBGE apontam características do cenário regional, que permitem compreender social e economicamente a economia da região.

Tabela 1 - Área, População, IDH e PIB per capita. 


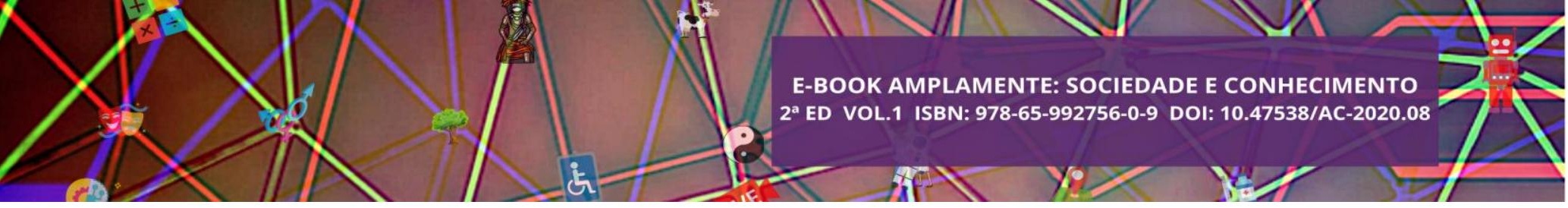

Tabela 3 - Trabalho e rendimento

\begin{tabular}{cc}
\multicolumn{2}{c}{ TRABALHO E RENDIMENTO } \\
\hline $\begin{array}{c}\text { Salário médio mensal dos trabalhadores } \\
\text { formais [2017] }\end{array}$ & $\mathbf{4}$ salários mínimos \\
Pessoal ocupado [2017] & $\mathbf{2 5 9 . 7 5 7}$ pessoas \\
População ocupada [2017] & $\mathbf{4 4 \%}$ \\
$\begin{array}{c}\text { Percentual da população com rendimento } \\
\text { nominal mensal per capita de até } 1 / 2 \\
\text { salário mínimo [2017] }\end{array}$ & $\mathbf{3 0 , 7} \%$ \\
\hline
\end{tabular}

Fonte: IBGE, 2020

Percebe-se que o rendimento da maior parte da população brasileira é próximo ou inferior ao salário mínimo determinado pelo governo, evidenciando que a base da pirâmide econômica aumenta ano após ano e o topo diminuindo ainda mais. Dessas pessoas estão inclusas também àquelas que trabalham na informalidade que é sabido que nos últimos anos e com o aumento da taxa de desemprego teve um aumento considerável.

Segundo os levantamentos do IBGE, o salário médio mensal em 2017, era de 4 (quatro) salários mínimos.

Em 2017, o salário médio mensal era de 4 (quatro) salários mínimos. A proporção de pessoas ocupadas em relação à população total era de $44.0 \%$. Na comparação com os outros municípios do estado, ocupava as posições 1 de 141 e 2 de 141, respectivamente. Já na comparação com cidades do país todo, ficava na posição 30 de 5570 e 112 de 5570, respectivamente. Considerando domicílios com rendimentos mensais de até meio salário mínimo por pessoa, tinha $30.7 \%$ da população nessas condições, o que o colocava na posição 134 de 141 dentre as cidades do estado e na posição 4549 de 5570 dentre as cidades do Brasil.

A Tabela 4 demonstra os percentuais econômicos gerais da cidade de Cuiabá em 2017 onde a diferença entre a receita e a despesa se registra em 110.086,81 R \$ (x1000) em 2017. 


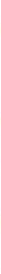

O Arranjo Produtivo Local (APL) de Economia Criativa do Vale do Rio Cuiabá constitui de exemplo de um projeto aprovado em edital do Ministério do Desenvolvimento, Indústria e Comércio Exterior (Mdic) em 2015, com duração de dois anos, que teve como objetivo fomentar a cadeia produtiva da cultura na região. A meta do projeto é construir uma rota turístico-cultural, em que o turista conheça o melhor de Mato Grosso. Segundo gestores da área cultural de Mato Grosso, investimentos da economia criativa tem retorno imediato para toda comunidade e também para os turistas.

O Secretário de Estado de Cultura, Fabiano Prates, destacou a importância do APL para o fomento e a preservação de manifestações culturais como o cururu e o siriri, cartões de visita do Estado. "O mais importante é fomentar estas manifestações, não as deixar morrer. Mato Grosso fica muito feliz com este presente. E nós também, ao entregarmos a pasta de Cultura com os recursos necessários para que esse projeto aconteça”. (...) A presidente do Comitê Gestor do APL, Cínthia Mattos, salientou não se tratar de uma ação de governo, mas sim de toda a sociedade, conclamando os atores sociais principais - os artistas e parceiros - para que continuem contribuindo. "Temos uma cultura pujante e belezas naturais riquíssimas, agora só falta mostrá-las. Para isso é preciso contar com a parte mais importante, que são os atores sociais. Com o APL, poderemos dinamizar estes setores e oferecer como produto final um roteiro completo a quem aqui vier. Queremos que o turista tenha condições de usufruir da Maria Izabel, da viola de cocho, dos quintais de siriri, da casa cuiabana, das belezas do Pantanal, enfim, de tudo o que o Estado tem a oferecer em termos de turismo e cultura". Cínthia é coordenadora de ações artístico-culturais da SEC-MT.

Observando a composição do APL, percebe-se a articulação do segmento cultural em Mato Grosso e como o mesmo atende ao desenvolvimento sustentável e regional: Associação Flor; Associação Morielo São Gonçalo Beira Rio, Associação de Artesãos São Gonçalo Beira Rio; Associação Cururueiro Coxipó São Francisco; SICME/PAB (Programa Artesanato Brasileiro), Centro Histórico Cultural Holístico $(\mathrm{CCH})$; Associação Quintal; Peixaria Coxipó São Geraldo Beira Rio, AMAV/ABDMT; Cia das Artes do Brasil; Secretaria de Estado de Cultura; Federação de Cururu e Siriri; TV AL-MT; Unic Gastronomia; Ponto de Cultura; SEDRAF (Secretaria de Estado de Desenvolvimento Rural e Agricultura Familiar - Sedraf), CIDES-URC; Secretaria de Estado de Desenvolvimento do Turismo (SEDTUR); Secretaria de Estado 


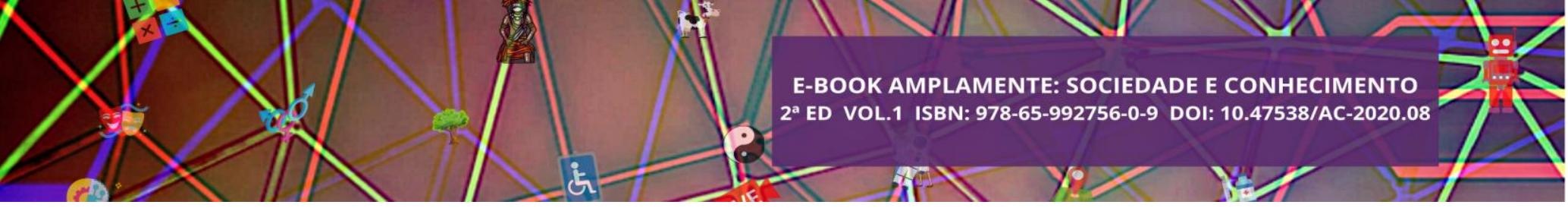

de Meio Ambiente (SEMA); Secretaria de Estado de Trabalho e Assistência Social (SETAS-MT); Nobres Vozes; APPA; Grupo Cururu e Siriri Raízes Cuiabanas; Associação Mato-grossense dos Cegos; Ponto de Cultura Instituto dos Cegos; Trade Turístico; JY Okamura Assessoria e Consultoria, Lamiré Cinema e Vídeo e Instituto Ecoss.

A cultural regional é outro aspecto que a economia criativa fomenta, o mestre cururueiro Benedito Pinto de Moraes (coordenador do Grupo Folclórico de Cururu, Siriri e Reza Cantada do Pantanal).

São precisos pelo menos seis meses para se formar um novo cururueiro, sentimos a dificuldade em ter infraestrutura para repassar aos nossos jovens este conhecimento. Sem investimento, a dança tradicional, os costumes tendem a morrer. Esperamos que com este investimento, possamos crescer cada vez mais no Estado.

Antônio João Batista Campos de Arruda, o Tote, um dos representantes da dança do Congo: "Esta dança é a manifestação de nossos ancestrais africanos. Lutamos por sua preservação".

\section{CONCLUSÕES}

Até o momento foi possível observar que o entretenimento favorece o bem-estar social e fomenta a economia, trazendo rentabilidade ao Estado; envolvendo ramos de atividades dos mais diversos, meio ambiente e espaços diferenciados e alternativos, que constituem processos de sociabilidade e inclusão social, além de formas de interdisciplinaridade cultural e inovação.

Foi possível perceber que as soluções para as novas exigências de diversidade do mercado consumidor perpassam uma gestão participativa, um aproveitamento sistemático da criatividade e uma efetividade nos empreendimentos.

Mato Grosso é um Estado de muitas belezas naturais e o turismo precisa se desenvolver com mais efetividade e responsabilidade sustentável, sendo que se faz necessário uma articulação do segmento cultural no Estado que atenda ao desenvolvimento sustentável e regional e promova o crescimento dessa área da economia criativa com inovações, diversidade cultural, sustentabilidade e inclusão social na região do vale do rio Cuiabá. 


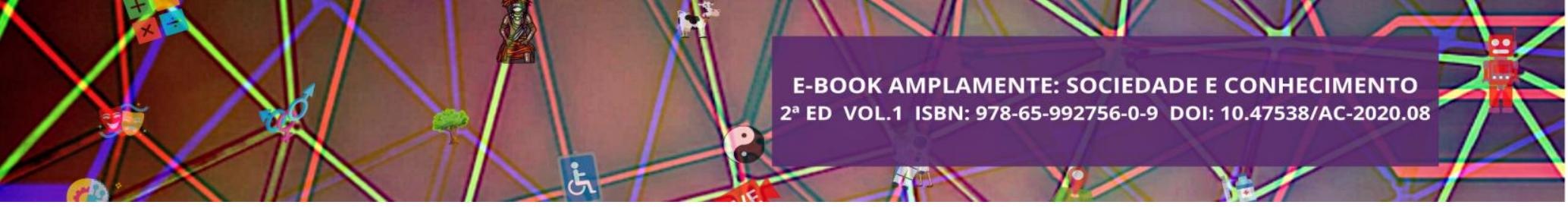

No entanto, ainda necessita de um trabalho mais efetivo nesta área para que possa haver um desenvolvimento mais efetivo e consistente; para isso faz-se necessária a criação de políticas públicas e incentivos atrativos para que tragam novos colaboradores/investidores nesta área da economia criativa.

\section{REFERÊNCIAS}

ALENCAR, E. L. S. Desenvolvendo a Criatividade nas Organizações: o Desafio da Inovação. RAE - Revista de Administração de Empresas São Paulo, v. 35, n. 6, p. 611 Nov./Dez. 1995.

BENDASSOLLI, P. F.; WOOD JR., T.; KIRSCHBAUM, C.; CUNHA, M. P. INDÚSTRIAS CRIATIVAS: DEFINIÇÃO, LIMITES E POSSIBILIDADES. RAE, São Paulo, v. 49, n.1, jan./mar. 2009. p. 010-018.

IBGE - Instituto Brasileiro de Geografia e Estatística. Brasil, Mato Grosso, Panorama. Disponível em: https://cidades.ibge.gov.br/brasil/mt/cuiaba/panorama. Acesso em 29 de maio de 2020.

MARINHO, E. S.; FAGUNDES, L. F.; SILVA, M. S. A.; SQUIRES, M.; GONZALEZ, A. O. A. Relação entre criatividade e inovação de produtos: uma revisão bibliográfica sistemática. Anais... XXXII ENCONTRO NACIONAL DE ENGENHARIA DE PRODUCAO. Desenvolvimento Sustentável e Responsabilidade Social: As Contribuições da Engenharia de Produção Bento Gonçalves, RS, Brasil, 15 a 18 de outubro de 2012.

MATO GROSSO. Economia. s.d. Disponível em: http://www.mt.gov.br/economia. Acesso em 07 de janeiro de 2018.

MATO GROSSO. LEI COMPLEMENTAR N ${ }^{\circ}$ 359, DE 27 DE MAIO DE 2009. Palácio Paiaguás, em Cuiabá, 27 de maio de 2009, $188^{\circ}$ da Independência e $121^{\circ}$ da República. Disponível em:

http://app1.sefaz.mt.gov.br/Sistema/legislacao/LeiComplEstadual.nsf/9733a1d3f5bb1ab 384256710004d4754/9fcbd862aa45ffa8042575c40046cb9d?OpenDocument. Acesso em 29 de maio de 2020.

MATO GROSSO. Programa de Desenvolviemnto de Economia Criativa. s.d. Disponínel em:

http://mtcriativo.mt.gov.br/images/RELATORIO_Economia_Criativa.pdf. Acesso em 08 de janeiro de 2018.

MATO GROSSO. Secretaria de Estado de Cultura, Esporte e Lazer. APL da Economia Criativa é apresentado em Cuiabá, 2014. Disponível em:

http://www.cultura.mt.gov.br/-/apl-da-economia-criativa-e-apresentado-em-cuiaba. Acesso em 08 de janeiro de 2018.

STAKE, R. E. A arte da Investigação com Estudo de Caso. Lisboa: Fundação Calouste Gulbenkian, 2000. 


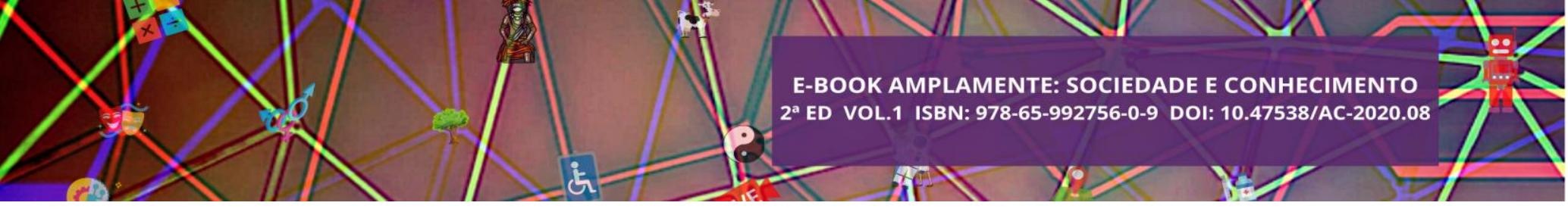

\title{
CAPÍTULO XXI
}

\author{
EDUCAÇÃO AMBIENTAL PARA A DEFESA JURÍDICA DO MEIO \\ AMBIENTE
}

\author{
Ana Flávia Monteiro Diógenes ${ }^{115}$; Leda Mourão da Silva ${ }^{116}$
}

DOI - Capítulo: 10.47538/AC-2020.08-21

\section{RESUMO:}

O estudo pautou-se em analisar o tema sobre a educação ambiental para a defesa jurídica do meio ambiente, e como problemática, verifica-se a necessidade de existir uma educação ambiental para que seja possível a utilização pela coletividade dos instrumentos jurídicos disponíveis para a defesa e a preservação do direito fundamental ao meio ambiente equilibrado, correlacionando-se, inclusive, com a dignidade da pessoa humana e o mínimo existencial. O objetivo geral foi apresentar o direito fundamental ao meio ambiente equilibrado e sua interação com a dignidade da pessoa humana e o mínimo existencial garantido por meio de documentos legislativos a educação ambiental desde os primeiros anos no ensino de crianças e adolescentes. Posteriormente, como objetivos específicos, pautou-se em analisar a educação ambiental como importante meio de ser garantido cada vez mais a exigência e fiscalização do cumprimento do dever estatal em manter diretrizes traçadas para a preservação do meio ambiente, além de analisar o instrumento jurídico para a defesa do meio ambiente, principalmente em razão da ação popular. $O$ artigo conta com menções de obras doutrinárias como Ingo Wolfgang Sarlet, André Ramos Tavares, Gilmar Mendes e Walber de Moura Agra, além de artigos científicos devidamente publicados no meio eletrônico. Como conclusão, ressalta-se a utilização da educação ambiental como meio e forma de se garantir a utilização da ação popular para a garantia do direito ao meio ambiente equilibrado, sem a devida formação e informação, torna-se cada vez mais dificultosa a atuação por meio de ações populares que ensejam a cobrança de melhores fiscalizações e políticas públicas pelo poder público.

PALAVRAS-CHAVE: Educação Ambiental. Ação. Popular. Coletividade. Dignidade.

\section{INTRODUÇÃO}

O presente estudo aborda o tema sobre a necessidade de se criar melhores métodos para educação ambiental em razão de se tratar o meio ambiente como um direito fundamental e que traz também a garantia da dignidade da pessoa humana no

115 Graduada em Direito (UEA), especialista em Direito (UFAM). Docente de Direito (IFAM). E-mail: anaflavia_diogenes@hotmail.com

116 Bacharel em Direito (UEA), Pós-graduada em Direito Público com capacitação para o Ensino no Magistério Superior pela Faculdade Damásio. Advogada inscrita na OAB/AM n. ${ }^{\circ}$ 10276. E-mail: leda.mourao@gmail.com 


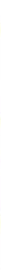

interior da individualidade do ser humano, bem como à coletividade que atua no meio em que está inserida.

Neste sentido, o artigo foi dividido em duas seções para apresentação da temática e problematização que se fundamenta em verificar que o direito ao meio ambiente equilibrado ressalta outros direitos corolários deste, como o direito à educação ambiental e a atuação na ação popular diante do direito à informação que advém juntamente com a educação ambiental.

Como metodologia utilizou-se o estudo em análise qualitativa em revisão bibliográfica, consultando principalmente doutrinas em direito constitucional e direitos humanos, além de artigos científicos que foram devidamente vinculados às revistas eletrônicas publicadas.

Na primeira seção, portanto, como objetivo geral, tem como escopo apresentar o direito fundamental ao meio ambiente equilibrado, e expor a dignidade da pessoa humana e o mínimo existencial correspondentes à garantia também de um direito ao meio ambiente equilibrado, sem esgotar o assunto, extenso com a produção acadêmica e doutrinária.

Após constatar esses aspectos, como objetivo específico, cumprido na segunda seção, apresenta-se a educação ambientação com o ressalte sobre sua importância para as demais garantias que são inseridas em respeito de matéria ambiental, demonstrando alguns títulos legislativos que se inferem na educação ambiental, e por fim, a utilização de instrumentos, principalmente a ação popular, para atuação da coletividade. Para efetivar e que seja possível o uso da ação popular, conclui-se que é necessária a garantia do direito à educação ambiental e à informação, sem esses dois direitos, torna-se dificultosa a utilização como instrumento de proteção jurídica ao meio ambiente.

\section{O DIREITO FUNDAMENTAL AO MEIO AMBIENTE EQUILIBRADO}

O meio ambiente no Brasil está devidamente inserido como um direito fundamental no texto da Constituição Federal de 1988. A partir dessa inserção, a doutrina e o ordenamento jurídico brasileiro atribuem suas produções no sentido de tratá-lo como um direito fundamental de terceira dimensão ${ }^{117}$. A qualidade e o

117 De forma breve, de acordo com Mendes e Branco (2018, p. 199-201), a terminologia atribuída às gerações (ou dimensões) dos direitos fundamentais em razão da evolução e constituição dos direitos, as três dimensões estão dispostas com o lema da Revolução Francesa: liberdade, referindo-se aos direitos de primeira dimensão que são os 


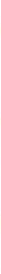

equilíbrio do meio ambiente são inseridos no sentido do entendimento, o direito ao meio ambiente equilibrado e sadio tem como norteamento a adaptação das novidades constitucionais.

Mendes e Branco (2018, p. 202) afirmam que tanto os direitos de liberdade e o conteúdo que antes de surgirem as próprias gerações dos direitos já existiam, está de acordo com as reivindicações de justiça social e de adaptação do que trouxe também a terceira geração, incluindo o meio ambiente. A compreensão também do direito de propriedade e do atendimento da função socioambiental deve ser considerada como um avanço atual e que tende a crescer nas próximas décadas. Os autores ainda consideram que a partir desses ensejos, podem ocorrer ainda novos direitos que sejam adaptados aos antigos diante de novas exigências do momento, como os direitos das minorias, a garantia contra manipulações genéticas, e que traz à baila o avanço das ciências medicinais, biotecnológicas e sociais (MENDES; BRANCO, 2018, p. 203).

Em uma vertente coletiva, constata-se que o bem-estar social envolve a garantia de um meio ambiente ecologicamente equilibrado como está disposto no artigo 225 da Constituição Federal de 1988, além de inserir uma política de ordenamento urbano que passe a assegurar o bem-estar dos seus habitantes conforme o artigo 182. Essa dimensão coletiva do bem-estar social e o meio ambiente atribui-se à propriedade em geral, presente no inciso XXIII do artigo $5^{\circ}$ e do inciso III do artigo 170 , e em particular, sobre a propriedade industrial e imóvel tanto urbano como rural para o atendimento das suas funções sociais, como trouxe a obra de Barcellos (2018, p. 161).

Etimologicamente, "ambiente" advém do latim ambiens, entis, e que de acordo com Agra (2018, p. 860), significa rodear, envolver. Assim, conclui que é o local em que se vive, englobando os elementos naturais e os elementos que passam a ser modificados e criados pelos homens. Agra (2018, p. 860) ainda assevera que o meio ambiente será um patrimônio público, e como o caput do artigo 225 da Constituição de 1988 aborda, será um bem de uso comum do povo, de forma a ser protegido pelo uso coletivo. Considera-se, nesta seara, que o meio ambiente deve ser entendido como algo a ser protegido por todos, sem exceção, tanto pelas pessoas físicas no interior dos lares e

direitos de defesa, de liberdade, considerados como a abstenção do Estado para que a pessoa aja em liberdade sem ofender a liberdade do outro; os direitos de segunda dimensão remetem-se aos direitos sociais, dos trabalhadores, e conduzem o entendimento de que nesta dimensão é necessário a atuação do Estado para que sejam garantidos esses direitos; e os direitos de terceira dimensão, os titulares a coletividade e direitos difusos, concebidos a partir de uma proteção não somente do homem isoladamente, mas das coletividades, incluindo com o direito à qualidade do meio ambiente, o direito à paz, ao desenvolvimento, à conservação do patrimônio histórico e cultural. 


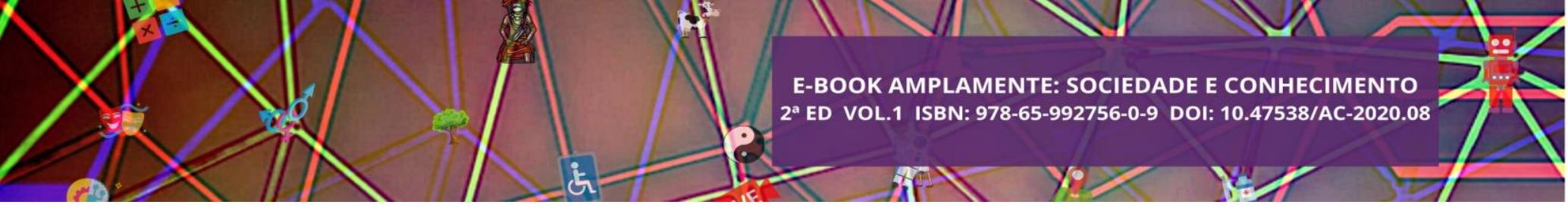

na atividade comum, como pelas pessoas jurídicas, com fábricas, indústrias e comércio agindo de acordo a manter o meio ambiente sadio. Esses elementos que devem ser observados envolvem "o solo, as águas, a flora e a fauna, bem como a preservação das áreas florestais, paisagísticas e outras riquezas naturais" (AGRA, 2018, p. 860).

O amparo ao meio ambiente, de acordo com Fiorillo (2001, p. 18) constata que o meio ambiente, como Agra (2018, p. 860) também afirmou, será tudo aquilo que se extrai e que circunda o ser humano, o termo "meio ambiente" costumava ser criticado por ser pleonástico, ou seja, redundante, pois o ambiente já é a constituição de se trazer o conteúdo da ideia de um "ambiente que circunda", tornando-se desnecessário o uso da palavra "meio", mas que perpetuou assim na construção acadêmica e legislativa. De todo modo, a preocupação com o meio se torna notadamente acentuada a partir de se perceber os evidentes estragos que a ação humana pode ocorrer na natureza, "só para se ter uma ideia das proporções já atingidas, basta lembrar o efeito estufa, a diminuição da camada de ozônio e outros tantos efeitos danosos" (AGRA, 2018, p. 861).

Assim, como inserção de um direito humano e fundamental, a proteção do ambiente no texto constitucional, pauta-se que deve ser assegurado demonstrando que o artigo 225 é um dos mais importantes neste tema, compreendendo como um direito em sentido amplo e que se decodifica em um conjunto diversificado e heterogêneo de posições jurídicas, inclusive no que correspondem as medidas, como tarefas e objetivos, aos poderes públicos, como bem inseriu Sarlet e Marinoni (2018, p. 723). O tema, portanto, aborda preceitos que se vinculam aos princípios e deveres que devem ser regidos em matéria da promoção e proteção ambiental, consagrados na normativa internacional, inclusive.

A seguir, correlacionando-se com a garantia do mínimo existencial e a dignidade da pessoa humana, pauta-se na análise da garantia e efetivação do respeito ao meio ambiente equilibrado como uma das premissas que devem acompanhar este direito fundamental.

\section{GARANTIA DO MÍNIMO EXISTENCIAL, DIGNIDADE DA PESSOA HUMANA E O RESPEITO AO MEIO AMBIENTE EQUILIBRADO}

A partir da revalorização dos direitos fundamentais que foram inseridos de forma extensa na Constituição Federal de 1988, percebe-se a correlação que pode existir entre a garantia do mínimo existencial e a dignidade da pessoa humana juntamente com 


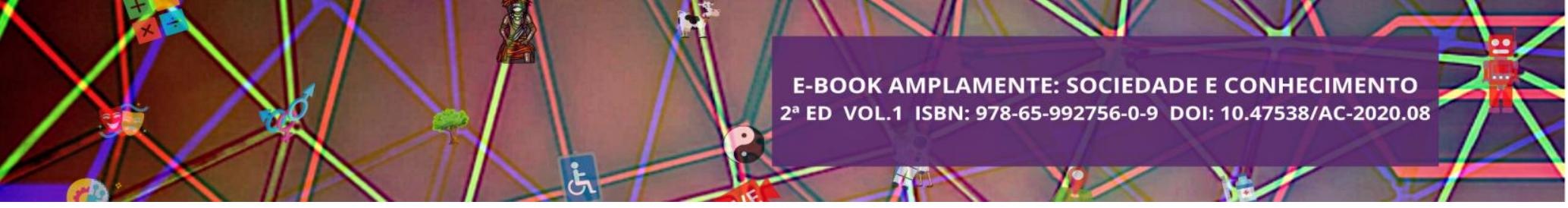

o respeito a ser atribuído ao meio ambiente equilibrado, enquanto também considerado como um direito fundamental, como visto anteriormente.

Neste ensejo, Tavares (2017, p. 130) expõe que a previsão expressa dos diversos direitos que até então não estavam presentes em outras constituições anteriores a de 1988, trouxe uma referência inequívoca sobre a sua incidência imediata, de forma a combater teorias que estavam em voga no Brasil, de que o rol extenso presente no texto Maior de 1988 reduziria a imperatividade dos mandamentos aos direitos fundamentais, e de forma contrária, abarcou a supremacia em entender a centralidade da dignidade da pessoa humana como estruturação para o Estado encontram-se proclamadas e com inovações, principalmente em razão do direito ao meio ambiente sadio.

A dignidade da pessoa humana está disposta em diversos dispositivos da Constituição Federal de 1988. Inicialmente no inciso III do artigo $1^{\circ}$ retrata que é um dos fundamentos para a formação do Estado Democrático de Direito a garantia da dignidade da pessoa humana. Posteriormente, no artigo 226, parágrafo sétimo sobre a determinação do planejamento familiar ser de livre decisão do casal com base na dignidade, e no artigo 227, traz à família, à sociedade e ao Estado o dever de assegurar a dignidade da criança, do adolescente e do jovem (BRASIL, 1988).

Com base nessa disposição, Ramos (2018, p. 84) explica que a dignidade humana "consiste na qualidade intrínseca e distintiva de cada ser humano, que o protege contra todo tratamento degradante e discriminação odiosa, bem como assegura condições materiais mínimas de sobrevivência”. Por sua vez, a dignidade consiste, como explica o autor, em um atributo que todo o indivíduo possui, inerente à sua condição de ser humano, e não importando qualquer outra condição referente à nacionalidade, opção política, orientação sexual, credo etc. Ramos (2018, p. 84) ainda assevera que diferente dos direitos de liberdade, igualdade, entre outros, a dignidade não possui um aspecto particular para a sua existência, mas sim, é uma qualidade inerente a todo ser humano que possui um valor e o identifica como tal, logo, "o conceito de dignidade humana é polissêmico e aberto, em permanente processo de desenvolvimento e construção" (RAMOS, 2018, p. 84).

Ramos (2018, p. 115) correlaciona o meio ambiente e a sua proteção como formas também de garantia do mínimo existencial e da dignidade humana ao afirmar sobre a introdução das regras tradicionais de interpretação que não são suficientes para a atualização dos direitos humanos. E dessa forma, as normas de direitos humanos devem 


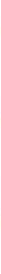

acompanhar o próprio avanço da sociedade, e com ela, adveio a proteção e a preservação do meio ambiente em um sentido amplo e ser garantido para toda a coletividade, não somente em uma esfera individualizada.

O mínimo existencial, por sua vez, embora também considerado como uma designação da vinculação dos direitos fundamentais sociais que trouxeram a garantia do mínimo existencial, este é considerado, como bem explana Sarlet e Marinoni (2018, p. 670), um alto grau de evolução de entendimento que se tornou evidente, embora o grau de relação que possa ser verificado na ordem doutrinária e jurisprudencial ainda é discutida. Por esta forma, busca-se correlacionar a garantia do mínimo existencial também com a garantia de um meio ambiente equilibrado e a necessidade de existir uma educação ambiental para que se formem cidadãos em busca da defesa e proteção ao meio ambiente.

\section{INSTRUMENTOS JURÍDICOS PARA A PROTEÇÃO DO MEIO AMBIENTE}

\section{A IMPORTÂNCIA DA EDUCAÇÃO AMBIENTAL COMO FORMAÇÃO DE CIDADÃO E DEFESA DO DIREITO FUNDAMENTAL AO MEIO AMBIENTE EQUILIBRADO}

Inicialmente, como marco da regulamentação em razão do meio ambiente e sua proteção, existe a Conferência de Estocolmo, do ano de 1968, que foi patrocinada pela Organização das Nações Unidas (ONU), que emitiu a Declaração de Estocolmo, que traçou os primeiros lineamentos de proteção à natureza. A legislação que traz a defesa e a proteção do meio ambiente, além do texto da Constituição Federal de 1988, conta com a Lei $n^{\circ}$ 6.938, de 31 de outubro de 1981 que abarcou uma definição sobre o termo do meio ambiente, e no inciso I do artigo $3^{\circ}$ trouxe como "o conjunto de condições, leis, influências e interações de ordem física, química e biológica, que permite, abriga e rege a vida em todas as suas formas" (BRASIL, 1981). A criação de diversos instrumentos normativos que buscam trazer maior proteção e defesa ao meio ambiente traz como resultado a atividade de diversos movimentos ecológicos.

Outro evento importante, verifica-se a ECO 92, realizada no Brasil, sendo um dos países mais influentes para discutir políticas de defesa do meio ambiente, segundo Agra (2018, p. 834). Foi publicada a Lei no 7.347 , de 1985, que criou a ação civil 


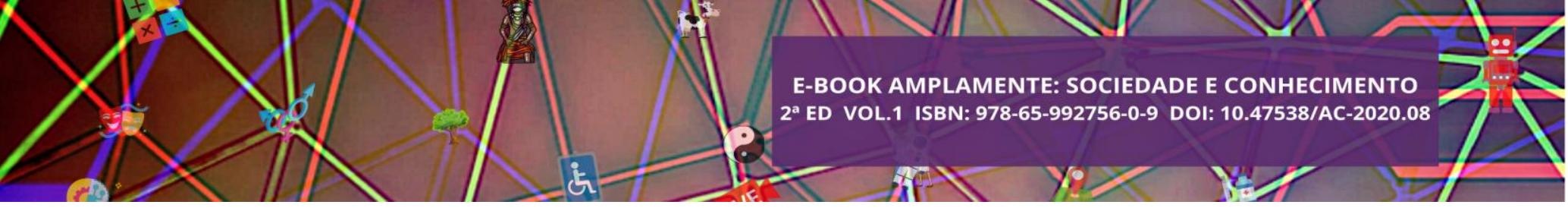

pública, instrumento jurídico importante que representa um outro avanço diante da consolidação da defesa da natureza que será abordado no próximo subitem. Contudo, o marco decisivo para o meio ambiente de fato foi a Constituição de 1988.

Não somente à atividade do Ministério Público, o papel da Defensoria Pública em razão da defesa dos direitos humanos, incluindo aqui o meio ambiente como um direito humano, inclusive, é de extrema importância para a defesa do meio ambiente, como preconiza o inciso $X$ do artigo $4^{\circ}$ da Lei Complementar $n^{\circ} 80 / 1994$ que afirma que as funções institucionais da Defensoria Pública, entre outras, será o de promover a mais ampla defesa dos direitos fundamentais dos necessitados, de forma a abranger os direitos individuais, coletivos, sociais, econômicos, culturais e ambientais, e são admissíveis todas as espécies de ações que são capazes para propiciar a tutela e efetivação do direito (MAZZUOLLI, 2014, p. 237).

A educação ambiental, como bem traz Jacobi (2003, p. 190), traz que a partir da Conferência Intergovernamental sobre Educação Ambiental que foi realizada em Tsibilisi nos Estados Unidos no ano de 1977 foi um marco diante do amplo processo em um nível mundial sobre a orientação de condições que fossem criadas para formas para uma nova consciência acerca do valor da natureza e da reorientação da produção de conhecimento em métodos interdisciplinares para a tratativa do meio ambiente. $\mathrm{O}$ autor ressalta que é a partir deste marco que surgem outros documentos que demonstram a necessidade de abordar a complexidade do tema em direito ambiental sobre a percepção de um processo de conscientização de novas racionalidades no espaço sobre a natureza, a fauna, a flora e o ambiente de forma geral.

Como bem traz o autor, "a realidade atual exige uma reflexão cada vez menos linear, e isto se produz na interrelação dos saberes e das práticas coletivas que criam identidades e valores comuns e ações solidárias diante da reapropriação da natureza" (JACOBI, 2003, p. 191). Dentro dessa perspectiva, existe a necessidade de que ocorra maior incrementação aos meios de informação e o acesso a eles para a educação ambiental ser, de fato, inserida desde os primeiros anos de estudo até a consolidação nos meios sociais, principalmente com a utilização da internet e das redes sociais.

Diante do artigo publicado por Higuchi e Azevedo (2004, p. 64), a questão ambiental se retrata como uma palavra em voga no século XXI, principalmente na última década, e que acarreta em diferentes modos que a sociedade humana pode se relacionar com o meio ambiente e aquilo que foi construído e aquilo que é natural. 


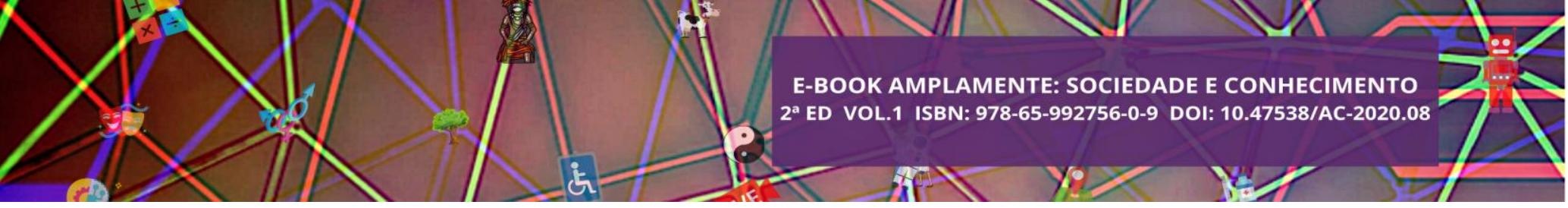

Propõem como formulação a educação ambiental e unificadora que pode transformar os meios os quais estão inseridos os brasileiros, implantando a educação ambiental nos currículos como um tema de debate e que retorna a disciplina como algo inserido em outros meios de análise, por exemplo, no ensino fundamental e médio, o meio ambiente é discutido nas diversas matérias, porém, não há uma matéria exclusiva que trate sobre o assunto como devidamente deveria ser abordado. E nos aspectos voltados para a comunidade e a formação cidadã em si, a abordagem do meio ambiente fica em um ponto tímido de debate.

Higuchi e Azevedo (2004, p. 66) expõem que o consenso que se chegou em iniciar a educação ambiental desde os primeiros anos das pessoas, passam a dar saltos importantes de evolução em razão de formar um processo de transformação e resgate de valores, cuidado e zelo com o meio ambiente em um sentido cada vez mais amplo. A crítica do autor é no sentido que cada vez mais se torna urgente que a sociedade reveja as relações que possuem com o mundo físico-natural e com o mundo social, "esse rever nos remete a um repensar as bases de sustentação do planeta Terra, desde as práticas mais elementares e aparentemente ingênuas do indivíduo, de jogar papel no chão, passando pelas práticas de consumo" (HIGUCHI; AZEVEDO, 2004, p. 66), e que complementam, até a elaboração e execução de políticas públicas que envolvam diretamente as pessoas e a coletividade de uma forma geral, sem que sejam práticas afastadas, tímidas e que não envolvem os cidadãos em si.

A solução intentada pelos autores é que ocorram incorporações dimensionadas voltadas para um trabalho popular nas comunidades, pressupondo: (i) processo de identificação e conquista dos atores sociais envolvidos; (ii) busca por parceria e programas elaborados de acordo com os interesses e perspectivas das populações (HIGUCHI; AZEBEDO, 2004, p. 67). Assim, conclui-se, que a dimensão de um processo educativo deve buscar o envolvimento de todas as pessoas para a construção de um novo paradigma que contemplo os anseios populares a uma melhor qualidade de vida, dignidade da pessoa humana, e atendimento do mínimo existencial.

Coaduna sobre essa percepção, que a demanda atual que a sociedade atualmente se encontra, pode ser percebida como uma maior motivação pelos brasileiros em se inferir em discussões mobilizadas nas redes sociais voltadas para a preservação e proteção do meio ambiente de forma mais efetiva, face a transferência e correlação de informações em uma velocidade maior que anteriormente era visto quando ainda não 


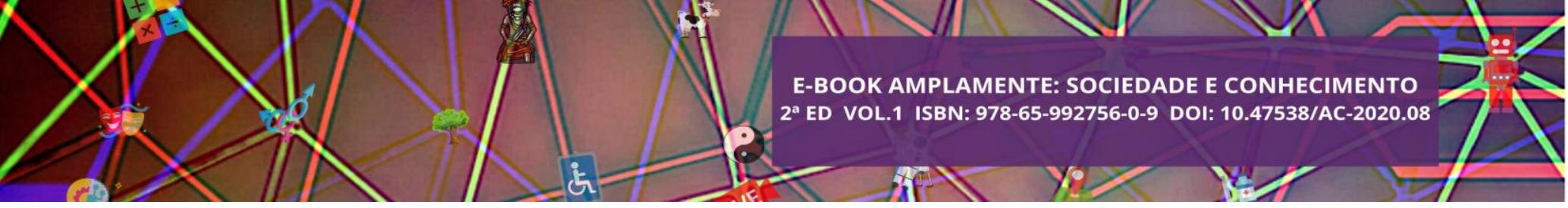

existia a ampla disseminação do acesso à internet de forma benéfica analisada pela sociedade brasileira e mundial. A falta de iniciativa governamental para implementação de novas políticas públicas voltadas para a sustentabilidade e o desenvolvimento sustentável dificulta de forma clara a promoção de uma inclusão da sociedade - e coletividade - para o debate sobre a melhoria da preservação do meio ambiente no Brasil.

\section{INSTRUMENTOS JURÍdICOS PARA DEFESA E PROTEÇÃO DO MEIO AMBIENTE}

Sobre a matéria ambiental que se prevê diante dos instrumentos jurídicos existentes para a defesa e proteção do meio ambiente, encontra-se principalmente correlacionado com o que existe determinado na Constituição Federal de 1988.

As ações preventivas, o licenciamento ambiental, o exercício do poder de política, as informações ambientais que são atreladas ao Poder Público, além das ações judiciais são mecanismos eficientes que estão à disposição da coletividade para que cobre, de forma enfática, as atuações neste sentido. As ações preventivas, portanto, devem ser aquelas que auxiliam, de alguma forma, na definição de diretrizes em uma política municipal que seja voltada para a preservação do meio ambiente. Esse planejamento ambiental, retrata também utilizações de políticas tributárias e uso de taxas, pagamento do Imposto Predial e Territorial Urbano (IPTU), entre outras medidas. Insta destacar, essas ações partem do Plano Diretor de um município e que se dispõe ao poder público em mantê-las em razão da maior fiscalização. A educação ambiental, portanto, é um dos mecanismos mais eficientes para manter a ação de prevenção e planejamento ambiental no município, pois conscientiza a coletividade de manter e auxiliar na fiscalização sobre o uso e equilíbrio do meio ambiente.

Entre outras atividades, considera-se como uma das mais importantes a voltada para a ação popular. A ação popular, nesta seara, faz parte dos processos e sistemas destinados à defesa de posições individuais, de proteção judiciária e que pode ser realizado como instrumento de defesa de interesse geral, como abordou Mendes e Branco (2018, p. 686). Assim, a Constituição Federal de 1988 prevê a ação popular com o objetivo de anular ato lesivo ao patrimônio público ou aos bens de entidades de que o Estado participe. O caráter é marcadamente público, e o autor, está em princípio, isento 


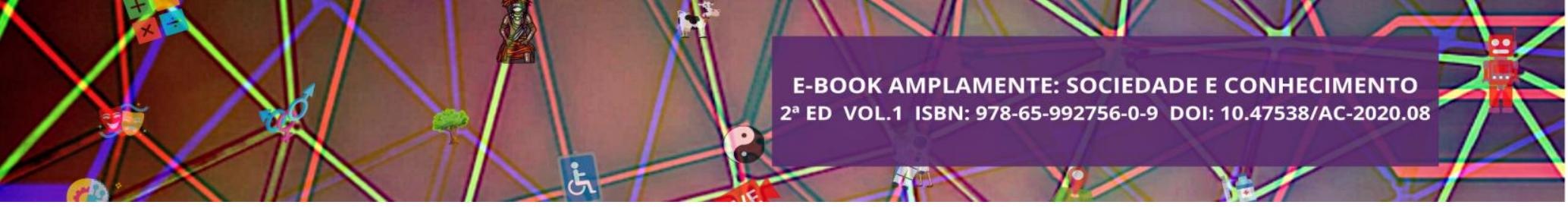

de custas judiciais e do ônus da sucumbência, de acordo com o inciso LXXIII do artigo $5^{\circ}$ do texto de 1988 , exceto quando verificada a má-fé.

Como instrumento de defesa do meio ambiente e do exercício da cidadania ambiental, a Lei $n^{\circ}$ 6.938/1981, que trouxe a Política Nacional do Meio Ambiente, atende os anseios e o princípio da educação ambiental a todos os níveis de ensino, inclusive sobre a educação da comunidade com o objetivo de capacitá-la para a participação ativa na defesa do meio ambiente (BRASIL, 1981). A Declaração do Rio no Princípio $\mathrm{n}^{\circ} 10$, traz a reafirmação da participação popular na tutela ambiental, conforme a seguir:

A melhor maneira de tratar questões ambientais é assegurar a participação, no nível apropriado, de todos os cidadãos interessados. No nível nacional, cada indivíduo terá acesso adequado às informações relativas ao meio ambiente de que disponham as autoridades públicas, inclusive informações acerca de materiais e atividades perigosas em suas comunidades, bem como a oportunidade de participar dos processos decisórios. Os Estados irão facilitar e estimular a conscientização e a participação popular, colocando as informações à disposição de todos. Será proporcionado o acesso efetivo a mecanismos judiciais e administrativos, inclusive no que se refere à compensação e reparação de danos (BRASIL, 1992).

Assim, o que se apresenta é a cooperação e a participação da população como um dever de preservar e defender o meio ambiente juntamente com o Poder Público, e neste sentido, insta destacar como aborda Costa (2009, p. 160), que "a obrigação de defesa e preservação do meio ambiente pertence ao Estado em geral e a cada cidadão em particular, observando-se essa função conjunta ressoa, ainda, nos processo decisórios, na escolha de prioridades (...)”, e ainda, sobre as escolha dos representantes políticos no município, estado e governo federal.

Para que seja possível a participação da coletividade, é preciso que tenha acesso a elementos e informações que são próprios para a preservação do meio ambiente e atingir a finalidade da ação popular neste sentido. Aborda Costa (2009, p. 161) que como corolários do princípio ao meio ambiente equilibrado, deverá ser abordado o direito à informação e à educação ambiental, para que seja de forma efetivo reforçado diante da incumbência do Poder Público em manter esse dever de promover a educação ambiental em todos os níveis de educação, como também foi tratado na Declaração Rio92. 


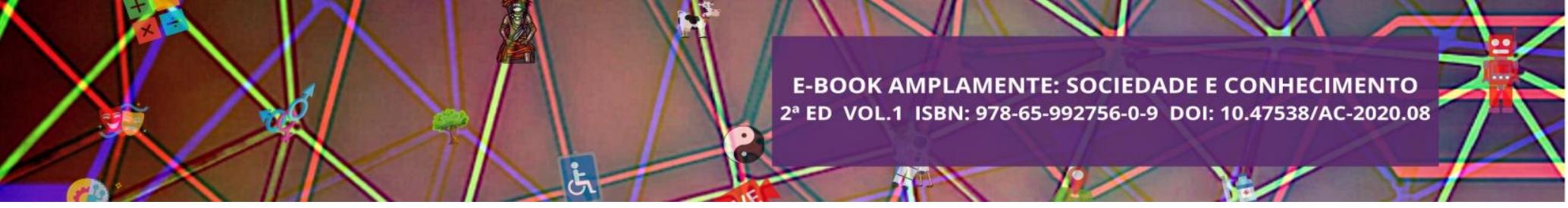

Costa (2009, p. 165) ainda retrata como entraves para a efetivação da ação popular ambiental encontra-se em decisões do Supremo Tribunal Federal em não permitir que a pessoa jurídica seja legítima para a propositura de ação popular, sendo apenas o cidadão considerado individualmente ou que esteja em litisconsórcio com outros cidadãos-autores, ficando apto à propositura de tal ação, vedando a atuação de ONGs, por exemplo, que possuem maior acesso e fundamentação para a organização da defesa fundamental por estarem diariamente contando com a atuação de pessoas em seu interior para a coleta de dados e fiscalizações.

Essa participação coletiva diante da ação popular retrata os conceitos de democracia participativa. De acordo com Passos (1988, p. 93), a democracia participativa tem como pressuposto a participação da sociedade civil nas decisões sempre que possível, além de possuir um controle da execução, em todas as circunstâncias, e o acesso às informações pelas pessoas para que seja assegurado, no mínimo, o respeito aos assuntos mais graves que envolvem a tratativa com o meio ambiente, diante dos setores representativos da sociedade civil e para a pessoa de forma geral.

\section{CONCLUSÃO}

O direito ao meio ambiente equilibrado foi adicionado ao texto da Constituição Federal de 1988 como um direito fundamental, e de fato, deve ser tratado como tal, tanto pelas pessoas em sua individualidade, como na seara coletiva e na apreciação pelo Poder Público de forma geral a consolidar melhores medidas que sejam atribuídas à preservação, à manutenção e condicionamento ao meio ambiente, além de incorrer em fiscalizações que ensejem a sanção e reparação de possíveis danos decorrentes da ação humana.

Sem retirar a obrigação do Poder Público em ingressar com mecanismos de melhor fiscalização dos licenciamentos ambientais de empresas e pessoas diante das atividades que tornam a ministrar alterações no meio ambiente, os mecanismos de utilização pela coletividade no sentido de inserir por meio da educação ambiental, também poderá ser um meio para a melhor preservação e qualidade do meio ambiente.

Como observado, a partir de uma melhor educação ambiental conclui-se tratar de uma melhor perspectiva da utilização da ação popular de forma efetiva para garantir 


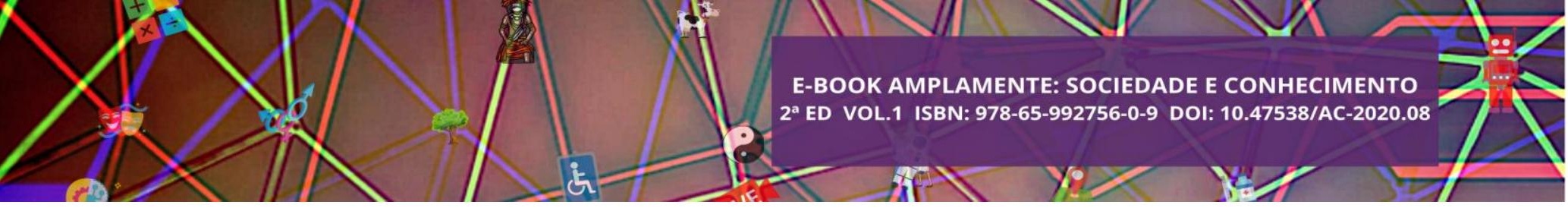

a preservação do meio ambiente. Porém, são encontrados verdadeiros entraves para a efetivação do exercício da ação popular ambiental, de acordo com o estudo, ao se verificar que mesmo na seara de grande relevância atualmente, o direito ao meio ambiente equilibrado ainda não é abordado de forma clara a disponibilizar melhores informações e tratativa da sociedade de forma efetiva.

A atuação das pessoas deveria ser mais enfática a partir das melhores políticas públicas a se atribuírem à educação ambiental, sendo este o ponto principal de análise da garantia da cidadania e participação efetiva na sociedade.

\section{REFERÊNCIAS}

AGRA, Walber de Moura. Curso de Direito Constitucional. 9. ed. Belo Horizonte: Fórum, 2018.

BARCELLOS, Ana Paula de. Curso de Direito Constitucional. Rio de Janeiro: Forense, 2018.

BRASIL. Constituição da República Federativa do Brasil de 1988. Disponível em http://www.planalto.gov.br/ccivil_03/Constituicao/Constituicao.htm. Acesso em 06 ago. 2020.

BRASIL. Lei $\mathbf{n}^{\mathbf{0}}$ 6.938, de 31 de outubro de 1981. Disponível em http://www.planalto.gov.br/ccivil_03/LEIS/L6938.htm. Acesso em 06 ago. 2020.

BRASIL. Lei $\mathbf{n}^{\mathbf{0}}$ 7.347, de 24 de julho de 1985. Disponível em http://www.planalto.gov.br/ccivil_03/leis/17347orig.htm. Acesso em 06 ago. 2020.

BRASIL. Lei $\mathbf{n}^{\mathbf{0}}$ 6.938, de 31 de agosto de 1981. Disponível em http://www.planalto.gov.br/ccivil_03/LEIS/L6938.htm. Acesso em 06 ago. 2020.

BRASIL. Declaração do Rio Sobre Meio Ambiente e Desenvolvimento, de junho de 1992. Disponível em https://cetesb.sp.gov.br/proclima/wpcontent/uploads/sites/36/2013/12/declaracao_rio_ma.pdf . Acesso em 06 ago. 2020.

COSTA, Melina de Oliveira Gonçalves Fernández. A ação popular como instrumento de defesa do meio ambiente e exercício da cidadania ambiental. Distrito Federal: Revista Estudos, Conferências e Notas, 2009. Disponível em https://www.portaldeperiodicos.idp.edu.br/direitopublico/article/download/1420/886. Acesso em 06 ago. 2020.

FIORILLO, Celso Antonio Pacheco. Curso de direito ambiental brasileiro. 2. ed. São Paulo: Saraiva, 2001.

JACOBI, Pedro. Educação ambiental, cidadania e sustentabilidade. São Paulo: Caderno de Pesquisa, n. 118, 2003. Disponível em 


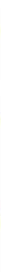

https://www.scielo.br/scielo.php?pid=S0100-

15742003000100008\&script=sci_abstract\&tlng=es. Acesso em 06 ago. 2020.

HIGUCHI, Maria Inês Gasparetto; AZEVEDO, Genoveva Chagas de. Educação como processo na construção da cidadania ambiental. Brasília: Revista Brasileira de Educação Ambiental, n. 0, 2004.

MAZZUOLLI, Valério de Oliveira. Curso de Direito Humanos. São Paulo: Método, 2014.

MENDES, Gilmar; BRANCO, Paulo Gustavo Gonet. Curso de Direito Constitucional. 13. ed. São Paulo: Saraiva, 2018.

PASSOS, J. J. Calmon. Democracia, participação e processo. In. GRINOVER, Ada Pellegrini (Org.). A tutela dos interesses difusos. São Paulo: Editora Revista dos Tribunais, 1988.

RAMOS, André de Carvalho. Curso de Direitos Humanos. 5. ed. São Paulo: Saraiva, 2018.

SARLET, Ingo Wolfgang; MARINONI, Luiz Guilherme. Curso de Direito Constitucional. 7. ed. São Paulo: Saraiva, 2018.

TAVARES, André Ramos. Curso de Direito Constitucional. 15. ed. São Paulo: Saraiva, 2017. 


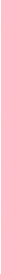

Este trabalho teve como objetivo produzir uma cerveja puro malte Summer Ale com adição da flor de lúpulo fresco durante a etapa de fervura, assim como caracterizar as propriedades físico-químicas e potencialmente funcionais da cerveja.

\section{METODOLOGIA}

Para elaboração da cerveja puro malte estilo Summer Ale, foram utilizados água, malte Château Pilsen, levedura cultura S-04 e flor de lúpulo fresco chinook cultivados em uma propriedade rural em Brasília - DF. A fabricação da cerveja seguiu as etapas fundamentais de moagem, mosturação, fervura, fermentação, maturação, envase, carbonatação e armazenamento em temperatura ambiente. A adição do lúpulo fresco chinook foi realizada no início da fervura adicionando $10 \mathrm{~g}$ da flor de lúpulo fresco, e aos 15 minutos finais desta etapa adicionou-se mais $30 \mathrm{~g}$.

Na cerveja descarbonatada e filtrada foram realizadas as análises de sólidos solúveis totais e pH (IAL, 2008). O teor alcoólico seguiu o método adaptado de Borszowskei et al. (2016). Para determinação da cor (EBC) foi utilizado o método descrito por Trindade (2016). Para determinação dos compostos fenólicos totais da cerveja utilizou-se o método descrito por Swain and Hillis (1959).

\section{RESULTADOS E DISCUSSÃO}

Os resultados das análises físico-químicas de cerveja puro malte Summer Ale acrescida de lúpulo fresco estão descritos na tabela 1.

Tabela 1 - Caracterização físico-química da cerveja puro malte Summer Ale elaborada com lúpulo fresco.

\begin{tabular}{ccccc}
\hline $\mathrm{pH}$ & $\begin{array}{c}\text { Sólidos Solúveis } \\
\text { Totais }\left({ }^{\circ} \mathrm{Brix}\right)\end{array}$ & $\begin{array}{c}\text { Teor alcoólico } \\
(\% \mathrm{ABV})\end{array}$ & Cor (EBC) & $\begin{array}{c}\text { Compostos Fenólicos totais } \\
\left(\mathrm{mg} \text { AGE. } \mathrm{mL}^{-1}\right)\end{array}$ \\
\hline $3,9133 \pm 0,0$ & $5,4703 \pm 0,2051$ & $5,0435 \pm 0,0926$ & $5,7838 \pm 0,6678$ & $6,5115 \pm 1,1979$ \\
\hline
\end{tabular}

Fonte: Autoria Própria.

O pH da cerveja Summer Ale produzida foi de 3,9, muito semelhante aos valores encontrados na literatura para o $\mathrm{pH}$ de cervejas Ale que variaram de 3,4 a 4,2. Durante a fermentação da cerveja, alguns compostos secundários são liberados pela levedura, 


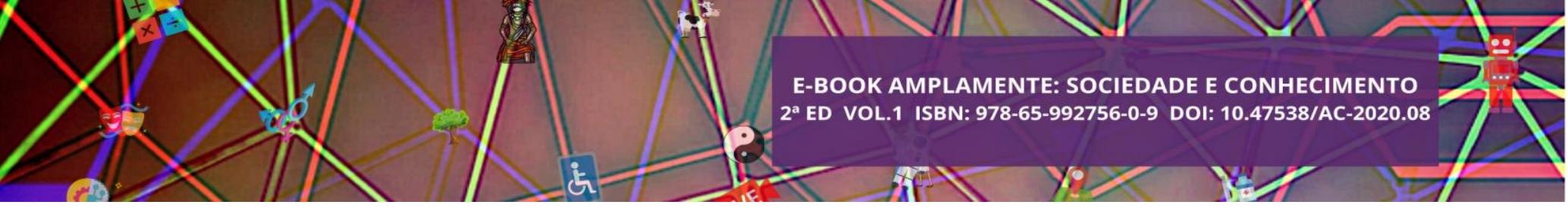

como ácido propiônico e acético, tornando o $\mathrm{pH}$ da cerveja ácido. A acidez total da cerveja também é característica da quantidade de gás carbônico dissolvido em água, que forma ácido carbônico, sendo característico de cervejas muito carbonatadas (BRUNELLI et al. 2014; CARNEIRO, 2016).

A cerveja desenvolvida apresentou teor alcoólico de 5,04\%. O teor alcoólico é proveniente da produção de etanol e $\mathrm{CO}_{2}$ pela levedura Saccharomyces cerevisiae, após a fermentação de açúcares fermentescíveis provenientes do cereal maltado. Kempka, Thomé e De Conto (2017) encontraram valores de 4,38 para cervejas tipo Ale. O valor encontrado neste estudo foi ligeiramente superior. Essa diferença pode advir da quantidade de açúcar fermentescível disponível durante a fermentação, pois também houve decréscimo da concentração de sólidos solúveis totais na cerveja, o que indica que possivelmente o açúcar foi convertido em álcool.

A cerveja produzida apresentou cor de 5,8 EBC, aproximadamente. A legislação vigente para bebidas fermentadas classifica como cerveja clara, valores de cor inferiores a 20 EBC (BRASIL, 1997).

Com relação aos compostos fenólicos Rampazzo (2014) encontrou concentração entre 0,674 e 0,865 mg AGE.mL $L^{-1}$ em cervejas Ale de marcas comerciais. Neste estudo foram encontrados valores superiores a estes, sendo que a adição da folha do lúpulo fresco pode estar ligada a essa alteração já que a forma mais utilizada de lúpulo é pelletizada. Siqueira, Bolini e Macedo (2008) relataram que aproximadamente $30 \%$ dos compostos fenólicos encontrados na cerveja advém do lúpulo.

\section{CONSIDERAÇÕES FINAIS}

A elaboração de cerveja com a adição de lúpulo fresco durante a etapa de fervura apresentou características físico-químicas similares à cerveja Ale utilizando lúpulo em pellets, formato habitualmente mais usado.

\section{REFERÊNCIAS BIBLIOGRÁFIAS}

BRUNELLI, L. T; MANSANO, A. R; VENTURINI FILHO, W. G. Caracterização físico-química de cerveja elaboradas com mel. Campinas: Brazilian Journal of Food Technology, v.17, n.1, p.19-27, 2014. 


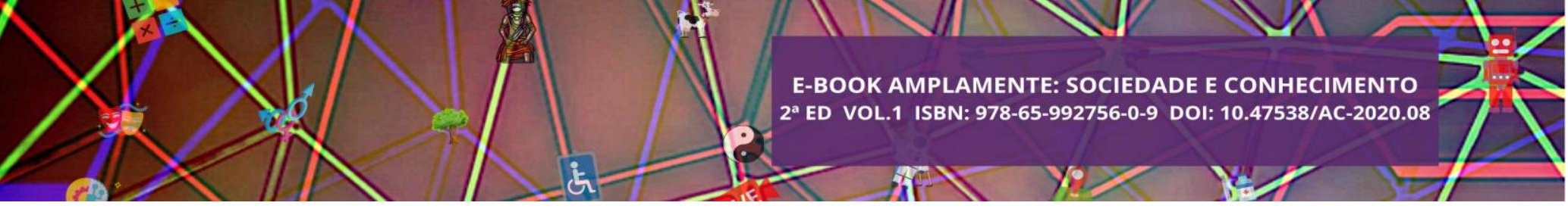

\title{
CAPÍTULO XXIII
}

\section{HÁ SEMPRE ALGUÉM MAIS PRISIONEIRO QUE EU: A PESTE DA NEGLIGÊNCIA E A SAÚDE DE REFUGIADOS EM TEMPOS DE PANDEMIA}

\author{
Lucas Tadeu Gonzaga Diniz ${ }^{125}$; Ana Carolina Guimarães Cerbino ${ }^{126}$; \\ Amanda Patrícia Vasconcelos Matos ${ }^{127}$; Catarine Wiggers de Campos ${ }^{128}$. \\ DOI - Capítulo: 10.47538/AC-2020.08-23
}

\section{RESUMO:}

Ao longo da história, pandemias afetam minorias e populações vulneráveis. Atualmente, a COVID-19 atinge ampla gama de refugiados devido a distribuições desiguais de espaços, recursos e informações a esses indivíduos, cuja capacidade de mitigação da transmissão se torna limitada frente à falta de acesso à saúde pública e informações sobre medidas protetivas, à insuficiente assistência médica e aos sítios de abrigo sem distanciamento social ou saneamento básico. Além disso, efeitos colaterais da pandemia como restrição ao movimento, agravo à saúde mental e intensificação de discriminações, polarizações políticas e disparidades linguísticas afetam desigualmente esse contingente vulnerável. Objetiva-se, assim, refletir multiprofissionalmente sobre a situação de saúde dos refugiados em tempos de pandemia, a partir de levantamentos histórico, epidemiológico, literário, social, político e filosófico. Para tanto, realiza-se, neste trabalho, um ensaio acadêmico como espaço para se expor pontos de vista a partir de revisão bibliográfica e interpretativa prévia sobre a temática, bem como identificar e propor estratégias aos profissionais da saúde e cidadãos em geral para refrear o impacto negativo ocasionado por pandemias aos refugiados.

PAlavRAS-CHAVE: Refugiados. COVID-19. Saúde. Pandemia. Processo Migratório.

\section{INTRODUÇÃO}

Entre os anos 1000 e 1300, a Europa experimentou crescimento populacional e relativa prosperidade, mas a chegada do século XIV acompanhou intensas mudanças; entre elas, a praga que devastou cerca de um terço da população, rapidamente assolada mediante intensa difusão temporal e geográfica da bactéria. Mais tarde, por volta de

125 Acadêmico do curso de Medicina (PUC Goiás). E-mail: lucasdinizmed@gmail.com

126 Acadêmica do curso de Medicina da Universidade Federal de Goiás. Presidente Local da IFMSA Brazil UFG e Diretora Científica do V Congresso de Escolas Médicas (CESMED) e do $32^{\circ}$ Encontro Científico de Acadêmicos de Medicina (ECAM). E-mail: anacarolinagcerbino@gmail.com

127 Interna de medicina - UFMA Campus V Pinheiro. onitora de Técnicas Cirúrgicas do Ciclo Clínico da UFMA e Coordenadora Regional Nordeste 1 da IFMSA Brazil. E-mail: amandapv94@ hotmail.com

128 Estudante de Medicina - UNISUL Campus Tubarão. Membro da Liga de Psicologia Médica e Medicina da Família da Comunidade, bolsista em pesquisa pelo Programa de Bolsas Universitárias de Santa Catarina e atua como Coordenadora Regional Sul da IFMSA Brazil. E-mail: catarinewgg@ gmail.com 


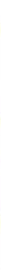

1490, quando Colombo chegou a Santo Domingo, reconheceu uma bela e povoada ilha; indígenas pacíficos habitavam o local, onde, em menos de três décadas, praticamente não mais se encontraria população nativa, situação que se reproduziu na totalidade da colonização americana. Isto, pois os contingentes nativos não reconheceram maioria dos patógenos e tiveram pequenos períodos para gerarem processos adaptativos como hospedeiros.

Desse modo, a partir dos contextos apresentados, observa-se, de um lado, uma Europa assolada pela pandemia medieval que submergiu o continente numa grave crise socioeconômica; de outro, uma América devastada pela trama de patógenos introduzida no continente por colonizadores europeus. O paradoxo é evidente: uma população oprimida torna-se opressora em menos de um século e oblitera o fato de que a vulnerabilidade é universal - o ser humano, por viver e se expor ao risco de ser ferido, ofendido e/ou melindrado por pessoas, animais e ambiente, é vulnerável, podendo estar invulnerável, mas nunca o ser (HOSSNE, 2009).

Atualmente, à medida que nações em todo o mundo implementam medidas eficazes ou não - para controlar a disseminação do novo coronavírus da síndrome respiratória aguda grave (SARS-CoV-2), incluindo bloqueios e restrições a fluxo de indivíduos, a pandemia lança luz sobre refugiados e migrantes, vítimas de uma das maiores crises humanitárias pré-existentes. Em situação semelhante ao período de colonização americana, percebe-se um polo de potências e autoridades que despreza vulneráveis, esquece a História e se recusa a acreditar que, um dia, também foi vulnerável.

Refugiado é todo sujeito que deixa seu país de origem em decorrência de fundados temores à perseguição, seja em razão de sua etnia, religião, nacionalidade, associação a determinado grupo social ou opinião política e, devido a isso, não quer ou não pode regressar a sua nação, em vista de uma grave e generalizada violação dos direitos humanos (ACNUR, 2020). Ao ingressar no país de destino, em busca de melhores condições de vida, o refugiado se depara com grandes desafios e circunstâncias desfavoráveis, que assumem ambientes hostis e de discriminação. Esse cenário também afeta significativa e negativamente o acesso e o cuidado à saúde desses indivíduos, cujos prejuízos são recrudescidos pelo contexto pandêmico.

A pandemia pela COVID-19 impacta de forma grave e abrangente a saúde dos refugiados, englobando diferentes perspectivas e consequências, sejam em relação a 


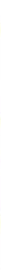

estratégias de prevenção de difícil adaptação a sua realidade; às maiores taxas de transmissão frente às péssimas condições de vida em campos de refugiados e habitações informais; às barreiras linguísticas que dificultam tanto o acesso à informação quanto o atendimento médico; ao aumento do risco de desenvolvimento de transtornos mentais; às discrepâncias econômicas e negligências do governo do país de refúgio e ao preconceito enraizado na sociedade.

A população de refugiados corresponde, nos dias atuais, a $1 \%$ da população mundial (ACNUR, 2020), ou seja, o processo migratório, diante de condições de vida precárias, representa um grave problema de saúde pública. Urge, então, analisar, discutir, mitigar o sofrimento e propor soluções de melhorias a esses indivíduos, que tantas vezes se tornam invisíveis aos olhos do mundo e negligenciados durante uma grave crise humanitária.

Este estudo busca, portanto, elencar e analisar o impacto provocado pela pandemia da COVID-19 à saúde dos refugiados, a partir da identificação de vulnerabilidades e da análise das circunstâncias de saúde por diferentes perspectivas, bem como propor estratégias de enfrentamento para a mitigação dos efeitos negativos e para a melhoria das condições de vida e saúde dessa população. Logo, objetiva-se refletir multiprofissionalmente sobre a situação de saúde dos refugiados em tempos de pandemias, especificamente daquela causada pelo SARS-CoV-2, a partir de levantamentos histórico, epidemiológico e literário que se referem à exclusão de minorias e à falta de alteridade em relação a essas minorias em momentos de crise. Também se busca construir argumentos de conteúdos social, político e filosófico sobre a situação de refugiados e migrantes durante a atual pandemia. Nesse sentido, acredita-se que perspectivas de variadas áreas do conhecimento podem contribuir para constituição crítica de opinião e procura por intervenções.

\section{DESCRIÇÃO METODOLÓGICA}

Realiza-se, neste trabalho, um ensaio acadêmico como espaço para se expor ideias e pontos de vista a partir de revisão bibliográfica e interpretativa prévia sobre a temática. Dessa forma, foram utilizadas as seguintes etapas para sua elaboração: (1) delimitação do tema e construção da pergunta norteadora da pesquisa; (2) levantamento das publicações nas bases de dados selecionadas; (3) classificação e análise das 


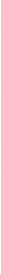

informações achadas em cada manuscrito; (4) análise dos estudos escolhidos; (5) inclusão, análise crítica dos achados e síntese da revisão da literatura.

Para a construção da pergunta norteadora da pesquisa foi utilizada a estratégia PICO, em que $(\mathrm{P})$ correspondeu à "população de refugiados na pandemia por COVID19"; (I), "estratégias de enfrentamento"; (C) não se aplica; (O), "identificar o impacto da pandemia na saúde". Dessa forma, a pesquisa foi direcionada pelo seguinte questionamento: "quais os impactos provocados pela pandemia por COVID-19 na saúde dos refugiados e quais as estratégias de enfrentamento para minimizá-los?”.

A busca avançada dos estudos foi limitada pela data de publicação entre os anos de 1947 a 2020. Esse recorte temporal possibilitou a pesquisa de publicações que englobam diferentes perspectivas em relação à saúde dos refugiados, histórico de pandemias, concepções resistentes ao totalitarismo, bem como de estudos que envolvem a crise humanitária e processos migratórios. Por outro lado, também foram selecionadas publicações específicas do ano de 2020, que envolviam COVID-19 e refugiados, mediante uma revisão compreensiva dos estudos e pesquisas acerca da saúde dos refugiados e de sua situação perante à pandemia por COVID-19.

Os descritores utilizados na busca foram "refugees", "COVID-19", “coronavirus" e "health vulnerabilities", vinculados a operadores booleanos "AND" e “OR", criando as seguintes estratégias de busca: refugees AND (COVID-19 OR coronavirus) e refugees AND health vulnerabilities. Também foram utilizados os termos em português: "saúde dos refugiados", "refugiados" e "pandemia por COVID19”. Após inclusão de artigos publicados há menos de um ano e excluídos aqueles não realizados em humanos, fora do período de inclusão e dissociados da pergunta norteadora, a base de maior relevância para o trabalho foi a National Library of Medicine and the National Institutes of Health (PubMed), seguida pelo Google Acadêmico. Foram analisadas 16 referências nos idiomas português e inglês com conteúdos que atendessem à pergunta norteadora. Não houve conflito de interesse na elaboração deste estudo.

\section{APRESENTAÇÃO E DISCUSSÃO DE DADOS}

Deixar o seu país natal e encontrar uma cultura totalmente nova e desconhecida envolve momentos difíceis e estressantes, ou seja, o imigrante passa por um árduo 


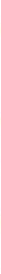

processo de adaptação e, muitas vezes, é forçado a enfrentar burocracias, péssimas condições de vida e de habitação, barreiras linguísticas e preconceitos no país de destino.

Diante de todo esse contexto sociopolítico e dos processos sociais aos quais os imigrantes são expostos, o cenário em que vivem nem sempre é favorável à sua saúde. Eles encontram discrepâncias no acesso à saúde e no cuidado do paciente, uma vez que a prática médica pode negligenciar suas crenças e sua cultura nativa, ou seja, essa é uma população repleta de vulnerabilidades e muito susceptível ao desenvolvimento de doenças infecciosas. A situação em que os refugiados vivem se torna uma espécie de "bomba relógio" frente à comorbidades graves com rápida transmissão, como a pandemia pela doença do novo coronavírus (COVID-19).

Nestes últimos anos, cerca de 79,5 milhões de pessoas por todo o mundo foram obrigadas a deixar seus países nativos em busca de melhores condições de vida. Dessa quantidade de pessoas, $40 \%$ equivale a crianças. Os principais países que apresentam maior caráter emigratório são a Síria, Venezuela, Afeganistão, Sudão do Sul e Myanmar, os quais, juntos, correspondem a 16,3 milhões dos refugiados espalhados pelo mundo.

De outro lado, os principais países com maior caráter imigratório são a Turquia, Colômbia, Paquistão, Uganda e Alemanha, que receberam cerca de 9,3 milhões de refugiados. Dentre os países de destino, que recebem os refugiados, 134 reportaram casos de COVID-19 (ACNUR, 2020). O mundo globalizado e interconectado derruba fronteiras, movimenta milhões de pessoas todos os anos e regozija-se frente à pandemia, demonstrando que o cuidado à população de refugiados é um grave problema de saúde pública, que salienta vulnerabilidades, e representa a necessidade de atenção a uma saúde global.

Nesse sentido, em poucos meses, a COVID-19 atravessou fronteiras políticas e geográficas e se espalhou por todo o mundo, causando uma pandemia sem precedentes, que não poupou qualquer população. A crise provocada pelo novo vírus gerou um medo disseminado, internações e mortes entre todos, porém também evidenciou sérias iniquidades sociais, as quais se mostraram importantes fatores de risco para populações marginalizadas e vulneráveis, dentre eles os refugiados. "Lave suas mãos, utilize máscaras e fique em isolamento dentro de sua casa" - o que acontece, então, quando um vírus com alta taxa de transmissibilidade atinge campos de refugiados e habitações 


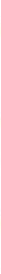

informais, com uma alta densidade demográfica e más condições hídricas e saneamento básico?

Em outras palavras, condições espantosas dos campos de refugiados são férteis para surtos de doenças infecciosas: com poucas latrinas e suprimentos de água, a higiene básica para impedir a propagação é dificultada e, com superlotação extrema, o distanciamento físico é impossível. Ademais, $80 \%$ dos refugiados vivem em países de baixa e média renda, locais onde as configurações de sistemas de saúde são fracas, observadas mediante dificuldades de acesso a máscaras, álcool gel e demais medidas, escasso equipamento de proteção individual a profissionais de saúde e baixa potencialidade para testes em massa e fornecimento de tratamento.

Além disso, minorias e populações refugiadas também enfrentam barreiras linguísticas e culturais, o que representa um grande desafio no atendimento médico e na interpretação de informações. Como resultado disso, o refugiado pode ser facilmente bombardeado e manipulado por falsas informações, o que pode minimizar os efeitos da pandemia e criar uma falsa sensação de segurança, favorecendo a negligência das formas de prevenção à doença e a diminuição da procura por testes e cuidados em saúde. A Era da Desinformação, arraigada às novas tecnologias e novas formas de comunicação, também atinge os refugiados e é fomentada diante de barreiras linguísticas.

Dessa forma, ao mesmo tempo em que o refugiado se depara com um turbilhão de informações e notícias acerca do novo coronavírus, ele precisa romper a barreira linguística, compreendê-las e verificar sua veracidade, ou seja, se depara com significativos desafios à comunicação e ao acesso ao conhecimento no país de destino. Esse fluxo exagerado de informações cria, então, prejuízos ao cuidado em saúde, inquietações àqueles que procuram abrigo em um novo território, como também contamina o imaginário coletivo, acentuando a crise humanitária já existente. É concebido um cenário de pânico moral, carregado de hostilidades e desconfianças, que ameaça a segurança e a integridade dos refugiados (DA SILVA, 2019).

Por outro lado, aquele refugiado que, ciente da gravidade da pandemia e dos sintomas de alerta, busca por ajuda médica pode ser mal atendido e pouco ensinado sobre a doença e suas consequências - vítima de preconceitos e de receios do profissional da saúde, que se depara com barreiras que desafiam seu atendimento e 


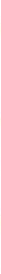

fogem de sua prática médica cotidiana. Desse modo, no contexto dos serviços de saúde, é importante refletir sobre a maneira com que os refugiados são tratados e atendidos.

É evidente que os profissionais da saúde não são preparados durante a sua graduação sobre como lidar com situações de barreiras linguísticas e adaptar o seu cuidado à cultura de seu paciente, o que pode engendrar consequências prejudiciais ao bem estar dos refugiados. O processo de saúde e doença, bem como as diferentes estratégias de atenção e prevenção adotadas entre os refugiados podem conter similaridades e distanciamentos com os modelos de atenção trabalhados pelos profissionais da saúde, os quais possuem poucos elementos e conhecimentos prévios para lidar com esse fenômeno complexo (MARTIN et. al, 2018).

Nos dias atuais, frente a um enorme fluxo de pacientes, quantidade limitada de testes e o medo generalizado de contaminação, esses desafios foram fomentados e o refugiado é, na maioria das vezes, esquecido. As pessoas com acesso precário aos cuidados de saúde que apresentam sintomas relacionados à COVID-19 podem atrasar ou até deixar de fazer o teste e, consequentemente, podem recorrer aos cuidados médicos apenas em estágios avançados, resultando em piores resultados e colocando suas famílias e comunidades em maior risco.

Os processos migratórios também representam grandes desafios aos sistemas de saúde locais e às agências de serviços voluntários. Afinal, a quantidade de recursos disponibilizada e o financiamento destinado ao cuidado dos refugiados pelos governos locais é limitado e não supre todas as necessidades de saúde apresentadas (JUNIOR et al., 2019). Exemplo disso são clínicas nos campos de refugiados no Quênia, as quais contam com apenas oito médicos para o atendimento de cerca de 200 mil pessoas (BEECH; HUBBARD, 2020).

Por conseguinte, a assistência aos casos de COVID-19 e as medidas de prevenção a serem tomadas envolvem um contexto sociopolítico de marginalização e negligência, no qual a assistência a necessidades básicas da população de refugiados é precarizada e, frequentemente, ignorada pelos governos dos países de destino. O estado de pleno bem estar não é simbolizado somente pela cura ou ausência de uma doença, uma vez que envolve condições de vida dignas e macroestruturas.

Desde os anos 1980, as políticas neoliberais que se estenderam pelo mundo destacaram a redução do Estado a uma estrutura mínima, promoveram privatização de serviços públicos e exaltaram o lucro de iniciativas privadas no setor da saúde. Em 


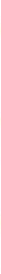

termos históricos, a atual pandemia revela a elitização dos serviços de saúde, de higiene e, de modo geral, da própria assistência estatal, representada na forma de governos autoritários e populistas.

O massacrante contexto de negligência frente aos refugiados desnuda anos de ataque à ciência e à saúde pública, de respostas insuficientes aos problemas de saúde como um todo, desde falhas de gestão até desinformação, pânico, caos e xenofobia. Antes de tudo, o desenvolvimento da saúde global é condição necessária para desenvolvimento socioeconômico de longo prazo, o que é olvidado diariamente por autoridades presumidamente “invulneráveis", porém absolutamente genocidas e oportunistas.

Hodiernamente, o posicionamento no espectro político de direita tão em voga nos países com essa herança neoliberal também possui efeitos no que tange a percepção sobre a pandemia. De acordo com pesquisa sobre o assunto, a intenção de violar o distanciamento social esteve mais presente em indivíduos declaradamente de direita, considerando contrastes entre recomendações de autoridades de saúde versus declarações de determinadas lideranças governamentais, além de status profissional e renda percebida (FARIAS; PILATI, 2020).

Nesse sentido, compreende-se que o posicionamento político tem impacto significativo nas atitudes referentes ao isolamento social, uma vez que crenças políticas podem induzir mais ou menos questionamentos sobre as medidas restritivas. Nessa perspectiva, é possível retornarmos, mais uma vez, ao contexto de colonização americana: a polarização no combate ao vírus representa o abandono da concepção de vulnerabilidade universal, uma vez que um lado do jogo partidário - os colonizadores europeus do presente - se sente inviolável e negligencia o cuidado ao outro lado, sem perceber que, na verdade, o interesse em mitigar o avanço da pandemia deve ser de todos. Exemplo disso é transfigurado nas últimas duas décadas da União Europeia, onde a extrema-direita se tornou presença constante no debate político frente às ameaças de crises migratórias: a clivagem criada entre instituições nacionais no controle da crise gerou forte insatisfação popular, a qual foi aproveitada por movimentos de extremadireita que convergiram na crítica nacionalista à interferência estrangeira como destruidora de economia e cultura europeias.

Em tempos de pandemia, a ofensiva contra essa população vulnerável é inclusive semântica: grupos conservadores propagam o discurso de que o conceito 


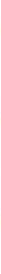

"refugiado" nada mais é do que uma estratégia propagandística de forças pró-imigração para carregar de sentido humanista uma situação que, segundo eles, não se deve legitimar (MARCHI; BRUNO, 2016).

O cenário não poderia ser mais análogo à obra "A Peste" (CAMUS, 1950), na qual se retrata uma erupção de ratos agonizantes e consequente adoecimento humano numa epidemia que segue seu ciclo mortal até desaparecer, porém não por completo: o bacilo responsável pela peste "não morre nem desaparece nunca" e, em estado de latência até novo surto, alude à ocupação nazista da França durante a Segunda Guerra Mundial e, de modo geral, às opressões totalitárias. Fato marcante é a narração sobre solidariedade durante a crise: o pensamento de que "há sempre alguém mais prisioneiro que eu" guiava personagens de resistência na tentativa de refrear o avanço da epidemia contra aqueles "colaboracionistas", sujeitos que celebravam, em meio à pandemia, impunidade de contravenções, discriminações e egoísmo indubitável.

A situação é ainda mais agravante ao se pensar nos índices de isolamento social que envolvem os países onde a situação pandêmica é grave. No Brasil, a título de exemplo, o isolamento social está em queda e completamente abaixo do índice considerado ideal: em maio, de acordo com dados aferidos pelo monitor In Loco, a média de isolamento social no país se encontrava em $43,4 \%$, enquanto a necessidade é de, no mínimo, 70\% (INLOCO, 2020).

As medidas de afrouxamento do distanciamento com aberturas de comércios e locais públicos, contudo, coincidem com superlotação do sistema público de saúde, o que demonstra um esquecimento prematuro da pandemia e dos efeitos que esta pode gerar ao país, se não controlada. Mais uma vez, a realidade imita a ficção e Gabriel García Márquez, em "Cem anos de solidão" (1967), relata conjuntura coincidente através do célebre episódio da epidemia de insônia. Como em "A peste", a população aqui não se alarma diante do fato, até que, acometidos pelo mal, não mais dormia e passava suas rotinas num estado de "alucinada lucidez".

(...) chegou o dia em que a situação de emergência passou a ser encarada como coisa natural e se organizou a vida de tal maneira que o trabalho retomou o seu ritmo e ninguém voltou a se preocupar com o inútil costume de dormir (MÁRQUEZ, 2017, p. 31).

Por fim, os habitantes da emblemática Macondo haviam se esquecido da doença violentamente transmissível. Portanto, compreende-se que a literatura e a história podem auxiliar autoridades a não mais repetirem erros sem previsão, rememorando a 


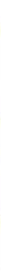

necessidade de distanciamento entre populações devidamente estabelecidas em seus países de origem e, concomitantemente, fornecendo a refugiados acesso a informações de saúde, testes de diagnóstico e assistência médica vitais à redução do impacto da pandemia do SARS-CoV-2 em todo o planeta.

Urge garantir que, ao procurar atendimento médico ou ao ser incluído no rastreamento de contatos, refugiados e migrantes não enfrentem nenhuma sanção ao se envolverem com autoridades do estado e até mesmo com profissionais de saúde e agentes responsáveis pela assistência. Para isso, há fundamental iminência em treinar tais agentes a agirem com alteridade e livres de condenações políticas e sociais.

Outrossim, o estresse e as situações traumáticas às quais os refugiados se deparam desencadeiam altos riscos de desenvolvimento de transtornos mentais. Alta densidade populacional, falta de saneamento básico, má nutrição e pouco acesso à alimentação de qualidade, dificuldade de acesso ao sistema de saúde, péssimas condições de habitação e discriminações não somente ocasionam maiores chances de surgimento de doenças infecciosas, como também afetam negativamente a saúde mental dos refugiados. Há, portanto, o favorecimento à evolução de transtornos póstraumáticos (TEPT), transtornos de ansiedade e de depressão, os quais ainda são agravados em uma situação pandêmica (GALINA et al., 2017).

Já fragilizados pelo temor de perseguição e traumatizados pelos desafios enfrentados em seus países de origem, esses indivíduos chegam ao país de refúgio em uma posição de extrema vulnerabilidade social e susceptibilidade ao desenvolvimento de transtornos mentais (MARTINS-BORGES, 2013). Com um deslocamento de caráter involuntário e repentino, os refugiados transportam consigo muito pouco do que até então caracterizava sua identidade e se deparam com contextos socioculturais, políticos e econômicos completamente diferentes - ambientes, na maioria das vezes, hostis e inadequados -, o que provoca sérios sofrimentos psicológicos associados a traumas vivenciados durante os períodos pré-migratório e migratório.

O medo é instintivo e garante a sobrevivência dos seres vivos, porém, quando exacerbado pode engendrar consequências críticas a saúde mental. Combinado às circunstâncias traumáticas vividas no processo migratório, o contexto pandêmico intensifica o medo e as inseguranças da sociedade e, em conjunto com o isolamento e a diminuição do contato social, cria um cenário de alto risco para o desenvolvimento de transtornos mentais. 


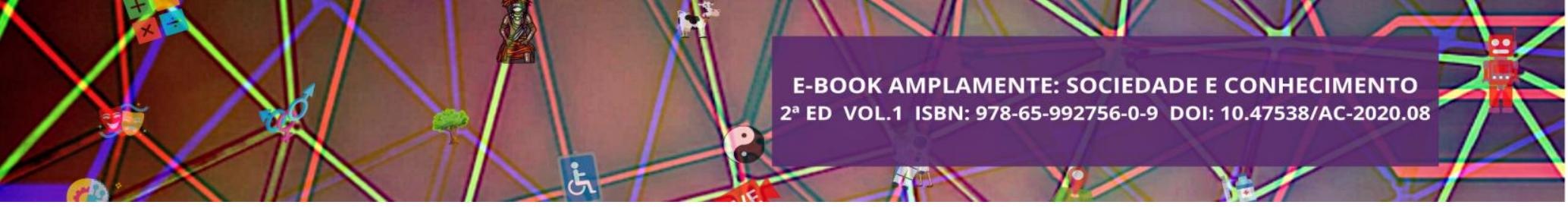

Assim, experiênciar os riscos e limitações de uma pandemia promove uma complexa combinação de emoções e reações comportamentais, que envolvem culpa, medo, raiva, melancolia, solidão. No entanto, esses estados emocionais podem evoluir para diversos distúrbios mentais, como Transtorno do Pânico, Transtorno de Ansiedade Generalizado, TEPT, Transtorno Depressivo Maior, entre outros (PEREIRA et al., 2020).

Os impactos à saúde dos refugiados também esbarram nas diferenças socioculturais existentes e nas raízes de preconceito que permeiam o território de refúgio (JUNIOR et al., 2020). Diante disso, os hábitos, crenças e costumes desses indivíduos são não somente abnegados nas relações sociais, como também são negados e vistos como estranhos ou equivocados. A xenofobia, mascarada e deixada debaixo dos panos, reforça hostilidades e afasta os refugiados do sistema de saúde e do cuidado longitudinal que deve ser estabelecido. Sendo assim, há menor adesão às estratégias de prevenção a doenças infecciosas e aos planos terapêuticos elaborados pelos médicos e há uma péssima construção dos conhecimentos acerca das doenças, desfavorecendo substancialmente a presença do letramento em saúde.

A xenofobia, já marcante desde os primórdios dos processos migratórios do homem, foi recrudescida com o surgimento da pandemia pelo COVID-19. De um lado, houve maiores prejuízos ao acesso à saúde de qualidade em virtude da sobrecarga dos sistemas e da má comunicação no processo de letramento sobre a doença. De outro, o medo do contágio reforçou barreiras de contato com os imigrantes, vistos como fontes de transmissão e como os principais carregadores do vírus ao país de destino. Os refugiados, então, ao mesmo tempo que sofrem as consequências de um vírus que rapidamente se espalha, são também culpabilizados pela amplitude da transmissão e ainda mais hostilizados nos ambientes em que vivem.

\section{CONCLUSÃO}

Não obstante, durante a pandemia pela COVID-19, não deve haver somente uma mobilização social para a contenção do vírus, mas também deve ser impulsionado um esforço coletivo em prol das populações vulneráveis, que são mais afetadas por esse contexto, seja biológica ou psicologicamente (JUNIOR et al., 2020). É evidente a 


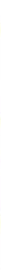

necessidade de um suporte holístico que atenda seus problemas e desafios humanitários e, simultaneamente, contenha o alastramento ainda maior da pandemia.

O preparo dos profissionais da saúde no cuidado dos refugiados é um fator fundamental na mitigação do impacto negativo causado pelo novo coronavírus. A equidade na saúde e o fácil acesso ao cuidado integral e atendimento profissional são soluções críticas e vitais à crise humanitária (ABBAS et al., 2018). O princípio de equidade significa que qualquer um deve ser assistido diante de uma necessidade em saúde e, principalmente, que os desiguais devem ser tratados de forma desigual em uma tentativa de equiparar suas diferenças. Sendo assim, um comprometimento com a saúde global reivindica a assistência e proteção aos imigrantes, garantindo-lhes uma saúde de qualidade, ou seja, a fim de haja a instauração de uma saúde verdadeiramente universal é essencial que o cuidado não esteja condicionado ao status que o indivíduo apresenta.

Nessa lógica, é essencial o treinamento de profissionais de saúde para reconhecimento de situações de vulnerabilidade, aquisição de habilidades no trabalho com refugiados e aplicação prática dos princípios de alteridade e equidade. A fim de melhor diagnosticar as precisões dessas comunidades, é necessário, então, que o profissional de saúde, especialmente médico, realize um anamnese detalhada, buscando identificar demandas básicas em saúde e segurança socioeconômica, como acesso a medicamentos, itens de higiene pessoal, roupas e alimentação mínima adequada, e de demandas jurídicas relacionadas à regularização de documentos importantes para vínculos empregatícios, contratos de compra e venda de móveis e imóveis, matrículas escolares e acesso ao sistema público de saúde.

A partir disso, podem ser encaminhados para cidades interioranas e, assim, fixados em locais com o devido distanciamento de fronteiras para evitar aglomerados. Ao chegarem nessas cidades, após primeira acolhida, devem encontrar amparo contínuo numa rede multiprofissional capacitada e mantida por insumos e estímulos governamentais.

Além disso, frente aos traumas, medos e perseguições vividos no país de origem, o apoio social e a construção de relações humanas recíprocas no país de refúgio podem ser fortes mediadores no manejo das experiências traumáticas e das consequências psicológicas (GALINA et al., 2017). A estruturação de vínculos contribui para a adaptação cultural e a integração de refugiados, auxiliando na promoção de um sentimento de pertencimento ao local de destino e colaborando com o aumento da 


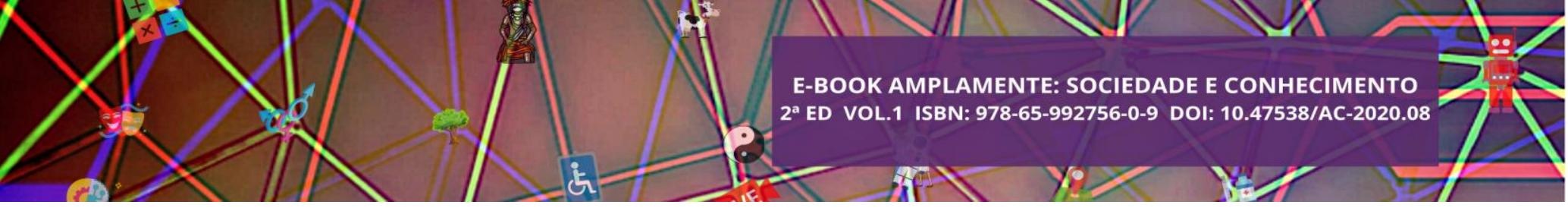

qualidade de vida desses indivíduos, a diminuição do sofrimento psíquico e a criação de fatores de proteção ao desenvolvimento de distúrbios mentais.

Ao voltar a atenção à saúde dos refugiados e às suas vulnerabilidades durante o processo migratório e no país de destino, há a abertura de um amplo campo de desenvolvimento de pesquisas, que avaliem tanto uma perspectiva geral das circunstâncias em que são encontrados quanto uma perspectiva local e específica, a fim de favorecer a criação de políticas singulares que atendam as demandas locais desses indivíduos.

Concomitantemente, as discussões propostas abrem espaço para autorreflexão acerca do comportamento individual com o "outro", como também questionam o papel dos cidadãos nos processos de cuidado e de saúde e doença. Finalmente, discutir o contexto migratório a partir de levantamentos histórico, social, filosófico e epidemiológico objetiva gerar inquietações ao leitor e dar voz a uma significativa parcela da população mundial, tantas vezes ignorada. É necessário perceber a importância de falar sobre isso e debater saúde nos mais diferentes âmbitos sociais, ampliando as discussões para fora do meio acadêmico e tornando-as essenciais no cotidiano da sociedade, para que mais estratégias de melhorias sejam criadas e colocadas em prática.

\section{REFERÊNCIAS}

ABBAS, Mohamed et al. Migrant and refugee populations: a public health and policy perspective on a continuing global crisis. Antimicrobial Resistance \& Infection Control, v. 7, n. 1, p. 113, 2018.

ACNUR. Dados sobre Refúgio. ACNUR Brasil, 18 de junho de 2020. Disponível em: <https://www.unhcr.org/data.html>. Acesso em julho de 2020.

BEECH, H., HUBBARD, B., 2020. Unprepared for the worst: world's most vulnerable brace for virus. The New York Times. Disponível em:

https://www.nytimes.com/2020/03/26/world/asia/coronavirus-refugees-campsbangladesh.html. Acesso em julho de 2020.

CAMUS, A. A Peste. Trad. de Graciliano Ramos. Rio de Janeiro: J. Olympio, 1950. (Coleção Fogos Cruzados, 101).

DA SILVA, Edna Fátima Pereira. Um ano de interiorização dos venezuelanos no

Brasil: xenofobia e fake news enquanto batalhas invisíveis dos refugiados. 2019. 


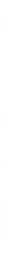

Neste contexto o presente artigo se propõe discutir a representação e o legado deixado para a sociedade brasileira pela Vereadora do PSOL (Partido Socialismo e Liberdade), Marielle Franco. Socióloga, política, feminista e defensora dos direitos humanos, foi eleita vereadora nas eleições de 2017, como a quinta parlamentar mais votada da cidade do Rio de Janeiro naquele ano, suas principais bandeiras de lutas e causas eram; das mulheres, dos negros, dos pobres, dos favelados, e LGBT+ (Lésbica, Gays, Bissexuais, transexuais). Falar da ex-vereadora é falar das lutas das classes minoritárias que compõem historicamente este país e suas lutas incansáveis ao longo da sua existência. Seu lugar de fala se destacar no campo social, com discursos voltados para o direito a existência, a uma vida digna, e igualdade de gênero, racial e social.

Para entender o contexto social em que a população negra, e pobre no Brasil está inserida, recorremos a Florestan Fernandes (1978), o autor aponta que a desigualdade social de classe, unicamente não consegue abranger a complexidade da desigualdade social e racial no país, visto que o elemento fundante dessa desigualdade perpassa as limitações de classe. Ou seja, para o autor a culpa não está nos sujeitos individuais, mas em um sistema estrutural que fora historicamente sedimentado.

Nesse sentido, essa conjuntura estar atrelada a raízes histórica demarcada na construção do País, a qual o modelo colonial ainda prevalece nos alicerces do Estado de forma cruel e excludente, excluído as minorias, os negros, favelados, LGBT, e dentre outros grupos que foram, e continuam sendo alvo de descasos e abandono por parte do poder público.

Foi em meio a esse contexto que Marielle revolucionou a história da política brasileira com seu espírito ativista ela representou o povo, as minorias, e se destacou nas lutas incessante em prol aos direitos humanos, e igualdade social. Se tornando motivo de orgulho para sociedade brasileira. E é provável que seu legado não seja esquecido tão brevemente, e suas lutas, projetos, e sonhos, continuaram vivos na esperança daqueles que esperam outras Marielles, que lhes estendam a mão e os possam levar a liberdade.

Assim, o estudo ora apresentado objetiva expor o legado deixando pela vereadora Marielle Franco na política brasileira, visando dessa forma compreender a relevância de uma figura política como ela frente aos movimentos de defesa a favor dos direitos humanos, e de políticas públicas voltadas para as necessidades dos indivíduos. 


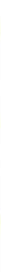

Dessa forma, na perspectiva de refletimos sobre o legado deixado pela vereadora tomamos como base para construção do estudo três indagações: Quem foi Marielle? Quais foram às contribuições que seu legado trouxe a sociedade, e a política brasileira? Por que o discurso em torno da sua imagem continua presente, mesmo após dois anos da sua execução? As reflexões teóricas e metodológica para essa pesquisa advêm de autores como Ianni (2001), Harvey (2011), Davis (2016), Weber (2004), Marx (1983), cujo seus discurso nos fornece subsídios para entender a dinâmica entre sociedade e classe social. No campo da sociologia, Comte, Weber, e Marx, buscam entender as bases da sociedade e sua estrutura, por meio da divisão de classe. Isso nos ajudará entender o contexto social a qual Marielle estava inserida, bem como as pessoas as quais ela defendia.

Os procedimentos metodológicos adotado neste estudo estão atrelados a pesquisas bibliográficas, que Para Gil (1999) São referências desenvolvida a partir de um material já elaborado, como os livros, artigos, entre outros materiais que fornecem embasamento teórico acerca de um determinado objeto. Assim recorremos a um levantamento bibliográfico a partir de textos, jornais, artigos, revista para compreender sua trajetória de vida, já para a construção da imagem pública e política de Marielle, foi feito, uma análise em documentários e entrevista de pessoas próximas a franco como sua irmã, mãe, pai, companheira, e amigos.

Por tanto, o trabalho encontra-se organizados em cinco seções: a atual seção encontra-se as considerações iniciais reflexões envolvendo o objeto de estudo, problemática, objetivo, referencial teórico metodologia e a estrutura do artigo. A segunda trata-se da trajetória de vida de Marielle Franco no campo público, e político. A terceira fora discutida as lutas, e projetos de lei aprovados da vereadora na câmara municipal, assim como as contribuições que eles trouxeram a sociedade. Na quarta seção, foi abordado a presença de Marielle na sociedade, nas ruas, nas manifestações, na música, e nos protestos que ecoam mundo fora. Vimos que seu discurso permanece vivo nas vozes das "Marielles". E por fim, chegamos as considerações finais acerca do estudo apresentado. Nessa seção foi visto o quanto seu legado contribuiu para nova forma de se fazer política no Brasil.

\section{A VIDA E AS LUTAS: MARIELLE FRANCO}




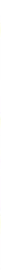

Marielle Francisco da Silva nasceu em 27 de julho de 1979, na cidade do Rio de Janeiro, filha de Marinete da Silva e Antônio Francisco da Silva Neto, no seio de uma família de princípios catolicista viveu no Morro do Timbau, Complexo da Maré - um conjunto composto por dezesseis favelas cariocas. Ali Marielle viveu e cresceu com sua família, frequentou escola pública, e dentro das limitações socioeconômicas que as circunstâncias da vida lhes impunham aos 11 anos de idade começou a trabalhar como camelô na comunidade com o propósito de juntar dinheiro visando a posterior investir em sua educação. Assim, viveu durante muito tempo tendo que trabalhar e estudar simultaneamente. Aos 16 anos frequentou a pastoral da juventude como catequista na paroquia Nossa Senhora dos Navegantes no município de Bonsucesso-RJ.

Pouco tempo depois iniciou ensino médio na rede pública estadual de ensino na própria comunidade, ali aprendeu por meio das observações empírica os valores morais que mas tarde se traduziram na sua postura enquanto agente público e ser social. Concluído o ensino médio aos 18 anos, fora convocada para ministrar aula em uma creche no complexo da Maré.

Na ocasião conheceu seu primeiro namorado, e em um curto período de tempo aproximadamente dois anos, ela casou-se, engravidou, e aos 19 anos conhecerá a maternidade dando à luz a sua única filha, Luyara Franco - fato corriqueiro em comunidade ditas favelizadas. Esse período foi muito difícil para ela, pois, foi abonada pelo marido que a deixou com a filha ainda pequena, tendo assim, que se desdobra entre o trabalho, a fazeres domésticos, estudos, e responsabilidades materna e paterna. Por esse motivo se afastou no período de dois anos das atividades escolares.

Dois anos depois ela retorna a vida escolar, nessa ocasião deu-se de conta que não estava preparada para ingressar em uma faculdade, por isso optou estudar no curso pré-vestibular comunitário da Maré, que na época chamado de "Bonde de intelectuais da favela" uma geração que fizeram curso de pré-vestibular comunitário e conseguiram acesso a boas universidades.

Foi nesse contexto que conheceu o professor Edson Dias, formado em história, e diretor da ONG redes da Maré, tal professor exercia um trabalho cujas lentes focavam para a realidade dos avanços da violência na comunidade, no qual indicadores eram denunciados escancaradamente nas páginas dos noticiários de toda comunidade e região. Logo a preocupação e os esforções empreendidos pelo então professor 


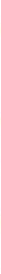

certamente fez brilhar os olhos da jovem Marielli que logo se somou a causa, a qual aprendeu princípios e valores que nortearam sua vida, e impulsionaram sua carreira.

Dado os esforços a persistência Marielle consegue quebra o ciclo educacional que segundo Bourdieu (2004) é relativamente dado como conservador nas escolas e passa a representar o ponto fora da curva ingressando dentro da sua própria comunidade em uma universidade pública do Rio de Janeiro, fato incomum para uma jovem pobre, negra, e mãe solteira.

Graduada em Ciências Sociais, não desanimara frente ao contexto social e econômico de sua realidade, alçou voo ainda mas ousados ingressando ao programa de Mestrado em Administração Pública na Universidade Federal Fluminense-UFF.

A trajetória e ascensão educacional de Marielle a tornou líder comunitária defendendo a bandeira dos direitos humanos e igualdade sociais, contrariando as ideias e práticas comuns de grupos dominantes no seio da comunidade.

\section{REPRESENTATIVIDADE POLÍTICA}

Dado o seu espirito emancipador Mariellle se torna vereadora pelo PSOL (Partido Socialismo e Liberdade) com 46.502 votos sendo a quinta vereadora mais votada no pleito eleitoral no ano de 2016 na cidade do Rio de Janeiro, e a segunda mulher mais votada ao cargo de vereadora em todo o país (CARIELLO; ROMEO, 2018).

Mas representava muito mais do que esses dados poderiam expressar. Marielle deu voz e corpo à população negra, silenciada nos espaços públicos e institucionais de poder. Com ideias a florados nas causas dos direitos humanos, enquanto vereadora apresentou dezesseis projetos de lei em prol dos diretos humanos, e política públicas voltadas para as minorias. Sua campanha foi um marco na história política da cidade. Com a bandeira de ser uma mulher, negra e favelada militante dos direitos humanos ela conseguiu o apoio de outros moradores de favelas, de intelectuais, de parte do movimento negros, de mulheres, de jovens universitários que viam ela como diferente dos outros candidatos uma oportunidade de fazer outra política, de fazer outro mundo possível. Com o lema "Eu sou porque nós somos", a campanha de Marielle articulava ideias muito importante, como a união, a representatividade, a possibilidade de ter na política alguém que não era como os políticos tradicionais. 


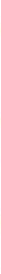

Sua militância lhe conferiu a nomeação em 28 de fevereiro de 2018 a vaga de relatora da Comissão dos vereadores que fiscaliza a intervenção militar no Estado carioca, se posicionando veementemente contraria a posição intervencionista, pois conhecia na prática e graças a sua origem a violência policial instaurada no estado, especialmente na comunidade da Maré. Onde era comum morosidade nos inquéritos em crimes da comunidade, cenas de opressão, e abuso de autoridades, entre outras ações incomum das forças de segurança.

Marielle representou a esperança de grupos historicamente marginalizados, ganhando forças e adeptos na sua causa, quando misteriosamente em uma noite de quarta -feira as 21h:30, do dia 14 de março de 2018, na Rua Joaquim Palhares, no Estácio, região central do Rio de Janeiro, sua vida foi interrompida por um grupo de criminosos que dispararam cerca 13 tiros de grosso calibre que ceifaram sua vida. Porém seu legado não morreu, pelo contrário se tornou inspiração para milhares de pessoas no mundo inteiro.

\section{O PENSAR E O AGIR: CONSTRUÇÃO TEÓRICA ENTRE LUTAS E CAUSAS SOCIAIS}

Marielle Franco externalizou sua militância no campo dos direitos humanos antes mesmo da sua filiação a partidos políticos. Para ela, a luta por direitos humanos era uma luta fundamental, pois se tratava da luta pela própria sobrevivência em um contexto a qual a desigualdade econômica, social, afetava diariamente aos moradores. Assim como, os avanços violentes e abusos sofridos das autoridades policiais. Foi nesse contexto que Marielle cresceu, e posteriormente iniciou seus primeiros passos na lutar a favor dos direitos humanos que se materializou em 2000, após a morte de sua amiga vítima de bala perdida durante um confronto entre policiais e traficantes no complexo da Maré.

Assim como Marielle, infelizmente, é comum que muitos moradores de favelas tenham perdido amigos e parentes seja para a violência dos traficantes, seja para a violência da polícia, seja durante o confronto entre as duas forças.

O que de fato percebe-se é a ausência de políticas públicas de inclusão e ascensão das populações pobres e negras, aliada ao crescimento da violência letal e à existência de milhares de micro-guerras nas comunidades periféricas, bem como a presença da política repressiva estatal nesses ambientes, que provocou nefastos danos ao 


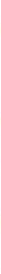

desenvolvimento econômico-social dessas populações, atingindo diretamente a juventude negra e pobre do país. A favela tornou-se o lugar perigoso que necessita ser exterminado, o racismo institucional materializado aponta que o problema está na periferia (SANTOS, 1978). Mas será que realmente o problema está nas favelas? Ou no abandono do poder público a essa região? Pois bem sabemos que as regiões periféricas em sua maioria são vítimas de descasos pelo poder público, e muitas das vezes são estereotipadas pela sociedade.

Como relata a autora (ZALUAR, 1985) ao escrever em sua obra "A máquina e a revolta: As organizações populares e o significado da pobreza" que as favelas são espaços heterogêneos, visto pela sociedade brasileira de forma generalizada como o lócus da pobreza, da desorganização social, e do crime.

Certamente Marielle não compactuava desses estereótipos, e sempre que surgia oportunidade elevava o nome da sua comunidade exigindo respeito pelas vidas existente naquele espaço. Foi nesse contexto que Marielle surgi como representante de minorias por dedicar seu mandato à ampliação de políticas públicas destinadas a levar cidadania a grupos minoritários. Para ela o problema não era a favela, mas sim, a falta de políticas públicas que atendesse a necessidade daquela região.

Dessa forma, sua candidatura foi marcada por uma atuação forte a qual defendia o exercício dos Direitos Humanos, as minorias, e criticava o abuso da força policial. Sua figura fazia-se e ainda se faz como uma representação de diversas forças e grupos sociais; sua imagem insurge em meio ao discurso dominante e acadêmico, onde grupos "invisíveis" não tem espaço e voz; sua figura desafiava a política predominantemente branca, onde no Brasil, somente 4,3\% dos políticos eleitos são negros ${ }^{131}$.

Djamila Ribeiro, em seu livro O que é lugar de fala? (2017), explica essa insurgência que foi citada acima: “A reflexão fundamental a ser feita é perceber que, quando pessoas negras estão reivindicando o direito a ter a voz, elas estão reivindicando o direito à própria vida" (RIBEIRO, 2017, p. 45)

Foi isso que Marielle fez durante toda sua trajetória, lutou por sua vida, e pala vidas das pessoas a sua volta. A princípio não foi fácil, pois, por ser vereadora de um partido de oposição e minoritário, era difícil para ela aprovar leis. No período que

131 KRÜGER, Ana. Só 4 dos eleitos em outubro são negros. Congresso em foco - Portal UOL, Disponível em: ongressoemfoco.uol.com.br/eleicoes/so-4-dos-eleitos-em-outubro-sao-negros-eram-107-das-candidaturas-em 2018. Acesso em: 20 de Maio. 2020. 


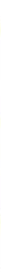

exerceu mandato apresentou dezesseis projetos de lei, sete foram aprovados, sendo que cinco foram consagrados somente depois de sua morte.

Os projetos de lei criados por ela tinha como objetivos promover melhorias aos moradores da comunidade da Maré, aos cidadãos negros, pobres, comunidade LGBT, e mulheres. Assim, em meio a seus projetos incluir-se o espaço Coruja (PL 17/2017). A ideia do programa é a acolher as crianças no período noturno, enquanto seus responsáveis trabalham ou estudam. Na discrição do PL, Marielle descreve que creches noturnas são essenciais para igualdade entre homens e mulheres, permitindo que mães com dupla jornada continuem seus estudos ou permaneçam em seus empregos. Foi criado também o dia da mulher negra (PL 103/2017), inclui no calendário oficial da cidade o dia de Thereza de Benguela uma homenagem à líder quilombola, símbolo de força, e resistência.

Foi criada, o dia de luta contra a homofobia, lesbofobia, bifobia e transfobia (PL 72/2017). Inclui esse dia ao calendário oficial da cidade. A data, 17 de maio, foi escolhida por ter sido o dia em que a homossexualidade foi excluída da Classificação Estatística Internacional de Doenças e Problemas Relacionados com a Saúde (CID) da Organização Mundial da Saúde (OMS), ocorrida em 1992.

Posteriormente o senado aprova a lei de n 0265/2017 "Das casas de parto" no Rio de Janeiro, cujo objetivo era contribuir para a saúde da mãe e do bebê, gerando menos custos para o Município e ainda amenizam as sobrecargas das maternidades de grande porte.

Foi aprovado ainda o projeto de lei 515/2017 que instituiu o programa de efetivação de medidas socioeducativas em meios aberto no município destinado aos ínvidos que cometeram atos infracionais menos graves, ou seja, sem violência ou ameaça.

Na ocasião foi aprovado ainda o projeto de lei "Assédio não é passageiro" (PL 417/2017) que prever a conscientização e enfrentamento ao assédio e violência sexual no município do Rio de Janeiro, espaços públicos, e transportes coletivos.

E por fim, "Dossiê Mulher Carioca" um projeto de Lei 555/2017 que reúne estatísticas periódicas sobre as mulheres atendidas pelas políticas públicas do município.

Aprovação desses projetos marcou a trajetória da vereadora na política brasileira, assim como ajudou e beneficiou muitos cidadãos. Marielle, fez em seu corpo 


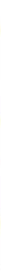

político a cor, a classe, a orientação sexual, e o endereço dos setores que mais sofrem com ataques do estado opressor. Certamente, as contribuições do seu legado foram muitas, e seu desempenho mostrou para Brasil a necessidade de termos mais mulheres negras e periféricas ocupando espaço na política brasileira. Para que dessa forma, haja mudança na forma de fazer política nesse País.

\section{ENTRE BECOS E VIELAS: MARIELLE PRESENTE!}

$\mathrm{Na}$ última década, movimentos de protesto e resistência têm eclodido no mundo todo, com reivindicações próprias, mas com características comuns, como as estratégias de ocupação do espaço público e a luta em torno de temas que atingem as minorias. Esses movimentos de organização coletiva ficaram conhecidos como movimentos de insurgência (FOUCAULT, 2010; COMITÊ INVISÍVEL, 2016). Cujo é notável capacidade de comunicação, com inovação e criatividade nas formas de disseminar seus propósitos.

As manifestações que acontecem após o assassinato de Marielle Franco têm essas características e há questões importantes que podem ser compreendidas ao observar esse fenômeno. Como a própria imagem posta de Marielle, e tudo o que ela representa para sociedade. Essas manifestações se tornaram mais intensas com o movimento Marielle Presente, que ficou mundialmente conhecido e que ainda permanece em expansão dentro das mais diversas comunidades. Sendo considerado uma forma de resistência e respeito a sua memória.

Dois anos se passaram até aqui, e Marielle ainda permanece presente no coração dos brasileiros, e como forma de reconhecimento a sua história ao longo desses dois anos, continua a receber diversas homenagens mundo a fora.

Ano passado foi homenageada com o samba enredo "história para ninar gente grande" da escola de samba Mangueira, - Rio de Janeiro, cujos seus versos reverenciava os grandes heróis da história brasileira que até tempos atrás eram ignorados nos livros: como as negras e os indígenas.

Outro acontecimento ocorreu também ano passado, em 08 de marco Dia Internacional da Mulher. Nessa ocasião em forma de protesto, Marielle teve seu rosto estampados em cartazes, faixas e camisetas. Seu nome também era evocado nas falas das mulheres, com a multidão sempre respondendo: Marielle, Presente! 


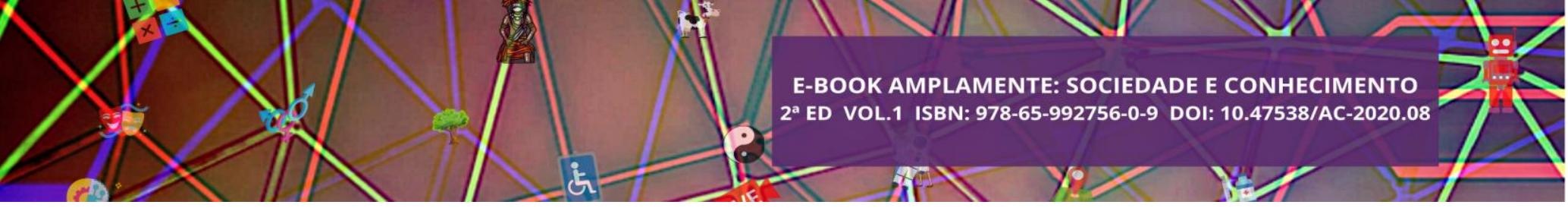

Em 14 de março de (2020), fez dois anos do seu assassinato, e por conta dos ricos de contagio do corona-vírus o evento que estava programado para essa data em alusão a sua memória, foi cancelado, na ocasião o Instituto Marielle Franco divulgou uma nota pedindo para as pessoas em ato de apoio ao seu legado colocassem em suas janelas lençóis, faixas, e que usem roupas amarelas.

A vereadora também recebeu homenagens oficializadas com seu nome batizado em Placa de rua, na zona norte da capital paulista, nome de Institutos, e imagens espalhadas com seu retrato ampliado em vários locais do País

Esses movimentos simbolizam a revência que teve o mandato eletivo deixado pela vereadora na política brasileira. Seus esforços não foram em vão, a semente plantada está dando frutos nas vozes das Marielles.

\section{CONSIDERAÇÕES FINAIS}

Por fim, chegamos as considerações finas desse estudo, a qual possibilitou inicialmente compreender o contexto social que Marielle Franco estava inserida, assim como as pessoas as quais ela defendia, posteriormente foi feita uma reflexão acerca da importância do legado que ela deixou na política brasileira, cujo o foco principal foi as necessidades das minorias, dos negros, das mulheres, e toda comunidade LGBT. Todas essas causas e luta se tornaram agenda política de Marielle, que surgiu para dar voz aos historicamente excluídos da política, e também para colorir o poder legislativo com os temas da diversidade.

Vimos que inicialmente não foi fácil, visto que ela não pertencia a classe majoritariamente branca, e rica do país. E por ser mulher, negra, favelada, e vereadora de um partido de oposição minoritário, era difícil para ela aprovar leis. Mas ela alcançou, e graças a sua determinação conseguiu por meio dos seus projetos beneficiar muitos cidadãos.

Franco performou uma trajetória de superação que os brancos apreciam contar para dizer que temos todos as mesmas oportunidades. Ela superou o contexto em que foi criada (a favela), o racismo, o machismo; fez uma universidade, se formou, foi eleita com votação extraordinária e se tornou representante parlamentar de um contingente de pessoas e grupos. Vereadora do Rio de Janeiro, fez todo o percurso singular e raro, 'a jornada do herói'. 


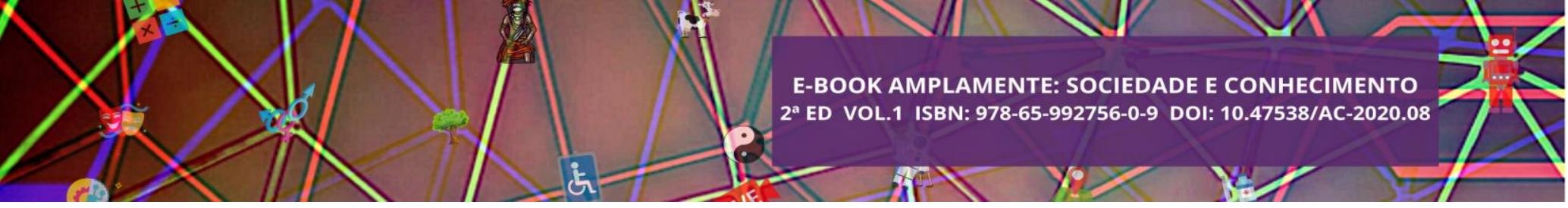

Sua morte significou uma grande perda para os movimentos de cunho social, e político no Brasil, e suas contribuições foram fundamentais para novo modelo de se fazer política. Sendo assim, esperamos que esta seja apenas uma interrupção, afinal muitas sementes foram plantadas para que surjam outras "Marielles", nos espaços de poder do nosso País.

\section{REFERÊNCIAS}

BOURDIEU, Pierre. Os usos sociais da ciência: por uma sociologia clínica do campo científico. São Paulo: UNESP, 2004.

CARIELLO, Gabriel; ROMEO, Madalena. Quantos mais vão precisar morrer para que essa guerra acabe? Escreveu Marielle um dia antes de ser morta. Jornal O Globo. 2018. Disponível em https://oglobo.globo.com/rio/quantos-mais-vao-precisar-morrer-para-queessa-guerra-acabe-escreveu-marielle-um-dia-antes-de-ser-morta-22491127

COMITÊ INVISÍVEL. Aos nossos amigos - Crise e insurreição. $1^{\text {a }}$ edição. N-1 Ediçoes, 2016.

DAVIS, Angela. Mulheres, raça e classe. Tradução de Heci Regina Candiani. São Paulo: Boitempo, 2016, 244p.

FERNANDES, Florestan. A integração do negro na sociedade de classes. São Paulo: Ática, 1978. Disponível em: <https://ayrtonbecalle.files.wordpress.com/2015/07/florestanfernandes-a-integrac3a7c3a3o-do-negro-na-sociedade-de-classes-vol-i-o-legado-darac3a7a-branca.pdf> Acesso em: 18 maio. 2020.

FOLHA DE SÃO PAULO. Da Maré, vereadora fazia parte do 'bonde de intelectuais da favela'. Publicado em: 15 de março de 2018. Disponível em: https://www1.folha.uol.com.br/cotidiano/2018/03/feminista-negra-e-cria-da-mare-quemfoi-a-vereadora-marielle-franco.shtml>. Acesso em: 26 março de 2020.

FOUCAULT, M. A ordem do discurso. São Paulo: Editora Loyola, 2010.

GIL, A. C. Métodos e técnicas de pesquisa social. 5.ed. São Paulo: Atlas, 1999.

HARVEY, David. O neoliberalismo: história e implicações. Tradução: Adail Sobral e Maria Stela Gonçalves. 2a ed. São Paulo: Edições Loyola, 2011.

IANNI, O. Teorias da Globalização. Civilização Brasileira: Rio de Janeiro, 2001.

MARX, K. O capital. V. I, tomo 1. São Paulo: Abril Cultural, 1983.

PORTAL Marielle Franco. Quem é Marielle?. Disponível em: Acesso em: https://www.mariellefranco.com.br/quem-e-marielle-franco-vereadora de março. 2020.

RIBEIRO, Djamila. O que é lugar de fala?. Belo Horizonte: Letramento, 2017. 


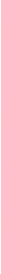

$\mathrm{Na}$ Antiguidade, os povos deixam de ser sedentários e de viver apenas da agricultura e começaram a viajar em busca de comércio e da troca de mercadorias, produtos e alimentos com outros povos, e como consequência pagando ou fazendo trocas por alimentação e abrigo, desse modo, já são entendidas como viagens, neste caso, com motivação econômica (BARRETTO, 2001; BADARÓ, 2003). No período clássico, as principais contribuições à atividade turísticas ficam por conta da Grécia e de Roma que dada sua modernidade para a época trouxeram contribuições importantes nas vias de acesso e transportes. Os antigos Jogos Olímpicos também eram grandes responsáveis pelas viagens em todo o mundo sob influência grega, daí, viagens motivadas por eventos, enquanto que, o Império Romano contribuiu com uma complexa malha de vias e estradas construídas por toda a Europa, onde também se desenvolveram os Spas e os balneários, assim, deslocamentos por motivos relacionados à saúde, e são desse período também as primeiras hospedarias (IGNARRA, 2013).

Já na Idade Média, a fé e a religião estavam acima de tudo, as Cruzadas fazem parte dessa cronologia, quando muitos homens faziam viagens motivados por razões religiosas, é o que se assemelha hoje as viagens em grupos. Nessa época, a Igreja Católica chegava a incentivar esse tipo de viagem cumprindo roteiros na Terra Santa, como forma de perdão dos pecados. A busca pelas especiarias orientais também data dessa época, fazendo o intercambio entre as culturas do oriente e do ocidente e assim despertando interesses nas viagens de motivação comercial muito mais longas, era o tempo das grandes navegações e do intercambio entre povos (BARRETTO, 2001; BADARÓ, 2003; ABUMANSSUR, 2003).

O movimento renascentista deixou a visão religiosa antiquada, encorajando assim a satisfação pessoal, e isso afetou o ramo das viagens na época. É desse período o desenvolvimento das feiras de troca de mercadorias por toda a Europa, e do princípio de algum crescimento industrial, crescimento este, que contribuiu para a formação de uma classe da sociedade com interesse por viagens e outras culturas. Já no século XIX, acontece um dos primeiros grandes impulsos as viagens e aos deslocamentos, com o surgimento das ferrovias, que proporcionou o transporte de cargas e de muitas pessoas e por grandes trajetos. Nessa época também surge o capitalismo, e a máquina a vapor, diante disso, desenvolvimento e acumulo de riquezas, para uma parcela da população, criando assim, um potencial mercado consumidor para o segmento das viagens (ANDRADE, 1999; IGNARRA, 2013). 


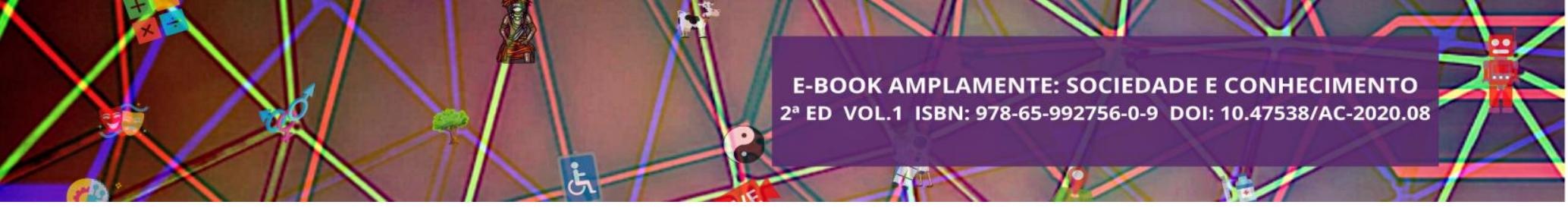

No Brasil, a história das viagens e do turismo se inicia a partir do momento do seu descobrimento e pelos deslocamentos exploratórios portugueses, entretanto, o turismo mais próximo como acontece hoje só veio a começar a se desenvolver a partir do momento que a Corte Portuguesa se muda para o Brasil, em 1808 (TRIGO, 1998; 2005). Após isso, houve uma série de melhorias sociais e desenvolvimento urbano, bem como melhorias nas vias e nos transportes movidos a vapor e o primeiro trecho ferroviário no estado do Rio de Janeiro, possibilitando os deslocamentos e as viagens (IGNARRA, 2013).

No começo do século XX, surgem os primeiros conceitos de turismo, (IGNARRA apud VON SCHULLARD, 2013, p. 12) “[...] a soma das operações, especialmente as de natureza econômica, diretamente relacionada com a entrada, a permanência e o deslocamento de estrangeiros para dentro e fora de um país, cidade ou região". Sendo um conceito mais relacionado ao alcance econômico da atividade. Após isso, na década de 40, a Escola de Berlim também conceituou o turismo basicamente voltado para o tempo de estadia e as relações e os fenômenos causados e excluindo sempre o turismo de negócios, pois eles não consideram turismo quando se torna alguma atividade produtiva. À época, Arthur Bornann definiu o turismo como o conjunto de viagens com objetivos de prazer ou profissionais, de modo temporário a residência habitual (ANDRADE, 1999).

Pode-se observar que esses conceitos, os primeiros que apareceram, são simplificados e racionalizados e basicamente direcionados para a esfera econômica e dão ênfase aos deslocamentos. Os primeiros conceitos de turismo são fortemente influenciados pela realidade da época, nesse caso, ganha forte abordagem econômica. Na década de 70, Jafari define turismo como "o estudo do homem longe de seu local de residência, da indústria das necessidades, e dos impactos que ambos, ele e a indústria, geram sobre os ambientes físico, econômico e sociocultural da área receptora" (BENI apud JAFARI, 1998). É possível perceber uma mudança no enfoque no conceito de turismo em que o enfoque econômico deixa de ser o foco e cede espaço as temáticas sociais, culturais e naturais que recebem devida importância.

Os conceitos mais atuais de turismo são ainda mais abrangentes como De La Torre (2003) relata que: "O turismo é um fenômeno social que consiste no deslocamento voluntário e temporário de indivíduos ou grupos de pessoas que, fundamentalmente por motivos de recreação, descanso, cultura ou saúde, saem de seu 


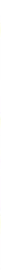

local de residência habitual para outro, no qual não exercem nenhuma atividade lucrativa ou remunerada, gerando múltiplas inter-relações de importância social, econômica e cultural". Por fim, a Organização Mundial do Turismo (OMT), o órgão vinculado a ONU, afirma que o turismo "é a atividade do viajante que visita uma localidade fora de seu entorno habitual, por período inferior a um ano, e com propósito principal diferente do exercício de atividade remunerada por entidades do local visitado" (OMT, 2014).

\section{A ATIVIDADE TURÍSTICA COMO VETOR DE DESENVOLVIMENTO}

Destas inter-relações o turismo se alastra como amplo ramo econômico e agregador. Muitos países têm sua economia baseada nesse ramo que cresce a cada ano e se firma como um propulsor da economia mundial. É uma atividade que tem a capacidade de abranger muitos setores da economia de uma localidade, dentre os equipamentos apreendidos pelo aspecto multiplicador do turismo estão: restaurantes e bufês, condutores locais e guias, locação de veículos, serviços terceirizados (chefes de cerimonial, tradutores, recepcionistas, manobristas, segurança etc.), serviços bancários, de saúde etc. O turismo quanto gancho da economia tem grande relevância. Graças ao seu grande alcance socioeconômico, capacidade de redistribuição de renda, geração de emprego e até no amparo ao meio ambiente, pois se apresenta como uma atividade econômica que, que quando feita seriamente, alia razões econômicas as sociais e a conservação natural (IGNARRA, 2013).

O setor de serviços, onde o turismo se encaixa, é grande favorecido na geração de empregos, a atividade turística mostra sua relevância nos indicadores econômicos. $\mathrm{O}$ turismo tem grande importância dentro de uma economia, além de multiplicador de renda e emprego, mas também de importações e impostos. Outro ponto de relevância econômica atribuída ao turismo é sua relação inseparável com a infraestrutura básica, como por exemplo, vias de acesso, transportes, saneamento, energia, comunicação, serviços bancários, entre outros. Sendo a primeira etapa para o surgimento de qualquer interesse turístico e estando relacionado ao setor público, essa infraestrutura também é de grande importância para a viabilização do turismo, além de contribuir imensamente para melhores condições e bem estar da população local (OMT, 2014). 


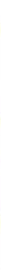

Há também vários outros aspectos políticos envolvendo o desenvolvimento do turismo. O poder público pode ser de grande importância no crescimento turístico de uma região, as vias de acesso, majoritariamente são responsabilidades dos governos e de extrema importância, pois assegura o acesso a região. Uma duplicação ou qualquer obra (sinalização, Rodoviárias, Aeroportos, postos da Polícia Rodoviária) que possibilite ou facilite o acesso também é de grande auxilio e são serviços vitais para qualquer localidade. A capacitação de mão de obra e investimentos em publicidade e propaganda também são também encargos que podem ser de esfera pública no desenvolvimento do turismo (ANDRADE, 1999; IGNARRA, 2013).

Ainda assim, são sabidos todos os benefícios que o turismo abrange desde os investimentos na montagem e manutenção da infraestrutura e também pela redistribuição de renda entre emissores e receptores. Mas nem tudo relacionado a atividade turística são benefícios, o turismo também provoca aumento do custo de vida, além de impactos físicos, que são um risco a manutenção da paisagem de um destino, que pode ser crucial para a sua sobrevivência. O fenômeno turístico é extremamente dinâmico e suas variáveis estão em constante mutação, dessa nova mentalidade, e a discussão sobre as questões ambientais vem sensibilizando pessoas ao redor do mundo. Cada vez mais governos e empresas estão vendo o nicho do ecoturismo como os grandes crescentes do século XXI, tanto que já representa uma fatia significativa no mercado do turismo internacional e embora o crescimento seja lento, é gradual, e atrai investimentos (RUSCHMANN, 2004; MINISTÉRIO DO TURISMO, 2008).

\section{NATUREZA E TURISMO: O SEGMENTO DO ECOTURISMO}

O Turismo como uma atividade de deslocamento ocasionada pelos mais diversos atrativos, no caso do Ecoturismo, esse deslocamento seriam motivados pelos Recursos Turísticos Naturais, em que, geralmente o público busca algo novo fora da rotina urbana. É um segmento turístico que se fundamenta na inclusão social e no respeito à natureza. É para o planejamento da área, uma busca ao equilíbrio de forma que o turismo e a atratividade da localidade não sejam causa de sua deterioração.

Viajantes motivados por razões ecológicas e até mesmo científicas já existem há muito tempo como, Darwin e Humboldt, mas foi apenas no século XX, com a realização das Conferencias Mundiais do Meio Ambiente, a primeira em 1972 na 


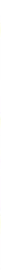

Suécia, que temas como degradação ambiental e preservação foram debatidos, assim gerando interesse público crescente nessas questões. Graças a essa convergência a respeito do tema ao redor do mundo o conceito de ecoturismo chega ao Brasil, e com a realização da Rio 92 esse nicho recebeu enorme visibilidade e impulso. Logo após surgiu a primeira conceituação de turismo ecológico, a EMBRATUR e o Ministério do Meio Ambiente definiram o ecoturismo como: [...] segmento que utiliza, de forma sustentável, o patrimônio natural e cultural, incentiva sua conservação e busca a formação de uma consciência ambientalista por meio da interpretação do ambiente, promovendo o bem-estar das populações (MINISTÉRIO DO TURISMO, 2008, p. 16).

Por ser um nicho do turismo segmentado tem como premissas, a preocupação com a população local, com a condição dos atrativos e causar menor dano possível a região. Por isso a parte estrutural precisa ser diferenciada, "[...] a estrutura receptiva deve ser pequena, refinada, integrada e harmoniosa em relação ao meio." (RUSCHMANN, 2004, p. 25). Em síntese, é uma atividade turística que deve se adaptar aos atrativos e a natureza e não o contrário.

Os atrativos naturais são inerentes a pratica do Ecoturismo e, de certa forma, constituem a essência do turismo sem o qual não seria possível desenvolve-lo. O Brasil é um país fartamente favorecido nessa área, e há uma extensa gama de atrativos naturais como exemplifica o quadro abaixo, como por exemplo, montanhas, planaltos e planícies, costas e litoral, terras insulares, dentre outros. Dado o tipo de atrativo, o perfil do ecoturista que busca esse segmento também é diferente do convencional, tem poder aquisitivo alto e costumam viajar nos períodos fora da alta temporada, o inverso do turismo de massa.

Sobre o ecoturista o Ministério Do Turismo (2008, p. 30) afirma:

[...] apresentam perfis diferenciados em função das diversas atividades motivacionais que determinam as características de cada público, abarcando, principalmente, uma faixa etária abrangente. Geralmente, os turistas desse segmento querem ver, sentir, cheirar, tocar e comer o inusitado; leem muito sobre o destino antes de planejar a viagem; anotam perguntas e querem respostas dos guias e do pessoal que os atendem; querem um tratamento personalizado e prezam pela segurança.

Desse modo, as atividades praticadas no ecoturismo são basicamente as experiências que cada um pode ter em contato com a natureza, as mesmas sempre deverão ocorrer seguindo as premissas de proteção ao meio ambiente. E um dos maiores 


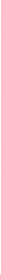

diferenciais desse nicho é o seu público que geralmente é instruído e consciente. Atualmente, o que se é mais praticado em relação ao ecoturismo são as trilhas, a apreciação de paisagem, tendo como recompensa no fim do passeio mergulhos em cachoeiras, lagos, rios, dentre outros.

Sendo o turismo formado por diferentes segmentos que se relacionam um mesmo atrativo pode ser empreendido por diferentes segmentos obtendo assim, agregação de valor. Uma cachoeira, ou trilha, por exemplo, pode ser empreendida tanto no segmento ecoturístico quanto no turismo de aventura. Além do turismo de aventura, ecoturismo também possui atividades inerentes ao turismo rural, náutico, etc. Há ainda alguns céticos quanto a esse grau de informação e de disciplina dos turistas. "Alguns estudiosos não acreditam que, para preservar o meio ambiente, as pessoas deixem de viajar em grupos, controlem seus impulsos consumistas e o desejo de conforto, para se transformarem em turistas bonzinhos" (RUSCHMANN, 2004, p. 23).

\section{REGULAMENTAÇÕES DE POLÍticas PÚBLICAS PARA A PRÁTICA DO ECOTURISMO NO BRASIL}

Quanto às políticas públicas e a legislação ambiental, que por consequência, pode ser aplicada aos turistas do segmento ecológico, é sabido que os países europeus foram os primeiros a ter essa consciência e foram os primeiros a elaborarem leis a respeito da preservação em empreendimentos turísticos, e a legislação brasileira relacionada a isso também caminha a passos largos, de acordo com Paiva (2003 p. 52$53)$ :

Atualmente, a Constituição brasileira é tida como uma das mais completas do mundo quanto ao assunto meio ambiente. A Lei número 6.513/1977, posteriormente regulamentada pelo Decreto número 86.176 de 6 de julho de 1981, e prevê que todos os planos turísticos deverão assegurar a preservação e valorização do patrimônio cultural e natural e estabelece normas de uso e ocupação do solo, pressupondo penalidades diversas, inclusive o embargo de obras.

A lei citada acima é da década de 1970, e é referente a Áreas Especiais e Locais de Interesse Turístico, para sua adaptação ao desenvolvimento das atividades turísticas. Por ser uma lei mais antiga, da década de 1970, sua regulação estava sob a responsabilidade da EMBRATUR (Empresa Brasileira de Turismo) que foi criada em 1966, já que não existia o Ministério do Turismo, apenas criado em 2003. A Lei 


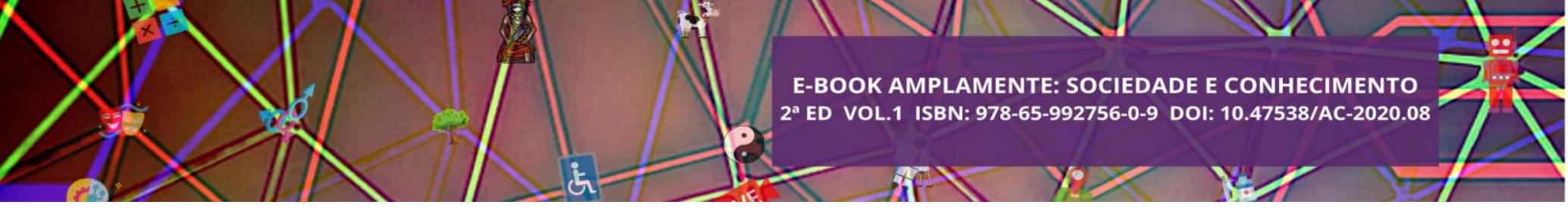

6.513/1977 classificava as Áreas Especiais de Interesse Turístico sob a seguinte forma: áreas prioritárias, em que são áreas de alta potencialidade turística, que devam ou possam ser objeto de planos ou programas de desenvolvimento turístico; áreas de reserva, que são áreas de elevada potencialidade turística, cujo aproveitamento deva ficar na dependência de da implantação dos equipamentos de infraestrutura indispensáveis, efetivação de medidas que assegurem a preservação do equilíbrio ambiental e proteção ao patrimônio cultural e natural nelas existentes (BRASIL, 1977).

Já na década de 1980, o Brasil passou a ter oficialmente uma política ambiental, nasce a Lei 6.938/1981, ou a Política Nacional do Meio Ambiente que estipula e define, dentre outras coisas, que o poluidor é obrigado a indenizar danos ambientais que causar, independente da culpa, e que o Ministério Público pode propor ações de responsabilidade civil por danos ao meio ambiente, como a obrigação de recuperar e/ou indenizar prejuízos causados. Também tem como pontos relevantes, como estabelecer o meio ambiente como sendo uma propriedade pública que, precisa ser cuidado e esclarecer a racionalização da utilização do subsolo, solo, ar e água. Outro ponto relevante é a instituição de instrumentos e ferramentas da política ambiental nacional, como o Zoneamento Ambiental, Avaliação de impactos ambientais (A.I.A.), Estudo de impacto ambiental (EIA) e relatório de impacto ambiental (RIMA). E tem como objetivo regulamentar as várias atividades que envolvam o meio ambiente, para que haja preservação, melhoria e recuperação da qualidade ambiental, tornando favorável a vida, assegurando à população condições propícias para seu desenvolvimento social e econômico (BRASIL, 1981).

Na década de 1990, foi criada a Lei dos Crimes Ambientais Lei 9.605/1998, que considera crimes ambientais toda e qualquer ação que causar poluição de qualquer natureza que resulte ou possa resultar em danos à saúde ou que provoque a mortandade de animais ou a destruição significativa da flora. As penas previstas pela Lei de Crimes Ambientais são aplicadas conforme a gravidade da infração, quanto mais reprovável a conduta, mais severa a punição, que pode ser a privação de liberdade, restrição de direitos ou multa (BRASIL, 1998). E em 1999, foi promulgada a Política Nacional de Educação Ambiental, em que a legislação ambiental surge com o objetivo de garantir o sadio desenvolvimento da humanidade (BRASIL, 1999). De acordo com esta lei, a divisão é feita em, meio ambiente natural, que é formado pelos recursos da natureza, o ar, a água, a fauna, a flora, e meio ambiente artificial dos quais houve modificação 


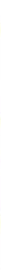

humana. A lei afirma também o incentivo à participação individual e coletiva, permanente e responsável, na preservação do equilíbrio do meio ambiente, entendendose a defesa da qualidade ambiental como um valor inseparável do exercício da cidadania.

Enquanto que, nos anos 2000, foi criado o Sistema Nacional de Unidades de Conservação da Natureza (SNUC) que foi estabelecido em julho de 2000 através da Lei número 9.985. Que estabeleceu que as áreas sob proteção são chamadas de Unidades de Conservação (UC's) e são administradas pelo ICMBio vinculado ao Ministério do Meio Ambiente. Todas as Unidades de Conservação são regulamentadas pelo Sistema Nacional de Unidades de Conservação (SNUC), como atesta o Departamento de Áreas Protegidas do Ministério do Meio Ambiente (2011):

[...] foi instituído o SNUC, com a promulgação da Lei $\mathrm{n}^{\circ} 9.985$, de 18 de julho de 2000. A Lei do SNUC representou grandes avanços à criação e gestão das UC nas três esferas de governo (federal, estadual e municipal), pois ele possibilita uma visão de conjunto das áreas naturais a serem preservadas. Além disso, estabeleceu mecanismos que regulamentam a participação da sociedade na gestão das UC, potencializando a relação entre o Estado, os cidadãos e o meio ambiente.

Dentre as finalidades do SNUC estão basicamente proteger e preservar o patrimônio natural (recursos hídricos, espécies em extinção, etc.), contribuir também contribuir para a sua manutenção, promover a pesquisa cientifica na área ambiental à educação ambiental e por fim divertimento na relação com o meio natural, ou seja, o turismo ecológico. O SNUC é uma importante ferramenta para o crescimento de atividades turísticas em áreas naturais no país, como descreve o Ministério Do Turismo (2008, p. 36-37):

Cabe ressaltar que a visitação ao SNUC é um dos principais recursos e atrativos para o desenvolvimento de inúmeras atividades turísticas no País, ocupando lugar de destaque na política ambiental, a partir de atividades compatíveis com a conservação da biodiversidade, [...] entre elas a promoção do Ecoturismo - "promoção da educação e interpretação ambiental, da recreação em contato com a natureza e do turismo ecológico".

O alcance e ações do SNUC chega a todas as esferas públicas, o Brasil conta com 71 parques nacionais, mas nem metade estão abertos para visitação, mas nem por isso o turismo em seus domínios se torna inibido, de acordo com o ICMBio (Instituto Chico Mendes de Conservação da Biodiversidade) desde de 2006 os números vem 


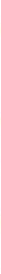

numa crescente (ICMBio, 2017). Dentre os mais visitados estão: o Parque Nacional de Foz do Iguaçu no Paraná e divisa com a Argentina, o Parque Nacional da Tijuca situado da cidade do Rio de Janeiro, que receberam mais de um milhão de visitantes cada. De acordo com o ICMBio (2017), quase quatro milhões de pessoas visitaram os parques nacionais na metade da década de 2010, enquanto em 2015 já eram cerca de oito milhões de pessoas que visitaram os parques. $\mathrm{O}$ desenvolvimento da atividade turística em áreas naturais pode gerar muitos benefícios na esfera econômica, sempre mantendo o foco, a preservação Ministério Do Turismo (2008).

\section{CONSIDERAÇÕES FINAIS}

Finalmente, por tudo que foi visto, a regulamentação de políticas públicas para a prática do ecoturismo no Brasil tem escopo legal, ao menos na esfera federal, bem pavimentado e está entre as mais abrangentes do mundo. Desde a década de 1970 e 1980 com a Política Nacional do Meio Ambiente, passando pela criação de Lei de Crimes Ambientais na década de 1990, onde passou a ser passível de punição quem agredir e poluir o meio ambiente, até a instituição do SNUC, já nos anos 2000, um elemento importante, pois é responsável por instituir e regular Unidades de Conservação em todas as esferas do poder público, assim contribuindo para a preservação e também para fins recreativos, ou seja, o turismo ecológico.

Além do fato da atividade turística tem grande potencial agregador e é uma das maiores empregadoras do mundo, se for bem planejado, o turismo pode ser uma saída para questões sociais. Tudo isso, de certa forma, contribuiu para o aumento do interesse do público, que se refletiu no aumento nas visitações aos parques nacionais, que quase chegaram a dobrar da década passada aos dias de hoje.

Áreas naturais protegidas por lei são a garantia que o segmento necessita para progredir porque assegura aos investidores e operadores turísticos que o recurso natural (principal atrativo) não corre perigo de depredação. Porém, é importante observar que o êxito econômico do desenvolvimento do segmento nessas áreas depende de uma série de outros fatores relacionados como alojamento, acesso, qualidade dos serviços de guias, capacidade de incorporar ativamente a população local, entre outros, reconhecendo que a proteção da qualidade do recurso natural deve ser a prioridade. 


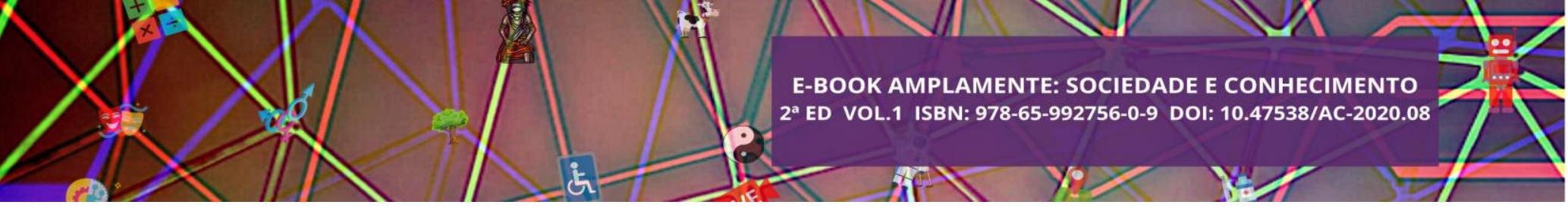

\section{REFERÊNCIAS}

ABUMANSSUR, E. S.(org.) Turismo Religioso: Ensaio Antropológico sobre Religião e Turismo. Campinas, Papirus, 2003.

ANDRADE, J.V. Turismo: Fundamentos e Dimensões. 6. ed. São Paulo: Ática, 1999.

BADARO, R. A. L. Direito do turismo: história e legislação no Brasil e no exterior. São Paulo: SENAC. 2003.

BARRETTO, M. Turismo e Legado Cultural. As possibilidades do planejamento. 6. ed. Campinas: Papirus, 2001.

BENI, M. C. Análise Estrutural do Turismo, São Paulo, Senac, 1998.

BRASIL, Lei 6.513/1977. Áreas Especiais de Interesse Turístico. Disponível em: <http://www.planalto.gov.br/ccivil_03/leis/16513.htm>. Acesso em: 20 jun. 2020, 14:00.

BRASIL, Lei Federal 6.938/1981. Política Nacional do Meio Ambiente. Disponível em: < http://www.planalto.gov.br/ccivil_03/LEIS/L6938.htm>. Acesso em: 20 jun. 2020, 16:00.

BRASIL, Lei Federal 9.605/1998. Lei dos Crimes Ambientais. Disponível em:< http://www.planalto.gov.br/ccivil_03/leis/19605.htm>. Acesso em: 29 jun. 2020, 16:00.

BRASIL, Lei Federal 9.795/1999. Política Nacional de Educação Ambiental. Disponível em: <http://www.planalto.gov.br/ccivil_03/leis/19795.htm>. Acesso em: 29 jun. 2020, 14:00.

DE LA TORRE. O. El turismo- fenómeno social. México, Fondo de Cultura Económica, 1992.

DEPARTAMENTO DE ÁREAS PROTEGIDAS DO MINISTÉRIO DO MEIO AMBIENTE. Sistema Nacional de Unidades de Conservação da Natureza - O SNUC. <Disponível em: http://www.mma.gov.br/sitio/index.php?ido=conteudo.monta\&idEstrutura=240>. Acesso em: 30 jun. 2020, 14:00.

INSTITUTO CHICO MENDES DE CONSERVAÇÃO DA BIODIVERSIDADE (ICMBio). Contribuições Do Turismo Em Unidades De Conservação Federais Para A Economia Brasileira. Brasília, 2017.

IGNARRA, L. R. Fundamentos do Turismo. 3 ed. Ver. E ampl. - São Paulo: Cengage Learning; Rio de Janeiro: Editora Senac Rio de Janeiro, 2013.

MINISTÉRIO DO TURISMO. Hábitos de Consumo do Turismo do Brasileiro. Brasília: Ministério do Turismo, 2009. 


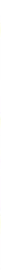

MINISTÉRIO DO TURISMO. Ecoturismo: Orientações Básicas. Brasília, 2008.

<Disponível em:

http://www.turismo.gov.br/turismo/o_ministerio/publicacoes/cadernos_publicacoes/14 manuais.html>. Acesso em: 28 jun. 2010, 15:00.

ORGANIZAÇÃO MUNDIAL DO TURISMO. Panorama OMT Del turismo mundial. 2014.

PAIVA, Maria das Graças Menezes. Sociologia do Turismo. São Paulo, Cornacchia, 2003.

REJOWSKI, M. et al. Desenvolvimento do Turismo modern. In: REJOWSKI, Mirian (org). Turismo no percurso do tempo. São Paulo: Aleph, 2002.

RUSCHMANN, D. Turismo e Planejamento Sustentável, A proteção do Meio Ambiente. Campinas, Papirus, 2004.

TRIGO, L.G.G. A sociedade pós industrial e o profissional em Turismo. 2. ed. Campinas: Papirus, 1998.

TRIGO, L. G. G. et al (Eds). Análises regionais e globais do turismo brasileiro. São Paulo: Roca, 2005. 


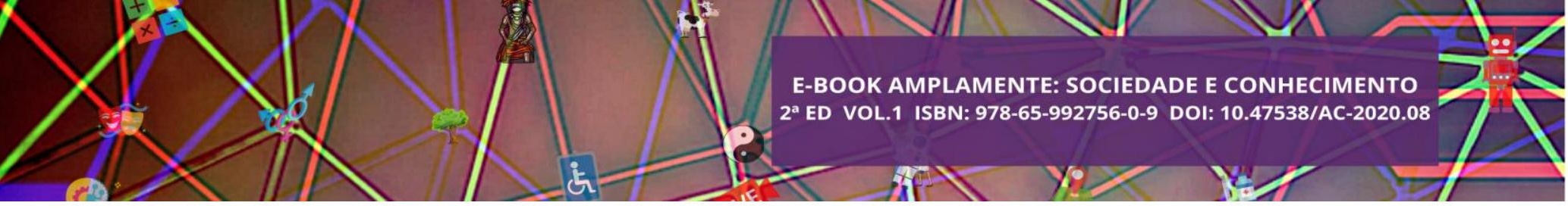

\title{
CAPÍTULO XXVI
}

\section{O DESABASTECIMENTO DA VACINA PENTAVALENTE NO ANO DE 2019 E SEUS POSSÍVEIS IMPACTOS NO ANO DE 2020: UMA ANÁLISE TEMPORAL}

\author{
Aline Grandis Guimarães ${ }^{134}$; Daniela Lacerda Santos ${ }^{135}$ \\ Gustavo Emanuel Martins Ferreira Torres ${ }^{136}$; Joana Gonzalez Ambrosio Izzo do Amaral ${ }^{137}$. \\ DOI - Capítulo: 10.47538/AC-2020.08-26
}

\section{RESUMO:}

O Ministério da Saúde demanda cerca de 800 mil doses mensais da vacina pentavalente e, evidentemente, seu desabastecimento em 2019 gerou impactos significativos na saúde da população; pois o Brasil não possui laboratório para a produção da vacina, realiza sua compra via Fundo Estratégico da Organização Pan-Americana da Saúde (OPAS). Este estudo objetivou: 1) entender os resultados do desabastecimento da vacina pentavalente no Programa Nacional de Imunização (PNI) em 2019; 2) cotejar como a pandemia possivelmente afetou a retomada da imunização no país. Foi realizada uma pesquisa exploratória descritiva, através das informações do Departamento de Informática do Sistema Único de Saúde (DATASUS) e análise de documentos ministeriais. Há divergências entre os meses que precederam o desabastecimento, onde janeiro de 2019 houve o melhor desempenho, com 800 mil doses foram aplicadas. No segundo semestre de 2019 houve considerável redução de doses aplicadas, retratando a crise de desabastecimento. A partir de março deste ano, com os casos de infecção e adoecimento pelo vírus Sars-Cov-2 e quarentena com isolamento social estabelecidos, observa-se que a curva de doses aplicadas não segue aos parâmetros dos anos anteriores (março a julho de 2017 a 2019). Ela se estabiliza em valores bem abaixo, inclusive registra seu menor valor anual no último mês analisado (maio). Sendo assim, torna-se importante discutir a capacidade de abastecimento do Programa Nacional de Imunização (PNI), as possibilidades para garantir sua autossuficiência; assim como reforçar o papel fundamental do Sistema Único de Saúde (SUS) na proteção e promoção da saúde da população de um país com dimensões continentais, principalmente em um cenário desafiador para a saúde pública mundial, com a pandemia pela Covid-19.

PALAVRAS-CHAVE: Vacinação. Programas de Imunização. Cobertura Vacinal.

134 Acadêmica do curso de Medicina pela Faculdade de Medicina de Petrópolis. Acadêmica do curso de Gestão Hospitalar pela Universidade Estácio de Sá. E-mail: alinegrandis@ hotmail.com

135 Doutora em Saúde Coletiva pelo Instituto de Medicina Social/UERJ. Professora do Centro Universitário Arthur Sá Earp Neto/Faculdade de Medicina de Petrópolis. E-mail: enfdanielalacerda@gmail.com

136 Acadêmico do curso de Medicina e Monitor da cadeira de Bioquímica pela Faculdade de Medicina de Petrópolis. E-mail: gustavo_mft@yahoo.com.br

137 Acadêmica do curso de Medicina pela Faculdade de Medicina de Petrópolis. E-mail: Joana.ambrosio@hotmail.com 


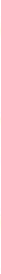

\section{A IMPORTÂNCIA DA IMUNIZAÇÃo NA PREVENÇÃO PRIMÁRIA DE GRAVES DOENÇAS}

A utilização das vacinas como tecnologias em saúde para a imunização e prevenção de graves doenças foi uma importante descoberta em termos de saúde pública, juntamente com a estrutura e oferta de saneamento básico para as populações em todo mundo; apesar do permanente desafio para garantir a homogeneidade do acesso e a distribuição dos mesmos (DUARTE, et al, 2019; LEVI; LEVI, 2019; SANTOS, 2018; BARRETO et al, 2011).

As vacinas são composições biológicas que trabalham com a lógica de imunidade artificialmente adquirida; ou seja, uma vez que o patógeno (vírus ou bactéria) é introduzido no organismo leva o sistema imunológico a produzir anticorpos específicos para a prevenção primária, evitando uma futura infecção. As estratégias de imunização adotadas têm a expectativa da imunidade coletiva, também chamada de imunidade em rebanho, onde o maior número de indivíduos imunizados favorece a menor disseminação da doença (SANTOS, 2018).

A vacina pentavalente em estudo, consiste na combinação de cinco vacinas, cuja proposta é a proteção múltipla e simultânea contra difteria, tétano, coqueluche, hepatite B e contra a bactéria haemophilus influenza tipo $b$, que provoca infecções na meninge e vias áreas superiores. Ela está presente no calendário nacional de Imunização do Programa Nacional de Imunização (PNI) e é recomendada ainda no primeiro ano de vida, aos dois, quatro e seis meses (BRASIL, 2020).

O PNI tem história mundial de sucesso, muito antes da Organização Mundial de Saúde (OMS) recomendar que todos os países com sistemas nacionais de saúde ou não, estruturassem um programa de imunização, o Brasil já havia organizado o seu, que data de 1973 e recebeu o selo de erradicação de importantes doenças ao longo desses anos (SANTOS, 2018; DOMINGUES, et al, 2014). Conforme consta o documento do Secretaria de Vigilância em Saúde:

Ao longo dos seus 40 anos de existência, o PNI vem contribuindo para a redução da morbimortalidade causada pelas doenças imunopreveníveis, buscando a qualidade e a segurança dos produtos oferecidos para a manutenção e a disponibilidade, em tempo oportuno, dos imunobiológicos preconizados nos calendários e nas campanhas nacionais de vacinação para a população brasileira. Neste sentido, o PNI vem desenvolvendo e aperfeiçoando ferramentas para possibilitar 


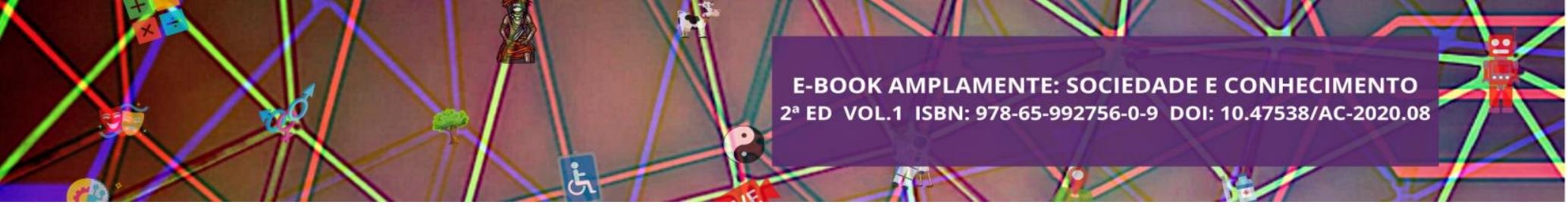

A vacina pentavalente, objeto do presente estudo, é uma das que compõem o Calendário Nacional de Vacinação, e configura uma combinação de cinco vacinas individuais em uma e garante a proteção contra a difteria, tétano, coqueluche, hepatite B e contra a bactéria haemophilus influenza tipo b. Esta vacina é aplicada em crianças aos 2, 4 e 6 meses de idade, seguindo esse intervalo de 2 em 2 meses, e possui seu reforço em 15 meses e 4 anos de idade. Além disso, os reforços e/ou complementações em crianças a partir de 1 ano são realizados com a vacina adsorvida difteria, tétano e pertússis (DTP). Esta importante vacina sofreu um intenso desabastecimento no ano de 2019, que, de fato permitiu vários debates e questionamentos no meio científico e político sobre a importância da produção nacional para a sustentabilidade do programa.

Anterior a esta análise, há menção de que no ano de 2017, por meio de notas informativas relacionadas a distribuição dos imunobiológicos na rotina, a CoordenaçãoGeral do Programa Nacional de Imunizações (CGPNI) revelou que nos meses de abril, maio e junho houve desabastecimento da vacina pentavalente. No mês de junho, também ocorreu a suspensão de uso e distribuição de lotes da vacina Rotavírus e meningocócica $\mathrm{C}$ conjugada devido a desvios de qualidade, mesmo motivo do desabastecimento sofrido no ano de 2019. Ainda no ano de 2017, no mês de julho, segundo a Nota Informativa do Ministério da Saúde (BRASIL, 2017), a vacina tríplice viral, a Vacina DTPa - CRIE e a Vacina rotavírus também se encontravam em situação lastimável de abastecimento. Ademais, outros imunobiológicos, como as imunoglobulinas, se encontravam em desabastecimento total, enquanto, os soros eram produzidos de forma parcial. Já no mês de novembro, houve ainda envio reduzido da vacina BCG e, no mês de dezembro, recebimento reduzido da vacina pentavalente e BCG.

Sendo assim, foi realizada uma pesquisa exploratória, descritiva, de análise quali-quantitativa, cujos dados quantitativos foram coletados através do Departamento de Informática do SUS (DATASUS), e análise de documentos ministeriais. Visando observar e cotejar as doses aplicadas nesse período, por região no país, correlacionando o grave desabastecimento da vacina pentavalente no ano de 2019 e as possíveis consequências enfrentadas no ano seguinte, ou seja 2020.

No início de 2020, a Organização Mundial da Saúde (OMS) declarou a epidemia, ora originária na China, como "Emergência de Saúde Pública de Importância Internacional (ESPIII), que corresponde ao mais alto nível de alerta previsto no 


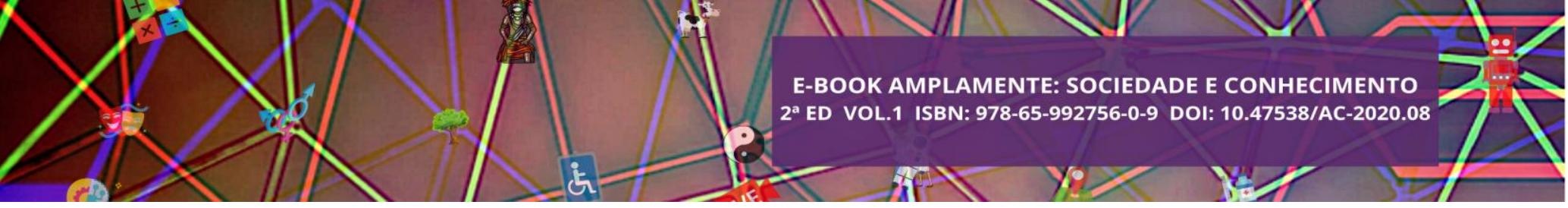

Regulamento Sanitário Internacional” (CAETANO et al, 2020, p 2). Seguidamente ocorre a declaração de pandemia e o Brasil adota as medidas de quarentena e isolamento social recomendados pelos órgãos sanitários (OPAS, 2020)

Portanto, os objetivos deste estudo foram: 1) Cotejar o período de desabastecimento da vacina pentavalente com os dados de doses aplicadas nesse período, por região no país; 2) Descrever e refletir os possíveis impactos da pandemia na tentativa de retomada da imunização, após o desabastecimento da pentavalente.

\section{METODOLOGIA}

O trabalho iniciou como uma pesquisa exploratória, cuja função foi a compreensão do cenário da vacina pentavalente no Brasil, em cada uma de suas regiões, em função do desabastecimento iniciado no meio do ano de 2019. Desse modo, foi feita uma análise majoritariamente quantitativa a partir do sistema de informação Departamento de Informática do SUS (DATASUS), observando a curva no volume de aplicações posteriores ao evento.

Assim, foi realizada uma comparação entre os valores posteriores ao desabastecimento, de agosto de 2019 a maio de 2020, com os anteriores ao evento. Além disso, para compreensão do fenômeno em meses pontuais, também foi realizada uma comparação dos dados com os anos anteriores de 2017 e de 2018. Posteriormente foi realizada busca de documentos em sites ministeriais, assim como análise dos mesmos, e de documentos de sociedades médicas, todos com foco no desabastecimento da pentavalente, tentando entender o cenário descrito e os desafios impostos ao sistema de saúde e usuários. Além de ter realizado pesquisa bibliográfica em bases sobre o tema em voga.

\section{RESULTADOS E DISCUSSÃO}

A partir de dados extraídos do DATASUS foi possível traçar uma análise do panorama de doses aplicadas da vacina pentavalente. Isto, principalmente, no que tange às situações prévias e posteriores a crise do desabastecimento iniciado no intervalo entre Julho e Agosto do ano de 2019. A eclosão do descompasso, além de ter gerado as consequências evidenciadas ao longo do trabalho, permeiam hipóteses acerca do futuro incerto da população brasileira, na medida em que o Brasil foi acometido pela pandemia 


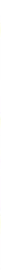

do Coronavírus logo após o carnaval, em meados de março de 2020, o que acentuou o abalo à saúde pública, inclusive no que tange à vacinação, mesmo com esforços governamentais para reverter o desabastecimento.

De acordo a figura abaixo, é possível observar que existem algumas divergências entre os meses que precedem o desabastecimento, de forma que o somatório das doses aplicadas da vacina pentavalente do mês de janeiro a junho não possuem impacto relevante. Contudo, é interessante destacar que, apenas o mês de janeiro de 2019 atingiu a meta das 800 mil doses mensais da vacina pentavalente correspondentes a demanda nacional, de acordo com o Ministério da Saúde (BRASIL, 2019). Já a partir dos meses de julho e agosto de 2019, é indiscutível a alarmante queda dos números de doses aplicadas, que se comportam numa constante decrescente, retratando a crise de desabastecimento.

Figura 1: Distribuição de doses totais da vacina pentavalente no período de janeiro de 2019 a maio de 2020

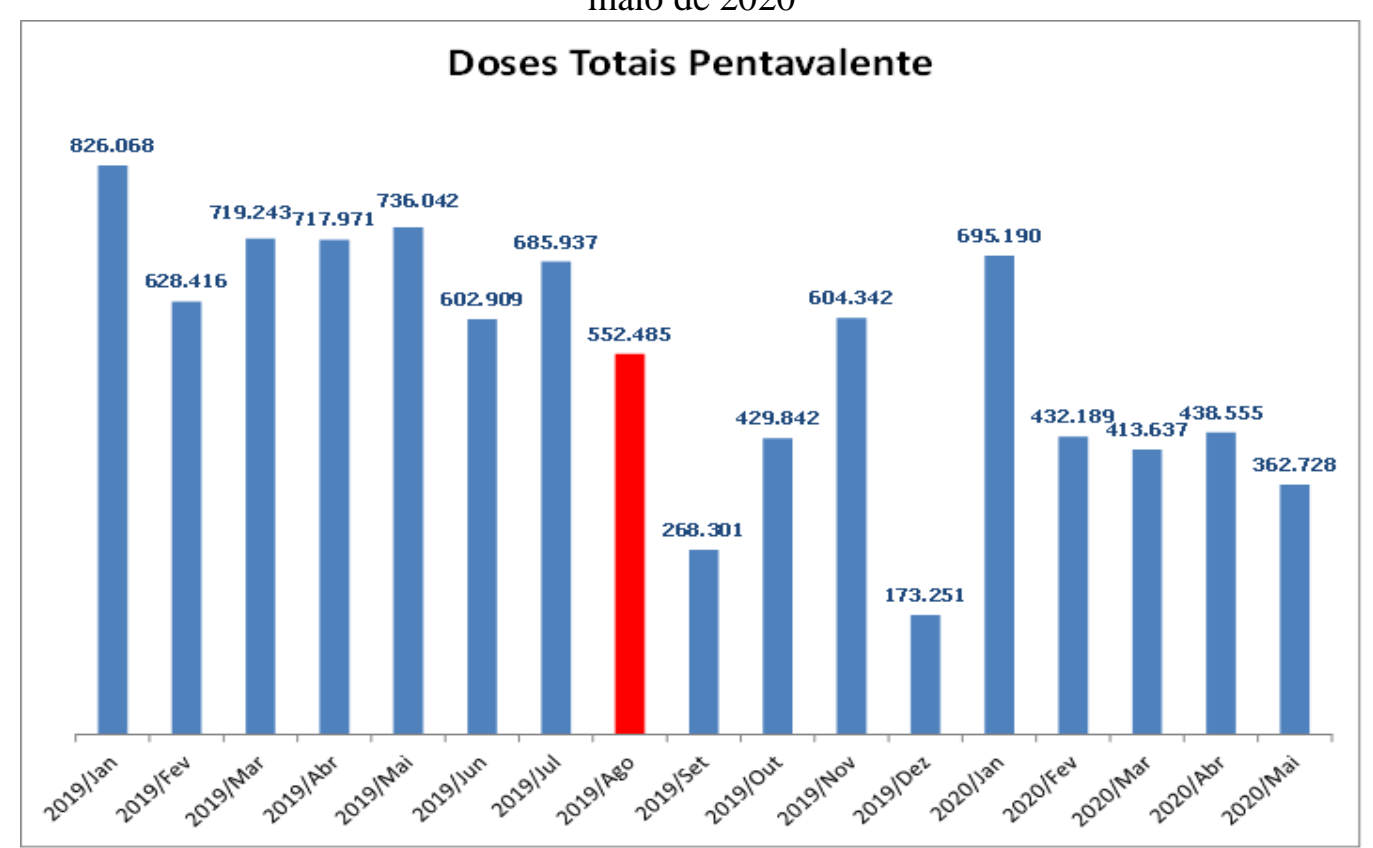

Fontes: Departamento de Informática do SUS (DATASUS), acesso em 09 de junho de 2020

O Brasil não possui laboratório produtor da vacina pentavalente e, por isso, realiza sua compra via Fundo Estratégico (Rotatório) da Organização Pan-Americana da Saúde (OPAS). Entretanto, em 2019, a vacina pentavalente adquirida por este intermédio foi reprovada em teste de qualidade feitos pelo Instituto Nacional de 


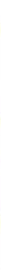

Controle de Qualidade em Saúde (INCQS) e análise da ANVISA. Com isso, as compras com o antigo fornecedor -a indiana Biologicals E. Limited - foram interrompidas pela OPAS, que pré-qualifica os laboratórios e, com isso, o abastecimento ficou parcialmente suspenso a partir de julho de 2019. Destaca-se que, segundo o MS o país demanda, atualmente, cerca de 800 mil doses mensais da vacina pentavalente e, o que supõe que este desabastecimento possa ter gerado impactos na saúde da população (BRASIL, 2019).

Com relação às doses por regiões, observa-se que na Região Sudeste, o mês de janeiro de 2019 apresentou 3,58 doses aplicadas a cada mil habitantes, o menor valor correspondente a este mês de todas as demais regiões brasileiras. Já o mês de julho foram 2,83 doses aplicadas a cada mil habitantes, com 2,05 em agosto. Esse valor já era um representativo da queda dos estoques em função do desabastecimento. Todavia, o menor valor apresentado pela região sudeste ocorreu no mês de setembro cujo alcance foi de apenas 0,60 doses aplicadas.

É interessante notar que no mês de novembro houve um aumento significativo, podendo estar relacionado a relocação da vacina. Entretanto, o mês de dezembro de 2019 apresentou novamente um valor alarmante, correspondente a 0,79 doses aplicadas por mil habitantes. Já no mês de janeiro de 2020, ocorreu novamente um crescimento considerável, equivalente a 3,40 doses por mil habitantes. Em contrapartida, nos meses seguintes esse valor reduziu, até atingir 1,56 no mês de maio.

A Região Sul, após o mês do desabastecimento (julho), apresentou 2,92 doses aplicadas a cada mil habitantes. Nos meses seguintes - setembro e outubro- a região revelou valores reduzidos importantes de 1,47 e 1,93 respectivamente. Assim como as demais regiões, a Sul apresentou no mês de dezembro, um valor reduzido de doses aplicadas, correspondendo a 0,62. Além disso, ela também apresentou crescimento de doses no mês de janeiro de 2020 com alcance de 3,61 doses aplicadas, porém esse fato não se perpetuou pelos meses de fevereiro e março, que apresentaram 1,64 e 1,71 doses aplicadas, respectivamente.

Na Região Norte, as doses aplicadas no mês de janeiro de 2019 foram de 5,10, sendo o maior valor alcançado entre todas as regiões do Brasil. Destaca-se que os meses que antecederam o desabastecimento também apresentaram números que excedem os das demais regiões em doses aplicadas. O mês de julho, revelou 3,72 doses aplicadas a cada mil habitantes, que após esse período decaíram para 2,71 no mês seguinte. O 


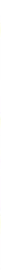

menor valor apresentado se deu no mês de dezembro, configurando 1,56 doses aplicadas. Interessante observar a discrepância do mês de janeiro de 2019 com o mesmo mês de 2020, no qual foi apontou apenas 3,54 doses a cada mil habitantes aplicadas seguida por uma constância de decréscimo até o mês de abril.

Na Região Nordeste, a taxa de doses aplicadas no mês de janeiro de 2019 foi somente inferior à taxa da Região Norte. O mês de agosto demonstrou 2,98 doses aplicadas a cada mil habitantes, que também decresceram no mês seguinte, configurando 1,80 doses. O menor mês de doses aplicadas, novamente, é o mês de dezembro, constando 0,84. O mês de janeiro de 2020 constituiu o menor valor de doses aplicadas referentes a este mês em relação às demais regiões, no valor de 2,74. As doses novamente decresceram nos meses seguintes, constando 1,95 e 1,60 nos meses de fevereiro e de março, respectivamente. No mês de abril às doses aplicadas alcançaram 1,97, porém, decresceram no mês de maio atingindo 1,65 doses aplicadas a cada mil habitantes.

De acordo com a análise acima demonstrada, foi possível observar alguns pontos em comum entre as regiões brasileiras. O mês de dezembro de 2019 revelou ser o mês que possuiu a menor taxa de doses aplicadas por mil habitantes. Além disso, o mês de fevereiro de 2020 acusou decréscimo, após o aumento revelado pelo mês de janeiro do mesmo ano. Em relação a este entrave, algumas reflexões foram levantadas, como as datas comemorativas de dezembro e ao carnaval. Ou então ao contexto de pandemia e às ações de prevenção adotadas e a falta de conhecimento sobre a necessidade de manter o a caderneta vacinal atualizada, ou outro fator não investigado.

Há várias notícias midiáticas, onde importantes organizações como OMS, Fundo Internacional de Emergência das Nações Unidas para a Infância (UNICEF) e organizações sanitárias ratificam a importância de manter o calendário vacinal de crianças e grupos de risco, e relatam todos os desafios impostos durante o período da pandemia; como relutância dos pais em imunizar seus filhos por medo da Covid-19, falta de informação, além dos atrasos na entrega de novas doses em decorrência das medidas de distanciamento social, influenciando negativamente na adesão à imunização (MELLO, 2020). Especialistas acreditam que o distanciamento social gera uma falsa sensação de proteção às outras doenças, já que o enfoque principal de caráter instrutivo se fixa no coronavírus e, com isso, outras enfermidades estão sendo menos abordadas 


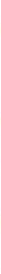

em conteúdos midiáticos. Os atrasos no transporte de vacinas também estão exacerbando a situação (CHADE, 2020).

Em nota emitida pela Sociedade Brasileira de Pediatria (SBP), membro que compõem o Comitê Técnico Assessor do PNI (SANTOS, 2018), relata a preocupação com os sucessivos episódios de desabastecimentos do programa; a necessidade de discutir mudanças nos processos produtivos, colocando que essa dependência da produção externa afeta as salas de imunizações em todo país, inclusive do setor privado (LEVI; LEVI, 2019). Para o Conselho Nacional de Secretários de Saúde (CONASS):

O fortalecimento da produção nacional de vacina é um dos grandes desafios do Brasil, ressaltando que ela difere muito da produção de medicamentos, pois depende do crescimento de produto biológico vivo e, se há alguma contaminação, ele deve ser desprezado e a produção começa do zero. Trata-se de um processo quase artesanal no qual as matérias-primas estão mais sujeitas à contaminação e justamente por primar pela segurança, se há algum problema ou indício, todo o lote é desprezado, muitas vezes levando ao desabastecimento (CONASS, 2017, p. 1).

Segundo o Ministério da Saúde a previsão da normalização da distribuição da vacina pentavalente deveria acontecer até o final do primeiro trimestre de 2020. Porém, nesse cenário de pandemia, a própria OMS chegou a recomendar que em março os países suspendessem temporariamente as campanhas para evitar aglomerações, o que explicaria em partes a queda da cobertura em relação ao mesmo período dos anos anteriores (PINHEIRO, 2020). Segundo a OMS, as campanhas de vacinação foram muito afetadas. Pelo menos 24 milhões de pessoas em 21 países de baixa renda estão em risco de falhar nas vacinas contra a pólio, sarampo, febre amarela, entre outras. Entretanto, com atuais protocolos mais estabelecidos de segurança nos serviços de saúde, a orientação é de que os países planejem a retomada de seus calendários (CHADE, 2020).

Devido à necessidade de voltar à normalidade nos quadros de vacinação, o Brasil estabeleceu uma meta de vacinar mais de 60 milhões de pessoas de alto risco aquelas com doenças subjacentes, mulheres grávidas, crianças, profissionais de saúde e idosos - contra a gripe, e está trabalhando para atingir essa meta vacinando pessoas idosas fora dos centros de saúde para evitar contato com indivíduos doentes. Dessa forma, foram estabelecidos diversos postos de vacinação, exemplos desses são em escolas vazias, em supermercados, em farmácias, na forma de "drive-thru" e em casa para pessoas que não conseguem ou podem sair de suas residências por motivos de 


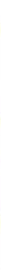

saúde (OPAS, 2020). Além disso, postos de saúde de algumas regiões do país, a exemplo de Santa Catarina, estão funcionando em horário estendido objetivando evitar aglomerações (SES, 2020). Ademais, não fosse esse período atípico, essa oscilação negativa seria totalmente desconexa do cenário de meses de desabastecimento vacinal que configurou o segundo semestre do ano anterior, assim como da alta procura resultante do mês de janeiro. Portanto, há fortes indícios de correlação entre os fatos.

Os vários esforços e debates realizados pelo MS com o intuito de ampliar seu parque produtivo e aumentar a sustentabilidade dos imunológicos, de forma a corroborar com as ações do PNI em constante ampliação para eliminação de doenças imunopreveníveis (BRASIL, 2019, DOMINGUES et al, 2015). Com isso, torna-se evidente a importância da vacinação na saúde pública, em especial, no que tange ao papel da atenção básica. Esta é a maior responsável pelas ações e produção de dados que contribuem para a manutenção da cobertura vacinal. Ressalta-se que a cobertura vacinal é um importante indicador da saúde da população e da qualidade dos serviços prestados e o fortalecimento do PNI necessita da ação conjunta de gestão entre todos os entes federados.

\section{CONSIDERAÇÕES FINAIS}

Os dados sugerem um padrão similar nos meses de dezembro e fevereiro, independente do ano, acredita-se que a baixa taxa cobertura de vacinação pode ter sido influenciada pelos feriados prolongados de final de ano e carnaval. Sabe-se que a Atenção Primária é responsável pela oferta da vacinação, contudo, toda essa situação imposta pela pandemia afeta a organização da assistência na Atenção Primária, bem como pode reduzir a procura dos serviços oferecidos neste nível de atenção.

Observou-se que a partir de março de 2020, o aumento do número de casos de coronavírus (Sars-Cov-2) no Brasil, fato esse que resultou em um decreto de estabelecimento de isolamento social e quarentena. $\mathrm{O}$ impacto dessa medida na curva de cobertura vacinal, pode ser percebida nos meses subsequentes abril e maio, pois a curva não regressa aos parâmetros normais, semelhantes ao intervalo março a julho dos anos de 2017, 2018 e 2019. Pelo contrário, ela se estabiliza em valores baixos, inclusive registra seu menor valor anual no último mês analisado (maio). 


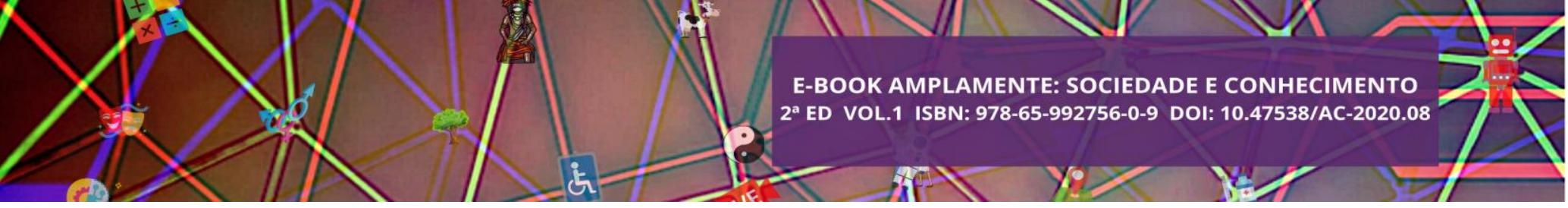

Diante de tal realidade nacional, destaca-se que a cobertura vacinal é um importante indicador de saúde da população e que por sua vez, tornou-se um desafio no contexto da pandemia. Os diferentes aspectos e circunstâncias presentes na cultura da população brasileira, o constante desabastecimento dos imunobiológicos, são outras questões que impactam diretamente na cobertura vacinal.

No entanto, vale enfatizar que todas as limitações apresentadas não ofuscam o sucesso do programa de vacinação do Sistema Único de Saúde. Nesse sentido, tais barreiras devem ser alvo de discussões por parte de gestores e profissionais de saúde, tendo em vista a universalização do acesso aos serviços e tecnologias em saúde. Assim é papel de toda população lutar em defesa dos princípios e diretrizes institucionais SUS e da saúde como um direito constitucional fundamental garantido por lei.

\section{REFERÊNCIAS}

BARRETO, M, L; TEIXEIRA, M, G; BASTOS, F, I; XIMENES, R, A, A; BARATA, R, B; RODRIGUES, L, C. Successes and failures in the control of infectious diseases in Brazil: social and environmental context, policies, interventions, and research needs. Lancet 2011; 377: 1877-89

BRASIL. Ministério da Saúde. Blog da saúde. Brasília, DF, 2020.Disponível em: https://saude.gov.br/saude-de-a-z/pentavalente. Acesso em: 09 de Junho de 2020.

BRASIL. Ministério da Saúde. Blog da saúde. Brasília, DF, 2019.. Disponível em: https://www.saude.gov.br/noticias/agencia-saude/45895-ministerio-da-saude-estudaestrategias-para-producao-nacional-da-pentavalente Acesso em: 09 de junho de 2020.

BRASIL. Presidência da república. Casa civil. Lei n8.080/90 de 19 de setembro de 1990 dispõe sobre as condições para promoção, proteção e recuperação da saúde, a organização e o funcionamento dos serviços correspondentes e dá outras providências.

BRASIL. Ministério da saúde. Secretaria de vigilância em saúde. Departamento de vigilância das doenças transmissíveis. Manual de rede de frio. Programa nacional de imunizações. Brasília, DF, 2013, 143p.

BRASIL. Ministério da saúde. Secretaria de vigilância em saúde. Departamento de vigilância das doenças transmissíveis. De manual de normas e procedimentos para vacinação. Brasília, DF, 2014, 178 p

BRASIL. Departamento de informática do sus (DATASUS) pentavalente: doses aplicadas. Brasília: SUS, 2020. Disponível em:

http://tabnet.datasus.gov.br/cgi/webtabx.exe?bd_pni/dpnibr.def. Acesso em 09 de junho. 


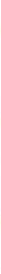

apontaram diferença estatística, quando comparados à testemunha. Para o tratamento curativo, a variável incidência não diferiu estatisticamente da testemunha, enquanto que para a severidade, os tratamentos apresentaram diferença estatística entre si, onde os óleos de menta $(0,75$ e $2,25 \%)$, cravo $(0,75$ e $1,5 \%)$ e aroeira $(0,75$ e $1,5 \%)$ foram semelhantes à testemunha, porém apresentaram uma eficiência maior.

PALAVRAS-CHAVE: Frutíferas. Controle Alternativo. Anacardiaceae.

\section{INTRODUÇÃO}

A cultura da manga (Mangifera indica L.) apresenta ampla adaptação às condições edafoclimáticas da região Nordeste brasileira, representando grande parcela no desenvolvimento econômico no país (LIMA, 2005; SALES JÚNIOR, 2003). A aparência dos frutos é um dos fatores mais importantes do sucesso em sua comercialização, o principal fator que reduz a sua qualidade pós-colheita e que acarreta grandes prejuízos, são as doenças de origem fúngica (LEMOS, et al. 2013).

A antracnose é uma das doenças fúngicas mais importantes, podendo acarretar em perdas de até $100 \%$ na produção (LOPES, et al. 2003) é ocasionada por Colletotrichum spp. que incide em uma ampla variedade de plantas atacando principalmente os frutos, que quando doentes apresentam sintomas como lesões circulares e deprimidas, que podem se intensificar durante a fase de pós-colheita.

Entre os patógenos do gênero Colletotrichum, existe uma especialização para determinados grupos de hospedeiros (SOUZA, et al. 2012). Para a cultura da manga a principal espécie relatada é C. gloeosporioides, entretanto, Lima e colaboradores, 2013 constataram que a espécie $C$. tropicale também é patogênica à cultura, sendo este o primeiro relato da ocorrência do fungo em frutos de manga.

O controle da antracnose normalmente é realizado através de métodos químicos, que acabam gerando resíduos tóxicos e prejuízos ao ambiente e à saúde humana, portanto é de extrema importância à utilização de métodos alternativos para controle de doenças pós-colheita (GUIMARÃES, 2016).

Dentre os métodos de controle alternativo, o uso de produtos naturais como extratos e óleos essenciais de diversas espécies botânicas tem se mostrado eficiente no controle de fungos, onde se constatou a inibição do crescimento micelial do patógeno (FIORI et al., 2000). Acredita-se que essa inibição seja devido a atividade biológica dos constituintes dos óleos essenciais que podem atuar como agentes fungicidas e ou/ 


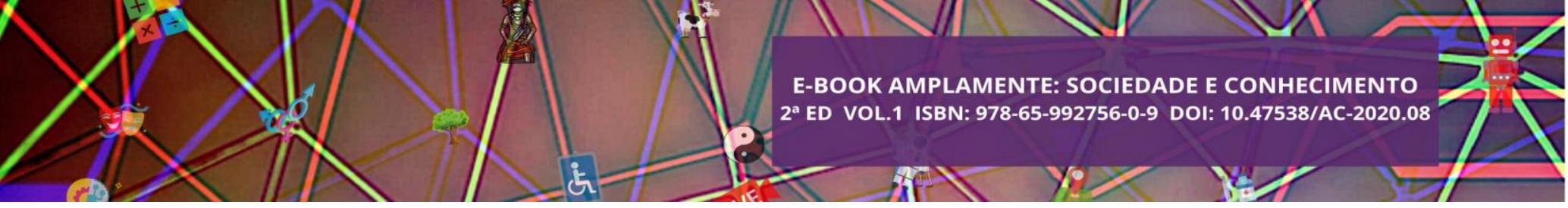

fungistáticos, dependendo das concentrações utilizadas. O presente trabalho teve como objetivo avaliar o efeito de óleos essenciais de Menta (Mentha piperita L.), Cravo (Syzygium aromaticum L.) e Aroeira Schinus terebinthifolius, em diferentes concentrações sobre o fungo $C$. tropicale, em frutos de manga em pós-colheita.

\section{MATERIAIS E MÉTODOS}

\section{LOCAL DO EXPERIMENTO}

Os experimentos foram conduzidos no Laboratório da Clínica Fitossanitária do Centro de Ciências Agrárias da Universidade Federal de Alagoas, localizado no Município de Rio Largo - AL.

\section{TESTE DE PATOGENICIDADE}

A patogenicidade do isolado de $C$. tropicale foi realizada nos frutos de $M$. indica variedade Tommy Atkins, previamente limpas e desinfestadas em hipoclorito de sódio, segundo Menezes e Silva (1998), onde discos de B.D.A com 0,5 cm de diâmetro, contendo crescimento micelial fúngico, retirados da extremidade de uma colônia jovem do patógeno, sendo depositados sobre incisões efetuadas com auxílio de agulha estéril na superfície das mangas e cobertos com algodão umedecido com água destilada esterilizada (ADE).

As testemunhas receberam somente discos de B.D.A, utilizando-se a mesma metodologia. As mangas foram mantidas em câmara úmida formada por um saco plástico e pedaço de algodão hidrófilo umedecido (ADE), onde foram mantidas por 48 horas, à temperatura ambiente, segundo Lins e Coelho (2004). Os frutos foram avaliados 5 dias após a inoculação do patógeno. As mangas que apresentaram sintoma de mancha de chocolate foram re-isoladas em placas de Petri com meio de cultura B.D.A mantidas sob condições de luz e temperatura ambiente e observadas quanto à semelhança, para confirmação da patogenicidade dos isolados.

\footnotetext{
AVALIAÇÃO DOS ÓLEOS ESSENCIAIS E DO FUNGICIDA EM CONDIÇÕES DE PÓS-COLHEITA NO CONTROLE DE C. tropicale
} 


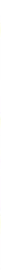

Os frutos de mangas cultivar Tommy Atkin, foram adquiridos no CEASA/AL. Na ocasião, foram selecionados 112 frutos sadios, que posteriormente passaram por um processo de assepsia, sendo desinfestados com detergente neutro e em seguida lavados em água corrente.

Teste curativo - A superfície dos frutos com cerca de $10 \mathrm{~cm}$ diâmetro, foi levemente perfurada em pontos equidistantes com auxílio de uma agulha esterilizada. Posteriormente, os frutos receberam um disco de B.D.A de 5mm diâmetro com micélio fúngico, estes foram recobertos por chumaço de algodão umedecidos com água destilada esterilizada. Esses discos foram retirados da cultura pura com idade de 7 dias. Passadas 4 horas, após a deposição dos discos, os frutos foram aspergidos com diferentes concentrações de solução dos óleos essenciais: menta, cravo e aroeira $(0,75$; $1,5 ; 2,25$ e $3,0 \%)$. Para o controle positivo utilizou-se o fungicida mancozeb (240mg/L), e como testemunha utilizou-se água destilada esterilizada. Em seguida, os frutos foram recobertos com sacos plásticos e mantidos em temperatura ambiente por 48 horas.

No teste preventivo, os frutos foram incialmente aspergidos com diferentes concentrações de solução dos óleos essenciais menta, cravo e aroeira $(0,75 ; 1,5 ; 2,25$ e $3,0 \%)$, e do fungicida mancozeb (240mg/L). Paralelo aos testes estabeleceu um grupo controle no qual os frutos receberam apenas água destilada esterilizada. Após 4 horas, os frutos receberam um disco de B.D.A de $5 \mathrm{~mm}$ diâmetro com micélio fúngico, estes foram recobertos por pedaços de algodão umedecidos com água destilada esterilizada. Em seguida, os frutos foram recobertos com sacos plásticos e mantidos em temperatura ambiente por 48 horas.

Quanto as variáveis analisadas, a severidade da doença, foi realizada por meio da mensuração do diâmetro das lesões, tomando-se medidas verticais e horizontais, com o auxílio de um régua. A média do tamanho das lesões foi obtida avaliando-se os pontos de inoculação representado por quatro frutos. Em relação a incidência, foi avaliada se o fruto possuía ou não sintomas, atribuindo notas de 0 (sem sintomas) e 1 (presença de sintomas).

O delineamento experimental utilizado para todos os ensaios foi inteiramente casualizado, com 14 tratamentos e quatro repetições. Os dados obtidos foram submetidos à análise de variância e as médias comparadas entre si pelo teste Tukey, a 5 $\%$ de probabilidade. 


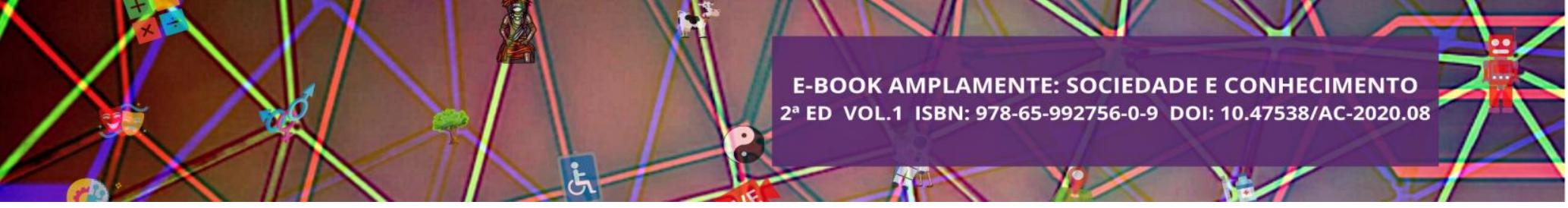

\section{RESULTADOS E DISCUSSÃO}

\section{TESTE DE PATOGENICIDADE}

O isolado de C. tropicale manifestou patogenicidade nos frutos de M. indica, após 2 dias da inoculação. O fruto apresentou os sintomas característicos de C. tropicale (manchas necróticas chocolate) (Figura 1), enquanto a testemunha permaneceu sadia. O aparecimento dos sintomas e o re-isolamento do fungo em meio de cultura B.D.A confirmaram a patogenicidade do isolado.

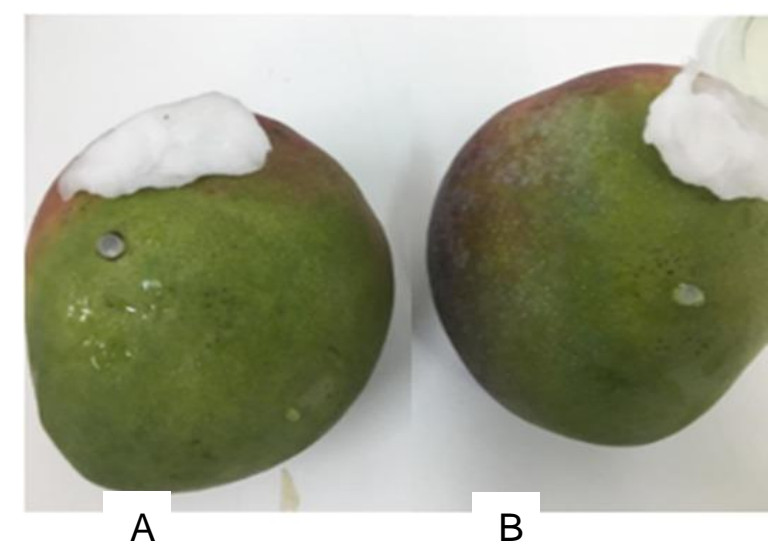

Figura 1- A, Frutos de M. indica com o isolado de C. tropicale apresentando sintomas de necrose 2 dias após a inoculação. $\mathrm{B}$, testemunha.

A identificação do patógeno foi realizada, posteriormente através de observações na morfologia, dimensão das estruturas reprodutivas, obtidas por meio de observações microscópicas: conídios hialinos, unicelulares, de forma cilíndrica a elipsoidal, com uma das extremidades afiladas (Figura 2- A e B). Segundo Lima et al. (2013) $C$. tropicale foi registrado causando antracnose em $M$. indica no Nordeste do Brasil.

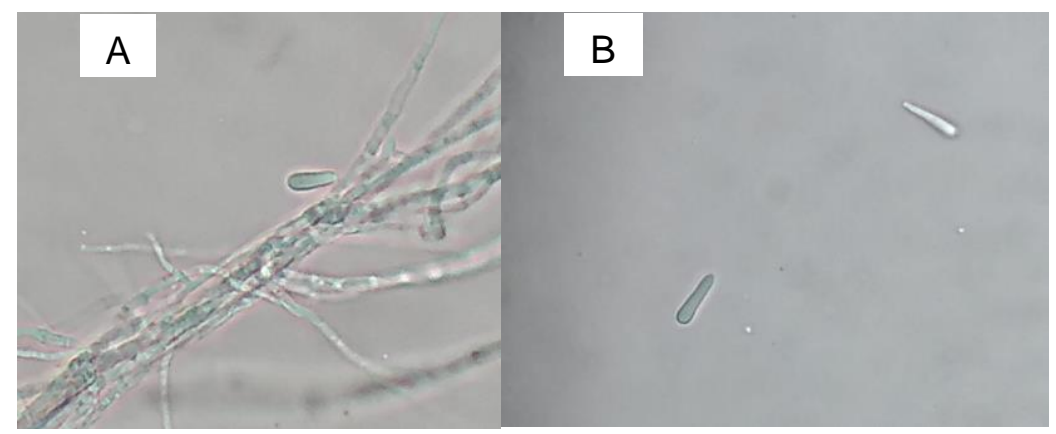

Figura 2- (A, B) Conídios hialinos, unicelulares, de forma cilíndrica a elipsoidal, com uma das extremidades arredondadas C. tropicale. 


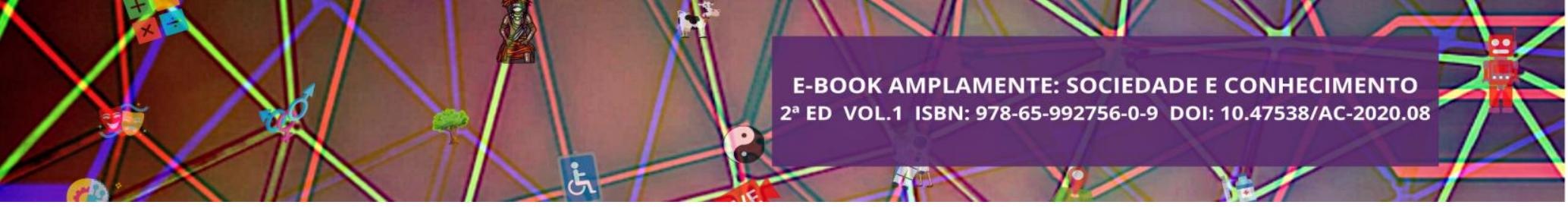

Figura 3: Influência dos óleos e do fungicida sobre a incidência no controle preventivo e curativo da antracnose (C.tropicale) em $M$. indica.

Quanto aos valores da severidade da doença, houve diferença apenas entre os tratamentos aplicados de forma curativa, onde os óleos de menta $(0,75$ e 2,25 \%), cravo $(0,75$ e $1,5 \%)$ e aroeira $(0,75$ e $1,5 \%)$ foram semelhantes à testemunha, porém com aplicação dos óleos houve uma eficiência maior. (Figura 4).

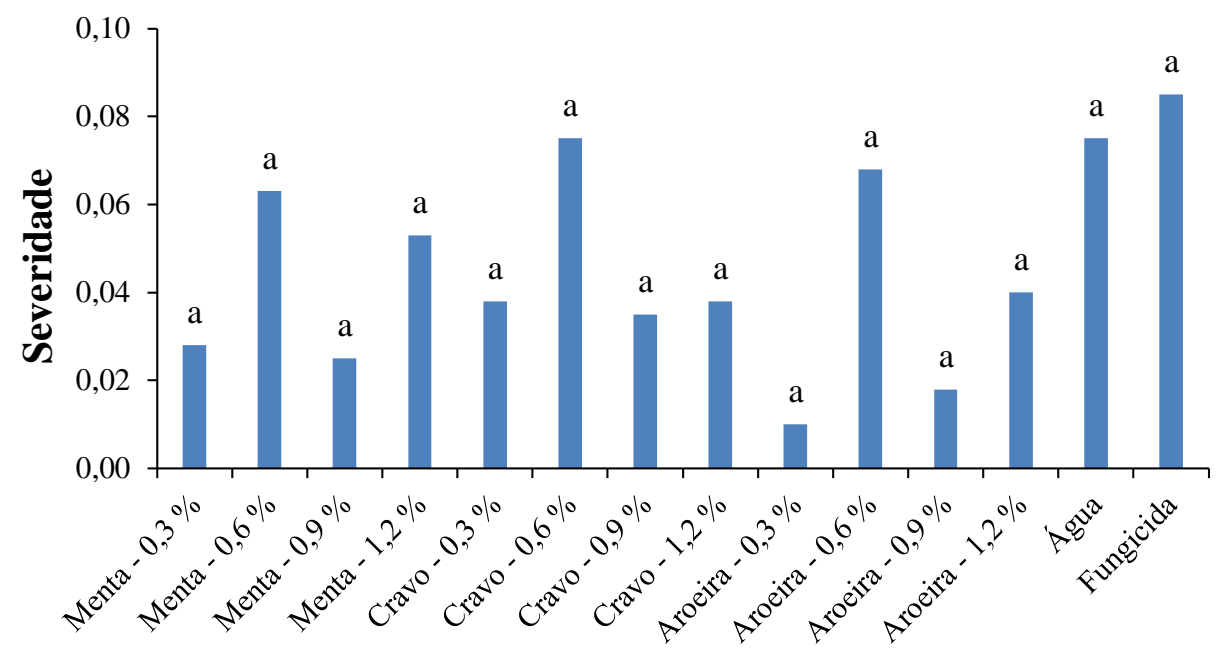

Tratamentos preventivos

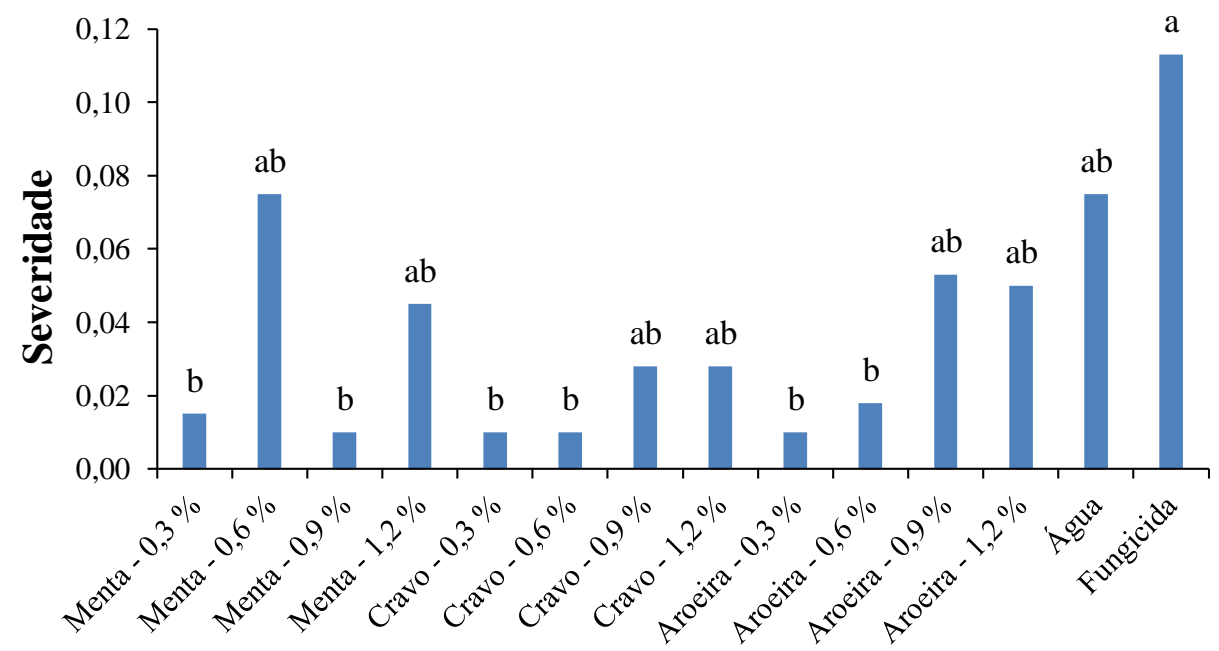

Tratamentos curativos 


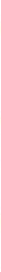

Figura 4: Influência dos óleos e fungicida sobre a severidade no controle preventivo e curativo da antracnose (C.tropicale) em Mangifera indica.

Embora tenha sido observados nos frutos que os óleos inibiram o crescimento do fungo, os valores de incidência e severidade não diferiram estatisticamente da testemunha. Sendo assim com base nos dados estatísticos os óleos não se mostraram eficientes. Fischet et al. (2012), avaliaram o efeito de produtos alternativos no controle da antracnose em frutos goiaba (Psidium guajava L.) e obtiveram resultados semelhantes, aos encontrados neste estudo, onde os produtos alternativos testados pelos autores também foram ineficientes na redução da incidência e severidade. A Figura 5 ilustra a incidência e severidade no controle preventivo e curativo, nos frutos de $M$. indica sobre $C$. tropicale, na imagem pode-se observar que a maioria dos frutos não apresentaram lesões.
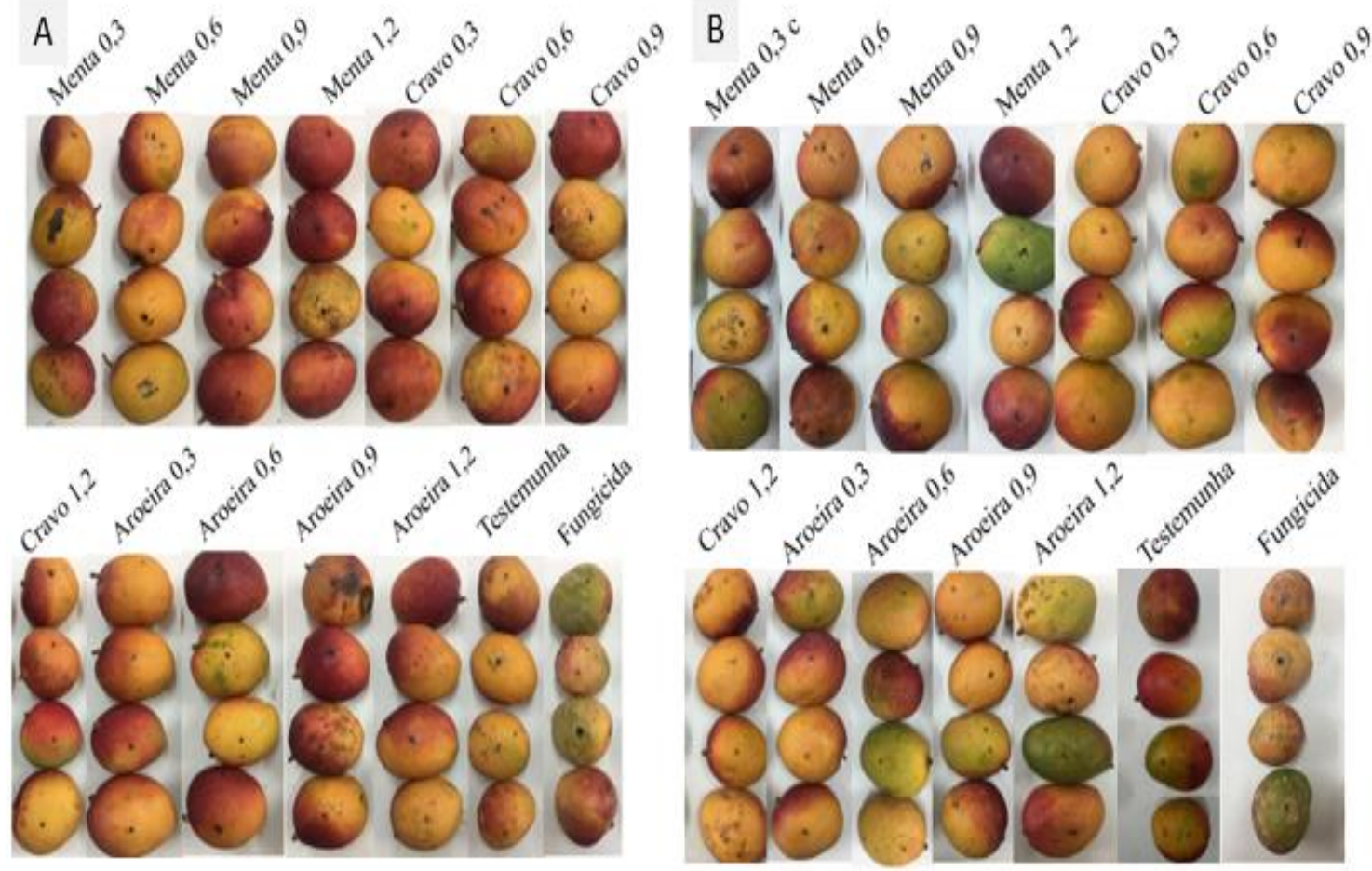

Figura 5: Efeito dos óleos e de fungicidas nos controle preventivo e curativo (A e B) da antracnose em Mangifera indica.

Os bons resultados obtidos in vitro nem sempre são garantias de eficiência em programas de manejo, muitas vezes, a eficácia dos óleos in vivo pode ser insuficiente perante uma série de fatores, enquanto que in vitro as condições em laboratório são controladas de forma que o isolado pode apresentar máximo desempenho. 


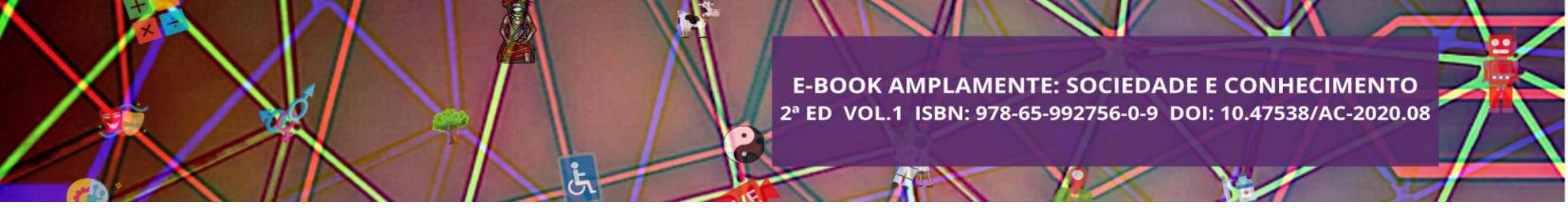

De acordo com Bueno (2006), a preservação de fungos fitopatogênicos por longos períodos de tempo é importante para que pesquisas possam ser realizadas a qualquer momento. No entanto, o método de preservação deve manter as características originais dos fitopatógenos, tais como capacidade de esporular e patogenicidade. Sendo assim este fator pode ser levado em consideração em relação aos resultados obtidos. Sendo assim, é válido concentrar pesquisas nessa área afim de realizar testes com demais óleos essenciais e concentrações.

\section{CONCLUSÃO}

Nos ensaios in vivo, os tratamentos não apresentaram diferença estatística da testemunha. De modo que, serão necessários novos testes para comprovar a eficácia dos óleos no controle de C.tropicale.

\section{REFERÊNCIAS}

BARGUIL, B. M. et al. 2005. Ocorrência de Colletotrichum gloeosporioides em Heliconia chartacea cv. Sex Pink. Fitopatologia Brasileira, Brasília, v.30, p.S136.

EDGINGTON, L. V.; KHEW, K. L.; BARRON, G. L. 1971. Fungitoxic spectrum of benzimidazole compounds. Phytopathology, v. 61, p. 42-44.

LINS, S. R. O. COELHO,R. S. B. 2004. Ocorrência de Doenças em Plantas Ornamentais Tropicais no Estado de Pernambuco. Fitopatologia Brasileira, v. 29, p. 332-335.

MENEZES, M.; SILVA, D. M. W. 1998. Técnicas laboratoriais para isolamento e identificação de doenças, UFRPE. 45 p.

LEITE, C.D. et al. Controle pós-colheita da podridão-amarga da maçã com o uso do óleo de Nim. Revista Brasileira de Agroecologia. v.4, n.2, p.1644-1648, 2009

YUKAWA, T.A.; KUROKAWA, M.; SATO, H.; YOSHIDA, Y.; KAGEYAMA, S.; HASEGAWA, T.; NAMBA, T.; IMAKITA, M.; HOZUMI, T.; SHIRAKI, K. Prophylactic treatment of cytomegalovirus infection with traditional herbs. Antiviral Research, v.32, n.2, p.63-70, 1996.

DORMAN, H.J.D.; DEANS, S.G. Antimicrobial agents from plants: antibacterial activity of plant volatile oils. Journal of Applied Microbiology, v.88, p.308-316, 2000.

MAZZAFERA, P. Efeito alelopático do extrato alcoólico do cravo-da-índia e eugenol. Revista Brasileira. Botucatu, v.26, n.2, p.231-238, 2003. 


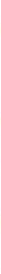

DELESPAUL, Q.; BILLERBECK, V.G.; ROQUES, C.G.; MICHEL, G.;

MARQUIERVINUALES, C.; BESSIERE, J.M. The antifungal activity of essential oils as determined by different screening methods. Journal of Essential Oil Research, v.12, n.2, p.256-266, 2000.

CHIEJINA, NV; UKEH, JA. Antimicrobial properties and phytochemical analysis of methanolic extracts of Aframomum melegueta and Zingiber officinale on fungal diseases of tomato fruit. Journal of Natural Sciences Research, v. 2, p. 10-15, 2012.

SILVA, JL. et al. Antifungal activity using medicinal plant extracts against pathogens of coffee tree. Revista brasileira de plantas medicinais, v.16, n. 3, p. 539- 544, 2014 


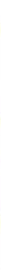

\section{CONSIDERAÇÕES INICIAIS}

O nascer e o morrer fazem parte do ciclo da vida. O primeiro, para muitos grupos sociais é entendido como um momento de felicidade, de festejos e que necessita de cuidados. No entanto, o fim da vida para alguns sempre esteve ligado a sofrimento, tristeza, perda, derrota, principalmente para os profissionais de saúde. Vida e morte são assuntos que levam a diversas reflexões. A morte, embora seja uma certeza, está longe de ser um tema de fácil abordagem (SILVA, 2014).

No Brasil e no mundo a oncologia e toda a parte cancerígena é um problema de saúde pública, em especial os números deflagrados sobre óbitos, diagnósticos, exames realizados onde a taxa de vítimas é alta, cerca de 600 mil casos, de acordo com a Política Nacional para Prevenção e Controle do Câncer (PNPCC), só em 2019 (RODRIGUES, 2020).

O termo eutanásia vem do grego e significa boa morte ou morte sem sofrimento. Diferente do suicídio assistido, quando o paciente solicita o auxílio de outra pessoa para morrer, onde há uma opção pela morte por parte do enfermo, a eutanásia ocorre em pacientes que estão no fim da vida por doenças incuráveis, por vezes, inconscientes, ligados a aparelhos que mantém as funções vitais e que estes são desligados. Em ambas as situações, a interrupção da vida gera uma postura reflexiva e uma revisão de princípios e crenças para muitos, quer seja enquanto profissionais, quer seja enquanto família (SILVA et al., 2020).

A ortotanásia, apesar da nomenclatura parecida, tem significado contrário à eutanásia. A primeira, tem sentido de morte no seu tempo, sem tratamentos invasivos. $\mathrm{O}$ objetivo maior é proporcionar conforto e alívio da dor. A distanásia, caracterizada pela morte demorada e com sofrimento, visa o adiamento da morte através de terapêuticas invasoras, mesmo que isso traga dor ao paciente (SILVA, 2014).

Em países como Holanda, Bélgica entre outros, a eutanásia já é legalizada, apesar de ser um tema polêmico para uma parte da população. O paciente e seus familiares devem estar conscientes do procedimento e assinar um pedido para realização do mesmo. Todavia, ainda existem muitos países nos quais a prática não é legitimada (SILVA et al., 2020).

O fim da vida está diariamente presente na vida de profissionais de saúde, principalmente da equipe de enfermagem, pois estes estão em maior parte do tempo à 


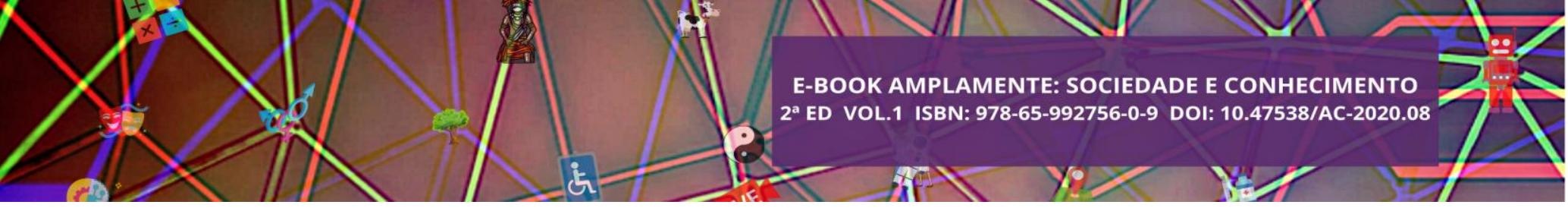

beira leito prestando todos os cuidados necessários. Vale ressaltar que cada profissional é um ser único, composto por princípios, crenças e valores. Portanto, evidencia-se uma divergência de opiniões desses profissionais em relação a morte, eutanásia, distanásia e ortotanásia (FERREIRA; NASCIMENTO; SÁ, 2018).

Do ponto de vista religioso, a interrupção da vida fere o princípio da mesma. Para a religião católica, a vida é um dom divino e não deve ser interrompida. No budismo, a prática da ortotanásia é aceita (AMORIM et al, 2011).

O presente estudo objetiva através de uma revisão de literatura, analisar e refletir sobre os dilemas éticos, legais e religiosos a respeito desse tema.

\section{MÉTODOS}

Trata-se de uma revisão de literatura de caráter reflexivo, com base em artigos. A referida pesquisa de artigos foi feita na base de dados Scientific Eletronic Library Oline (SCIELO), Biblioteca Virtual em Saúde do Ministério da Saúde (BVSMS) e Google Acadêmico, a partir do cruzamento entre os seguintes Descritores em Ciências da Saúde (DeCS): Eutanásia, Ética em enfermagem, Religião e Jurisprudência.

Os critérios de inclusão foram artigos sobre estudos feitos com seres humanos e em português. Os critérios exclusão foram artigos baseados em estudos feitos com animais. Foram encontrados 371 artigos, dos quais foram usados quatorze artigos.

O presente estudo foi feito a partir de dados de domínio público, não sendo precisa análise por parte do Comitê de Ética.

\section{RESULTADOS E DISCUSSÕES}

\section{O ENSINO DA ÉTICA PARA PROFISSIONAIS DE SAÚDE}

A ética e a bioética fazem parte da formação do profissional de saúde. Diante de muitos assuntos específicos a serem abordados, entende-se que há uma preocupação dos docentes em relação à forma de ensino, tendo em vista que existem várias formas de ensino e não existe uma forma padrão (NUNES, 2017).

Apesar da ética não ser um assunto que gera interesse em todos os estudantes, torna difícil o trabalho dos docentes na escolha da melhor forma de ensino, por se tratar de dilemas éticos, que muitas vezes são vistos com tabu. É preciso uma abordagem que 


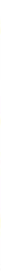

gere interesse por parte dos alunos. A ética é essencial para a formação do profissional, pois os dilemas são vividos diariamente por profissionais de saúde (MALUF; GARRAFA, 2015).

Não existe uma forma certa para o ensino da ética, a diversidade de temas permite vários tipos de abordagens, e o intuito do estudo da ética é a reflexão e o crescimento profissional. Todas as abordagens didáticas que levam a reflexão são válidas, como, filmes, séries, leitura de artigos, aulas mais dinâmicas, em ambientes fora da sala de aula, rodas de conversas, resenhas críticas, fóruns, exposição de situações que levam ao aluno a refletir um pouco mais sobre seus princípios e valores (NUNES, 2017).

A eutanásia é um dos assuntos abordados no ensino da ética. No Brasil a prática da eutanásia é proibida, o Conselho Federal de Enfermagem (COFEN) do Brasil, órgão fiscalizador e normalizador do exercício profissional, repudia qualquer forma de antecipação da morte. É dever do profissional de enfermagem prestar assistência aos pacientes, garantindo sempre seu bem estar, respeitando seus direitos e da família. Aos pacientes terminais, cabe ao enfermeiro prestar cuidados paliativos e respeitar o direito do paciente de tomar decisões sobre sua saúde (BERALDO; ALMEIDA, 2015).

Para alguns profissionais da saúde, o processo de morte é algo comum, no entanto, para muitos, este tema tão presente no dia a dia ainda se apresenta como um tabu. Os profissionais não estão preparados para lidar com as perdas, e são tomados por sentimento de impotência ao presenciar a morte (FERREIRA; NASCIMENTO; SÁ, 2018).

O assunto morte é pouco trabalhado na graduação e nas unidades de saúde. Os profissionais não possuem o hábito de falar abertamente sobre o tema. Existe um receio em falar, pois é vista como algo distante, apesar de ser uma certeza para todo e qualquer ser humano. A morte gera uma sensação que o dever não foi comprido, que algo mais poderia ter sido feito (FERREIRA; NASCIMENTO; SÁ, 2018).

A equipe de enfermagem por estar mais próxima do paciente, cria vínculos, que influencia diretamente na tomada de decisões. O profissional de saúde por não saber como abordar esse tema, opta por omitir para o paciente e sua família sobre seu real estado de saúde, como uma forma de mascarar a real situação e consolar o enfermo que está em fase terminal (FERREIRA; NASCIMENTO; SÁ, 2018). 


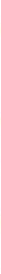

$\mathrm{Na}$ atuação profissional é necessário passar por um processo de adaptação, é necessário se colocar no lugar do paciente e pensar como se fosse seu familiar. $\mathrm{O}$ enfermeiro deve ter um olhar holístico, entender as necessidades de cada paciente e fazer o possível para proporcionar conforto ao mesmo em fase terminal, sempre respeitando os preceitos éticos e legais. Para os enfermeiros iniciantes, se juntar aos profissionais mais experientes irá tornar sua prática melhor (FERREIRA; NASCIMENTO; SÁ, 2018).

De fato, a morte nunca será algo fácil de lidar, por isso a importância do ensino da ética e seus dilemas na academia. Após o óbito de um paciente, o profissional passa por um misto de sentimentos, que vai desde o sentimento de impotência até a aceitação. O enfermeiro também é responsável pelo período do luto, a assistência antes prestada ao paciente, vai ser direcionada a família, dando todo suporte nessa fase que para muitos é tão difícil e dolorosa (BERALDO; ALMEIDA, 2015).

\section{CONTEXTUALIZAÇÃO HISTÓRICA DA EUTANÁSIA}

A palavra EUTANÁSIA foi criada no séc. XVII pelo filósofo inglês Francis Bacon, quando prescreveu, na sua obra "História vitae et mortis", como tratamento mais adequado para as doenças incuráveis. $\mathrm{Na}$ sua etimologia estão duas palavras gregas: "EU”, que significa bem ou boa, e "THANASIA", equivalente a morte. Em sentido literal, a "eutanásia" significa "Boa Morte", a morte calma, piedosa e humanitária (BARBOSA; LOSURDO, 2018).

A eutanásia sempre esteve presente na história da humanidade. Na época das primeiras populações, as pessoas sobreviviam da pesca, da caça e das plantações, com isso necessitava-se de pessoa jovens e fortes para trabalhar. Os idosos e doentes crônicos por não poder contribuir, eram eliminados. Em 400 a.c., em Atenas, Platão cravava no $3^{\circ}$ livro de sua "República", o sacrifício de velhos, fracos e inválidos, sob o argumento do fortalecimento de bem-estar e da economia coletiva". (BARBOSA; LOSURDO, 2018).

A eutanásia também é vista de uma outra forma, na qual é uma maneira mais branda para cessar o sofrimento intenso do paciente. Contudo, a medicina ver a eutanásia como um modo de aliviar as dores e sofrimentos de uma pessoa adoentada, que tem um diagnóstico fatal ou encontra-se em estado de coma irreversível, sem a 


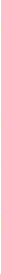

presente possibilidade de sobrevivência, tendo a função de antecipar a morte ou apresentando os meios para alcança-la. Entretanto o significado da palavra eutanásia evolucionou ao longo dos anos e exigiu uma terminologia específica para mencionar condutas diferentes, concentrando a sua significação somente para a "morte causada por conduta do médico sobre a situação de paciente incurável e terrível sofrimento" (NETO, 2003, p. 2).

$\mathrm{Na}$ Austrália, na década de 90 foi sancionada uma lei que autorizava formalmente a eutanásia. Entretanto, os critérios para o cumprimento do procedimento eram diversos, tais como: vontade do paciente, idade mínima de 18 anos, doença incurável, inexistência de qualquer medida que possa curar o paciente, precisão do diagnóstico, inexistência de depressão, conhecimento do paciente dos tratamentos disponíveis, capacidade de decisão tanto do paciente como de seus familiares.

No Brasil, foi sugerido um projeto de lei no Senado Federal em 1996 (projeto de lei 125/96), estabelecendo a probabilidade de efetivação de procedimentos de eutanásia no país. Mas o projeto não progrediu. Esse fato demonstra a possibilidade de em um futuro breve, a prática ser aceita no país (CASTRO et al, 2016).

Os preparativos para a morte de um paciente é um procedimento triste e doloroso tanto para família como para os profissionais que fazem isso. É nesse momento que acontece as despedidas e pedidos de desculpas. Essa preparação não é feita somente com o paciente, e sim com todos aqueles que fazem parte diretamente da vida dessa pessoa, tais como: esposa/esposo, filhos, pais. Esse processo é de suma importância pois acaba por colaborar com a melhor aceitação de morte (LISBOA, 2003).

Portanto, a eutanásia perdura toda a história da vida humana, dos primórdios aos dias atuais. Uns a criticam, outros a defendem. É um assunto que desperta reflexões. Grupos sociais têm opiniões distintas, mas o respeito aos princípios uns dos outros sempre será a melhor alternativa (LISBOA, 2003).

\section{ASPECTOS ÉTICOS E LEGAIS DA EUTANÁSIA NO BRASIL}

Alguns países como Colômbia, Estados Unidos (somente em cinco estados), Canadá, Holanda, Bélgica, Suíça, Luxemburgo a prática da eutanásia já é legalizada. No 


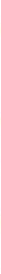

Brasil, o procedimento ainda não é aceito, embora seja motivo de discussões entre vários grupos (CASTRO et al, 2016).

De acordo com o Código Penal brasileiro, em seu artigo 121, a eutanásia é considerada não só crime por homicídio, mas induzimento ou a ajuda na prática do suicídio. Nada despenaliza sua prática. No artigo 74 do Código de Ética de Enfermagem/RESOLUÇÃO 564/2017, consta a proibição da promoção e participação de práticas de antecipação da morte. Vale ressaltar que a prática ainda é restrita no Brasil devido à complexidade. (BARBOSA; LOSURDO, 2018)

A Lei $n^{\circ} 7.209 / 84$, fez uma alteração no Código Penal, diminuindo a pena por homicídio privilegiado, a mesma pena é usada em casos de homicídio por eutanásia. A diminuição da pena pode variar de um sexto até um terço, de acordo com o caso, por exemplo, se o crime por fatores sociais e morais relevantes (BARBOSA; LOSURDO, 2018).

E em comparação ao antigo código e o atual, no que se refere ao homicídio eutanásico, percebe-se uma forma estranha em seu contexto, pois as consolidações das Leis Penais de 1932, repetiu as disposições do código do Império de 1890, no qual referia o artigo 295, parágrafo 2 “[...] que se a morte resultar não da verificação de um mal mortal, mas sim por ter o ofendido, deixado de observar o regime médico-higiênico reclamado pelo seu estado, a reprimenda cominada ao agente sofre aguda redução em relação ao homicídio simples, sendo graduada de dois a oito anos de prisão celular”. O artigo 24, refere quanto a não criminalização e justificativa da conduta criminosa, onde ações contrárias as leis e que não forem realizadas com intenção criminosa e não resultarem em negligência, imprudência ou imperícia, não serão passiveis de pena (BARBOSA et al, 2018).

Nesse contexto, os profissionais de saúde devem ter consciência que a prática eutanásia, não os deixará impunes no Brasil, e que apesar de o juiz entender como homicídio piedoso, a pena sofrerá somente uma redução. Alguns profissionais temem negligenciar, e erroneamente fazem procedimentos para prolongar a vida de pacientes terminais, por vezes, sem o consentimento do paciente ou de seus familiares (BARBOSA et al, 2018).

A ortotanásia objetiva oferecer conforto até o último dia de vida do paciente, ou seja, pacientes terminais têm a autonomia de escolher por uma morte digna e no seu percurso natural. Tal prática é bem assegurada pela Constituição brasileira. $\mathrm{O}$ fato de a 


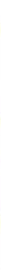

eutanásia não ser aceita no Brasil, não significa que não devem ser prestados cuidados paliativos a esses pacientes (CASTRO et al, 2016).

De acordo com a legislação vigente, a morte do indivíduo também se compreende pela perda total das funções cerebrais, mesmo que as funções cardiovasculares ainda permaneçam, visto que nos séculos passados, a morte era vista apenas pela cessação dos batimentos cardíacos (BARBOSA et al, 2018).

Em relação aos questionamentos sobre vida e morte, os fatores religiosos, culturais, éticos, morais e filosóficos, sempre permanecem entrelaçados, elencando assim vários debates e formação de opinião pessoal, não somente no Brasil, mas em todo o mundo (BARBOSA et al, 2018).

Através da Constituição Federal de 1988, em seu artigo $1^{\circ}$, inciso III, está prevista a dignidade da pessoa humana, e seu valor, com a finalidade de assegurar aos seres humanos, um mínimo de direitos que devem ser respeitados tanto pela coletividade, como pelo poder público. Esses são pontos cruciais para tomada de decisão sobre a legalização da eutanásia no Brasil (BARBOSA et al, 2018).

O Supremo Tribunal Federal, enquanto Corte Constitucional da Pátria, segue analisando a possibilidade de acordo com as interpretações do texto constitucional, sobre o valor da vida e a dignidade da pessoa humana, para uma possível legalização da eutanásia no país (BARBOSA et al, 2018).

\section{DO PONTO DE VISTA RELIGIOSO E ESPIRITUAL}

Nos últimos anos, iniciou-se pesquisas sobre o tempo de vida (início e fim), tendo isso como tema de vários estudos. Em diversos artigos encontramos discussões sobre a emergência do debate em torno da definição de critérios entre o início e o término da vida. Nesse contexto, observamos os processos legais referentes a temas como aborto e eutanásia que se tornaram evidentes, porém com diferentes posicionamentos políticos no espaço público (MENEZES; GOMES 2012).

Nessa questão, ainda encontramos dois grupos contraditórios, de um lado, os religiosos, e, de outro, os movimentos sociais. Onde os religiosos por suas crenças acreditam que não se deve tirar a vida de outra pessoa, ainda esse sendo um caso para o benefício do mesmo. Do outro lado temos o grupo que acredita que cada um de nós 


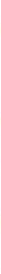

temos o direito de escolhermos à hora da própria morte, desde que isso seja no caso de uma doença em estado terminal (MENEZES; GOMES, 2012).

Para os cristãos, a vida é um dom sagrado e o único que pode tirá-la é o criador da mesma. Tirar a vida do outro, ou a própria vida, para esse grupo religioso é um pecado grave. Entretanto, em pacientes que estão nos últimos estágios da doença, em que tratamentos que visam adiar a vida do paciente, tragam mais malefícios que benefícios, a eutanásia é costuma ser aceita (LOUZADA, 2018).

A Igreja Católica, defende o direito à vida, a qual está ligada à dignidade da pessoa humana, e condena todo e qualquer crime contra a vida, tais como: homicídio, genocídio, suicídio, aborto e eutanásia. Afirma que a vida humana além de dom divino, tem valor moral e social. Em resumo, religião católica só aceita a eutanásia passiva, apesar de alguns pensadores não aceitarem, sendo a favor apenas da ortotanásia (LOUZADA, 2018).

A doutrina espírita acredita em vida após a morte (reencarnação), onde o indivíduo vem para este plano com o intuito de cumprir a sua missão, prestar contas de vidas anteriores, por exemplo. E a medida que acontece a ruptura dessa vida, através da eutanásia é como se o profissional estivesse descumprindo o processo de reencarnação e acertos de conta desse paciente (LOUZADA, 2018).

$\mathrm{Na}$ visão espírita, a eutanásia é entendida e determinada como uma forma de homicídio, tendo em vista que os profissionais que participam deste ato, responderão pela atitude tomada, ainda que o profissional tenha a melhor das intenções, mesmo objetivando ajudar a cessar o sofrimento do próximo, ele estará cometendo um crime de lesa-natureza. Isso pelo fato de estar tirando algo de melhor que Deus deu ao ser humano, a vida (LOUZADA, 2018).

Segundo o espiritismo a eutanásia não pode ser praticada. Pois se o paciente mesmo com todos os cuidados prestados se encontra em uma situação de fase terminal onde os cuidados médicos não têm mais valia, o paciente deverá passar por tudo o que foi de seu merecimento sendo o resultado a morte ou a recuperação (LOUZADA, 2018).

O judaísmo, presa pela vida e não permite práticas que antecipem a mesma, porém, não defende o fato de mantê-la a todo custo. A religião é contra procedimentos que prolonguem o sofrimento do enfermo (LOUZADA, 2018).

Para o budismo, a vida tem um valor significativo, mas não possui dom divino, pois a religião não acredita na existência de um ser supremo, que para os cristãos é 


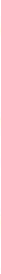

Deus. Apesar de entender que a vida é passageira e que a morte é inevitável, os budistas defendem a morte em seu tempo natural. Eles anseiam em realizar os rituais da morte e não de pôr um fim na mesma (LOUZADA, 2018).

No islamismo, Alá concede a pessoa humana a capacidade de decisão, visto que são seres racionais. Apenas a eutanásia passiva, em que o paciente não apresenta possibilidades de cura, é aceita pela religião. A eutanásia ativa é totalmente condenada.

Diante de tudo que foi exposto, ressalta-se que o processo de término da vida é visto como uma certeza para todos, independente da religião, que pode ser doloroso tanto para o paciente, que muitas vezes fica ansioso com a espera de sua partida, como para a família e a equipe de saúde. Durante a fase terminal do paciente, a espiritualidade entra como recurso terapêutico. Alguns estudos demonstram que a espiritualidade é um recurso relevante para o estado emocional do enfermo e de seus familiares. Mesmo esse recurso apresentando melhoras para o paciente, ainda é pouco utilizado, alguns profissionais não possuem o hábito de falar da espiritualidade, negando esse meio ao enfermo por não se sentirem seguros ao falar do assunto (EVANGELISTA, 2016).

\section{CONSIDERAÇÕES FINAIS}

Tal estudo reflexivo abordou sobre dilemas éticos, legais e religiosos no mundo sobre os termos eutanásia, ortotanásia e distanásia, que são corriqueiramente discutidos em todo o mundo e que despertam reflexões e revisão de valores e princípios.

Para algumas religiões, todo ser é personificado à imagem e semelhança de Deus. É impossível tratar a morte como algo biológico, que é o que vem acontecendo em todo mundo. Aspectos jurídicos, sociais, psicológicos, culturais e religiosos sempre estarão presentes nesse debate sobre o valor da vida.

Esse assunto é muito complexo, tendo em vista que há inúmeros vertentes, como: pensamentos, razões, emoções, sentimentos e desejos. A Eutanásia é sem dúvida algo difícil de se pensar, pois para alguns, o ato de desligar uma máquina ou a administração de um medicamento fatal, objetivando interromper uma vida, é desumano, é cruel, é inadmissível.

No contexto político, sistema pode ser culpado pela superlotação de leitos, pelas poucas condições para oferta de cuidados de qualidade aos pacientes, mas isso não dá o direito de ninguém intervir na vida fatídica de um ser humano a ponto de matá-lo. 


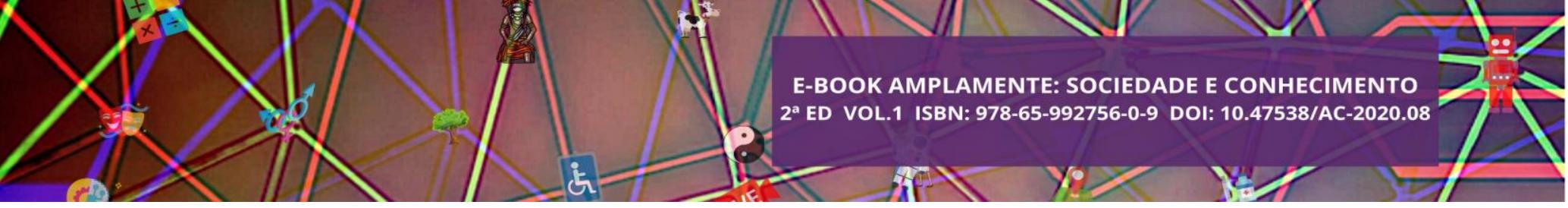

Falar sobre cuidados paliativos é algo bastante desafiador, complexo, pois saber que alguém vai morrer e não poder fazer nada para intervir é tarefa difícil. Sempre que o paciente está em cuidados paliativos, deve-se ofertar todo o conforto possível, como: oferecer um leito limpo e seco; realizar todas as mudanças de decúbito como prevenção; realizar medicações (bem como analgésicos) para alívio da dor; fazer com que ele se sinta confortável, mesmo que ele esteja em ME (morte encefálica). Prestar toda a assistência necessária, visando não a morte e sim o bem estar do paciente em um momento tão difícil. E ainda, cabe o profissional preparar os familiares pois tudo isso só acontecerá se tivermos a autorização deles.

É um enorme problema de saúde pública a ocorrência de casos de antecipação da vida, pois ao faltar leitos, faltar medicamentos nas unidades torna-se responsabilidade do sistema. Esse é um assunto repleto de polêmicas por despertar divergentes opiniões. Os profissionais devem ser educados desde a academia sobre a valorização da vida, a prestação de cuidados livre de danos, o respeito à vida e aos princípios do próximo.

Salientamos a importância do respeito à opinião do outro e que independente da religião, cultura, princípios e valores, os pacientes em fase terminal são dignos de uma assistência humanizada.

\section{REFERÊNCIAS}

AMORIM, Mariana Morais Soares et al. EUTANÁSIA, ORTOTANÁSIA E SUICÍDIO ASSISTIDO: aspectos jurídicos, religiosos e éticos. XVI Congresso de Ciências da Comunicação na Região Sudeste - São Paulo - SP. São Paulo, 2011. Disponível em http://www.intercom.org.br/papers/regionais/sudeste2011/expocom/EX24-0983-1.pdf Acessado em 13 Jun. 2020

BARBOSA, Gabriela Sousa da Silva; LOSURDO, Frederico. Eutanásia no Brasil: entre o Código Penal e a dignidade da pessoa humana. Rev. Investig. Const. Curitiba vol.5, no.2, May/Aug. 2018. Disponível em https://www.scielo.br/scielo.php?script=sci_arttext\&pid=S2359-56392018000200165 Acessado em 14 Jun. 2020.

BERALDO, Lívia Maria; ALMEIDA, Débora Vieira de; BOCCHI, Silvia Cristina Mangini. Da frustração ao enfrentamento do cuidado para a morte por técnicos de enfermagem. Rev. Bras. Enferm. Brasília, v. 68, n. 6, Nov/Dec. 2015. Disponível em https://www.scielo.br/scielo.php?script=sci_arttext\&pid=S0034$71672015000601013 \& \operatorname{lng}=$ pt\&tlng=pt Acessado em 15 Jun. 2020.

CASTRO, Mariana Parreira Reis de et al. Eutanásia e suicídio assistido em países ocidentais: revisão sistemática. Rev. Bioét. Brasília, vol.24, n.2, May/Aug. 2016. 


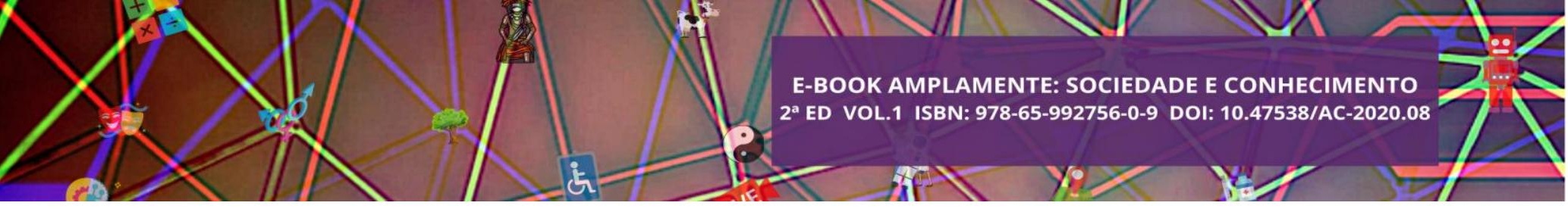

Disponível em https://www.scielo.br/scielo.php?script=sci_arttext\&pid=S1983-

$80422016000200355 \& \operatorname{lng}=$ pt\&tlng=pt Acessado em 13 Jun. 2020.

EVANGELISTA, Carla Braz et al. Cuidados paliativos e espiritualidade: revisão integrativa da literatura. Rev. Bras. Enferm. Brasília, v. 69, n. 3, Jun. 2016. Disponível em:

https://www.scielo.br/scielo.php?script=sci_arttext\&pid=S0034-71672016000300591 Acessado em 16 Jun. 2020.

FERREIRA, Julia Messina Gonzaga; NASCIMENTO, Juliana Luporini; SÁ, Flávio César de. Profissionais de saúde: um ponto de vista sobre a morte e a distanáisa. Rev. bras. educ. med, Brasília vol.42, n.3, July/Sept. 2018. Disponível em https://www.scielo.br/scielo.php?script=sci_arttext\&pid=S010055022018000300087\&lang=pt Acessado em 10 de Jun. 2020

LOUZADA, Thiago Galvão. Eutanásia: uma abordagem ética, jurídica e religiosa. Rev. Humanidades e inovação. Tocantins, v.5, n.6, Sep. 2018. Disponível em https://revista.unitins.br/index.php/humanidadeseinovacao/article/view/826 Acessado em 13 Jun. 2020.

LISBOA, Márcia Lucrecia; CREPALDI, Maria Aparecida. Ritual de despedida em familiares de pacientes com prognóstico reservado. Paidéia (Ribeirão Preto), Ribeirão Preto, V. 13, n. 25, Jun. 2003. Disponível em https://www.scielo.br/scielo.php?script=sci_arttext\&pid=S0103-863X2003000200009 Acessado em 13 de junho 2020.

MALUF, Fabiano; GARRAFA, Volnei. O Core Curriculum da Unesco como Base para Formação em Bioética. Rev. bras. educ. med., Rio de Janeiro, v. 39, n.3, Sept. 2015. Disponível em: https://www.scielo.br/scielo.php?script=sci_arttext\&pid=S010055022015000300456 Acessado em 15 Jun. 2020.

MENEZES, Rachel Aisengart; GOMES, Edlaine de Campos. Uma "morte suave": valores religiosos e laicos nos discursos sobre ortotanásia. Relig. soc. Rio de Janeiro, v. 32, n. 2. 2012. Disponível em https://www.scielo.br/scielo.php?script=sci_arttext\&pid=S0100$85872012000200005 \& \operatorname{lng}=$ en\&nrm=iso\&tlng=pt Acesso em 16 Jun. 2020.

NETO, Luís Inácio de Lima. A legalização da eutanásia no Brasil. Teresina, 2003. Disponível em: <www.jusnavigandi.com.br>.

NUNES, Lucília. Do ensino de bioética e as escolhas temáticas dos estudantes. Rev. Bioét, Brasília, v. 25, n. 3, Oct/Dec. 2017. Disponível em https://www.scielo.br/scielo.php?script=sci_arttext\&pid=S1983-80422017000300512 Acessado em 15 Jun. 2020.

RODRIGUES, Dayse Maria de Vasconcelos; ABRAHÃO, Ana Lúcia; LIMA, Fernando Lopes Tavares de. Do começo ao fim, caminhos que segui: itinerações no cuidado paliativo oncológico. Saúde em Debate, v. 44, p. 349-361, 2020. 


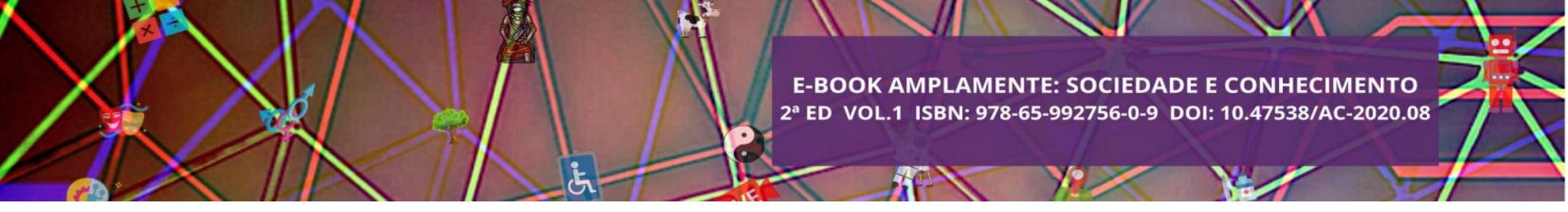

\title{
CAPÍTULO XXIX
}

\section{POLUIÇÃO SONORA: REFLEXÕES SOBRE O PERÍODO DE PANDEMIA DO COVID-19}

\author{
Carlos Antônio Freitas da Silva ${ }^{154}$; Luciano Luan Gomes Paiva ${ }^{155}$
}

DOI - Capítulo: 10.47538/AC-2020.08-29

\section{RESUMO:}

Este trabalho tem como principal objetivo apresentar dados evidenciando os efeitos gerados pela diminuição dos ruídos antropogênicos, a partir do isolamento social provocado pela pandemia do novo coronavírus. Assim sendo, traremos a temática da Poluição Sonora, principalmente à luz dos pressupostos de Murray Schafer (1991), mas, também com dados de diversos âmbitos, inclusive direcionados à realidade brasileira e, sobretudo, a partir do isolamento social causado pela pandemia do Coovid-19. Podemos evidenciar neste trabalho que, ao longo dos anos, o homem vem alterando negativamente a paisagem sonora ao seu redor. Essa mudança vem prejudicando a saúde humana, como a saúde de diversas espécies de animais. Além disso, nos primeiros meses do isolamento social, com a diminuição nos níveis de ruído em diversas partes do mundo, foi possível perceber o quão nocivo às espécies é a ação humana.

PALAVRAS-CHAVE: Poluição Sonora. Ruídos Antropogênicos. Pandemia. Covid19.

\section{INTRODUÇÃO}

Estamos vivendo uma situação atípica em todo mundo. A Pandemia provocada pelo novo coronavírus (SARS-COV-2) vem provocando uma grave crise sanitária em escala mundial e está afetado diretamente vários setores da nossa sociedade, como Saúde, Cultura, Turismo, Esporte, Comércio, Agropecuária, Indústria, Educação, entre outros segmentos.

No início do mês de dezembro de 2019, foi identificado em Wuhan, capital da província de Hubei, República Popular da China, uma doença respiratória aguda causada pelo novo coronavírus, a COVID-19. Em janeiro desde ano, a Organização Mundial da Saúde (OMS), declarou que o surto do novo coronavírus, constitui-se como

154 Professor de Música na educação básica. YouTuber. Aluno especial no Programa de Pós-Graduação em Educação (UFRN). E-mail: csilva310@ hotmail.com

155 Mestre em Música (UFRN). Professor. Coach Educacional. E-mail: luciano.90@hotmail.com. ORCID: https://orcid.org/0000-0001-6192-6075. 


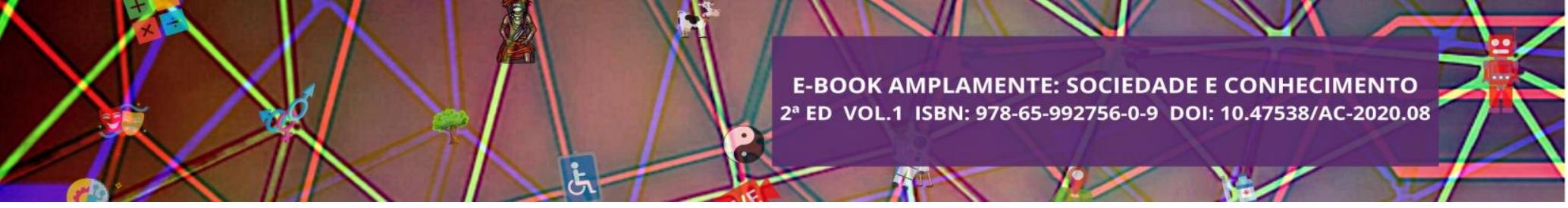

um caso de Emergência de Saúde Pública de Importância Internacional. Em março, o mesmo órgão declarou que a doença se caracterizava como uma pandemia.

Para proteger a população e tentar minimizar os impactos da doença, muitos países adotaram diversas medidas protetivas para conter o vírus. Entre as medidas adotadas decretada para tentar barrar a rápida propagação e transmissão do viral, foi o distanciamento e isolamento social. Tal ação, surtiu efeitos imediatos na diminuição, circulação e aglomeração entre pessoas, como também, foi uma ação muito eficaz na tentativa de separar pessoas sintomáticas de pessoas assintomáticas, e ainda, proteger grupos mais vulneráveis à doença, como idosos, crianças e pessoas com doenças crônicas (por exemplo: Diabetes, Hipertensão, Asma).

Como medida preventiva, a redução de diversas atividades presenciais para uma parcela da população foi diminuída ou interrompida, abarcando atividades industriais, comerciais, escolares, culturais, educacionais, de transportes, entre outros. Consequentemente, provocaram mudanças humanas e ambientais, sobretudo pela diminuição dos ruídos antropogênicos, que são aqueles que são derivados a partir das ações e atividades humanas.

Nesse sentido, este trabalho tem como principal objetivo apresentar dados evidenciando os efeitos gerados pela diminuição dos ruídos antropogênicos, a partir do isolamento social provocado pela pandemia do novo coronavírus. Por ser uma temática recente e com poucos estudos, nos pautamos em referências sólidas conceituais publicadas anteriormente para fundamentar nosso discurso, bem como notícias enfatizando a emergência de debates sobre o fenômeno sonoro-ambiental presente em nosso cotidiano.

Neste texto, traremos a temática da Poluição Sonora, principalmente à luz dos pressupostos de Murray Schafer (1991), mas, também com dados de diversos âmbitos, inclusive direcionados à realidade brasileira e, sobretudo, a partir do isolamento social causado pela pandemia do Coovid-19.

\section{POLUIÇÃO SONORA}

O Som é um tipo de onda mecânica, longitudinal e tridimensional, que está presente em nosso dia a dia. Ele é extremamente importante para nós, pois, traz consigo, uma variedade de informação que ajuda a interpretar o que está acontecendo no 


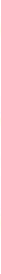

ambiente em nossa volta. Por exemplo, a aceleração e desaceleração de um carro vindo em nossa direção, o som do despertador, os diferentes tipos de choro de um bebê (fome, dor, manha), o sino da escola e assim por diante. Para alguns animais, o som serve parar a reprodução, demarcação de território, cuidado parental, acasalamento, alertam e fuga de predadores, procuram seus filhotes entre outros comportamentos.

No entanto, a produção indiscriminada do som produzido por veículos, buzinas, sirenes, construções, transportes urbanos, aglomeração de pessoas em festas, estádios de futebol, aparelhos de som, fones de ouvidos, máquinas e/ou os diversos tipos de motores que dominam a paisagem sonora pelo mundo (SCHAFER, 1991), e vem se tornando um problema crescente em nossa sociedade. Isso ocorre porque, no decorrer da história, a paisagem sonora vem se modificando de forma dinâmica, transformável ao ponto de afetar nossa saúde e alterar o comportamento natural dos animais.

\begin{abstract}
A recente urbanização tem causado diversas dificuldades às espécies animais. Um exemplo é a poluição sonora, que provoca modificações no ambiente acústico, as quais podem afetar a comunicação acústica de espécies animais, pela degradação e a atenuação dos sinais sonoros, podendo impactar a fauna de diferentes maneiras, além da influência na transmissão das emissões sonoras, provocando interferência em muitos aspectos da vida selvagem (OLIVEIRA, 2014, p. 09).
\end{abstract}

Sabemos que, a poluição sonora refere-se a qualquer tipo excessivo de som, barulho que pode vir a afetar negativamente na qualidade de vida do ser humano. Segundo Schafer (2001), a poluição sonora caracteriza-se como um problema de proporções mundiais. O referido autor chama atenção para os perigos da difusão imperialista do som, que, por sua vez, gera um grande problema de ordem social, ambiental e de saúde pública.

Historicamente, o conjunto de mudanças ocorridas na Europa entre os séculos XVIII e XIX, na Revolução Industrial, impactaram diretamente na forma como nos relacionamos com o meio ambiente. Esse período, foi o início de grandes desenvolvimentos e transformações. Os avanços tecnológicos produzidos na época, como por exemplo, a invenção da primeira máquina a vapor, construída em 1698, Thomas Newcomen, trouxeram ao mundo grandes transformações nas áreas da indústria, tecnologia, comercio, processos produtivos e no estilo de vida do ser humano.

Com o passar do tempo, a mecanização, o surgimento das primeiras fábricas, a ascensão do sistema fabril, os novos métodos aplicados nas linhas de produção (Taylorismo e o Fordismo), o desenvolvimento dos transportes, o uso energia elétrica e, 


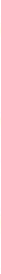

consequentemente, desenvolvimento tecnológico, o aparecimentos de grandes cidades, o crescimento populacional urbano desorganizado, sem planejamento, com estruturas urbanas caóticas, e ainda, o surgimentos de equipamentos de som, contribuíram, substancialmente, para modificar drasticamente a paisagem sonora, poluindo nosso ambiente sonoro ao ponto do tema ser tratado como caso de saúde pública.

A Organização Mundial da Saúde (OMS) considera a poluição sonora como um problema de saúde pública, haja vista que a exposição a níveis sonoros elevados pode ocasionar diversos sintomas como a irritação, fadiga, incidências de zumbidos, tontura, aumentando as chances de infarto, e outros fatores que podem, a longo prazo, ocasionar a diminuição ou até mesmo a perda total da audição.

Ainda segundo a OMS, o nível do barulho admitido nos grandes centros urbanos é de até 50 decibéis (unidade de medida do som), entretanto, os sons que são produzidos nas grandes cidades, seja o som produzidos pelos carros, motos e transportes coletivos, indo e vindo de um lugar para o outro, os sons produzidos pelas reformas ou construções de casas, prédios e comércios, ou ainda, os sons utilizados pelos diversos comércios para atrair nossa atenção, normalmente passam dos 50 decibéis.

Diversos segmentos da sociedade, entre a OMS, Ministério do Meio Ambiente, as Organizações Não Governamentais, poder público brasileiro, pesquisadores e educadores, vêm desenvolvendo leis, ações e pesquisas, debatendo em eventos os temas referentes à intensidade, qualidade e difusão indiscriminada do som.

A Constituição Federal (BRASIL, 1988) em seu a Artigo 225, nos diz que, todos nós temos direito ao meio ambiente ecologicamente equilibrado. A Lei 9.605/98, que trata dos crimes ambientais, em seu Artigo 54, configura crime ambiental, causar poluição de qualquer natureza em níveis tais que resultem ou possam resultar em danos à saúde humana.

O Conselho Nacional do Meio Ambiente (CONAMA, 1990) em sua resolução de $n^{\circ} 1$, de 8 de março de 1990, dispõe sobre critérios de padrões de emissão de ruídos decorrentes de quaisquer atividades industriais, comerciais, sociais, recreativas ou propaganda política. A resolução de n. ${ }^{\circ}$ 002, 8 de março de 1990, institui o Programa Nacional de Educação e Controle da Poluição Sonora - SILÊNCIO. Associação Brasileira de Normas Técnicas (ABNT), que estabeleceu procedimentos para medir a avaliar níveis de pressão sonora em áreas habitadas (ABNT NBR 10151) e em 


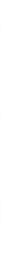

ambientes internos e edificações (ABNT NBR 10152), e ainda, tramita na Câmara dos Deputados, o Projeto de Lei 3169/19 (BRASIL, 2019), que define o crime de perturbação da qualidade ambiental por meio da produção de poluição sonora, com pena de detenção - de três meses a um ano - e multa. O texto insere dispositivo na Lei dos Crimes Ambientais (9.605/98).

Contudo, mesmo com as diversas ações descritas acima, que servem para informar, inibir e combater a poluição sonora, ao fazermos uma breve pesquisa em sites de informação, como jornais, revistas e outros com o termo poluição sonora, podemos evidenciar que o problema está longe de ser resolvido. As ocorrências causadas pela poluição sonora demanda um número expressivo nas ocorrências policiais pelo 190 em diversos lugares do Brasil.

Segundo a direção do Centro Integrado de Operações (CIOP, 2019), órgão que integra as seis instituições que compõem o sistema de segurança pública do Estado do Pará, de janeiro a maio de 2019 foram registradas 22.027 ocorrências de poluição sonora, via central 190, na Região Metropolitana de Belém. O que chama atenção é que este tipo de ocorrência diminuição de $23,52 \%$, em relação ao o ano de 2018 . No ano de 2017, foram contabilizados 75.256 registros.

Em dezembro de 2019, o portal de notícias G1 (G1-SP, 2019) noticiou que, a cidade de São Paulo registrou, no primeiro semestre de 2019, 9.449 reclamações de barulho. Outro dado nos chama a atenção, o portal de notícias G1 (G1-BA, 2019), revelou que, no período de oito meses em 2019, a cidade de Salvador registrou mais de mais de 26 mil denúncias de poluição. Infelizmente, os dados apresentados aqui evidenciam que, a poluição é um mal e acomete grande parte da nossa sociedade.

\section{COVID-19 E A POLUIÇÃO SONORA}

A partir de medidas preventivas para conter a proliferação do coronavírus pelo país, muitas atividades foram interrompidas ou, para alguns casos, passaram a ser feitas à distância, gerando diversas mudanças sociais e ambientais. Comércios fechados, indústrias e fábricas paradas, escolas e empresas de diversos ramos fechadas, diminuição intensa do fluxo de pessoas e veículos nas ruas, e, consequentemente, viabilizando um ambiente menos impactado pela ação humana. 


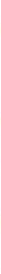

Em um breve levantamento, constatamos que a redução dos níveis do ruído antropogênico nos primeiros meses de 2020 vêm reduzindo a ação negativa do homem contra o meio ambiente, contribuindo assim, com efeitos positivos para o meio ambiente (CORREIO BRAZILIENSE, 2020).

O site de notícias do jornal The Guardian, noticiou um estudo (MCVEIGH, 2020) (ainda em andamento), que está examinando sinais sonoros subaquáticos em tempo real de observatórios do fundo do mar administrados pela Ocean Networks Canada. Os dados preliminares demonstram que a redução significativa no tráfego de navios perto do porto de Vancouver, vem reduzindo os níveis de poluição sonora no oceano. Segundo os pesquisadores, tal mudança pode vir a ser positiva no benefício de atividades sociais de baleias e outros animais marinhos como se alimentar, comunicar, encontrar parceiros e se reproduzir.

Em outro caso, um artigo publicado em julho de 2020, pela Revista Science (LECOCQ, 2020), reunindo dados de 268 estações sísmicas em 117 países, evidenciando uma redução significativa no chamado ruído sísmico. Tal fato, contribui positivamente no fornecimento de informações mais precisas que monitoram possíveis alterações sísmicas.

Um monitoramento de mudanças no ambiente sonoro realizado pela Bruitparif (BRUITPARIF, 2020), uma organização ambiental sem fins lucrativos responsável pelo monitoramento do ruído ambiental na aglomeração de Paris, evidenciou que durante o período de confinamento, houve uma redução significativa na emissão de ruído de origem antropogênica, que provocou um silêncio incomum na região de Île-de-France. Tal redução só foi possível por causa da paralisação de determinadas atividades humanas, como a paralisação temporária de certos canteiros de obras, fechamento de muitas atividades e locais festivos, a redução do tráfego de veículos e outras ações de origem antropogênica.

No Brasil, dados da Associação Brasileira para a Qualidade Acústica (PROACÚSTICA, 2020), apontam que as medidas de isolamento social para combate do novo coronavírus, conseguiram uma redução de até 10 decibéis no nível de ruído produzido em determinadas áreas da região central da cidade de São Paulo.

Esse fenômeno permite contemplar o reaparecimento de alguns sons que não se ouviam mais, nos ajuda na prevenção e detecção de catástrofes naturais, como contribui para o melhoramento da comunicação entre diversas espécies de animais como: 


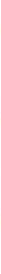

golfinhos, baleias, morcegos, passarinhos, entre outros. Vale ressaltar que o desaparecimento de alguns sons naturais ao nosso redor, antes em abundância, pode ser um indicativo não só de uma extinção sonora, como também, pode se caracterizar como desaparecimento de espécies.

\section{CONSIDERAÇÕES FINAIS}

Podemos evidenciar neste trabalho que, ao longo dos anos, o homem vem alterando negativamente a paisagem sonora ao seu redor. Essa mudança vem prejudicando a saúde humana, como a saúde de diversas espécies de animais. Além disso, nos primeiros meses do isolamento social, com a diminuição nos níveis de ruído em diversas parte do mundo, foi possível perceber o quão nocivo às espécies é a ação humana.

Mesmo não sendo contemplado neste artigo, reconhecemos a infinidade de efeitos nocivos à espécie humana, sobretudo na perda de vidas com a ampla dimensão que ganhou o Coronavírus. Os esforços dos governos de todos os países, sobretudo com a produção de uma vacina para prevenção do vírus está, cada vez mais, perto de ser concluída, enquanto medidas de afrouxamento vão sendo desencadeadas para evitar uma quebra maior na economia.

Esperamos que, com este e outros trabalhos, reflexões sejam aplicadas em ações que permitam uma coexistência harmoniosa entre economia e meio ambiente, mas, principalmente, colocando as vidas e a preservação da natureza como norte das medidas tomadas. A partir disso, podemos intensificar estudos para uma convivência mais harmoniosa entre homem e natureza, aprofundando pesquisas de diversas áreas de conhecimento, como Educação Ambiental e Educação Musical, que podem trabalhar em prol de uma conscientização da preservação da natureza, juntando e construindo saberes necessários à nossa sobrevivência.

\section{REFERÊNCIAS}

BRASIL. Lei 3169/19, que define o crime de perturbação da qualidade ambiental por meio da produção de poluição sonora, com pena de detenção - de três meses a um ano e multa. O texto insere dispositivo na Lei dos Crimes Ambientais (9.605/98).

Disponível em: <(https://cd.jusbrasil.com.br/noticias/735569783/propostacriminaliza-a-perturbacao-da-qualidade-ambiental-pela-poluicao-sonora)>. Acesso em: 27/07/2020. 


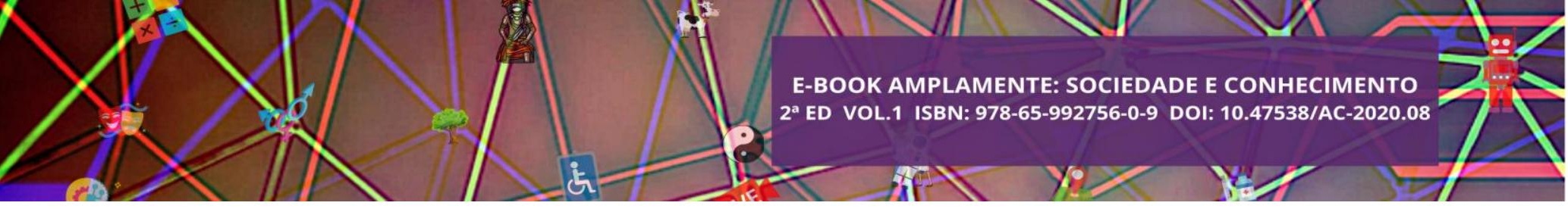

BRUITPAIF. Monitoramento de mudanças no ambiente sonoro relacionadas a contenção e desconfiança. Disponível em: <https://www.bruitparif.fr/suivi-desmodifications-de-l-environnement-sonore-en-lien-avec-le-confinement-et-ledeconfinement1/>. Acesso em: 16 de mai. de 2020.

CIOP. Balanço de poluição sonora via CIOP 190 de janeiro a maio de 2019. 2019. Disponível em:

<http://www.ciop.pa.gov.br/images/balanco_190/RELEASE_BALANCO_DE_POLUICA O_SONORA_CIOP_190_jan_a_maio2019.pdf)>. Acesso em: 27/07/2020.

CORREIO BRAZILIENSE. Imagens de satélite mostram como a quarentena reduz a poluição. Disponível em:

$<$ (https://www.correiobraziliense.com.br/app/noticia/brasil/2020/04/13/internabrasil,844116/imagens-de-satelite-mostram-como-a-quarentena-reduz-a-poluicao.shtml)>. Acesso em: 27/08/2020.

G1-BA. Em oito meses, mais de 26 mil denúncias de poluição sonora foram registradas em Salvador, aponta levantamento. 2019. Disponível em:

$<$ (https://g1.globo.com/ba/bahia/noticia/2019/09/02/em-oito-meses-mais-de-26-mildenuncias-de-poluicao-sonora-foram-registradas-em-salvador-apontalevantamento.ghtml)>. Acesso em: 27/07/2020.

G1-SP. São Paulo tem 9,4 mil reclamações de barulho no $1^{\circ}$ semestre; Pinheiros é recordista, região de Paraisópolis fica em $\mathbf{7 6}^{\circ}$ lugar. 2019. Disponível em:

$<$ (https://g1.globo.com/sp/sao-paulo/noticia/2019/12/03/sp-tem-94-mil-reclamacoes-debarulho-no-1o-semestre-pinheiros-e-recordista-regiao-de-paraisopolis-fica-em-76olugar.ghtml)>. Acesso em: 27/07/2020.

LECOCQ, Thomas et al. Global quieting of high-frequency seismic noise due to COVID-19 pandemic lockdown measures. Science. Washington, DC. July, 2020. Disponível em: <https://science.sciencemag.org/content/early/2020/07/22/science.abd2438>. Acesso em: 01 de ago. de 2020.

MCVEIGH, Karen. O silêncio é de ouro para as baleias, pois o bloqueio reduz o ruído do oceano. The Guardian. 2020. Disponível em: <

https://www.theguardian.com/environment/2020/apr/27/silence-is-golden-for-whales-aslockdown-reduces-ocean-noise-coronavirus>. Acesso em: 16 de mai. de 2020.

OLIVEIRA, Vera Lúcia Cunha. Influência do ruído ambiente em canções de um pássaro oscine e um suboscine da mesma população. 2014. Dissertação (Mestrado) Universidade Federal de Alfenas. Alfenas-MG, 2014.

PROACÚSTICA. Associação Brasileira para a Qualidade Acústica. Disponível em: $<$ http://www.proacustica.org.br/noticias/proacustica-releases-sobre-as-acoes-daassociacao/levantamento-da-proacustica-demonstra-que-na-pandemia-a-poluicao-sonorareduziu-em-sp.html>. Acesso em: 16 de maio de 2020.

SCHAFER, Raymond M. O Ouvido pensante. Tradução de Marisa Trench de O. Fonterrada, Magda R. Gomes da Silva e Maria Lúcia Pascoal. São Paulo: Unesp, 1991.

SCHAFER, Raymond Murray. A Afinação do Mundo. São Paulo: Unesp, 2001. 


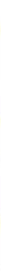

migrado para um campo mais intimista e psicológico, dando mais valor ao "agente empreendedor" do que ao "processo empreendedor". Mais recentemente, nos últimos dez anos, um certo movimento tem se consolidado no sentido de propor um conjunto de estruturas explicativas ao surgimento e consolidação de ambientes socialmente construídos para dar suporte ao empreendedorismo - são os chamados Ecossistemas Empreendedores (ISENBERG, 2010; STAM, 2015; MASON; BROWN, 2013).

Um dos autores proeminentes no desenvolvimento do conceito de "Ecossistemas Empreendedores" é Daniel Isenberg, professor da Babson College. Isenberg define um ecossistema de empreendedorismo como "um conjunto de instituições em rede [...] com o objetivo de ajudar o empreendedor a percorrer todas as etapas do processo de desenvolvimento de novos empreendimentos" (ISENBERG, 2010). Ele caracteriza ainda um ecossistema empreendedor em quatro partes: (1) consiste de seis pilares/domínios (política, finanças, cultura, apoios, capital humano, mercados); (2) Cada ecossistema empreendedor é único, não podendo ser replicado; (3) A especificação de causas genéricas do ecossistema empresarial tem um valor prático limitado; (4) Os ecossistemas empreendedores tornam-se (relativamente) autossustentáveis assim que os seis pilares/domínios são suficientemente fortes (ISENBERG, 2010).

Com base nesse conceito de Ecossistemas Empreendedores, e em outros conceitos anteriormente desenvolvidos, como o de Sistemas Nacionais de Inovação, nos últimos anos, uma série de organismos internacionais vêm apresentando metodologias distintas de análise e comparação desses ambientes empresariais. O Banco Mundial realiza, desde 2004, uma pesquisa cross-country, que visa analisar as diferentes as regulamentações que as empresas devem cumprir, ao longo de sua existência, para atuarem em seus mercados locais. Tais resultados são divulgados anualmente através do Relatório Doing Business. Entre as regulamentações analisadas, estão desde o processo de abertura das empresas, as formas de operações, os acessos ao comércio internacional, a carga tributária, entre outros indicadores. Após a análise, o Relatório classifica os países quanto à facilidade de se fazer negócios. No ano de 2004, o Relatório apontou que no Brasil eram necessários 152 dias para completar o processo de abertura de um novo negócio, enquanto a média na Austrália era de apenas dois dias. O Relatório Doing Business, de 2015, apontou, ainda, que um processo de falência no Brasil leva, em média, dez anos para ser concluído. 


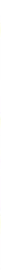

Outro importante estudo, desenvolvido pelo Grupo Endeavor, é o Índice de Cidades Empreendedoras (ICE). No Brasil, tal Índice é aferido desde 2014, de forma anual. No ICE 2016, por exemplo, foram analisadas 32 cidades brasileiras, de 22 estados. Com exceção da região Norte, onde são analisadas apenas Belém e Manaus, todos os estados das demais regiões foram representados ao menos por suas capitais. Além da grande abrangência geográfica, juntas essas cidades representam também cerca de $40 \%$ do PIB nacional. O ICE avalia o desempenho de cada cidade, nos seis pilares que constituem um ecossistema empreendedor: ambiente regulatório, infraestrutura, mercado, acesso a capital, inovação e capital humano ${ }^{158}$.

O presente artigo pretende realizar uma reflexão a cerca das possibilidades de elevar o desempenho da cidade de Porto Alegre, capital do Rio Grande do Sul (Brasil) $^{159}$. Porto Alegre, segundo o ICE 2016, ocupa a $7^{\text {a }}$ posição entre as 32 cidades brasileiras analisadas. Porém, ao se observar o resultado em cada pilar do ecossistema verifica-se que em determinados pontos, Porto Alegre está entre as últimas colocadas, como é o caso do ambiente regulatório. O objetivo principal do presente trabalho é levantar, a partir da análise das opiniões de representantes das principais organizações que compõem o ecossistema empreendedor de Porto Alegre, sugestões para elevar os índices da cidade.

O presente artigo pretende apresentar alternativas viáveis, a partir do olhar dos agentes participantes no ecossistema empreendedor de Porto Alegre, para melhoria do desempenho do mesmo. Pretende-se, com isso, auxiliar a criação de um planejamento de ações objetivas, que visem a obtenção de melhores resultados nos próximos levantamentos do ICE. Igualmente, pretende-se verificar as possibilidades de ações conjuntas entre os diversos agentes, no sentido de promover um ambiente sistêmico "pró-inovação". Preliminarmente, observa-se que algumas iniciativas já começam a ser tomadas, sobretudo pela ação conjunta entre o poder público e organizações de apoio empresarial, no sentido de melhorar o desempenho de Porto Alegre, em especial no que tange à redução da burocracia para abertura e fechamento de empresas.

158 O ICE inclui um sétimo pilar (cultura empreendedora), em associação com os Relatórios produzidos pela Global Entrepreneurship Network (GEN).

159 Porto Alegre possui uma área total de $496,682 \mathrm{~km}^{2}$, com uma população estimada de 1.476 .867 habitantes (2015); PIB (2013): PIB per capita (2013): US\$ 12.215,00 (71 a posição no Rio Grande do Sul e 350 no Brasil), Maior Índice de Desenvolvimento Humano (2010) no estado: 0,805 (alto). Participação por setores econômicos: Agropecuária: 0,05\%, Indústria: 15,89\%. Serviços: 84,06\%. 


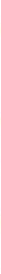

Uma vez que os ecossistemas empreendedores contêm componentes múltiplos e interligados (e o caso de Porto Alegre é um bom exemplo), a construção de tais ecossistemas implica uma abordagem equilibrada e coordenada - e neste ponto entende-se a importância do presente trabalho: possibilitar aos atores a análise dos pilares constitutivos do ecossistema, possibilitando um olhar crítico sobre esses, bem como a sugestão de mecanismos de melhoria de seu desempenho.

Ao abordar esses obstáculos, o que se pretende é desenvolver as condições de uma política pública e de um quadro institucional propício ao empreendedorismo. No entanto, ainda que as políticas públicas e as instituições sejam incluídas como fatores-chave em diferentes modelos de ecossistema empresarial, na prática é frequentemente o elemento mais negligenciado (NADGRODKIEWICZ, 2013). A razão é simples: embora seja fácil prestar louvor à necessidade de políticas que apoiem o empreendedorismo, é muito mais difícil alcançálas, sobretudo considerando a inconstância e falta de continuidade das políticas públicas, marcas do modelo brasileiro de gestão pública.

\section{FUNDAMENTAÇÃO TEÓRICA}

\section{CONCEITO DE ECOSSISTEMA EMPREENDEDOR}

Os primeiros registros do conceito de ecossistema empreendedor estão associados ao trabalho de James F. Moore (2006). Para ele, o ecossistema é uma metáfora para representar a forma como os diversos atores articulam-se entre si para produzir valor.

O autor baseou-se nos conceitos de coevolução, do antropólogo Gregory Bateson, que defende a existência de uma interdependência entre a evolução das espécies em ciclos intermináveis e recíprocos; também, baseou-se no conceito do biólogo Stephen Jay Gould, de que os sistemas naturais, muitas vezes, entram em colapso devido às mudanças em condições radicais, dando lugar a outros atores e novos ecossistemas. Moore (2006) sugere que é possível estender estes conceitos para ecossistemas de negócios.

Ron Adner e Rahul Kapoor (2010) foram autores que contribuíram na junção destes dois conceitos. Para eles, os ecossistemas são uma forma de explicitar os vínculos de interdependência dos atores para a criação e captura de valor.

Do ponto de vista teórico, o conceito de um ecossistema empreendedor trata da interação existente entre um conjunto de atores institucionais e individuais, com vistas a 


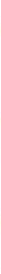

fomentar o espírito empresarial, a inovação e o crescimento das Pequenas e Médias Empresas (PME's). Este conceito tornou-se mais proeminente em 2010, por meio do professor Daniel Isenberg, da Babson College, através do seu artigo publicado na Harvard Business Review (ISENBERG, 2010). Para Isenberg, os componentes básicos de um ecossistema empreendedor estão expressos pelos domínios que se interrelacionam, formando um Ecossistema Empreendedor (Figura 1).

FIGURA 1 - Domínios do Ecossistema Empreendedor

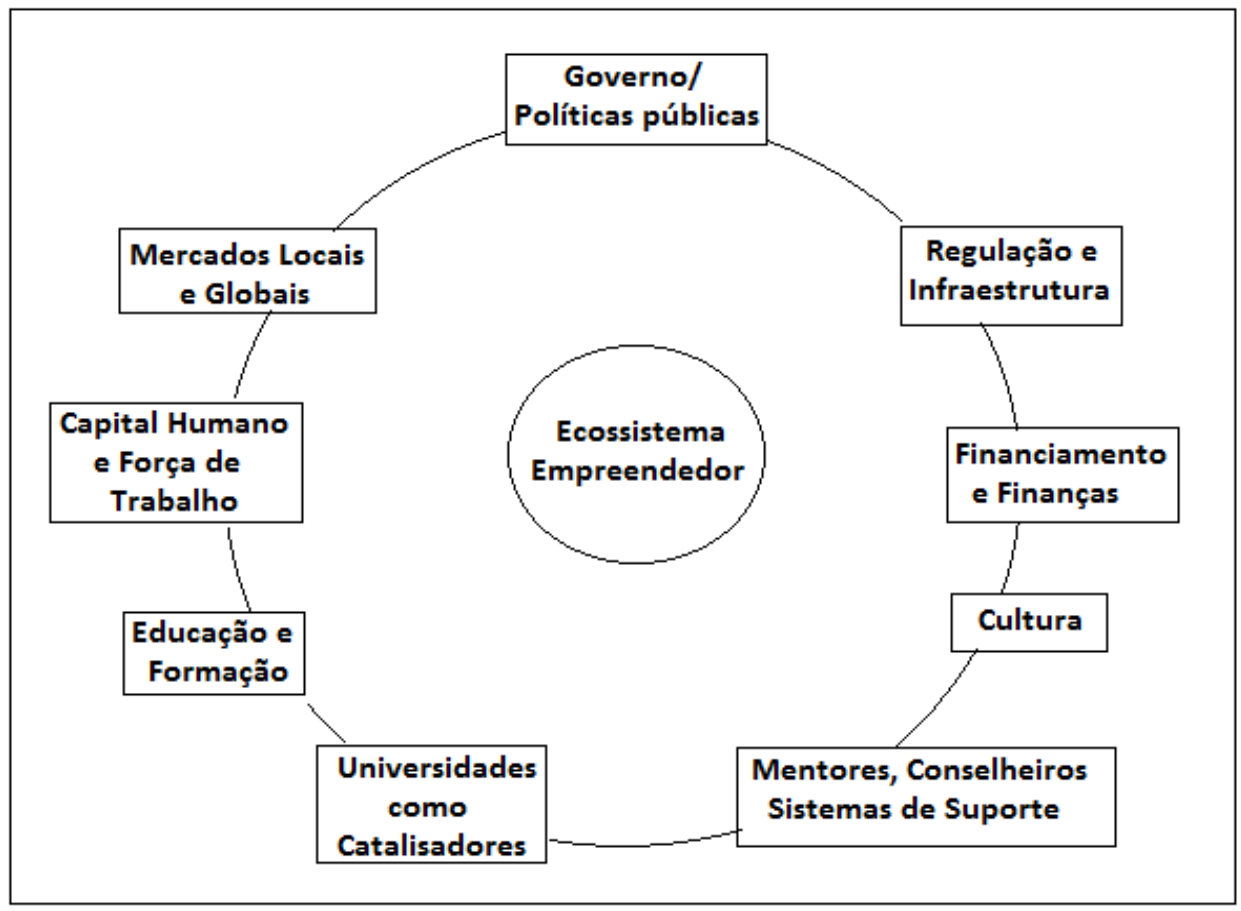

Fonte: adaptado de ISENBERG (2010).

No entanto, o conceito tem os seus antecedentes em trabalhos anteriores que se referiam a agrupamentos regionais de empresas de diversos setores e de outras entidades (PORTER, 1998; KRUGMAN, 1991), condições para a promoção do empreendedorismo tecnológico (VENKATRAMAN, 2004) bem como, a criação de Sistemas Nacionais de Inovação.

Para Cohen (2006), ecossistema de empreendedorismo corresponde a:

[...] um conjunto diversificado de atores interdependentes que, dentro de uma região geográfica, influenciam na formação e eventual trajetória de todo o grupo de atores e potencialmente na economia como um todo. Os ecossistemas empreendedores evoluem a partir de um conjunto de componentes interdependentes que interagem para gerar a criação de novos negócios ao longo do tempo. (COHEN; 2006, p. 2-3). 


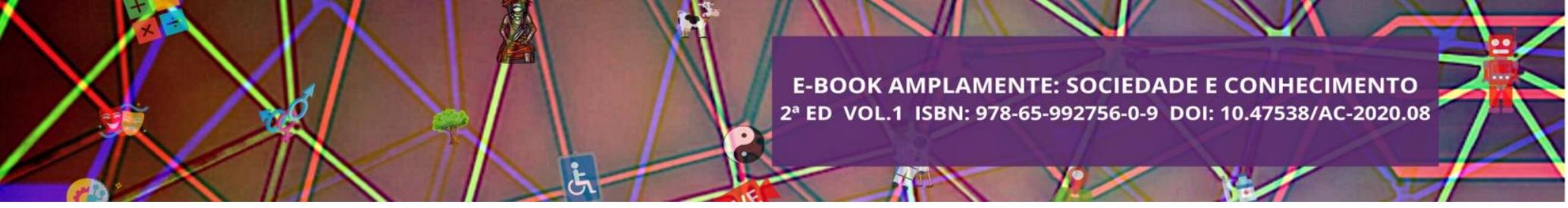

Isenberg (2010) apresenta a existência de nove condições para o

desenvolvimento de um ecossistema empreendedor, descritos a seguir:

1) Ainda que o Vale do Silício seja um ecossistema empreendedor bem-sucedido é exclusivo da sua região e é improvável ser replicado em outras áreas;

2) Formar o ecossistema em torno das condições locais, ou seja, olhar para as indústrias de base local com potencial de crescimento e a partir daí construir os alicerces do ecossistema empreendedor;

3) Envolver o setor privado desde o início, ou seja, o processo deve ser liderado pelo setor privado e o papel do governo é o de facilitador;

4) Dar especial atenção ao fomento das empresas com potencial de crescimento e com a capacidade de inovação e seu engajamento no mercado mundial;

5) Usar o caso ou os casos de sucesso para estimular e motivar as outras empresas;

6) Enfrentar os desafios, evitando que a atividade empresarial seja sufocada por uma cultura avessa ao risco ou conservadora, e apostando em programas de comunicação e educação;

7) As empresas orientadas para o crescimento não devem ser inundadas com 'dinheiro fácil' através de subvenções ou fluxos de capital de risco. As empresas devem ser rentáveis e sustentáveis, aplicando uma gestão financeira;

8) Não investir apenas em clusters tecnológicos, pois deve-se ajudar os clusters a crescerem organicamente. Por vezes o entusiasmo do governo na construção de clusters industriais precisa ser temperado por uma percepção permitindo que estes surjam de forma orgânica através de indústrias existentes e não da tentativa de "escolher vencedores" ou através da construção de parques de ciência e tecnologia);

9) Reforma dos quadros jurídicos, burocráticos e regulamentares. O governo tem um papel fundamental para as empresas na regulação de um conjunto de normas e regulamentos que podem facilitar o processo empreendedor e diminuir a burocracia (ISENBERG, 2010, pp. 3-10).

Desta forma, os ecossistemas de empreendedorismo são ambientes complexos, de caráter evolutivo, holístico e dinâmico. Os mesmos também são particulares a determinada região - como uma cidade, por exemplo. Até mesmo diferentes distritos de uma cidade podem ter ecossistemas de empreendedorismo com configurações distintas entre si (ISENBERG, 2010, p. 10). 


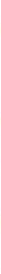

A constituição de um ecossistema empreendedor é bem diversa e um ator pode estar em mais de um ecossistema ao mesmo tempo. Pode-se dividir a formatação de um ecossistema empreendedor em seis conjuntos: redes informais, redes formais, o governo, apoios profissionais de serviços, serviços de acesso a capital e profissionais qualificados.

O propósito principal em estar participando de um ambiente empresarial sistêmico é primeiramente reconhecer limitações e compreender quais são os agentes que podem mitigar potenciais riscos do negócio nascente. Dessa forma, um dos papéis fundamentais dos ecossistemas empreendedores é dividir incertezas do ambiente para, assim, diminuir as chances de fracasso dos empreendimentos. A abordagem ecossistêmica possibilita ampliar o campo de visão empresarial e a formação de uma atitude de colaboração voltada à construção de valor para os clientes e para a própria empresa.

Cabe ressaltar que não há uma fórmula ou modelo específico para criação ou desenvolvimento de ecossistemas empreendedores, pois existem aspectos particulares para cada tipo de arranjo, que variam de acordo com a região na qual os agentes estão inseridos, inerentes à dinâmica interna de cada um deles. Amaral Filho (2002) afirma que nos casos exitosos de organização coletiva de micro e pequenas empresas verificouse a presença de quatro elementos estruturantes. Estes elementos, de acordo com o autor, são: capital social, estratégias coletivas de organização da produção, estratégias coletivas de mercado e articulação político-institucional.

Ao mencionar o capital social ${ }^{160}$, o autor se refere a um fator intangível por natureza, representando um acúmulo de compromissos sociais consolidados pelas interações sociais em uma determinada localidade. Por sua vez, este capital social serve de apoio a outro componente, conhecido como estratégia coletiva de organização da produção. Esta estratégia se relaciona com as decisões coordenadas, entre os produtores, no que se refere a quem vai produzir, o que produzir e como produzir. E é por meio desta estratégia que a aglomeração das pequenas empresas determina seu poder em relação às grandes empresas, por exemplo, através da equivalência da vantagem em relação à escala da compra dos insumos, do uso de máquinas e equipamentos, da produção em geral etc. De igual modo, é por meio da estratégia coletiva de organização

160 Para maior entendimento, ver Albagli e Maciel (2003); Portes (2000); Costa e Costa (2005). 


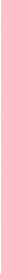

da produção que se revela e se processa a aprendizagem coletiva, fonte das inovações e da competitividade.

O terceiro elemento, conforme Amaral Filho (2002) está direcionado à estratégia coletiva de mercado. Esta também está voltada para as ações coordenadas e convergentes entre os produtores. Sem uma estratégia comum entre os produtores, as pequenas empresas veriam reduzidos os ganhos conseguidos nas economias de escala, alcançados nas esferas da compra dos insumos e na realização da produção.

O último ponto citado por Amaral Filho (2002) está voltado para a articulação político-institucional, também decorrida do capital social. Este é o instrumento pelo qual os empreendimentos se articulam com instituições públicas e privadas, responsáveis pelas políticas públicas, e com as organizações privadas de apoio às empresas. Amaral Filho aponta que "as evidências revelam que, quanto mais capital social acumulado dentro de num determinado núcleo ou aglomeração de empresas, melhor e mais eficiente será a articulação com as organizações e instituições" (2002: $580)$.

Outro conceito, correlato ao constructo dos ecossistemas empreendedores são os sistema produtivos de inovação. Cassiolato e Szapiro (2002) propõem que os sistemas produtivos e inovativos locais que são "aqueles arranjos produtivos em que interdependência, articulação e vínculos consistentes resultam em interação, cooperação e aprendizagem, com potencial de gerar o incremento da capacidade inovativa endógena, da competitividade e do desenvolvimento local" (CASSIOLATO; SZAPIRO, 2002: 17).

Os pesquisadores da REDESIST definem os sistemas produtivos e inovativos locais como “[...] conjuntos de agentes econômicos, políticos e sociais, localizados em um mesmo território, desenvolvendo atividades econômicas correlatas e que apresentam vínculos expressivos de produção, interação, cooperação e aprendizagem”. Portanto,

[...] geralmente incluem empresas - produtoras de bens e serviços finais, fornecedoras de equipamentos e outros insumos, prestadoras de serviços, comercializadoras, clientes, etc., cooperativas, associações e representações - e demais organizações voltadas à formação e treinamento de recursos humanos, informação, pesquisa, desenvolvimento e engenharia, promoção e financiamento (REDESIST, 2005, p. 1).

Pode-se dizer que o embrião da ideia de sistemas e arranjos localizados é o conceito de sistema nacional de inovação. Desenvolvido por Lundvall (1992) e Freeman 


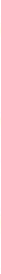

(1995), tal conceito tem por base a consideração de que os atores econômicos e sociais e as relações entre eles determinam em grande medida a capacidade de aprendizado de um país e, portanto, a capacidade de inovar e de se adaptar às mudanças do ambiente. Desempenhos nacionais, relativos à inovação, derivam de uma confluência social e institucional, particulares entre si e de características histórico-culturais específicas (LASTRES et al, 1999). Esse conceito já vem sendo discutido em níveis locais e regionais.

Os sistemas nacionais, regionais ou locais de inovação podem ser tratados, dessa forma, como uma rede de instituições dos setores público (instituições de pesquisa e universidades, agências governamentais, empresas públicas e estatais, entre outros) e privado (como empresas, associações empresariais, sindicatos, organizações nãogovernamentais etc.) cujas atividades e interações geram, adotam, importam, modificam e difundem novas tecnologias, sendo a inovação e o aprendizado aspectos cruciais para o seu desempenho exitoso (FARIAS, 2010).

Percebe-se que a ótica dos sistemas de inovação e de ecossistemas empreendedores são complementares, e se apresentam como uma importante unidade de análise, captando a relação que se estabelece entre os agentes pertencentes a um território específico, desenvolvendo nesse local, um espaço de aprendizagem particular. Dessa forma, cabe destacar a importância do aprendizado interativo entre os agentes, pondo em evidência, para além das trocas de bens e insumos entre as empresas, a importância das trocas de informação e conhecimento, não apenas entre as firmas, mas destas com uma gama de organizações, muitas delas criadas para proporcionar esse fim: uma maior interação entre agentes em um território definido.

\section{PROCEDIMENTOS E MÉTODOS}

Sob o ponto de vista metodológico, a pesquisa teve um caráter exploratóriodescritivo, com uma abordagem quanti-qualitativa, fazendo uso de técnicas de coleta de dados baseadas em entrevistas e análise documental. Inicialmente, tendo por referência o ICE 2016, elaborou-se um roteiro de entrevistas semiestruturado. O estudo ouviu algumas das principais organizações pertencentes ao ecossistema, ligadas a quatro estruturas-chave: órgãos governamentais; instituições de ensino e pesquisa; organizações de apoio empresarial; empresários e profissionais liberais. Entrevistou-se 


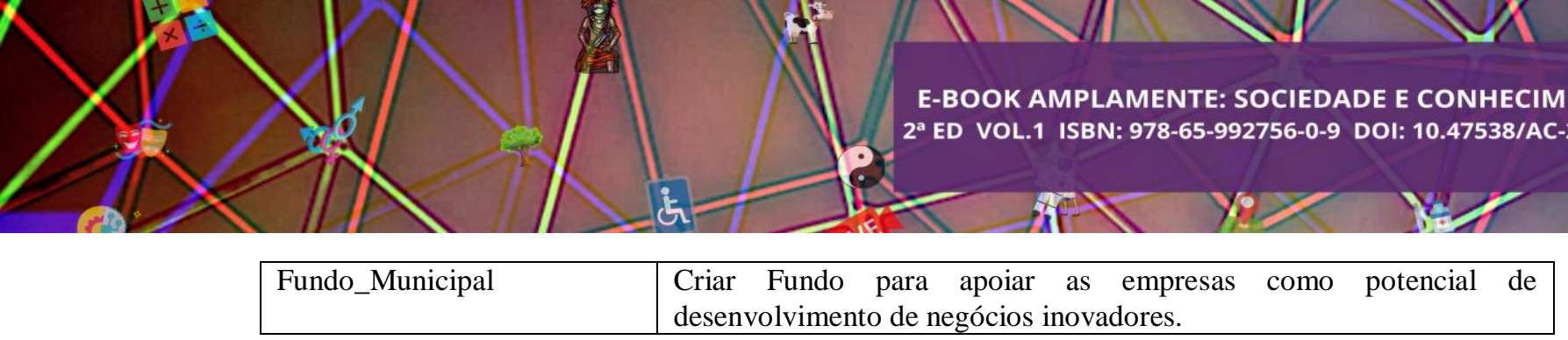

Fonte: elaborado pelos autores

Igualmente, foi apresentado aos entrevistados uma lista com os seis domínios de um ecossistema empreendedor, segundo Isenberg (2010), sendo solicitado que os mesmos classificassem, por ordem de prioridade, os domínios que, segundo suas percepções e experiências, necessitariam de maior intervenção, a fim de que o índice de empreendedorismo de Porto Alegre viesse a ter uma melhor desempenho.

Por fim, os entrevistados tinham um tempo para apresentarem outras medidas, para além daquelas avaliadas, que em suas percepções, poderiam ser adotadas para melhor o desempenho da cidade. Dessa forma, realizou-se tanto uma avaliação tanto quantitativa quanto qualitativa das percepções dos entrevistados.

Em termos de análise dos dados, para a etapa quantitativa, optou-se, por ser um estudo preliminar, por usar as ferramentas da estatística descritiva, a partir de cálculos das médias e distribuições de frequências. Utilizou-se o software de tratamento estatístico SPSS. Para a etapa qualitativa, utilizou-se a análise de conteúdo como ferramenta analítica. Os principais resultados estão presentes na seção seguinte.

\section{RESULTADOS}

Inicialmente, cumpre realizar uma breve descrição da amostra dos entrevistados. Dos dezesseis entrevistados, $69 \%$ eram homens e $31 \%$ mulheres. A formação acadêmica mais frequente é a o mestrado e doutorado, citado por $56 \%$ dos entrevistados. Em termos de tempo de experiência/envolvimento com o ecossistema de Porto Alegre, $60 \%$ dos entrevistados mencionaram que participam a mais de 10 anos de atividades ligadas ao desenvolvimento empreendedor da cidade.

Tabela 1 - Média, Moda e Desvio Padrão das respostas

\begin{tabular}{l|c|c|c}
\hline \multicolumn{1}{c|}{ Variável } & Média & Moda & $\begin{array}{c}\text { Desvio } \\
\text { Padrão }\end{array}$ \\
\hline ISS_lucro & 4,29 & 5 & 1,36 \\
\hline ISS_carência & 3,83 & 5 & 1,42 \\
\hline Redução_tempo & 4,53 & 5 & 1,18 \\
\hline Ampliar_informatização & 4,53 & 5 & 1,12 \\
\hline EGoverment & 4,35 & 5 & 1,17 \\
\hline Dívidas_fiscais & 3,76 & 4 & 1,03 \\
\hline
\end{tabular}




\begin{tabular}{l|l|l|l}
\hline Novas_potencialidades & 4,41 & 5 & 1,23 \\
\hline Instalação_empresas & 4,11 & 5 & 1,11 \\
\hline Interação_governo_sociedade & 4,29 & 5 & 1,10 \\
\hline Comércio_Exterior & 3,94 & 5 & 1,20 \\
\hline Educação_Empreendedora & 4,47 & 5 & 1,00 \\
\hline Cursos_capacitação & 4,23 & 5 & 1,09 \\
\hline Encontro_empreendedores & 4,23 & 5 & 1,09 \\
\hline Campanha_institucional & 3,88 & 5 & 1,27 \\
\hline Microcrédito & 4,17 & 5 & 1,27 \\
\hline Integrar_IES & 4,70 & 5 & 0,98 \\
\hline Compras_públicas & 4,29 & 5 & 1,10 \\
\hline Fundo_Municipal & 4,05 & 5 & 1,29 \\
\hline
\end{tabular}

Fonte: dados da pesquisa

A Tabela 1 apresenta um resumo das respostas dos entrevistados. Os entrevistados foram questionados com relação ao grau de concordância, em relação a uma série de medidas que poderiam, em tese, melhorar o desempenho empreendedor de Porto Alegre. De modo surpreendente, o a variável com maior grau de concordância foi a associada a necessidade de uma maior interação entre as instituições de ensino superior e centros de pesquisa $(4,70)$, seguida da adoção de medidas para a redução dos prazos para abertura de empresas $(4,53)$ e a ampliação da informatização dos processos $(4,53)$, bem como a implementação de programa efetivos de educação empreendedora, tendo início no ensino básico e indo até o ensino superior $(4,47)$.

Tais resultados estão em concordância com as pesquisas desenvolvidas pela Endeavor, sobretudo com as avaliações realizadas através da pesquisa do Índice de Cidades Empreendedoras (ICE). A referida pesquisa aponta que as principais fragilidades de Porto Alegre estão associadas aos processos burocráticos de abertura e fechamento de empresas, bem como a ausência de uma cultura empreendedora consolidada. A falta de integração entre as universidades e centros de pesquisa é apontada como a principal medida a ser empreendida para efetivar a melhoria dos índices da cidade. Porto Alegre possui uma gama de excelentes universidades e centros de pesquisa, que se destacam entre as melhores do Brasil. A ausência de integração entre tais instituições, na opinião dos entrevistados, faz surgir barreiras ao desenvolvimento de negócios, sobretudo aqueles ligados a um ambiente tecnológico mais sofisticado.

Importante ressaltar que, no senso comum, as principais medidas debatidas, em especial pela classe empresarial, estão associadas às reduções tributárias. No entanto, 


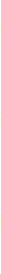

para os entrevistados, todas as medidas ligadas às questões tarifárias são entendidas como de menor importância.

Quanto solicitados a elencar os domínios do ecossistema, conforme Isenberg (2010), que deveriam ser priorizados, a fim de melhorar o desempenho empreendedor da cidade, os entrevistados apresentaram as seguintes respostas, resumidas na Tabela 2.

Tabela 2 - Priorização dos Domínios do ecossistema empreendedor de Porto Alegre

\begin{tabular}{lcccccc}
\hline & $\begin{array}{c}\text { Políticas } \\
\text { Públicas }\end{array}$ & $\begin{array}{c}\text { Mercado } \\
\text { Financeiro }\end{array}$ & $\begin{array}{c}\text { Cultura } \\
\text { Empreendedora }\end{array}$ & $\begin{array}{c}\text { Instituições } \\
\text { Suporte }\end{array}$ & $\begin{array}{c}\text { Recursos } \\
\text { Humanos }\end{array}$ & Mercados \\
\hline $\begin{array}{l}\text { Moda } \\
\text { Desvio }\end{array}$ & 1 & 5 & 1 & 3 & 4 & 6 \\
padrão & 1,43 & 1,55 & 1,79 & 1,22 & 1,32 & 1,77 \\
$\begin{array}{l}\text { Confiança } \\
(95,0 \%)\end{array}$ & 0,73 & 0,79 & 0,92 & 0,62 & 0,68 & 0,91 \\
\hline
\end{tabular}

Fonte: dados da pesquisa

$\mathrm{Na}$ opinião dos entrevistados, os dois domínios que necessitam ser priorizados são aqueles vinculados à formulação de políticas públicas e às ações focadas no desenvolvimento de uma cultura empreendedora efetiva. A priorização de tais domínios, mais uma vez, encontra respaldo na pesquisa ICE, que aponta esses dois domínios como aqueles que apresentam pior desempenho de Porto Alegre, em comparação com outras capitais brasileiras.

Em seguida, na opinião dos especialistas, devem ser priorizados, nessa ordem: o fortalecimento das instituições de suporte à atividade empreendedora; o fomento ao desenvolvimento, qualificação e ampliação da oferta de recursos humanos; o desenvolvimento de uma estrutura financeira que dê suporte às iniciativas empreendedoras; e, por fim, a consolidação da organização de mercados, entendido como os mecanismos de interação entre firmas e seus consumidores.

\section{OPINIÕES DOS ESPECIALISTAS}

Esta seção está baseada nas opiniões livres, apresentadas pelos dezesseis entrevistados. As ações indicadas no instrumento de coleta de dados foram debatidas e aprofundadas, e os resultados são expostos a seguir:

Políticas Públicas - A tributação é uma temática relevante para as empresas e para o desenvolvimento das cidades. O principal imposto é o ISS (Impostos sobre Serviços), tendo como fato gerador do cálculo o faturamento. Mesmo em situação de 


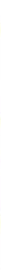

prejuízo, a empresa deve pagar. Soma-se a isso a guerra fiscal entre as cidades e Estados, tendo levado à saída de empresas de setores estratégicos, como o da tecnologia, para outros municípios, em função das políticas de alíquotas mais atrativas. Os novos empreendimentos também não têm carência e/ou subsídios. Sendo a legislação de competência federal, o município só pode agir sobre o valor das alíquotas.

Embora a política de recuperação de dívidas das empresas, por vezes, seja percebida como uma forma de privilegiar o mau pagador, em verdade é uma forma de reconhecimento de que o Estado deve apoiar o ato de empreender, no qual concorrem riscos de toda ordem. Tem-se, ainda, um forte componente cultural que não aprecia dar uma nova oportunidade ao empreendedor-devedor, desconsiderando o duro, mas relevante, aprendizado de um fracasso. Neste sentido, é auspiciosa a orientação também da nova proposta do Programa de Microcrédito do Estado, que estará criando uma linha de crédito para saneamento financeiro, procurando levar em conta o impacto da conjuntura nos empreendimentos.

O tema da redução do tempo de abertura das empresas faz parte de um processo mais amplo que é o excesso de burocracia presente na gestão pública brasileira. Segundo o Relatório ICE-2017, publicado pela Endeavor, o Brasil figura entre os 15 piores países do mundo, em termos de tempo de tramitação para abrir novos negócios. No Estado do Rio Grande do Sul, em um significativo número de municípios, implantou-se o Projeto da Rede Nacional para a Simplificação do Registro e da Legalização de Empresas e Negócios - REDESIM, instituída em 2007 pelo Governo Federal, segundo a Lei $\mathrm{n}^{\circ}$ 11.598, que visa acelerar a abertura de novos empreendimentos através de unificação e simplificação da burocracia. Há casos em que, em 48 horas, consegue-se sair com toda a empresa registrada de ponta a ponta da Junta Comercial até o seu Alvará de Funcionamento. Porto Alegre mantém na referida pesquisa a última colocação dentre os municípios abrangidos, em função da complexidade do processo e da lentidão na implantação do Projeto Simplificar. Dentro do projeto, inclui-se a instalação da denominada Sala do Empreendedor, onde estarão integrados todos os órgãos relacionados com o processo de abertura de novos negócios.

O Programa Fornecedor, uma política de governo que dá preferência às compras das pequenas empresas no setor público, embora bem-intencionado, não surte os efeitos pretendidos, seja pela falta de recursos públicos para sua viabilização, seja pela reduzida abrangência em termos de categoria de produtos/serviços, ou pela 


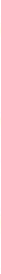

própria falta de estrutura dos empreendimentos para atender às demandas que lhe são oferecidas.

Estimular a geração, a atração e a instalação de novas empresas é uma política pública de cunho estratégico. Para crescer, uma cidade precisa desenvolver não apenas condições sociais atraentes, mas também uma atividade econômica robusta e recorrente (KOTLER, 2005). O Entrevistado 2 (E2) faz um alerta, esclarecendo que: (...) as políticas públicas de instalação de empresas deviam ser políticas públicas não só de incentivos, de manutenção, mas de como essas empresas se comprometem com o desenvolvimento das cadeias porque você tem que trabalhar para os habitats. (...) a GM foi criticada mas conseguiu desenvolver uma cadeia de fornecedores de pequenos negócios e mobilizou a economia. (...) Este é um bom exemplo da materialização do entendimento de que as cidades têm para alavancar a sua vida econômica, que atrair e estimular negócios não apenas com o aporte das pequenas e médias empresas, como também das grandes corporações nacionais e internacionais (KOTLER, 2005). Nesse sentido, Porto Alegre necessita rever a estratégia adotada de desindustrialização, cujas motivações são questionáveis pelos efeitos de empobrecimento da economia local.

Mercado de Finanças - Para suportar o surgimento e o desenvolvimento dos atuais e dos novos negócios, precisa-se dispor de recursos para investimento, e isto é verdadeiro para todos os setores e porte dos empreendimentos. Conforme registra o Entrevistado 5:

\footnotetext{
"Joseph Schumpeter, já na década de 50 dizia (...) em se tratando do desenvolvimento da inovação tecnológica, que o outro lado da inovação era o crédito, e que deveriam ser criados mecanismos inovadores também para este, atendendo às especificidades de um empreendimento que oriente pela inovação. No Brasil (...) o financiamento não supera a fase de desenvolvimento, para alcançar o 'salto mortal' que é assumir o risco de viabilidade do mercado" (E5).
}

Parece estranho que o relatório ICE-2017 aponte Porto Alegre como a segunda colocada em acesso das empresas ao capital. Esta situação de facilidade não tem sido confirmada na presente pesquisa. Dentre às alternativas, em nível local, há o financiamento via Fundos Públicos. No que diz respeito aos novos negócios de base tecnológica, os investidores-anjo e as aceleradoras têm cumprido um papel fundamental, como impulsionadoras desses empreendimentos.

Em relação a os micro e pequenos empreendimentos, uma das fontes de financiamento é o Programa de Microcrédito. Sendo público, o mesmo fica dependente 


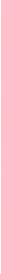

da disponibilidade de recursos que, em uma crise como a atual, gera a sua descontinuidade. Além disso, o Programa Gaúcho de Microcrédito está em fase de transformação, deixando claro que não se constituirá em um programa de distribuição de recursos, senão que será voltado para a capacitação de gestão, a melhoria dos processos e dos produtos; enfim, ao desenvolvimento dos negócios, de forma geral.

Cultura empresarial - À semelhança do relatório do ICE-2017, a presente pesquisa indicou a cultura empreendedora como uma das fragilidades da Capital. A partir desta constatação procurou-se encontrar as causas. A falta de investimentos em iniciativas de educação empreendedora, promovidas pelas instituições de ensino ao longo do percurso formativo. Nas de ensino superior, especialmente as que implementaram os seus parques tecnológicos, incubadoras, centros de empreendedorismo etc. Verificam-se iniciativas importantes para disseminar e materializar os efeitos de uma cultura empreendedora: (...) o Programa Talentos que visa estimular desde a idade escolar o empreendedorismo e o Núcleo de Empreendedorismo que (...) oferece três disciplinas transversais em todos os cursos de graduação. Constituem-se em ilhas de excelência, não chegando a impactar na cultura da sociedade com relação ao empreendedorismo. Além disso, pouco se fala de empreendedorismo e das lideranças empresariais que não são valorizadas e reconhecidas pela sua trajetória.

No que diz respeito à questão estrutural, Porto Alegre e o RS encontram-se em uma situação econômica e financeira alarmantes. O processo de formação de lideranças é um aspecto que tem sido negligenciado pelas instituições de ensino e pesquisa, que têm precipuamente essa missão. Contribui, ainda, para aprofundar este quadro, acirrando os conflitos e precarizando as relações de coesão entre as instituições e, entre as pessoas, a baixa intensidade de interação e comunicação entre estas organizações.

Instituições de suporte - Percebe-se que a estrutura do ecossistema em Porto Alegre existe, porém, ainda há pouca conexão entre os atores. Existe pouco diálogo entre as agências, não havendo uma agenda articulada de atividades. Um bom exemplo de coesão institucional é o da cidade de São Leopoldo (Região Metropolitana de Porto Alegre), através da governança (modelo Tríple Hélice) do Parque Tecnológico da Universidade do Rio dos Sinos (Unisinos). Em Porto Alegre, houve o caso da criação do Fórum de Ensino Superior, o qual foi criado há três anos. Quando ficou claro que o governo municipal não ia aportar financiamento público, além do esforço de 


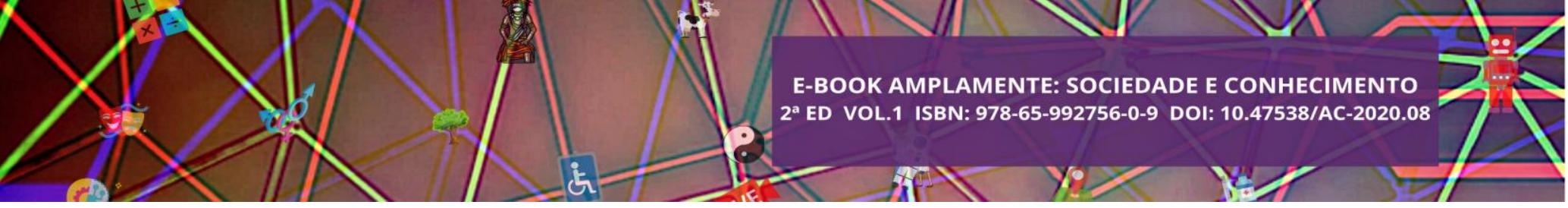

coordenação, ocorreu a desarticulação do movimento. Há dificuldade de encontrar instituições para liderar e para integrar às iniciativas que são desenvolvidas na cidade. Fica claro que, da mesma forma que se percebe uma baixa cultura empreendedora, o mesmo ocorre com a cultura associativa.

Recursos Humanos - Se, por um lado, Porto Alegre e o Rio Grande do Sul têm a melhor estrutura universitária do país, percebe-se, por outro lado, dificuldades de diferentes ordens, a saber: tanto na retenção quanto na atração de talentos para o Brasil; na orientação dos currículos dos cursos que exigem atualizações nos conteúdos e nas metodologias de ensino; no viés da pesquisa que, mesmo apresentando reconhecida qualidade, por vezes, a ênfase da avaliação está mais na elaboração de artigos científicos do que no desenvolvimento de negócios e tecnologias capazes de gerarem impactos na renda, no emprego e nos tributos. Os aspectos comportamentais também são determinantes no desempenho empreendedor. Dentre as carências técnicas, chama a atenção à ausência de domínio de outros idiomas, em especial o inglês, constituindo-se num fator limitante para desenvolver um diálogo internacional. O perfil educacional dos empreendedores reflete os problemas históricos da educação no Brasil.

Mercados - A existência de mercados é essencial para o desenvolvimento e para a atração de empresas às cidades, promovendo prosperidade - traduzido em riqueza empregos e qualidade de vida à população. A propensão de abertura de novos negócios em uma cidade se relaciona com vários aspectos, a saber: poder de compra da população residente, infraestrutura, capital humano disponível, ambiente regulatório favorável, cultura local, interesse de governantes e de políticos etc.

Por meio da pesquisa, solicitou-se aos entrevistados que avaliassem alguns setores que entendessem possui potencial econômico para o seu desenvolvimento na cidade de Porto Alegre. Além de ser confirmada a maioria das proposições, foram indicados alguns nichos de negócios nos mercados indicados como noutros que estão emergindo com possibilidades de se afirmar e de se consolidar em um perfil econômico para a cidade.

Por ser Porto Alegre uma capital voltada ao setor de serviços, uma das possibilidades levantadas pelos entrevistados diz respeito à constituição de uma rede de empresas (ex. Tradings) ou de uma Zona Franca para o desenvolvimento de atividades de comércio exterior. Em função da orientação e da complexidade da legislação de comércio exterior, torna-se difícil definir uma cidade para centralizar negócios desta 


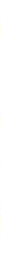

natureza. O Brasil é o maior armazém do mundo. O maior produtor de grãos, o maior produtor de proteínas do mundo. (E 16). Soma-se a isso que (...) estamos na iminência de abrir o acordo com a União Europeia. É um acordo que vai facilitar, ajudar a nossa agroindústria, principalmente à pecuária, (...) mas vai impactar fortemente os produtos manufaturados, porque o europeu vai entrar aqui (E14).

Em relação à pequena empresa, considera-se que, sendo o mercado brasileiro tão grande e o mercado externo tão complexo, em função das exigências burocráticas e das necessidades de capital, torna-se desinteressante operar nesse mercado. Mostra disso é que (...) apenas $2 \%$ das pequenas empresas conseguiram exportar e que se bem o incentivo ao mercado externo abre uma porta importante, mas tem que se ter muito cuidado para não levar à empresa ao buraco (E1). Para a grande empresa, às vezes, o mercado externo é uma alternativa, “porém, uma empresa só vai para fora quando está difícil aqui dentro" (E16).

O setor de saúde apresenta infraestrutura e potencial de desenvolvimento para diversos tipos de negócios. Em relação aos hospitais, Porto Alegre tem a melhor rede hospitalar do Brasil, alguns deles certificados internacionalmente, o que tem incentivado a avançar na implementação de prestação de serviços nas diversas especialidades à população local e à estrangeira (E2). Aí temos "um foco para desenvolvimento de uma grande indústria de engenharia biomédica, porque falta tudo nessa área (...)" (E3). Estáse pensando também em um Centro de Telemedicina. (E11). Criou-se o Curso de Engenharia Biomédica oferecido pela Unisinos, o qual foi pioneiro no Brasil, vindo a suprir a eventual demanda de profissional nessa área. Também, “dispomos de grande potencial para o desenvolvimento da indústria de biofármacos (...)” (E5).

Se há um segmento que divide opiniões quanto ao seu potencial, esse segmento é o turismo. Embora seja um dos setores que mais cresce no mundo, Porto Alegre, mesmo tendo sido indicada como a capital cultural do Mercosul, contando com diferentes etnias européias, principalmente alemã e italiana, e uma infraestrutura adequada e reconhecida como a terceira cidade do Brasil para sediar grandes eventos, depois de São Paulo e do Rio de Janeiro, ainda não se posiciona como um destino turístico relevante. Em consequência disso, alguns entrevistados reafirmaram essa condição, enquanto outros se aventuraram a identificar o que deve ser corrigido para que Porto Alegre realize a sua vocação turística. 


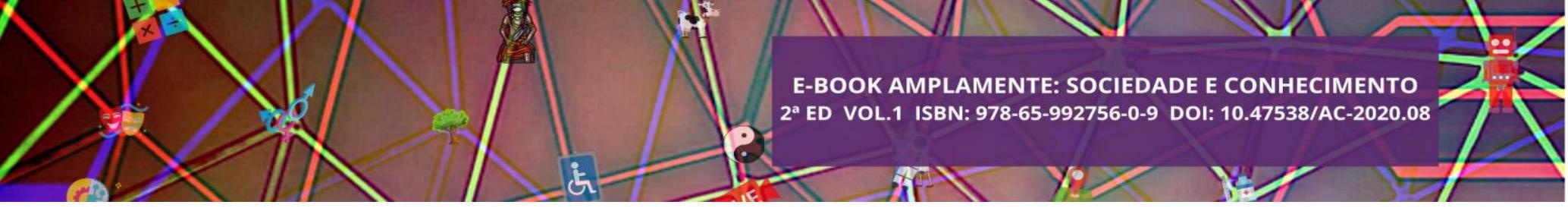

$\mathrm{Na}$ avaliação feita por vários entrevistados, a cidade deu as costas ao seu principal atrativo natural - o Lago Guaíba - que, de tão extenso, é chamado de Rio Guaíba. À semelhança de outros países, investiu-se na revitalização do porto da cidade, com o potencial de gerar negócios inovadores, especialmente vinculados ao esporte e ao lazer, somado ao patrimônio cultural do Centro Histórico da cidade. Há, ainda, uma qualificada infraestrutura hoteleira e gastronômica. Em relação aos espaços culturais, existem problemas pela falta de investimentos e de divulgação, gerando descontinuidade das atividades. Soma-se a isso a falta de um grande centro de eventos público, o que também restringe uma das poucas atividades com possibilidades reais de desenvolvimento que é o turismo de eventos.

O Estado se constitui no segundo polo de microeletrônica do país. No Rio Grande do Sul, temos quinze parques tecnológicos. Em Porto Alegre, destacamos o Tecnopuc, vinculado à Pontifícia Universidade Católica (E13), que está participando do projeto do $4^{\circ}$. Distrito em Porto Alegre, uma região deprimida, em que se estão aproveitando as estruturas imobiliárias para abrigar empreendimentos inovadores no segmento da economia criativa, incluindo negócios de produção audiovisual, de moda, de cerveja artesanal etc. Os parques tecnológicos têm ajudado a sensibilizar para que a pesquisa acadêmica tenha aplicabilidade (E2). A Universidade é essencial para gerar patentes e inovação, superando a condição de um empreendedorismo pouquíssimo inovador (...) (E15). Por último, indicou-se o setor de tecnologias sustentáveis (eólica e solar) com bom potencial para desenvolver.

\section{CONSIDERAÇÕES FINAIS}

Como restou desenvolvido ao longo deste texto, existem, ao mesmo tempo, aspectos que potencializam e que permitem ambicionar uma melhor posição do ecossistema empreendedor de Porto Alegre, e diversos pontos considerados precários e de difícil transformação, sem um compromisso explícito do governo, da sociedade e de cada um dos componentes do sistema.

A ausência marcante de lideranças políticas, empresariais e sociais qualificadas e comprometidas com os destinos da cidade é um dado crítico e de difícil superação, e que surge de modo preponderante nas falas dos entrevistados. As instituições, especialmente as universidades e os partidos políticos, têm negligenciado essa missão. 


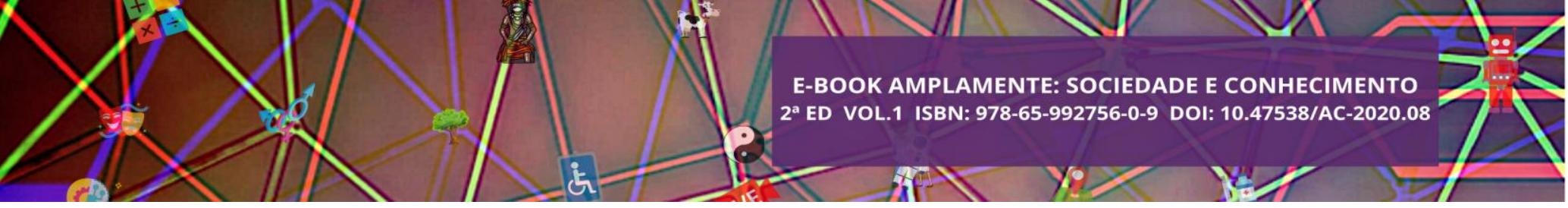

Ao longo da história, o Rio Grande do Sul foi pródigo na formação de lideranças voltadas para os campos político e militar, e pouco para o segmento empresarial. Na opinião de muitos dos entrevistados, há necessidade de se fortalecer o papel de uma liderança empresarial ativamente comprometida com o desenvolvimento do ecossistema inovador de Porto Alegre.

O meio empresarial gaúcho parece não se afinar muito com a possibilidade de dar a sua contribuição no setor público, especialmente aportando a sua experiência de gestão. É bem possível que isso decorra da forma como se concebe a inserção dos futuros dirigentes na vida pública, controlada pelos caciques dos partidos políticos que ambicionam, a partir da sua eleição nas casas legislativas, ingressar ao executivo, na maior das vezes sem experiência na vida empresarial.

Também, é importante registrar um aspecto que envolve todas as relações institucionais, qual seja a cultura pouco cooperativa e beligerante, democrático às avessas e imediatista da população do Rio Grande do Sul e por decorrência do portoalegrense. Por vezes, avaliando a história do Rio Grande do Sul, fica evidente que a defesa de interesses pessoais ou de um grupo, sobressai aos interesses da cidade. Neste cenário, promover um trabalho em rede, que conte com a participação de diversas instituições, resta cada vez mais impossibilitado. E, como se sabe, um dos fatores relevantes ao ecossistema empreendedor é a formação de um forte suporte de capital social.

O imediatismo é outra característica presente neste caldo de cultura. Como planejar uma cidade, como superar os gargalos que não são poucos e tão complexos, esperando que a transformação se dê num passe de mágica. O processo político eleitoral traz consigo este viés cultural. Existem quatro anos para se fazer algo que tenha o seu impacto junto ao eleitorado, para conquistar a sua reeleição. Tomam-se decisões estratégicas, como no caso mais marcante da economia de Porto Alegre, que é o processo de desindustrialização, sem levar em conta as consequências. Em algum momento, a conta desse processo chega, e inevitavelmente, quem paga é a população da cidade.

\section{REFERÊNCIAS}




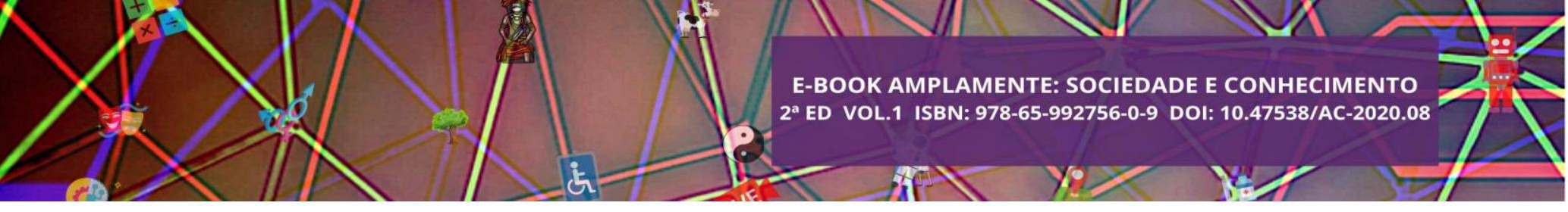

Adner, R. Kapoor, R. (2010). Value creation in innovation ecosystems: How the structure of technological independent affect firm performance. IN: New technology generations, Strategy management journal, 31(3): 306-333.

Albagli, S., \& Maciel, M. L. (2003). Capital social e desenvolvimento local. Pequena empresa: cooperação e desenvolvimento local. Rio de Janeiro: Relume Dumará, 423440 .

Amaral Filho, J. D. (2002). É negócio ser pequeno, mas em grupo. Desenvolvimento em debate. Rio de Janeiro: Banco Nacional de Desenvolvimento Econômico e Social: Mauad, 3, 85-118.

Arruda, C. et al. (2013). Causa da Mortalidade de Startups Brasileiras: O que fazer para aumentar as chances de sobrevivência no mercado?. Fundação Dom Cabral.

Cassiolato, J. E., \& Szapiro, M. (2002). Arranjos e sistemas produtivos e inovativos locais no Brasil. Notas técnicas da fase II do Projeto "Proposição de políticas para a promoção de sistemas produtivos e inovativos locais de micro, pequenas e médias empresas brasileiras.

Cohen, B. (2006). Sustainable Valley Entrepreneurial Ecosystem. Business Strategy and the Environment. v. 15, n. 1, p. 1-14.

Costa, Achyles B. \& Costa, Beatriz M (2005). Cooperação e Capital Social em Arranjos Produtivos Locais. In: XXXIII Encontro Nacional de Economia (ANPEC), Natal-RN.

Freeman, C.(1995). The national system of innovation in historical perspective.

Cambridge Journal of Economics, v. 19, n. 1, pp. 5-24.

Isenberg, D. (2010). How to Start an Entrepreneurial Revolution. Harvard Business

Review. Retrieved June 2010. https://hbr.org/2010/06/the-big-idea-how-to-start-anentrepreneurial-revolution/ar/1

Kotler, P. (2015). Conquistando mercados mundiais: como as empresas investem e prosperam na cidades dinâmicas do mundo. Rio de Janeiro, RJ: Alta Books

Krugman, P. (1991). Geography and Trade. Cambridge (Mass.): MIT-Press.

Lastres, H. M., Cassiolato, J. E., Lemos, C., Maldonado, J., \& Vargas, M. A. (1999). Globalização e inovação localizada. Nota técnica, 1, 98.

Lundvall, B.A. (1992). National Systems of Innovation: towards a theory of innovation and interactive learning. Pinter, London

Mason, C.; Brown, R. (2013). Entrepreneurial ecosystems and growth oriented entrepreneurship. Background paper prepared for the workshop organised by the OECD LEED Programme and the Dutch Ministry of Economic Affairs on Entrepreneurial Ecosystems and Growth Oriented Entrepreneurship, The Hague, Netherlands. 


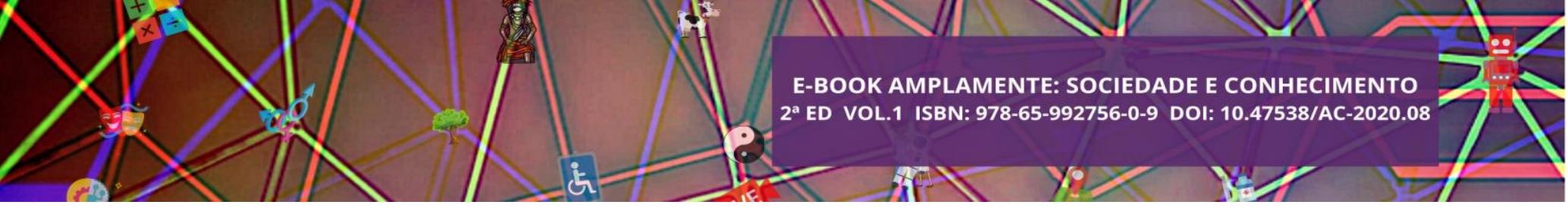

Moore, J. (2006). Business ecosystems and the view from the firm. The Antitrust Bulletin. 51, 1 (Spring): 31.

Nadgrodkiewicz, A. (2013). Building Entrepreneurship Ecosystems. Global Programs Center for International Private Enterprise.

Porter, M. (1998). Clusters and the New Economics of Competition. Harvard Business Review, November-December 1998.

Portes, A. (2000). Capital social: origens e aplicações na sociologia contemporânea. Sociologia, Problemas e práticas, v. 33, p. 133-158.

REDESIST (2005). Glossário sobre arranjos e sistemas produtivos e inovativos locais. Rio de Janeiro.

Stam, E. (2015). Entrepreneurial Ecosystems and Regional Policy: A Sympathetic Critique. Discussion Paper Series. Utrecht School of Economics / Tjalling C. Koopmans Research Institute.

Venkatraman, N. (2004). Strategic Orientation of Business Enterprises: The Construct, Dimensionality, and Measurement. Management Science, v.35, n. 8, p. 942-962. 


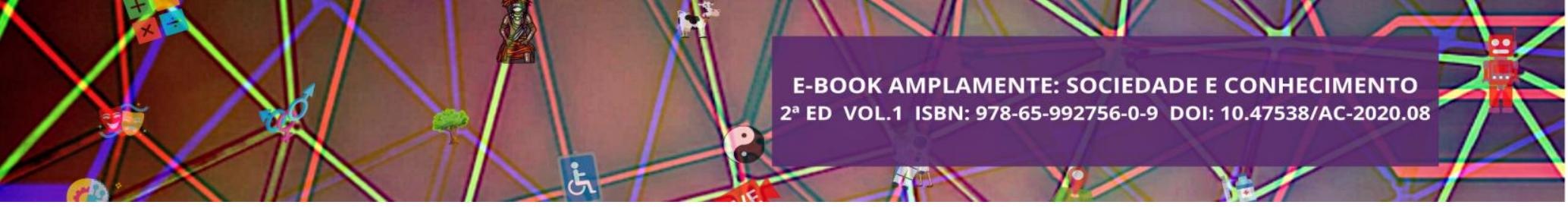

\section{INTRODUÇÃO}

No Brasil, especificamente na região Norte, a pecuária leiteira é desenvolvida em pequenas propriedades e possui grande importância socioeconômica devido à produção de alimentos, intensiva ocupação de mão de obra, geração de renda e contribuição para melhoraria da qualidade de vida da população rural (SANTANA; SANTANA, 2015).

Na região Norte, a atividade leiteira apresenta-se em plena expansão com um total de 2.084.186 vacas ordenhadas e uma média de 900 litros/vaca/ano. A participação do Estado do Pará na atividade leiteira da região Norte é de $35 \%$ em número de vacas ordenhadas (732.936 animais) e $21 \%$ em produção de leite, com uma média de 788 litros/vaca/ano (IBGE, 2018). Entretanto, a produtividade regional ainda está aquém do verdadeiro potencial, e para que a atividade se torne mais competitiva é necessário aumentar os índices produtivos, melhorar a comercialização, e a qualidade do produto oferecido aos consumidores.

A produção leiteira na Região Norte caracteriza-se pela heterogeneidade dos sistemas de produção que se diferenciam principalmente quanto a escala produtiva e nível tecnológico adotado. Assim, a bovinocultura de leite é desenvolvida por produtores que são especializados na atividade e utilizam altos níveis tecnológicos, e por aqueles não especializados, que ainda atuam de forma artesanal, sendo considerados produtores de subsistência (CUNHA et al., 2018).

Nas propriedades leiteiras da Região Norte, os principais problemas são a baixa produtividade das vacas (média de 3,44 litros por vaca dia) decorrente principalmente do inadequado manejo alimentar, sanitário e reprodutivo, genética dos animais utilizados, pequena efetividade dos serviços de assistência técnica e gerenciamento precário das propriedades (SANTOS et al., 2017).

Dentre os problemas, a qualidade genética dos animais para a produção de leite tem sido um gargalo para a atividade na Região Norte, e merece maior atenção, visto que a maioria dos produtores priorizam os investimentos na alimentação do rebanho, deixando para segundo plano o melhoramento genético do plantel. Entretanto, quando não se trabalha com rebanhos que possuem aptidão para produção de leite, a 


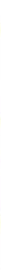

produtividade é menor, e o produtor precisa buscar estratégias que reduzam essa problemática, com o uso de tecnologias como a inseminação artificial.

A inseminação artificial (IA) foi desenvolvida com o intuito aumentar o potencial produtivo dos rebanhos por meio do uso de material genético proveniente de reprodutores de elevado mérito para produção de carne ou leite, utilizando-se procedimentos relativamente simples e de baixo custo em relação a outras biotécnicas reprodutivas (MOORE; HASLER, 2017).

De acordo com a Associação Brasileira de Inseminação Artificial - ASBIA, no ano de 2017 o uso da IA no Brasil foi de 10,01\%, e a porcentagem de matrizes leiteiras e de corte inseminadas foi de 6,23\% e 11,7\%, respectivamente. Adicionalmente, a utilização da IA no Estado do Pará representou somente 1,8\% em 2017 (ASBIA, 2017). Apesar da IA ter sido a primeira tecnologia reprodutiva utilizada para bovinos, ainda existe a necessidade de maior difusão desta na Região Norte do País, pois o nível de adoção da técnica ainda é baixo, cerca de 2,03\%, com predominância da monta natural a campo como sistema de acasalamento (SANTOS et al., 2017). Baseado nisto, vários estímulos devem ser propostos para a promover a intensificação no uso da IA em pequenas propriedades leiteiras da Região Norte.

Neste contexto, a Universidade tem um papel importante na formação profissional, geração de conhecimento por meio da pesquisa e na disseminação das tecnologias, através da extensão. Assim, reveste-se de importância a adoção de ações que oportunizem aos acadêmicos a prática dos conhecimentos teóricos, possibilitando que conheçam e interfiram na sua comunidade ao oferecerem o acesso a tecnologias como à inseminação artificial a pessoas que normalmente seriam excluídas de ações públicas com esta finalidade. Adicionalmente, a troca de experiências e informações que ocorrem durante a execução dos cursos enriquecem e qualificam a vida dos produtores e alunos envolvidos, uma vez que tendem a renovar seus conhecimentos através das práticas e vivências uns dos outros (BEZERRA et al., 2011).

A realização de trabalhos voltados para a democratização desta tecnologia, além de contribuir com a formação dos discentes das Universidades, auxilia também com a melhoria do potencial genético do rebanho leiteiro de pequenos produtores rurais, e consequentemente, em médio prazo aumentar a produção de leite destas propriedades, além de criar um elo de difusão desta tecnologia, pois os produtores envolvidos podem 


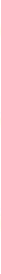

repassar os conhecimentos adquiridos para outras pessoas que trabalham com a atividade leiteira.

Neste contexto, objetivou-se relatar as ações e resultados obtidos com a realização do projeto DA UNIVERSIDADE PARA A COMUNIDADE: Implantação e acompanhamento da Inseminação Artificial de bovinos leiteiros em assentamentos de reforma agrária do Município de Parauapebas-PA.

\section{MATERIAL E MÉTODOS}

A execução do projeto ocorreu por meio da parceria entre a Universidade Federal Rural da Amazônia/Campus de Parauapebas e a FUNDAÇÃO AMAZÔNIA PARAENSE DE AMPARO À PESQUISA - FAPESPA/financiadora através da aprovação no edital $n^{\circ}$ 006/2010 de apoio a projetos de pesquisa e extensão tecnológica e inovadora à agricultura familiar, além de cooperação técnica com a Secretaria de Produção Rural de Parauapebas (SEMPROR), para o fortalecimento do Projeto Leite a Pasto. Além disso, contou-se com a parceria do Sindicato dos Produtores Rurais de Parauapebas (SIPRODUZ) que cedeu às instalações do Parque de Exposições Lázaro de Deus Vieira Neto para a realização de cursos de capacitação e palestras propostos no projeto.

$\mathrm{O}$ projeto beneficiou vinte pequenos produtores rurais do município de Parauapebas-PA, sendo dez no assentamento Palmares I, e dez no Assentamento Palmares II, cadastrados junto a SEMPROR, no Programa Leite a Pasto desenvolvido por esta secretaria. A seleção das propriedades beneficiadas pelo projeto deu-se por meio de entrevista com os produtores e aplicação de questionário socioeconômico, identificando aqueles que possuíam as características favoráveis à implantação do Projeto.

Após a seleção, foram realizadas visitas as propriedades para avaliar as condições técnicas necessárias ao início das ações, e as que não dispuserem de infraestrutura mínima, a qual constituía-se de um tronco de madeira coberto, para a contenção dos animais a serem inseminado, os proprietários foram orientados quanto à construção do mesmo, com materiais já existentes na propriedade, para que as atividades fossem realizadas proporcionando o mínimo de conforto e segurança para a equipe técnica e animais. 


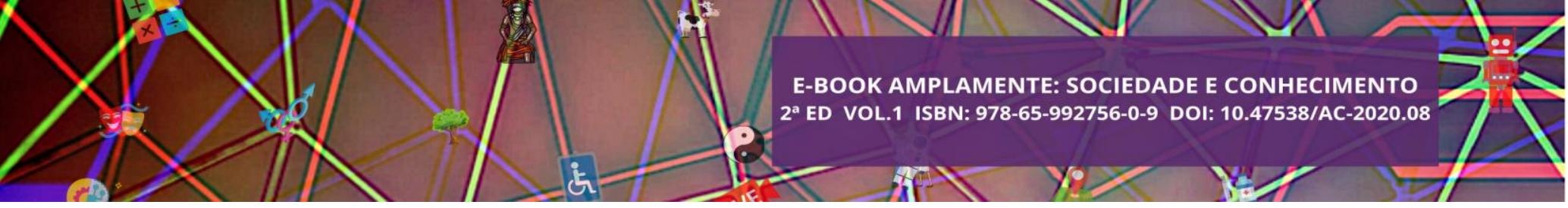

Os colaboradores foram doze discentes do Curso de Graduação em Zootecnia da UFRA - Campus de Parauapebas que receberam treinamento acerca da técnica de inseminação artificial de bovinos em conformidade com o padrão da ASBIA (Associação Brasileira de Inseminação Artificial), por meio de Curso de Inseminação Artificial, custeado com recursos do projeto, na Central ABS Pecplan em Uberaba/MG, onde foram devidamente capacitados para que realizassem as inseminações nas propriedades rurais, além de orientar os proprietários sobre a importância econômica de se melhorar geneticamente o rebanho e proporcionar as condições de nutrição e sanidade adequadas para melhorar a produtividade e consequente ampliar a renda familiar, por meio do incremento financeiro com a venda de leite.

Em cada propriedade, as vacas em idade reprodutiva foram avaliadas (Figura 1) com aparelho de Ultrassom (AQUILA VET - Pie Medical Equipment BV, Holanda), para verificar o estado gestacional e atividade ovariana.

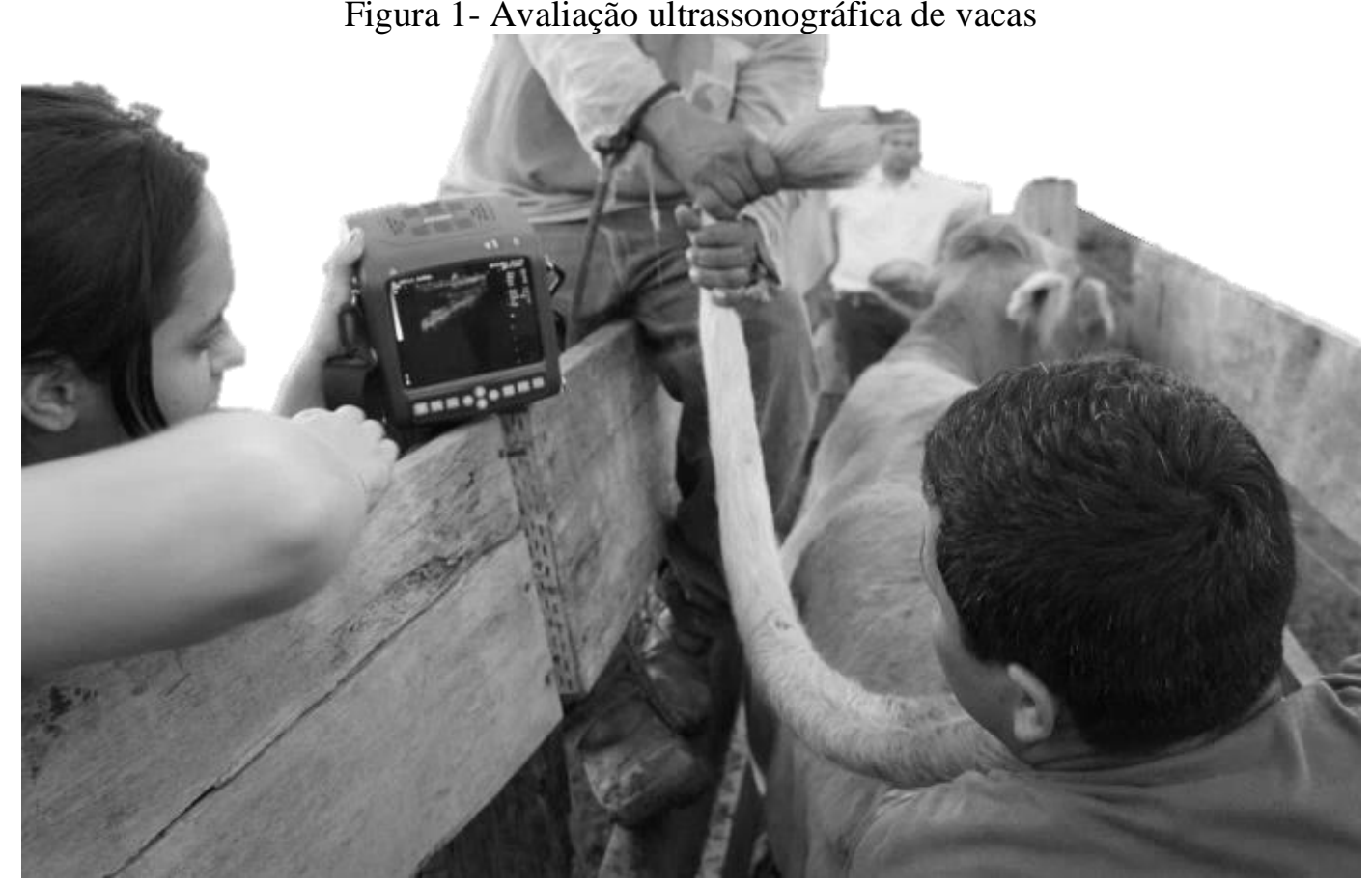

Créditos da foto: Oliveira (2014).

Após a verificação do estado gestacional e atividade ovariana, os animais foram classificados de acordo com o escore ovariano proposto por Baruselli et al. (2004). As vacas e novilhas sem problemas de fertilidade e não gestantes foram submetidas a sincronização das ovulações para serem inseminadas artificialmente em tempo fixo. 


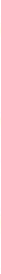

As vacas gestantes foram separadas em pasto distinto para esta categoria animal, até o momento do parto e depois de transcorrido o período do puerpério (quarenta e cinco dias), foram novamente avaliadas, e as que se encontravam em condições, também entraram no protocolo de Inseminação Artificial em Tempo Fixo (IATF).

As inseminações foram realizadas em tempo fixo, por meio da utilização de protocolos hormonais (Figura 2).

Figura 2- Esquema do protocolo hormonal utilizado na IATF.

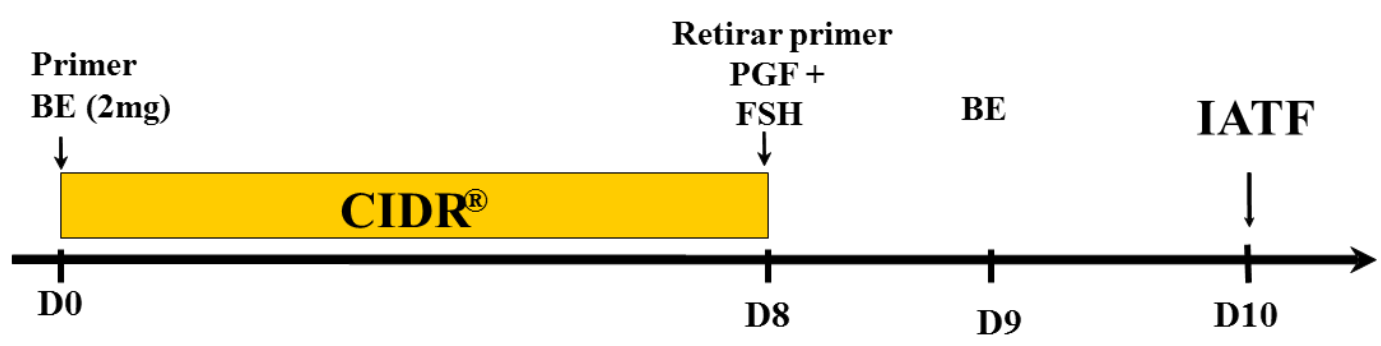

Fonte: Elaborado pelos autores.

No dia zero (D0), todos os animais foram avaliados para confirmação do estado gestacional. Na mesma ocasião (D0), após a confirmação da não prenhez, as novilhas acima de 18 meses $/ 300 \mathrm{~kg}$ ou vacas após quarenta e cinco dias pós-parto, receberam um dispositivo intravaginal de progesterona (1 g Primer, ${ }^{\circledR}$, Agener União, São Paulo/SP). Logo após a inserção do dispositivo intravaginal, foi administrado $2 \mathrm{mg}$ de Benzoato de Estradiol (Estrogin®, Farmavet, São Paulo/SP) por via intramuscular. No dia 08 (D8) os dispositivos de todos os animais foram removidos, e em seguida, aplicou-se $2 \mathrm{~mL}$ de Prostaglandina (PGF2 $\alpha$ ), hormônio à base de D-cloprostenol (150 mg, PROLISE ${ }^{\circledR}$, Agener União, São Paulo/SP) e $0,5 \mathrm{~mL}$ de hormônio folículo estimulante purificado (FSH-p) (FOLLTROPIN ${ }^{\circledR}$ ). No dia posterior (D9) foi aplicado 1mg de Benzoato de Estradiol e no dia seguinte (D10), foram realizadas as inseminações artificiais.

No primeiro ano (implantação do projeto), as inseminações foram realizadas pela equipe técnica do projeto (docentes e discentes), através do agendamento com os produtores de forma a não alterar a rotina de trabalho dos mesmos, com prévia formação dos lotes de vacas a serem inseminadas, de acordo com a localidade das propriedades, como demonstrado nas figuras 3 e 4. 


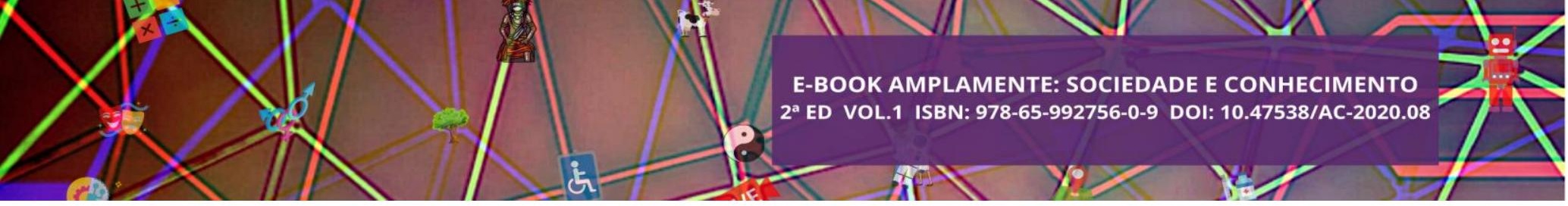

Figura 3 - Discente de graduação de Zootecnia inseminando vacas, aplicando conhecimentos adquiridos em capacitação promovida com ações do projeto.

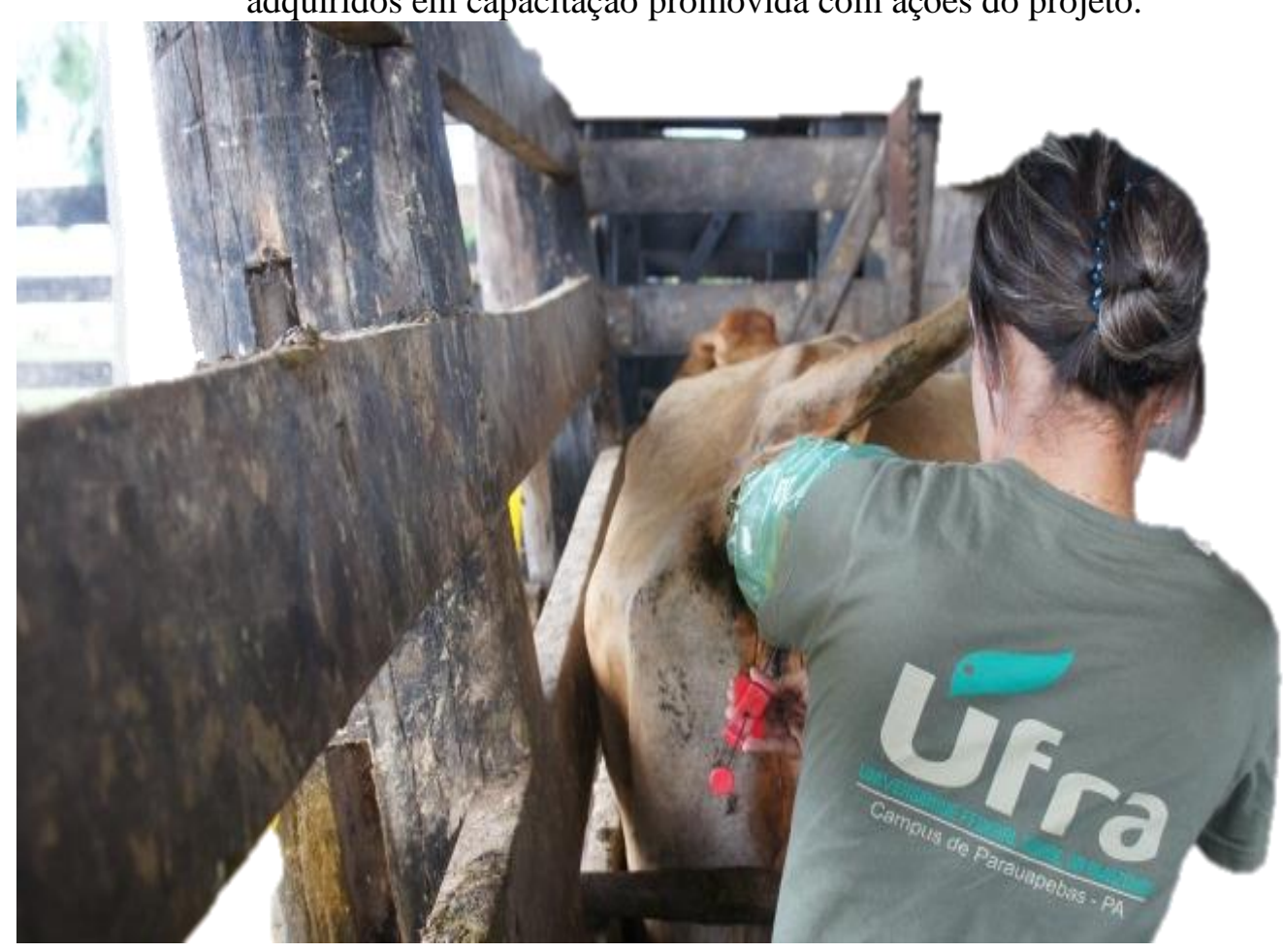

Créditos da foto: Oliveira, 2014.

Adicionalmente, foram realizados três cursos de capacitação em inseminação artificial, com turmas de doze alunos cada, tendo como público-alvo os proprietários rurais ou familiares indicados por eles, geralmente filhos ou sobrinhos. Os cursos foram ministrados no Centro de Treinamento em Reprodução Animal do Sul e Sudeste do Pará, localizado na UFRA Campus de Parauapebas, e tinham carga horária total de quarenta horas, sendo quinze horas reservadas a aulas teóricas (conteúdo: histórico da Inseminação Artificial em tempo fixo, vantagens e limitações da técnica, anatomia e fisiologia do aparelho reprodutivo da vaca e do touro, instalações, protocolos de Inseminação Artificial em tempo fixo, manejo de botijão e equipamentos, prática de descongelamento de sêmen, prática em peças anatômicas, prática de passagem de aplicador em vacas) e vinte e cinco horas de aulas práticas, realizadas em animais, com a filosofia de aprender a fazer fazendo (Figura 4). 


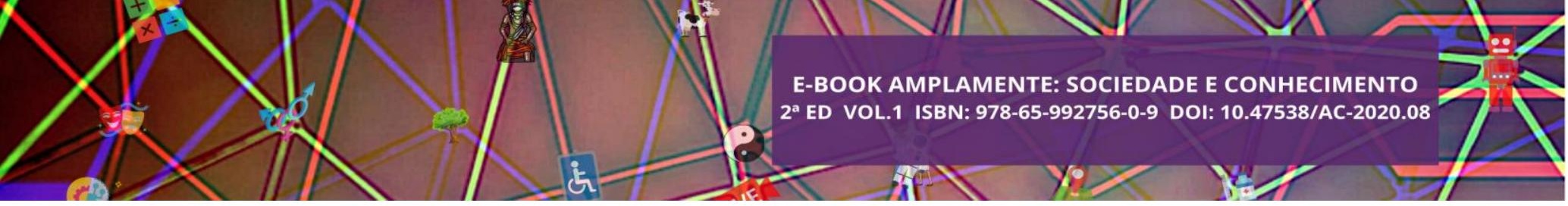

Figura 4 - Assentados de reforma agrária participando de curso de capacitação em inseminação artificial, orientados por estudantes universitários.

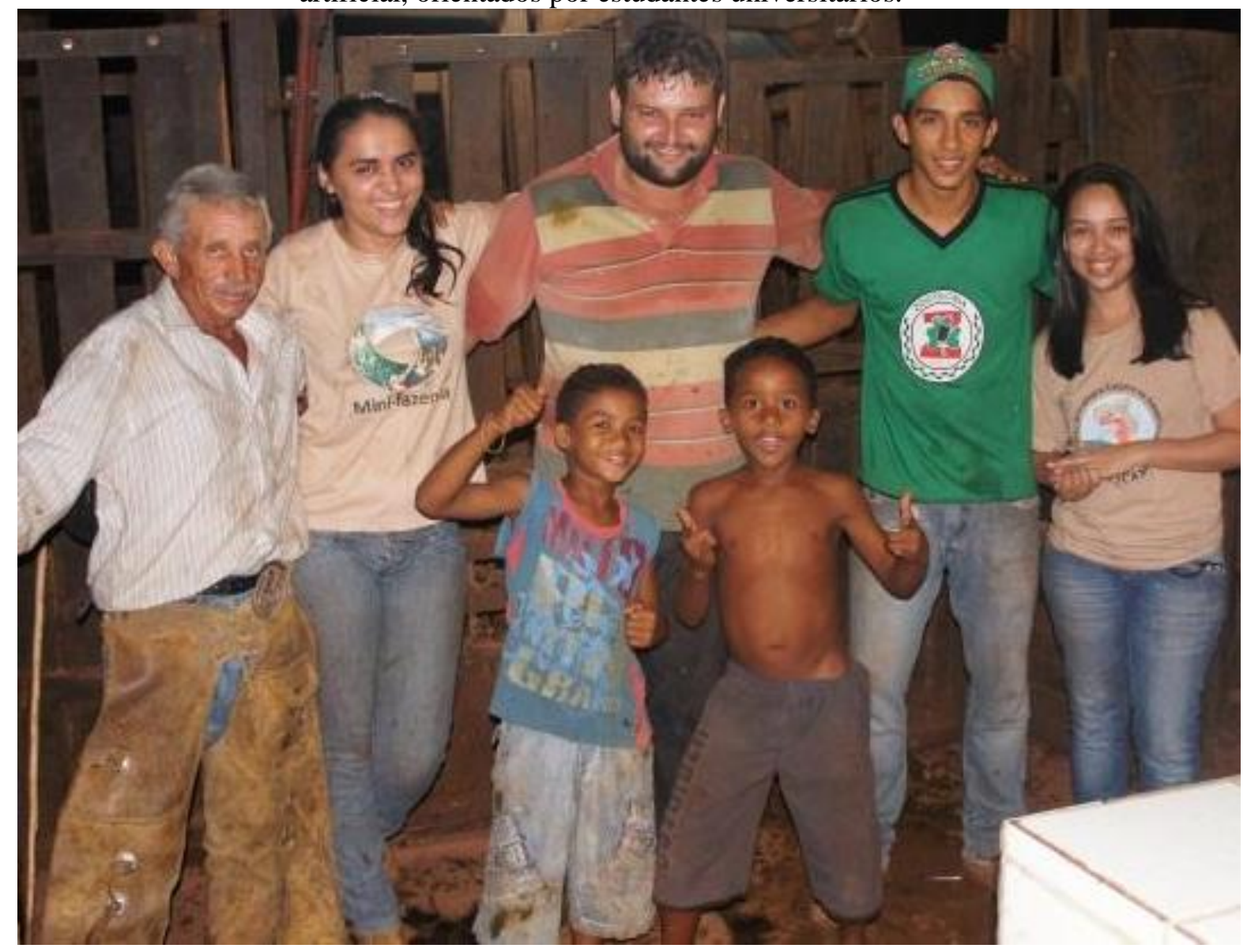

Créditos da foto: Oliveira, 2014.

A metodologia utilizada nos cursos foi do tipo participativa, levando-se em consideração os saberes tradicionais dos participantes e os conhecimentos adquiridos pelos discentes de graduação, que tiveram a oportunidade de interagir e compartilhar os conhecimentos adquiridos com os produtores rurais. Ao final do curso, os participantes passaram por avaliação prática e os considerados aprovados, receberam certificado de capacitação para atuarem como inseminadores de bovinos.

A partir do segundo ano de vigência do projeto, não foram realizados os protocolos de IATF nos animais, ficando por conta do produtor identificar a manifestação do cio, que seria o momento ideal para a realização das inseminações, de acordo com os conhecimentos adquiridos nos cursos de capacitação promovidos nas ações do projeto (Figura 5). 


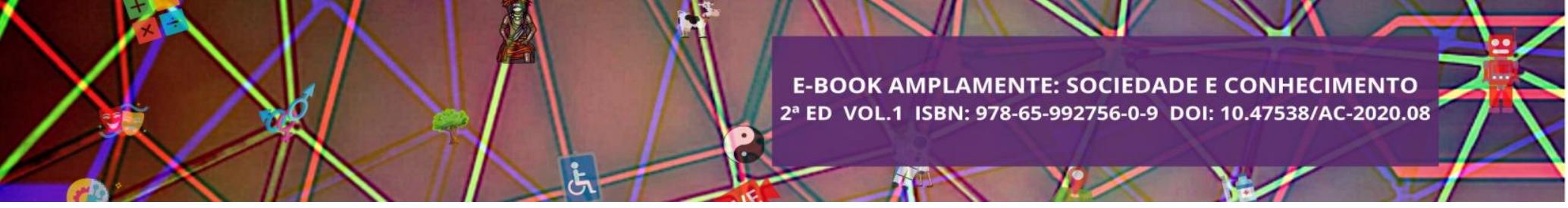

Figura 5 - Preparação do material para inseminação artificial, realizada por filhos dos

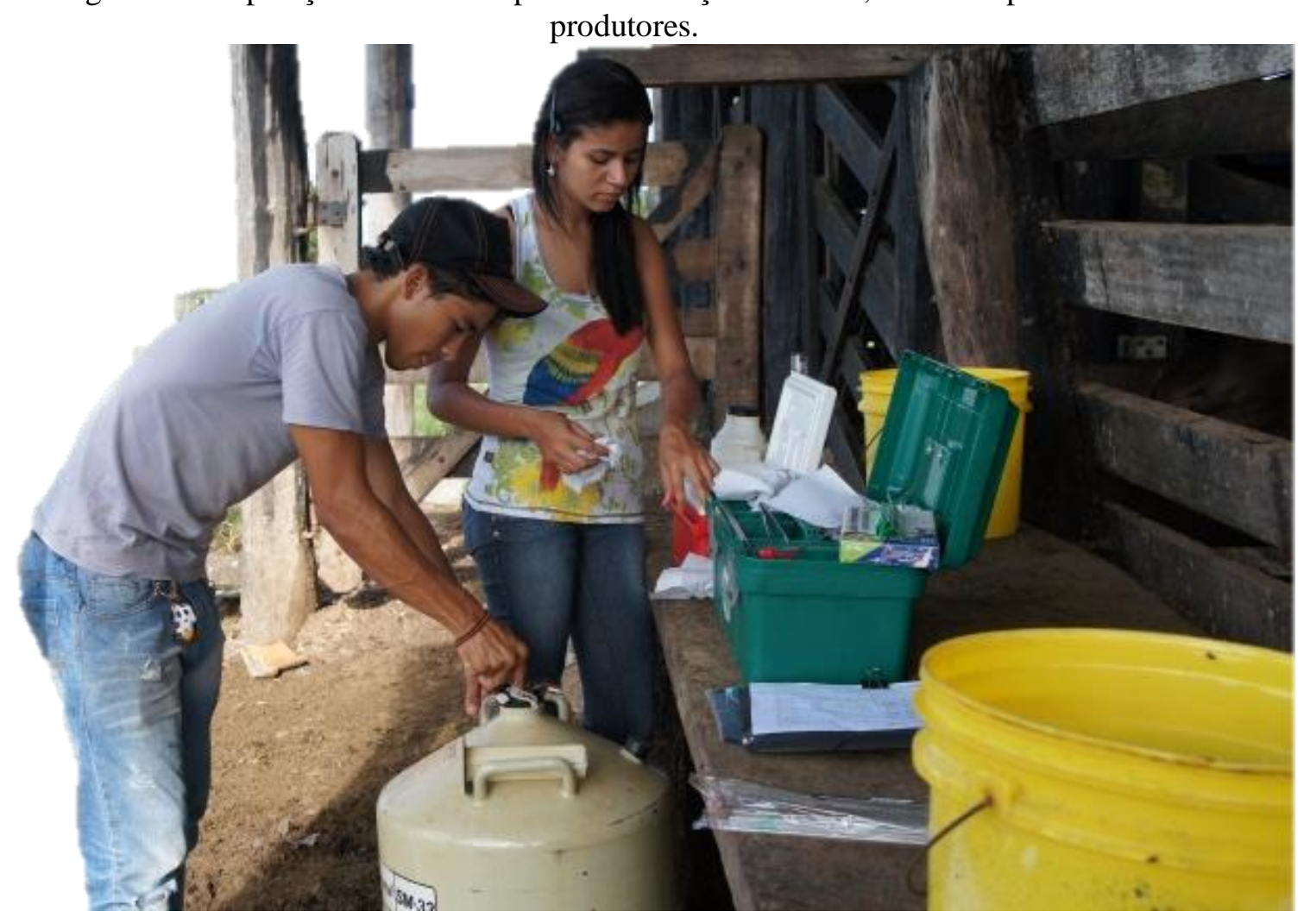

Créditos da foto: Oliveira, 2014.

Foram adquiridos com recursos do projeto, três touros da raça Holandesa PO (Figura 5), filhos de vacas com histórico de alta produção de leite elevada e persistência de lactação.

Figura 5 - Touro da raça Holandesa adquirido com recurso do projeto. 

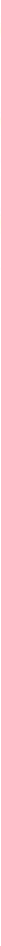

Os touros adquiridos com o recurso do projeto são submetidos à coleta e congelamento do sêmen no próprio campus da UFRA em Parauapebas (Figura 6), com o objetivo de promover a continuidade dos programas de inseminação, pela disponibilização de sêmen com baixo custo em relação aos comercializados por empresas provadas, aos produtores beneficiados com a realização do projeto e outros que venham a ter interesse na implantação de programas de inseminação em suas propriedades.

Figura 6 - Equipamento utilizado para o congelamento de sêmen.

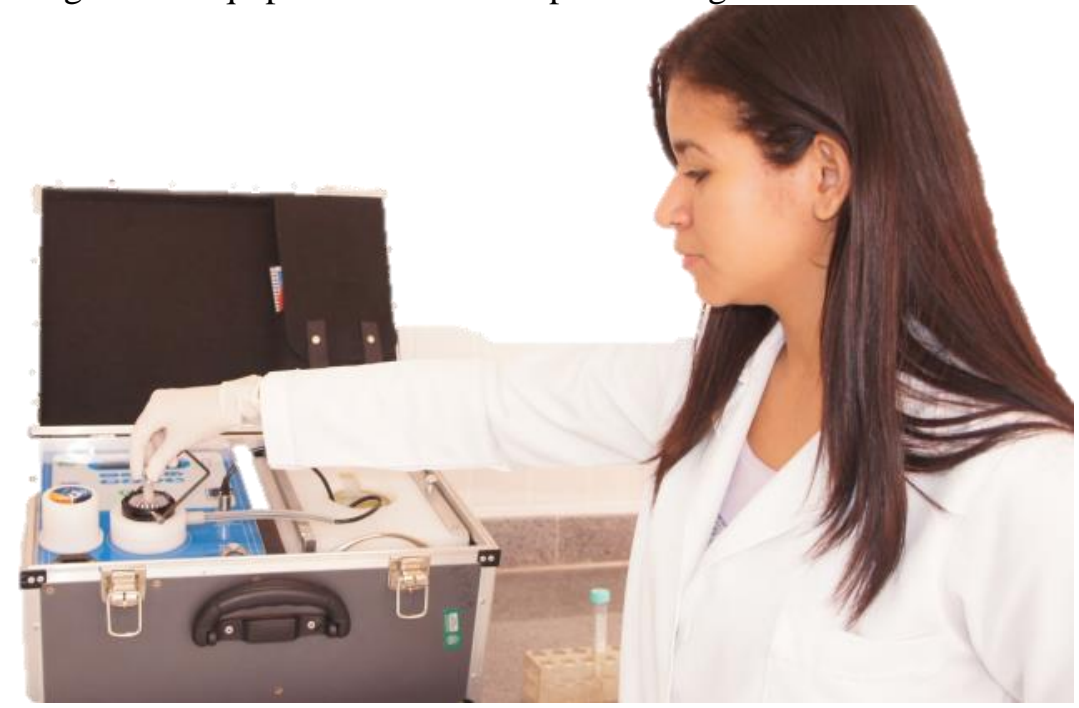

Créditos da foto: Oliveira, 2014.

\section{RESULTADOS E DISCUSSÃO}




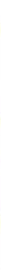

Durante a execução do projeto, realizou-se dois protocolos de IATF totalizando 991 (novecentos e noventa e uma) inseminações efetuadas (Tabela 1). Destas, obteve-se $464(70,73 \%)$ prenhezes no período de 36 meses de vigência do projeto.

No primeiro protocolo de Inseminação artificial em tempo fixo, foi inseminado um total de 656 animais, tendo como resultado, 321 prenhezes, o que corresponde a $48,93 \%$, do total de animais inseminados. No segundo protocolo foram inseminadas 335 vacas, com 148 gestações confirmadas o que correspondeu a 44,17\% do total inseminado no segundo procedimento.

Tabela 1. Resultados dos protocolos de inseminação artificial durante a vigência do projeto

\begin{tabular}{|c|c|c|c|c|c|}
\hline Propriedade & $\begin{array}{c}\text { № } \\
\text { animais } \\
1^{\circ} \text { IATF }\end{array}$ & Prenhez & $\begin{array}{c}\text { № } \\
\text { animais } \\
2^{\circ} \text { IATF }\end{array}$ & Prenhez & Total \\
\hline Sítio Moreira & 18 & $10(55,55 \%)$ & 08 & $04(50,00 \%)$ & $14(77,77 \%)$ \\
\hline Faz. Galvão & 19 & $08(42,10 \%)$ & 11 & $05(45,45 \%)$ & $13(68,42 \%)$ \\
\hline Sítio bom Jesus & 22 & $10(45,45 \%)$ & 12 & 07 (58,33\%) & $17(77,27 \%)$ \\
\hline Faz. WM & 23 & $12(47,82 \%)$ & 11 & $05(45,45 \%)$ & $17(48,04 \%)$ \\
\hline Sítio Seu Chico & 26 & $14(53,84 \%)$ & 12 & $05(41,66 \%)$ & $19(73,07 \%)$ \\
\hline Faz. São Francisco & 26 & $12(46,15 \%)$ & 14 & $04(28,57 \%)$ & $16(61,53 \%)$ \\
\hline Chácara Belo Vale & 27 & $17(58,62 \%)$ & 10 & $03(30,00 \%)$ & $20(74,07 \%)$ \\
\hline Chácara Helena & 28 & $18(64,28 \%)$ & 10 & $06(60,00 \%)$ & $24(85,71 \%)$ \\
\hline Crescendo com Leite & 28 & $18(64,28 \%)$ & 10 & $05(50,00 \%)$ & $23(82,14 \%)$ \\
\hline Faz. Sousa & 29 & $13(44,82 \%)$ & 16 & $09(56,25 \%)$ & $22(75,86 \%)$ \\
\hline Sítio Casa do Gil & 32 & $10(31,25 \%)$ & 22 & $08(36,36 \%)$ & $18(39,25 \%)$ \\
\hline Faz. São João & 32 & $17(53,12 \%)$ & 15 & $06(40,00 \%)$ & $23(71,87 \%)$ \\
\hline Faz. Lima & 34 & $12(35,29 \%)$ & 22 & $10(45,45 \%)$ & $22(64,70 \%)$ \\
\hline Chácara Moraes & 38 & $20(52,63 \%)$ & 18 & $08(44,44 \%)$ & $28(73,68 \%)$ \\
\hline Sítio Aurora & 39 & $22(56,41 \%)$ & 17 & 07 (41,17\%) & $29(74,35 \%)$ \\
\hline Recanto do gaúcho & 43 & $19(44,18 \%)$ & 24 & $11(45,83 \%)$ & $30(69,76 \%)$ \\
\hline Faz. Cachoeira & 43 & $24(55,81 \%)$ & 19 & $08(42,10 \%)$ & $27(62,79 \%)$ \\
\hline Sítio Resende & 45 & $16(35,55 \%)$ & 29 & $14(48,27 \%)$ & $30(66,66 \%)$ \\
\hline Faz. Sartório & 48 & $26(54,16 \%)$ & 22 & $10(45,45 \%)$ & $36(75,00 \%)$ \\
\hline Faz. Maria do Carmo & 56 & $23(41,07 \%)$ & 33 & $13(39,39 \%)$ & $36(64,28 \%)$ \\
\hline Total & 656 & $321(48,93 \%)$ & 335 & $148(44,17 \%)$ & $464(70,73 \%)$ \\
\hline
\end{tabular}




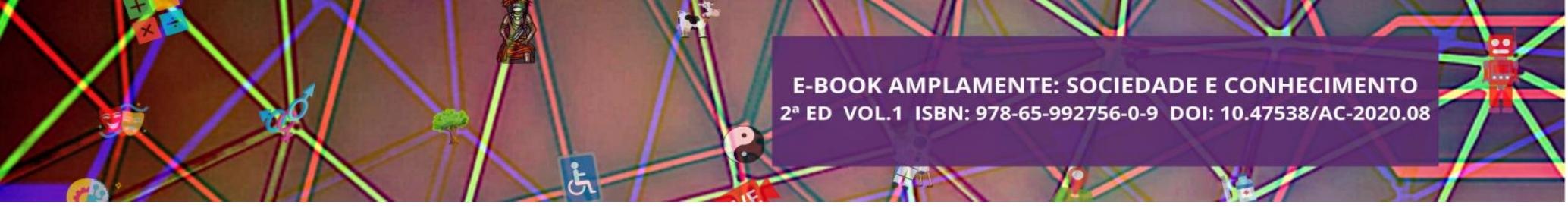

A taxa de gestação considerando os dois protocolos, variou de $39,25 \%$ a $85,71 \%$ (Tabela 1), demonstrando grande diferença entre os locais, o que pode ser explicado pelo fato das propriedades em assentamentos de reforma agrária possuírem diferentes níveis de aplicação e uso de tecnologias e/ou infraestrutura mínima para o uso da inseminação artificial. Observou-se que as propriedades que apresentaram menores taxas de gestação foram aquelas em que os proprietários possuíam menor fonte de renda e não dispunha de manejo de pastagens adequado e consequentemente os animais passavam por restrição alimentar nas épocas de escassez de alimentos, apresentando baixo escore de condição corporal no momento das inseminações, o que pode ter reduzido a resposta aos protocolos hormonais de indução e sincronização da ovulação e consequentemente ter interferido na taxa de gestação (FERREIRA et al., 2013; TORRES et al., 2015).

Em relação aos resultados sociais/interação com a comunidade, verificou-se que num momento em que a nova ordem do setor leiteiro nacional aponta para o aumento de eficiência e da produtividade, a implantação de um projeto de extensão tecnológica em inseminação artificial, especialmente em assentamentos de reforma agrária que naturalmente seriam alijados do processo de inclusão tecnológica é, sem dúvida, junto com um bom manejo sanitário e nutricional a chave para garantir bons resultados na pecuária de leite em propriedades da agricultura familiar.

Bezerra et al. (2011), avaliaram a importância de cursos de extensão rural na formação de inseminadores em bovinos de leite no Rio Grande do Sul e demostraram que estes projetos se configuram o caminho mais seguro, facilitado e curto entre o conhecimento científico, a pesquisa e sua difusão ao produtor rural. Este exemplo pode ser seguido pelo estado do Pará, que há muito tempo tem se mantido estagnado no que diz respeito a políticas públicas de difusão de tecnologias, especialmente as que possam ser incorporadas aos sistemas de agricultura familiar. Assim, a interação do aluno com a comunidade (Figura 7) é talvez o maior legado a ser deixado em projetos de extensão universitária, exercitando a plenitude da tríade: Ensino, pesquisa e extensão.

Figura 7- Bezerros nascidos do processo de inseminações artificiais realizadas durante o projeto. 

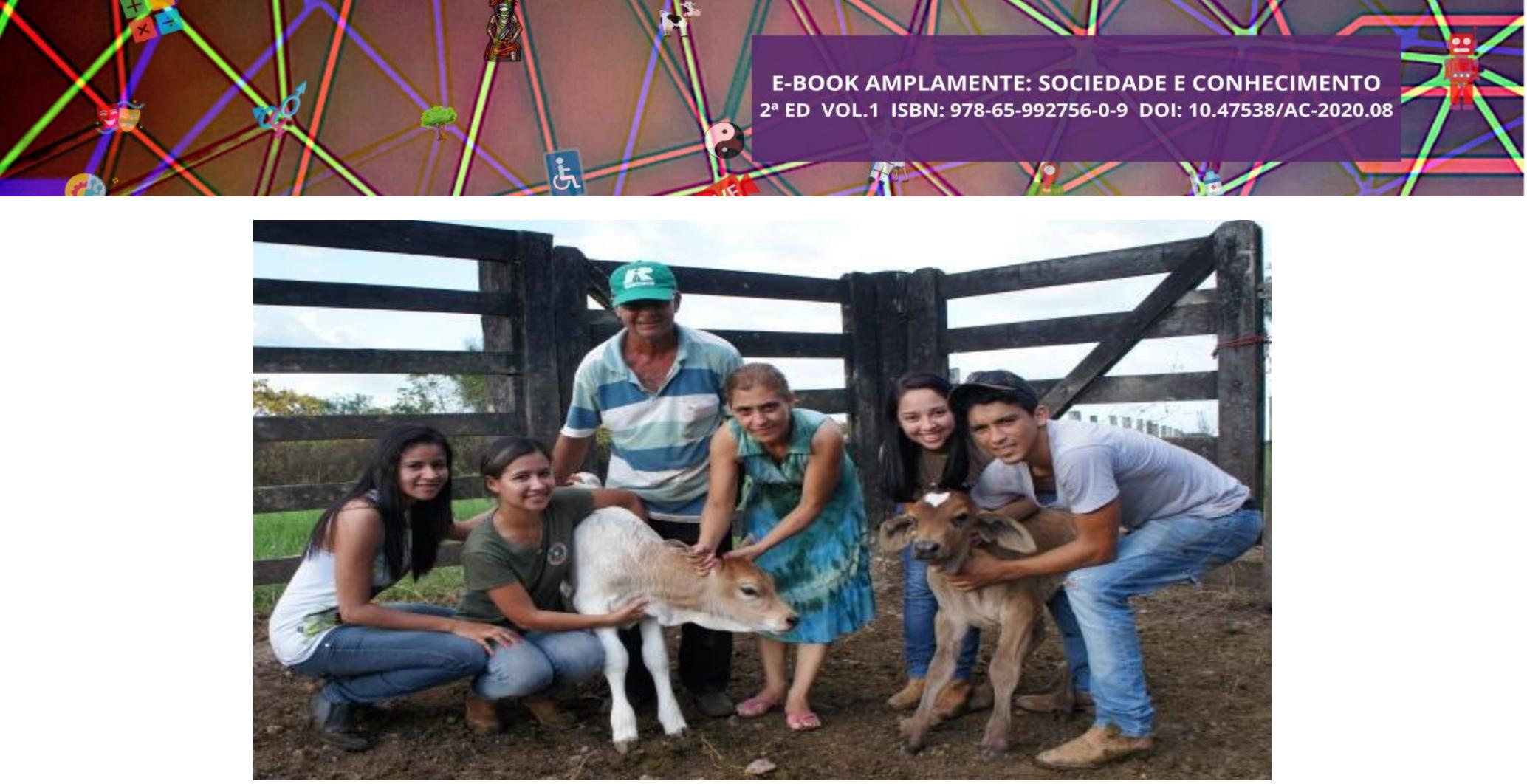

Créditos da foto: Oliveira, 2014.

\section{CONSIDERAÇÕES FINAIS}

Uma iniciativa aparentemente simples pode a médio e longo prazo, contribuir para a formação de uma nova bacia leiteira no estado do Pará, em especial, dentro dos assentamentos de reforma agrária, uma vez que este projeto pode se tornar em uma vitrine para outros produtores que ao visualizarem o sucesso do uso desta tecnologia, também possam aderir ao processo, contribuindo assim para difusão do projeto a um grande número de pessoas.

Constatou-se também que de maneira geral os objetivos propostos foram alcançados, pois proporcionou aos discentes do curso de Zootecnia a vivência prática e interação com produtores no momento de ensinar a técnica de inseminação artificial em bovinos leiteiros. Adicionalmente, percebeu-se que os anseios dos produtores foram atendidos, conforme o relato daqueles que participaram do projeto de extensão oferecido pela universidade e alunos envolvidos.

\section{REFERÊNCIAS}

ASSOCIAÇÃO BRASILEIRA DE INSEMINAÇÃO ARTIFICIAL - ASBIA. Index ASBIA 2017. Acessado em 01/05/2019. Disponível em: http://www.asbia.org.br/

BARUSELLI, P. S.; REIS, E.L.; MARQUES, M.O.; NASSER, L.F.; BÓ, G.A. The use of hormonal treatments to improve reproductive performance of anestrous beef cattle in tropical climates. Animal Reproduction Science, v.82-83, p.479-486, 2004. 


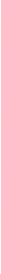

CUNHA, A.S.; RUFINO, L.M.A.; LEITE, R.C.; SILVA, M.X.; SALVARANI, F.M. Caracterização dos sistemas produtivos e dos produtores de leite da região Lago de Tucuruí, Pará, Brasil. Pubvet, v.12, n.12, p. 1-6, 2018.

FERREIRA, M.C.N.; MIRANDA, R.; FIGUEIREDO, M.A.; COSTA, M.O.;

PALHANO, H.B. Impacto da condição corporal sobre a taxa de prenhez de vacas da raça Nelore sob regime de pasto em programa de inseminação artificial em tempo fixo (iatf). Semina Ciências Agrárias, v.34, n. 4, p. 1861-1868, 2013.

INSTITUTO BRASILEIRO DE GEOGRAFIA E ESTATÍSTICA-IBGE. Indicadores leite e derivados 2018. Acessado em 10/05/2019. Disponível em:

https://ww2.ibge.gov.b

MOORE, S.G.; HASLER, J.F. A 100-Year Review: Reproductive technologies in dairy science. Journal of dairy science, v. 100, n. 12, p. 10314-10331, 2017.

SANTANA, A.C.; ÁDINA, L.A. A pecuária leiteira no Brasil e na Amazônia: desafios metodológicos. In: LOURENÇO JÚNIOR, J.B.; SANTOS, M.A.S. Qualileite:

qualidade e tecnologia na cadeia produtiva do leite no estado do Pará. Belém:

Marques Editora, 2015.

SANTOS, A.S.S.; LOURENÇO JÚNIOR, J.B.; SANTANA, A.C.; HOMMA, A.K.O.; ANDRADE, S.J.T.; MACIEL E SILVA, A.G. Caracterização do nível tecnológico da pecuária bovina na Amazônia Brasileira. Revista de Ciências Agrárias, v.60, n.1, p. 103-111, 2017.

TORRES, H. A. L.; TINEO, J. S. A.; RAIDAN, F. S. S. Influência do escore de condição corporal na probabilidade de prenhez em bovinos de corte. Archivos de zootecnia, v. 64, n. 247, p. 255-259, 2015. 


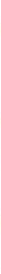

perpetua uma visão negativa e com graves repercussões para o funcionário. A gestão apresenta deficiências em suas estruturas física e administrativa, com ênfase para o controle interno deficiente, o que compromete os processos de atendimento e os cuidados relativos à saúde e à segurança dos pacientes. Há necessidade de conhecimento, por parte dos gestores, do Programa Nacional de Segurança do Paciente e a constante educação em saúde sobre o tema.

PALAVRAS-CHAVE: Segurança do paciente. Programa Nacional de Segurança do Paciente. Gestão hospitalar.

\section{INTRODUÇÃO}

A atenção com a qualidade da assistência e segurança do cliente nos serviços de saúde tem alcançado destaque em escala mundial. O movimento que resultou em críticas e a necessidade de uma melhora na qualidade do cuidado teve seu início no século XX, posteriormente à divulgação dos resultados das pesquisas do Institute of Medicine dos EUA que evidenciou a situação crítica dos estabelecimentos de saúde, onde das 33,6 milhões de internações hospitalares, cerca de 44.000 a 98.000 pacientes iam a óbito em consequências de eventos adversos (KOHN; CORRIGNAN; DONALDSON, 2000).

Desta forma, a Organização Mundial da Saúde-OMS (2007) tem apresentado um maior cuidado com esses aspectos, elevando o assunto a nível emergencial na agenda política dos seus países participantes com início do ano 2000. No ano de 2004 foi criado a World Alliance for Patient Safety com a finalidade de propor medidas para minimizar os efeitos adversos dos incidentes que resultam em danos ao paciente. Entretanto, foi no ano de 2007 que se teve a publicação das metas para a redução dos eventos adversos. Ademais, no campo atual foram estabelecidas seis metas que são: "Identificar os Pacientes Corretamente"; "Melhorar a Comunicação Efetiva"; "Melhorar a Segurança de Medicamentos de Alta-Vigilância”; "Assegurar Cirurgias com Local de Intervenção Correto"; "Procedimento Correto e Paciente Correto"; "Minimização do Risco de Infecções Associadas aos Cuidados de Saúde"; "Redução do Riscos Quedas" (INCA, 2011).

No Brasil, foi instituído o Programa Nacional de Segurança do Paciente (PNSP) com o propósito de contribuir para a qualificação do cuidado em saúde em todos os estabelecimentos de saúde, visando promover a implantação da gestão de risco e dos Núcleos de Segurança do Paciente, com o envolvimento de todos (PORTARIA No 529, 


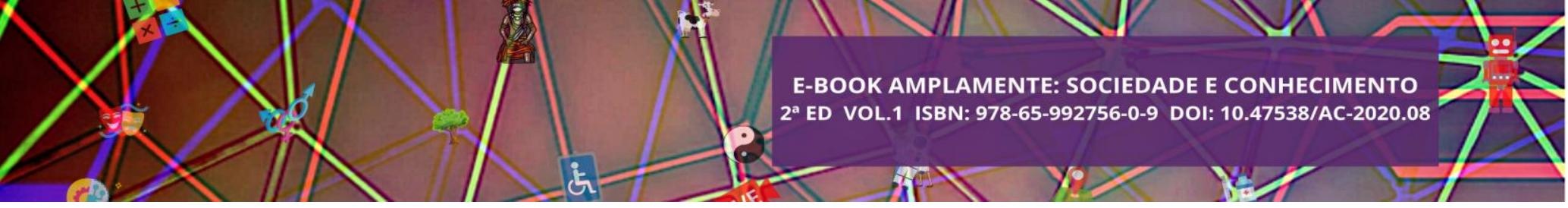

2013). Desde então, estudos mostram que, a maior complexidade apresentada pelos especialistas em segurança do paciente é a associação dos valores administrativos e dos assistenciais voltados para que tenha uma melhora da qualidade da assistência, sendo esta além dos fins lucrativos (SILVA, 2010).

Perante o exposto, o presente estudo teve como objetivo discorrer sobre os desafios nas gestões hospitalares na implementação do Programa Nacional de Segurança do Paciente na perspectiva da literatura cientifica.

\section{METODOLOGIA}

Trata-se de uma revisão integrativa da literatura. Tal instrumento metodológico é indispensável ao processo de avaliação e comunicação dos resultados dos estudos científicos publicados, pois cria a possibilidade de se analisar as pesquisas por meio de uma síntese dos resultados expostos, gerando conhecimento e proporcionado uma visão ampla (MENDES; SILVEIRA; GALVÃO, 2008). Para o direcionamento desta pesquisa, utilizou-se da formulação da questão norteadora pelo o método PICo: Quais os desafios dos gestores hospitalares para a implementação do Programa Nacional de Segurança do Paciente?

O método PICo, é uma metodologia complementar que auxiliou na formulação desta revisão de literatura, sendo que o "PICo" um acrônimo para Pacientes ou problema (P), Interesse (I), Contexto (Co). Para selecionar os estudos que respondessem à pergunta da pesquisa utilizou-se os seguintes descritores: Segurança do paciente, Gestão Hospitalar, sendo tais descritores indexados no Descritores em Ciências da Saúde (DeCS).

A obtenção dos dados foi realizada através da busca eletrônica no período de janeiro de 2020 na Biblioteca Virtual de Saúde - BVS. Os critérios de inclusão definidos foram: estudos completos disponíveis na integra, publicados nos últimos cinco anos, de 2015 até 2020, no idioma português. Foram excluídos capítulos de livros, resumos, textos incompletos, teses de doutorado, dissertações de mestrados, monografias e demais estudos que não respondessem ao objetivo da pesquisa. 
Quadro 01 - Estratégias de busca utilizadas nas bases de dados (Biblioteca Virtual da Saúde BVS), Caxias - MA, 2019.

\begin{tabular}{|l|l|c|c|c|}
\hline Base de Dados & \multicolumn{1}{|c|}{$\begin{array}{c}\text { Estratégia de } \\
\text { Busca }\end{array}$} & Resultado & Filtrado & Selecionados \\
\hline $\begin{array}{l}\text { Biblioteca Virtual } \\
\text { de Saúde - BVS }\end{array}$ & $\begin{array}{l}\text { (tw:(Segurança do } \\
\text { paciente)) AND } \\
\text { (tw:(gestão } \\
\text { hospitalar)) }\end{array}$ & 3.823 & 38 & 6 \\
\hline
\end{tabular}

Os estudos foram pré-selecionados de acordo com os critérios de inclusão e exclusão da pesquisa, segundo o fluxograma descrito na figura 01 .

Figura 01. Processo de seleção dos estudos para a revisão de literatura.

Questão Norteadora: Quais os desafios dos gestores hospitalares para a implementação do Programa Nacional de Segurança do Paciente?

\begin{tabular}{|c|}
\hline $\begin{array}{c}\text { Coleta de Dados } \\
\text { (Definição e }\end{array}$ \\
\hline $\begin{array}{c}\text { Utilização dos } \\
\text { Filtros }\end{array}$ \\
\hline
\end{tabular}

Análise dos Dados
(Pré-Seleção)

Estudos

Selecionados para

a Amostra Final
Biblioteca Virtual da Saúde - BVS

\subsection{3}

Textos Disponíveis, nos Últimos dez anos (2015 até 2020), em português

\section{8}

Artigos excluídos pela Leitura do Resumo: 12 Artigos em Duplicatas: 06

\section{0}

Artigos excluídos após a Leitura da Integra: 04

Artigos que não corresponde a questão norteadora: 10

\section{6}

Fonte: Dados da Pesquisa, 2020.

\section{RESULTADOS E DISCUSSÃO}




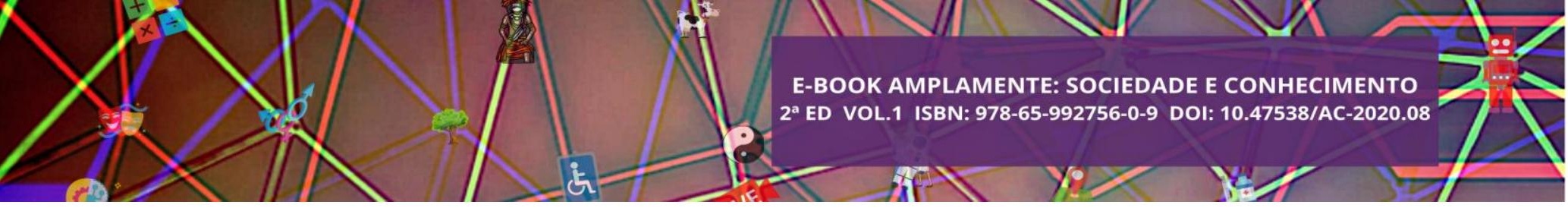

De acordo com os dados obtidos e apresentados no quadro abaixo podemos observar predominância de estudos descritivos, sendo o período de publicação desses artigos de 2015 a 2018.

\begin{tabular}{|c|c|c|}
\hline Periódico, Ano & Objetivo & Tipo do estudo \\
\hline $\begin{array}{l}\text { Ciência \& Saúde Coletiva, } \\
2018\end{array}$ & $\begin{array}{l}\text { Avaliar a cultura de segurança do paciente e } \\
\text { fatores associados em hospitais brasileiros com } \\
\text { diferentes tipos de gestão: federal, estadual e } \\
\text { privado. }\end{array}$ & $\begin{array}{l}\text { Observacional } \\
\text { do tipo transversal, } \\
\text { com } \\
\text { analítica }\end{array}$ \\
\hline Cogitare Enferm., 2016 & $\begin{array}{l}\text { Conhecer a situação dos hospitais de referência } \\
\text { quanto ao uso de normas e protocolos sobre } \\
\text { segurança do paciente diante da implantação da } \\
\text { respectiva política nacional }\end{array}$ & $\begin{array}{l}\text { Descritivo de } \\
\text { abordagem quantitativa }\end{array}$ \\
\hline Cogitare Enferm., 2016 & $\begin{array}{l}\text { Identificar as principais temáticas abordadas em } \\
\text { ambiente hospitalar para a segurança do paciente }\end{array}$ & Revisão integrativa \\
\hline Rev enferm UERJ, 2018 & $\begin{array}{l}\text { Compreender a dimensão prescrita e real das } \\
\text { práticas de profissionais de saúde no contexto da } \\
\text { segurança do paciente. }\end{array}$ & $\begin{array}{l}\text { estudo de caso } \\
\text { qualitativo }\end{array}$ \\
\hline $\begin{array}{l}\text { Rev Gaúcha Enferm., } \\
2016 .\end{array}$ & $\begin{array}{l}\text { Identificar mudanças na prática de enfermagem } \\
\text { com vistas à melhoria da qualidade do cuidado e } \\
\text { da segurança do paciente. }\end{array}$ & Estudo de caso, \\
\hline $\begin{array}{l}\text { REME- Rev Min Enferm, } \\
2015\end{array}$ & $\begin{array}{l}\text { Compreender a percepção dos enfermeiros acerca } \\
\text { do gerenciamento de risco hospitalar e analisar as } \\
\text { dificuldades e facilidades encontradas. }\end{array}$ & $\begin{array}{l}\text { Qualitativa, de caráter } \\
\text { exploratório, descritivo }\end{array}$ \\
\hline
\end{tabular}

Nos estudos de Siman e Brito (2018) é ressaltado sobre as diferentes concepções apresentadas, as prescritivas e da prática. Logo, é orientado uma remodelação efetiva começando da gerência e dos núcleos de segurança do paciente, abordando sua aplicação não somente na enfermagem, e sim com foco em toda a equipe multidisciplinar.

Andrade et al. (2018) evidenciam que a credibilidade, atos e percepção dos profissionais de saúde sobre a segurança do paciente é bastante incipiente, embora, eles afirmem que a segurança, no estabelecimento pesquisado era aceitável. A partir do exposto é proposto uma intervenção a nível gerencial para a implementação da cultura de segurança do paciente. 


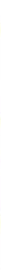

Já em Serra et al. (2016) é ratificado sobre a necessidade da melhoria da qualidade da assistência, e relata que pesquisa no âmbito da segurança do paciente não são formas de melhorar a qualidade, contudo, são o caminho para o processo. E vem confirmando que há uma fragilidade no meio, sendo esta iniciada a nível gerencial.

De acordo com Siqueira et al., (2015), o processo de segurança do paciente, envolve, não somente mudança de culturas nos profissionais, mas mudanças no meio administrativo, pois a cultura de gerenciamento de risco na visão do profissional é compreendida como um fator de risco, haja vista que seu tocante gera punições e acusações. Logo, de antemão, o profissional cria uma aversão como mecanismo de autoproteção, dando origem às subnotificações das situações.

Baseado nesse contexto, acredita-se que os desafios dos gestores sejam em torno da criação de uma cultura de segurança nos trabalhadores, pacientes e acompanhante. Ademais, os gestores devem priorizar a segurança acima das metas financeiras, sendo necessário criar no empregado o conhecimento e valorização de notificações e resolução de problemas, haja visto que, no meio atual, apontar as falhas é visto como algo negativo e que implicaria em futuros danos ao funcionário.

Nas pesquisas de Silva et al., (2016) é exposto que tem ocorrido um avanço sobre o emprego da necessidade de melhorar a qualidade da assistência embasada na prevenção de risco, contudo, é ausente o relato sobre a importância de uma gestão que valorize a segurança em vez de metas financeiras, assim sendo, há imprescindibilidade de se discutir e unir conceitos assistencial e gerenciais.

Além disso, os desafios gerenciais estão voltados para sensibilização sobre as notificações, criação de uma cultura de segurança aplicada em todos os envolvidos, proporcionar uma estrutura adequada, ausência recursos financeiro, carência de recursos humanos, consequentemente, dando início a sobrecarga de trabalho e alta rotatividade de profissionais (SIMAN; BRITO, 2016).

\section{CONSIDERAÇÕES FINAIS}

A gestão hospitalar no Brasil e no mundo apresenta deficiências em suas estruturas física e administrativa, com ênfase para o controle interno deficiente, o que compromete os processos de atendimento e os cuidados relativos à saúde e à segurança dos pacientes. Ressalta-se a importância que ocorra a implementação de campanhas de 


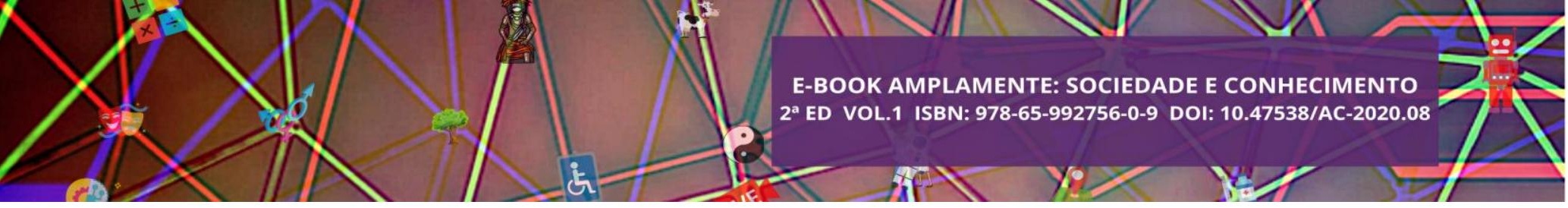

comunicação sobre segurança do paciente, voltada a sociedade a fim de que a cultura de segurança seja difundida.

\section{REFERENCIAS}

1. ANDRADE, L. E. L.; LOPES, J. M.; SOUZA FILHO, M. C. M.; JÚNIOR, V.; FONSECA, R.; FARIAS, L. P. C; SANTOS, C.C.M.; GAMA, Z. A. S. Cultura de segurança do paciente em três hospitais brasileiros com diferentes tipos de gestão. Ciência \& Saúde Coletiva, v. 23, p. 161-172, 2018.

\section{INCA. Adoção Das Metas De Segurança Dos Pacientes Da Oms Dá}

Qualidade Na Assistência Hospitalar. 2011. Acesso: 20/01/2020. Disponível em:< https://www.inca.gov.br/sites/ufu.sti.inca.local/files//media/document//rede-cancer-13capa.pdf $>$.

3. KOHN, L.T; CORRIGNAN, J.M; DONALDSON, M.S. To err is human: building a safer health system. Washington: National. Academy Press; 2000

4. MENDES, K. S.; SILVEIRA, R. C. C. P.; GALVÃO, C. M. Revisão integrativa: método de pesquisa para a incorporação de evidências na saúde e na enfermagem. Texto \& Contexto-Enfermagem, v. 17, n. 4, p. 758-764, 2008

5. $\quad$ Ministério da Saúde (BR). Portaria $\mathbf{n}^{\circ} 529$, de $\mathbf{1}^{\circ}$ de abril de 2013. Institui o Programa Nacional de Segurança do Paciente (PNSP). Diário Oficial da União 02abr 2013. Acesso em: 01/01/2020. Disponível em:

<http://bvsms.saude.gov.br/bvs/saudelegis/gm/2013/prt0529_01_04_2013.html>

6. SERRA, J.N.; BARBIERI, A. R.; CHEADE, M.F.M. Situação dos hospitais de referência para implantação/funcionamento do núcleo de segurança do paciente. Cogitare enferm (Online), v. 21, n. 5, p. 1-9, 2016.

7. $\quad$ SILVA, A. C. A.; Silva, J. F., SANTOS, L. R. O., AVELINO, F. V. S. D., SANTOS, A. M. R., PEREIRA, A. F. M.A. segurança do paciente em âmbito hospitalar: revisão integrativa da literatura. Cogitare Enfermagem, v. 21, n. 5, 2016

8. SILVA, A. E. B.C. Segurança do paciente: desafios para a prática e a investigação em Enfermagem. Revista Eletrônica de Enfermagem, v. 12, n. 3, p. $422-$ 4, 2010 .

9. SIMAN, A. G.; BRITO, M. J. M. A dimensão prescrita e real de práticas de profissionais de saúde no contexto da segurança do paciente. Revista Enfermagem UERJ, v. 26, p. 237-03, 2018.

10. SIMAN, A. G.; BRITO, M. J. M. Mudanças na prática de enfermagem para melhorar a segurança do paciente. Revista Gaúcha de Enfermagem, v. 37, n. spe, 2016. 


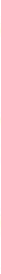

11. SIQUEIRA, C. L.; SILVA, C. C.; TELES, J. K. N.; FELDMAN, L B. GERENCIAMENTO DE RISCO: PERCEPÇÃO DE ENFERMEIROS EM DOIS HOSPITAIS DO SUL DE MINAS GERAIS, BRASIL. REME • Rev Min Enferm.; v.19.n.4. p.919-926.2015

12. World Health Organization. Geneva: World Health Organization (SW), WHO launches. Nine patient safety solutions. Solutions to prevent health carerelated harm. 2007 Acesso em: 10/01/2020. Disponível em:<

http://www.who.int/mediacentre/news/releases/2007/pr22/en/index.html4.> 


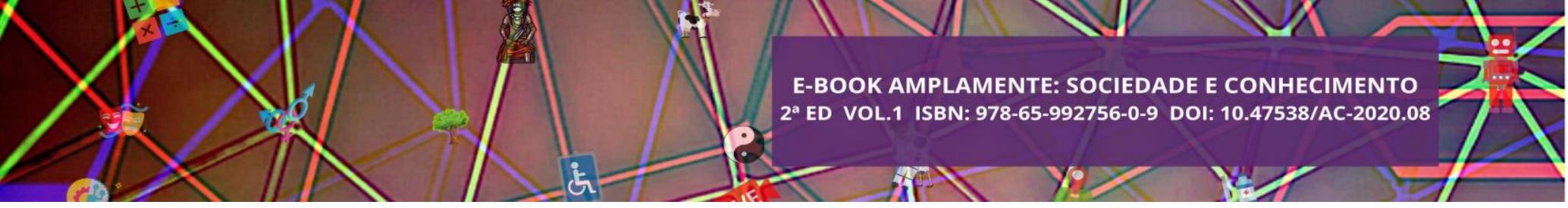

2012), a apatridia é uma condição humana que priva e limita a vida pública e torna vulneráveis aqueles classificados como apátridas.

O objetivo deste artigo é desenvolver uma reflexão teórica, nos moldes de um ensaio (MENEGHETTI, 2011; MESQUITA; MATOS, 2014), sobre os temas da apatridia e dos direitos humanos a partir da busca de artigos, que combinem ou utilizem ambos para sua realização, em uma das principais bases de dados mundiais, a Web of ScienceTM (MOURA et al., 2017). A procura resultou em 62 resultados, com o primeiro no ano de 1981 - apesar da busca revir-se ao ano de 1945 como inicial - um hiato de produção até o ano de 2006, e o ano de 2017 como último completo utilizado. A produção de conhecimento se concentra nos Estados Unidos e Reino Unido, com $29 \%$ e $19 \%$ do total respectivamente. Não há um grupo definido de autores ou instituições que investiguem a temática, mas publicações isoladas cujos autores têm, no máximo três (apenas KINGSTON, 2010, 2015, 2017) ou dois artigos sobre o assunto.

\section{DIREITOS HUMANOS}

Durante o século XII, na atual Inglaterra, foi desenvolvido o primeiro documento que abrangeria os direitos humanos. Entretanto, após conflitos e intervenções da Igreja Católica, a questão pausa por um longo hiato que finda na Declaração dos Direitos do Homem e do Cidadão, documento redigido no período da Revolução Francesa e considerado um marco para os direitos do homem (ROCHA; PADILHA, 2016). Tal declaração passa a ser ampliada com a promulgação da Declaração Universal dos Direitos Humanos em 1948, ancorada na criação do Tribunal Europeu dos Direitos Humanos, reduzindo o aparecimento de regimes ditatoriais em tentativa de garantir a dignidade de todos os indivíduos, ao demonstrar a evolução positiva que a temática passou ao longo dos anos (ROCHA; PADILHA, 2016).

O debate que a Declaração Universal dos Direitos Humanos de 1948 introduziu sobre migrantes no contexto, implicou em um olhar mais vigilante das comunidades acadêmicas e civil. Pode-se afirmar que, com a criação do Alto Comissariado das Nações Unidas para Refugiados (ACNUR), a ideia de que os migrantes necessitam ser vistos no campo específico de incidência dos Direitos Humanos entram em pauta de forma assertiva e com ênfase (ROCHA; PADILHA, 2016). As migrações mantêm estrita relação com o desenvolvimento humano, uma vez que desde seus primórdios as 


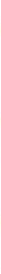

primeiras sociedades deixavam seus lugares à procura de melhores condições de sobrevivência. Com isso, ao longo da história, os fluxos migratórios têm colaborado com o povoamento de terras e também com aspectos políticos, econômicos e sociais (MEYER, 2010; O’NEILL, 2007).

$\mathrm{Na}$ Europa, esse processo se deu de forma intensa, principalmente devido ao abalo econômico sofrido pela população européia no século XIX, que, em meio às guerras e perseguições religiosas migrou para países americanos, tornando-se mão de obra nos países em que se instalavam (BAPTISTA; LISBOA, 2016). Além disso, frente ao término da Segunda Guerra Mundial e a consequente escassez de mão de obra, povos de diversas regiões migraram rumo ao continente europeu, auxiliando na reconstrução dos países devastados pela guerra. É perceptível ainda em tempos atuais, principalmente dentro da União Europeia, discursos conservadores e xenófobos, atribuindo culpa aos imigrantes pelos problemas socioeconômicos de seus países e os responsabilizando pelas novas dificuldades no contexto trabalhista (DE GROOT; VONK, 2012; DURÀ, 2015).

De fato, à medida em que os refugiados e apátridas se viram destituídos, com a perda da cidadania, dos benefícios do princípio da legalidade, não puderam se valer dos direitos humanos, e não encontrando lugar - qualquer lugar - num mundo como o do século $\mathrm{XX}$, inteiramente organizado e ocupado politicamente, tornaram-se efetivamente desnecessários, porque indesejáveis erga omnes, e acabaram encontrando o seu destino e lugar natural nos campos de concentração (LAFER, 2007, p. 58).

O termo refugiado surge a partir das guerras religiosas na Europa Moderna, com o drama dos judeus expulsos e perseguidos. Ao fim das guerras mundiais, grandes massas de imigrantes refugiados percorrem a Europa em todas as direções. Em contexto hodierno, uma dessas ondas migratórias decorrente principalmente da Primavera Árabe e da guerra civil na Síria leva indivíduos a se deslocarem a procura de um refúgio, colocando suas vidas em perigo devido à travessia marítima, encontrando condições bastante precárias ou até mesmo fronteiras fechadas (BAPTISTA; LISBOA, 2016). Somam-se a estas migrações aquelas provocadas por conflitos de nacionalidade e violação de direitos humanos.

Neste sentido, o termo apátrida remete ao indivíduo sem nacionalidade reconhecida por nenhuma federação, não possuindo conexões formais com um Estado. Sem tais vínculos, indivíduos apátridas se encontram desamparados de direitos ou 


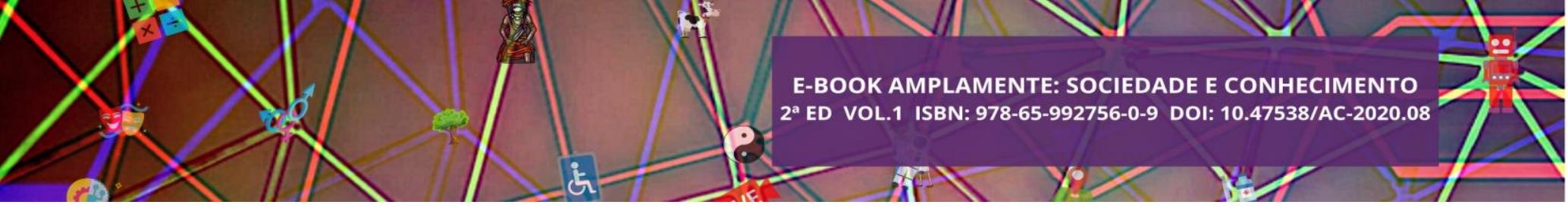

deveres, uma vez que os direitos humanos mantêm uma forte associação com a nacionalidade atribuída (ZEN, 2007; NASCIMENTO; PORTELLA, 2016). Nessa perspectiva, a apatridia se constitui uma problemática relevante, visto que implica em sofrimentos psicológicos e físicos aos indivíduos, que ficam desprovidos da proteção do Estado, tornando-se estrangeiros em todos os lugares e ausentes de reconhecimento nacional. Pode-se afirmar, ainda, que a questão da apatridia engloba a identificação que o indivíduo tem para com seu Estado, já que geralmente tal vínculo não é reconhecido judicialmente, acarretando prejuízos à sua dignidade (ZEN, 2007).

Concebendo a participação social como uma necessidade básica e inerente a todos os seres humanos, é possível afirmar que sua ausência gera violência tanto no âmbito público como privado, ao construir uma segregação do indivíduo perante a sociedade, limitando sua cidadania e considerando apenas a exclusão delimitada por leis nacionais (NASCIMENTO; PORTELLA, 2016). A apatridia interessa substancialmente a área do direito internacional, pelo fato de lidar com questões de lei aplicável nas diferentes situações jurídicas envolvendo os apátridas. Nesse contexto, apesar de ainda haver forte resistência à adoção de medidas uniformes de prevenção à apatridia, é vedado qualquer tipo de discriminação ou desrespeito entre apátridas (ZEN; 2007; NASCIMENTO; PORTELLA, 2016). Apesar da vedação e das recomendações internacionais, muito se discute sobre a efetiva aplicação destas determinações (ALNAKIB, 2011; BHABHA, 2009; BLITZ, 2011; BROLAN, GOUDA, 2017; FOSTER; LAMBERT, 2016).

A questão da apatridia é envolta pelos Direitos Humanos a partir da Declaração Universal de 1948. O texto descreve o direito de todo ser humano a ter uma nacionalidade, enfatizando que nenhuma pessoa pode ser privada de sua nacionalidade mesmo em casos de mudança desta, quando tal privação é conduzida de forma arbitrária (LA ROCCA; PROSPERI, 2017). O ser humano, assim, estabelece vínculos, inclusive jurídicos, com seu Estado e, por esta razão, constitui-se em direito humano, com responsabilidades do Estado em conferir proteção e respeito aos seus direitos fundamentais (BICHARA, 2017).

\section{A QUESTÃO DA APATRIDIA}




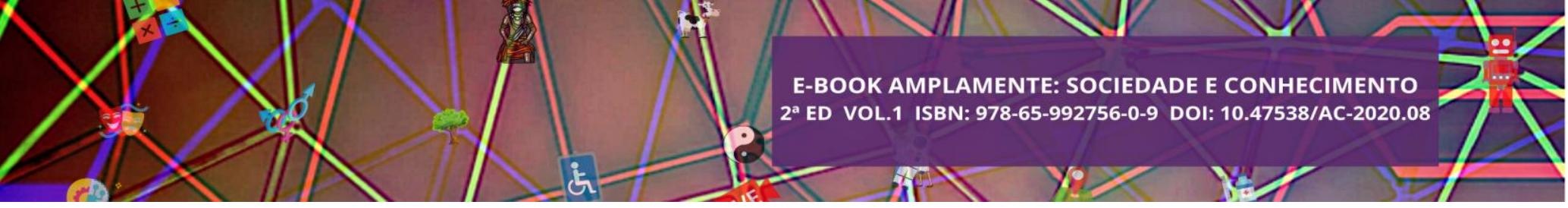

A apatridia não é uma problemática recente, mas se observa o destaque nas discussões internacionais em decorrência do crescente número de pessoas nesta condição nas últimas décadas (SALES JARDI, 2016; VAN WAAS, 2014; VRĂBIESCU, 2017; ZEDNER, 2016). Até o final do ano de 2015 este número já chegava a quase quatro milhões de pessoas de acordo com o Alto Comissariado das Nações Unidas para Refugiados (ACNUR). A Organização das Nações Unidas busca a proteção destas pessoas por meio de ações que procuram garantir os direitos fundamentais do ser humano. Podem ser destacadas várias ações para o enfrentamento desta problemática, como a realização de encontros pela comunidade internacional, destacando-se a Convenção de Genebra realizada em 1951 e as Convenções de Nova York realizadas em 1954 e 1961, que embasam a discussão sobre a apatridia e as alternativas cabíveis para garantia de direitos fundamentais (OLAY, 2008).

Com exceção da apatridia causada pela renúncia voluntária à nacionalidade, desnacionalização ou transferência territorial, todos os incidentes de apatridia decorrentes do nascimento, como a apatridia ao nascer, são causados por leis de conflito de nacionalidade. A apatridia acontece quando a nacionalidade é perdida sob as leis de um estado, sem a aquisição de uma nova nacionalidade, com base nas leis de outro estado (WALKER, 19981). Guerra (2014) acrescenta em tipologia que a nacionalidade de um indivíduo pode ser originária - quando do nascimento; ou adquirida - quando da mudança da primitiva nacionalidade ou da que a esta se sucedeu. $\mathrm{O}$ tipo originário é apresentado de três formas: jus soli - nacionalidade do território de nascimento sem influência da nacionalidade dos pais. Critério adotado pelos países do continente americano, dada a necessidade de formação de uma população nacional; jus sanguinis forma mais antiga de adquirir a nacionalidade. A nacionalidade provém dos genitores, qualquer que seja o local do nascimento. Critério adotado pelo continente europeu, pois o Estado tem interesse de vincular os filhos à nacionalidade do país, devido intensa migração que ocorre nestes países e por fim, o sistema misto, combinação dos critérios anteriores. O Direito Internacional privado ainda acrescenta: o ius domicilii - que considera o critério de domicilio da pessoa para estabelecer a sua nacionalidade, o critério mais utilizado para resolver conflitos pertinentes à nacionalidade e o ius laboris - que utiliza o critério da prestação de serviços para um Estado como um reconhecimento dos serviços prestados a um Estado que não era de sua nacionalidade (DOLINGER, 2008). 


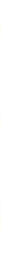

Em menos de quatro décadas passadas, apátridas e refugiados eram englobados no mesmo grupo de pessoas e já se configuravam preocupação das autoridades internacionais (BICHARA, 2017). A questão só passou a ser tratada separadamente após a Segunda Guerra Mundial. Há duas principais formas de apatridia: o apátrida de facto e o de jure. A categoria de jure se remete ao Estatuto dos Apátridas de 1954, classificando o individuo que não possui vínculo jurídico com nenhum Estado, não possuindo reconhecimento legal de nacionalidade. Neste caso, o Estado que recebe o individuo sem nacionalidade reconhece a inexistência de vínculo jurídico de nacionalidade do indivíduo com outro Estado e tem a obrigação de conferir proteção à pessoa.

Embora a categoria de facto seja abrangente e sugestão de acadêmicos para englobar outras condições que estão além da definição de jure, a maioria que se enquadra nesta definição é vítima de repressões políticas (WEISSBRODT; COLLINS, 2006). O apátrida de facto comumente possui nacionalidade de acordo com a lei, mas sua nacionalidade não é efetiva ou não há provas para que ela seja verificada e comprovada (WEISSBRODT; COLLINS, 2006). Embora tradicionalmente entendido como um problema jurídico técnico, a apatridia ocorre comumente como resultado da privação arbitrária da nacionalidade, podendo se basear na discriminação racial e de gênero (GONZALEZ-GALLEGO, 2008; HOWARD-HASSMANN, 2006; MENZ, 2016; RÜRUP, 2016). Suas consequências são cada vez mais concebidas em termos de direitos humanos, pois se resulta em discriminação e privação de acesso aos direitos básicos, como trabalho, a saúde e à educação no próprio país, conduzindo à vulnerabilidade a outras violações dos direitos humanos, como o tráfico de pessoas (LAMBERT, 2015; LIMBADA; DAVIES, 2016). A migração se torna a única opção, dada a situação insustentável que os próprios migrantes relatam (FOSTER; LAMBERT, 2016).

Para Blitz e Otero-Iglesias (2011) existem certos aspectos do sistema de asilo do Reino Unido que podem levar a situações análogas à apatridia, baseando-se para isso em Hannah Arendt, citando três perdas: o lar (exílio), a proteção do Estado (direitos básicos) e o seu lugar no mundo (direitos políticos) (GÓMEZ, 2016; SALES JARDI, 2016; STONEBRIDGE, 2011). Blitz (2011), em outro estudo, examina a perspectiva de deslocamento ambiental e a criação de populações apátridas no contexto de ilhas de baixa altitude na Melanésia (Ilhas Carteret e Vanuatu), na Micronésia (Kiribati), na 


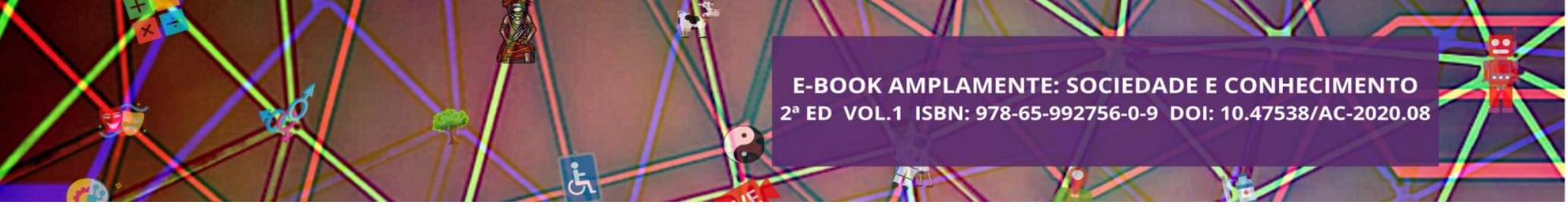

Polinésia (Tuvalu) e nas Maldivas, apresentando considerações sobre como os Estados receptores devem respeitar os direitos dos apátridas.

A experiência de judeus, como protagonistas de contexto de apatridia e como advogados especialistas em discussões e direitos de minorias no período entre e pós guerras e suas ONGs criadas para esta mesma finalidade levou a uma produção de conhecimento na área e abriu espaço para eventos e acordos, como a Convenção das Nações Unidas sobre o status dos apátridas em 1954 (RÜRUP, 2017). A contribuição de Hannah Arendt é ímpar e amplamente citada, seja pela sua condição de judia apátrida que lhe permitiu um olhar particular e apurado sobre a temática, seja pela profundidade com que discutia em seus escritos filosóficos.

\section{O CONTEXTO CONTEMPORÂNEO E OS APÁTRIDAS}

A apatridia é, de uma só vez, um problema velho, novo e eterno (VAN WAAS, 2014, p. 342).

Em meados do segundo semestre do ano de 2017, uma migração de cerca de 370 mil mulçumanos Rohingyas, saindo de Mianmar para Bangladesh, chamou a atenção global e da ONU (BBC, 2017). Um êxodo que já perdura por cinco décadas de um povo que vive apátrida, de origem ainda debatida, sem direitos ao casamento, viagens ou à propriedade e que tem recebido apoio das Nações Unidas e de ONGs para a revisão da Lei de Cidadania de Mianmar de 1982. O foco neste contexto de apatridia tem sido alvo de investigações acadêmicas (BROOTEN, 2015; BROOTEN et al., 2015; KINGSTON, 2015; KINGSTON et al., 2010; MAHMOOD et al., 2017; PARNINI et al., 2013), propondo, baseando-se nos achados, negociações bilaterais e multilaterais que solucionem o problema deste grupo de mulçumanos.

Os Rohingyas se somam ao número aproximado de 10 milhões de apátridas que povoam o globo e sofrem as consequências da limitação de direitos que esta condição traz consigo. O ano de 1982 pode ser considerado o marco da expatriação, por causa da impossibilidade de diversas pessoas em cumprir os requisitos básicos para provar seus antepassados em Burma antes de 1823 (MAHMOOD et al., 2017). Apesar das pressões internacionais constantes, das solicitações dos grupos ativistas locais para que o governo encerre as violências contras os apátridas, pouco tem sido observado em resultados positivos para estas disputas (AHSAN ULLAH, 2016). 


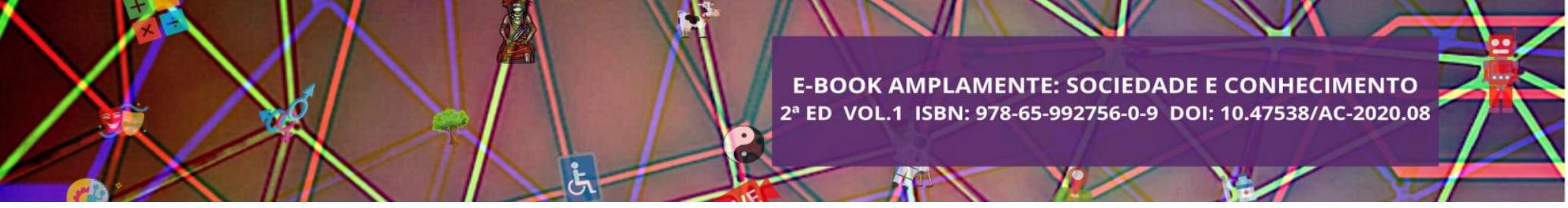

Israel violou o direito internacional ao expatriar civis palestinos no período entre 1947-1949 ou mesmo ao recusar a sua repatriação? Kent (2012) argumenta que, embora as aspirações dos deslocados para retornar à sua pátria sejam compreensíveis e convincentes, os dados de seu estudo apontam que diversas pessoas foram expulsas de seus países durante o século XX antes de o direito internacional começar a reconhecer essa prática como ilegal, antes mesmo do direito internacional começar a exigir que os refugiados possam voltar para casa em algumas circunstâncias.

A questão da cidadania, por conseguinte limitação ou vulnerabilidades que os apátridas possuem em comparação aos povos de nacionalidade definida, é um tema bastante recorrente (FEIN; STRAUGHN, 2014), como em Cahn (2012) que, baseandose na constituição da União Europeia, analisa novas formas de status e exclusão, limitando direitos com base em argumentos etnonacionalistas, afetando principalmente grupos romanichéis e russos. O povo Romani também foi objeto de estudo de Avara e Mascitelli (2014) e Illuzi (2010) com resultados que corroboram os argumentos de Cahn (2012) e De Chickera (2012). Ainda sobre a União Europeia, Kattago (2017) asserta que os direitos humanos, a tolerância e a livre circulação de pessoas, construtos basilares da constituição do bloco de países, têm sido questionados neste momento em que o asilo aos refugiados Sírios é negado constantemente, as ameaças de terrorismo também são comuns e a hospitalidade tem sido convertida em uma política de fechamento de fronteiras (KINGSTON; STAM, 2017)

Quando o contexto é de enfrentamento ao terrorismo, Zedner (2016) apresenta que a privação da cidadania de pessoas que ameaçam os interesses do Estado foi revivida como uma ferramenta fundamental para a segurança e o antiterrorismo. Contudo, esta privação levanta questões para os direitos humanos no Reino Unido, especialmente pelas consequências que envolvem atentado à vida, torturas, tratamentos ou punições desumanos ou degradantes.

Acrescenta-se ainda que as noções atuais da comunidade política e do ser humano precisam ser reavaliados, conforme Lechte e Newman (2012, 2013). Somente após uma reconfiguração, uma mudança de paradigma do pensamento político internacional, será possível abordar as questões cruciais que atualmente enfrentam os direitos humanos, tais como a tensão entre os princípios dos direitos humanos universais e o da soberania do Estado, o crescente problema da apatridia e da redução dos direitos humanos. Ong (2006) complementa informando que: na zona da União Europeia, 


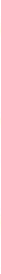

mercados não regulamentados e fluxos de migrantes desafiam a cidadania liberal e as bases constituintes do grupo de países; nas zonas asiáticas, os estrangeiros que se mostram empreendedores ganham direitos e benefícios da cidadania; nos acampamentos dos privados de direitos ou refugiados, a pura sobrevivência se torna o fundamento das reivindicações políticas. Assim, grupos particulares moldam problemas específicos e resoluções para questões de vida contemporânea, desterritorializando aspectos da cidadania que são reconfigurados em cada espaço.

Na Índia, Encinas (2017) argumenta que leis extraordinárias impedem a justiça inclusiva de três maneiras distintas: contornando os princípios internacionais de não repulsão; desafiando a jurisdição do Supremo Tribunal da Índia; e deslegitimando leis favoráveis aos migrantes nas regiões de Assam, Jammu e Caxemira. O problema também é percebido ao norte da Índia, onde há enclaves que são remanescentes da divisão da Índia britânica em 1947 e que, por causa das reivindicações de soberania e dificuldades de contatos administrativos com o Reino Unido devidas à distância, provocaram violações aos direitos de pessoas que habitavam a região (JONES, 2009).

Identidade e cidadania são reforçadas quando os sistemas de registro civil e de estatísticas de vida são administrados efetivamente pelo Estado (BROLAN; GOUDA, 2017). Ainda de acordo com Brolan e Gouda (2017), os contextos sociopolíticos em que esses dois conceitos coexistem são interligados com o registro e esta ação, fundamentada em convenções internacionais, pode auxiliar na mitigação da apatridia. Vrăbiescu (2017) também argumenta neste favor. Neste sentido, Foster et al. (2016) apresenta a situação da Austrália indicando que esta deveria adotar um procedimento dedicado para a identificação e conferência de status legal para pessoas apátridas no país, pois isto auxiliaria na sua proteção e na garantia de direitos. Em adição e com recomendações semelhantes, Haina e Wanyuan (2017) e Pan (2015) introduzem as questões de nacionalidade na China.

Rawlings (2012) analisou como a condição de apatridia nas Novas Hébridas (New Hebride, hoje Vanuatu), no período de 1906 a 1980, resultou em experiências cumulativas de limitações que a ausência de cidadania legal trouxe em direitos políticos e sociais, especialmente sobre propriedade e alfândega, questões vitais no processo de descolonização de Vanuatu. Al-Nakib (2011) entrevistou grupos de estudantes sobre cidadania, nacionalismo, direitos humanos e democracia no Kuwait, identificando inconsistências sobre as compreensões dos conceitos. No país, a cidadania é baseada na 


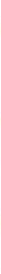

nacionalidade, gênero e idade e diversas pessoas sofrem com a negação de direitos e serviços, inclusive os Bidoons - grupo apátrida local.

Outros artigos que compõem o universo desta pesquisa desenvolveram estudos paralelos em que a apatridia não era o tema central, mas aparecia de alguma forma. Chawla et al. (2017) analisaram tratados legais internacionais sobre os cuidados cirúrgicos urgentes e essenciais e a anestesia, conduzindo uma revisão de literatura baseada em direitos humanos. Com um viés reflexivo-crítico, Durham (2013) aborda a questão do outro, do indígena que é costumeiramente percebido com aquele que precisa de ajuda e que, apesar de ser o usuário original da terra, deve ser "ajudado" com a colonização e a atribuição de uma nacionalidade. Staples (2011) que aborda a dificuldade da teoria política em atualizar o debate sobre direitos humanos, principalmente no que concerne às suas bases liberais. Hann (2015) que analisa três livros sobre direitos humanos frente o pensamento de Hannah Arendt. Jengić, Jonovska e Perkić (2008) que avaliaram o estado de saúde de apátridas doentes mentais na Croácia. E Gibbings (2010) que identifica as condições em que a campanha para celebrar as pessoas que morreram no SIEV X passou de ser um interesse minoritário para se tornar uma causa amplamente apoiada por australianos em todo o país.

\section{CONSIDERAÇÕES FINAIS}

A condução deste trabalho resultou em um ensaio argumentativo que cobriu o estado da arte sobre apatridia e direitos humanos, tomando por universo a pesquisa na base de dados Web of Science ${ }^{\mathrm{TM}}$ e o período compreendido entre os anos de 1981 e 2017. Lidar com estado da arte é um desafio particular, pois o termo pode ser entendido como o universo de estudos sobre determinado tema. Aqui a delimitação é clara e objetiva, podendo ser expandida para cobrir as limitações deste ensaio, como uma pesquisa que abranja outras bases de dados de reconhecimento internacional, tal como Scopus, ou um estudo exclusivamente brasileiro, que poderia mapear a produção nacional.

Como principais resultados da leitura e interpretação dos textos selecionados, indicam-se a renovada atenção que a ONU e demais organizações internacionais têm prestado quando se consideram os julgamentos entregues pelos tribunais regionais de direitos humanos, bem como casos específicos que têm atraído a atenção de 


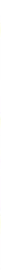

acadêmicos, por exemplo, a migração dos mulçumanos Rohingyas. A dificuldade na implantação de ações contrárias à apatridia pode ser resumida na ausência de procedimentos de determinação de apatridia, resistência contra a concessão de residência legal, interpretações variadas da definição de apátrida acompanhadas das dificuldades de monitoramento e supervisão internacionais. Parafraseando Hannah Arendt, os direitos humanos só podem existir através de acordos e garantias mútuos, estabelecidos por uma comunidade de nações. Desta forma, a atenção e o debate sobre a apatridia continuam válidos, mas precisam atingir às comunidades internacionais e demonstrar que há melhorias com o investimento de organizações como a ONU, mas ainda há espaço para atuação e melhorias na garantia à cidadania.

A produção acadêmica sobre apatridia e direitos humanos, aqui entendidos como indissociáveis no estudo da condição humana daqueles que não possuem nacionalidade, ainda é escassa e concentrada em poucos países. Os artigos foram publicados na última década, no período de 2006 a 2017, com ápices nos últimos anos. Tanto a escassez de publicações sobre o tema, especialmente em trabalhos teóricos, quanto rápido crescimento de interesse no assunto nos últimos cinco anos são indicativos de um campo de pesquisa ainda frutífero e em pleno desenvolvimento, implicando na possibilidade de novos estudos teóricos e empíricos que vislumbrem este alcance.

\section{REFERÊNCIAS}

AHSAN ULLAH, A. K. M. Rohingya Crisis in Myanmar: Seeking Justice for the "Stateless". Journal of Contemporary Criminal Justice, v. 32, n. 3, p. 285-301, 2016.

AL-NAKIB, R. Citizenship, nationalism, human rights and democracy: a tangling of terms in the Kuwaiti curriculum. Educational Research, v. 53, n. 2, p. 165-178, 2011.

AVARA, H.; MASCITELLI, B. 'Do as We Say, Not as We Do': EU to Turkey on Roma/Gypsy Integration. European Review, v. 22, n. 1, p. 129-144, 2014.

BAPTISTA, D. M. T.; LISBOA, M. V. União Europeia, seus imigrantes e direitos humanos. Cadernos do CEAS: Revista crítica de humanidades, n. 239, p. 973-993, 2017.

BBC Brasil. Quem são os rohingyas, povo muçulmano que a ONU diz ser alvo de limpeza étnica. British Broadcasting Corporation, 2017. Disponível em: http://www.bbc.com/portuguese/internacional-41257869 Acesso em: 31 jan 2018.

BELTON, K. A. Dry land drowning or rip current survival? Haitians without status in the Bahamas. Ethnic and Racial Studies, v. 34, n. 6, p. 948-966, 2011. 


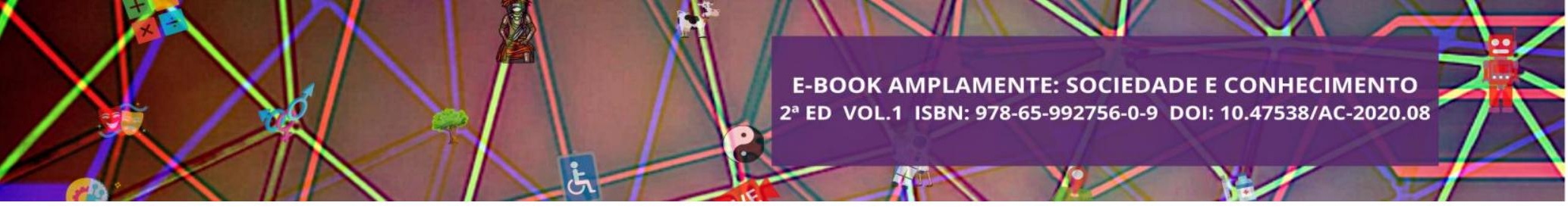

BICHARA, J. O tratamento do apátrida na nova lei de migração: entre avanços e retrocessos. Revista de Direito Internacional, v. 14, n. 2, 2017.

BHABHA, J. Arendt's Children: Do Today's Migrant Children have a right to have rights?. Human Rights Quarterly, v. 31, n. 2, p. 410-451, 2009.

BLITZ, B. K. Statelessness and environmental-induced displacement: future scenarios of deterritorialisation, rescue and recovery examined. Mobilities, v. 6, n. 3, p. 433-450, 2011.

BLITZ, B. K.; OTERO-IGLESIAS, M. Stateless by any other name: refused asylumseekers in the United Kingdom. Journal of Ethnic and Migration Studies, v. 37, n. 4, p. 657-573, 2011.

BRADLEY, M. Rethinking refugeehood: statelessness, repatriation, and refugee agency. Review of International Studies, v. 40, n. 1, p. 101-123, 2014.

BROLAN, C. E.; GOUDA, H. Civil Registration and Vital Statistics, Emergencies, and International Law: Understanding the Intersection. Medical law review, v. 25, n. 2, p. 314-339, 2017.

BROOTEN, L.; ASHRAF, S. I.; AKINRO, N. A. Traumatized victims and mutilated bodies: Human rights and the 'politics of immediation'in the Rohingya crisis of Burma/Myanmar. International Communication Gazette, v. 77, n. 8, p. 717-734, 2015 .

BROOTEN, L. Blind Spots in Human Rights Coverage: Framing Violence Against the Rohingya in Myanmar/Burma. Popular Communication, v. 13, n. 2, p. 132-144, 2015.

CAHN, C. Minorities, citizenship and statelessness in Europe. European journal of migration and law, v. 14, n. 3, p. 297-316, 2012.

CHAWLA, K. S.; RUTKOW, L.; GARBER, K.; KUSHNER, A. L.; STEWART, B. T. Beyond a Moral Obligation: A Legal Framework for Emergency and Essential Surgical Care and Anesthesia. World journal of surgery, v. 41, n. 5, p. 1208-1217, 2017.

DE CHICKERA, A. The Human Rights of Stateless Persons in Europe-Interview wit Commissioner Thomas Hammarberg. Eur. J. Migration \& L., v. 14, p. 327, 2012.

DE GROOT, R; VONK, O. Nationality, statelessness and ECHR's article 8: Comments on Genovese v. Malta. European Journal of Migration and Law, v. 14, n. 3, p. 317$325,2012$.

DOLINGER, J. Direito Internacional Privado. 9. ed. Rio de Janeiro: Renovar, 2008.

DURÀ, J. Refugees and stateless persons. Political asylum and international protection in spain: trends in numbers and red tape. Mètode Science Studies Journal, n. 5, p. 5963, 2015.

DURHAM, J. Against internationalism. Third Text, v. 27, n. 1, Special Issue, p. 29-32, 2013. 


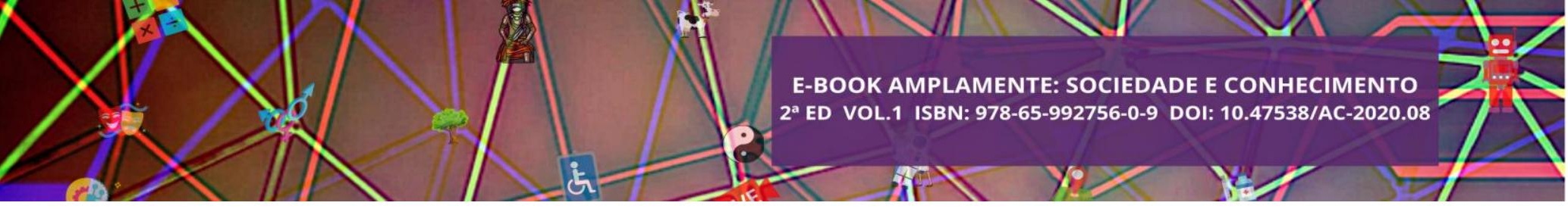

ENCINAS, M. Migrant Rights and Extraordinary Law in India: The Cases of Assam and Jammu \& Kashmir. South Asia: Journal of South Asian Studies, v. 40, n. 3, p. 463-480, 2017.

FEIN, Lisa C.; STRAUGHN, J. B. How citizenship matters: narratives of stateless and citizenship choice in Estonia. Citizenship Studies, v. 18, n. 6-7, p. 690-706, 2014.

FOSTER, M.; LAMBERT, H. Statelessness as a Human Rights Issue: A Concept Whose Time Has Come. International Journal of Refugee Law, v. 28, n. 4, p. 564$584,2016$.

FOSTER, M.; MCADAM, J.; WADLEY, D. Part one: The protection of stateless persons in Australian law-the rationale for a statelessness determination procedure. Melb. UL Rev., v. 40, p. 401, 2016.

GIBBINGS, B. Remembering the SIEV X: who cares for the bodies of the stateless, lost at sea?. The public historian, v. 32, n. 1, p. 13-30, 2010.

GÓMEZ, N. B. A critical approach to Hannah Arendt's concept of worldliness and its applicability in the social sciences. Human Affairs, v. 26, n. 2, p. 201-211, 2016.

GONZALEZ GALLEGO, A. The oblivion of human rights (G. Agamben, R. Esposito). Convivium, v. 21, p. 83-97, 2008.

GUERRA, S. Curso de Direito internacional Público. 8. ed. São Paulo: SARAIVA, 2014.

HAINA, L.; WANYUAN, H. Protection of Stateless Persons in China: A Human Rights Perspective. Frontiers of Law in China, v. 12, n. 3, p. 404-428, 2017.

HANN, M. Human rights, the state, and recognition. Journal of Moral Philosophy, v. 12, n. 5, p. 639-650, 2015.

HOWARD-HASSMANN, R. E. The human rights of stateless persons - reply. Human Rights Quarterly, v. 28, n. 1, p. 277-278, 2006.

ILLUZZI, J. Negotiating the 'state of exception': Gypsies' encounter with the judiciary in Germany and Italy, 1860-1914. Social history, v. 35, n. 4, p. 418-438, 2010.

JENGIĆ, V. S.; JONOVSKA, S.; PERKIĆ, N. Mental illness and ethnicity-being a stateless person (apatride). Psychiatria Danubina, v. 20, n. 3, p. 443-445, 2008.

JONES, R. Sovereignty and statelessness in the border enclaves of India and Bangladesh. Political Geography, v. 28, n. 6, p. 373-381, 2009.

KATTAGO, S. The End of the European Honeymoon?: Refugees, Resentment and the Clash of Solidarities. Anthropological Journal of European Cultures, v. 26, n. 1, p. 35-52, 2017.

KENT, A. Evaluating the Palestinians' Claimed Right of Return. University of Pennsylvania Journal of International Law, v. 34, p. 149, 2012. 


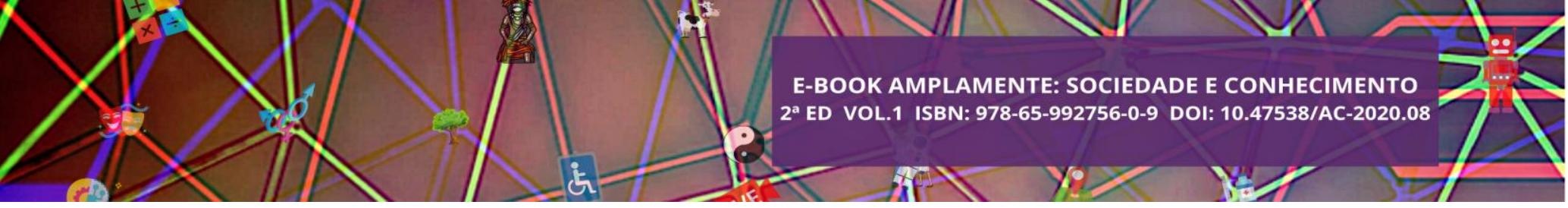

KINGSTON, L. N. Protecting the world's most persecuted: the responsibility to protect and Burma's Rohingya minority. The International Journal of Human Rights, v. 19, n. 8, p. 1163-1175, 2015.

KINGSTON, L. N.; COHEN, E. F.; MORLEY, C. P. Debate: Limitations on universality: the "right to health" and the necessity of legal nationality. BMC international health and human rights, v. 10, n. 1, p. 11, 2010.

KINGSTON, L. N.; STAM, K. R. Recovering from statelessness: Resettled BhutaneseNepali and Karen refugees reflect on the lack of legal nationality. Journal of Human Rights, v. 16, n. 4, p. 389-406, 2017.

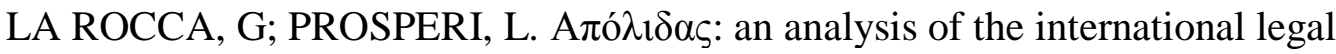
framework in the field of statelessness and the UNHCR's communication campaign. International Review of Sociology, v. 27, n. 2, p. 261-276, 2017.

LAFER, C. A reconstrução dos direitos humanos: a contribuição de Hannah Arendt. Estudos avançados, v. 11, n. 30, p. 55-65, 1997.

LAMBERT, H. Comparative Perspectives on Arbitrary Deprivation of Nationality and Refugee Status. International \& Comparative Law Quarterly, v. 64, n. 1, p. 1-37, 2015.

LECHTE, J.; NEWMAN, S. Agamben and the politics of human rights: statelessness, images, violence. Edinburgh University Press, 2013.

LECHTE, J.; NEWMAN, S. Agamben, Arendt and human rights: Bearing witness to the human. European Journal of Social Theory, v. 15, n. 4, p. 522-536, 2012.

LIMBADA, Z.; DAVIES, L. Addressing the Foreign Terrorist Fighter Phenomenon from a Human Rights Perspective. International Community Law Review, v. 18, n. 5, p. 483-493, 2016.

MAHMOOD, S. S.; WROE, E.; FULLER, A.; LEANING, J. The Rohingya people of Myanmar: health, human rights, and identity. The Lancet, v. 389, n. 10081, p. 18411850, 2017.

MENZ, S. Statelessness and Child Marriage as Intersectional Phenomena: Instability, Inequality, and the Role of the International Community. California Law Review, v. 104, p. 497, 2016.

MENEGHETTI, F. K. O que é um ensaio-teórico? RAC-Revista de Administração Contemporânea, v. 15, n. 2, 2011.

MESQUITA, R. F.; MATOS, F. R. N. A abordagem qualitativa nas ciências administrativas: aspectos históricos, tipologias e perspectivas futuras. Revista Brasileira de Administração Científica, v. 5, n. 1, p. 7-22, 2014.

MEYER, J. W. World society, institutional theories, and the actor. Annual review of sociology, v. 36, p. 1-20, 2010. 


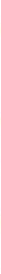

STAPLES, K. Statelessness, sentimentality and human rights: A critique of Rorty's liberal human rights culture. Philosophy \& Social Criticism, v. 37, n. 9, p. 1011-1024, 2011.

STONEBRIDGE, L. Refugee style: Hannah Arendt and the perplexities of rights. Textual Practice, v. 25, n. 1, p. 71-85, 2011.

SWIDER, K.; DEN HEIJER, M. Why Union Law Can and Should Protect Stateless Persons. European Journal of Migration and Law, v. 19, n. 2, p. 101-135, 2017.

VAN WAAS, L. 'Are we there yet?'The Emergence of Statelessness on the International Human Rights Agenda. Netherlands Quarterly of Human Rights, v. 32, n. 4, p. 342-346, 2014.

VRĂBIESCU, I. Non-and dedocumenting citizens in Romania: Nonrecording as a civil boundary. Focaal, v. 2017, n. 77, p. 22-35, 2017.

WALKER, D. J. Statelessness: Violation or conduit for violation of human rights. Human Rights Quarterly, v. 3, p. 106, 1981.

WEISSBRODT, D. S.; COLLINS, C. The human rights of stateless persons. Human Rights Quarterly, v. 28, n. 1, p. 245-276, 2006.

WILMER, S. E. Playing with citizenship: NSK and Janez Janša. Citizenship Studies, v. 16, n. 5-6, p. 827-838, 2012.

ZEDNER, L. Citizenship deprivation, security and human rights. European Journal of Migration and Law, v. 18, n. 2, p. 222-242, 2016.

ZEN, C. E. A prevenção a apatridia no contexto internacional. Revista Brasileira de Direito Internacional-RBDI, v. 5, n. 5, p. 93-115, 2007. 


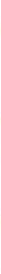

e mulheres presos, convivendo em constantes conflitos e sob o jugo da violação dos direitos humanos.

Trata-se de uma realidade resultante da ausência de uma política institucional definida e estruturada em níveis nacionais que construa novos parâmetros e objetivos para o sistema penitenciário além da segurança e do encarceramento (TORRES, 2001).

Conforme Thompson (1993), seja qual for a pessoa confinada em uma prisão, ela se sujeita, em alguma medida, ao fenômeno de prisionização. Trata-se do aprisionamento que é, sem dúvida, um processo necessário para a ordem social, porém de assimilação sociocultural lenta por parte dos detentos, ou seja, é o entender a cultura da prisão, a qual dificilmente é aceita.

Convém pontuar dois aspectos peculiares da situação caótica do sistema prisional brasileiro atual, de acordo com as notícias veiculadas nos jornais televisivos e online: primeiro a superlotação, que não se conta apenas por um maior número de novos infratores, mas pelo problema da reincidência; segundo as misérias decorrentes da superlotação, que são absurdas porque consistem na própria falta de humanização, em que os presos são obrigados a conviver em espaços minúsculos — por cela — durante horas seguidas, suportando-se.

Há, ainda, detalhes sórdidos não só no mesmo contexto, mas no âmbito dos presídios como um todo, sendo nele e para ele que o Serviço Social tem incumbências legal e eticamente estabelecidas, sempre fundamentado no que se encontra definido na Declaração Universal dos Direitos Humanos. Assim, o Assistente Social tem atribuições de extrema importância e permeada de consideráveis desafios no âmbito do sistema penitenciário, que teve início na década de 40 (CFESS, 2008).

Deste modo, considerando a situação caótica do sistema penitenciário brasileiro e destacando-se a superlotação, em contrapartida aos Direitos Humanos, surgiram os seguintes questionamentos: a) Quais as atribuições específicas do Assistente Social relativas ao sistema penitenciário?; b) Quais os principais desafios do Serviço Social frente ao caos em que se encontra o sistema penitenciário?; e c) O Serviço Social pode contribuir para a concretização dos Direitos Humanos no sistema penitenciário brasileiro?

Assim, o presente estudo parte hipótese segundo a qual "o Serviço Social contribui com êxito para a concretização dos Direitos Humanos, conforme o que é designado ao profissional assistente social nas unidades penais, pela Lei de Execução 


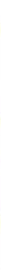

Penal (LEP), n. 7.210, de 11 de julho de 1984, nos seus artigos 22 e 23, que tratam da Assistência Social”.

Contudo, além de ser necessário que o Assistente Social conheça o Código de Ética Profissional e a LEP, é relevante, também, que conheça os principais tratados de proteção dos direitos humanos acordado pela Organização das Nações Unidas (ONU), buscando aprofundar a respeito da defesa dos direitos humanos, a exemplo dos presos que se encontrem sobre pena privativa de liberdade, haja vista que o compromisso do Serviço Social no Campo da Execução Penal deve ser o de garantir os direitos humanos dos internos, fortemente violados no espaço prisional (SANTOS, 2015).

Por essas razões, o tema proposto neste artigo de revisão de literatura é importante para profissionais atuantes no sistema penitenciário, não apenas assistentes sociais, bem como para os acadêmicos de Serviço Social e para a sociedade.

Assim sendo, o artigo em questão tem como objetivo analisar o Serviço Social na concretização dos direitos humanos no contexto do sistema penitenciário, com base nos estudos até então publicados e especificamente apontar os principais desafios do sistema penitenciário para o Serviço Social, apresentar os tipos de atividades desenvolvidas pelo Serviço Social junto aos apenados e respectivos familiares na instituição prisional e por fim discutir acerca dos limites e possibilidades no tocante à realização de atividades socioeducativas com os apenados.

Para elaboração deste artigo de revisão, foi realizada pesquisa bibliográfica, tendo como método de coleta pesquisa de artigos e livros, via Internet, bem como na Biblioteca da Universidade Tiradentes e nos respectivos acervos particulares das pesquisadoras. Assim sendo, a pesquisa bibliográfica se caracteriza conforme os seguintes tipos: de acordo com o gênero, o método é teórico; segundo o objetivo, é descritiva e explicativa; conforme a abordagem, é qualitativa; e, no tocante à natureza, é uma pesquisa básica.

Desse modo, as pesquisadoras, após leitura, selecionaram os estudos, bem como leis pertinentes ao tema, a exemplo da já citada LEP. Dentre as publicações pesquisadas, compuseram a pesquisa, principalmente, os seguintes autores: Fabio Lobosco Silva (2016), Claudiana Avelino Almeida; Suelen Saraiva da Cruz (2014), Sandra Regina de Abreu Pires (2013), Simone Felix Marques (2012) e Wesley Botelho Alvim (2006). 


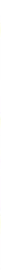

No quadro abaixo, encontram-se informações sobre os principais artigos (periódico/ano, autor(es), título e método) utilizados para a elaboração do presente artigo de revisão:

Quadro 1: Principais trabalho e artigos referenciados neste artigo de revisão

\begin{tabular}{|c|c|c|c|}
\hline PERIÓDICO/ANO & AUTOR(ES) & TÍTULO/ANO & MÉTODO \\
\hline $\begin{array}{l}\text { Universidade } \\
\text { Presbiteriana } \\
\text { Mackenzie, } \\
\text { Doutoramento em } \\
\text { Direito Político e } \\
\text { Econômico/2016 }\end{array}$ & Fabio Lobosco Silva & $\begin{array}{l}\text { Sobre um novo } \\
\text { conceito de } \\
\text { prisionização: o } \\
\text { fenômeno da } \\
\text { assimilação prisional } \\
\text { de acordo com a } \\
\text { realidade prisional } \\
\text { brasileira }\end{array}$ & $\begin{array}{l}\text { Estudo teórico } \\
\text { (criminológico, } \\
\text { filosófico e } \\
\text { psicológico) } \\
\text { descritivo, } \\
\text { exploratório e quali- } \\
\text { quativativo. }\end{array}$ \\
\hline $\begin{array}{l}\text { Revista Direito \& } \\
\text { Dialogicidade / } \\
\text { 2014. }\end{array}$ & $\begin{array}{l}\text { Claudiana Avelino } \\
\text { Almeida; Suelen } \\
\text { Saraiva da Cruz. }\end{array}$ & $\begin{array}{l}\text { Sistema penitenciário } \\
\text { brasileiro: uma } \\
\text { análise da } \\
\text { Penitenciária } \\
\text { Industrial Regional } \\
\text { do Cariri - PIRC. }\end{array}$ & $\begin{array}{l}\text { Estudo descritivo e } \\
\text { exploratório, de } \\
\text { campo e qualitativo. }\end{array}$ \\
\hline $\begin{array}{l}\text { Textos \& Contextos } \\
\text { / } 2013\end{array}$ & $\begin{array}{l}\text { Sandra Regina de } \\
\text { Abreu Pires. }\end{array}$ & $\begin{array}{l}\text { Sobre a prática } \\
\text { profissional do } \\
\text { assistente social no } \\
\text { sistema penitenciário. }\end{array}$ & $\begin{array}{l}\text { Estudo exploratório e } \\
\text { descritivo de } \\
\text { pesquisas } \\
\text { bibliográficas e de } \\
\text { campo. }\end{array}$ \\
\hline $\begin{array}{l}\text { Superintendência } \\
\text { dos Serviços } \\
\text { Penitenciários } \\
\text { (SUSEPE) / } 2012 .\end{array}$ & Simone Felix Marques. & $\begin{array}{l}\text { O Desacreditável e o } \\
\text { Desacreditado: } \\
\text { Considerações sobre } \\
\text { o fazer técnico do } \\
\text { Assistente Social no } \\
\text { Sistema Prisional. }\end{array}$ & $\begin{array}{l}\text { Estudo descritivo } \\
\text { subanalítico do } \\
\text { trabalho de Erving } \\
\text { Goffman, in: Notas } \\
\text { sobre a manipulação } \\
\text { da identidade } \\
\text { deteriorada (1988). }\end{array}$ \\
\hline $\begin{array}{l}\text { UFSC - Centro de } \\
\text { Ciências Jurídicas / } \\
2006 .\end{array}$ & Wesley Botelho Alvim. & $\begin{array}{l}\text { A ressocialização do } \\
\text { preso brasileiro. }\end{array}$ & $\begin{array}{l}\text { Estudo descritivo, } \\
\text { explicativo e } \\
\text { analítico. }\end{array}$ \\
\hline
\end{tabular}

Fonte: Autoras da Pesquisa (2017).

Por se tratar de uma pesquisa qualitativa, os dados foram analisados pelo método "análise de conteúdo", que busca o(s) sentido(s) dos estudos, sendo muito comum nesse tipo de abordagem, conforme esclarecido por Campos (2004).

Assim sendo, o conteúdo do desenvolvimento a ser analisado, encontra-se na segunda seção - Revisão da Literatura -, que está dividida em duas subseções, a primeira das quais apresenta um item, e que tratam do seguinte:

A primeira subseção aborda o Sistema Penitenciário Brasileiro, no que diz respeito à realidade atual (conhecidamente caótica) e que vai de encontro aos Direitos 


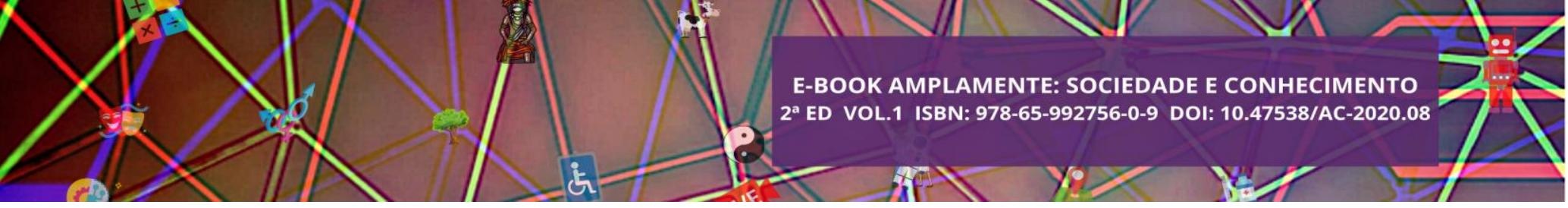

Humanos, assim como revela problemas de segurança pública e quantitativos conforme o Levantamento Nacional de Informações Penitenciárias (Infopen) de 2014.

O item 2.1.1 apresenta incoerência entre o que estabelece a Declaração Universal dos Direitos Humanos e a Constituição Federal Brasileira de 1988 e a realidade do Sistema Penitenciário Brasileiro, que consiste em obstáculo para que os presos retornem ao convívio social, na condição de seres humanos dignos e, portanto, detentores de direitos e deveres.

A segunda subseção apresenta a contribuição do Serviço Social para a concretização dos Direitos Humanos no sistema penitenciário brasileiro, destacando pontos como reincidência criminal e ressocialização dos presos, e de que modo o Assistente Social deve agir, e se tem meios, para reduzir tal realidade.

\section{REVISÃO DA LITERATURA}

\section{SISTEMA PENITENCIÁRIO BRASILEIRO}

Qualquer menção referente ao sistema penitenciário brasileiro atual vincula-se à questão da segurança pública, porque, conforme a própria expressão indica, significa garantir tranquilidade aos cidadãos. Uma das interpretações iniciais é que o número de presos é elevado porque existem políticas públicas de segurança. Cabe destacar que políticas públicas de segurança consistem em polícias, centros de reabilitação, cursos de aperfeiçoamento, sistema prisional, judiciário etc.

Todavia, conforme Robson Sávio Reis Souza (2011, p. 1), pesquisador do Centro de Estudos de Criminalidade e Segurança Pública (Crisp) da Universidade Federal de Minas Gerais (UFMG) e associado do Fórum Brasileiro de Segurança Pública:

Os problemas da segurança pública brasileira são reflexos de um legado político autoritário: uma engenharia político-institucional que conecta os dilemas da violência urbana atual ao passado da violência rural. As bases do sistema público de segurança (ainda) estão assentadas numa estrutura social historicamente conivente com a violência privada, a desigualdade social, econômica e jurídica e os "déficits de cidadania" de grande parte da população.

Nota-se, portanto, que os empecilhos institucionais, sobretudo aqueles referentes às modificações substantivas não realizadas nas estruturas organizacionais das agências 


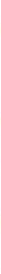

responsáveis pela concretização das políticas de segurança, dificultaram transformações estruturais que seriam essenciais para o fim dos antigos padrões que fundamentam a política de segurança pública no Brasil, a qual conserva e intensifica o caótico sistema penitenciário.

Em 2014, foi publicado o último Levantamento Nacional de Informações Penitenciárias (Infopen) (BRASIL, 2014) que mostra, dentre outros dados, 1424 (mil quatrocentos e vinte e quatro) unidades prisionais no Brasil, das quais, quatro são federais e as outras são estaduais. Em Roraima, encontra-se o menor número (cinco) e em Minas Gerais, 184, que é o maior número dessas unidades. Porém, embora não se destaque nos quesitos de população carcerária, em que se encontra em $7^{\circ}$ lugar; nem em taxa de aprisionamento, que é liderada pelo Mato Grosso do Sul; tampouco em taxa de ocupação do sistema prisional (proporção de pessoas encarceradas por vagas), sendo muito maior a de Pernambuco, o Ceará tem o terceiro maior número de unidades prisionais em seu território, sendo o primeiro e segundo, respectivamente, Minas Gerais e São Paulo.

Também conforme o referido levantamento, a capacidade de vagas nas prisões brasileiras não é uniforme, destacando-se São Paulo com 2.696 vagas e Tocantins com maior capacidade, pois pode encarcerar 432 indivíduos. Ademais, devido ao inchaço populacional brasileiro e considerando o contexto histórico, muitas unidades prisionais mantêm presos de diferentes regimes, embora tenham como proposta original manter determinado tipo penal. Isto se justifica pelo fato de que $18 \%$ dessas unidades têm mais de trinta anos de existência.

A esse respeito, em sua tese que aborda o sistema prisional enquanto fenômeno da assimilação prisional conforme a realidade prisional no Brasil, Silva (2016, p. 133) ressalta:

Cotejando tais dados é possível afirmar que apesar de mais da metade das unidades se destinarem a presos provisórios, $84 \%$ delas também albergam condenados. Das destinadas ao regime fechado, $80 \%$ também albergam indivíduos de outros regimes. Por fim, oito em cada dez unidades custodiam pessoas de mais de um tipo de regime ou natureza de prisão (SILVA, 2016, p. 133).

O autor conclui afirmando ser evidente que para os fins a que se propõe, "tal mistura não pode ser positiva", tendo em vista o fato de que "a assimilação prisional é fenômeno de interesse variável", dependente de fatores próprios dos presos, como 


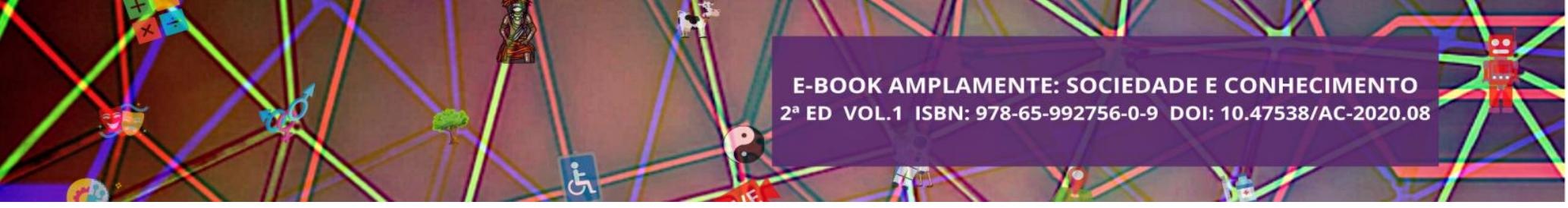

aspectos subjetivos, motivações e características pessoais. Desse modo, o fato de manter condenados juntos com presos provisórios, os quais apresentam diferentes graus de aprisionamento, promove-se influência mútua (SILVA, 2016, p. 133).

No que diz respeito à privação da liberdade, foi apenas no século XIX, que "consagrou-se como a mais conveniente forma de punição, sustentada em discurso que ressaltava seu caráter retributivo, a preservação da integridade do condenado, bem como a possibilidade de sua posterior reintegração social” (GALVÃO, 2016, p. 476).

O autor acrescenta que:

A liberdade que é atingida pela pena é apenas a liberdade ambulatória [não locomoção para fora dos limites da prisão], preservando-se ao preso todas as demais formas de manifestação da liberdade que não impliquem em locomoção para fora dos limites físicos do estabelecimento prisional. Portanto, o condenado ainda é livre para pensar, manifestar licitamente seu pensamento, comunicar-se com as demais pessoas etc. (GALVÃO, 2016, p. 476).

Contudo, a privação da liberdade é mais ampla do que sua concepção no contexto do estabelecimento prisional. Acerca disto, Pires (2013, p. 362) afirma que:

Em meio aos estudos já existentes acerca da trajetória histórica das sanções penais, é consensual o reconhecimento de que a pena privativa de liberdade e de que a prisão como espaço para seu cumprimento nascem e se desenvolvem tendo como propósito, pelo menos em termos de discurso, o atendimento de uma tripla finalidade: punir o infrator, prevenir novos delitos e recuperar a pessoa presa. É consensual também que a ênfase deveria recair sobre a ressocialização, se constituindo essa na finalidade primordial atribuída socialmente à prisão moderna desde o seu surgimento em fins do século XVIII.

Referindo-se a outras palavras relacionadas à ressocialização do preso, a autora destaca com o que se concorda para fins do presente estudo: "Ou outros termos afins como recuperação, reeducação, reintegração, reabilitação" (PIRES, 2013, p. 371).

Desse modo, entende-se que, no sistema penal atual, a privação da liberdade apresenta-se como forma de intervenção repressiva, atingindo diretamente a liberdade do condenado, que ficará recolhido em estabelecimento prisional.

Assim sendo, concorda-se com Sá (2005) que, ao afirmar que os termos "reabilitação" e "ressocialização" são contrapostos por meio da responsabilidade que a sociedade passa a ter em tal processo, ou seja, (re)inclui, através da reintegração social aqueles que ela excluiu, a fim de que tenham uma participação ativa. Esta participação resulta da perspectiva dessas pessoas como sujeitos, não como objetos de assistência. 


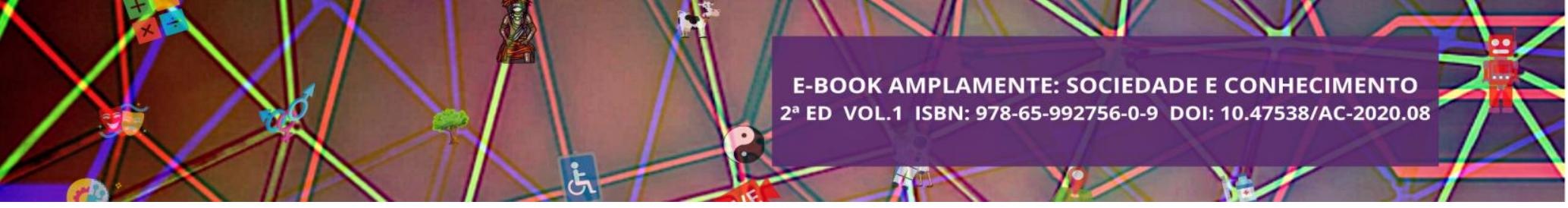

\section{DIREITOS HUMANOS $X$ SISTEMA PENITENCIÁRIO}

Algumas das instituições que compõem o sistema sociojurídico, as prisões são instrumentos do Estado, no tocante ao seu caráter burocrático bem como de legalidade, que têm como objetivos preservar ou suprimir direitos, garantir a ordem pública, extinguir conflitos no âmbito privado, punir e custodiar, proteger e assegurar direitos, ou seja: elas formam um conjunto de ações contraditórias e inerentes à função do próprio Estado de direito (PEREIRA, 2005).

Considerável parte dos Direitos Humanos encontra-se na Constituição Federal de 1988 , no tocante às garantias individuais e coletivas dos cidadãos brasileiros; no caput do art. $5^{\circ}$ : "Todos são iguais perante a lei, sem distinção de qualquer natureza, garantindo-se a brasileiros e estrangeiros residentes no país a inviolabilidade do direito a vida, a liberdade, a igualdade, a segurança e a propriedade".

Assim sendo, os presos fazem parte deste "Todos", de modo que deveriam ser sujeitos de direitos. Deveriam porque a realidade é outra, uma vez que tais direitos são violados de forma que "vivem" “em uma condição de liberdade privada e excluídos, impedidos do convívio social” (ALMEIDA; CRUZ, 2014, p. 75).

Ainda conforme os referidos autores, além de não se apropriarem dos próprios direitos, os presos deveriam cumprir o que determinam as normas de execução das penas, mas, sempre em conformidade com os direitos humanos, ou seja, tendo integridade física e moral respeitada por parte das autoridades e de todos os que trabalham na esfera do sistema prisional (ALMEIDA; CRUZ, 2014).

De fato, não resta dúvida sobre a existência de direitos e deveres legalmente constituídos, no entanto, encontram-se no texto da lei e em outros discursos em que cidadãos conscientes reclamam sobre esta difícil realidade, no intuito de chamar a atenção das autoridades competentes, acerca da violação dos direitos civis, sociais e políticos dentro das unidades prisionais brasileiras.

Cabe frisar que se trata de processo que advém da falta de uma política institucional estabelecida com novas bases e objetivos voltados para o sistema prisional, que não se limitem aos quesitos segurança e o encarceramento (TORRES, 2001). 


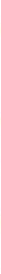

O referido autor adverte, também sobre a relação de causa e efeito envolvendo, respectivamente, as violações (físicas e morais, como espancamentos, maus-tratos, condições insalubres de habitação, castigos arbitrários e ausência de atendimento médico), e as rebeliões, algumas das quais violentas, conforme divulgado por meios de comunicação, em que os presos colocam as próprias vidas e de outras pessoas em risco, além da frustrada tentativa de fuga, que é o principal objetivo das rebeliões.

Nesse sentido, cabe ressaltar que o aumento da população carcerária manifesta a realidade da superlotação, que colabora para a inércia de uma condição de cumprimento da pena digno, obstando, desse modo, o resgate da autoestima. "Sem dúvida, este é um fator que acaba por submeter o sujeito preso a penas cruéis, humilhantes e degradantes" (MARQUES, 2012, p. 4).

Pessoas que não conseguem viver plenamente a sua humanidade, não conseguem também ver a humanidade do outro. Ainda mais se esse outro foi capaz de subtrair bens alheios, matar ou cometer outros crimes. A sociedade os rejeita imediatamente e transfere para o Estado a responsabilidade da punição - que nesses casos espera-se que sejam os mais severos possíveis - assim se sentem mais seguros (ALVIM, 2006).

O mesmo autor entende que essa realidade é devida, sobretudo, à falta de um programa que atenda as especificidades de cada preso, de modo a possibilitar o retorno dos mesmos à sociedade. Eles entram como "ladrões de galinhas" e saem "bandidos profissionais" (ALVIM, 2006). Sendo assim, não é a severidade da pela que solucionará o caos instalado, mas a criação e concretização de uma política voltada à recuperação da "humanidade", de forma a conquistar tranquilidade social.

O contexto prisional funciona com pouquíssima ou quase nula nitidez no que se refere: à gestão do dia-a-dia de presos e seus familiares; vigilância, disciplina e o controle, que aparecem como constantes e permanentes; isolamento mudo, surdo e cego; hostilidade no ambiente, com insegurança física e psicológica tanto para os presos quanto para os que trabalham nas unidades prisionais; aspectos de pré-modernidade em termos de legislação, além de promover uma série de arbitrariedades, autoritarismos, julgamentos moralizantes, ou seja, o que vai de encontro aos direitos humanos (ALMEIDA, 2006).

Desse modo, embora exista a Declaração Universal dos Direitos Humanos, a própria Lei Maior Brasileira - Constituição Federal de 1988 - e outras leis que visam à 


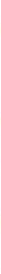

concretização desses Direitos, o Sistema Penitenciário no Brasil oferece tratamento desumano e degradante aos presos, o que parece ser devido à falta de comprometimento por parte das autoridades.

Neste sentido, parece óbvio que a superlotação só pode ser solucionada pela ampliação dos presídios existentes e pela construção de novas penitenciárias. Quanto à reintegração ao meio social, depende não apenas da expansão dos presídios, mas, também de uma série de ações, a exemplo de atividades socioeducativas, recreação, trabalho em troca de redução da pena, suporte à saúde e à família dos presos etc.

\section{O ASSISTENTE SOCIAL E SUA ATUAÇÃO NO SISTEMA PENITENCIÁRIO}

A partir dos avanços/conquistas profissionais, legalmente estabelecidos, assistentes sociais do sexo masculino começaram a atuar nas penitenciárias brasileiras, principalmente nos estados de São Paulo e do Rio de Janeiro. Em 1940, esses profissionais passaram a trabalhar no âmbito da Justiça da Juventude, como perito social, inicialmente, na condição de estagiários, ou de membros do Comissariado de Vigilância (CFESS, 2008).

Frente aos esforços pelo controle e soluções da questão social, a ocupação dos espaços institucionais do Serviço Social foi ampliada, tornando em espaço privilegiado de ação da justiça da infância e juventude, resultando na formalização do trabalho do assistente social no final da década de 40 (CFESS, 2008, p. 20).

Cabe esclarecer que

A questão social diz respeito ao conjunto das expressões das desigualdades sociais engendradas na sociedade capitalista madura, impensáveis sem a intermediação do Estado. [...]. A questão social expressa, portanto, disparidades econômicas, políticas e culturais das classes sociais, mediatizadas por relações de gênero, características ético-raciais e formações regionais, colocando em causa as relações entre amplos segmentos da sociedade civil e o poder estatal (IAMAMOTO, 2001, p. 16).

As práticas dos Assistentes Sociais consolidaram-se a partir da década de 50, quando esses profissionais tornaram-se essenciais no atendimento de populações vulneráveis, sobretudo, dos cidadãos privados de liberdade, os quais devem ser protegidos conforme a Declaração Universal dos Direitos Humanos.

Todavia, foi a partir da aprovação da LEP, n. 7.210/1984, que movimentos profissionais iniciaram a produção de diretrizes do fazer técnico no sistema prisional, 


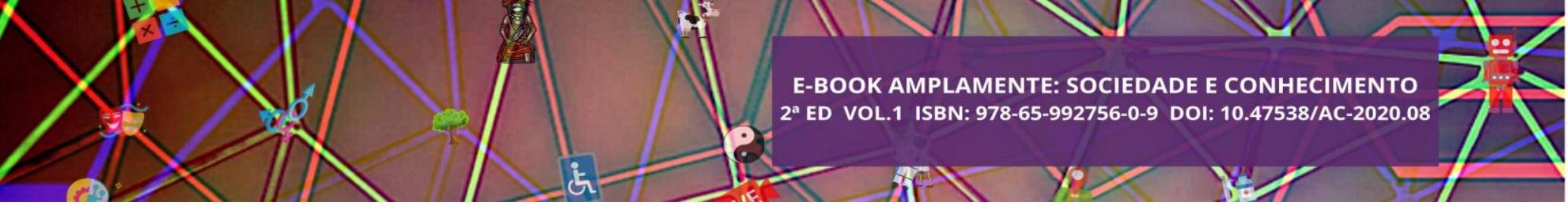

contexto em que o assistente social foi instituído nas unidades penais (IAMAMOTO, 1997).

É importante ressaltar que o sistema penitenciário se encontra legitimado pela LEP, que prevê na Seção VI - "Da Assistência Social”, precisamente no artigo 22, que "A assistência social tem por finalidade amparar o preso e o internado e prepará-los para o retorno à liberdade", também de acordo com o artigo 23:

Art. 23. Incumbe ao serviço de assistência social:

I - conhecer os resultados dos diagnósticos ou exames;

II - relatar, por escrito, ao Diretor do estabelecimento, os problemas e as dificuldades enfrentadas pelo assistido;

III - acompanhar o resultado das permissões de saídas e das saídas temporárias;

IV - promover, no estabelecimento, pelos meios disponíveis, a recreação;

$\mathrm{V}$ - promover a orientação do assistido, na fase final do cumprimento da pena, e do liberando, de modo a facilitar o seu retorno à liberdade;

VI - providenciar a obtenção de documentos, dos benefícios da Previdência Social e do seguro por acidente no trabalho;

VII - orientar e amparar, quando necessário, a família do preso, do internado e da vítima.

Assim sendo, os atendimentos sociais derivam de três frentes originárias de trabalho: espontânea, identificada ou determinações judiciais. Quando provêm de demandas espontâneas, os atendimentos se configuram prioritários nos casos em que os presos solicitam atendimento técnico através de listas por eles assinadas. Tal modalidade pode, também, concretizar-se a partir de encaminhamentos internos advindos de outras áreas técnicas, a exemplo de enfermagem, psicológica e jurídica, ou de agentes penitenciários. Pode, ainda, derivar de contato de familiares, obviamente, a partir do que entenderem ser necessário ao encarcerado (VIEGAS, 2015).

No mesmo sentido, o Assistente Social também pode, a partir dos seus instrumentais técnico-operativos, identificar a necessidade de acompanhar o usuário, realizando entrevista periodicamente, enquanto estiver cumprindo a pena que cabe ao mesmo (VIEGAS, 2015).

O Código de Ética dos Assistentes Sociais, de 1993, resulta da história do Serviço Social no Brasil, expressando um avanço ético e político, produto de uma construção coletiva, sendo uma ferramenta de orientação para o profissional fundamentar suas ações, que consistem no atendimento as demandas sociais colocadas à profissão. Assim sendo, ao visarem garantir uma sociedade justa e igualitária, os valores 


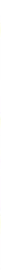

éticos e políticos fundamentam-se, sobretudo, nos seguintes princípios: equidade, democracia, cidadania, liberdade (TORRES, 2001).

No entanto, conhecidas como depósitos de indivíduos socialmente excluídos, as prisões reforçam, desde sempre, o próprio caráter repressor e punitivo. Nesse contexto, a atuação do Assistente Social voltada para a ressocialização dos presos situa-se em conflito com os objetivos da instituição penitenciária.

Assim sendo, um dos desafios enfrentados pelo Assistente Social no contexto do sistema prisional no Brasil encontra-se nas dificuldades para promover a reintegração dos presos à sociedade, após longos períodos de reclusão, porque muitos deles perdem vínculo familiar, não conseguem emprego e alguns cogitam o retorno à criminalidade. É com essas possibilidades que o assistente social trabalha na proteção e defesa dos direitos dos apenados. Esse profissional busca mecanismos e articulações para que sejam esgotadas todas as possibilidades de reintegração social de forma digna, dando suporte não apenas aos presos, mas, também, a familiares a eles vinculados (FERREIRA; OLIVEIRA, 2016).

Nesse sentido, as referidas autoras afirmam que:

É pertinente atribuir a devida importância para o profissional assistente social que se posiciona com fidelidade ao projeto éticopolítico da categoria profissional, pois buscam romper com o conservadorismo e a busca incessável pelo aprimoramento intelectual caracterizam este profissional que pretende a efetivação da justiça social e a ampliação e consolidação da cidadania. Ressalta-se que o profissional que atua no sistema penitenciário vivencia cotidianamente entraves históricos, econômicos e ideológicos. Assim, deve ser competente e habilitado para lidar com a mediação de interesses divergentes de classes antagônicas de forma propositiva, caso contrário esse será apenas mais um profissional burocrático e tecnicista (FERREIRA; OLIVEIRA, 2016, p. 10).

Desse modo, é necessário que a intervenção da profissão nos presídios ocorra articuladamente em termos multiprofissional, de modo a avigorar, na prática diária, a competência ética, técnica, teórica e política, apoiando as transformações necessárias.

Sabe-se que a reincidência criminal tem mostrado que a reintegração do preso à sociedade não está surtindo o efeito almejado. Por isto, concorda-se com uma das sugestões apresentadas pela Dra. Pires (2013, p. 369), quanto à atuação do profissional de Serviço Social em penitenciárias e demais espaços destinados à privação de liberdade, no contexto penal: 


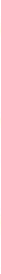

uma intervenção que não tenha como direção o reforço aos malefícios já intrínsecos à prisão e a introdução de adicionais, mas que possa contribuir para o enfrentamento, ao máximo possível, dos fatores determinantes da histórica exclusão social que marca majoritariamente a população carcerária, bem como para evitar, também ao máximo, que o tempo de prisão produza tais malefícios adicionais. Sob nosso entendimento, transformar o trabalho profissional em uma intervenção desse gênero pressupõe uma mudança de postura no tocante à visão normalmente detida acerca da pessoa presa. (Sem destaques no original).

Assim sendo, a fim de que o Magistrado desempenhe a ação Jurisdicional correspondente e preencha a íntegra do tratamento a ser aplicado, faz-se indispensável à atuação de uma equipe interdisciplinar, da qual faz parte o Assistente Social. Este prestará assessoria nas decisões que necessitem de apoio e reconhecimento sociáveis, realizado pela equipe interdisciplinar, através de auxílio e subsídio às autoridades.

Apesar de tudo o que já foi discutido sobre as prisões desde os tempos mais remotos, o que se constata no Brasil atual é o mesmo que ocorre em muitos outros países, isto é, instituições penitenciárias conhecidas como "escolas do crime", que não cumprem seu papel ressocializante (ALVIM, 2006).

De fato, reality shows, a exemplo de "As piores prisões do mundo", veiculados em TVs por assinatura, mostram caos em prisões, inclusive, de países desenvolvidos, por exemplo: Penitenciária do Estado da Louisiana (EUA): 23 horas por dia trancafiado; Bang Kwang (Tailândia): correntes nas pernas; Guantánamo (Cuba): presos sem direito à defesa; Tadmor (Síria): no meio do deserto em meio a uma guerra civil; Gitarama (Ruanda): amputações e doenças; Prisão da Ilha Petak (Rússia): isolados por 25 anos; Campo 22 (Coreia do Norte): fome e execuções (HISTORY, 2017).

Acerca das prisões no Brasil, Suarez (2017, p. 1) revela que

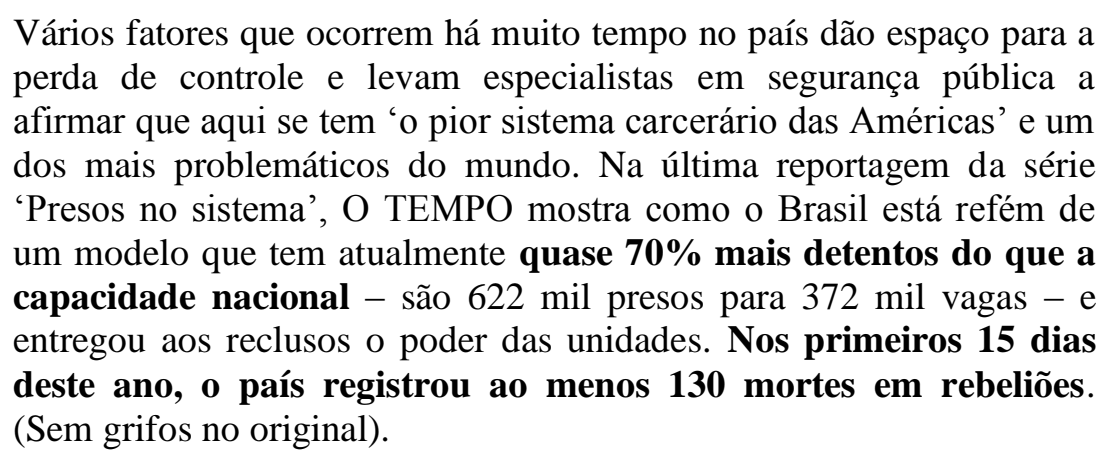

Assim sendo e considerando o fato de que uma das finalidades da Assistência Social, conforme a LEP, é "amparar o preso e o internado e prepará-los para o retorno à 


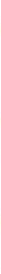

liberdade" (Artigo 22), fica evidente a impossibilidade do cumprimento desta e das outras determinações legais neste contexto caótico e, atualmente, sem previsão de soluções devido à crise política pela qual passa a nação brasileira.

Desse modo, concorda-se com Pires (2013, p. 362), ao afirmar que:

[...] em essência e apesar das particularidades, ressocialização sempre denotou o propósito de empreender sobre a pessoa presa uma reforma moral. O esperado sempre foi o de que, durante o período de prisão e através de um tratamento penal, ela fosse habilitada a retornar à sociedade extramuros apta a viver em harmonia com os padrões sociais instituídos; que ela fosse submetida a um processo (re)educativo que permitisse uma reforma em sua forma de pensar e de se comportar e, como resultado disso, se obtivesse sua moldagem aos padrões de normalidade socialmente aceitos.

Desse modo, contextualizado nesse sistema, o Serviço Social inclui questões diversas, mas sempre referentes à privação da liberdade. Esta, por sua vez, traz outros aspectos que necessitam da atuação interdisciplinar por parte de profissionais, dentre os quais o Assistente Social.

A referida autora prossegue afirmando que esta finalidade deve ser, primordialmente, alcançada

pelos profissionais de diferentes áreas que passaram a ser recrutados para concretizar o referido tratamento penal. Nesta medida, do mesmo modo que ocorreu com outras áreas profissionais ${ }^{185}$, a transformação da prisão em espaço ocupacional dos assistentes sociais não se deu por outra razão que não a de intentar, por intermédio de sua intervenção técnica, esta reforma moral sobre a pessoa presa. Todas as responsabilidades e demandas que foram (e são) postas para os profissionais de Serviço Social são decorrentes do exercício desta tarefa (PIRES, 2013, p. 362).

De acordo com Marques (2012), não se pode excluir os sonhos daqueles que produzem a engrenagem carcerária, que não se restringe ao trabalho contra a agressividade em ressentimento e má-consciência. Tal realidade se deve ao fato de que “o discurso e o fazer técnico não são integrados e quando se dirigem às situações

185 No caso do Brasil, destaca-se a Psicologia e a Psiquiatria que, com o Serviço Social, são mencionadas na LEP Lei n. 7.210, de 11 de julho de 1984. Apesar das alterações processadas posteriormente nesse instrumento legal, os profissionais dessas três áreas são os únicos inclusos legalmente como membros da Comissão Técnica de Classificação (CTC). Pelo atual texto da LEP, essa Comissão é responsável pela classificação do condenado "segundo os seus antecedentes e personalidade, para orientar a individualização da execução penal" (Art. $5^{\circ}$ ), pela elaboração de um "programa individualizador da pena privativa de liberdade adequada ao condenado ou preso provisório" (Art. $6^{\circ}$ ) e, no caso de presos em cumprimento de pena em regime fechado, pela realização de "exame criminológico para a obtenção dos elementos necessários a uma adequada classificação e com vistas à individualização da execução" (Art. 8) (PIRES, 2013, p. 362). 


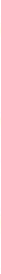

problemáticas tendem a cumprir um papel de controle, se pensarmos a partir da criminologia administrativa de caráter etiológico ${ }^{186, " ~(M A R Q U E S, ~ 2012, ~ p . ~ 9) . ~}$

Assim sendo, a supressão da autonomia e da competência, fazem com que o corpo técnico seja convidado a reproduzir o seu próprio desaparecimento institucional, ou modificar-se meramente em executor de laudos, segundo mencionado por Guindani (2001, p. 5): “O Serviço Social junto às equipes de CTC construíram, no decorrer de sua história, uma identidade instituída, vinculada aos mecanismos de controle social, com caráter tarefeiro, subalterno, sem base teórica e intencionalidade ético política".

Nota-se que as perspectivas do trabalho do Assistente Social, apesar do compromisso ético-político desse profissional, não se mostram favoráveis, haja vista a problemática frente à violação dos direitos humanos e à ineficácia da lógica de ressocialização a que são submetidos os presos.

Ressalte-se que, todavia, embora o Assistente Social deva realizar suas atribuições no sistema penitenciário brasileiro, contribuindo para que os presos cumpram as penas a quem estejam submetidos, sem que sejam desrespeitados em seus direitos, ele não depende, unicamente, do seu compromisso ético, político e profissional, mas de uma reforma no sistema prisional como um todo.

Desse modo, para que esse profissional atue de forma eficaz, é indispensável que sejam criadas políticas públicas destinadas a sanar as questões que mantêm um considerável número de indivíduos sob o jugo de uma miserabilidade que agravam a realidade deles mesmos e da sociedade em geral.

De fato, sozinho, o Assistente Social não consegue reverter tal vergonhosa realidade (ALMEIDA, 2006).

Assim sendo, o desenvolvimento da prática profissional do Assistente Social exige que esse profissional tenha domínio de sua instrumentalidade para trabalhar com a equipe multiprofissional, de modo a promover a troca de elementos sobre os encarcerados e, portanto, melhor proteger seus direitos. Neste sentido, cabe considerar que o trabalho desses profissionais ultrapassa o processo de preenchimento de instrumentos técnicos, tendo em vista o desenvolvimento complexo de suas ações na defesa intransigente dos direitos no âmbito contraditório, que é o sistema prisional (FERREIRA; OLIVEIRA, 2016).

186 A criminologia administrativa de caráter etiológico é aplicada no controle da criminalidade. Em níveis mais elevados, encontramos modelos de criminologia etiológica que se estende ao controle das consequências (BARATTA, 1997). 


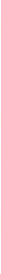

Assim sendo, embora o Assistente Social deva atuar com demandas que evidenciam a transformação da realidade, ele se depara com dois consideráveis desafios para exercer o Serviço Social nos presídios, sendo: o caos instalado nos estabelecimentos prisionais, onde não encontra subsídios, tampouco respaldo, e a sociedade que evidencia significativas desigualdades.

\section{CONCLUSÃO}

Conforme os objetivos propostos no presente estudo, verificou-se que as finalidades do Serviço Social previstas legalmente, no sentido de garantir amparo dos presos e internos, bem como prepará-los para o retorno à liberdade, não são cumpridas por força do caos instalado ao longo de muitos anos e, na atualidade, sem previsão de soluções devido à crise política pela qual passa a nação brasileira.

Neste sentido, a reforma moral pretendida na reintegração social da pessoa presa requer um tratamento penal digno e, portanto, que favoreça o retorno dela à sociedade fora das prisões e albergues, estando apta a viver de acordo com os padrões sociais. Esse tratamento precisa considerar um processo de (re)educação, que promova uma real transformação no pensar e comportar-se. Assim, o que determina a Declaração Universal dos Direitos Humanos e os deveres dos presos serão concretizados.

Desse modo, fica claro que a redução da reincidência criminal e a reintegração social do preso dependem da atuação dos membros das equipes multidisciplinares destinadas atuantes no sistema prisional brasileiro, incluindo a prisão enquanto espaço ocupacional dos Assistentes Sociais, através de sua intervenção técnica.

Também foi possível constatar que, não obstante o que se encontra determinado pelas normas que regulamentam o Serviço Social, destacadamente, aqui, tudo o que se refira às ações do Assistente Social no sistema penitenciário, é necessário que se fundamente na mediação e na flexibilização frente a diferentes segmentos, assim como no planejamento técnico social das ações e projetos aos quais se almeja execução.

Portanto, não é possível afirmar a hipótese do estudo, segundo a qual o Serviço Social contribui com êxito para a concretização dos Direitos Humanos, conforme o que é designado ao profissional Assistente Social nas unidades penais, pela LEP, nos seus artigos 22 e 23, específicos da Assistência Social, tampouco pelas outras normas pertinentes. 


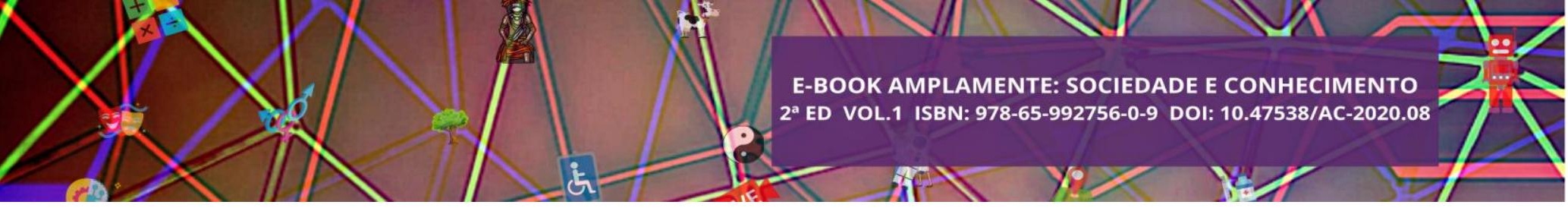

\section{REFERÊNCIAS}

ALMEIDA, Claudiana Avelino; CRUZ, Suelen Saraiva da. Sistema penitenciário brasileiro: uma análise da penitenciária industrial regional do Cariri - PIRC. Revista Direito \& Dialogicidade, Crato, CE, v. 5, n. 2, jul./dez. 2014.

ALMEIDA, Janaina Loeffler de. Os limites e as potencialidades de uma ação profissional emancipatória no sistema prisional brasileiro. 2006. 133f. Dissertação (Mestrado em Serviço Social) - Universidade Federal de Santa Catarina. FlorianópolisSC, 2006.

ALVIM, Wesley Botelho. A ressocialização do preso brasileiro. UFSC - Centro de Ciências Jurídicas, 10 out., 2006. Disponível em:

<http://www.egov.ufsc.br/portal/sites/default/files/anexos/12761-12762-1-PB.pdf>. Acesso em: 21 maio 2017.

BARATA, Alessandro. Defesa dos direitos humanos e política criminal. Rio de Janeiro: Revan, 1997.

BRASIL. Constituição da República Federativa do Brasil de 1988. Institui a Lei de Execução Penal. Disponível em:

<http://www.planalto.gov.br/ccivil_03/constituicao/constituicao.htm>. Acesso em: 18 nov. 2017.

Lei n. 7.210 de 11 de julho de 1984. Institui a Lei de Execução Penal.

Disponível em: <http://www.planalto.gov.br/ccivil_03/leis/L7210.htm>. Acesso em: 20 abr. 2017.

Levantamento Nacional de Informações Penitenciárias - Infopen.

Departamento Penitenciário Nacional; Ministério da Justiça, junho de 2014. Disponível em: <http://www.justica.gov.br/noticias/mj-divulgara-novo-relatorio-do-infopen-nestaterca-feira/relatorio-depen-versao-web.pdf >. Acesso em: 20 nov. 2017.

CAMPOS, Claudinei José Gomes. Método de análise de conteúdo: ferramenta para a análise de dados qualitativos no campo da saúde. Rev. bras. enferm., v. 57, n. 5, pp. 611-614, out. 2004.

CFESS. Código de Ética Profissional dos Assistentes Sociais. Lei n. 8.662, de 15 de março de 1993. Alterado pela Resolução CFESS n. 290, de 11 de fevereiro de 1994. Disponível em: 〈http://www.cfess.org.br/pdf/legislacao_etica_cfess.pdf〉. Acesso em: 21 maio 2017.

CFESS (Org.). O estudo social em perícias, laudos e pareceres técnicos: contribuição ao debate no judiciário, no penitenciário e na previdência social. 8. ed. São Paulo: Cortez, 2008.

GALVÃO, Fernando. Direito penal: parte geral. 7. ed. rev. ampl. e atual. Belo Horizonte: DPlácido, 2016. 


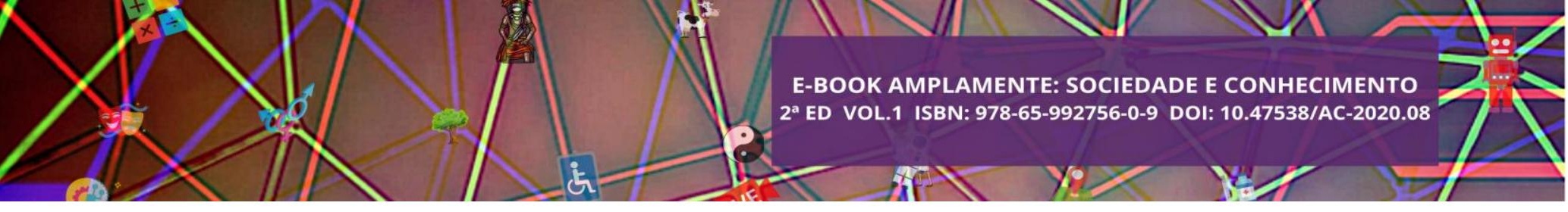

FERREIRA, Edlene Santiago; OLIVEIRA, Maria F. Gualberto de. A atuação do assistente social no sistema penitenciário: Estudo de caso da saúde básica das apenadas do regime semiaberto na cidade de Manaus. Anais... II Congresso de Assistentes Sociais do Rio de Janeiro, 11 a 13 de maio de 2016. Conselho Regional de Serviço Social do Rio de Janeiro, 2016.

HISTORY. Saiba quais as piores prisões do mundo e por que. Disponível em: $<$ https://seuhistory.com/noticias/saiba-quais-piores-prisoes-do-mundo-e-por-que>. Acesso em: 21 maio 2017.

IAMAMOTO, Marilda V. A questão social no capitalismo. Brasília: Temporális, 2001.

Renovação e conservadorismo: ensaios críticos. São Paulo: Cortez, 1997.

MARQUES, Simone Félix. O Desacreditável e o Desacreditado: Considerações sobre o fazer técnico do Assistente Social no Sistema Prisional. Susepe, Rio Grande do Sul, 2012. Disponível em:

<http://www.susepe.rs.gov.br/upload/1326743484_Artigo.\%20Simone\%20vers\%C3\%A 3o\%20final.pdf>. Acesso em: 21 maio 2017.

PEREIRA, Tânia Maria Dahmer. Identidade profissional do assistente social no sistema penitenciário. Palestra. In: Caderno Especial, n. 18, p. 1-16, 2005; 08 a 29 de julho de 2005. Disponível em: <www.assistentesocial.com.br>. Acesso em: $17 \mathrm{dez}$. 2017.

PIRES, Sandra Regina de Abreu. Sobre a prática profissional do assistente social no sistema penitenciário. Textos \& Contextos, Porto Alegre, v. 12, n. 2, p. 361-372, jul./dez. 2013.

SÁ, Alvino A. Sugestão de um esboço de bases conceituais para um sistema penitenciário: manual de projetos de reintegração social. São Paulo: SAP/DRSP, 2005.

SANTOS, Raquel dos. O trabalho do assistente social no sistema penitenciário brasileiro: uma reflexão sobre as condições de trabalho. Jus Navigandi, 08 ago. 2015. Disponível em: <https://jus.com.br/artigos/41468/o-trabalho-do-assistente-social-nosistema-penitenciario-brasileiro-uma-reflexao-sobre-as-condicoes-de-trabalho $>$. Acesso em: 18 maio 2017.

SILVA, Fabio Lobosco. Sobre um novo conceito de prisionização: o fenômeno da assimilação prisional de acordo com a realidade prisional brasileira. 2016. $269 \mathrm{f}$. Tese (Doutoramento em Direito Político e Econômico) - Universidade Presbiteriana Mackenzie. São Paulo, 2016.

SOUZA, Robson S. Reis. Política de segurança pública: grandes desafios. Fórum Brasileiro de Segurança Pública, Carta Capital, 18 jul. 2011. Disponível em: $<$ https://www.cartacapital.com.br/sociedade/politica-de-seguranca-publica-grandesdesafios>. Acesso em: 6 jun. 2017.

SUAREZ, Joana. Realidade das cadeias no Brasil está entre as piores do mundo. O Tempo, 22 jan. 2017. Disponível em: <http://www.otempo.com.br/hotsites/presos-no- 


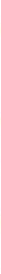

sistema/realidade-das-cadeias-no-brasil-est $\% \mathrm{C} 3 \% \mathrm{~A} 1$-entre-as-piores-do-mundo1.1426306>. Acesso em: 21 maio 2017.

TORRES, Andrea Almeida. Direitos Humanos e o Sistema Penitenciário Brasileiro: desafios éticos e político do Serviço Social. Revista Serviço Social e Sociedade, São Paulo: Cortez, n. 67, set. 2001.

THOMPSON, Augusto. A questão da penitenciária. 4. ed. Rio de Janeiro: Forense, 1993.

VIEGAS, Tamires dos Santos. O processo de trabalho do serviço social no sistema penitenciário. Revista Contraponto, v. 2, n. 3, p. 159-169, out./nov. 2015. 


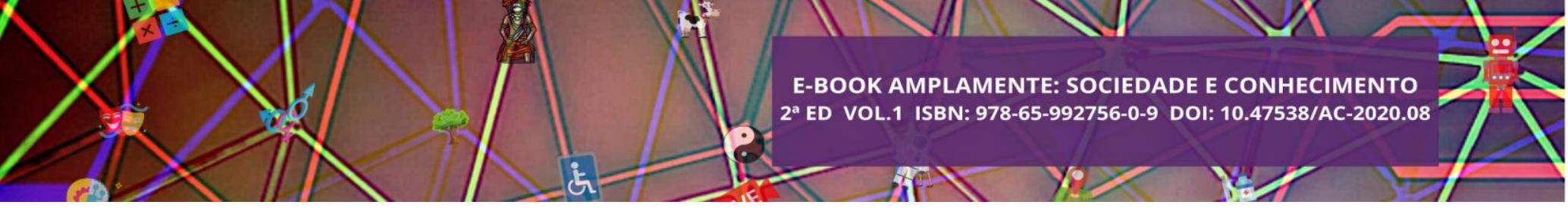

relações, com o objetivo último de conseguir melhorar o desenho e funcionamento do sistema representado pelo modelo".

Os modelos, de uma forma geral, podem diferir entre si com relação:

- Aos objetivos que podem ser descritivos ou otimizados.

- Ao modo de análise que pode ser analítico ou numérico.

- À aleatoriedade que pode ser determinística ou probabilística.

Este estudo atentar-se-á somente aos modelos matemáticos e, mais precisamente, aos modelos que envolvem aleatoriedade probabilística. A construção de modelos, a sua adequação e comparação com a realidade e o seu refinamento incidem sobre cada fase da resolução de problemas estatísticos, não só na análise experimental de dados, como também no desenvolvimento teórico. A partir dessa premissa, é possível identificar cinco fases no método de estruturação de um modelo (ACKOFF; SASIENI, 1971, p. 14):

1. Formulação do problema: envolve a fase de escolha de cenários, levantamento de dados reais e definição dos objetivos.

2. Construção do modelo: nesta fase, procura-se determinar qual o melhor modelo dentre os vários que podem ser aplicados, ou seja, o que melhor se adapta ao cenário estudado.

3. Obtenção da solução: tendo selecionado o modelo, procura-se determinar, através de simulações em computadores, qual a melhor solução para o problema estudado.

4. Teste do modelo e avaliação da solução: a solução ou as soluções só poderão melhorar o desempenho do sistema se o modelo for uma boa representação do mesmo. A relação entre o modelo e a realidade deverá ser testada e a solução avaliada.

5. Implantação e acompanhamento da solução: sendo o modelo representativo do sistema, o mesmo deve ser implementado e as soluções devem ser acompanhadas e controladas. É a fase de manutenção do modelo.

\section{O MÉTODO DE MONTE CARLO}

O Método de Monte Carlo originou-se durante a segunda guerra mundial. Era um código dado pelos físicos - que gostavam de jogos de azar - os quais, na época, estavam desenvolvendo a bomba atômica e queriam determinar a probabilidade da 


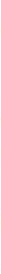

reação em cadeia necessária para que a bomba funcionasse. Mas foi o matemático Stanislaw Ulan, em 1946, que desenvolveu sistematicamente o método. Ele tentou determinar, através de análise combinatória, a probabilidade de sair uma particular jogada em um jogo de paciência; posteriormente, o matemático notou que poderia repetir algumas jogadas um número limitado de vezes, por exemplo, 100 vezes ou 1000, e contar quantas vezes cada resultado se repetia. Esse estudo de Ulan foi publicado, posteriormente, em 1949, em um artigo intitulado "Monte Carlo Method", em conjunto com Jonh Von Neumann.

Monte Carlo é um método utilizado rotineiramente em muitos campos de conhecimentos, que vão desde a simulação de complexos fenômenos físicos a econômicos. Eis alguns exemplos de aplicação:

- Atuária: tábua de expectativa de vida, casamento de ativos/passivos etc.;

- Finanças: séries macroeconômicas, opções futuras, hedge etc.;

- Computação gráfica: redução de artefatos, espalhamento etc.;

- Geologia: caracterização de reservatórios;

- Análise de projetos: opções reais;

- Jogos: geração de redes (grafos);

- Estatística e Matemática: demonstração de alguns teoremas.

Para Messeti \& Queiroz (2002, p. 40), "Monte Carlo é um método numérico auxiliar, para resolver problemas matemáticos mediante simulação de variáveis aleatórias, na qual não é possível obter solução de forma analítica".

Uma exigência do método de Monte Carlo é que o fenômeno físico ou matemático seja descrito por uma distribuição de densidade de probabilidade e não através das equações diferenciais que descrevem o fenômeno. Uma vez conhecida a distribuição de probabilidade, o método de Monte Carlo pode ser usado selecionando-se amostras aleatórias dessa distribuição, e esse processo pode ser repetido um número definido de vezes, extraindo-se dessas amostras as estatísticas necessárias para um estudo, média, variância etc.

Segundo Anderson (1999, p. 1): "Monte Carlo é a arte de aproximar uma expectativa pela amostra média de uma função de variáveis aleatórias simuladas". A técnica de Monte Carlo, então, consiste em gerar números aleatórios independentes e estatisticamente uniformes dentro de um intervalo aberto $(0,1)$. É a geração de objetos aleatórios através de computador; esses objetos podem surgir de forma natural na 


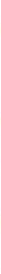

simulação de situações reais ou, em muitos casos, os objetos aleatórios são introduzidos artificialmente com o intuito de resolver problemas determinísticos e, nesse caso, o método de Monte Carlo (MCM) envolve a amostragem aleatória de certas distribuições de probabilidades. A ideia do MCM é repetir a experiência muitas vezes para se obter muitas informações de interesse usando a lei dos grandes números ou outros métodos de inferência estatística.

Podem-se citar alguns usos do MMC: a amostragem, em que o objetivo é obter informações sobre um elemento aleatório, observando-se muitas ocorrências do mesmo; a estimação, em que a preocupação é determinar quantidades numéricas relacionadas com o modelo simulado; e a otimização, em que o MMC é uma poderosa ferramenta para a otimização de funções objetivas complexas na procura, de forma mais eficiente, do domínio dessas funções.

Em termos matemáticos, o MMC pode ser estimado da seguinte forma: considere uma variável aleatória $X$ com a função de distribuição de probabilidade ou com a função de densidade de probabilidade $f_{X}(x)$, a qual é maior do que zero para um conjunto de valores $X$. Então a esperança de uma função $g$ de $X$ :

Se X é discreta: $E[g(X)]=\sum_{x \in X} g(X) . f_{X}(x)$

Se X é contínua: $E[g(X)]=\int_{x \in X} g(X) \cdot f_{X}(x) d x$

Para uma amostra n de $\mathrm{X}\left(x_{1}, x_{2}, x_{3}, \cdots, x_{n}\right)$, a estimativa do MMC para $E[g(X)]$ será dada por (3):

$$
\widetilde{g_{n}}(x)=\frac{1}{n} \sum_{i=1}^{n} g\left(x_{i}\right)
$$

Pode-se dizer, alternativamente, que a variável aleatória em (4)

$$
\widetilde{g_{n}}(X)=\frac{1}{n} \sum_{i=1}^{n} g\left(X_{I}\right)
$$

É o estimador de Monte Carlo para $E[g(X)]$.

Se $E[g(X)]$ existe, então existe um número arbitrário infinitamente pequeno $\varepsilon>$ 0 em (5) tal que:

$$
\lim _{n \rightarrow \infty} P\left(\left|\widetilde{g_{n}}(X)-E[g(X)]\right| \geq \varepsilon\right)=0
$$




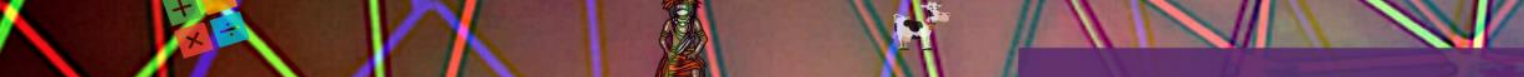

Para valores de n muito grande, a probabilidade de $\widetilde{g_{n}}(X)$ desviar de $E[g(X)]$ é muito pequena. Esse fato pode também ser comprovado pela Lei dos Grandes Números. Temos que $\widetilde{g_{n}}(X)$ é um estimador não aviesado para $E[g(X)]$, como mostrado em (6).

$$
E\left(\widetilde{g_{n}}(X)\right)=E\left[\frac{1}{n} \sum_{i=1}^{n} g(X)\right]=\frac{1}{n} \sum_{i=1}^{n} E[g(X)]=\frac{1}{n} \cdot n E[g(X)]=E[g(X)]
$$

A variância do estimador de Monte Carlo $\widetilde{g_{n}}(X)$ será dada por (7), Se $X$ é discreta:

$$
\begin{aligned}
\operatorname{Var}\left[\widetilde{g_{n}}(X)\right]= & \operatorname{Var}\left[\frac{1}{n} \sum_{i=1}^{n} g(X)\right]=\frac{\operatorname{Var}(g(X))}{n} \\
& =\frac{1}{n} \sum_{x \in X}[g(x)-E[g(X)]]^{2} \cdot f_{X}(x)
\end{aligned}
$$

ou por (8), Se $X$ é contínua:

$$
\operatorname{Var}\left[\widetilde{g_{n}}(X)\right]=\frac{\operatorname{Var}(g(X))}{n}=\frac{1}{n} \int_{x \in X}[g(x)-E[g(X)]]^{2} \cdot f_{X}(x) d x
$$

Para Assis (2010), o método de simulação de Monte Carlo desenvolve-se em quatro fases:

- Fase 1: Define-se a função de distribuição acumulada $P(x)$, da variável aleatória $x$, a qual pode ser uma distribuição teórica (Uniforme, Triangular, Normal, Beta, Weibull etc.) ou uma distribuição empírica qualquer.

- Fase 2: Escolhe-se um número aleatório equiprovável entre 0 e 1 numa tabela de números aleatórios. Representa-se esse número yp no eixo das ordenadas da função $P(x)$

- Fase 3: Projeta-se $y p$ horizontalmente até à curva $P(x)$, definindo-se o ponto $P$. Este ponto é projetado, por sua vez, sobre o eixo das abcissas, definindo-se o valor $x p$ de uma amostra;

- Fase 4: Repete-se o procedimento um número determinado de vezes até obter uma amostra.

\section{GERAÇÃO DE NÚMEROS ALEATÓRIOS DE DISTRIBUIÇÕES DE PROBABILIDADE}




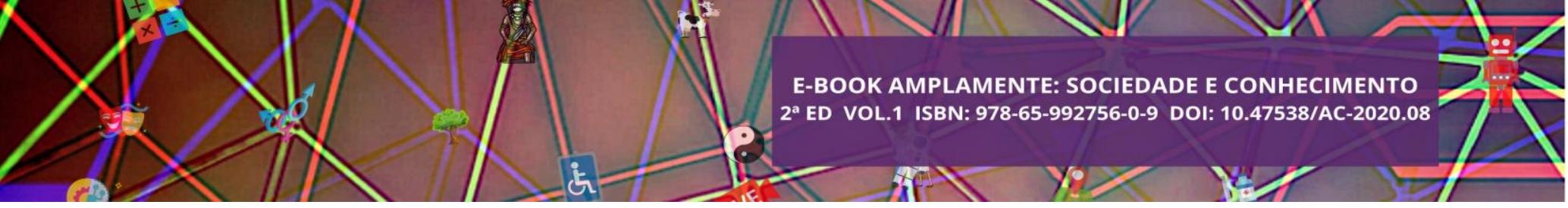

Seja $F(x)$ a função de distribuição acumulada para uma variável aleatória $x$, a qual fornece uma probabilidade, $P$, em que $X$ é menor ou igual a $x$. Assim

$$
F(x)=P(X \leq x), \text { onde } 0 \leq F(x) \leq 1
$$

Da equação (9) pode-se obter a função inversa $G(F(x)$ ), onde da função $F(x)$ são gerados os valores de $x$. Então $G(F(x))=x$.

É de suma importância o conceito de função inversa para geração de valores aleatórios. Primeiramente é gerado um número $r$ a partir de uma distribuição uniforme com intervalo $(0,1)$. Cada valor de $r$ representará um valor da função de distribuição acumulada; através da função inversa será determinado o valor a ser gerado para a distribuição: $G(r)=x$.

Para dar igual oportunidade de que os valores de $\mathrm{x}$ tenham as mesmas probabilidades em cada percentil, o número gerado $r$ será originário de uma distribuição uniforme $(0,1)$.

Em situações práticas, às vezes não é possível determinar uma função inversa para alguns tipos de distribuições de probabilidades; nessa situação existem algoritmos alternativos, variando em complexidade, acuidade e velocidade que precisam ser utilizadas para a retirada de amostras. O princípio do método se mantém.

São vários os algoritmos para geração de números aleatórios, e como foi dito anteriormente, eles estão intrinsicamente ligados com algum tipo de função de distribuição de probabilidade. A seguir, serão exemplificados algoritmos gerados a partir de algumas distribuições de probabilidade.

\section{DECAIMENTO EXPONENCIAL}

Esta é uma aplicação comum para o método da função inversa, é usado o fato de que se $r$ é uniformemente distribuído no intervalo $(0,1),(1-r)$ também o é. Considere uma exponencial com a função de densidade de probabilidade dada por (10).

$$
f(t)=\frac{1}{\lambda} \exp \left(-\frac{t}{\lambda}\right) ; \text { para } a \leq t \leq b
$$

Para gerar o tempo de decaimento de t de acordo com a fdp, primeiro calcula-se em (11) os valores de $\alpha$ e $\beta$.

$$
\alpha=\exp (-a / \lambda) e \beta=\exp (-b / \lambda)
$$




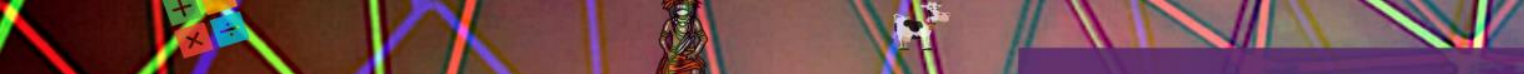

Então é gerado $r$ e determina-se $t$ em (12)

$$
t=-\lambda \ln (\beta+r(\beta-\alpha))
$$

Para $(a, b)=(0, \infty)$, simplesmente tem-se $t=-\lambda \ln r$

\section{DISTRIBUIÇÃO GAUSSIANA (OU NORMAL)}

Seja $u_{1}$ e $u_{2}$ duas variáveis aleatórias uniformes no intervalo $(0,1)$, então os valores $z_{1}$ e $z_{2}$ são dados por (13).

$$
z_{1}=\operatorname{sen}\left(2 \pi u_{1}\right) \sqrt{-2 \ln u_{2}} \text { e } z_{2}=\cos \left(2 \pi u_{1}\right) \sqrt{-2 \ln u_{2}}
$$

São independentes e possuem distribuição Normal $\operatorname{com} \mu=0 e \sigma=1$, isto é, são $N(0,1)$.

Aí há muitas variantes desse algoritmo básico, as quais podem ser extensas. Por exemplo, tomadas duas variáveis $v_{1}=2 u_{1}-1$ e $v_{2}=2 u_{2}-1$, ambas são uniformes no intervalo $(-1,1)$. Calcule $r^{2}=v_{1}^{2}+v_{2}^{2}$, e se $r^{2}>1$, recomece o processo. Se $r^{2}<1$, ela é uniforme em $(0,1)$, então por (14):

$$
z_{1}=v_{1} \sqrt{\frac{-2 \ln r^{2}}{r^{2}}} e z_{2}=v_{2} \sqrt{\frac{-2 \ln r^{2}}{r^{2}}}
$$

\section{DISTRIBUIÇÃO BINOMIAL}

Inicia-se com $k=0$ e é gerado $u$ uniformemente distribuído em $(0,1)$. Calcula-se $P_{k}=(1-p)^{n}$ que é armazenado em $B$. Se $u \leq B$ aceita-se $r_{k}=k$ e o processo é parado, caso contrário incrementa-se $k$ de uma unidade e é calculado o próximo $P_{k}$ como $P_{k} \cdot \frac{p}{1-p} \cdot \frac{n-k}{k+1}$ e acrescenta-se ele a $B$. Novamente se $u \leq B$, aceita-se $r_{k}$ e finda o processo, caso contrário incrementa-se novamente $k$ de uma unidade e o processo segue até o valor de $r_{k}$ ser aceito. Se $p>1 / 2$, ele será mais eficiente para gerar $k$ sobre $f(r ; n, q)$, isto é, com $p$ e $q$ intercambiáveis, e então o conjunto será dado por $r_{k}=n-r$.

\section{Distribuição de Poisson}

Inicie com $k=1$ e o conjunto $A=1$ para começar. Gere $u$ e substitua $A$ por $u A$, se agora $A<\exp (-\mu)$, onde $\mu$ é parâmetro da distribuição de Poisson, aceite $n_{k}=k-$ 1 e pare. Caso contrário incremente $k$ de uma unidade, gere um novo valor para $u$ e repita, sempre iniciando o valor de $A$ vindo da esquerda da expressão da prova anterior. 


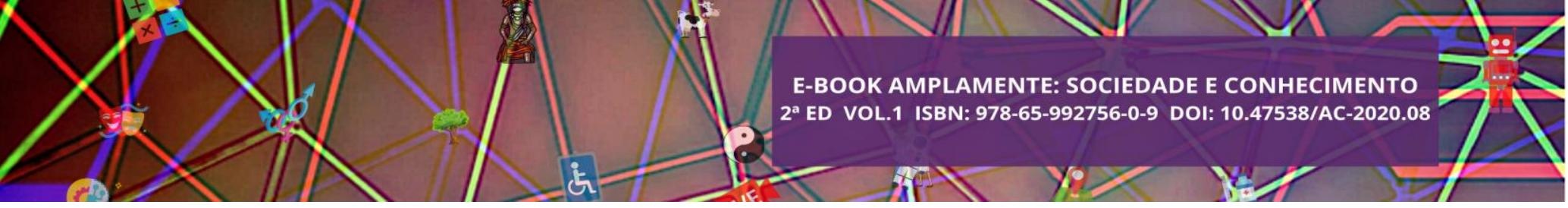

\section{DISTRIBUIÇÃO $t$ DE STUDENT}

Gere $u_{1}$ e $u_{2}$ utilizando da distribuição uniforme $(0,1)$; então,

$$
t=\operatorname{sen}\left(2 \pi u_{1}\right)\left[n\left(u_{2}^{-2 / n}-1\right)\right]^{1 / 2} \text { segue a distribuição } t \text { de Student }
$$

com $n$ graus de liberdade, onde $n$ não é necessariamente um número inteiro.

Um gerador de números aleatórios deve ser eficiente, isto é, gerar números verdadeiramente aleatórios (equiprováveis), ser rápido, não necessitar de muito espaço de armazenamento, repetir sequências que estejam predefinidas, ter um longo período de ciclo, não degenerar e passar por qualquer teste estatístico de aleatoriedade.

Quando se inicia o tratamento de um modelo de simulação, existem dois períodos distintos: um período de regime transitório e um de regime estacionário. $\mathrm{O}$ interesse da análise pode estar no regime transitório, ou no regime estacionário ou em ambos, dependendo das características que se pretende capturar.

\section{SIMULAÇÃO DO TEOREMA DO LIMITE CENTRAL UTILIZANDO MÉTODO DE MONTE CARLO}

Antes de se falar da simulação do Teorema do Limite Central, primeiramente será definido o mesmo, para posteriormente proceder à simulação.

Teorema do Limite Central ou Teorema Central do Limite foi desenvolvido por um matemático russo, Aleksandr Mikhailovich Lyapunov (1857-1918), que procurou explicar como as variáveis normais, comumente encontradas na teoria, são amplamente difundidas na natureza. Para ele "se uma variável aleatória $X$ constitui a soma de um número muito grande de variáveis aleatórias mutuamente independentes, a influência de cada uma delas em toda a soma sendo desprezível, então $X$ tem uma distribuição próxima da normal". (GMURMAN, 1983)

Supondo, por exemplo, que se realize a medição de uma certa grandeza física, qualquer medição dá somente um valor aproximado da grandeza medida, pois no resultado da medição influem bastantes fatores aleatórios independentes (temperatura, oscilações do aparelho, umidade etc.). Cada um desses fatores introduz um erro parcial desprezível. No entanto, como o número desses fatores é muito grande, a sua influência conjunta já produz um erro total notável. 


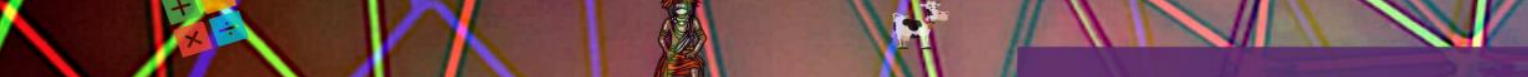

A formulação do Teorema do Limite Central estabelece as condições sob as quais a soma de um grande número de parcelas independentes tem uma distribuição próxima da normal.

Seja $X_{1}, X_{2}, X_{3}, \cdots, X_{n}, \cdots$ uma sucessão de variáveis aleatórias independentes, tendo em cada uma delas esperança matemática e variância finitas:

$$
E\left(X_{k}\right)=a_{k}, \operatorname{Var}\left(X_{k}\right)=b_{k}^{2}
$$

Utilizando as fórmulas em (15) serão introduzidas as notações:

$$
S_{n}=X_{1}+X_{2}+\cdots+X_{n} ; \quad A_{n}=\sum_{k=1}^{n} a_{k} ; \quad B_{n}=\sum_{k=1}^{n} b_{k}^{2}
$$

Das notações (16) a função de distribuição da soma normatizada será denotada por:

$$
F_{n}(x)=P\left(\frac{S_{n}-A_{n}}{B_{n}}<x\right)
$$

Diz-se que o Teorema do Limite Central é aplicável à sucessão $X_{1}, X_{2}, \cdots$ se, para qualquer $x$, a função de distribuição da soma normatizada em (17) tende para a função da distribuição normal de média zero e variância um, quando $n$ tende para infinito, isto é de (17), temos em (18) que:

$$
\lim _{n \rightarrow \infty} P\left(\frac{S_{n}-A_{n}}{B_{n}}<x\right)=\frac{1}{\sqrt{2 \pi}} \int_{-\infty}^{x} e^{-Z^{2} / 2} d z
$$

Em particular, todas as variáveis aleatórias $X_{1}, X_{2}, \cdots$ sendo igualmente distribuídas, o Teorema do Limite Central será aplicável a essa sucessão, se as variâncias de todas as variáveis $X_{i}(i=1,2, \cdots)$ são finitas e diferentes de zero.

Será utilizada uma simulação para demonstrar o Teorema do Limite Central e também que o desvio-padrão das médias amostrais pode ser dado por (19), analiticamente, pelo desvio-padrão da população dividido pela raiz quadrada do tamanho da amostra, simbolicamente:

$$
\sigma_{\bar{x}}=\frac{\sigma}{\sqrt{n}}
$$

Para essa simulação, foi tomada uma população de 9600 números aleatórios gerados a partir de uma distribuição exponencial negativa (com média 20), por ser uma distribuição bem assimétrica. E a partir dessa população foram determinados grupos de amostras de tamanhos distintos como demonstrado no quadro (1). 


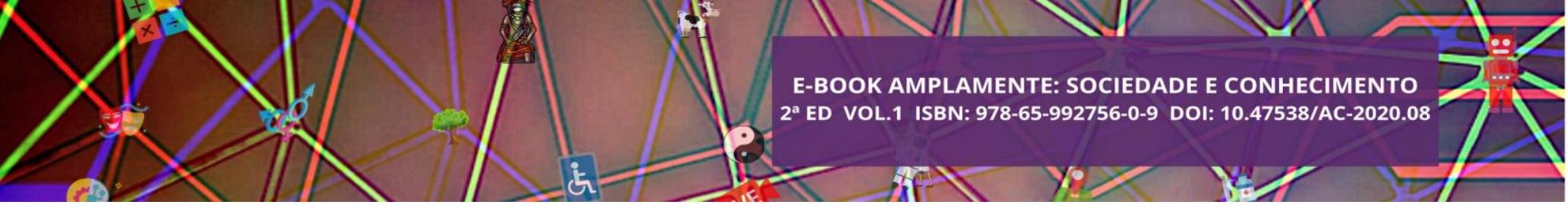

Para a população o gráfico será dado pelo histograma do gráfico (1):

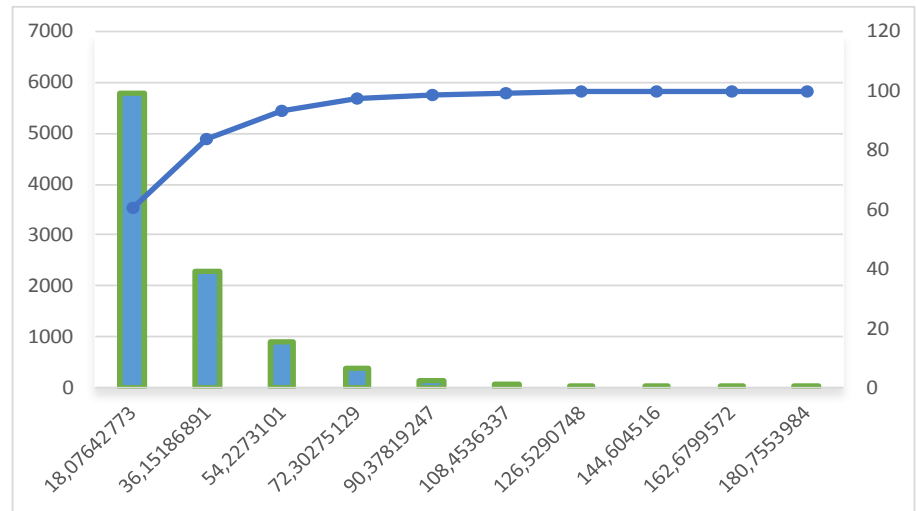

Gráfico 1: População com distribuição exponencial

Para as amostras de tamanhos 8 e 16 os gráficos serão dados por (2) e (3).

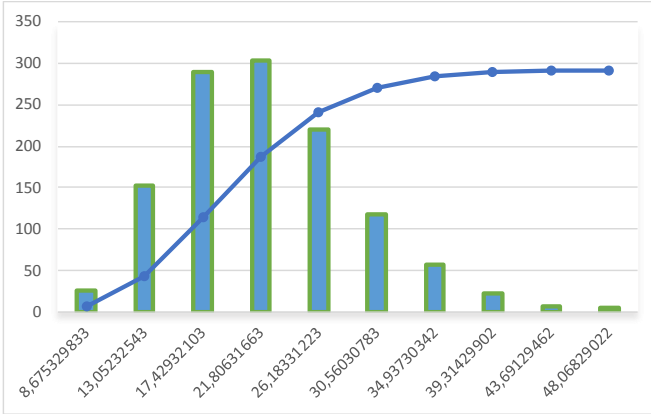

Gráfico 2: Amostras de dimensão 8

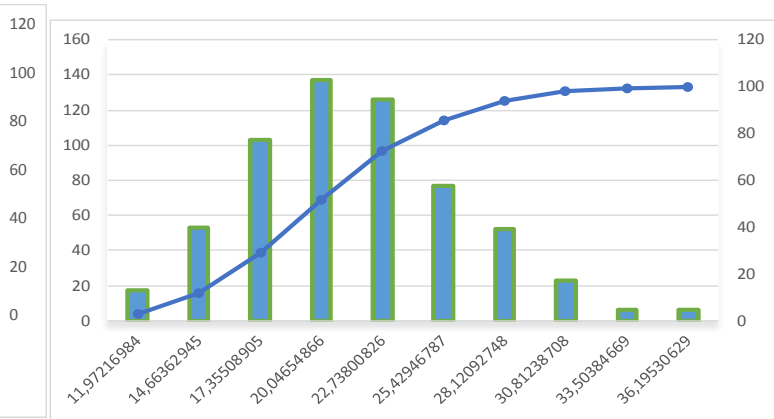

Gráfico 3: Amostras de dimensão 16

Para as amostras de tamanhos 32 e 64 os gráficos serão dados por (4) e (5).

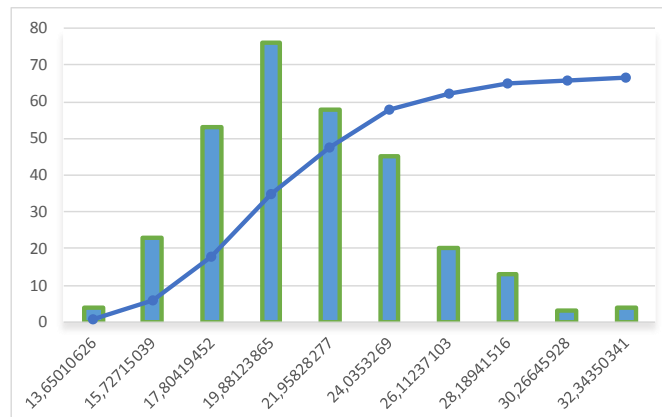

Gráfico 4: amostras de dimensão 32

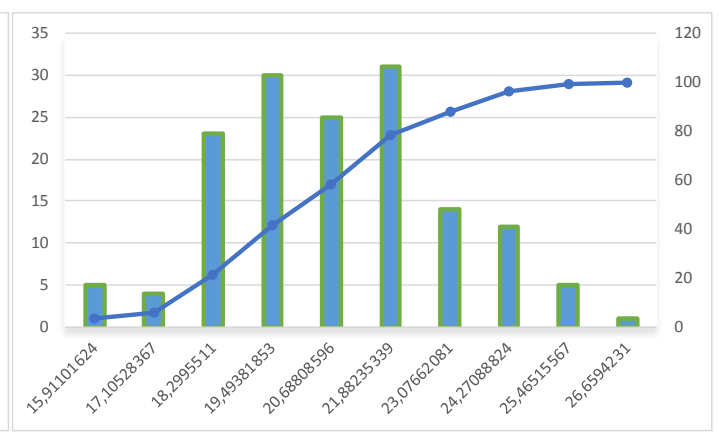

Gráfico 5: amostras de dimensão 64 


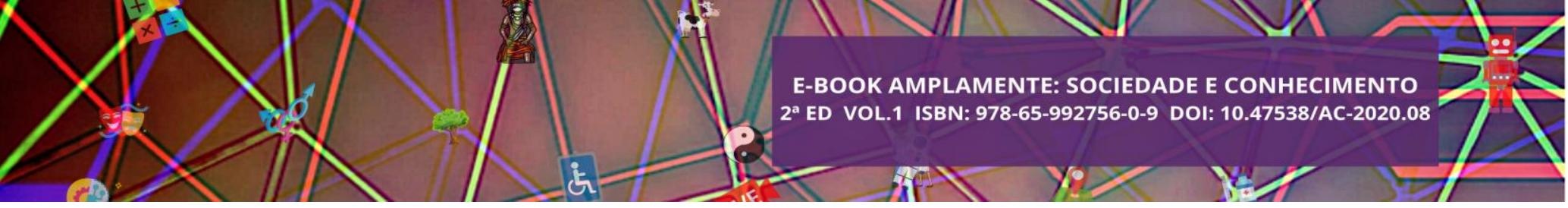

Pode-se notar, graficamente, que, partindo-se de uma distribuição assimétrica, caracterizada por uma exponencial, à medida que se aumenta o tamanho da amostra, o conjunto de médias amostrais geradas a partir de amostras de mesma dimensão tende para uma distribuição normal, como se pode verificar nos histogramas.

\section{CONSIDERAÇÕES FINAIS}

Procurou-se, neste artigo, através da simulação do método de Monte Carlo, demonstrar o Teorema do Limite Central, um dos teoremas mais importantes da Estatística.

O que se verificou com esta aplicação é que o Método de Monte Carlo se mostrou eficiente na demonstração do referido teorema, que apresenta uma certa complexidade na sua demonstração. Existem controvérsias com relação à aplicabilidade do método em situações reais com a afirmação de que existem métodos mais eficientes, mas a simulação de tal método poderia ser usada para demonstração de uma vasta gama de teoremas com certa complexidade matemática, como, por exemplo, determinação de uma integral definida, os limites fundamentais do cálculo, convergências de séries ou funções, etc. Nesse contexto, pode-se considerar a simulação do método de Monte Carlo uma ferramenta muito eficiente.

\section{REFERÊNCIAS}

ACKOFF, R. L.; SASIENI, M. W. Pesquisa operacional. Rio de Janeiro/São Paulo: LTC/Editora da Universidade de São Paulo, 1971.

ANDERSON, E. C. Monte Carlo Methods and Importance Sampling. Lecture Notes for Stat 578C Statistical Genetics, Berkeley, College of Letters and Science/University of California, out. 1999.

ASSIS, Rui. Técnicas Básicas de Simulação. In: . Apoio à Decisão em Manutenção na Gestão de Activos Físicos. Lisboa: Lidel, 2010. Anexo VI.

CASALINHO, G. D’Agostini de O. et al. Uso de simulação de eventos discretos para análise da implementação de conceitos de produção enxuta. Revistas Sociais e Humanas, Rio Grande do Sul, v. 24, n. 1, p. 87-100, jan.-jun. 2001.

GMURMAN, V. E. Teoria das probabilidades e estatística matemática. Moscou: MIR, 1983.

MESSETI, A. V. L.; QUEIROZ, S. C. Método de Monte Carlo: Técnica de redução da variância. Unopar Cient., Ciên. Exatas Tecnol., Londrina, v. 1, n. 1, p. 39-44, nov. 2002. 


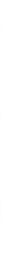

para o avanço das forças produtivas de um país, em decorrência dos vários benefícios decorrentes desse desenvolvimento. Pretende-se analisar a utilização das energias renováveis no Brasil e o estado da arte da geração de CT\&I nos subsistemas de energia eólica e solar. Com base no arcabouço teórico supramencionado, é possível identificar o grau de aderência das principais políticas públicas brasileiras destinadas à construção institucional de instrumentos. Ademais, permite observar os prováveis impactos dos mecanismos legais e de implementação de ações de incentivo para o setor produtivo específico. Nesse sentido, o objetivo desta pesquisa é analisar a construção, a geração e a difusão de conhecimentos de CT\&I dos sistemas produtivos de energias renováveis, em particular associados aos subsistemas de energia eólica e solar.

A importância de diversificar a matriz energética do país tem se intensificado nas últimas décadas, tendo em vista a crescente conscientização dos impactos causados ao meio-ambiente pela utilização de combustíveis fósseis. Nessa perspectiva, as primeiras usinas eólicas implantadas no Brasil datam dos anos noventa, com a primeira planta eólica instalada em Fernando de Noronha, Pernambuco.

Araújo e Freitas (2008) destacam que, no Brasil, o uso do vento para produção de energia elétrica ainda é considerado de baixa escala com relação à produção total. Apesar disso, o país tem apresentado crescimento significativo em implementação de grandes campos de energia dos ventos. De 1997 até 2005 o país apresentou aumento de mais de 14 vezes sua produção eólica, de $2 \mathrm{MW}$ para 28,6 MW, com turbinas eólicas conectadas diretamente à rede elétrica. $\mathrm{O}$ aumento da produção eólica e o avanço tecnológico doa aerogeradores reduziu o custo de geração, com valores entre 50 a 70 dólares por MWh em 2006. No final 2019, o preço médio de venda da energia eólica nos leilões de energia era de $\mathrm{R} \$ 100$, o equivalente a menos de 25 dólares à época. Em 2015 a eólica havia se tornado a fonte de energia de menor custo no Brasil, com preços médios nos leilões em patamares inferiores aos da energia hidroelétrica. Já em junho de 2019 a energia solar se tornou a mais barata.

A participação dessas fontes de energia na matriz elétrica brasileira cresceu entre 2018 e 2019. A eólica passou de 7,6\% para 8,6\% e a solar foi de $0,5 \%$ para $1 \%$ da matriz, o que correspondeu a um aumentou 92\% na geração solar só em 2019, enquanto a produção de energia eólica cresceu $15,5 \%$ naquele ano, quando a participação de renováveis na matriz elétrica brasileira foi de $83 \%$ (EPE, 2020). 


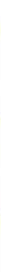

\section{REFERENCIAL TEÓRICO}

Com o advento do paradigma das tecnologias da informação e comunicação (TICs), diversos países passaram a incorporar novas tecnologias de base microeletrônica em seus processos produtivos, bem como direcionaram suas estruturas industriais para os setores mais dinâmicos deste novo paradigma, como por exemplo, os segmentos eletroeletrônicos. Essas características levaram a estrutura industrial brasileira a se descolar dos patamares tecnológicos internacionais, bem como a reduzir a participação relativa dos setores relevantes em relação ao resto do mundo desenvolvido.

Cassiolato e Lastres (2005) destaca a importância do crescimento dos ativos intangíveis na economia do conhecimento. Sob este prisma, é que os subsistemas de energia eólica e solar são considerados grandes dinamizadores da chamada economia do conhecimento, uma vez que faz parte da natureza deles possuir alto grau de intangibilidade, tornando-as altamente pervasivas no sistema produtivo e inovativo nacional. A partir disso, é possível afirmar que a indústria de energias renováveis contribui para o desenvolvimento da economia do conhecimento, permitindo a produção, difusão e utilização de novos conhecimentos, tanto de caráter produtivo, quanto de caráter cultural e imaterial.

Para Staub (2001), na atualidade, a economia depende da geração e incorporação de inovações, seja na competição entre nações ou empresas propriamente ditas. Dominar o conhecimento tecnológico e endogeneizá-lo em seu território, do ponto de vista estratégico, permite ao país autonomia para conduzir o desenvolvimento econômico e social (menor grau de dependência) e maior taxa de acumulação. Silva (2012) observa que o crescimento da renda per capita nos países desenvolvidos, ao longo da história do capitalismo, é fruto do aumento da produtividade do trabalho dessas economias nacionais, que decorre da revolução tecnológica, associada ao processo de industrialização. A conclusão do referido autor é que a ciência e a tecnologia possuem capacidade de contribuir para o desenvolvimento do país.

$\mathrm{Na}$ competição intercapitalista, o conhecimento cria as condições para que as empresas se mantenham competitivas ao longo do tempo, requerendo novos investimentos em desenvolvimento tecnológico e processo continuado. Contudo, a inovação e o desenvolvimento tecnológico não são resultados apenas da ação 


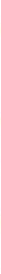

individualizada das empresas, eles existem como produto da coletividade e conformamse na interação entre vários agentes econômicos para produzi-los. Adicionalmente, o processo de inovação está definido pela densidade do conhecimento científico. Os novos paradigmas tecnológicos utilizam intensivamente conhecimentos na fronteira do conhecimento científico.

Ao tratar do contexto científico nacional e internacional, no período recente da história do país, Borges (2010) propõe transformar a ciência em desenvolvimento tecnológico e inovação, no sentido de melhorar a competitividade nacional com base numa política de valorização da educação e da ciência, como pilares para garantir o desenvolvimento social e econômico sustentável. Inclui a necessária institucionalização do fomento à ciência, tecnologia e inovação, com recomendações que poderão, por um lado, indicar os estrangulamentos e, por outro, ajudar na elaboração de uma política coerente para a ciência do país.

No mesmo sentido, Pereira (2004) discute a necessidade de o Brasil construir sua política industrial e tecnológica, como base no conhecimento e na inovação tecnológica, para atuarem como indutores do desenvolvimento econômico. $\mathrm{O}$ autor propõe definir um novo modelo de política industrial, tecnológica e de comércio exterior para o país. Uma vez que, para ele, a política industrial assume um papel estratégico na medida em que orienta os agentes produtivos, que precisam tomar decisões de investir e/ou inovar em ambientes permeados por incertezas. A definição de uma política industrial que incorpore o incentivo à inovação e às exportações tem a sua viabilidade condicionada à capacidade do Estado de regular, de estabelecer políticas de compras, bem como de prover financiamento e incentivos fiscais.

A contribuição de Mendes; Oliveira e Pinheiro (2013) corresponde à análise dos possíveis impactos da Política Nacional de Ciência, Tecnologia e Inovação, tendo o propósito de avaliar o marco regulatório com base nos indicadores do processo inovativo. Traz uma visão geral sobre as relações entre a Lei da Inovação e a Lei do Bem, e examina os indicadores de inovação mais empregados: investimento em Pesquisa e Desenvolvimento, bem como, considera o dispêndio privado em P\&D. Os resultados apontam para o aumento dos investimentos privados em P\&D após a vigência das leis.

Outrossim, os desdobramentos teóricos neo-schumpeterianos tratam dos regimes tecnológicos, tais como: a combinação das condições de oportunidade, apropriabilidade, 


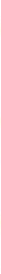

cumulatividade do conhecimento tecnológico e das características da base do conhecimento Malerba e Orsenigo (1995; 1997), Malerba (2009). Os autores atribuem várias dimensões, níveis e naturezas das propriedades básicas das tecnologias, que combinadas podem ser utilizadas de forma inovadora para identificar os regimes tecnológicos de sistemas e/ou subsistemas produtivos.

\section{ENERGIAS RENOVÁVEIS NO BRASIL E NO MUNDO}

Entre todas as fontes renováveis, as energias oriundas do vento e do sol são consideradas as mais rápidas e promissoras para substituição das fontes de energias tradicionais. Neste contexto, Kumar et al (2016) destaca que a confiança na energia eólica pode ser percebida no recente crescimento da tendência de investimento das grandes potências econômicas mundiais, no mercado de energia. A Organização das Nações Unidas (ONU), percebendo a necessidade global de acesso à energia (especialmente em países subdesenvolvidos), declarou o ano de 2012 como "O ano Internacional de Energia Renovável para todos". No referido artigo, os autores trazem, por meio de uma rica base de dados e gráficos, os maiores países produtores de energia eólica do mundo até o ano de 2012. Soma-se a isso as baixas produções encontradas, sobretudo nos países emergentes.

Ainda de acordo com Kumar et al (2016), nas últimas décadas o mundo presenciou um crescimento significativo na produção de energia eólica. o Em 2012, a geração eólica equivaleu a $36 \%$ da produção total global de energias renováveis. Até o final do ano de 2011, a Europa possuía os níveis mais altos de capacidade total instalada no ranking dos continentes (96,7 GW), seguida pela Ásia (82,4 GW) e América do Norte $(52,18 \mathrm{GW})$. No entanto, em números de adição anual de nova capacidade eólica, o continente Asiático lidera com margem elevada, tendo instalado sozinha, 21,3 GW no ano de 2011, seguida pela Europa 10,3 GW e América do Norte 8 GW. A liderança asiática no ranking de instalação adicional anual, se deve pelo crescimento sem precedentes das indústrias eólicas da China e Índia.

No Brasil, a partir da década de 1980, os incentivos governamentais ao desenvolvimento da energia eólica e solar e o consequente desenvolvimento tecnológico das turbinas eólicas, permitiram a consolidação da atividade industrial de produção de aerogeradores (PODCAMENI, 2014). Os primeiros investimentos brasileiros em 


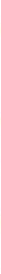

energia eólica e solar ocorreram como resposta à crise energética dos anos 1970 . No final daquela década, o governo militar, promove uma série de iniciativas voltadas ao desenvolvimento de capacitações científicas e tecnológicas em fontes de energias alternativas aos combustíveis fósseis. A mais conhecida delas foi o Programa Nacional do Álcool (Proálcool). Entre as demais, a pesquisa em energia eólica recebe algum destaque e um Centro de Energia Eólica é criado no Centro Tecnológico da Aeronáutica (CTA). Os investimentos em energia eólica não estavam, portanto, associados a questões ambientais, mas sim a preocupações associados ao abastecimento energético (PODCAMENI, 2014).

De acordo com Araújo e Freitas (2008), em 1992 foi instalada a primeira turbina eólica para operação comercial da América do Sul, em Fernando de Noronha. Uma parceria feita entre a empresa FolkCenter da Dinamarca, Universidade Federal de Pernambuco e a Companhia de Energia de Pernambuco (CELPE). Uma torre de 23 metros de altura, com hélices de 17 metros de diâmetro foi instalada na ilha. No ano de 2006, a energia dos ventos fazia parte de $4 \%$ da produção total da ilha de Noronha, que antes tinha sua produção pela termoeletricidade, baseada no óleo diesel, que causava sérios impactos ambientais na ilha.

Nos anos noventa, também foi instalada a usina do Morro do Camelinho, em Minas Gerais, com capacidade de $1 \mathrm{MW}$ e custo total de US\$1,5 mi, que foram divididos entre o Programa Eldorado de Ciência e Tecnologia da Alemanha, o qual arcou com 51\% do investimento, e a Companhia Energética de Minas Gerais (CEMIG), que investiu os $49 \%$ restantes. Nos anos que se sucederam foram executados mais projetos de energia eólica no Brasil, quais sejam: Usina de Palmas no Paraná, com capacidade de 2,5 MW; Usina do Porto Mucuripe no Ceará, com capacidade de 1,2 MW; Usina de Taiba e a usina de Prainha, ambas no estado do Ceará, com capacidade de 5 MW e 10 MW respectivamente.

A partir do objetivo proposto, destaca-se que a importância da análise do processo do desenvolvimento da CT\&I fundamenta-se na sua concatenação histórica, observada nos países desenvolvidos. O pós-II Guerra marca o início do desenvolvimento do capitalismo tecnológico, nesse sentido a CT\&I constitui peça fundamental para o crescimento e desenvolvimento econômico das nações. Antes do conflito, a união entre ciência e tecnologia foi o grande desafio apresentado pela competição capitalista. Enquanto no início do novo século, a inovação passa a integrar o 


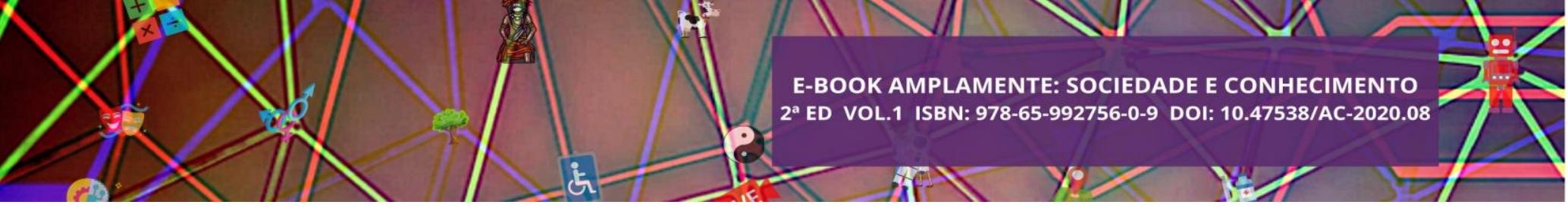

tripé do novo modelo de desenvolvimento capitalista. Com isso, a ideia de desenvolvimento de tecnologia é parte importante de inserção no processo produtivo global. Agora, a dinâmica proposta orienta-se na expansão do conhecimento como resultado de interações sociais.

O conhecimento é a palavra chave que dá ênfase à CT\&I nos tempos modernos, sendo a variável que desencadeia o desenvolvimento e potencializa a competitividade nos diferentes setores da economia (BRASIL, 2002). A geração de conhecimento baseado em CT\&I demanda altos investimentos em educação e em mecanismos de difusão desse próprio conhecimento, seja ele criado ou apropriado. É um processo contínuo, que envolve o funcionamento e a articulação de diversos atores e redes de instituições. Essas redes, desempenham papéis específicos dentro de cada área, capazes de fazerem frente aos crescentes riscos inerentes ao processo.

Nesse sentido, as políticas públicas de apoio à CT\&I destinam-se a fortalecer a estrutura institucional no país, bem como proporcionar a inclusão de novos arranjos entre os diferentes setores nacionais, alterando a relação entre o setor público e o setor privado (BRASIL, 2002). Para Silva (2012), a alocação de recursos financeiros necessários (de forma continuada), constitui o conjunto de condições necessárias ao desenvolvimento das atividades de CT\&I, mas ainda assim elas não são suficientes.

Para Filgueiras e Silva (2003), a dependência das hidrelétricas, combinada com a escassez de outras fontes alternativas de energia, colocou em risco toda a produtividade do país após a crise de 2001, no setor elétrico, demonstrando a importância da diversificação das fontes energéticas. Um exemplo é o Rio São Francisco, localizado na região nordeste. Em época de seca as hidrelétricas são prejudicadas, mas os ventos fortes daquela estação facilita o trabalho de turbinas eólicas, produzindo grande quantidade de energia limpa e alternativa.

\section{RESULTADOS E DISCUSSÃO}

A importância da instalação de fontes alternativas de energia, para desenvolvimento da capacidade produtiva energética brasileira é consenso entre os especialistas. Os impactos ambientais causados pelo uso abusivo de combustíveis fósseis, somado à necessidade de ampliação da produção de energia, levaram várias potências mundiais a criarem novas "Tecnologias para produção de Energias 


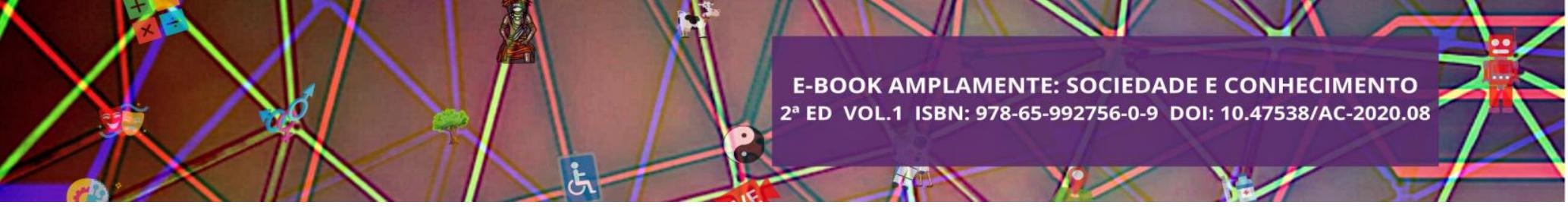

Renováveis" (RET). Projetos de incentivos à produção de energia renovável foram criados por governos de vários países, gerando milhões de empregos na área. Contudo, para Simas e Pacca (2014) os estudos sobre a geração de empregos no ramo energético são direcionados com dados vagos e incompletos. No presente artigo, os autores discorrem, de forma precisa e inovadora, sobre a importância de geração de empregos no âmbito das Energias Renováveis no Brasil, trazendo maiores detalhes sobre a geração desses, na energia eólica.

De acordo com Simas e Pacca (2014), apesar do consenso entre pesquisadores de que as tecnologias para produção de energia renovável demandam uma capacidade maior de empregos, se comparada às tecnologias movidas a combustíveis fósseis, os estudos produzidos anteriormente, para analisar a geração de emprego em usinas eólicas apresentam muitas divergências. Isso se explica pelo fato desses estudos associarem o emprego à capacidade instalada das usinas eólicas. O presente artigo estima o emprego com base na capacidade de produção do Brasil, combinando a estimativa de possíveis empregos diretos, requisitos materiais na produção de equipamentos, construção e operação de usinas eólicas, com um sistema de avaliação econômica do ciclo da vida insumo-produto, para avaliar o emprego na cadeia de suprimentos, a montante de insumos materiais.

A geração de energia eólica e solar apresenta vantagens significativas, podendo contribuir para a redução de perdas na transmissão de energia e para o aumento da eficiência do setor elétrico, assim como, para uma redução consistente dos custos de geração eólica e solar, visto que o estímulo à produção e à compra de materiais em grande quantidade gera competitividade e, automaticamente, redução de preços. Além disso, possibilita a redução de $\mathrm{CO} 2$, o que gera um impacto positivo no meio ambiente. Ademais, há geração de emprego, especialmente nas implantações de parques eólicos e solares, onde profissionais serão treinados e qualificados.

Após a crise energética de 2001, o Brasil passou por um processo de reestruturação da sua produção e controle de energia. Assim, importantes instituições foram criadas para melhorar a geração, transmissão, distribuição e comercialização de energia, como: Agência Nacional de Energia Elétrica (Aneel), Operador Nacional do Sistema (ONS) e o Mercado Atacadista de Energia (MAE). Além de programas como o Programa de Incentivo a Fontes Renováveis (PROINFA), que estimula, junto com a Eletrobrás, projetos de energias renováveis no país. Ademais, as políticas industriais 


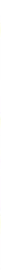

adotadas na última década (PITCE, PACTI e PDP) desempenharam papel relevante para o impulso inicial ao sistema produtivo de energia eólica e solar brasileiro.

Apesar disso, a partir de 2013 as políticas industriais adotadas perderam o apoio de boa parte da opinião pública. A construção dos sistemas produtivos de energias renováveis constitui um elemento central para o progresso das forças produtivas brasileiras. O caminho para o desenvolvimento de energias sustentáveis no Brasil, tem embasamento na Lei 9.991 de 24 de julho de 2000 que dispõe sobre o compromisso, por parte das empresas do ramo de geração de energia, do investimento e desenvolvimento de energias renováveis. Desta forma, de acordo com a ANEEL (Agência Nacional de Energia Elétrica) foi previsto um investimento de $\mathrm{R} \$ 400$ bilhões de reais em pesquisa e desenvolvimento por parte das empresas do ramo energético no ano de 2017. Ainda, cabe salientar o enorme potencial que o Brasil possui para a geração de energias limpas, o qual não vem sendo aproveitado. Devido ao alto custo das máquinas e equipamentos apropriados para geração de energia limpa, existem poucas empresas nacionais dedicadas a essa atividade (RAIS, 2018).

Silva et al (2013) destacam que os programas governamentais como o PROINFA, que incentivaram inúmeros leilões, também foram de suma importância para a expansão da capacidade instalada no país e, especialmente, para tornar o mercado eólico brasileiro mais competitivo. O trabalho do autor mostra que o preço da energia eólica no Brasil foi reduzido a $60 \%$ desde o primeiro leilão efetuado. Porém, o país enfrenta algumas barreiras que, eventualmente, comprometem o crescimento da geração de energia eólica em território nacional, como por exemplo: incertezas econômicas, que ampliam a percepção de risco dos investidores, além disso, a falta de apoio político gera atraso na implementação de novos programas, bem como a escassez de financiamento adequado a longo prazo é outro desafio, entre outras barreiras ao investimento em capacidade de geração eólica.

\section{CONSIDERAÇÕES FINAIS}

Em suma, o sistema produtivo e inovativo de energias renováveis brasileiro é concentrado em equipamentos de baixo valor agregado e menor complexidade tecnológica, tendo em vista os altos custos materiais que tornam a produção nacional inviável. As possibilidades de migrar para segmentos de maior valor agregado são 


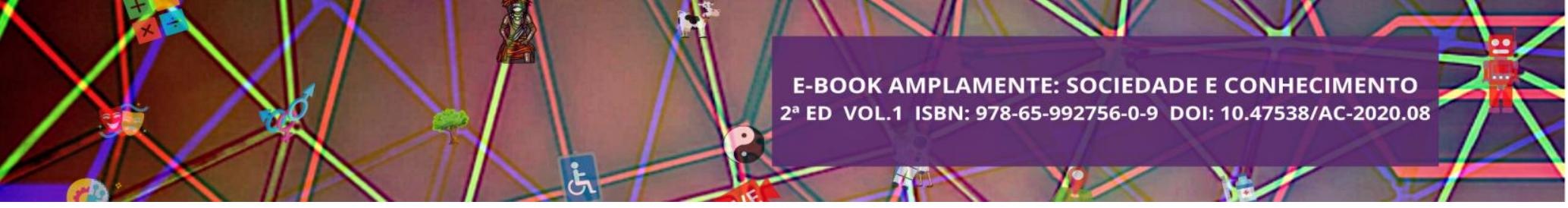

limitadas e dependentes de políticas de incentivo e forte investimento. Contudo, existem iniciativas que podem, no futuro, fortalecer a criação de mecanismos mais dinâmicos na cadeia produtiva, em especial, os fundos setoriais e subvenção econômica, que são relacionados à sinalização dos segmentos e/ou produtos e serviços em que a indústria apresenta determinado déficit, ou mesmo que o Estado pretende desenvolver através de incentivos públicos. Assim, pode-se concluir que a política nacional de desenvolvimento de energias renováveis, praticamente abandonada nos últimos anos, precisa ser retomada, uma vez que representa um esforço de intervenção estatal, através das políticas públicas de apoio, em que foram desenvolvidos instrumentos e mecanismos para atingir as prioridades, objetivos e metas.

O estado da arte da evolução do conhecimento científico e tecnológico identifica as possibilidades de intervenção e necessidade da realização de investimentos específicos para o desenvolvimento de subsistemas estratégicos para o Brasil. Esse entendimento possibilita novas agendas para planejar intervenções nas políticas públicas de apoio, que coordene ações para superar o atraso tecnológico brasileiro em relação a Alemanha, França, Inglaterra, China e EUA, entre outros países.

Portanto, o enfrentamento das "barreiras" econômicas, políticas, sociais e ambientais para o desenvolvimento de energias renováveis é um grande desafio brasileiro para a diversificação da matriz energética. Combinado a isso, as necessidades de fortalecimento de uma organização nacional; atratividade ambiental de recursos renováveis; adoção de mais programas de incentivo a recursos renováveis; ações destinadas a regulação do mercado energético e principalmente o incentivo a pesquisas e estudos no setor de energias renováveis, são medidas que, quando forem tomadas, trarão ao Brasil o desenvolvimento na produção de energia.

\section{REFERÊNCIAS}

ARAÚJO, M. S. M.; FREITAS, M.A. V. Acceptance of renewable energy innovation in Brazil: case study of wind energy. Renewable and Sustainable Energy Reviews. Volume 12, p. 584-59. Issue 2, February 2008. https://doi.org/10.1016/j.rser.2006.03.017.

BORGES, M. N. Ciência, tecnologia e inovação. CEP, Vol. 30, p. 080, 2010.

BRASIL. ANEEL: Programa de Eficiência Energética. Disponível em: <http://www.aneel.gov.br/programa-eficiencia-energetica>. Acesso em: 29 jun. 2019. 


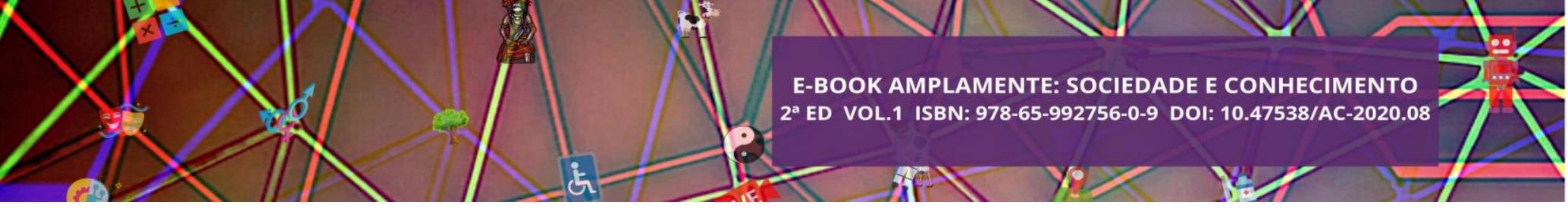

REPÚBLICA FEDERATIVA DO BRASIL. Lei nº 9.991, de 24 de julho de 2000, Brasília.

SILVA, C.H.R.T. Ciência, Tecnologia e Inovação. Boletim do Legislativo $n^{\circ} 10$, de 2012.

SILVA, N. F.; ROSA, L. P.; FREITAS, M. A. V.; PEREIRA, M. G. Wind energy in Brazil: From the power sector's expansion crisis model to the favorable environment. Renewable and Sustainable Energy Reviews Volume 22, p. 686-697. June, 2013. https://doi.org/10.1016/j.rser.2012.12.054

SIMAS, M. PACCA, S. Assessing employment in renewable energy technologies: A case study for wind power in Brazil. Renewable and Sustainable Energy Reviews Volume 31, p. 83-90. March 2014. https://doi.org/10.1016/j.rser.2013.11.046.

STAUB, E. Desafios estratégicos em ciência, tecnologia e inovação. IEDI. Brasília, 2001. Disponível em:< http://www.iedi.org.br > Acesso em: 10 Set. 2017. 


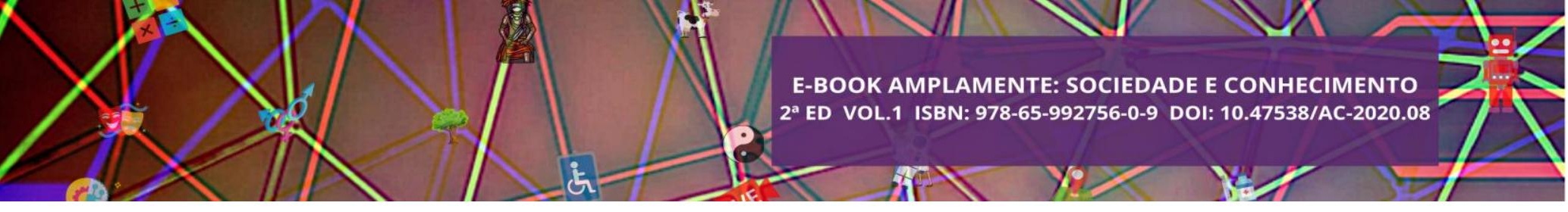

\title{
CAPÍTULO XXXVII
}

\section{TEMPO E ESPAÇO: ELEMENTOS DETERMINANTES DA CONSTRUÇÃO DE SENTIDO NA LINGUAGEM CINEMATOGRÁFICA}

\author{
Rita de Cássia Dias Verdi Fumagalli \\ DOI - Capítulo: 10.47538/AC-2020.08-37
}

\section{RESUMO:}

A temática deste estudo consiste em sistematizar e aplicar o conceito de cronotopia na análise da narrativa fílmica Cópia Fiel (Copie Conforme, 2010), do Diretor iraniano Abbas Kiarostami, tendo como base o pensamento de Bakhtin (1990). O objetivo da pesquisa volta-se para a união entre o tempo e o espaço como elementos determinantes na construção de sentido na linguagem cinematográfica. Sob esse aspecto, a figura da estrada é tomada como ponto de partida para a observação do modo como se cria a relação espaço-tempo no corpus selecionado. Tal proposta se justifica em virtude de que os preceitos teóricos bakhtiniano, embora voltados para análise da linguagem literária, podem ser aplicados como recurso facilitador e esclarecedor das significações geradas pela linguagem cinematográfica, uma vez que é no cronotopo que os nós do enredo são feitos e desfeitos. A partir dos resultados encontrados, observou-se que para compreender o sentido no filme de Kiarostami é necessário recorrer aos cronotopos, que se cruzam e se confrontam, determinando a imagem do personagem no mundo que ele representa de acordo com o tempo no qual ele se encontra.

PALAVRAS-CHAVE: Espaço. Tempo. Análise fílmica. Copie Conforme.

\section{CONSIDERAÇÕES INICIAIS}

O tema deste estudo tem como foco a análise de uma narrativa fílmica sob o viés dos preceitos teóricos de Bakhtin (1990), mais especificamente o conceito de cronotopo, que contribui na estruturação das categorias de espaço e de tempo em diferentes manifestações artísticas. A delimitação do trabalho está atrelada ao papel que a estrada

\footnotetext{
${ }^{193}$ Doutora em Letras pela Universidade de Passo Fundo (UPF/2019). Mestre em Letras (Literatura Comparada) pelo Programa de Pós-Graduação em Letras da Universidade Regional Integrada do Alto Uruguai e das Missões (URI/2015), titular do diploma de Especialização em Análise do Discurso: O Discurso e suas Interfaces: arte, comunicação e cultura (URI/2012) e graduada em Letras (Português/Espanhol e respectivas literaturas) pela mesma IES (URI/2011). Tem experiência na área de Linguística, atuando principalmente nos seguintes temas: identidade cultural e Análise do Discurso de filiação francesa em interlocução com outras materialidades significantes. Atualmente, é Diretora de Departamento na Secretaria Municipal de Educação, Cultura e Desporto do Município de Derrubadas/RS. E-mail: ritacassiafumagalli@gmail.com
} 


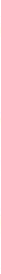

desempenha no desenrolar da trama narrativa de Copie Conforme (2010), sendo a grande responsável por atribuir movimento ao enredo.

Em vista disso, o objetivo da pesquisa volta-se para a relação espaço-tempo como elemento determinante na construção de sentido na linguagem cinematográfica. $\mathrm{O}$ filme é tomado como manifestação artística e como tal é marcado por um espaço e por um tempo que podem mudar a todo instante, constituindo significados infinitos que dialogam entre si.

Portanto, observou-se que diferentes cronotopos se cruzam e se confrontam na narrativa cinematográfica de Kiarostami. Esses cronotopos são responsáveis por construir o sentido na obra fílmica, pois determinam a imagem das personagens inseridas no mundo, em constante movimento, com mescla de passado, presente e futuro na história narrada.

\section{O CRONOTOPO BAKHTINIANO}

Bakhtin (1990), ao elaborar sua teoria do romance, criou um conceito para estruturação de tempo e de espaço, no gênero literário, chamado cronotopo. Nas palavras do teórico, o conceito de cronotopo, formado pelas palavras gregas crónos (tempo) e tópos (espaço), foi empregado, inicialmente, "nas ciências matemáticas e foi introduzido e fundamentado com base na teoria da relatividade (Einstein)". (BAKHTIN, 1990, p. 211).

Bakhtin toma emprestado esse conceito da teoria da relatividade como uma metáfora para a análise da crítica literária, objetivando, unicamente, demonstrar como o cronotopo expressa a inseparabilidade do espaço e do tempo (tempo como a quarta dimensão do espaço). Dessa forma, no ensaio Formas de tempo e de cronotopo no romance: ensaio de poética e história, da obra Questões de Literatura e de Estética: a teoria do romance (1990), cronotopo é apresentado por Bakhtin como uma categoria constitutiva do texto literário - por nele se expressar a fusão tempo/espaço e assim determinar a imagem do homem na literatura. Segundo o autor,

no cronotopo artístico-literário ocorre a fusão dos indícios espaciais e temporais num todo compreensivo e concreto. Aqui o tempo condensa-se, comprime-se, torna-se artisticamente visível; o próprio espaço intensifica-se, penetra no movimento do tempo, do enredo e da história. Os índices do tempo transparecem no espaço, e o espaço reveste-se de sentido e é medido com o tempo. Esse cruzamento de 


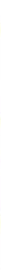

séries e a fusão de sinais caracterizam o cronotopo artístico. (BAKHTIN, 1990, p. 211).

A partir do cronotopo é possível entender toda e qualquer unicidade de uma obra. Esse termo é entendido como um dos fatores que atua tanto na organização interna da narrativa, ou seja, na escolha do tema até o arranjo estrutural da sequência cronológica e do tratamento de espaço, como pelo momento social e histórico de sua produção e recepção.

Assim, o cronotopo tem um papel fundamental e específico em quase todos os gêneros literários. Nas palavras de Bakhtin (1990), cada gênero é determinado justamente por um tipo de cronotopo, sendo esse o princípio condutor da sua formação. Para o autor, "o cronotopo como categoria conteudístico-formal determina (em medida significativa) também a imagem do indivíduo na literatura”. (BAKHTIN, 1990, p. 212). Essa imagem sempre é, fundamentalmente, cronotópica.

Embora não tenha referenciado a narrativa fílmica em seus estudos, os pressupostos teóricos bakhtinianos são perfeitamente ajustáveis a esse gênero, como por exemplo, o conceito de cronotopo. Tal como outras linguagens e expressões artísticas, o cinema é um meio para que o homem expresse e problematize seu tempo e sua existência, as pessoas procuram no cinema uma fuga à sua própria realidade.

Se, conforme Bakhtin (1990), no romance, o tempo é o princípio condutor do cronotopo, transformando-se em algo artisticamente visível. No cinema o tempo passa a ser personagem central, responsável por conferir movimento à narrativa e produzir sentidos, em que várias visões sobre o homem, sobre sua existência, em um determinado espaço (tópos) e tempo (crónos), se reescrevem na produção histórica.

Nesse processo, as relações de espaço e de tempo na obra literária e artística, como o cinema, de um modo geral, configuram-se como uma espécie de denominador comum no qual se aglutinam, se debatem e emergem as particularidades dos seres construídos por meio de interações sociais. O tempo, acoplado ao espaço, é responsável por construir a imagem do homem em formação, a cada momento novo tem-se um homem novo.

No desenvolvimento de suas reflexões em torno da relação espaço-tempo no romance, Bakhtin (1990) apresenta três formas de cronotopos do mundo antigo que ainda sobrevivem na tradição literária: o cronotopo da aventura, o cronotopo da vida privada e do cotidiano e o cronotopo da biografia e autobiografia. Dentre os três tipos de 


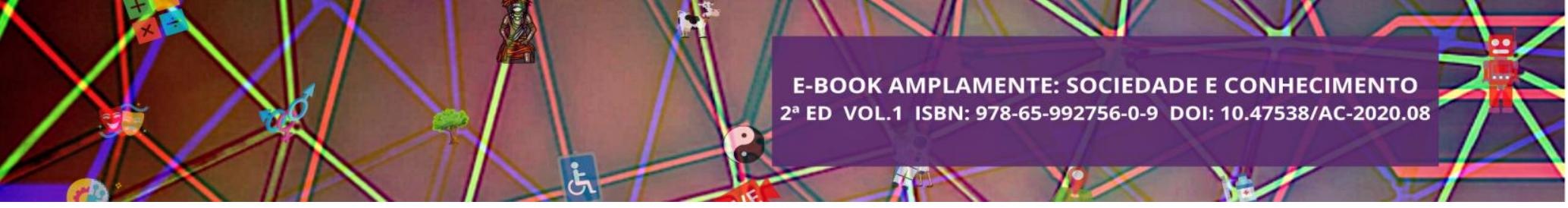

cronotopo interessa a esse trabalho, principalmente, o cronotopo de aventuras, caracterizado pelas sucessões operadas no espaço físico.

Bakhtin (1990, p. 217, grifo do autor) corrobora que no tempo de aventura, "um dia, uma hora e até mesmo um minuto, mais cedo ou mais tarde, têm sempre significado decisivo e fatal". Nesse cronotopo, o tempo é marcado pela casualidade e é da relação espaço-tempo que depende todo o desdobramento da aventura experimentada pelas personagens. A aventura compõe-se, assim, de uma série de breves segmentos, dentro de cada um deles o tempo está organizado exteriormente, ligando-se aos momentos que se repetem da vida humana e natural.

Nas palavras de Bakhtin (1990, p. 222), há vários motivos que constituem o cronotopo de aventuras, como "despedida (separação), perda, buscas, descobertas, reconhecimento, não reconhecimento". Dentre eles, o teórico cita "o motivo do encontro" como o mais importante. Segundo Bakhtin (1990, p. 222), o motivo do encontro "entra como elemento constituinte da composição do enredo e da unidade concreta de toda a obra", pois engendra um forte grau de intensidade de valor emocional.

Ainda, para Bakhtin (1990), o motivo do encontro está intrinsecamente ligado ao que denomina "cronotopo da estrada", que são os vários tipos de encontros que acontecem pelo caminho quando as personagens se colocam em movimento. De fato, na estrada cruzam-se em um único ponto espacial e temporal,

os caminhos espaço-temporais das mais diferentes pessoas, representantes de todas as classes, situações, religiões, nacionalidades, idades. [...] parece que o tempo se derrama no espaço e flui por ele (formando caminhos); daí a tão rica metaforização do caminhoestrada: "o caminho da vida". (BAKHTIN, 1990, p. 350).

$\mathrm{Na}$ perspectiva bakhtiniana, a estrada é a representação da trajetória ou da viagem das personagens durante o tempo de aventura. Seguindo essa linha de raciocínio, Amorim (2010) evidencia que o cronotopo da estrada indica "o lugar onde se desenrolam as ações principais, onde se dão os encontros que mudam a vida dos personagens. [...] onde se escande e se mede o tempo da história. A cada vez, é preciso voltar a ela para que o tempo avance" (AMORIM, 2010, p. 102). 


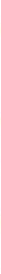

Com o objetivo de exemplificar o cronotopo da estrada, Amorim (2010) analisa alguns filmes road movie ${ }^{194}$ para ilustrar a ideia bakhtiniana da relacionalidade inerente entre tempo e espaço. Nesses filmes, há a recorrência de duas figuras: a estrada, onde se dá o deslocamento das personagens; e o carro, que funciona não apenas como veículo do trânsito, mas também como elemento que delimita a dimensão espacial em que circunscrevem esses sujeitos. Conforme a autora, o carro desempenha um verdadeiro papel de cronotopo, pois dele é possível inferir uma determinada visão de homem.

Nos filmes de Kiarostami, o cronotopo da estrada aparece de maneira recorrente na constituição dos enredos. Na estrada, o tempo se dissolve no espaço e os inúmeros momentos que compõem a história de cada indivíduo são fixados. Nas palavras de Amorim (2010), a relação intrínseca entre carro e estrada submete as personagens da ação cinematográfica a territórios outros: outros lugares, outras culturas, outras pessoas.

É nesse sentido que o conceito bakhtiniano de cronotopo aplica-se a análise da narrativa fílmica, uma vez que os sentidos gerados a partir das relações espaçotemporais em que as personagens estão vinculadas influem na compreensão dos fatos narrados.

\section{ESPAÇO E TEMPO NA CONSTRUÇÃO DE SENTIDOS NA LINGUAGEM CINEMATOGRÁFICA}

Após lançamento do filme Khane-ye Doust Kodjast? (Onde é a Casa do Amigo? 1987), os filmes de Abbas Kiarostami passaram a ser presença constante em grandes festivais de cinema. Kiarostami se destaca por ser um cineasta difícil, que procura retratar em seus filmes a vida cotidiana de uma forma pouco convencional e normalmente prática um cinema da curiosidade. O que ele pede ao espectador é a capacidade de imaginar, de completar aquilo que sugere e instiga em seus filmes.

Outra característica marcante nos filmes do cineasta iraniano é a predominância de cenas de paisagens, onde se busca o registro de como as pessoas vivem. Kiarostami procura captar essa vida, esse mundo, a forma como as pequenas coisas vão influindo em cada cena que é apresentada. Talvez essa seja a grande essência no tipo de cinema feito por esse Diretor, tão prestigiado e premiado.

${ }^{194}$ O termo designa aqueles filmes que se desenrolam inteiramente na estrada. (AMORIM, 2010, p. 102). 


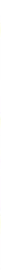

Além desses aspectos, os filmes de Kiarostami ganham destaque pelo estilo frugal, cheios de sutilezas e humanidades. Cópia Fiel (2010) é um exemplo de filme carregado de simbolismo, que evolui como um drama simples, repleto de inclinações românticas, metalinguagens e encadeamento narrativo complexo.

Lançado em 18 de março de 2011, na França, Copie Conforme (2010) foi o primeiro filme produzido por Kiarostami fora do Irã, a primeira grande obra de caráter universal. Ganhador da Palma de Ouro no Festival de Cannes, por Gosto de Cereja (1997), e do prêmio especial do júri no Festival de Veneza, por O Vento nos Levará (1999), Kiarostami foi um dos responsáveis pela popularização do cinema iraniano no Ocidente nos últimos anos. Em seu primeiro filme europeu, tira o foco do seu país e usa relações amorosas para fazer uma bela homenagem ao cinema.

Cópia Fiel (2010) inicia com um ambiente simples, um plano detalhe, dois microfones, uma mesa com uma garrafa de água e dois copos, alguns papéis e um exemplar do livro Copie Conforme. Não há a presença de vozes nos primeiros minutos do filme, é possível apenas escutar o "Zunzunzum" do público que aguarda a chegada do escritor James Miller (William Shimell).

Aos 2 minutos e 15 segundos James entra no quadro e pede desculpas pelo atraso, agradece a atenção que o público dá a seu livro e coloca em evidência a polêmica defendida: "A cópia de uma obra de arte possui o mesmo valor que a obra original? O fato do produto não ser autêntico não implica em sua desvalorização" (CÓPIA FIEL, 2010).

Aos 4 minutos e 20 segundos do filme, uma mulher atravessa o quadro e senta na primeira fileira, o fato dessa mulher ocupar um assento reservado remete à pergunta: Será que eles se conhecem? Mas James, em nenhum momento, se abala com o olhar curioso de Elle (Juliette Binoche), dona de uma galeria de arte e, aparentemente, fã do pesquisador e escritor.

Analisando os cronotopos presentes em Cópia Fiel, percebe-se que o que constrói e dá sentido ao drama do filme é a relação de mistério que envolve Elle e James. Aos 5 minutos entra no quadro um menino, o filho adolescente de Elle que, impaciente, convida a mãe para acompanhá-lo. Nesse momento, Elle anota alguma coisa e entrega para o empresário do escritor, talvez esteja nesse papel o segredo para o primeiro grande cronotopo que se desenvolve na trama, o encontro entre o escritor e sua fã, em sua galeria de arte, aos 15 minutos do filme. 


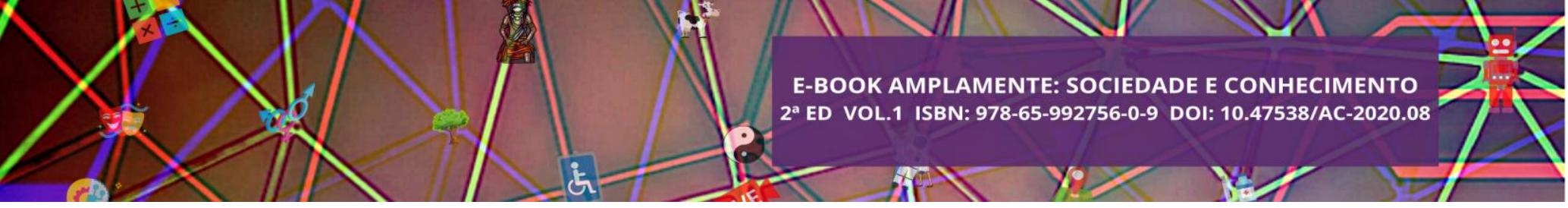

Segundo Bakhtin (1990), o cronotopo do encontro destaca-se por um forte grau de intensidade do valor emocional. Duas personagens se encontram em um lugar determinado em um momento determinado e esse encontro estabelece o curso da narração. Em Cópia Fiel (2010), toda a tensão do enredo se desenvolve em torno do primeiro e único encontro entre Elle e James, na galeria de arte. Sem dúvida o cronotopo do encontro é o ponto de partida do filme, é a base que caracteriza as atitudes e a relação espaço-tempo que as personagens se encontram.

O encontro de James com Elle dá início aos diálogos que contribuirão para a transformação dos protagonistas no transcorrer da narrativa. Nas palavras de Amorim (2010, p. 105), em uma obra, "quando se ouvem vozes, ouvem-se também, com elas, mundos: cada um com o espaço e o tempo que lhe são próprios". O que e quem as personagens eram antes do encontro vai dando lugar a uma nova história de vida, repleta de fantasias e coincidências que os aproxima e os afasta ao mesmo tempo. Ou, como evidencia Bakhtin (1990, p. 223), “o encontro determina diretamente todo o destino de um indivíduo", daí a importância desse cronotopo na narrativa fílmica de Kiarostami.

O espaço da galeria de artes dá lugar ao cronotopo da estrada. James e Elle fazem um passeio de carro por uma estrada cercada de ciprestes e vagam por pequenas ruas de um vilarejo no interior da Toscana. Parece que a vida de ambos vai ficando para trás, junto com reflexos das paredes e prédios que espelham no rosto das personagens um sentido cronotópico novo.

A estrada assume um papel metafórico, um corpo que conduz os protagonistas a um território desconhecido. Inicia um fascinante jogo de cena envolvendo a dupla principal, que passa a discutir sobre sua própria vida, como se fossem íntimos e conhecessem um ao outro.

O espaço restrito do carro se abre para uma nova dimensão, não é só o estilo de atuação que sofre mudanças, mas a própria essência das personagens: nas primeiras cenas do filme Elle se mostrava insegura diante do escritor e até mesmo reverente "Não consigo acreditar que estamos em meu carro" (CÓPIA FIEL, 2010, 20min30seg), eventualmente passa a tratá-lo com agressividade e cobranças. Em contrapartida, se o escritor a princípio apresentava uma atitude de homem contido e seguro de si, essa postura acaba se metamorfoseando em uma atitude ressentida, raivosa e de incontestável imaturidade e egoísmo. 


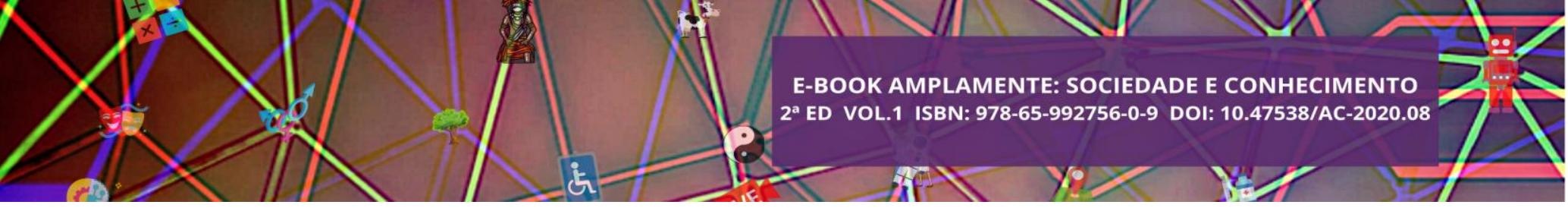

A dúvida do início do filme volta a roubar a cena, ao espectador fica a impressão de que Elle e James tiveram um relacionamento passado ou estão vivenciando a insatisfação de um casamento fracassado. Esses "elos" vão sendo feitos e desfeitos na narrativa a partir dos cronotopos, é a relação entre o espaço e o tempo que fornece as imagens substanciais para a organização do enredo fílmico. Amorim (2010, p. 107) corrobora que "ao tempo da velocidade que o carro poderia proporcionar, opõe-se o tempo lento que um verdadeiro diálogo exige". Pode-se dizer que, no interior do carro, Elle e James vivenciam um movimento de transformação individual através do enfrentamento do outro, do diferente, do desbravamento de um território particular.

As personagens andam sem rumo, não sabem para onde ir. A viagem propicia um colóquio que mescla humor e ironia. Aos 26 minutos do filme, Elle menciona sobre o marido de sua Irmã Marie, um homem simples e gago. A protagonista imita a forma como chama, carinhosamente, sua esposa: "Ma-ma-ma-ma-Marie!”, e afirma: "Para ela, ele é como uma canção de amor". (CÓPIA FIEL, 2010, 25min06seg). Essa pode ser considerada a fala mais importante do filme porque permite entender a última cena em que Elle pede para James ficar na pequena cidade da Toscana, o escritor, no entanto, avisa-a que precisa estar na estação às 21 horas, Elle gagueja o nome de James, como o marido “simples” da sua irmã: “Já-já-já-já-James”. (CÓPIA FIEL, 2010, 01h41min).

Percebe-se, nesse momento, que o filme está todo interligado em sua linguagem cronotópica. Elle, na cena final do filme, utiliza-se do discurso que utilizara aos 25 minutos, sobre o marido da sua irmã, é como se ela transmitisse a mensagem para James "Eu saboreio o seu nome, seu nome é uma canção de amor para mim, você é importante, você é original, você é como o marido de Marie não precisa mudar". Os dois passam a representar uma realidade utópica, uma cópia, assim como uma obra de arte, quase perfeita da realidade de um casal, que vive suas adversidades conjugais e conflitos particulares.

James, que antes era apenas o escritor, passa a figurar o papel de marido e pai desatento e ausente de forma tão verídica e fascinadora que é difícil não acreditar no protagonista. O tempo e o espaço agora são outros, há a presença de longas cenas que, criadas a partir de planos extensos e estáticos, conferem um ritmo realista às conversas. Os acontecimentos narrados vão se sobrepondo: ora surge o passado remoto, quando Elle cita fragmentos da sua vida particular e de sua família; ora o presente, momento em que a dupla assume o papel de marido e mulher; ora o passado recente, uma fã que 


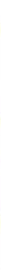

recebe a visita do seu ídolo escritor e oferece um passeio de carro para mostrar as belíssimas paisagens do local.

Passada uma hora do filme, a trama ganha nova dimensão cronotópica, Elle transforma-se em uma nova mulher, vai ao Toalete, passa batom marcante, escolhe brincos e se arruma para o marido. Retorna à mesa do restaurante enquanto James escolhe o cardápio para o jantar, o "marido" não se mostra interessado na aparência da esposa e começa a discutir sobre a qualidade do vinho, do lugar e dos atendentes. Os dois saem do restaurante e sentam-se em frente a um hotel, de repente ela pergunta ao homem se ele se lembra do lugar em que passaram a lua de mel, confundindo o espectador, levando-o a pensar que os protagonistas, realmente, formam um casal.

Kiarostami apresenta um filme rico em detalhes, enquadramentos precisos, apresenta belíssimos planos próximos às personagens. Outro fator cronotópico presente é a enorme preocupação estética do Diretor com os mínimos detalhes de composição do quadro: o uso de superfícies claras em contraposição com escuras resulta em um efeito que aumenta o impacto dramático dos acontecimentos e enfatiza os estranhos impulsos da relação conturbada entre as personagens.

O final do filme é belo, silencioso e instigante, o que remete a varias dúvidas universais e humanas: quantos casais poderiam transformar Cópia Fiel filme em cópia fiel da realidade de suas vidas? Quantas pessoas transformam suas vidas em cópias da vida de alguém que parece ser feliz e vivem escondidos atrás dessa encenação? A vida que se leva é uma cópia? Ou é retrato original de uma realidade verdadeiramente vivida?

A essência em Cópia Fiel é a discussão sobre as relações afetivas da sociedade. Quando o casal de Kiarostami discute a relação turbulenta que inventou para si, está discutindo o papel de cada um na sociedade. Normalmente, as pessoas pensam que suas atitudes são as mais corretas e suas expectativas são as mais originais, mas acabam lidando muito mal com situações que exigem diálogos e comprometimento com o outro.

Dessa forma, Cópia Fiel é um filme que deixa em aberto a história final, possibilitando diferentes pontos de vista sob um mesmo fato, o que obscurece o rumo do que seria uma verdade única. Kiarostomi abre caminhos a outras possibilidades ocultas no tempo vivido de cada personagem e fornece a visão que cada uma delas possa ter a respeito de suas próprias experiências de vida. Tempo e espaço assim concebidos mesclam fronteiras entre sonho e realidade, uma relação que traz como 


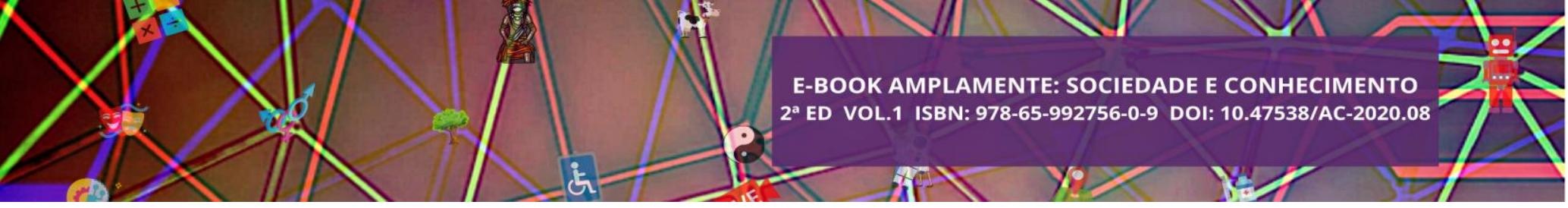

consequência a sensação de que a vida é algo que ocorre fora do tempo e do espaço apresentado na obra cinematográfica.

\section{CONSIDERAÇÕES FINAIS}

$\mathrm{Na}$ análise do filme Cópia Fiel (2010) foi possível observar que tempo e espaço são inseparáveis. Evidentemente, o tempo na narrativa de Kiarostami é uma ponte entre ficção e realidade, ou seja, as relações temporais dentro do filme estabelecem um elo com a realidade, um ponto de ligação. A partir disso, não é demais dizer que a mudança no caráter dos protagonistas é uma imagem cronotopicamente constituída, os acontecimentos vivenciados antes do encontro entre as personagens forma uma nova história, e tudo isso é tempo ou se passa dentro do tempo e, congruentemente, dentro do espaço, isto é, num momento e em um determinado lugar, aqui e agora.

Ao analisar os cronotopos presentes no filme Cópia Fiel foi possível perceber que o que constrói e dá sentido ao drama do filme são as transformações sofridas pelas personagens através do tempo. Em Copie Conforme (2010) os diálogos mais importantes da trama narrativa ocorrem no interior de um carro, em que mudanças, desejos e conquistas mesclam-se com as belas paisagens da estrada, transcorrendo construções históricas, lugares tradicionais de arte e cafés, que remetem o espectador a outra colocação no tempo. É na estrada que os diálogos ganham vida, as personagens são conhecidas, os fatos revelados, se escande e se mede o tempo da história. A obra de Kiarostami direta ou indiretamente parece atrelar, sem dúvidas, seu enredo em tempo e espaço bem determinados.

Nesse viés, a ideia de cronotopo, desenvolvida por Bakhtin e seu círculo para análise das estruturas espaço-temporais concretas na literatura, parece ser adequada quando se pensa na relação profícua que essas categorias exercem no cinema. $O$ cronotopo cinematográfico, assim como na literatura, funde-se em um todo concreto cuidadosamente elaborado, é o lugar em que o tempo transforma-se em algo artisticamente visível e o espaço torna-se impregnado dos movimentos do tempo, da trama e da história, reagindo a eles.

\section{REFERÊNCIAS}




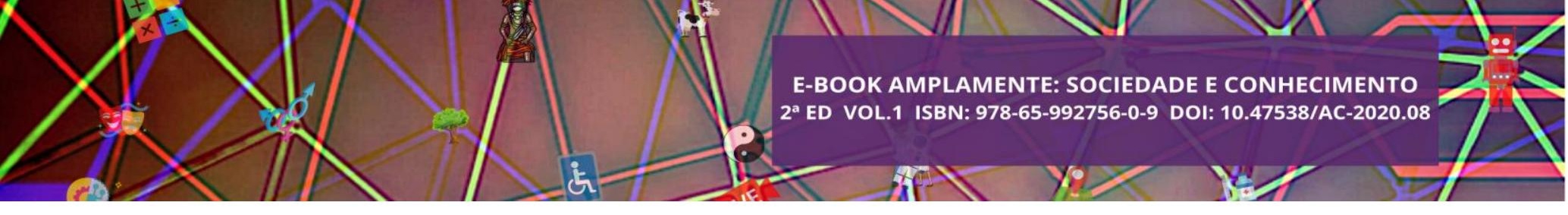

\section{SOBRE OS ORGANIZADORES}

PAIVA, Luciano Luan Gomes: Diretor de Arte na Editora Amplamente Cursos, coordenando toda a produção visual e ações de publicidade nas redes sociais e site da empresa. No campo da Educação, atua como Coach Educacional, Palestrante, Ministrante de Oficinas (presenciais e on-line), Tutor a Distância na Universidade do Estado do Rio Grande do Norte (UERN) e Professor de Música em múltiplos contextos. Como pesquisador, tem feito estudos sobre Aprendizagem mediada por Tecnologias Digitais sob a ótica da Complexidade; Formação Docente no âmbito das Tecnologias Digitais; e Mediação Pedagógica no Ciberespaço. Também é membro do Grupo de Estudos e Pesquisa em Música (GRUMUS-UFRN). Tem formação acadêmica, como Mestre em Música (com ênfase em Educação Musical) pela Universidade Federal do Rio Grande do Norte (UFRN). Especialista em Tecnologias Educacionais e Educação a Distância pelo Instituto Federal de Educação, Ciência e Tecnologia (IFRN). Licenciado em Música pela Universidade Federal do Rio Grande do Norte (UFRN). Orcid: https://orcid.org/0000-0001-6192-6075. Lattes: http://lattes.cnpq.br/0772088747598226. Email: luciano.90@hotmail.com.

FREITAS, Dayana Lúcia Rodrigues de: Mestra em Ciências da Educação pelo Centro de Educação Continuada e Aperfeiçoamento Profissional (CECAP). Especialista em Mídias na Educação pela Universidade Estadual do Rio Grande do Norte (UERN). Especialista em Tecnologias Educacionais e Educação a Distância pelo Instituto Federal de Educação Ciências e Tecnologia do Rio Grande do Norte (IFRN). Especialista em Metodologia do ensino de Biologia e Química pelo Instituto Pedagógico de Minas Gerais (IPEMIG/MG). Especialista em Educação Ambiental e Geografia do semiárido pelo Instituto Federal de Educação Ciências e Tecnologia do Rio Grande do Norte (IFRN). Especialista em Ensino de Ciências Naturais e Matemática pelo Instituto Federal de educação Ciências e Tecnologia do Rio Grande do Norte (IFRN). Especialista em Língua Portuguesa, Matemática e Cidadania pelo Instituto Federal de Educação Ciências e Tecnologia do Rio Grande do Norte (IFRN). Graduada em Licenciatura Plena em Biologia pelo Instituto Federal de Educação Ciências e Tecnologia do Rio Grande do Norte (IFRN). Técnica em Meio Ambiente pelo Serviço Nacional de Aprendizagem Comercial (SENAC/RS). Palestrante. Pesquisadora. Professora e Orientadora de cursos de Pós-Graduação e Graduação em instituições da rede privada em Macau/RN. Professora; Orientadora de TCC e Orientadora de Estágio Curricular Supervisionado da Escola Técnica Fanex Rede de Ensino - Macau/RN. Professora da Educação Básica do município de Guamaré/RN. Orcid: https://orcid.org/0000-0001-5355-3547. Lattes: http://lattes.cnpq.br/5122671799874415. E-mail: dayannaproducoes@gmail.com.

FERNANDES, Caroline Rodrigues de Freitas: Especialista em Mídias na Educação pela Universidade Estadual do Rio Grande do Norte (UERN). Pós-graduanda em Educação Inclusiva pelo Instituto Federal de Educação Ciências e Tecnologia do 


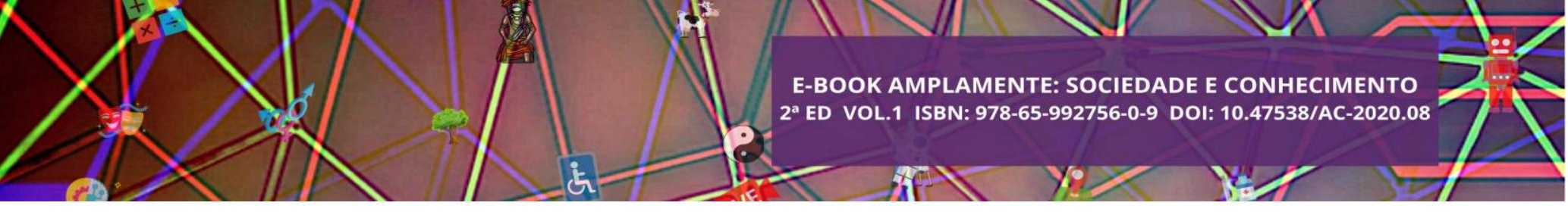

\section{SOBRE OS AUTORES}

ALMEIDA, Rosângela Nunes: Mestre em Biodiversidade, Ambiente e Saúde, UEMA. Doutoranda em Enfermagem pela UFPI. E-mail: rnadasilva@ hotmail.com

ALVES, Felipe Rabelo Rodrigues: Mestre em Engenharia de Produção e Sistemas pela Pontifícia Universidade Católica de Goiás (Goiânia-GO, 2018), Especialista em Engenharia de Segurança do Trabalho pela Faculdade Araguaia (Goiânia-GO, 2018) e Bacharel em Engenharia Mecânica pela Universidade Paulista (São Paulo-SP, 2013). Atualmente realiza pesquisas nas áreas de Engenharia de Segurança do Trabalho, Energia Solar Fotovoltaica e Gerenciamento de Resíduos Sólidos. Atua nas áreas de Gerenciamento Industrial e de Gestão de Projetos de Viabilidade Técnica/Econômica. Possui experiência em indústrias, atuando nas áreas: Industrial, Desenvolvimento e Projetos, Manufatura de polímeros e de metais.

ALVES, Kaliandra Souza: Possui graduação em Zootecnia pela Universidade Estadual do Sudoeste da Bahia (2000), mestrado (2002) e doutorado (2006) em Zootecnia pela Universidade Federal Rural de Pernambuco. É docente da Universidade Federal Rural da Amazônia - Campus Parauapebas (desde 2004). Atualmente é professora Associada III. Docente permanente do Programa de Pós-Graduação em Saúde e Produção Animal na Amazônia (PPGSPAA) desde o início (2010) e do Programa de Pós-Graduação em Produção Animal na Amazônia (PPGPAA), Campus de Parauapebas, desde o início (2017). Desde a formação em 2008 é líder do Grupo de Pesquisa em Produção Animal na Amazônia (http://dgp.cnpq.br/dgp/espelhogrupo/30906). É membro do Comitê Gestor do Laboratório de Nutrição Animal da UFRA- Campus de Parauapebas. Atua na área de Zootecnia, com ênfase em Alimentação e Produção de ruminantes. Email: kaliandra.souza.alves@gmail.com. Lattes: http://lattes.cnpq.br/9359491719219283

AMARAL, Joana Gonzalez Ambrosio Izzo do: Acadêmica do curso de Medicina pela Faculdade de Medicina de Petrópolis.

AMORIM, Edna da Rocha: Graduação em Agronomia pela Universidade Federal de Alagoas (1981), mestrado em Fitossanidade pela Universidade Federal Rural de Pernambuco (1990) e doutorado em Agronomia (Proteção de Plantas) pela Universidade Estadual Paulista Júlio de Mesquita Filho (1997). Atualmente é professora titular da Universidade Federal de Alagoas. Recebeu a Comenda do Mérito FAPEAL"”" em reconhecimento à colaboração em diversos projetos, participação em Comitês e Conselho, contribuição à Fapeal, contribuições à pós-graduação e à pesquisa do Estado de Alagoas.Tem experiência na área de Agronomia, com ênfase em Fitopatologia, atuando principalmente nos seguintes temas: diagnóstico e manejo de doenaçs de plantas. http://lattes.cnpq.br/2913233886693304

ANJOS, José Ayron Lira Dos: Possui graduação em Química pela Universidade Federal de Pernambuco (2000), mestrado em Química pela Universidade Federal de Pernambuco (2002) e doutorado em Química pela Universidade Federal de Pernambuco (2008). Atualmente é professor adjunto IV da Universidade Federal de Pernambuco. Tem experiência na área de Química, com ênfase em Ensino de Química, atuando principalmente nos seguintes temas: formação de professores, Pibid, metodologias ativas de aprendizagem, ensino de química e jogos didáticos. É professor permanente do Programa de Pós-Graduação em Educação em Ciências e Matemática e participa do Grupo de Pesquisa em Educação, História e Cultura Científica (GPEHCC) 


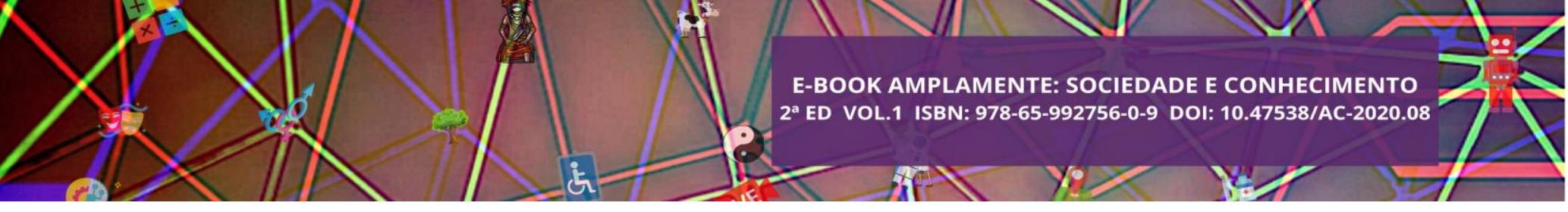

experiência na área de Microbiologia Aplicada e Biotecnologia, atuando principalmente nos seguintes temas: Biodiversidade microbiana, taxonomia de leveduras, otimização de processos fermentativos para obtenção de biomoléculas. E-mail: claudiacastro@utfpr.edu.br

BRITO, Silvana Rossy de Graduada em Ciência da Computação (UFPA), Mestre em Informática (UFES) e Doutora em Engenharia Elétrica (UFPA), atualmente é professora e Pró-Reitora de Planejamento e Desenvolvimento Institucional da Universidade Federal Rural da Amazônia (UFRA). Já atuou como Coordenadora Institucional do Programa de Bolsas de Iniciação à Docência da UFRA e como PróReitora Adjunta de Assuntos Estudantis da UFRA. Tem experiência, atuou e atua em projetos de sistemas de informação, desenvolvimento de software, inclusão digital, mineração de dados, análise de redes sociais, sistemas multiagentes, educação em computação e gerência de projetos. Lattes: http://lattes.cnpq.br/3862009446096908

CALDAS, Cláudia Siqueira: Graduanda do curso de Zootecnia pela Universidade Federal Rural da Amazônia, Campus de Parauapebas-PA. Email: claudiasiqueira455@gmail.com. Lattes: http://lattes.cnpq.br/0370182795493819

CAMPOS, Catarine Wiggers de: Estudante do $4^{\circ}$ ano de Medicina da Universidade do Sul de Santa Catarina - UNISUL Campus Tubarão. Foi monitora do projeto de pesquisa e extensão "Amigos do Amanhã". Foi diretora local de intercâmbios nacionais e presidente do Comitê Local UNISUL da Federação Internacional das Associações dos Estudantes de Medicina do Brasil (IFMSA Brazil). Atualmente, é ligante da Liga de Psicologia Médica e Medicina da Família da Comunidade, bolsista em pesquisa pelo Programa de Bolsas Universitárias de Santa Catarina e atua como Coordenadora Regional Sul da IFMSA Brazil.

CAMPOS, Moisés Alves Silva: Graduando em Psicologia, orientando do Programa de Iniciação Científica, PIBIC/PIVIC da Universidade Federal de Goiás, Regional Jataí (UFG/REJ), Jataí, Estado de Goiás. E-mail: moises340@ outlook.com

CARVALHO, Luiz Filipe Lago de: Doutorando em Bioética no Programa de Pós-graduação Strictu Sensu da Universidade de Brasília - UNB. Mestre em Bioética no Programa de pós-graduação Strictu Sensu em Bioética da Universidade de Brasília UNB -2019. Advogado. Graduado em Direito pelo Centro Universitário de BrasíliaUNICEUB. E-mail: louiscarvalho93@gmail.com

CECCATO, Bruno Telli: Graduado em Engenharia Química pela Universidade Tecnológica Federal do Paraná campus Francisco Beltrão (UTFPR-FB). Mestrando de Engenharia Química na Universidade Estadual de Campinas - UNICAMP. Habilitado em Auditoria da Qualidade ISO 9001:2015, ISO 14001:2015 e MASP Six Sigma Yellow Belt. Tem experiência na área cervejeira com ênfase em produção. E-mail: bruno.ceccato@hotmail.com

CERBINO, Ana Carolina Guimarães: Acadêmica do curso de Medicina da Universidade Federal de Goiás. Membro do Departamento de Apoio Estudantil do Centro Acadêmico XXI de Abril, na gestão de 2018 a 2020. Diretora do projeto de extensão "58 Show do Esqueleto". Membro Fundador da International Federation of Medical Students Associations of Brazil na UFG (IFMSA Brazil UFG). Atualmente, é Presidente Local da IFMSA Brazil UFG e Diretora Científica do V Congresso de Escolas Médicas (CESMED) e do $32^{\circ}$ Encontro Científico de Acadêmicos de Medicina (ECAM). 


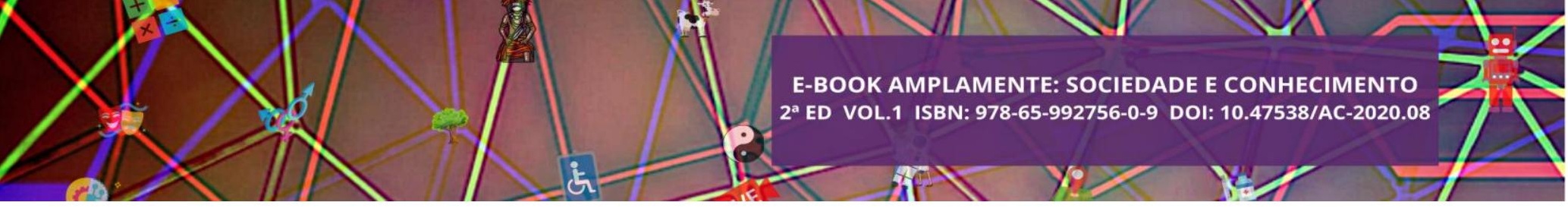

CHACON, Sylha Suane Camilo: Graduada em Licenciatura plena em História pela Universidade do Estado do Rio Grande do Norte no Campus Avançado Walter de Sá Leitão (UERN - CAWSL), especialista em Culturas Políticas, História e Historiografia pela Faculdade do Complexo Educacional Santo André (FACESA) e docente de escola pública. E-mail: sylhachacon@ hotmail.com

CHAVES, Lívia Francyne Gomes: Engenheira Agrônoma, formada pela Universidade Federal de Alagoas (UFAL). Mestre em Agronomia/Produção Vegetal pela UFAL (2017). Tem experiência na área de Agronomia, com ênfase em Fisiologia de Plantas Cultivadas, Tecnologia e Produção de Sementes e Mudas. Doutoranda em Proteção de Plantas pela Universidade Federal de Alagoas, com ênfase em Virologia. http://lattes.cnpq.br/7037599740632051

CONCEIÇÃO, Hayla Nunes da: Graduada em Enfermagem pela Universidade Estadual do Maranhão. Mestranda do Programa de Pós-Graduação em Saúde e Comunidade da Universidade Federal do Piauí (UFPI). E-mail: haylanunes_cx@hotmail.com

COSTA, Josilene Dantas Santos: Mestranda do curso de Ciências da Educação pela Faculdade (FACEM). Especialista em Psicopedagogia Clínica e Institucional pela FAIBRA. Especialista em Docência na Educação Infantil Anos Iniciais pela FAVENE. Discente do curso de Pós-graduação em Libras e Pós-graduação em Literatura e Língua Português. Graduada em Letras - Língua Portuguesa pela UERN. Graduada em Pedagogia pela Faculdade Integrada do Brasil (FAIBRA). Docente há mais de 15 anos. Atualmente atua como professora nos Municípios de Pendência/RN e Guamaré/RN.

DINIZ, Lucas Tadeu Gonzaga: Acadêmico do curso de Medicina da Pontifícia Universidade Católica de Goiás (PUC Goiás). Formação complementar em Ferramentas para o Processo Decisório concluída em PUC Goiás. Foi assessor do Centro Acadêmico Paulo Francescantônio, Diretor Financeiro Local e Secretário Geral Local entre 2018 e 2019 do comitê local PUC Goiás da International Federation of Medical Students' Associations of Brazil (IFMSA Brazil). Ainda na IFMSA Brazil, ocupou cargo de Assistente Regional Oeste do Time Nacional Administrativo. Atuou como Diretor de Marketing da Liga Acadêmica de Ortopedia e Traumatologia da PUC Goiás (LAOT) e como membro da Liga Acadêmica de Endocrinologia e Nutrologia da UFG (LAEN) e da Liga Acadêmica de Cuidados Paliativos da PUC Goiás (LaPallium). Também trabalhou como Coordenador de Marketing e Comunicação do IV Congresso de Escolas Médicas (IV CESMED), bem como de comissões organizadoras de outros eventos locais e regionais. Atualmente, é Coordenador Regional Oeste da IFMSA Brazil, Moderador de Marketing e Comunicação do V Congresso de Escolas Médicas (V CESMED), Monitor na disciplina Relação Médico-Paciente e Diretor Científico da Liga Acadêmica de Doenças Endocrinometabólicas da PUC Goiás (LADEM). É bolsista de Iniciação Científica na PUC Goiás pelo projeto de pesquisa intitulado "O Impacto de Obras de Arte sobre Estudantes de Medicina".

DIÓGENES, Ana Flávia Monteiro: Graduada em Direito pela Universidade do Estado do Amazonas (UEA), especialista em Direito Público pela Universidade Federal do Amazonas (UFAM). Docente de Direito no Instituto Federal de Ciência e Tecnologia do Amazonas (IFAM).

FAGUNDES, Filipe Calixto: Acadêmico do Curso de Administração da Universidade Federal da Fronteira Sul (UFFS) Campus de Chapecó. 


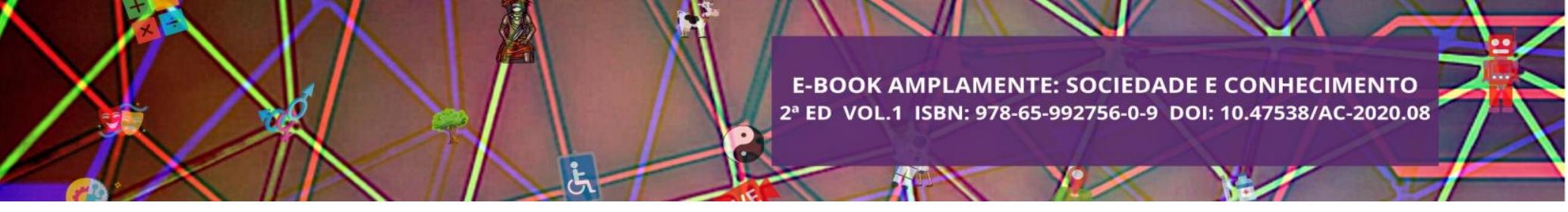

FARIAS, Anderson da Silveira: Mestrando em Ciências do Movimento Humano pela Universidade Federal do Rio Grande do Sul (UFRGS). Especialização em Ciência Aplicada ao Futebol e Futsal pela Universidade Federal do Rio Grande do Sul (UFRGS). Licenciatura Plena em Educação Física pela Universidade Luterana do Brasil (ULBRA). Integrante do Grupo de Estudos Socioculturais em Educação Física (GESEF/ UFRGS). Membro associado do Colégio Brasileiro de Ciências do Esporte (CBCE). Possui experiência em Desenvolvimento de Projetos, Organização de Eventos Esportivos, Culturais e de Lazer. Professor na rede municipal de Alvorada/RS, atuando na educação de jovens e adolescentes. Árbitro de Futebol membro da Federação Gaúcha de Futebol (FGF). Árbitro de Futebol membro da Confederação Brasileira de Futebol (CBF).

FARIAS, Cláudio Vinícius Silva: Doutor em Desenvolvimento Rural (PGDR/UFRGS). Mestrado em Economia (Unisinos). Graduado em Administração de Empresas (UFRGS). Ganhador do Prêmio Edson Potsch Magalhães, pela melhor Tese de Doutorado em Economia Rural no ano de 2016, concedido pela Sociedade Brasileira de Administração, Economia e Sociologia Rural (SOBER). Experiência docente e de pesquisa na área de Administração e Economia Industrial, atuando principalmente nos seguintes temas: Cooperação e Coordenação de Setores Produtivos, Economia Institucional, Competitividade, Inovação e Aprendizagem Organizacional e Tecnológica, Educação Empreendedora e Empreendedorismo. Atualmente é Coordenador do Mestrado Profissional em Propriedade Intelectual e Transferência de Tecnologia para a Inovação (PROFNIT), ponto focal IFRS. Professor Dedicação Exclusiva do Campus Porto Alegre do Instituto Federal de Educação, Ciência e Tecnologia do Rio Grande do Sul. E-mail: claudio.farias@poa.ifrs.edu.br

FERNANDES, Raquel Martins: Pós-doutora em Psicologia Social pela Universidade Federal da Paraíba (2019), possui graduação em Filosofia pela Universidade Federal de Minas Gerais (1999), mestrado (2003) e doutorado (2012) em Educação pela Universidade Federal de Mato Grosso. É professora do Instituto Federal de Educação, Ciência e Tecnologia de Mato Grosso, campus Cuiabá Bela Vista, e do Mestrado em Ensino Associação Ampla UNIC/IFMT. Tem experiência na área de Filosofia, com ênfase em Teoria do Conhecimento, Filosofia da Educação e Direitos Humanos, atuando principalmente nos seguintes temas: ensino, fenomenologia, teoria do conhecimento, epistemologia, transdisciplinaridade, ética, ética e educação ambiental, abuso e exploração sexual de crianças e adolescentes, violência escolar, bullying, espiritualidade e cristianismo.

FERNANDES, Victor Mateus Pinheiro: Discente do curso de Enfermagem do $7^{\circ}$ período da Universidade Estadual do Maranhão-UEMA. E-mail: vmpf13@gmail.com

FERREIRA, Maria Denislane Temóteo: Técnica em enfermagem pelo instituto educacional integrado(SEI) de Quixeramobim Ceará (2012); Graduanda em enfermagem pela Universidade Católica de Quixadá; Integrante do Grupo de Estudos e pesquisa em saúde do adulto e assistência de enfermagem (GEPSAAE)- Unicatólica; Qualificação em Urgência e Emergência pelo Centro de Preparação em atendimento pré-hospitalar (CEPAPH); Atualmente trabalhando como técnica em enfermagem no Hospital Maternidade Professor Waldemar de Alcântara (HMPWA) -Itapiúna Ceará. Email: denislane_ferreira@hotmail.com 


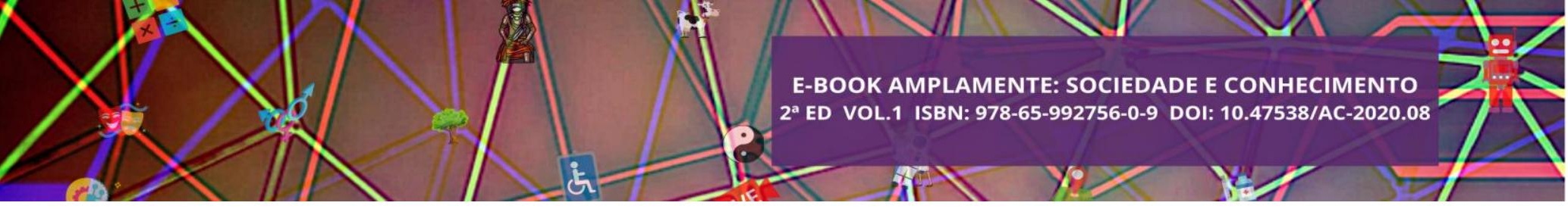

FERRO, Mayra Machado de Medeiros: graduação em Gestão Ambiental pelo Instituto Federal de Alagoas - Campus Marechal Deodoro (2011), graduação em Agronomia pela Universidade Federal de Alagoas (2013). Possui Mestrado e Doutorado em Proteção de Plantas pela Universidade Federal de Alagoas. Tem experiência na área de Agronomia, com ênfase em Fitopatologia, atuando principalmente nos seguintes temas: planta daninha, diversidade genética e geminivírus. http://lattes.cnpq.br/5576760016804643

FONSECA, Paulo Soares da: Licenciado em Ciências Biológicas, pelo Instituto Federal de Educação, Ciências e Tecnologia do Rio Grande de Norte- IFRN. Técnico em Cooperativismo, EAJ-UFRN. Técnico em agricultura familiar, EJA-UFRN. Atualmente é digitador da Prefeitura Municipal De Guamaré.

FREITAS, Maria Carolina Carvalho de Almendra: Graduação em Direito pelo Centro de Ensino Unificado de Teresina - CEUT -2003; Especialização em Direito Público e em Direito Privado pela Universidade Federal do Piauí - UFPI -2004; Mestre em Direito Internacional e Econômico pela Universidade Católica de Brasília - UCB 2012; Doutoranda em Direito Político e Econômico do Programa de Pós-Graduação Stricto Sensu da Universidade Presbiteriana Mackenzie - UPM. E-mail: mcfreitas@hotmail.com

FUMAGALLI, Rita de Cássia Dias Verdi: Doutora em Letras pela Universidade de Passo Fundo (UPF/2019). Mestre em Letras (Literatura Comparada) pelo Programa de Pós-Graduação em Letras da Universidade Regional Integrada do Alto Uruguai e das Missões (URI/2015), titular do diploma de Especialização em Análise do Discurso: O Discurso e suas Interfaces: arte, comunicação e cultura (URI/2012) e graduada em Letras (Português/Espanhol e respectivas literaturas) pela mesma IES (URI/2011). Tem experiência na área de Linguística, atuando principalmente nos seguintes temas: identidade cultural e Análise do Discurso de filiação francesa em interlocução com outras materialidades significantes. Atualmente, é Diretora de Departamento na Secretaria Municipal de Educação, Cultura e Desporto do Município de Derrubadas/RS. E-mail: ritacassiafumagalli@gmail.com

GABIATTI, Cristhian de Lemos: Acadêmico em Engenharia Química na Universidade Tecnológica Federal do Paraná campus Francisco Beltrão (UTFPR - FB). Técnico em Agropecuária pelo Colégio Estadual de Educação Profissional do Sudoeste do Paraná (CEEP) de Francisco Beltrão. E-mail: cgabiatti27@gmail.com

GEREMIA, Fabiano: Possui graduação em Ciências Econômicas (2000, Mestrado em Economia pela Universidade Federal de Santa Catarina (2004) e Doutorado em Economia pela Universidade Federal do Rio de Janeiro (2012). Atualmente é professor adjunto da Universidade Federal da Fronteira Sul (UFFS) e pesquisador do Núcleo de Pesquisa da Indústria e da Tecnologia (NPIT) da Universidade Federal de Santa Maria. Tem experiência em História do Pensamento Econômico e Economia Industrial e suas relações com políticas públicas de apoio setorial, atuando principalmente nos seguintes temas: Inovação, tecnologia, sistema de Inovação e Competitividade.

GOMES, Andreza Jeronimo: Graduanda em enfermagem pelo Centro Universitário Católica de Quixadá- Unicatólica. Socorrista pelo Centro de Preparação em Atendimento Pré-Hospitalar - CEPAH. Membro do Grupo de Estudos e Pesquisas em Saúde do Adulto e Assistência de Enfermagem - GEPSAAE. E-mail: jeronimo.andreza@bol.com.br 


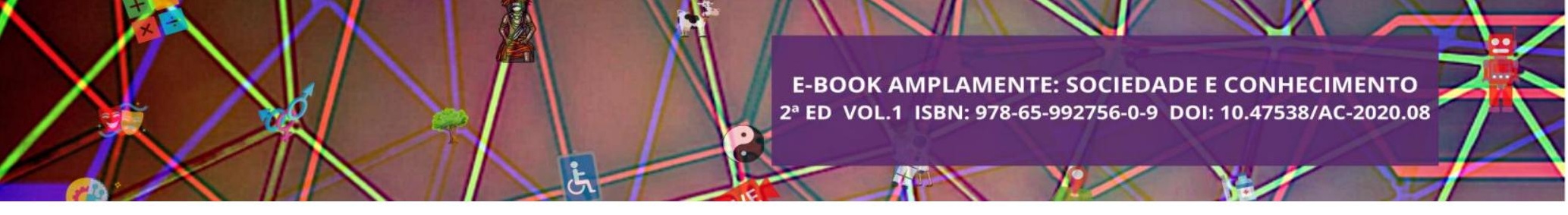

GONÇALVES, Guilherme de Oliveira: Mestrando em Ciências do Movimento Humano pela Universidade Federal do Rio Grande do Sul (UFRGS). Bacharel em Educação Física pela Universidade Luterana do Brasil (ULBRA). Licenciado em Educação Física pela Universidade Luterana do Brasil (ULBRA). Especialização em Ciências da Saúde e do Esporte pela Pontifícia Universidade Católica (PUCRS). Especialização em Educação Física Escolar e Recreação pela Faculdade (FAVENI). Integrante do Grupo de Estudos Socioculturais em Educação Física (GESEF/ UFRGS). Membro associada do Colégio Brasileiro de Ciências do Esporte (CBCE). Professor do Centro Universitário Fadergs (Laureate International Universities) e da Rede Estadual de Ensino.

GUASCO, Eduardo Rodrigues Da Cunha: Mestrado em andamento em Engenharia de Produção e Sistemas (Conceito CAPES 3), Pontifícia Universidade Católica de Goiás, PUC GOIÁS, Brasil. Especialização em Lato Sensu em Informática, Universidade Paulista, UNIP, Brasil. Graduação em Bacharel em Estatística, Universidade de Brasília, UnB, Brasil. Atualmente é professor da Universidade Estadual de Goiás.

GUIMARÃES, Aline Grandis: Acadêmica do curso de Medicina pela Faculdade de Medicina de Petrópolis. Acadêmica do curso de Gestão Hospitalar pela Universidade Estácio de Sá.

HONORATO, Hercules Guimarães: Mestre em Educação pela Universidade Estácio de Sá (UNESA), na linha de pesquisa de Políticas Públicas e Gestão, ano de conclusão 2012. Doutor e Mestre em Política e Estratégia Marítimas pela Escola de Guerra Naval (EGN), ambiência do Sistema de Ensino Naval, ano de conclusão, respectivamente, 2007 e 1999. Especialista em Logística e Gestão Internacional pelo Instituto COPPEAD de Administração, da Universidade Federal do Rio de Janeiro (UFRJ), anos de conclusão, respectivamente, 2009 e 2007. Especialista em Docência do Ensino Superior pelo Instituto A Vez do Mestre (AVM), da Universidade Cândido Mendes (UCAM), ano de conclusão 2008. Bacharel em Ciências Navais, com habilitação em Administração de Sistemas, pela Escola Naval, ano de conclusão 1982. Oficial da reserva da Marinha do Brasil e ex-professor da Escola Naval, período de 2012 a 2017, das disciplinas de Metodologia da Pesquisa e Introdução à Logística Naval. Atualmente integrante do corpo docente da Escola Superior de Guerra (ESG). Autor do livro "Relato de uma experiência acadêmica: o 'eu' professor pesquisador", volumes I e II. Orcid: https://orcid.org/0000-0001-7340-1532. E-mail: hghhhma@gmail.com. Lattes: http://lattes.cnpq.br/8129815602916167.

IGNÁCIO, Mauro Castro: Mestrando em Ciências do Movimento Humano pela Universidade Federal do Rio Grande do Sul (UFRGS). Cursando Superior em Gestão Desportiva e de Lazer pelo Instituto Federal do Rio Grande do Sul (IFRS). Bacharel em Educação Física pela Universidade Federal do Rio Grande do Sul (UFRGS). Licenciado em Educação Física pela Universidade Federal do Rio Grande do Sul (UFRGS). Integrante do Centro de Desenvolvimento do Esporte Recreativo e do Lazer (REDE CEDES). Integrante do Grupo de Estudos Socioculturais em Educação Física (GESEF/ UFRGS). Membro associado do Colégio Brasileiro de Ciências do Esporte (CBCE). Atua nas áreas de políticas públicas para o esporte e o lazer, treinamento físico e grupos especiais

JUNQUEIRA, Filipe Ribeiro: Graduado em Psicologia pelo Centro Universitário São Francisco de Barreiras - UNIFASB. Realizou estágios nas áreas: 


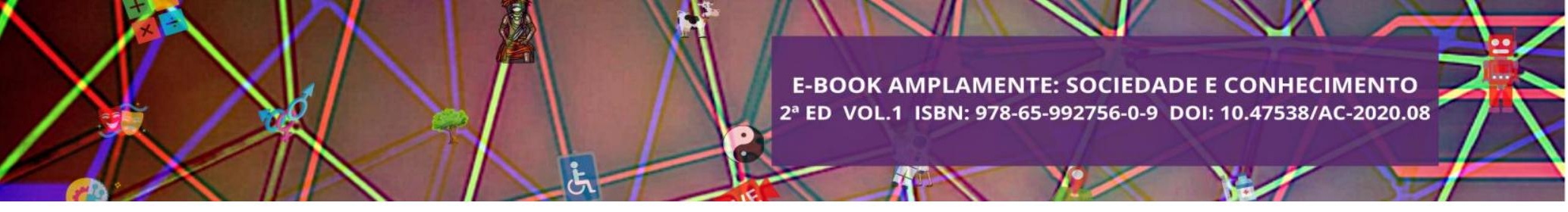

Psicologia Escolar com foco em crianças da educação infantil; Psicologia Organizacional e do Trabalho em Instituições de Ensino, desenvolvendo atividades e intervenções com os docentes e demais colaboradores; Avaliação Psicológica no contexto do trânsito; e também em Clínica de Psicologia realizando atendimentos com o viés Psicanalítico. Atuou no Serviço de Atendimento Estudantil - SAE, localizado no Núcleo de Serviços da UNIFASB.

KOBAYASTI, Leimi: Graduação em Agronomia pela Universidade Federal de Mato Grosso (1994), mestrado em Agronomia (Fitopatologia) pela Universidade Federal de Lavras (1998) e doutorado em Agronomia (Fitopatologia) pela Universidade Federal de Lavras (2002). Atualmente é professora titular da Universidade Federal de Mato Grosso. Tem experiência na área de Agronomia, com ênfase em Fitopatologia, atuando principalmente, em patologia de sementes, controle alternativo e manejo de doenças.

LAGO, Eliana Campêlo: Odontóloga pela Universidade Federal do PiauíUFPI. Enfermeira pela Universidade Federal do Piauí-UFPI. Bacharel em Direito pela UniFACID WYDEN. Pós-doutorado - Programa de Pós-Graduação em Medicina Tropical da Universidade de Brasília-UNB. Pesquisadora do Núcleo de Pesquisa em Morfologia e Imunologia Aplicada - NuPMIA - UNB. Doutora em Biotecnologia pela Universidade Federal do Piauí-UFPI. Mestre em Clínicas Odontológicas pela Universidade Federal do Pará-UFPA. Especialista em Odontopediatria pela Universidade Federal do Pará-UFPA. Especialista em Implantodontia pela Associação Brasileira de Cirurgiões-dentistas - ABCD-PI. Especialista em Enfermagem Obstétrica pela Universidade Estadual do Pará-UEPA. Especialista em Enfermagem do Trabalho pelas Faculdades Integradas São Camilo CEDAS-SP. Professora Adjunto do Programa de Pós-Graduação em Biodiversidade, Ambiente e Saúde- PPGBAS e da graduação do Departamento de Enfermagem -Universidade Estadual do Maranhão-UEMA. E-mail: anaileogal@gmail.com. Lattes: http://lattes.cnpq.br/2913451575350769.

LEAL, Kércia Karenina Camarço Batista Rodrigues: Graduação em Direito pelo Centro de Ensino Unificado de Teresina - CEUT -2002; Especialização em Direito Público e em Direito Privado pelo Centro de Ensino Unificado de Teresina- 2004; Mestre em Direito Internacional e Econômico pela Universidade Católica de Brasília UCB -2013; Doutoranda em Políticas Públicas do Programa de Pós-Graduação Stricto Sensu da Universidade Federal do Piauí- UFPI. Professora do Curso de Direito na UNIFACID e ICEV (Instituto de Ensino Superior). E-mail: kerciabatista@ hotmail.com

LEÃO, José Bruno Martins: Advogado e colunista jurídico. Bacharel em Direito e licenciado em Filosofia. Especialista em Análise Criminal, Direito Penal e Processual Penal, Docência Jurídica e Gestão em Segurança Pública.

LEÃO, Luciana Carrilho de Moraes Marinho Arêa: Mestra em Direito Constitucional pela Universidade de Fortaleza - UNIFOR- 2014; Especialista em Direito e Processo do Trabalho pela UNISINOS- 2011; Graduada em Direito pelo Instituto Camilo Filho-2009; Professora da UNIFACID na graduação. Tabeliã Interina do Ofício Único de Simões - PI. E-mail: lucianacarrilho18@hotmail.com

LEITE, Giovana Fernandes: Psicóloga Clínica. Graduada em Psicologia pelo Centro Universitário São Francisco de Barreiras - UNIFASB. Especialista em Neurolinguística pela Faculdade Dom Alberto - Centro Educacional FAVENI. Pósgraduanda em Psicanálise Clínica e Saúde Mental pela Faculdade UniBF - Grupo IBF. Durante a graduação atuou como estagiária na Unidade de Serviços da UNIFASB 


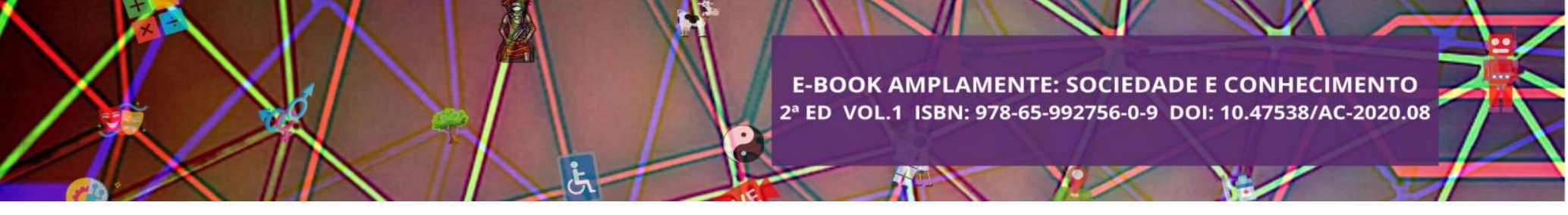

(Clínica Escola) na prática clínica com abordagem psicanalítica, e também com processo de triagem e acolhimento psicológico no Centro Integrado de Saúde (CIS) da UNIFASB. Realizou demais estágios nas áreas: Psicologia do Trânsito, Psicologia da saúde voltada a psicologia Penitenciária e na Estratégia de Saúde da família com gestantes.

LEONEL, Ana Leticia Anarelli Rosati: Doutoranda em Direito Público pela Universidade do Vale do Rio dos Sinos (UNISINOS). Mestre em Direito Público pela Universidade do Vale do Rio dos Sinos (UNISINOS)-2014; Pós-graduada em Direito Público com ênfase em Direito Constitucional pela Universidade Potiguar (UnP) -2007; Pós-graduada em Direito Civil pela Universidade Federal do Piauí (UFPI)-2006; Graduada em Direito pelo Centro Universitário Padre Anchieta -2001; Professora da UNIFACID na graduação e pós-graduação em Direito. Professora do Centro de Ensino Superior Vale do Parnaíba (CESVALE) na pós-graduação. Consultora Jurídica Especial de Gabinete do Tribunal de Justiça do Estado do Piauí. E-mail: analeticialeonel@hotmail.com

LIMA, Bianca de: Acadêmica de Engenharia de Alimentos da Universidade Tecnológica Federal do Paraná campus Francisco Beltrão (UTFPR - FB). Atuou como bolsista do Programa de Educação Tutorial - PET. Habilitada em Auditoria da Qualidade MASP Six Sigma Yellow Belt. E-mail: biadlima@outlook.com

LIMA, Elizanne de Moura: Possui Graduação em Zootecnia pela Universidade Federal Rural da Amazônia/Campus de Parauapebas (2010-2015). Mestrado pelo Programa de Pós-Graduação em Saúde e Produção Animal na Amazônia da Universidade Federal Rural da Amazônia/Campus de Belém (2015-2017) na área de concentração em Produção Animal. Doutoranda pelo Programa de Pós-Graduação em Zootecnia na Universidade Federal de Lavras (UFLA). Membro do Núcleo de Estudos em Forragicultura (NEFOR/ UFLA). Desenvolvendo pesquisas nas áreas de avaliação de alimentos para animais, produção e nutrição de ruminantes e qualidade de produtos de origem animal. Email: elizannem.lima@gmail.com. Lattes: http://lattes.cnpq.br/9511472447873181

LIMA, Flávio Pedro Silva de: Licenciado em Geografia pela Universidade Federal do Rio Grande do Norte. Licenciado em Educação Física, pela UFRN. Pósgraduado em Direito Ambiental pela Universidade Potiguar -UNP. Pós-graduado em Mídias Educacionais pela Universidade Estadual do Rio Grande do Norte-UERN. Atuou como tutor do Instituto Federal de Educação, Ciência e Tecnologia do Rio Grande do Norte do curso de Gestão Ambiental. Lecionando na rede Pública e privada de Guamaré, lecionando as disciplinas de Geografia e Educação Física. Mestrando em Ciências da Educação.

LIMA, Liene Ribeiro de: Foto Graduada em Enfermagem pela Universidade Regional do Cariri (2007), Especialista em Enfermagem Obstétrica pela Universidade Estadual do Ceará (2011) e Mestre em Saúde Pública da Universidade Federal do Ceará (2017). Professora do Centro Universitário Católica de Quixadá - UNICATÓLICA do curso de Enfermagem e coordenadora do curso de Enfermagem. Tem experiência na área de Enfermagem, com ênfase em Enfermagem de Saúde Pública, Atenção Primária à Saúde, Saúde da mulher, Biossegurança, Ética e Legislação Profissional, Controle de Infecção Hospitalar, Educação em saúde e Abordagem multiprofissional.

LIMA, Mayara Oliveira de: Engenheira Agrônoma formada pela Universidade Federal de Alagoas (UFAL) em 2018. Mestre pelo Programa de Pós-Graduação em 


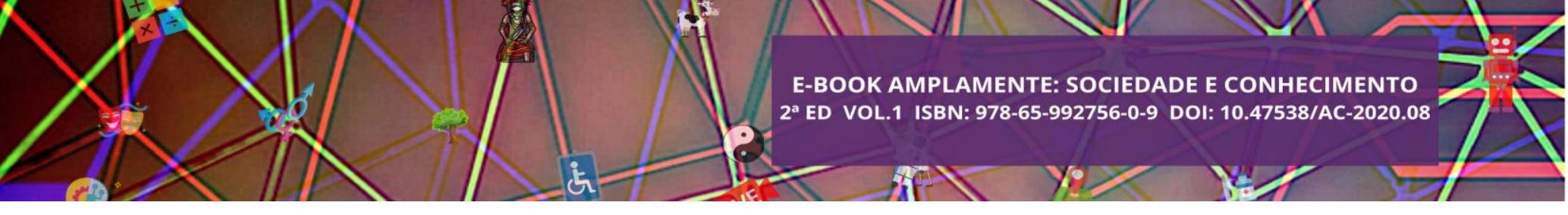

coordenadora e professora do curso de Psicologia do Centro Universitário Tocantinense Presidente Antônio Carlos. Atuando principalmente nos seguintes temas: Psicologia Organizacional, Avaliação Psicológica e Grupalidades.

MARCHI, João Francisco: Graduado em Agronomia pela Universidade Federal de Santa Catarina (UFSC), Especialista em Agronegócio pela Universidade Federal do Paraná (UFPR) e Mestre em Ciência e Tecnologia de Alimentos pela Universidade Federal de Viçosa (UFV). Atua como professor do Curso de Engenharia de Alimentos da Universidade Tecnológica Federal do Paraná câmpus Francisco Beltrão (UTFPR - FB). Tem experiência na área de Ciência e Tecnologia de Alimentos, com ênfase na área de produtos de origem animal. E-mail: joaomarchi@utfpr.edu.br

MARTINS, Vânia Paiva: Graduanda de enfermagem do 9 semestre, na instituição de ensino centro universitário católica de Quixadá. Participação do projeto de extensão ablac-RJ e ablam. Apresentação do trabalho intitulado incidência de mortalidade por câncer de colo do útero no Ceará no período de 2013 a 2017 no Expresso católica. Participação do grupo de estudo e pesquisa em saúde do adulto e assistência de enfermagem. Participação do 5 congresso brasileiro de especialidades em enfermagem.

MATOS, Amanda Patrícia Vasconcelos: Interna de medicina na Universidade Federal do Maranhão - UFMA Campus V Pinheiro. Foi diretora do Centro Acadêmico de Medicina Pericumã por quatro anos (segunda secretária, presidente e diretora de apoio); Presidente e fundadora da Liga Acadêmica de Pneumologia e Cirurgia Torácica; Vice-Presidente e fundadora da Liga Acadêmica de Radiologia e Diagnóstico por Imagem; Diretora de Marketing e fundadora da Liga Acadêmica de Anestesiologia, Dor e Cuidados Paliativos; Monitora bolsista e fundadora do Programa de Assistência Ambulatorial às Pneumopatias do Adulto e do Idoso; Presidente e fundadora do Comitê Local UFMA Pinheiro da International Federation of Medical Students' Associations of Brazil (IFMSA Brazil); Monitora do Projeto de Pesquisa e Extensão de Educação ao Ensino Médio público; Membro da Comissão Organizadora do Congresso Médico Acadêmico Brasileiro por dois anos, do Congresso de Ligas Acadêmicas do Norte e Nordeste, dentre outros eventos locais e regionais. Atualmente é monitora de Técnicas Cirúrgicas do Ciclo Clínico da UFMA e Coordenadora Regional Nordeste 1 da IFMSA Brazil.

MESQUITA, Gerardo Vasconcelos: Médico ortopedista. Especialista em Medicina Esportiva. Mestre em cirurgia pela Universidade Federal de Pernambuco UFPE. Doutor em Cirurgia ortopédica pela Universidade Federal de Pernambuco UFPE. Professor titular do Centro Universitário Uninovafapi. Professor Adjunto da Universidade Federal do Piauí-UFPI. E-mail: gvmesquita@uol.com.br

MILES, Duílio Castro: Doutor em Educação pela Universidade do Vale do Rio dos Sinos. Possui Mestrado em Administração pela Universidade do Vale do Rio dos Sinos (2006), Especialização em Recursos Humanos e Administração Esportiva, Graduação em Ciências Jurídicas e Sociais pela Pontifícia Universidade Católica do Rio Grande do Sul (1994) e Graduação em Administração de Empresas e Administração Pública pela Universidade Federal do Rio Grande do Sul (1986). Foi Coordenador de Pós Graduação e Extensão Universitária do SENAC-RS, e Consultor Organizacional, nas áreas de Recursos Humanos, Administração Estratégica e Marketing e Pesquisador na área de Estratégia Empresarial, Estudos Organizacionais, Empreendedorismo e Inovação, Pequenas Empresas, Gestão de Cidades e Turismo. Atualmente é professor 


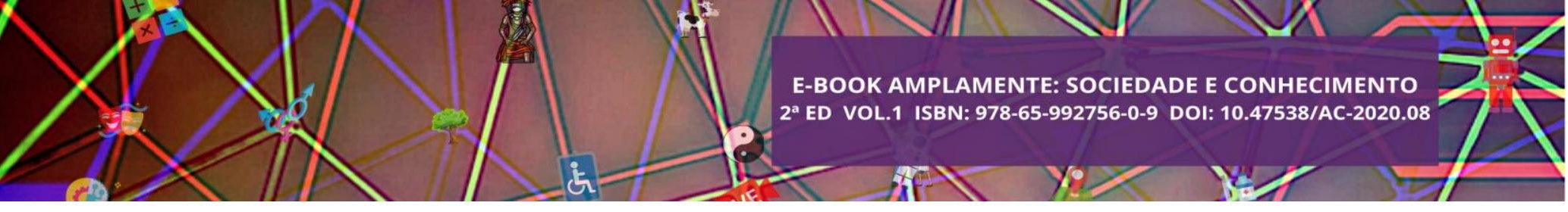

do Instituto Federal de Educação Ciência e Tecnologia do Rio Grande do Sul- Campus Porto Alegre. Foi Coordenador do Curso Superior de Tecnólogo em Processos Gerenciais e da Incubadora Tecno-Social. Foi Coordenador do Curso de Especialização em Gestão Empresarial, com ênfase na Pequena Empresa, junto ao IFRS - Campus Porto Alegre. Coordenou os processos de construção dos Cursos Superiores em Turismo, de Graduação de Comércio Exterior e de Mestrado Profissional de Administração com foco na Gestão de Pequena Empresa. Participa de Grupos de Pesquisa -Grupo de Pesquisa Gestão, Empreendedorismo e Desenvolvimento Econômico e Social (IFRS-Porto Alegre).Parecerista da Revista de Empreendedorismo e Gestão de Pequenas Empresas - REGEPE e da Associação Nacional de Cursos de Graduação em Administração - ANGRAD

MINUZI, Gabrielle Assunção: Possui graduação em Gastronomia pela Universidade de Santa Cruz do Sul (2013). Atualmente é pesquisadora da Universidade Federal de Santa Maria (2020) Tem experiência na área de Turismo, com ênfase em Gastronomia. Cursa Mestrado em Educação Profissional e Tecnológica, na UFSM. Onde realiza pesquisa na área de formação de professores com ênfase na análise dos currículos dos cursos de gastronomia. E-mail: gabrielleminuzi@gmail.com

MOTA JÚNIOR, Antônio Ananias: Especialista em Engenharia de Segurança do Trabalho - IMP. Possui Graduação em Administração pela Faculdade de Cuiabá e graduação em Engenharia de Produção pela Universidade de Cuiabá, Graduação em Turismo pela Faculdade Afirmativo. Tem experiência na área de Engenharia de Produção, com ênfase em Engenharia de Segurança do Trabalho, logística e auditoria.

NASCIMENTO, David Emanuel Eufrásio: Graduando em enfermagem Centro Universitário católica de Quixadá- Quixadá- CE

NEIS, Andressa: Possui graduação em Ciências Econômicas (2017), pela Universidade Federal de Santa Maria (UFSM). Atualmente é mestranda em Economia e Desenvolvimento (PPGE\&D) pela mesma Universidade.

NOVAES, Danilo de Souza: Bacharel em Sistemas de Informação pela Universidade Federal Rural da Amazônia - UFRA, estudante de Pós-Graduação em Governança de Tecnologia da Informação pela PUC Minas. Exerceu cargo de Diretor Administrativo e Financeiro da UTIC - Empresa Junior de Tecnologia da Informação e Comunicação da UFRA nos anos de 2016 e 2017. Desenvolvedor Full Stack com experiência nas linguagens PHP, HTML, CSS, Javascript. Com experiência nas áreas de Empreendedorismo, Inovação, Gestão do Conhecimento e Desenvolvimento Web, nas empresas Brasil Dicect Software Soluções e Serviços (2018-2019) e Amcom Sistemas de Informação (2019-2020). Lattes: http://lattes.cnpq.br/5336303262386293

NUNES, Júlia Leite: Graduação em andamento em Direito, Universidade do Estado de Mato Grosso, UNEMAT, Brasil.

OLIVEIRA, Luis Rennan Sampaio: Graduado em Medicina Veterinária pela Universidade Federal Rural de Pernambuco (2004), possui Mestrado em Medicina Veterinária pela Universidade Federal Rural de Pernambuco (2007) e Doutorado em Medicina Veterinária pela Universidade Federal Rural de Pernambuco (2009). Atualmente é Professor Associado II da Universidade Federal Rural da Amazônia Campus de Parauapebas. Email. rennanvet@yahoo.com.br. Lattes: http://lattes.cnpq.br/9978244091099092 


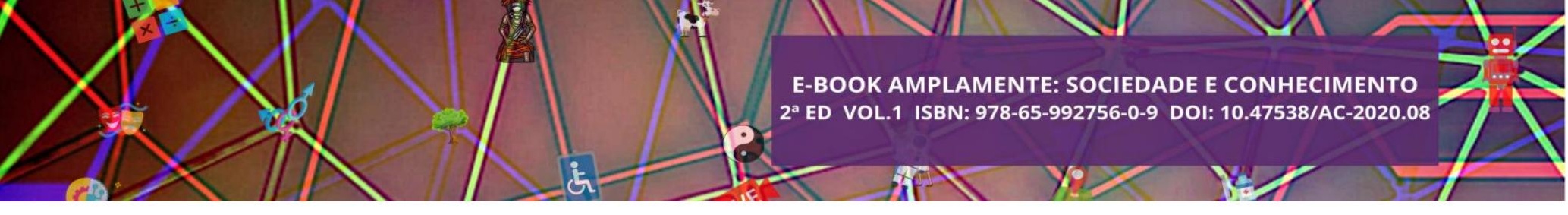

OLIVEIRA, Maria Helloá Costa de: Graduação em Agronomia pela Universidade Federal de Alagoas (2014), mestre pelo Programa de Pós Graduação em Proteção de Plantas -CECA/UFAL (2019), atuando como como membro do Grupo de Pesquisa em Proteção de Plantas com em ênfase em Fitopatologia, atuando nos seguintes temas: Begomovirus, Biologia Molecular e Clonagem. Tem experiência na área de Agronomia, atuando como Agente de Assistência Técnica e Extensão Rural ATER com ênfase em Agroecologia no agreste alagoano. Atuou também com Treinner no segmento sucroalcooleiro e com outras culturas como o Eucalipto, Sorgo e Cana Energética. Atualmente é doutoranda pelo Programa de Pós Graduação em Proteção de Plantas - CECA/UFAL. http://lattes.cnpq.br/9912017738659560

OLIVEIRA, Rodrigo Ribeiro de: Doutorado em Engenharia de Produção pela Universidade Metodista de Piracicaba. Instituto Federal de Educação, Ciência e Tecnologia de São Paulo. Possuí graduação em Administração pelo Centro Universitário Adventista de São Paulo (2005), mestrado em Administração pela Universidade Metodista de São Paulo (2008), doutorado em Engenharia de Produção pela Universidade Metodista de Piracicaba (2012) e realizou estágio Pós Doutoral na Universidade Metodista de São Paulo (2016). Atualmente é professor no Instituto Federal de Educação, Ciência e Tecnologia de São Paulo (IFSP). Parecerista de periódicos, projetos de pesquisa e eventos científicos nacionais e internacionais como: Research, Society and Development (RSD), Brazilian Journal of Production Engineering (BJPE), Revista Organizações em Contexto (ROC), Simpósio de Engenharia de Produção (SIMPEP), Encontro da ANPAD (EnANPAD), Seminários em Administração (SemeAd), Programa Institucional de Bolsas de Iniciação Científica do IFSP (PIBIFSP) dentre outros. Orientador de Projetos de Iniciação Científica do IFSP. Temas de interesse: empreendedorismo; gestão da qualidade; gestão de pessoas; hospitalidade; hostels; logística; qualidade de vida no trabalho; trabalho docente; patrimônio imaterial e material. Líder do Núcleo de Estudos do Patrimônio Imaterial e Material - NEPIM (IFSP) e pesquisador dos Grupos: Humanidades e Sociedade Contemporânea (IFMT); Projeto Sustentare - desenvolvimento de práticas sustentáveis (IFSP).

OLIVEIRA, Thales do Rosário de: Professor de Filosofia Pela SEE-MG, formado em filosofia (IMP) e mestrando em estudos de literatura comparada (UnB), tem como principal foco de pesquisa a morte como elemento social nas suas mais diversas variações sempre tendo como pilares fundamentais a filosofia, literatura e a psicanálise freudiana. E-mail: profess.thales@ hotmail.com

PAIVA, Luciano Luan Gomes: Mestre em Música (com ênfase em Educação Musical) pela Universidade Federal do Rio Grande do Norte (UFRN). Licenciado em Música, Técnico em Guitarra Elétrica, todos pela Universidade Federal do Rio Grande do Norte (UFRN). Especialista em Tecnologias Educacionais e Educação a Distância pelo Instituto Federal de Educação, Ciência e Tecnologia (IFRN). Como professor, atua em projetos sociais e em aulas particulares de música, assim como já atuou em escolas especializadas. Foi bolsista do PIBID Música Universidade Federal do Rio Grande do Norte (UFRN). No âmbito da pesquisa, produz artigos científicos abordando temas como: Tecnologias digitais, Formação docente e aprendizagem de guitarra elétrica. É membro do Grupo de Estudos e Pesquisa em Música - GRUMUS (UFRN). Sócio na Empresa Amplamente Cursos e Formação Continuada, atuando com Edição e publicação de Livros e cursos on-line. Coach Educacional para professores e gestores. 


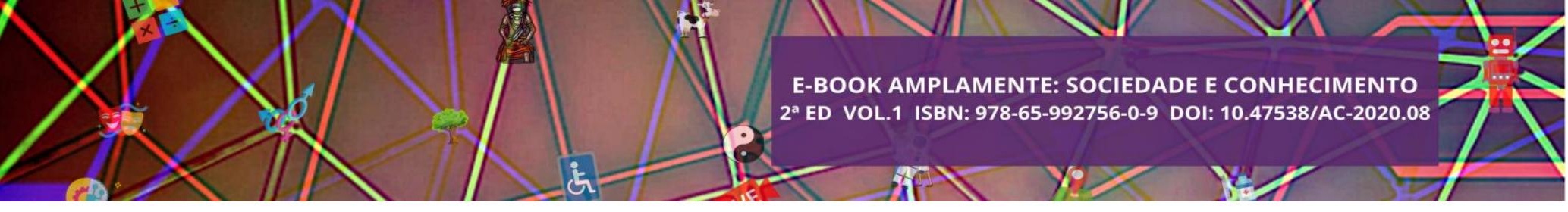

Saúde da Mulher (GPESM). Curso de APH pelo Centro De Preparação em Atendimento pré-hospitalar (CEPAPH). Diversos trabalhos científicos apresentados. Técnico em enfermagem pelo Instituto de Saúde e Gestão Hospitalar com ênfase em UTI adulto. Diversos cursos de qualificação em Saúde, de diversas áreas. E-mail: eeepdv.gabrielsilva@gmail.com

SANTOS, Leila Maria Araújo: Possui graduação em Sistemas de Informação pelo Centro Universitário Franciscano (2000), mestrado em Educação pela Universidade Federal de Pelotas (2003) e doutorado em Informática na Educação pela Universidade Federal do Rio Grande do Sul (2009). Atualmente é professora associada da Universidade Federal de Santa Maria. Atua no Programa Especial de Graduação para EPT (PEG) e no Mestrado Acadêmico em Educação Profissional e Tecnológica (PPGEPT), e é líder do grupo de pesquisa Metodologias Ativas para EPT, desenvolve estudos e pesquisas nas áreas de Metodologias Ativas no Ensino, Práticas Inovadoras de ensino, Tecnologias Educacionais e Educação Profissional e Tecnológica. E-mail: leilamas@gmail.com

SILVA, Carlos Antônio Freitas da: Professor de Música na educação básica. No YouTube, comanda o canal Musicalizando com Tio Carlos. Aluno especial no Programa de Pós-Graduação em Educação, pela Universidade Federal do Rio Grande do Norte (UFRN). Possui graduação em licenciatura em Música pela UFRN, foi colaborador e bolsista de iniciação à pesquisa no Grupo de Estudos e Pesquisa em Música (GRUMUS) da Escola de Música da UFRN (EMUFRN). Possui publicações em revista e artigos científicos nos principais congressos de Educação Musical e áreas afins do Brasil. Ministrou o Curso "CONTO e CANTO: a iniciação musical de crianças com contação de histórias, num processo de imitação", no Fórum Latino Americano de Educação Musical, ministrou o Curso ?Música na Educação Infantil: escuta, execução e releitura de poemas, histórias e canções? no XXIV Congresso Nacional da ABEM, É autor da pesquisa, MUSICALIZAÇÃ̃̃ INFANTIL: a iniciação musical de crianças a partir do processo de imitação gestual, rítmica e sonora. Lattes: http://lattes.cnpq.br/0879089505251263

SILVA JUNIOR, Valdecir da: Possui mestrado em Biologia Vegetal pela Universidade Federal de Pernambuco. É Biólogo licenciado pela Universidade Federal da Paraíba. Possui experiência em atividades de Ensino de Ciências e Biologia no Ensino Fundamental e Médio, Pesquisa científica com foco em etnobiologia e Projetos de Extensão em comunidades pesqueiras. Já atuou nas áreas de Botânica (Fitossociologia), Aquicultura, Ecologia aquática, Ensino de Ciências e Educação ambiental. Atualmente tem interesse em desenvolver projetos nas áreas de Ecologia de Paisagem e Etnobiologia.

SILVA, Aleksandra do Socorro da Bacharel em Ciência de Computação pela Universidade Federal do Pará, Mestre em Informática pela Universidade Federal de Campina Grande e Doutora em Engenharia Elétrica pela Universidade Federal do Pará. Atualmente é professora efetiva da Universidade Federal Rural da Amazônia - UFRA. Atua nas áreas de Tecnologias e Desenvolvimento de Sistemas de Informação aplicáveis em diversos domínios de conhecimento, Inteligência Artificial, Ambientes Virtuais de Aprendizagem (LMS - Learning Management Systems) e Análises de Redes Sociais (SNA - Social Network Analysis) no contexto de programas de Formação. Lattes: http://lattes.cnpq.br/9825582909788318 


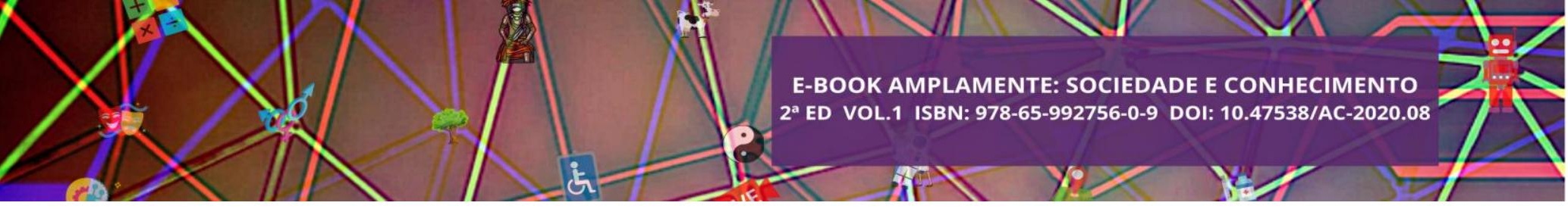

SILVA, Ana Paula Freitas Da: Graduação em química bacharelado (UFAL), mestrado em química e biotecnologia, subárea: química de produtos naturais (UFAL), doutorado em química, subárea química orgânica (UFPE). Professora adjunta da Universidade Federal de Pernambuco, Campus do Agreste. Trabalha com formação de professores e educação ambiental.

SILVA, Anny Luize de Araújo: Graduada em Serviço Social pela Universidade Federal do Rio Grande do Norte (UFRN). Estagiária no Cadastro Único vinculado a Secretaria Municipal de Assistência Social - SEMTAS/Natal (2019).

SILVA, Bruna Brogni da: Mestranda em Ciências do Movimento Humano, pela Universidade Federal do Rio Grande do Sul (UFRGS). Bacharela em Educação Física pela Universidade Federal do Rio Grande do Sul (UFRGS). Licenciada em Educação Física pela Universidade Federal do Rio Grande do Sul (UFRGS). Vinculada ao Centro de Desenvolvimento do Esporte Recreativo e do Lazer (REDE CEDES). Integrante do Grupo de Estudos Socioculturais em Educação Física (GESEF/ UFRGS). Membro associada do Colégio Brasileiro de Ciências do Esporte (CBCE). Atua no âmbito no lazer, com ênfase no treinamento físico.

SILVA, Debora Cristina da: Doutoranda em Proteção de Plantas pela Universidade Federal de Alagoas atuando na área de Fitopatologia, com pesquisas vinculadas a Universidade Federal do Cariri cearense. Possui mestrado em Produção Vegetal pela Universidade Federal Rural de Pernambuco (2017) e graduação em Agronomia pela Universidade Federal do Maranhão (2015). Tem experiência na área de Agronomia, com ênfase em manejo de culturas anuais em Sistema de cultivo em Aleias, plantas daninhas e Hidrodinâmica do sistema solo-planta-atmosfera. http://lattes.cnpq.br/0343031182551501

SILVA, Eloyse Valéria da - Graduanda em Serviço Social pela Universidade Federal do Rio Grande do Norte (UFRN). Extensionista no Projeto Trilhas Potiguares nos anos de 2018 e 2019. Estagiária no Serviço Social do Comércio - SESC/Natal (2019) e no Cadastro Único vinculado a Secretaria Municipal de Assistência Social SEMTAS/Natal (2018).

SILVA, Leda Mourão Da: Bacharel em Direito pela Universidade do Estado do Amazonas (UEA), Pós-graduada em Direito Público com capacitação para o Ensino no Magistério Superior pela Faculdade Damásio. Advogada inscrita na OAB/AM n. ${ }^{\circ}$ 10276.

SILVA, Marcelo Alves da: Professor Universitário, Mestrado em Teologia pela Faculdades Batista do Paraná (FABAPAR, 2017); MBA em Gestão de Projetos pela Faculdade de Araucária (FACEAR, 2016); Pós-graduado em Docência do Ensino Superior pela (UNIASSELVI, 2016); Pós-graduado em Gestão de Recursos Humanos pela (UNIASSELVI, 2014); Pós-Graduado em Psicologia Organizacional; Pósgraduado em Psicologia Clínica; Pós-graduado em Psicologia Jurídica e Avaliação Psicológica; Pós-Graduado em Psicanálise (FACULDADE FUTURA, 2018); PósGraduado em: Gestão Escolar e Direito Educacional; Pós-graduado em Psicopedagogia Institucional, Clínica e Educação Especial; Pós-graduado em Aconselhamento e Psicologia Pastoral (FACULDADE DOM ALBERTO); Pós-graduado em Neuropsicologia; Pós-graduado em Neuropsicopedagogia Clínica; Pós-graduado em Direitos Humanos e Questões Ético-Sociais (FACULDADE FUTURA); Graduado em Administração pela Universidade Luterana do Brasil (ULBRA, 2013); Graduado em Psicologia (UNINORTE, 2017); Graduado em Teologia pela (FABIN, 2002) e curso 


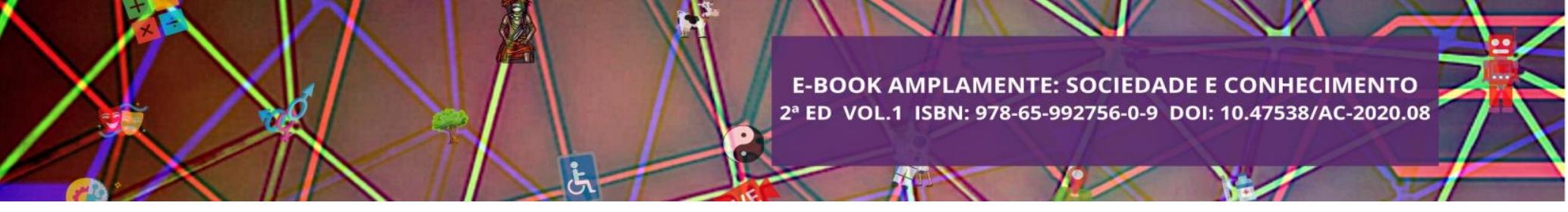

convalidado pela Faculdade Evangélica do Piauí (FAEPI, 2016); Licenciatura em Pedagogia (FAEL); Licenciatura em Letras Português/ Inglês; Experiência na área de Administração, com ênfase em Administração de Recursos Humanos e Gestão de Projetos. Experiência como Palestrante. Atualmente atua como docente na Faculdade de Estudos Sociais (FES) na Universidade Federal do Amazonas (UFAM). Atua como docente nos cursos de Pós-graduação em Psicopedagogia, Gestão de Projetos e Auditoria em Finanças Corporativas; Metodologia da Pesquisa Cientifica (ESBAM). Orientador de TCC em graduação e Pós-Graduação; Atuou como docente no Curso de graduação em Administração na Escola Superior Batista do Amazonas (ESBAM), ministrando as disciplinas de Trabalhos Acadêmicos e Científicos em Administração, Marketing de Varejo, Gestão de Custos, Estágio Supervisionado I e II.

SILVA, Maria Lindalva Alves da: Graduada em Ciências da Natureza/Biologia pela Universidade Estadual do Piauí. Mestre pelo Programa de PósGraduação em Biodiversidade, Ambiente e Saúde/PPGBAS/ CESC/ UEMA/Caxias (2017). E-mail: lindalva.maria@hotmail.com

SILVA, Vitor Emanuel Sousa da: Técnico em Agroindústria pelo Instituto Federal do Maranhão - IFMA. Discente do curso de Enfermagem do $7^{\circ}$ período da Universidade Estadual do Maranhão-UEMA. Presidente da Liga de Feridas da Universidade Estadual do Maranhão-UEMA. E-mail: gaarakasekaque@gmail.com

SILVA, Viviane Simas da: Mestranda do Programa de Pós Graduação em Direito Ambiental da Universidade do Estado do Amazonas. Especialista em Direito do Trabalho e Previdenciário pela PUC Minas Gerais (2018). Especialista em Direito do Consumidor e Direito Registral Imobiliário (2015). Graduada em Direito pelo Centro Universitário de Ensino Superior do Amazonas (2008). Bacharel em Educação Religiosa - Faculdades Batista Ida Nelson (2003). Advogada. Experiência de 14 anos como advogada de entidades sociais na área cultural. Professora credenciada pela Universidade do Estado do Amazonas na disciplina Relações Internacionais Privadas.

SILVA, Viviane Siqueira: Graduanda em Serviço Social pela Universidade Tiradentes - UNIT, Aracaju/SE. Técnica em Nutrição e Dietética, pelo Centro de Estudos Aplicados em Saúde (CEAS), Aracaju/SE. E-mail: viviane1783@ hotmail.com

SOAR, Fabio Montalvão: Doutor em Psicologia pela Universidade Federal do Rio de Janeiro. Mestre em psicologia pela Universidade Federal Fluminense. Professor adjunto do curso de psicologia da Universidade Federal de Goiás, Regional Jataí (UFG/REJ), Jataí, Estado de Goiás. E-mail: professor.fabiomontalvao@gmail.com

SOARES, Danielle Cevallos: Possui graduação em Direito pela Universidade do Estado de Mato Grosso (2009). Atualmente é professora efetiva do Curso de Direito da Universidade do Estado de Mato Grosso - UNEMAT, campus de Cáceres, bem como ministra a disciplina de Direitos Fundamentais, Direito Constitucional e Direito Administrativo.

SOARES, Fernanda Ellen da Silva: Graduada em Serviço Social pela Universidade Federal do Rio Grande do Norte (UFRN). Extensionista no Projeto Trilhas Potiguares (2019).

SOUZA, Gleyce Karenina França Queiroz de: Graduada em Serviço Social pela Universidade Federal do Rio Grande do Norte (UFRN). 


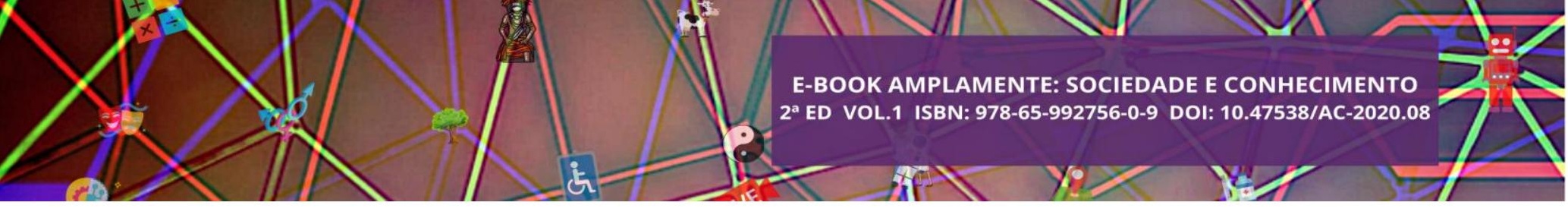

SOUZA, Lucas Tomazi de: Acadêmico de Engenharia de Alimentos da Universidade Tecnológica Federal do Paraná campus Francisco Beltrão (UTFPR - FB). Tem experiência na área cervejeira com ênfase em produção e análise sensorial. E-mail: tomazi.exitotreinamentos@gmail.com

STACK, Daniel da Silva: Programa de Pós-Graduação em Ciências Sociais PPGCS/UFSM. Possui graduação em Ciências Sociais pela Universidade Federal de Santa Maria (2019). Mestrando em Ciências Sociais PPGCS/UFSM. Tem experiência na área de Sociologia e Antropologia, com ênfase em sociologia da saúde, sociologia digital e antropologia digital, atuando principalmente nos seguintes temas: gênero, sexualidade, mídias digitais, corpo, saúde e educação. E-mail: danielsstack@outlook.com http://lattes.cnpq.br/5942099225527487

TORRES, Gustavo Emanuel Martins Ferreira: Acadêmico do curso de Medicina e Monitor da cadeira de Bioquímica pela Faculdade de Medicina de Petrópolis. Bacharel em Comunicação Social - Publicidade e Propaganda - pela Pontifícia Universidade Católica do Rio de Janeiro. Bacharel em Administração pela Universidade Federal do Estado do Rio de Janeiro.

VENTURA, Marla Jalinne: Psicóloga. Graduada em Psicologia pelo Centro Universitário São Francisco de Barreiras - UNIFASB. Pós-graduanda em Psicologia Social pela Faculdade Dom Alberto - Centro Educacional FAVENI. Palestrante na área da Psicologia da Saúde com foco na prevenção do suicídio. Pesquisadora nas áreas de Psicologia Social e Saúde. Psicóloga do Projeto "Nossas histórias curam" e da Comunidade "Anti Frágil".

VIEGAS, Thales de Oliveira: Professor Adjunto da Universidade Federal de Santa Maria desde 2015. Técnico em Administração (2002), graduado (2006) e mestre (2008) em Economia pela Universidade Federal de Uberlândia e doutor (2013) em Economia pela Universidade Federal do Rio de Janeiro. Realizou parte do doutorado na Universidade de La Laguna (Espanha-2011) e na Universidade do Texas (EUA-2012). Trabalhou no Grupo de Economia da Energia (IE-UFRJ entre 2009 e 2013). Foi consultor interno de Inteligência de Mercado da Camargo Corrêa (2013-2015). Foi coordenador (2016-2017) e chefe do Departamento de Economia da UFSM (20182019). Tem experiência em Economia Brasileira, Economia Industrial e Economia da Energia.

VIEIRA, Juliana Rocha: técnica e graduanda em enfermagem pela universidade católica rainha do sertão, situada no município de Quixada-CE. Participou de diversos cursos, entre eles: curso de APH pelo centro de preparação em atendimento pré-hospitalar (CEPAPH), apresentação em trabalhos científicos na universidade federal do Ceará, curso de enfermagem da editora brasileiro e passos, jornada de ginecologia e obstetrícia ofertada pela universidade católica rainha do sertão, entre outros que estão expostos em seu currículo. Atualmente está cursando o $9^{\circ}$ semestre de enfermagem.

XAVIER, Jacqueline Nascimento: Especialista em Organização e Gestão de Politicas Sociais, pela Faculdade Serigy; Graduanda em Serviço Social pela Universidade Tiradentes - UNIT, Aracaju/SE. E-mail: jacqueline_xavier@unit.com 


\section{INDÍCE REMISSIVO}

A

Afetividade, $\underline{53}$

Ambientes Virtuais, $\underline{69}$

Anáforas, 14

Análise fílmica, 442

Análises físico-químicas, 251

Apatridia, $\underline{381}$

Arte, $\underline{132}$

Avaliação heurística, $\underline{69}$

B

Balé, $\underline{62}$

C

Cidadania, $\underline{381}$

Ciências, 191

Coletividade, $\underline{238}$

Compostos bioativos, 251

Conhecimento, 191

Controle Alternativo, $\underline{307}$

Convivência Familiar, $\underline{82}$

Copie Conforme, 442

Corpo, 132

Covid-19, 329

COVID-19, 255

Culpabilização, $\underline{38}$

D

Desafios, $\underline{180}$

Desempenho empreendedor, $\underline{337}$

Desenvolvimento Regional, 225

Desertificação, 157

Direito ambiental, $\underline{157}$

Direitos, 107

Direitos Humanos, 269, $\underline{381, \underline{398}}$

$\mathbf{E}$

Economia Criativa, $\underline{225}$

Ecossistema, $\underline{337}$
Ecoturismo, 281

Educação Ambiental, $\underline{238}$

Efeitos, $\underline{53}$

Empresário de futebol, 29

Energias Renováveis, $\underline{430}$

Ensino superior militar, $\underline{123}$

Epiclese, 14

Escola Naval, $\underline{123}$

Espírito Santo, 14

Ética, $\underline{316}$

Eutanásia, $\underline{316}$

Evolução histórica, 29

Extensão universitária, $\underline{359}$

Extratos vegetais, $\underline{143}$

F

Família, $\underline{82}$

Fotografia, 191

Fungo, 143

G

Gestão hospitalar, 374

Grupo de Crianças, $\underline{62}$

H

Hábitos alimentares, $\underline{116}$

I

Inclusão de gênero, 123

Inseminadores, $\underline{359}$

J

Jovens e Adultos, $\underline{116}$

Jurisprudência, $\underline{316}$

L

Legislação Ambiental, $\underline{281}$

Leis, 107

Literatura, $\underline{46}$

Liturgia, 14 


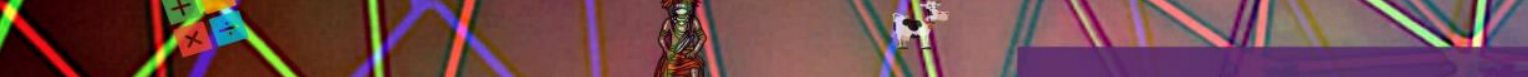

E-BOOK AMPLAMENTE: SOCIEDADE E CONHECIMENTO $2^{\text {a }}$ ED VOL.1 ISBN: 978-65-992756-0-9 DOI: 10.47538/AC-2020.08

$\mathbf{M}$

Transtorno Espectro Autista, 107

Meio Ambiente, $\underline{281}$

Método de Monte Carlo, $\underline{417}$

Morte, $\underline{46}$

V

Vacinação, 293

Mulheres Trans, 180

Multiparentalidade, $\underline{53}$

$\mathbf{N}$

Números Aleatórios, $\underline{417}$

$\mathbf{P}$

Pandemia, 255, $\underline{329}$

Paternidade, $\underline{53}$

Política, $\underline{92}$

Políticas Púbicas, $\underline{82}$

Políticas Públicas, $\underline{204}$

Poluição Sonora, $\underline{329}$

População Negra, 219

Programa Nacional de Segurança do

Paciente, 374

Proteção Social, $\underline{82}$

Psicanálise, $\underline{46}$

Psicologia do Esporte, $\underline{62}$

Puro malte, 251

$\mathbf{R}$

Racismo, 219

Refugiados, $\underline{255}$

Regime Tecnológico, $\underline{430}$

$\mathbf{S}$

Saúde, 219

Segurança, 374

Serviço Social, $\underline{398}$

Sexualidade, $\underline{132}$

Sistema Único de Saúde, 204

Sociedade, $\underline{92}, \underline{180}$

Sustentabilidade, $\underline{225}$

$\mathbf{T}$

Teorema do Limite Central, $\underline{417}$

Transexualidade, 204 


\section{iff}

E-BOOK

AMPLAMENTE: SOCIEDADE E CONHECIMENTO

$2^{\circ}$ EDIÇÃO. VOLUME 01.

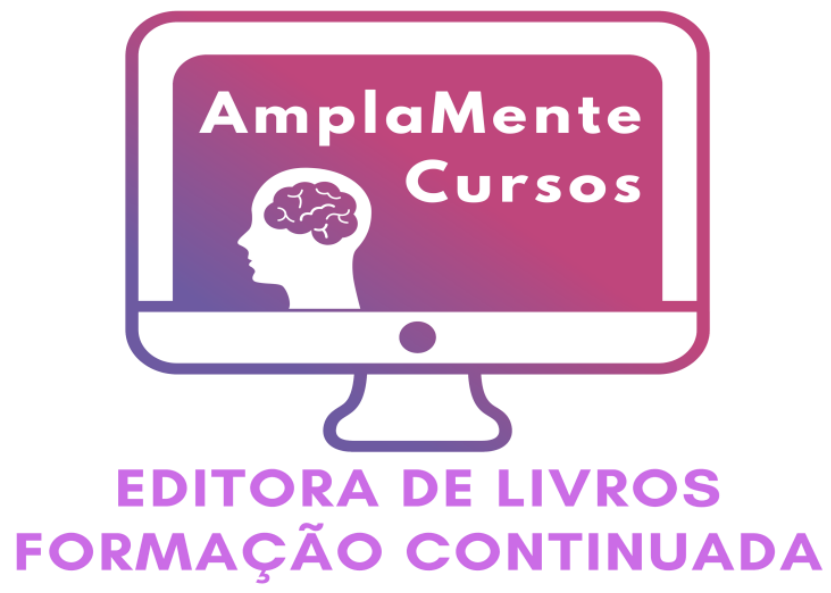

ORGANIZADORES

Luciano Luan Gomes Paiva

Dayana Lúcia Rodrigues de Freitas

Caroline Rodrigues de Freitas Fernandes

DOI: $10.47538 / A C-2020.08$

ISBN: 978-65-992756-0-9

(84) 997072900

(0)@amplamentecursos

f amplamentecursos

Mpublicacoes@editoraamplamente.com.br

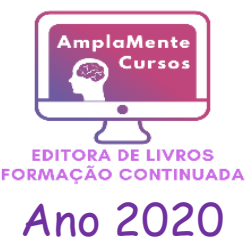

